\title{
ANÁLISE EXPERIMENTAL DA PUNÇÃO EM LAJES DE CONCRETO ARMADO E PROTENDIDO
}

JOSÉ LUIZ PINHEIRO MELGES

Tese apresentada à Escola de Engenharia de São Carlos, da Universidade de São Paulo, como parte dos requisitos para obtenção do Título de Doutor em Engenharia de Estruturas.

ORIENTADOR: Libânio Miranda Pinheiro 
"A realização mais plena do engenheiro não nasce dos conhecimentos que ele adquire, das técnicas que ele desenvolve, dos títulos que obtém e nem do lucro de suas obras. Ela nasce do bem estar que ele proporciona à sociedade."

À Ana Célia e ao Mateus, estrelas guias de minha existência. 


\section{AGRADECIMENTOS}

A Deus, pela vida.

Ao professor Libânio, pela zelosa orientação e pela amizade que tenho a honra de desfrutar.

Aos professores Augusto Carlos de Vasconcelos, Ronaldo Barros Gomes, Ibrahim Shehata, Guilherme Sales S. A. Melo, Paul Regan e Fernando R. Stucchi, pelas valiosas sugestões dadas na elaboração deste trabalho.

Aos professores João Bento de Hanai, José Samuel Giongo e Jasson R. Figueiredo Filho, pelas sugestões dadas no Exame de Qualificação.

Ao professor Toshiaki Takeya, pela orientação dada durante os ensaios.

Ao professor Maximiliano Malite, pelo auxílio no projeto das vigas metálicas usadas como sistema de reação.

Ao professor Antônio C. R. Laranjeiras, pelo envio de algumas referências bibliográficas, consultadas na realização deste trabalho.

Ao eng. Eugênio Luiz Cauduro e em especial à Companhia Siderúrgica Belgo -Mineira, pela doação das cordoalhas de protensão.

À MAC-Protensão, ao professor Evandro Porto Duarte e ao eng. Renato Calderaro, cuja perícia e experiência tornaram possível a protensão dos modelos ensaiados.

Aos funcionários do Laboratório de Estruturas da EESC-USP, pela valiosa colaboração na realização dos ensaios.

À CAPES e à FAPESP, pela bolsa de doutorado e pelo auxílio à pesquisa, respectivamente.

À SABESP, pelo empréstimo da máquina usada para serrar um dos modelos ensaiados.

À empresa Jeruelplast, pela doação dos espaçadores usados neste trabalho.

À bibliotecária Maria Nadir Minatel, pela sua dedicação e eficiência.

Aos engenheiros da Universidade Sagrado Coração, de Bauru, que permitiram o acompanhamento da protensão em um de seus edifícios.

A todos que direta ou indiretamente contribuíram para a realização deste trabalho. 


\section{SUMÁRIO}

RESUMO

ABSTRACT

ii

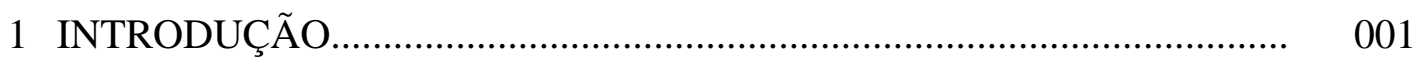

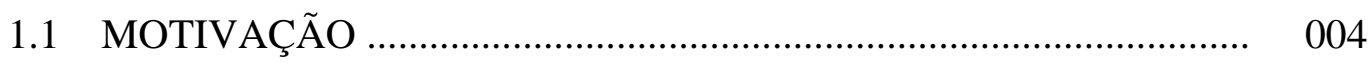

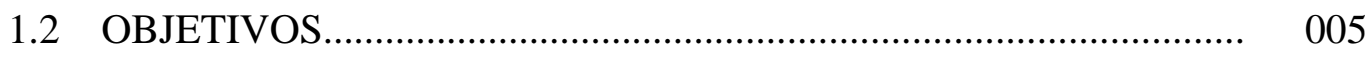

1.3 PLANEJAMENTO........................................................................ 006

2 REVISÃO BIBLIOGRÁFICA …………………………....................... 008

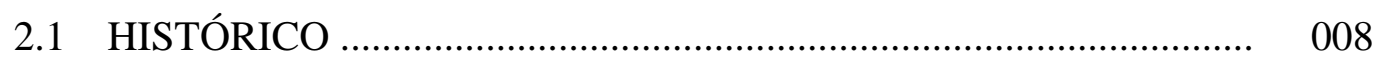

2.1.1 Pesquisas internacionais ............................................................... 008

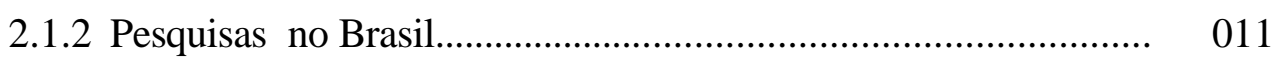

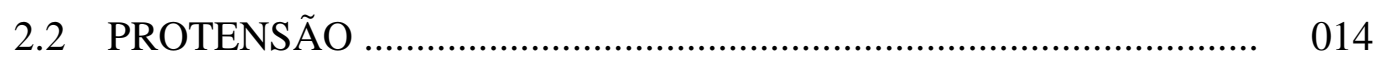

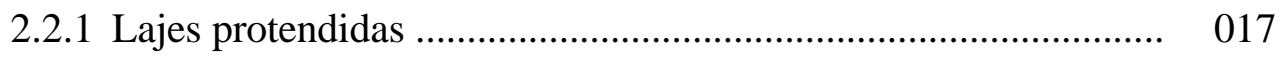

2.2.2 Tipos de protensão ………………………………................ 019

2.2.3 Traçado dos cabos ...................................................................... 021

2.3 RESISTÊNCIA DO CONCRETO AO CISALHAMENTO ................. 026

2.4 RESISTÊNCIA DAS LAJES À PUNÇÃO ............................................ 027

2.5 ANÁLISE DOS ESFORÇOS ........................................................ 030

2.6 COMPORTAMENTO OBSERVADO EM ENSAIOS .......................... 033

2.7 ANÁLISE DA SUPERFÍCIE DE RUÍNA ……………………………... 034

2.7.1 Superfície de ruína para pilares de borda e de canto ...................... 035

2.7.2 Superfície de ruína para ligações com armadura de punção .......... 036

2.8 PARÂMETROS ENVOLVIDOS _..................................................... 039

2.8.1 Espessura ou altura útil da laje .................................................. 039

2.8.2 Dimensões, formato e posição do pilar ………………………....... 040

2.8.3 Resistência do concreto ................................................................ 041

2.8.4 Relação momento fletor / força cortante ........................................ 041

2.8.5 Taxa de armadura de flexão ...................................................... 041

2.8.6 Efeito de escala ("size effect") .................................................... 042

2.8.7 Influência do tipo de carregamento .............................................. 042

2.8.8 Armadura de punção .................................................................. 043 
2.9 TIPOS DE ARMADURA DE PUNÇÃO .............................................. 043

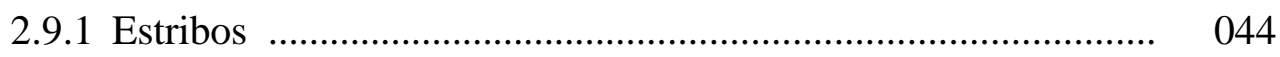

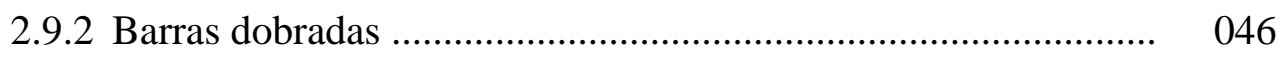

2.9.3 "Shearheads" ....................................................................... 046

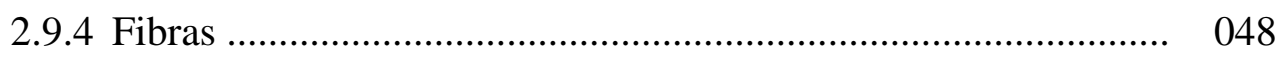

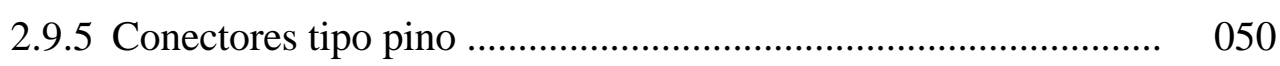

2.9.6 Segmentos de perfis metálicos .................................................... 053

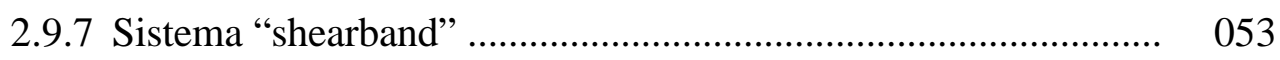

2.10 MODELOS DE CÁLCULO ................................................................. 054

2.10.1 Método da superfície de controle ............................................... 054

2.10.2 Método de bielas e tirantes ........................................................ 055

2.10.3 Modelos mecânicos .................................................................... 056

3 INVESTIGAÇÃO EXPERIMENTAL ...................................................... 058

3.1 DIMENSÕES DOS MODELOS E ESQUEMA DO ENSAIO ............. 058

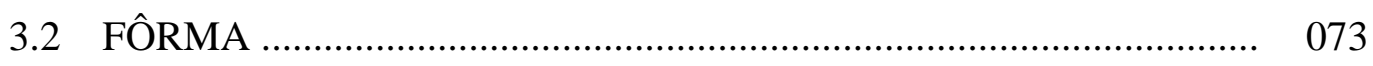

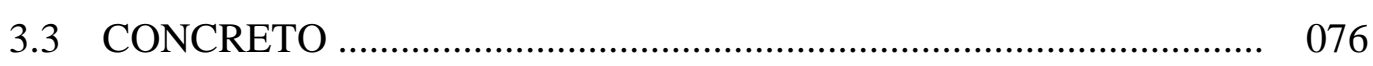

3.4 PROJETO, EXECUÇÃO E CARACTERIZAÇÃO DOS

3.4.1 Modelos de concreto armado ........................................................ 085

3.4.2 Modelos de concreto protendido ................................................ 091

3.4.3 Caracterização dos materiais ........................................................ 098

3.5 PROJETO, EXECUÇÃO E CARACTERIZAÇÃO DOS

MATERIAIS USADOS NA ARMADURA DE PUNÇÃO .......... 100

4 INSTRUMENTAÇÃO DOS MODELOS E RESULTADOS OBTIDOS ........ 107

4.1 INSTRUMENTAÇÃO DA ARMADURA

DE FLEXÃO TRACIONADA ……………………. 111

4.2 INSTRUMENTAÇÃO DA ARMADURA

DE FLEXÃO COMPRIMIDA .............................. 119

4.3 INSTRUMENTAÇÃO DO CONCRETO ………………………......... 123

4.4 INSTRUMENTAÇÃO DOS DESLOCAMENTOS ............................... 129

4.5 INSTRUMENTAÇÃO DA ARMADURA DE PUNÇÃO ……………... 135

4.5.1 Comparação entre os modelos M2 e M5 …………………….... 135

4.5.2 Comparação entre os modelos M3 e M6 .................................... 140

4.6 INSTRUMENTAÇÃO DAS CORDOALHAS DE PROTENSÃO ........ 142 
4.7 FOTOS DA RUPTURA DOS MODELOS ……….............................. 145

4.7.1 Modelo M1 …………………………………................... 146

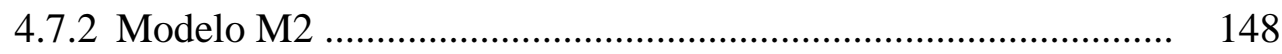

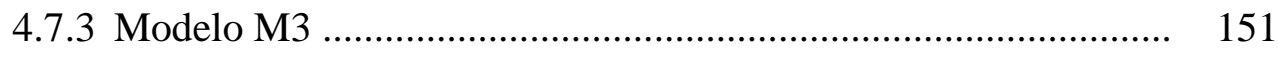

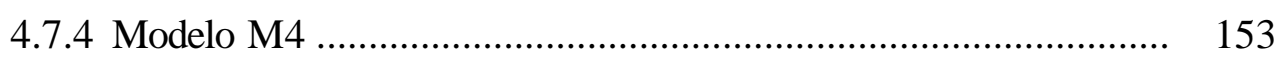

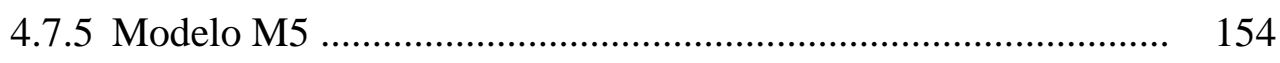

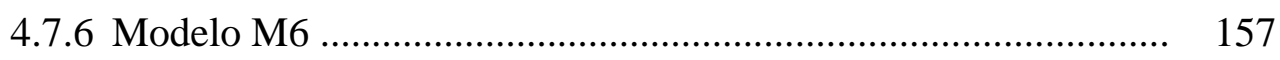

5 ANÁLISE DOS RESULTADOS _............................................................ 160

5.1 ANÁLISE DOS RESULTADOS EXPERIMENTAIS OBTIDOS ......... 160

5.1.1 Modelo M1 ……………………………………................. 160

5.1.2 Modelo M2 …………………………………………...... 166

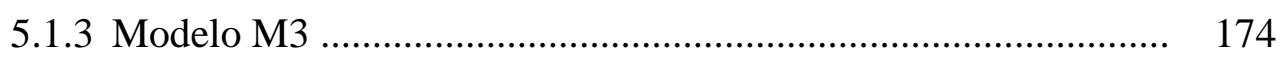

5.1.4 Modelo M4 …………………………………….................. 183

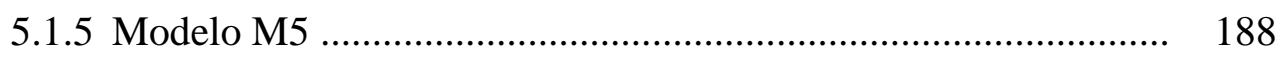

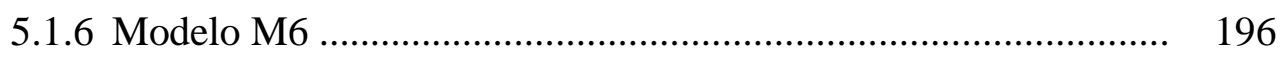

5.2 ANÁLISE DA PROTENSÃO APLICADA AOS MODELOS ............... 203

5.3 PREVISÃO DA FORÇA RESPONSÁVEL

PELA RUÍNA DO MODELO .......... 204

5.3.1 Dimensionamento dos modelos de concreto armado à flexão ......... 204

5.3.2 Dimensionamento das lajes de concreto protendido à flexão ......... 208

5.3.3 Previsão do carregamento de ruína devido à punção .................... 211

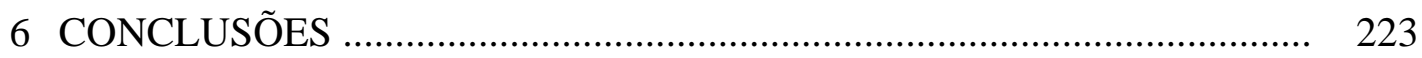

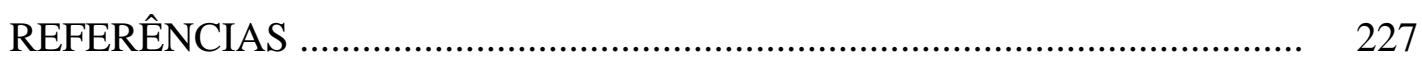




\section{RESUMO}

MELGES, J.L.P. (2001). Análise experimental da punção em lajes de concreto armado e protendido. São Carlos. 2v. Tese (Doutorado) - Escola de Engenharia de São Carlos, Universidade de São Paulo.

As lajes lisas podem oferecer diversas vantagens quando comparadas ao sistema de lajes, vigas e pilares, sendo, em muitos casos, mais econômicas. O uso da protensão pode oferecer outras vantagens, tais como um melhor controle da fissuração e dos deslocamentos transversais da laje.

Como a punção é um dos pontos fracos das lajes lisas protendidas, face à grande esbeltez destas lajes, apresentam-se resultados experimentais de ligações laje-pilar interno, com carregamento concêntrico, com e sem armadura de punção (conectores tipo-pino), com e sem protensão por pós-tração (cabos não aderentes).

Os principais aspectos analisados foram as influências da armadura de punção e da protensão na resistência da ligação laje-pilar. Fez-se também uma análise envolvendo a previsão da resistência da ligação, dada por algumas normas e códigos.

Observa-se que, de um modo aproximado, a armadura de punção eleva significativamente a resistência do modelo à punção, seja ele de concreto armado ou protendido. Observa-se ainda que, embora diminuindo a taxa de armadura dos modelos de concreto armado, para que se introduzissem as cordoalhas de protensão, os valores experimentais obtidos mostram que a presença da protensão aumentou a resistência da ligação.

De um modo geral, a melhor norma que reflete o comportamento da ligação lajepilar é a Revisão da NB-1 (2000). Com relação aos modelos protendidos, o ACI poderia ter tido um bom desempenho, caso não houvesse uma restrição tão rígida com relação ao uso de armaduras de punção.

Palavras-chave: punção; laje lisa; protensão; concreto armado 


\section{ABSTRACT}

MELGES, J.L.P. (2001). Experimental punching shear analysis of reinforced and prestressed concrete slabs. São Carlos. 2v. Tese (Doutorado) - Escola de Engenharia de São Carlos, Universidade de São Paulo.

The use of flat plates may offer some economical and aesthetic benefits when compared with other structural systems. The use of post-tensioned slabs may offer other advantages, as a better crack and deflection control and a thinner slab for the same span and load conditions.

This work presents some experimental results and conclusions about the punching shear failure, as it is a critical problem for flat plate structures, post-tensioned or not.

The main aspects analyzed are the influence of the shear reinforcement (studs) and of the post-tensioning with unbonded tendons on a slab - internal column connection strength.

A comparison between experimental results and those given by some standards is presented. This comparison aims to verify if the codes accurately predict the punching shear strength of the connection.

It can be noted that, in an specific comparison, the studs enhance the punching shear strength of the slab-column connection. In spite of the use of less flexural reinforcement in the post-tensioned models, the punching shear strength of the connection had a higher value when compared with the reinforced ones. This fact is due to the presence of the prestressed strands.

Keywords: punching shear; flat plate; post-tensionning; reinforced concrete 


\section{INTRODUÇ̃̃}

O sistema estrutural tradicionalmente conhecido como lajes-cogumelo, no qual as lajes estão diretamente apoiadas e rigidamente ligadas aos pilares, surgiu em 1905, com a iniciativa pioneira de C. A. P. Turner. Para garantir a segurança e diminuir as tensões de cisalhamento nas ligações, o uso de capitéis e de "drop panels" era comum no início. Embora tenham a mesma função, GHOSH (1983) menciona que, no projeto, considera-se o capitel como sendo um aumento da seção transversal do pilar, próximo à sua ligação com a laje, ao passo que "drop panel" é o aumento da espessura da laje nessa região (figura 1.1).
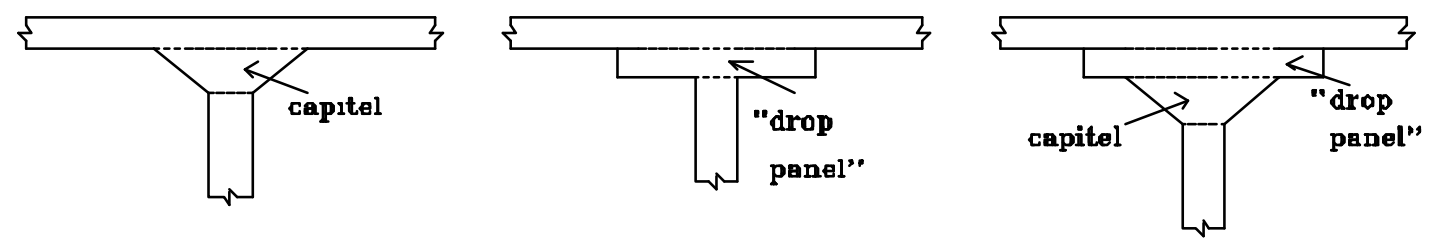

Figura 1.1 - Exemplos de capitel e de "drop panel"

O uso de capitéis e de "drop panels" fez com que os conjuntos constituídos pelas lajes, capitéis e pilares se assemelhassem a cogumelos. Dessa semelhança nasceu a denominação laje-cogumelo, que também é largamente usada nos idiomas europeus, como, por exemplo, o francês (plancher champignon), o espanhol (losas fungiforme), o italiano (solai a fungo) e o alemão (pilzdecke). 
$\mathrm{Na}$ figura 1.2 têm-se alguns exemplos de cogumelos reais que, segundo SANTOS (1958), têm sido fonte de inspiração para o cálculo estrutural.
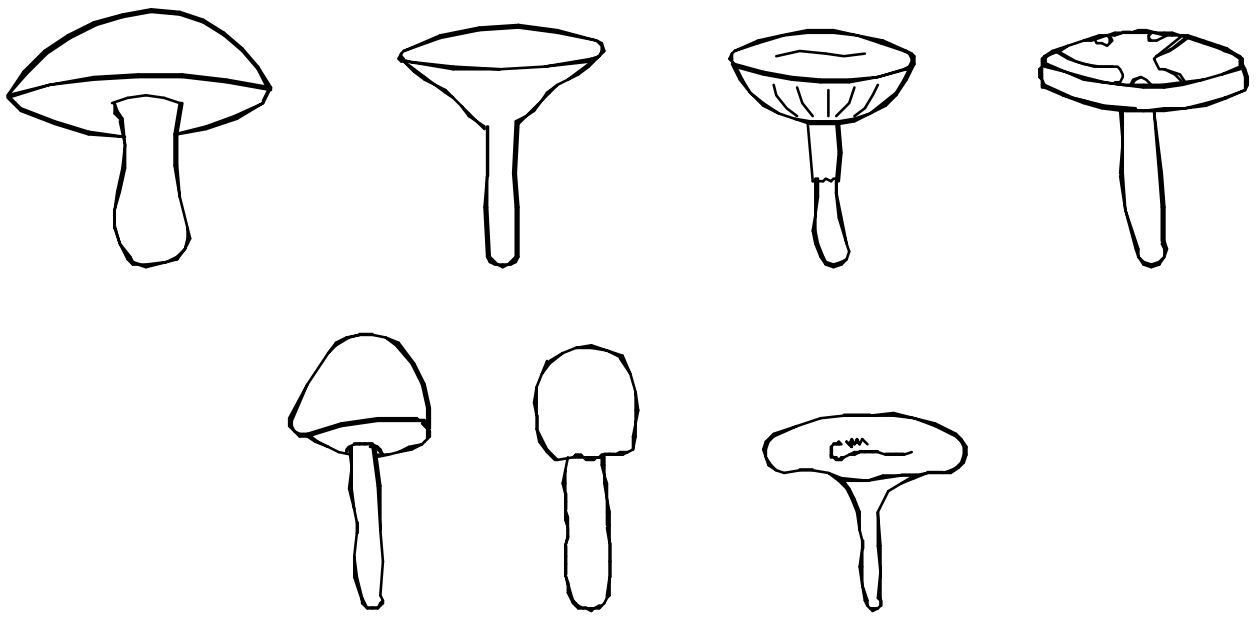

Figura 1.2 - Exemplos de cogumelos reais

Atualmente, tanto o "drop panel" como o capitel estão sendo cada vez menos usados, em decorrência das grandes vantagens de se obterem tetos planos. Neste caso, as estruturas podem ser denominadas lajes livres (GANTE, 1991), lajes planas, lajes lisas ou mesmo lajes sem vigas.

Segundo a revisão da NB-1 (2000), no item 14.6.8, lajes-cogumelo são definidas como sendo as lajes que estejam diretamente apoiadas em pilares com capitéis, enquanto que lajes lisas são aquelas apoiadas em pilares sem capitéis (figuras 1.3 e 1.4).

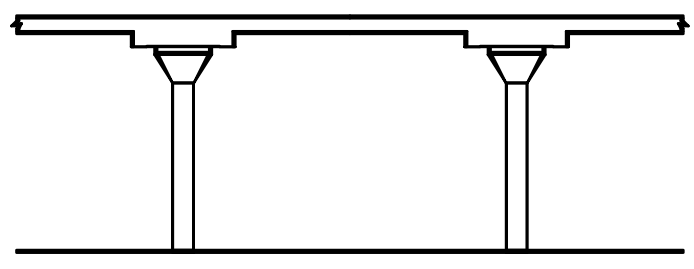

Figura 1.3 - Laje-cogumelo

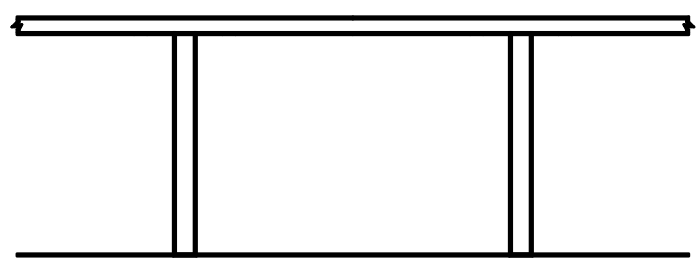

Figura 1.4 - Laje lisa 
Algumas das vantagens oferecidas pelas lajes lisas, mencionadas por FIGUEIREDO FILHO (1989), são: simplificação de fôrmas, de armaduras, de concretagem e das instalações elétrica, hidráulica e de ar condicionado; redução da altura total do edifício e ampla liberdade na definição de espaços internos. Já como principais desvantagens, têm-se os grandes deslocamentos transversais das lajes, os problemas relacionados à estabilidade global de edifícios e a punção das lajes pelos pilares.

Com relação aos deslocamentos transversais excessivos, algumas soluções possíveis são a adoção de vigas nas bordas livres das lajes (onde os deslocamentos são maiores) e o uso da protensão. A protensão é vantajosa porque, ao equilibrar parte das ações atuantes, tem-se uma diminuição dos deslocamentos transversais da laje na região central dos vãos.

Com relação à estabilidade global, a ausência de vigas faz com que as lajescogumelo e as lajes lisas apresentem pequena rigidez às ações horizontais, caracterizadas por ventos, desaprumo, excentricidades, efeitos de segunda ordem e terremotos. Para combater os efeitos dessas ações pode-se associar as lajes-cogumelo ou lisas a sistemas de núcleos rígidos, tais como poços de elevadores e caixas de escadas, a paredes estruturais ou, ainda, a pórticos que seriam projetados para resistir a essas ações.

A punção é um tipo de ruína que pode ocorrer quando forças concentradas, ou atuando em pequenas áreas, são aplicadas diretamente nas lajes, causando a sua perfuração. Nas lajes lisas, esta situação é típica na região da ligação laje-pilar.

A punção está associada a esforços de cisalhamento e provoca uma separação completa entre a laje e o pilar (figura 1.5). Como esta ruína é do tipo frágil, deve-se, como diretriz de projeto, garantir que, caso a ruína ocorra, ela não se dê por punção, mas

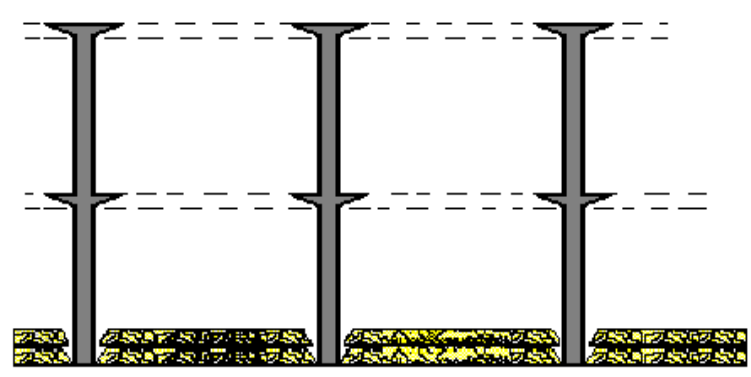

Figura 1.5 - Separação entre a laje e o pilar sim por flexão. 
Este tipo de ruína também pode ocorrer em outros elementos estruturais, tais como: lajes de piso ou pavimentos apoiados sobre estacas (figura 1.6), lajes de fundação que suportam diretamente os pilares (figura 1.7), caixas d'água apoiadas sobre pilares ou estacas (figura 1.8), sapatas e blocos flexíveis (figura 1.9) e cortinas atirantadas (figura 1.10). Este assunto será melhor detalhado no próximo capítulo.

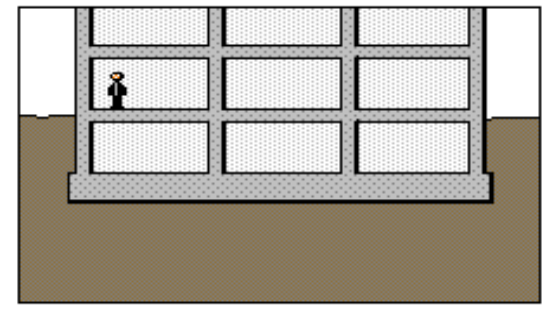

Figura 1.7 - Laje de fundação (MICROSOFT encarta 96 encyclopedia, s.d.)

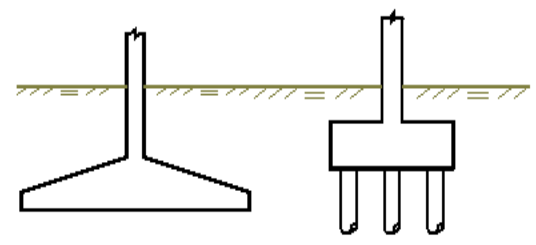

Figura 1.9 - Sapatas e blocos flexíveis

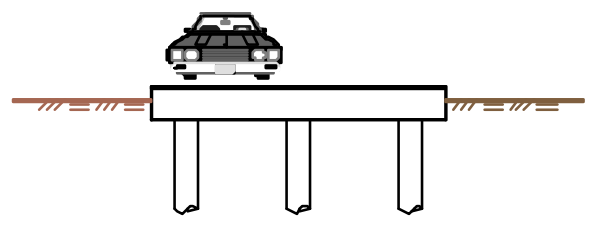

Figura 1.6 - Pavimento

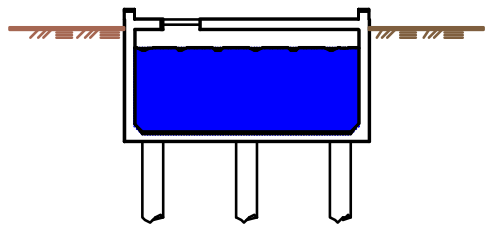

Figura 1.8 - Caixa d'água

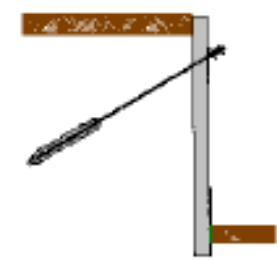

Figura 1.10 - Cortina atirantada

\subsection{MOTIVAÇÃO}

Embora as lajes lisas protendidas com cordoalhas não aderentes sejam comuns em outros países, só recentemente é que a Companhia Siderúrgica Belgo-Mineira disponibilizou para o mercado as cordoalhas engraxadas. Deste modo, destaca-se a ausência de resultados experimentais, no meio técnico nacional, envolvendo ligações lajepilar pós-protendidas com essas cordoalhas. 
Como as recomendações de diversas normas são baseadas em resultados empíricos, quanto maior for o número de ensaios, com parâmetros variados (por exemplo: espessura da laje, taxa de armadura e resistência do concreto), mais fundamentadas serão essas recomendações.

Além disso, em diversas obras envolvendo lajes-cogumelo protendidas, o uso do capitel ainda tem sido preferido em relação ao uso dos conectores tipo pino, baseado na falta de resultados experimentais, mesmo perdendo as vantagens da obtenção de uma laje lisa. Sendo assim, este trabalho visa contribuir efetivamente para um melhor conhecimento de uma tecnologia utilizada em vários países, inclusive no Brasil.

\subsection{OBJETIVOS}

Os objetivos deste trabalho são:

a) fornecer resultados experimentais por meio de um programa de ensaios de modelos de concreto armado e protendido com cordoalhas não aderentes, com e sem armadura de punção, para concretos com resistência da ordem de $50 \mathrm{MPa}$;

b) verificar e quantificar a eficiência da armadura de punção tipo pino, tanto para os modelos de concreto armado como para os de concreto protendido, esperando-se que o uso dessa armadura aumente a resistência da ligação, provoque uma superfície de ruína externa à região transversalmente armada e aumente a quantidade e a abertura das fissuras;

c) analisar o comportamento da ligação com três e duas linhas conectores, para avaliar a influência dessa diminuição na resistência à punção, e verificar se a introdução da armadura de punção diminui a contribuição do concreto, como preconizam algumas normas, embora essas em geral não recomendem o uso de menos de três linhas de conectores. 
d) comparar a resistência dos modelos de concreto armado com a dos de concreto protendido, enfocando a influência da protensão, tanto com relação à resistência, como com relação ao comportamento do modelo após a ruína da ligação;

e) verificar a precisão com que algumas normas e associações avaliam a força concentrada responsável pela ruína da ligação, entre as quais: a ASSOCIAÇÃO BRASILEIRA DE NORMAS TÉCNICAS (NBR 6118/1978, NBR 7197/1989, revisão da NB-1/2000), o AMERICAN CONCRETE INSTITUTE - ACI (ACI 318/95), o COMITE EURO-INTERNATIONAL DU BETON (CEB-FIP model code 1990/1991), a FEDERATION INTERNATIONALE DU BETON (ib/1999) e a FEDERATION INTERNATIONALE DE LA PRECONTRAINTE (FIP/1999).

Portanto, a meta a ser alcançada com este trabalho é o melhor conhecimento de uma tecnologia já aplicada no mundo, mas só recentemente introduzida no Brasil, contribuindo com o avanço e a difusão de um sistema estrutural com grande potencial de aplicação.

\subsection{PLANEJAMENTO}

Este trabalho está dividido em seis capítulos.

Capítulo 1 - Introdução: Apresentação do assunto, mostrando a importância da punção no projeto de lajes lisas (protendidas ou não), que por sua vez apresentam, em algumas condições, grandes vantagens técnicas e econômicas frente ao sistema convencional de lajes, vigas e pilares; apresentação da motivação, dos objetivos e do planejamento da tese. 
Capítulo 2 - Revisão bibliográfica: apresentação de um pequeno histórico envolvendo o estágio atual do conhecimento relativo a pesquisas sobre punção, no mundo e no Brasil. Apresentação de conceitos relativos à punção, protensão e modelos de cálculo usados para verificar uma ligação laje-pilar com relação à punção.

Capítulo 3 - Investigação experimental: justificativa do tipo de ensaio realizado, apresentação dos modelos e dos procedimentos usados na sua construção e nos ensaios. São ainda apresentadas as propriedades dos materiais e os equipamentos utilizados para a instrumentação.

Capítulo 4 - Instrumentação dos modelos e resultados obtidos: Apresentação de todas as informações obtidas nos ensaios realizados, tais como valores dos deslocamentos, das forças, das deformações, bem como uma descrição do comportamento dos modelos durante os ensaios.

Capítulo 5 - Análise dos resultados: faz-se uma análise dos resultados obtidos para cada um dos modelos, apresentam-se algumas análises específicas com relação à protensão aplicada ao modelo e, por fim, apresenta-se uma comparação entre os resultados obtidos e a previsão da carga de ruína dada por algumas normas e códigos. Esta análise visa a elaboração de conclusões referentes ao emprego de conectores tipo pino em lajes de concreto armado e protendido.

Capítulo 6 - Conclusões: apresentação das conclusões relativas aos objetivos do trabalho.

\section{Referências}

Em outro volume, são apresentados os anexos. 


\section{REVISÃO BIBLIOGRÁFICA}

Apresenta-se um pequeno histórico sobre o desenvolvimento das pesquisas relacionadas à punção, bem como alguns conceitos relacionados à protensão e à punção de lajes lisas.

\subsection{HISTÓRICO}

São abordadas as principais pesquisas internacionais e no Brasil, relacionadas ao fenômeno da punção.

\subsubsection{PESQUISAS INTERNACIONAIS}

O início dos estudos sobre a punção é atribuído a TALBOT ${ }^{1}$ apud TAKEYA (1981), tendo ele ensaiado 197 sapatas sem armadura de cisalhamento e observado a ruína por punção em vinte delas.

Outros ensaios foram feitos por GRAF $^{2}$ apud TAKEYA (1981) e novas observações foram feitas, comparando-se a resistência do concreto com a resistência à punção dos modelos.

1 TALBOT, A. N. (1913) Reinforced concrete wall footings and column footings. University of Illinois, Engineering Experiment Station. Bull. n.67, 114p. apud TAKEYA, T. (1981) Estudo experimental da ruína de ligações laje -pilar em bordas de lajes -cogumelo. São Carlos. Dissertação (mestrado), EESC-USP.

2 GRAF, O. (1933) Tests of reinforced concrete slabs under concentrated load applied near one support (Versuche über die wiederstandsfähigkeit von eisenbetonplatten unter konzentrierter last nahe einem auflager), Deutscher Ausschuss für Eisenbeton, Berlim, n.73, p.28 apud TAKEYA, T. (1981) Estudo experimental da ruína de ligações laje-pilar em bordas de lajescogumelo. São Carlos. Dissertação (mestrado), EESC-USP. 
RICHART (1948) observou acréscimos de resistência à punção em função do aumento da taxa de armadura, através do ensaio de sapatas.

A primeira tentativa de quantificar a influência da resistência à flexão na resistência à força cortante foi feita por HOGNESTAD (1953).

ELSTNER \& HOGNESTAD (1956) fizeram a primeira proposta para o cálculo da contribuição da armadura de punção na resistência da ligação.

SCORDELIS et al. (1959) ensaiaram lajes protendidas com cordoalhas não aderentes, visando a análise da distribuição das cordoalhas em diferentes faixas da laje.

MOE (1961) também foi um dos primeiros a analisar os casos assimétricos, caracterizados por pilares de borda, de canto e pilares internos com carregamentos assimétricos.

KINNUNEN; NYLANDER ${ }^{3}$, KINNUNEN $^{4}$ e NYLANDER ${ }^{5}$ apud TAKEYA (1981) realizaram ensaios de diversas lajes circulares com pilar central.

Com base nestes resultados, eles propuseram um modelo mecânico cujo cálculo considera a influência da flexão e da força cortante em conjunto. Neste modelo, que é a base do Regulamento Sueco com respeito à punção, a carga de ruína é determinada através do equilíbrio entre esforços internos e carregamentos externos.

YITZHAKI (1966) propôs uma nova formulação para o problema, baseado em ensaios de lajes circulares com e sem armadura de punção, que, por sua vez, eram constituídas essencialmente de barras dobradas.

3 KINNUNEN, S.; NYLANDER, H. (1960) Punching of concrete slabs without shear reinforcement. Estocolmo, Kungl. Tekniska Hoegskolans Handlingar, n.158 apud TAKEYA, T. (1981) Estudo experimental da ruína de ligações laje-pilar em bordas de lajes-cogumelo. São Carlos. Dissertação (mestrado), EESC-USP.

4 KINNUNEN,S. (1963) Punching of concrete slabs with two-way reinforcement. Estocolmo, Kungl. Tekniska Hoegskolans Handlingar, n.198 apud TAKEYA, T. (1981) Estudo experimental da ruína de ligações laje-pilar em bordas de lajes-cogumelo. São Carlos. Dissertação (mestrado), EESC-USP.

5 NYLANDER, H. (1964) Punching of concrete slabs. Paris, CEB Bulletin d'information, n.44, p.159-183 apud TAKEYA, T. (1981) Estudo experimental da ruína de ligações laje-pilar em bordas de lajes-cogumelo. São Carlos. Dissertação (mestrado), EESC-USP. 
Também em 1966, LANGENDONCK6 ${ }^{6}$ apud LIBÓRIO (1985) criticou a complexidade do método sueco (Kinnunen e Nylander) para o uso corrente dos engenheiros. Langendonck concluiu que o método de Moe, para lajes sem armadura de punção, apresentou resultados mais próximos das cargas de ruína observadas em ensaios do que os de outras teorias. Observou, no entanto, uma grande dispersão de resultados para ligações com armadura de punção.

Em 1968, CORLEY \& HAWKINS (1968) realizaram ensaios utilizando perfis metálicos ("shearheads") como armadura de punção para pilares internos.

PARK \& ISLAM (1976) analisaram a influência da armadura de punção em lajes assimetricamente carregadas.

LANGOHR et al. (1976) e SEIBLE et al. (1980) estudaram tipos especiais de armadura de punção, tais como segmentos de perfis metálicos tipo "I", conectores providos com chapas e com "cabeças" em forma de pregos e também telas soldadas.

Em SHEHATA (1982), são apresentados alguns ensaios de lajes pós-tensionadas com cordoalhas aderentes e não aderentes.

Em SHEHATA (1985), é apresentado um modelo racional para o cálculo da punção em pilares internos com carregamento simétrico e sem armadura de punção.

Em REGAN (1985), tem-se a menção da existência de três possibilidades de ruptura da ligação laje-pilar reforçada com armadura de punção: a primeira refere-se a uma superfície de ruptura junto à face do pilar, a segunda na região transversalmente armada, e a terceira além da região armada.

Em SHEHATA (1990), é apresentado um modelo simplificado composto de bielas comprimidas e tirantes radiais. PINTO (1993) menciona que este modelo é de fácil aplicação e em geral fornece bons resultados. Porém, para ensaios onde a resistência do concreto à compressão é elevada, o modelo superestimou os valores das cargas de ruína.

6 LANGENDONCK, T. (1966) Remarques sur le calcul des dalles au poinçonnement. CEB Bulletin d'information, n.57, p.141-144 apud LIBÓRIO, J. B. L. (1985) Estudo experimental da ruína de ligações laje-pilar em bordas com pilares de seção retangular. São Carlos. Dissertação (mestrado), EESC-USP 
ELGABRY \& GHALI (1990) apresentam detalhes sobre como projetar conectores tipo pino.

FOUTCH et. al. (1990) apresentam ensaios relativos a ligações de pilares de borda com lajes protendidas e sugerem algumas modificações nas recomendações dadas pelo ACI 318-83.

GOMES (1991) realizou diversos ensaios relativos ao uso de conectores em lajes de concreto armado, além de desenvolver um modelo mecânico.

MELO (1994) apresenta um estudo sobre a importância do uso de uma armadura, junto à armadura de flexão inferior na laje, de modo a evitar o colapso progressivo, caso ocorra a ruptura da ligação laje-pilar.

Em ELGABRY \& GHALI (1996a), são apresentados resultados experimentais sobre o uso de conectores tipo pino em ligações laje-pilar, submetidas a um momento fletor desbalanceado. Além disso, ELGABRY \& GHALI (1996b) apresentam algumas propostas sobre o assunto para a revisão do ACI.

Atualmente estão sendo pesquisados novos tipos de armadura para combater a punção, como por exemplo o uso de faixas metálicas, pesquisado por PILAKOUTAS \& LI (1997), o uso de concreto de alto desempenho (HALLGREN, 1996, e RAMDANE, 1996) e o uso de fibras na ligação laje-pilar (ALEXANDER \& SIMMONDS, 1992)

\subsubsection{PESQUISAS NO BRASIL}

No Brasil existem diversos pesquisadores que se dedicam ao estudo da punção.

\section{a) Pesquisas na Escola de Engenharia de São Carlos}

Em São Carlos, em 1972, o Prof. Dante Martinelli iniciou um amplo projeto de pesquisa sugerido pelo Prof. Telemaco van Langendonck, que visava o estudo experimental da resistência de ligações laje-pilar em cantos e em bordas de lajescogumelo. 
Sendo assim, vários ensaios foram realizados no Laboratório de Estruturas da Escola de Engenharia de São Carlos (LE-EESC), cujos resultados forneceram material para a sua tese de livre docência (MARTINELLI, 1974). É importante destacar a grande contribuição ao estudo da punção feita pelo Prof. Martinelli, tanto através de sua tese, como também através de sua orientação nas dissertações de mestrado dos engenheiros FIGUEIREDO FILHO (1981), TAKEYA (1981), LIBÓRIO (1985), GONÇALVES (1986) e MODOTTE (1986).

MELGES (1995) fez uma comparação entre resultados experimentais e os dados por normas, além de exemplificar diversas situações de cálculo para ligações da laje com pilares internos, de extremidade e de canto, com e sem armadura de punção, segundo as recomendações do EUROCODE N.2 (1990), do CEB/90 (1991), do ACI 318/89 e da revisão da NB-1 (1993).

ZAMBRANA VARGAS (1997) comparou o desempenho de ligações laje-pilar interno em função dos seguintes parâmetros: presença e ausência de fibras de aço incorporadas ao concreto; presença e ausência de armadura de cisalhamento e variação da resistência do concreto à compressão, usando, em parte dos modelos, concreto com resistência convencional e, em outra parte, concreto de alta resistência. Segundo ele, a combinação de uma determinada taxa de fibras, juntamente com o uso da armadura transversal tipo pino, pode elevar de modo significativo a resistência da ligação com relação à punção. Foi observado que, com a adição de fibras, aparentemente o modo de ruptura tornou-se mais dúctil, sendo esta ductilidade mais significativa para os concretos de resistência convencional.

AZEVEDO (1999), dando continuidade ao trabalho de ZAMBRANA VARGAS (1997), também realizou ensaios de ligações laje-pilar interno, com concreto de resistência convencional e de alta resistência, variando o volume de fibras de aço incorporadas ao concreto e analisando também a influência da presença da armadura de punção. A principal diferença entre os dois trabalhos é que AZEVEDO (1999) usou um sistema de ensaio dotado de atuador hidráulico servo-controlado, programado para ensaio com deformação controlada e aquisição contínua dos dados. 
Isto permitiu a avaliação do comportamento da ligação após o carregamento máximo aplicado ao modelo, bem como a realização de medições de resistência residual.

Percebeu-se que o emprego do concreto de alta resistência, juntamente com o uso de conectores tipo pino como armadura de punção, aumentou substancialmente a resistência da ligação e, quando combinado com fibras de aço, obteve-se um considerável aumento na ductilidade.

\section{b) Pesquisas em outras instituições}

FUSCO (1985), através de ensaios experimentais de lajes armadas com conectores tipo pino, verificou que a entrosagem dos agregados ao longo da superfície de ruptura e o efeito de pino da armadura de flexão são elementos essenciais na resistência das lajes ao cisalhamento. Ele menciona ainda que o esquema resistente tipo treliça existe somente na vizinhança da força concentrada.

GOMES (1994) ensaiou diversas lajes com furos na região próxima da ligação lajepilar interno, visando analisar a diminuição da resistência com relação à punção, em conseqüência da presença destes furos. Conforme o autor, os resultados apontaram para um significativo aumento da resistência da ligação, em função da presença dos conectores.

CORDOVIL (1995) realizou ensaios em modelos com e sem armadura de punção, constituída por pinos. A inovação deste trabalho consistiu em aplicar, ao modelo, um momento fletor atuando em uma das direções. Para a aplicação deste momento, foi usado um dispositivo de modo a quantificar a excentricidade efetiva do carregamento aplicado. A resistência do concreto usado nos modelos foi da ordem de $30 \mathrm{MPa}$.

OLIVEIRA (1998) realizou vários ensaios de punção em lajes de concreto armado de elevado desempenho (resistências variando entre $60 \mathrm{MPa}$ e $69 \mathrm{MPa}$ ), com o objetivo de comparar a eficácia de estribos retangulares convencionais com estribos inclinados, que podem ser posicionados após a colocação da armadura de flexão. Como principal conclusão, verificourse que os estribos inclinados tiveram um desempenho significativamente melhor do que os estribos convencionais. 
Em ANDRADE (1999), encontram-se os resultados de ensaios de diversas lajes, cujo objetivo foi o de se verificar a possibilidade dos conectores tipo pino não envolverem a armadura de flexão. Sendo assim, estes conectores estariam posicionados acima da malha inferior da laje e abaixo da malha superior. Este posicionamento apresenta a vantagem de permitir uma maior facilidade na colocação e na fixação da armadura de cisalhamento. No entanto, quando não há o envolvimento da armadura de flexão pela de cisalhamento, ocorre uma diminuição da resistência da ligação e uma modificação no seu modo de ruptura. Segundo o autor, a grande facilidade da colocação desta armadura torna viável seu uso, desde que se conheça esta limitação.

\subsection{PROTENSÃO}

$\mathrm{O}$ concreto apresenta boa resistência à compressão, mas uma baixa resistência à tração, sendo esta da ordem de $8 \%$ a $14 \%$ daquela. Como conseqüência, tem-se que, mesmo para estágios iniciais do carregamento, ocorre um processo de fissuração do concreto, oriundo dos esforços de flexão.

Visando a redução ou mesmo a eliminação dessas fissuras, uma força de compressão axial ou excêntrica é imposta na direção longitudinal do elemento estrutural.

Esta força, geralmente obtida através de uma armadura de alta resistência prétracionada, resolve o problema da fissuração através da eliminação ou da redução das tensões de tração nas seções críticas, relativas ao meio do vão e ao apoio, no estado em serviço.

Sem fissuras, as seções possuem uma maior resistência com relação à flexão, à torção e ao cisalhamento, comportando-se elasticamente, no estado em serviço.

Segundo o ACI, concreto protendido é um concreto no qual são introduzidas tensões internas, de uma determinada magnitude e distribuição, de modo a equilibrar, em um determinado grau, as tensões provenientes dos carregamentos externos. 
Já a NBR 7197 menciona que "uma peça de concreto protendido é aquela que é submetida a um sistema de forças especialmente e permanentemente aplicadas, chamadas de forças de protensão e tais que, em condições de utilização, quando agirem simultaneamente com as demais ações, impeçam ou limitem a fissuração do concreto". Esta norma só considera o caso em que as forças de protensão são produzidas por armaduras.

LIN (1966) desenvolveu o conceito de que, para traçados parabólicos ou poligonais de cabos, a protensão provoca um carregamento que equilibra a ação externa aplicada (método do "load balancing").

Como a protensão é um sistema auto-equilibrado, observa-se que, embora a tendência dos cabos em se retificar produza uma força vertical linearmente distribuída ao longo do vão, ela também produz uma força concentrada na região dos apoios.

Esta força possui uma componente horizontal, que provoca uma compressão na direção do eixo do elemento estrutural, e uma componente vertical, que equilibra a força linearmente distribuída. Para a análise do efeito da protensão em uma estrutura com cabos parabólicos ou poligonais, LIN (1966) sugere que a cordoalha de protensão seja substituída pelas forças que ela provoca na estrutura (método do "load balancing", figura 2.1).

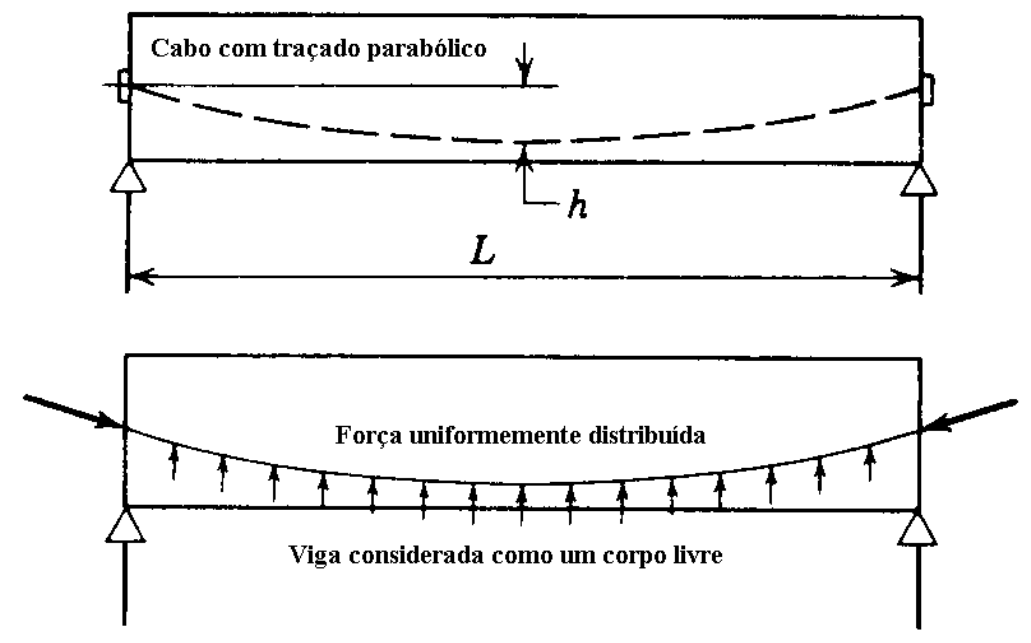

Figura 2.1 - Substituição do cabo por uma força concentrada e outra uniformemente distribuída (LIN, 1966) 
Deste modo, o efeito da protensão pode, então, ser considerado como um meio de equilibrar parte das ações de gravidade. Sendo assim, estruturas submetidas a flexão, tais como lajes e vigas, não estariam mais submetidas a tensões oriundas da flexão, para uma determinada condição de carregamento, mas sim submetidas a uma determinada tensão de compressão. Esta consideração permite a transformação de um elemento fletido em um elemento comprimido, e, assim, simplifica-se o projeto e a análise da estrutura. Conforme já mencionado, para que esta análise possa ser feita, é necessário que se tome o concreto com sendo um corpo-livre e se substituam os cabos por forças agindo no concreto.

Como exemplo, tem-se, na figura 2.1, uma disposição parabólica do cabo de protensão, provocando uma força de compressão aproximadamente paralela ao eixo do elemento e uma força uniformemente distribuída para cima, cujo valor é dado pela expressão:

$$
\begin{aligned}
& \mathrm{f}=\frac{8 \cdot \mathrm{P}_{\mathrm{e}} \cdot \mathrm{h}}{\mathrm{L}^{2}} ; \quad \text { onde: } \\
& \mathrm{f}=\quad \text { força linearmente distribuída devida à protensão; } \\
& \mathrm{h}=\quad \text { "altura" da parábola; } \\
& \mathrm{P}_{\mathrm{e}}=\text { força de protensão na cordoalha; } \\
& \mathrm{L}=\text { vão. }
\end{aligned}
$$

LIN (1966) conclui que o uso de traçados curvos para os cabos, além de fornecer um acréscimo de resistência ao cisalhamento, em função da componente vertical da força de protensão, também proporciona uma pré-compressão no concreto, que aumenta o atrito entre as superfícies separadas pela fissuração inclinada, e consequientemente aumenta a transmissão de esforços através do engrenamento dos agregados, reduzindo o valor da tensão de tração diagonal (figura 2.2). 


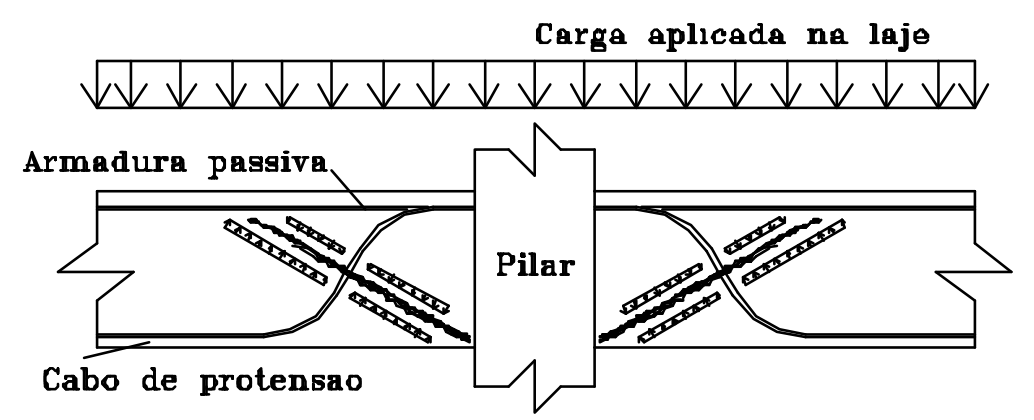

Figura 2.2 - Efeito da protensão com relação à resistência da ligação: compressão entre as superfícies separadas pela fissura e componente vertical da força de protensão na região da ligação laje-pilar

Nas lajes, devido à incerteza da real inclinação dos cabos na seção onde o cisalhamento deve ser analisado, algumas normas consideram conveniente desprezar a componente vertical da força de protensão.

Segundo NILSON (1987), existem valores mínimos e máximos da tensão de compressão aplicada ao concreto, visando, respectivamente, minimizar a abertura de fissuras, produzindo uma superfície impermeável, e evitar o perigo de encurtamentos elásticos, retração e fluência excessiva nas lajes.

Segundo MONTANARI (1988), é necessário calcular as perdas por atrito, perdas por deformação lenta e retração do concreto e por fluência do aço. Além disso, antes do lançamento do concreto, é preciso ter em mente o seu encurtamento elástico.

A perda de protensão por atrito é calculada de forma direta. Já as perdas por deformação lenta e retração são inicialmente estimadas e, após a determinação das tensões, são confirmadas ou corrigidas.

\subsubsection{LAJES PROTENDIDAS}

As lajes-cogumelo e as lajes lisas protendidas surgiram por volta da década de 50 e até hoje são largamente usadas em edifícios nos Estados Unidos. Na figura 2.3 tem-se o esquema de uma laje protendida. 


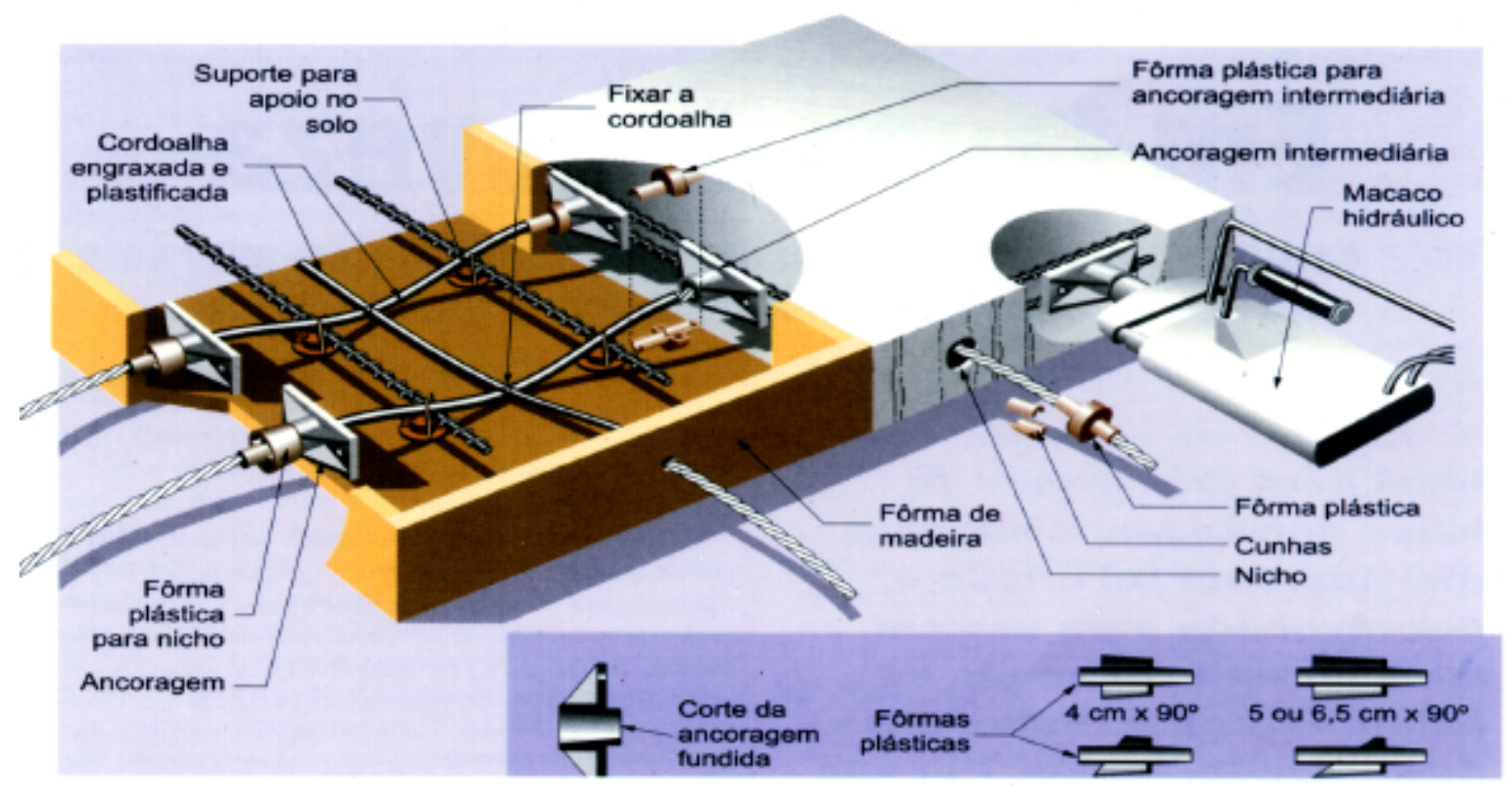

Figura 2.3 - Esquema de uma laje protendida (CAUDURO, 1997)

Segundo SOUZA \& CUNHA (1994), os cabos protendidos numa laje-cogumelo possuem o traçado indicado na figura 2.4. Conforme já foi visto, a protensão dos cabos tende a retificá-los, criando um carregamento dirigido para o centro de curvatura desses cabos (de baixo para cima nos vãos das lajes). Deste modo, a protensão gera um précarregamento transversal, de sentido oposto ao do carregamento externo. Se, em cada vão, houver uma distribuição uniforme de força ascendente igual, em valor absoluto, à carga a ser equilibrada, então a laje não será solicitada à flexão e, conseqüientemente, não apresentará deslocamentos e nem fissuração, estando submetida a uma ação de uma compressão uniforme. Esta situação é bastante favorável, uma vez que o concreto apresenta uma boa resistência à compressão.

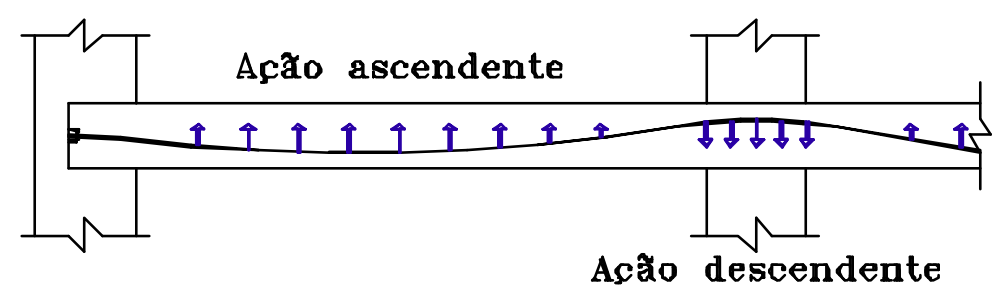

Figura 2.4 - Efeito da protensão nas lajes (SOUZA \& CUNHA, 1994) 
Deste modo, o uso da protensão é extremamente vantajoso, possibilitando vencer vãos maiores e reduzir a espessura e os deslocamentos transversais da laje, além de permitir um melhor controle da fissuração.

No entanto, a punção nas lajes lisas protendidas também pode ser um problema, em virtude da maior esbeltez dessas lajes.

\subsubsection{TIPOS DE PROTENSÃO}

A protensão pode ser feita através de cordoalhas aderentes ou não aderentes.

Nas cordoalhas aderentes, segundo CAUDURO (1996), após a protensão é feita uma injeção de pasta de cimento e água dentro das bainhas, através de uma bomba especial.

As cordoalhas ficam então aderidas à pasta de injeção que, através das bainhas corrugadas, aderem ao concreto da peça estrutural, impedindo o movimento relativo entre as cordoalhas e o concreto (figura 2.5).

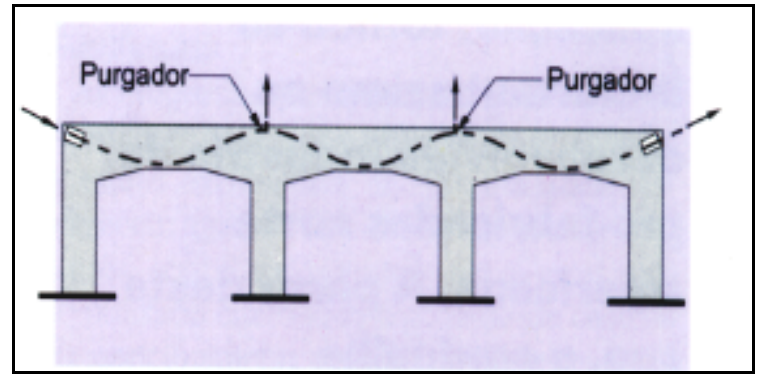

a) Injeção de pasta de cimento

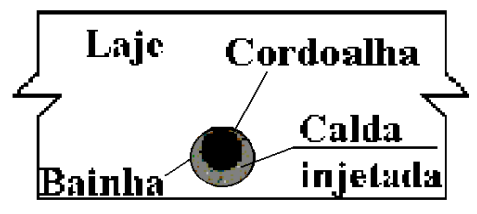

b) Aderência entre a laje e a cordoalha

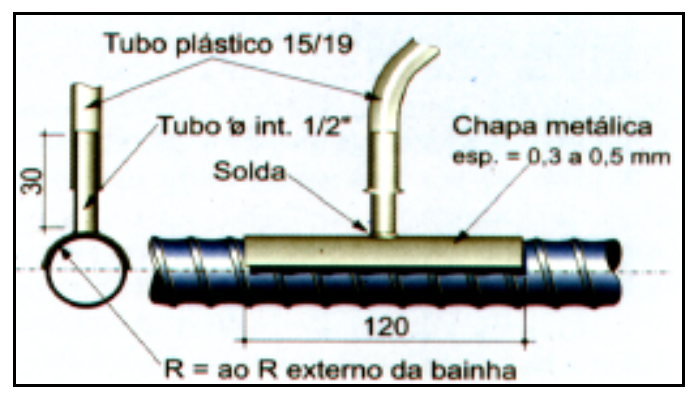

c) Detalhe do purgador

Figura 2.5 - Pós-tensão com cabos aderentes (CAUDURO, 1997) 
Já os cabos não aderentes são vendidos em bainhas plásticas, sendo envolvidos por uma graxa especial que, além de protegê-los contra a corrosão, proporciona excelente lubrificação entre a cordoalha e a capa (figura 2.6).

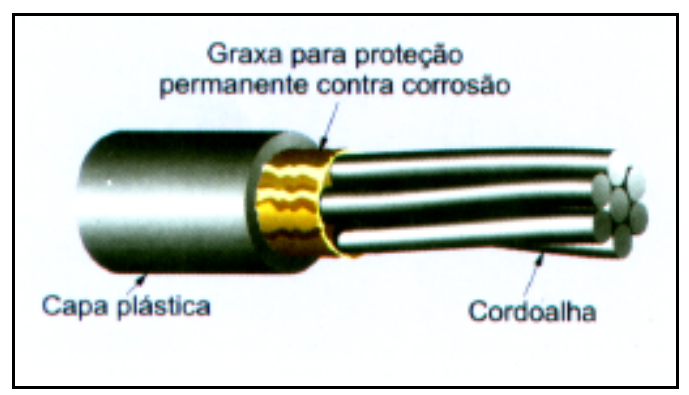

Figura 2.6 - Cordoalha engraxada (CAUDURO, 1997)

Segundo CAUDURO (1996), a protensão com aderência apresenta as seguintes vantagens: melhor distribuição das fissuras, maior segurança com relação ao estado limite último e diante de situações extremas e raras como incêndios, explosões e cismos. Entretanto, embora o uso de cabos aderentes seja mais vantajoso do ponto de vista estrutural, ele apresenta algumas desvantagens do ponto de vista econômico e construtivo. Algumas delas são: necessidade de uma maior fricção durante a protensão dos cabos destinados a um posterior "grouteamento"; necessidade de proteção dos cabos com relação à corrosão durante o período de construção e, por fim, problemas associados ao "grouteamento" de um grande número de cabos posicionados em ductos de pequeno diâmetro (NILSON, 1987).

Já a protensão sem aderência, conforme CAUDURO (1996), apresenta maior facilidade e rapidez na colocação das cordoalhas nas fôrmas, maior excentricidade possível, menor perda por atrito, ausência de operações referentes à injeção de pasta de cimento e maior economia.

Segundo NASSER (1969), o uso de uma certa quantidade de armadura passiva pode superar as desvantagens, do ponto de vista estrutural, da não aderência dos cabos. Além disto, o aço de protensão já chega ao canteiro protegido pela graxa e pela capa plástica. 
No entanto, em LAJE concentrada (1993), Stucchi recomenda programas de manutenção mais rigorosos para estas estruturas, advertindo sobre o risco de ocorrer o fenômeno de "corrosão sob tensão", que pode levar ao colapso inesperado da estrutura.

Segundo o prof. T. Y. Lin (NOTABLE structures ..., 1976), já em 1976, a utilização de cabos não aderentes era preponderante com relação aos cabos aderentes em estruturas pós-tencionadas.

DUARTE (1994) também menciona que as aplicações em vários países, como Austrália, Japão e Estados Unidos, são feitas, de modo preponderante, através de cabos não aderentes.

No Brasil têm sido executadas mais lajes com aderência posterior. No entanto, esta situação pode ser modificada, uma vez que a Companhia Siderúrgica Belgo-Mineira introduziu no mercado brasileiro, em julho de 1996, as cordoalhas plastificadas e engraxadas.

Essas cordoalhas proporcionam grandes vantagens econômicas, quando comparadas com o uso de cabos aderentes.

\subsubsection{TRAÇADO DOS CABOS}

A disposição dos cabos (ou cordoalhas) de protensão pode ser feita através de dois modos distintos, detalhados a seguir.

\section{a) Primeiro tipo de disposição}

Neste caso, a ação uniformemente distribuída deve ser equilibrada através da disposição de uma malha de cabos protendidos, com traçado parabólico, uniformemente espaçados segundo as duas direções e com concavidade voltada para cima (figura 2.7).

A proporção do carregamento a ser equilibrado em cada uma das direções é mais ou menos arbitrário. 
O painel é então considerado como estando apoiado ao longo de uma estreita faixa, definida a partir da linha que une os centros de gravidade dos pilares. Nesta região, a concavidade do traçado dos cabos se modifica, estando voltada para baixo e, desta forma, criando reações neste sentido.

Estas reações devem então ser equilibradas por uma segunda malha de cabos, agrupados ao longo desta faixa (figura 2.8).

O arranjo final é obtido através da superposição dos dois arranjos de cabos.

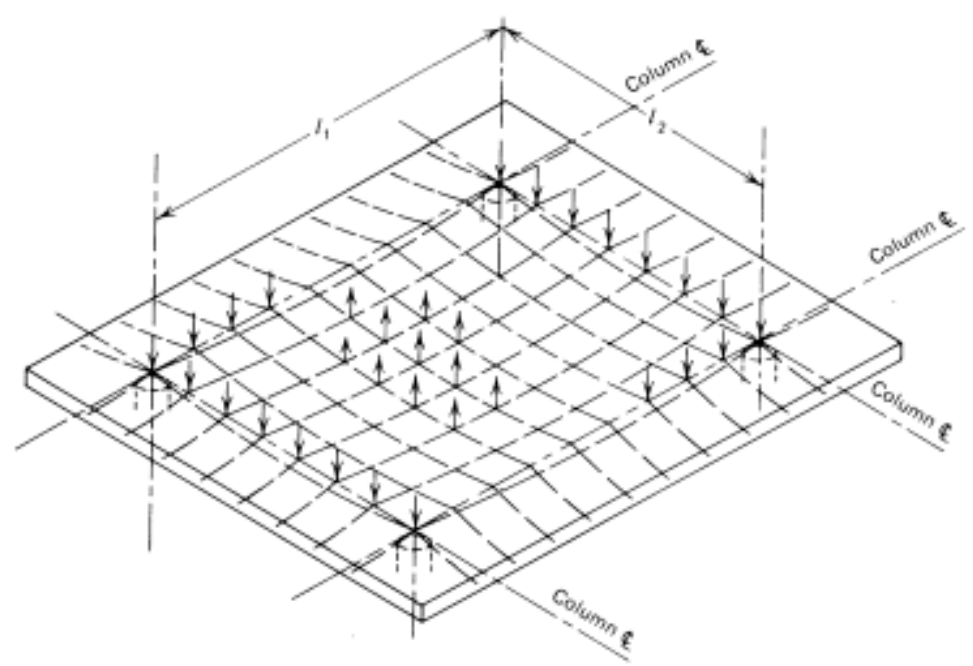

Figura 2.7 - Cabos distribuídos na porção central da laje (NILSON, 1987)

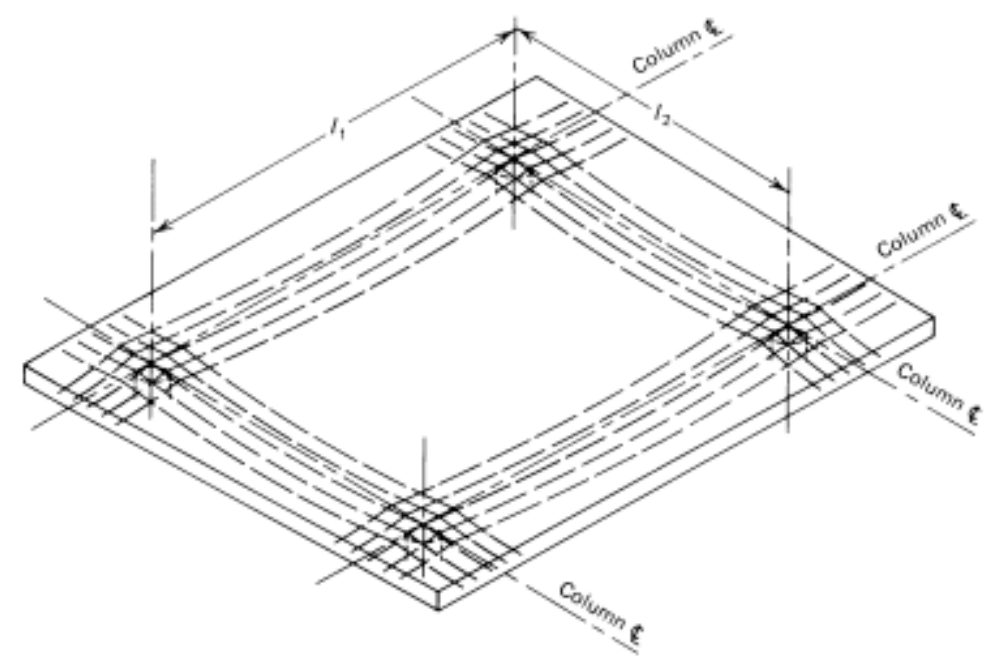

Figura 2.8 - Cabos concentrados próximos à linha que une os centros de gravidade dos pilares (NILSON, 1987) 


\section{b) Segundo tipo de disposição}

Neste caso, adota-se o método do "load balancing" e considera-se a laje como sendo um sistema ortogonal de vigas de pequena altura, e cada sistema resistindo a $100 \%$ do carregamento, com a largura total do painel. Como exemplo, tem-se, na figura 2.9, que na direção do vão $\ell_{1}$, a laje é considerada como estando apoiada ao longo das linhas ab e $\underline{\mathrm{cd}}$, transversais à direção do vão $\ell_{1}$. Sabe-se, no entanto, que a distribuição transversal dos momentos fletores não é uniforme, mas tendendo a se concentrar próximo às linhas que unem os centros de gravidade dos pilares. Desde modo o projetista tende a posicionar um maior número de cabos nesta faixa. Na figura 2.10 tem-se o mesmo número de cabos que na figura 2.9, sendo que a diferença está na porcentagem de cabos posicionados na faixa dos pilares, maior na figura 2.10. Na figura 2.11, tem-se a superposição dos traçados ilustrados nas figuras 2.9 e 2.10 .

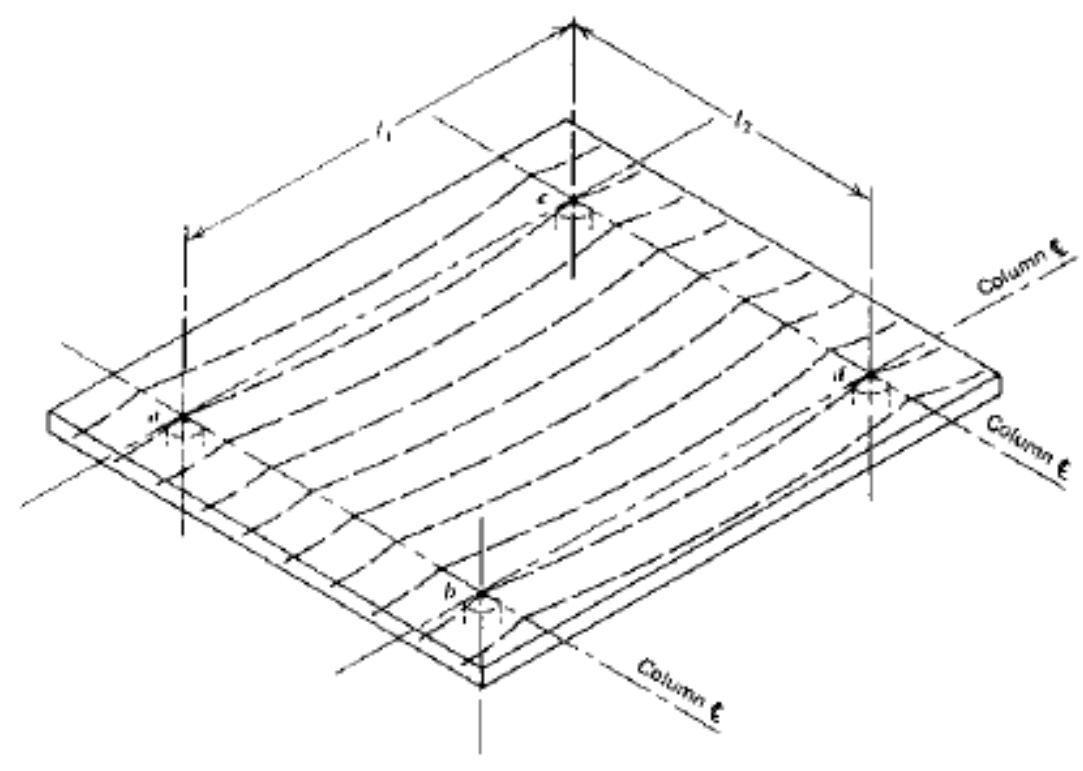

Figura 2.9 - Cabos uniformemente distribuídos 


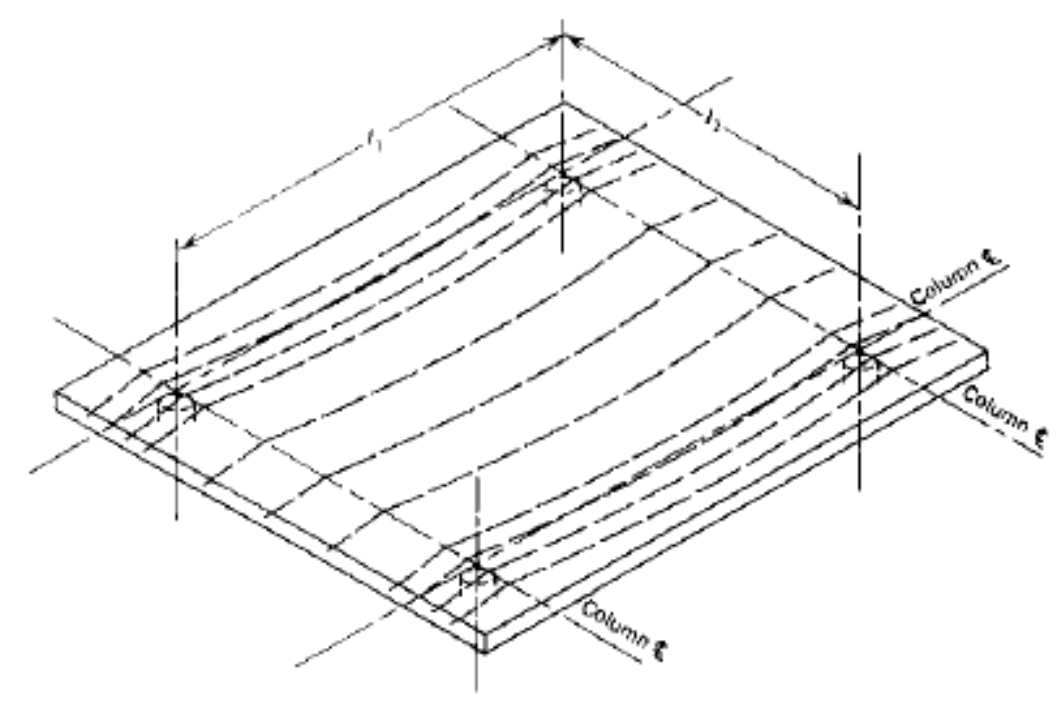

Figura 2.10 - Cabos mais concentrados na faixa dos pilares

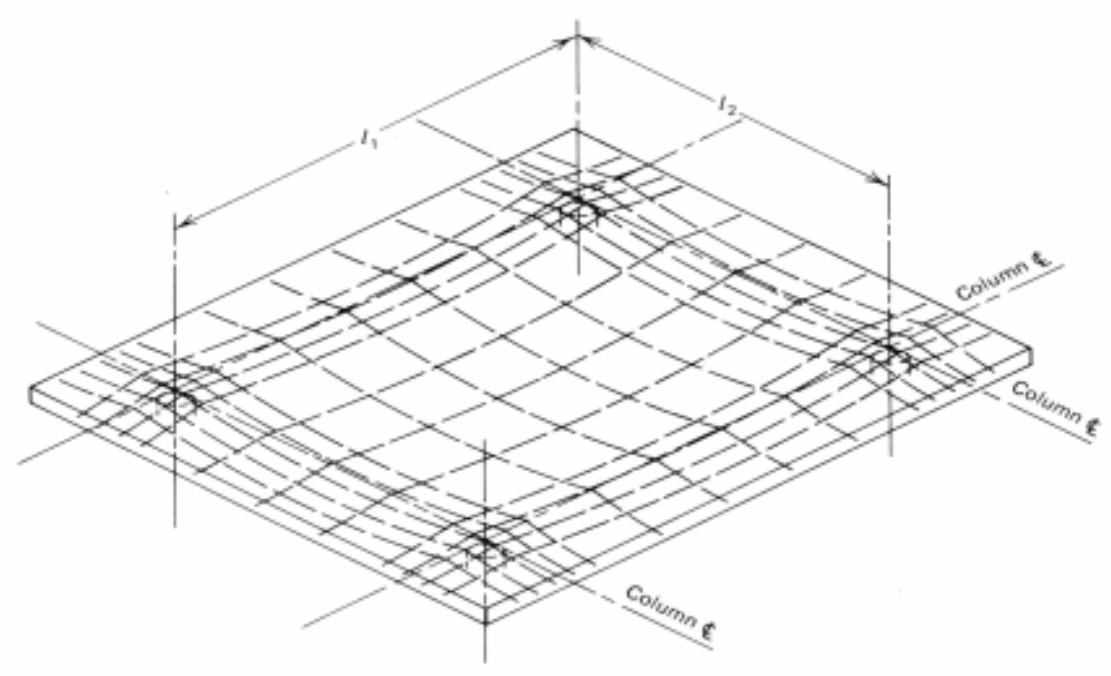

Figura 2.11 - Padrão de distribuição dos cabos nas duas direções

Na prática a análise feita através do item b) é mais simples de ser realizada.

Ainda segundo NILSON (1987), pesquisas com cabos não aderentes indicam que não é necessário concentrar os cabos na faixa dos pilares nas duas direções, conforme sugere a figura 2.11 . 
A resistência à flexão de lajes armadas em duas direções parece estar mais relacionada com a resistência total dos cabos e a quantidade e localização de armadura passiva aderente, do que com relação à distribuição dos cabos.

Ressalta-se, no entanto, a importância de que alguns cabos passem sobre os pilares, dentro do perímetro crítico relativo ao cisalhamento.

Sendo assim, muitos edifícios estão sendo construídos com a distribuição dos cabos ilustrada na figura 2.12. Esta distribuição consiste em se concentrar os cabos na faixa dos pilares em uma direção e distribuí-los uniformemente na outra, simplificando o posicionamento dos cabos na obra, com conseqüente redução de custos. Deste modo, a laje se comporta como estando simplesmente apoiada na direção onde os cabos estão uniformemente distribuídos.

Segundo NILSON (1987), o ACI permite o uso de cabos concentrados tanto em duas direções como em uma, desde que se obedeçam algumas prescrições com relação ao espaçamento dos cabos, a valores máximo e mínimo da tensão média de compressão no concreto e ao uso de taxas de armadura mínima aderente.

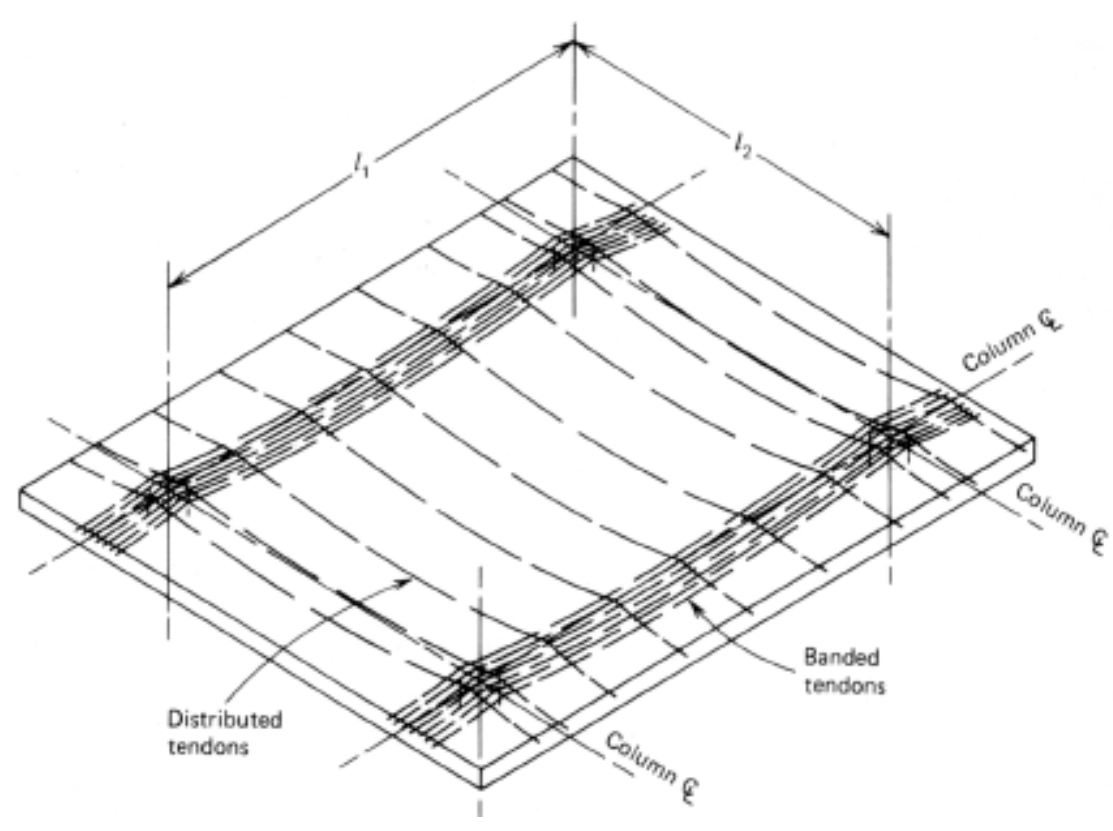

Figura 2.12 - Cabos concentrados nas faixas dos pilares em uma direção e uniformemente distribuídos na outra (NILSON, 1987) 


\subsection{RESISTENNCIA DO CONCRETO AO CISALHAMENTO}

Segundo FUSCO (1995), do ponto de vista macroscópico, a ruptura dos materiais sob a ação de estados múltiplos de tensão pode ser classificada em dois tipos: ruptura por separação e ruptura por deslizamento. A ruptura por separação é uma "ruptura por tração", isto é, ela apresenta uma superfície de fratura bastante nítida, tangente em cada ponto ao plano onde age a tensão principal de tração. Já na ruptura por deslizamento, não existe uma superfície nítida de fratura. Neste caso, o material sofre desagregação ao longo de uma faixa que acompanha a superfície média de deslizamento. No concreto, as rupturas por deslizamento são apenas aparentes. Analisando detidamente esse tipo de ruptura, observa-se que ela somente ocorre depois de uma intensa desagregação do concreto, por efeito de rupturas diagonais de separação na microestrutura do material. Desde os primórdios do concreto armado, foram realizados ensaios do tipo mostrado na figura 2.13, buscando-se definir o que seria a resistência do concreto ao cisalhamento, sob a ação de tensões de corte $\tau_{\mathrm{v}}$.
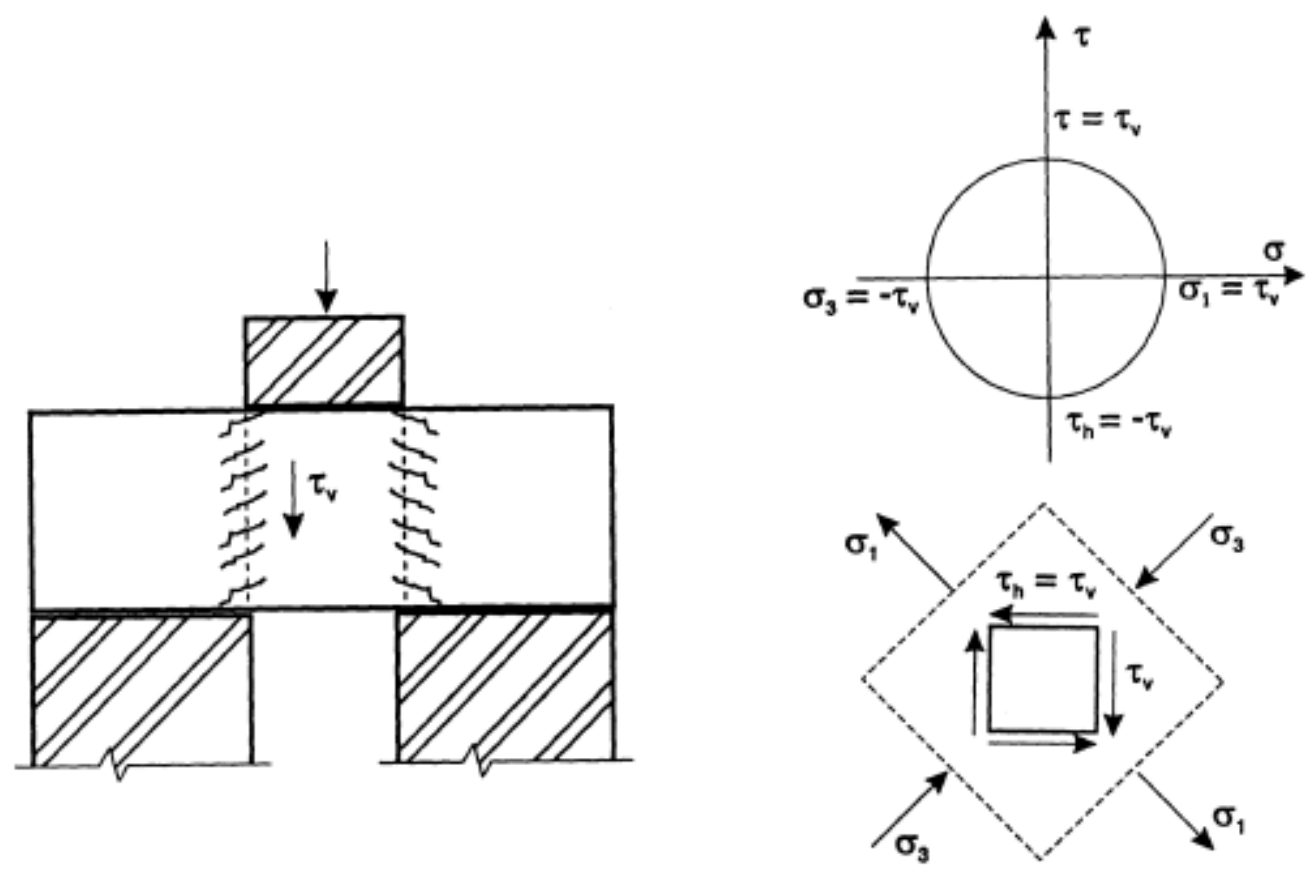

Figura 2.13 - Ensaio de cisalhamento direto 
No entanto, a ruptura que ocorre com tal tipo de ensaio não é uma ruptura de deslizamento, como acontece com os metais. No concreto, em virtude de sua baixa resistência à tração, dá-se a fissuração diagonal, nos planos onde atuam as tensões principais de tração $\sigma_{1}=\tau_{\mathrm{v}}$. A ruptura macroscópica por deslizamento somente poderia ocorrer se fossem pulverizadas as faixas de concreto ao longo dos planos de deslizamento macroscópicos (figura 2.14a). O que acontece, na realidade, é uma ruptura por compressão diagonal (figura 2.14b). A fissuração provocada pelas tensões diagonais de tração apenas diminuem a resistência à compressão diagonal do concreto fissurado.

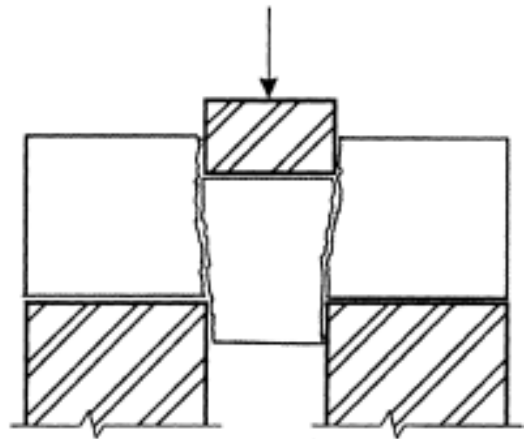

a) Ruptura ideal por cisalhamento

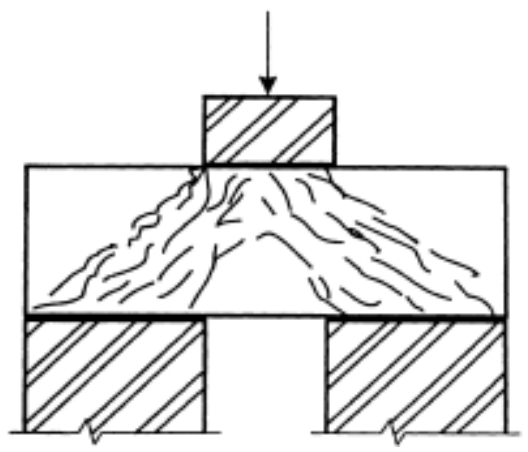

b) Ruptura real por compressão diagonal macroscópico

Figura 2.14 - Ruptura teórica por corte (FUSCO, 1995)

\subsection{RESISTÊNCIA DAS LAJES À PUNÇÃO}

Conforme FUSCO (1995), de modo geral, o cisalhamento nas lajes de concreto devido a cargas distribuídas não é problema que cause muita preocupação, o que nem sempre acontece na presença de cargas concentradas. 
Durante muito tempo, o dimensionamento das lajes sob a ação de cargas praticamente concentradas foi considerado como se fosse um problema distinto do fenômeno de cisalhamento. Admitia-se que a ruptura se desse na forma indicada na figura 2.15 e que as eventuais armaduras de cisalhamento tivessem pouca eficiência nos correspondentes mecanismos resistentes.

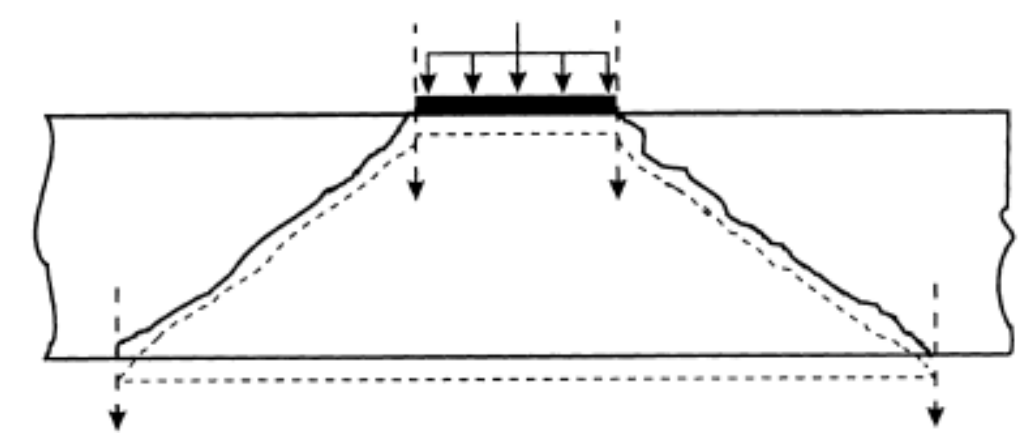

Figura 2.15 - Deslocamento paralelo teórico (FUSCO, 1995)

Segundo FUSCO (1995), para que isso fosse possível, seria necessário que houvesse a perda do engrenamento dos agregados e que a armadura de tração sofresse ruptura.

Nos ensaios realizados por FUSCO (1985), esse modo de ruptura apenas se iniciou quando as deformações na armadura de tração já eram muito grandes, com fissuras de flexão com aberturas da ordem de uma dezena de milímetros.

Já com relação ao funcionamento das armaduras de cisalhamento, FUSCO (1995) menciona que as barras dobradas e os estribos comuns são pouco eficientes nessa situação.

Os estribos comuns em peças de pequena altura dificilmente têm seus ramos resistentes perfeitamente retilíneos, e tanto eles quanto as barras dobradas sofrem pequenos deslocamentos ao se ancorarem no concreto.

Desse modo, antes que os estribos comuns e as barras dobradas sejam efetivamente solicitados, pode ocorrer a ruptura do concreto. 
Para contornar essa dificuldade, o autor sugere o emprego de estribos perfeitamente retilíneos, com ancoragens mecânicas nas extremidades, conforme a figura 2.16.

Ainda segundo o autor, é importante observar o detalhe de solda mostrado nessa figura, o qual garante a perfeita ligação da barra de aço às chapas de extremidade.

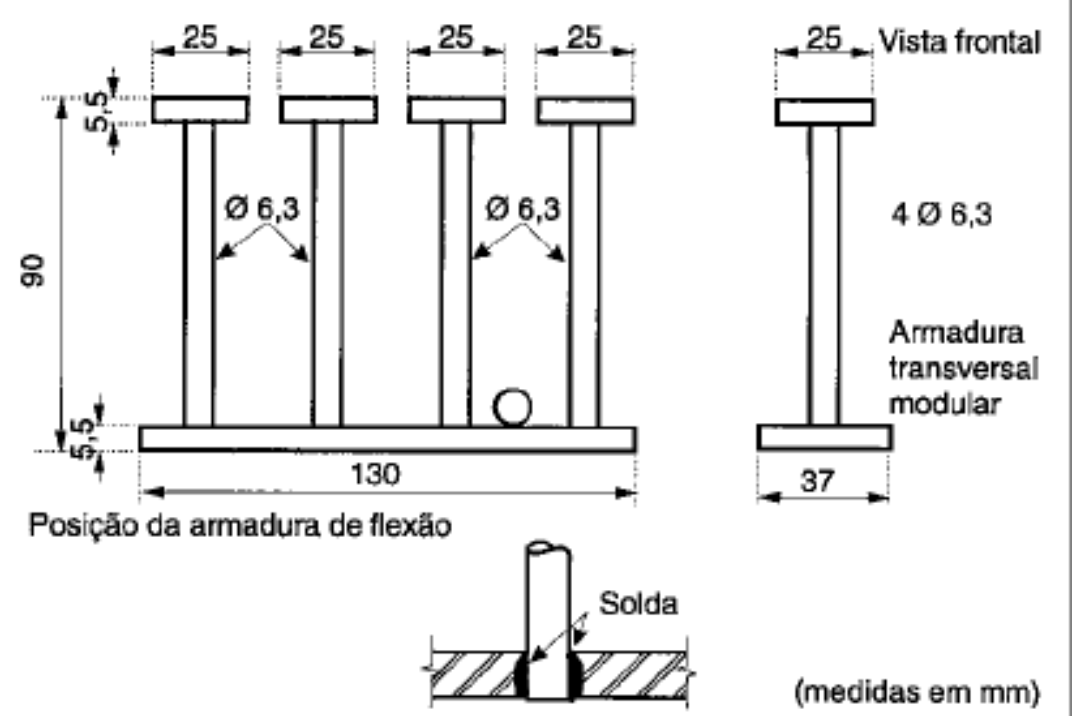

Figura 2.16 - Armadura recomendada de punção (FUSCO, 1995)

Este tipo de estribo será visto em detalhes, a seguir, e será definido como conectores tipo pino.

Resultados mostrados em FUSCO (1985) mostram que, com o emprego dos conectores tipo pino, as tensões na armadura de cisalhamento seguem um andamento análogo ao que ocorre nas vigas sob ação de cargas concentradas.

À medida que se consideram perímetros cada vez mais afastados da carga concentrada, as tensões de cisalhamento vão diminuindo.

Em um dos ensaios experimentais, já a partir de perímetros afastados de duas vezes a espessura da laje, o concreto resiste ao cisalhamento e os estribos estão comprimidos, em vez de tracionados. 
Tendo-se em vista o princípio de que a segurança em relação aos estados limites últimos não deve depender da resistência do concreto à tração, sempre que houver um apoio direto das lajes sobre os pilares, deverá ser empregada uma armadura de cisalhamento do tipo mencionado, calculada pelos mesmos raciocínios que levam à determinação das armaduras transversais das vigas junto a cargas concentradas, distribuídas de acordo com os critérios apresentados pelo CEB/90.

\subsection{ANÁLISE DOS ESFORÇOS}

Segundo LEONHARDT \& MÖNNIG (1978), pode-se observar que a força cortante aumenta hiperbolicamente em direção ao pilar, com relação à linha de eixo dos pilares (figura 2.17). Sendo assim, o valor máximo da força cortante vai ocorrer na região onde os momentos fletores negativos também são máximos. A situação fica mais desfavorável quando esses momentos fletores não estão auto-equilibrados.

\section{$\llbracket \downarrow \downarrow \downarrow \downarrow \downarrow \downarrow \downarrow \downarrow \downarrow \downarrow \downarrow \downarrow \downarrow \downarrow \downarrow \downarrow \downarrow \downarrow \downarrow \downarrow \downarrow \downarrow$}
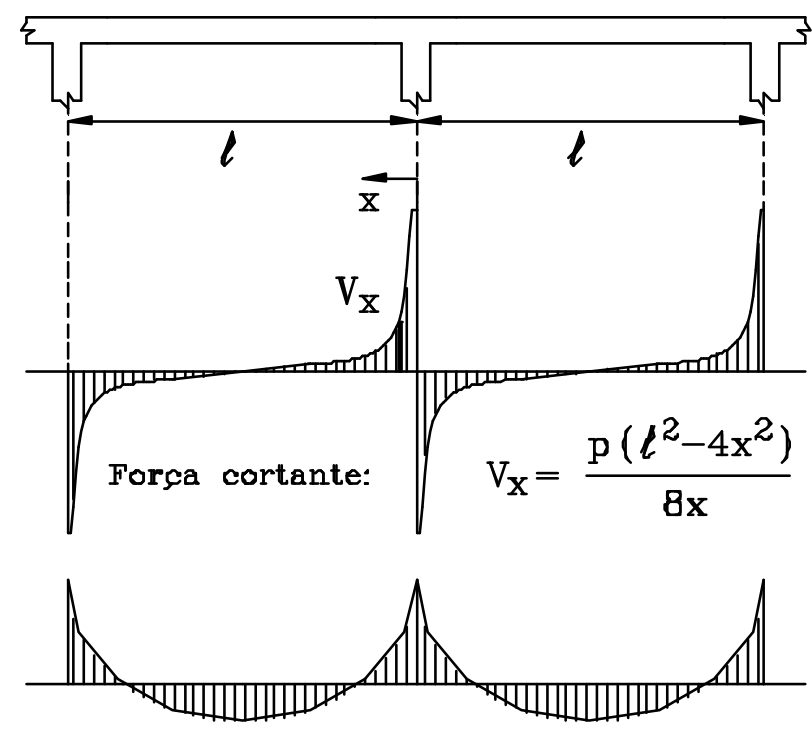

Momento fletor

Figura 2.17 - Diagramas de força cortante e de momento fletor 
Para pilares de borda e de canto, o problema é mais crítico, uma vez que essas ligações apresentam maiores momentos fletores desbalanceados, menor área de contato da laje com o pilar e torção nas bordas da laje junto da ligação com os pilares.

Ainda segundo LEONHARDT \& MÖNNIG (1978), existem vários trabalhos referentes a ligações de pilares circulares internos com uma laje de piso submetida a um carregamento uniformemente distribuído. Nesses casos, as trajetórias dos diagramas dos momentos principais, que se desenvolvem radial e tangencialmente $\left(\mathrm{m}_{\mathrm{r}}\right.$ e $\left.\mathrm{m}_{\mathrm{t}}\right)$, mostram que ambos são negativos na região da ligação (figura 2.18).

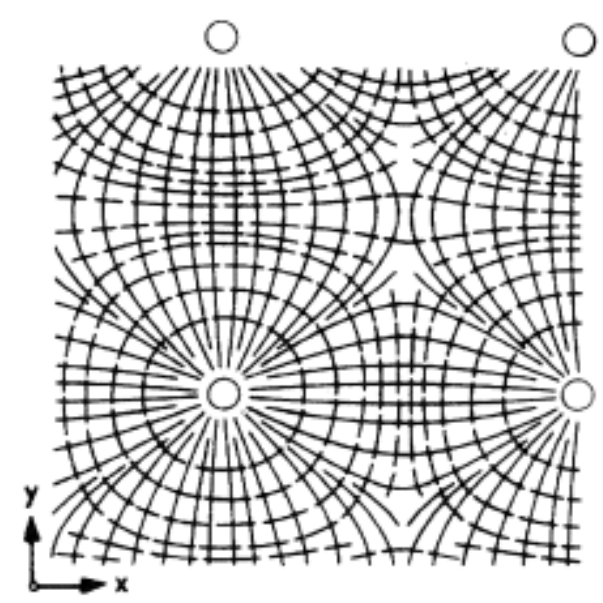

Figura 2.18 - Momentos principais radiais e tangenciais

O ponto de momento nulo dos momentos radiais situa-se sobre uma circunferência em torno do centro do pilar, com um raio $\mathrm{r} \cong 0,22 \ell$, onde $\ell$ é o vão dos painéis quadrados adjacentes ao pilar (figura 2.19).

Pode-se então considerar que, na seção da laje ao longo desta circunferência, têmse apenas momentos tangenciais pequenos e uma força cortante linearmente distribuída $v_{r}$, definida pela expressão:

$$
\mathrm{v}_{\mathrm{r}}=\frac{\mathrm{P}_{\mathrm{r}}}{2 \pi \mathrm{r}_{\mathrm{r}}}
$$

onde, de uma maneira simplificada, considera-se o valor de $\operatorname{Pr}$ como sendo a reação do pilar (figura 2.20). 
Sendo assim, a maioria dos ensaios sobre punção procura representar apenas essa região, através dos "elementos-de-laje", cujas bordas procuram representar essas linhas de inflexão de momentos fletores em lajes contínuas (figura 2.21).

As grandes vantagens destes modelos são a simplicidade, a facilidade para o ensaio e a economia, quando comparados com ensaios de painéis completos.

Uma outra vantagem é que, testando-se o elemento isolado, tem-se o sistema estaticamente determinado, podendo-se medir diretamente os momentos fletores e forças cortantes (FOUTCH et al., 1990).

Como desvantagens FOUTCH et al. (1990) mencionam que as condições de contorno do "elemento-de-laje" não representam uma estrutura real, uma vez que este modelo não permite uma completa redistribuição de momentos e não leva em conta a restrição lateral oferecida pelas regiões da estrutura adjacentes ao pilar.

Além disso, a posição da linha que passa pelos pontos de inflexão dos momentos fletores não é constante em um sistema de concreto protendido.

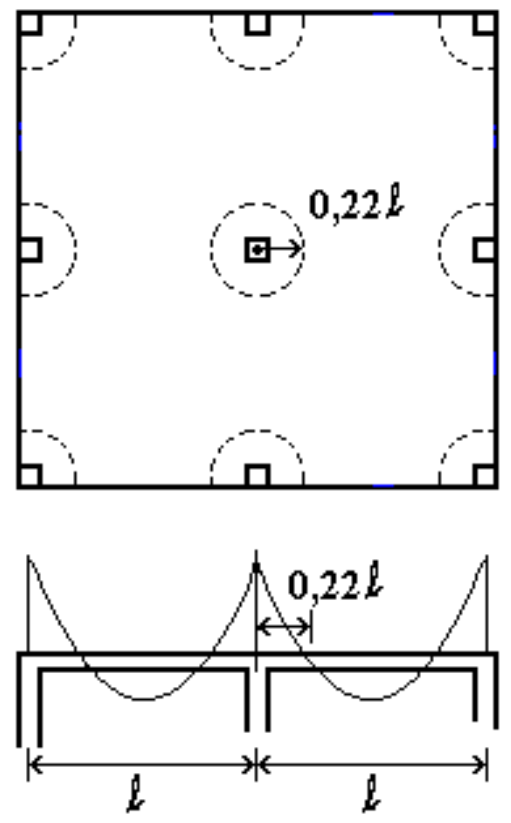

Figura 2.19 - Pontos de momento nulo

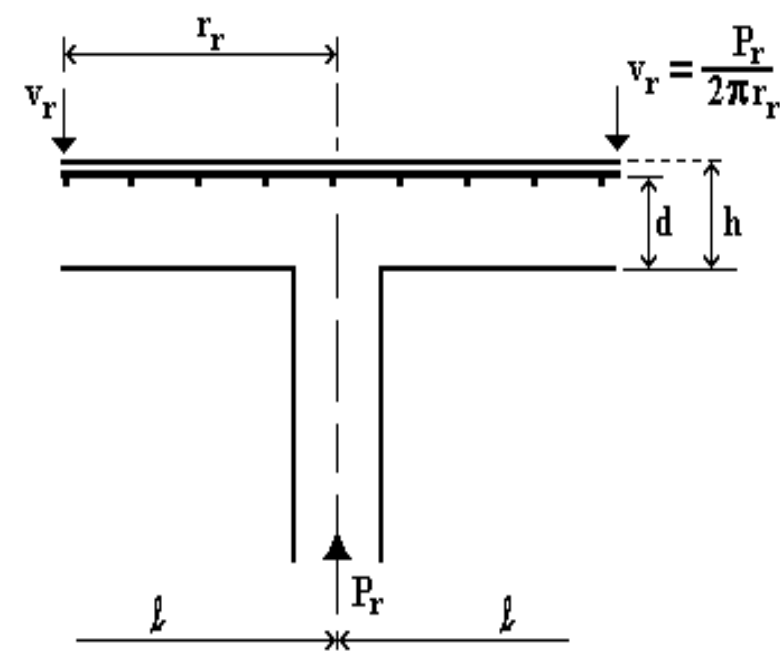

Figura 2.20 - Representação dos esforços atuantes na região de momentos nulos 

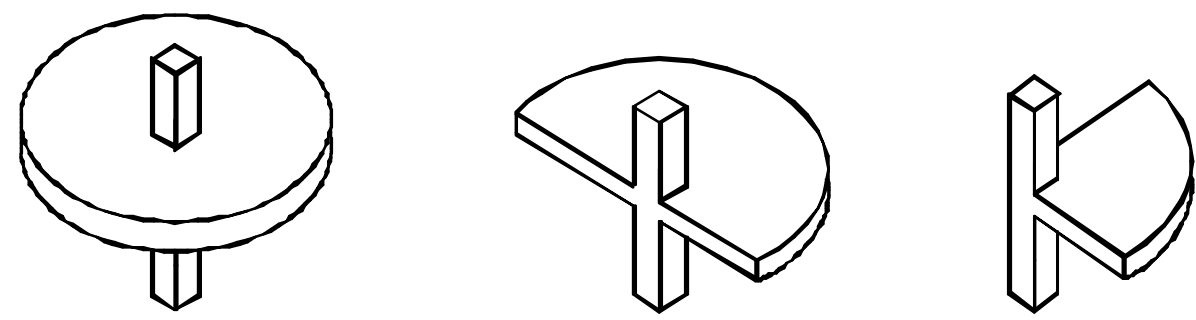

Figura 2.21 - "Elementos-de-laje"

\subsection{COMPORTAMENTO OBSERVADO EM ENSAIOS}

Para ligações da laje com pilares internos, submetidas a carregamento concêntrico, ensaios experimentais mostram que as deformações tangenciais inicialmente são maiores que as deformações radiais, independente do tipo de armadura. Surgem então em primeiro lugar as fissuras radiais, que se iniciam no centro da laje e se propagam em direção aos apoios (Figura 2.22a). Essas fissuras praticamente dividem a laje em segmentos radiais. Somente para elevados estágios de carga é que aparecem algumas poucas fissuras circulares (figura 2.22b), indicando a formação de uma fissuração inclinada interna, causada pela tração diagonal.

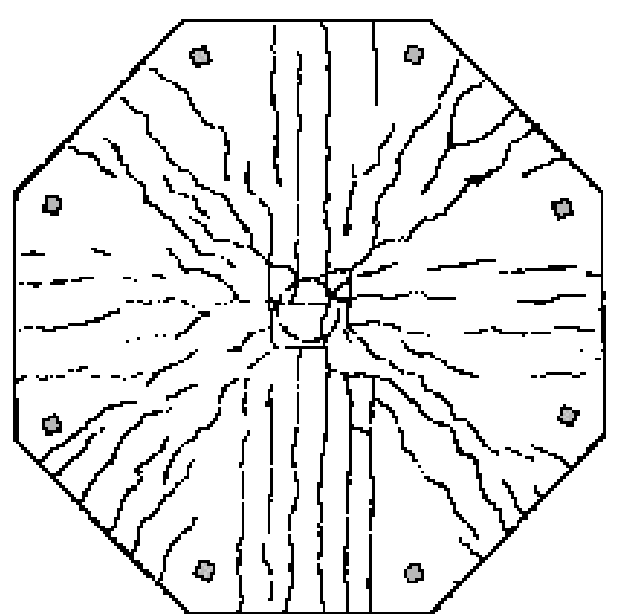

a) Para carga de utilização

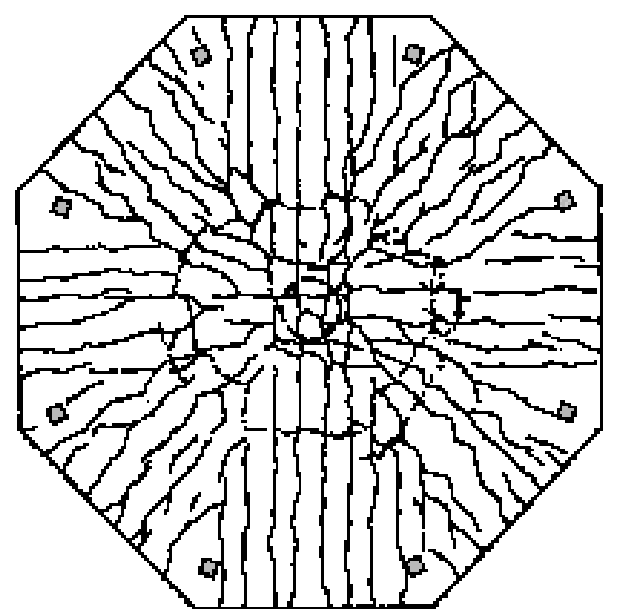

b) Próximo à carga de ruína

Figura 2.22 - Padrão de fissuração para ligações com pilares internos, submetidas a carregamento simétrico (BRAESTRUP \& REGAN, 1985) 
Segundo BRAESTRUP \& REGAN (1985), essa fissuração inclinada ocorre com carregamento aproximado de meio a dois terços da carga de ruína.

Após o aparecimento destas fissuras, a condição da laje ainda é estável, podendo ser descarregada e novamente carregada, sem que a sua resistência seja afetada (figura 2.23).

Considerando-se ainda a figura 2.23, conforme SHEHATA ${ }^{7}$ apud STUCCHI; KNAPP (1993), as flechas das lajes ensaiadas, na direção radial, apresentaram perfil quase linear, indicando assim a rotação dos segmentos da laje como corpos rígidos. Este comportamento é também confirmado pelas deformações específicas do aço e do concreto, medidas na direção tangencial ao longo do raio das lajes, as quais foram proporcionais a $1 / \mathrm{r}$.

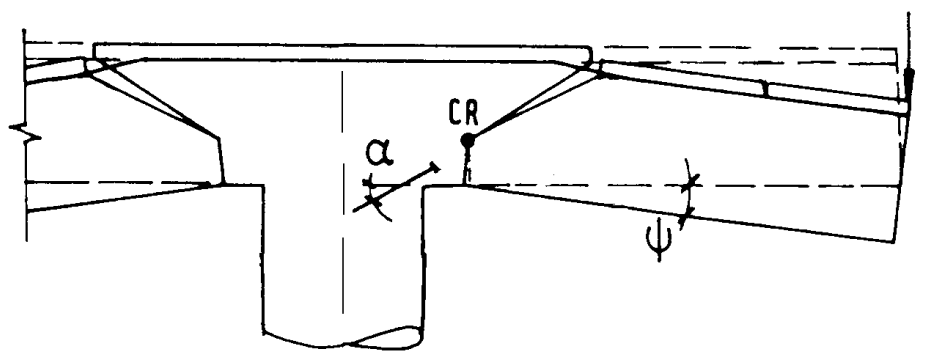

Figura 2.23 - Esquema da fissuração inclinada e da rotação dos segmentos da laje

\subsection{ANÁLISE DA SUPERFÍCIE DE RUINA}

Em virtude da existência da fissuração diagonal, a ruína para pilares internos, com lajes e carregamento simétricos (casos simétricos), apresenta uma superfície de ruína troncônica ou tronco-piramidal, partindo do contorno da área carregada e se estendendo até a outra face da laje, com uma inclinação entre $30^{\circ}$ a $35^{\circ}$ em relação ao plano médio da laje (figura 2.24).

7 SHEHATA, I.A.M. (1993) Punção em lajes. In.:COLÓQUIO SOBRE ESTRUTURAS DE CONCRETO, 6. apud STUCCHI, F.R.; KNAPP, L.M. (1993) Punção em lajes. In.: SIMPÓSIO EPUSP SOBRE ESTRUTURAS DE CONCRETO, 3., São Paulo. Anais. p.209-232. 


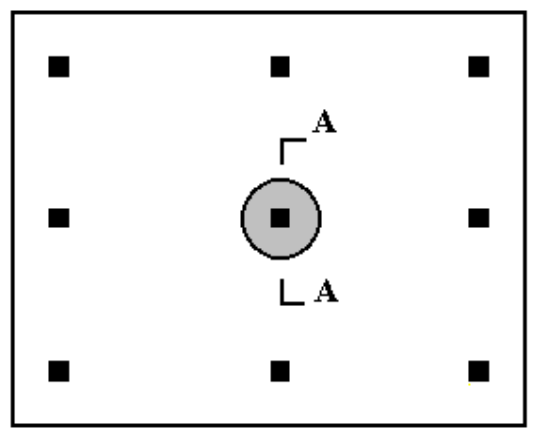

a) Planta

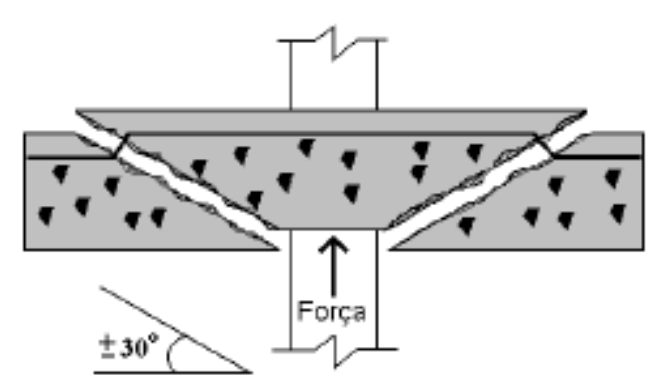

b) Corte A-A

Figura 2.24 - Superfície de ruína para casos simétricos

Esta superfície de ruína pode, no entanto, ser alterada em função de dois parâmetros: posição do pilar e presença de armadura de punção.

\subsubsection{SUPERFÍCIE DE RUÍNA PARA PILARES DE BORDA E DE CANTO}

Para os pilares de borda e de canto (casos assimétricos), a superfície de ruína se altera junto às bordas livres, permanecendo, no entanto, com a mesma forma dos casos simétricos junto ao canto interno dos pilares de canto e junto à face interna dos pilares de borda (Figura 2.25).

Segundo MARTINELLI (1974) e TAKEYA (1981), esta modificação na superfície de ruína se deve, principalmente, à presença de momentos torçores e fletores, que são típicos nessas ligações.

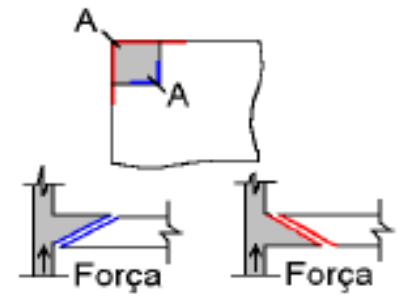

Corte A-A Vista Lateral

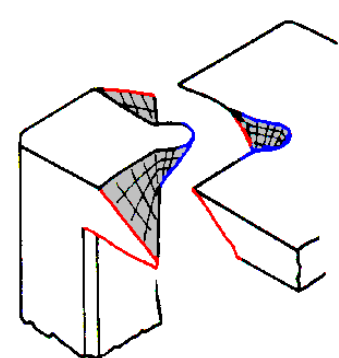

a) Pilar de canto (MARTINELLI, 1974)

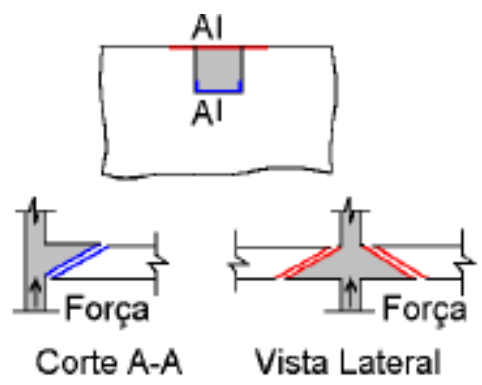

b) Pilar de borda (TAKEYA, 1981)

Figura 2.25 - Superfície de ruína para pilares de canto e de borda 


\subsubsection{SUPERFÍCIE DE RUÍNA PARA LIGAÇÕES COM ARMADURA DE PUNÇÃO}

Segundo REGAN (1985), existem várias possibilidades de ruínas para lajes com armadura de punção. Embora a ruptura por cisalhamento também seja possível, considerando-se a laje como sendo uma viga de grande largura, ela é muito improvável no caso das lajes lisas. Sendo assim, são três as possibilidades de ruptura, mencionadas a seguir e ilustradas na figura 2.26 .

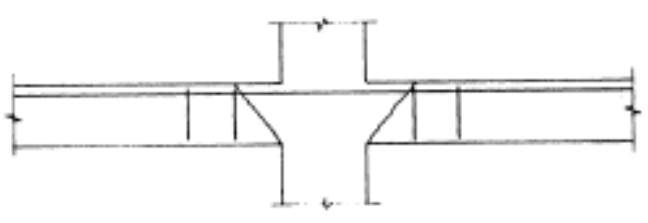

a) Entre o pilar e a armadura de punção

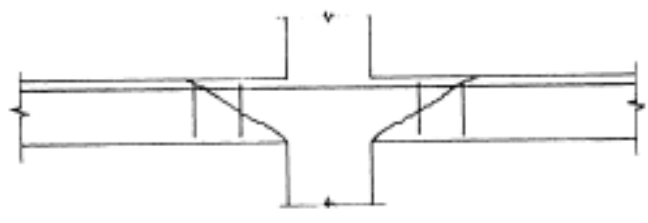

b) Atravessando a região transversalmente armada

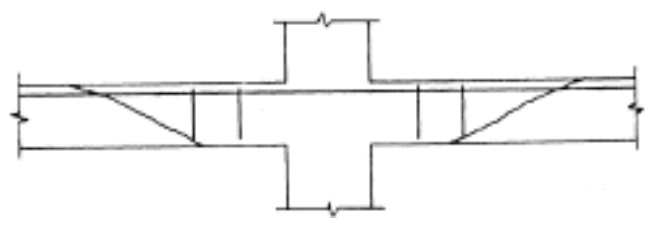

c) Além da região transversalmente armada

Figura 2.26 - Tipos de ruptura por punção em lajes com armadura de punção

(REGAN, 1985)

\section{a) Superfície de ruptura entre a armadura de punção e a face do pilar}

Conforme REGAN (1985), em uma laje sem armadura de cisalhamento, a ruína por punção ocorre em uma superfície que oferece a menor resistência, geralmente posicionada a um ângulo de $25^{\circ}$ em relação ao plano médio da laje.

Caso essa superfície seja forçada a modificar a sua inclinação, então a força necessária para causá-la sofre um aumento, ou seja, para romper uma superfície que não a natural, a resistência proporcionada pela laje é maior. 
Conforme mostrado na figura 2.27, o aumento na resistência não é significativo até uma inclinação de $45^{\circ}$. Para inclinações maiores, o aumento de resistência passa a ser significativo, sendo proporcional à tangente do ângulo da superfície de ruína provocada.

\begin{abstract}
Sendo assim, caso a resistência necessária à ligação seja $\eta$ vezes a resistência de uma laje similar, mas sem armadura de punção, a distância entre o pilar e a armadura de punção mais próxima a ele não deve ser superior a $(d / \eta)$, onde $d$ é a altura útil média da laje.

Uma distância da ordem de $\mathrm{d} / 2$ geralmente é adequada, uma vez que é rara a situação onde o dobro da resistência de uma laje sem armadura de punção seja necessária.
\end{abstract}

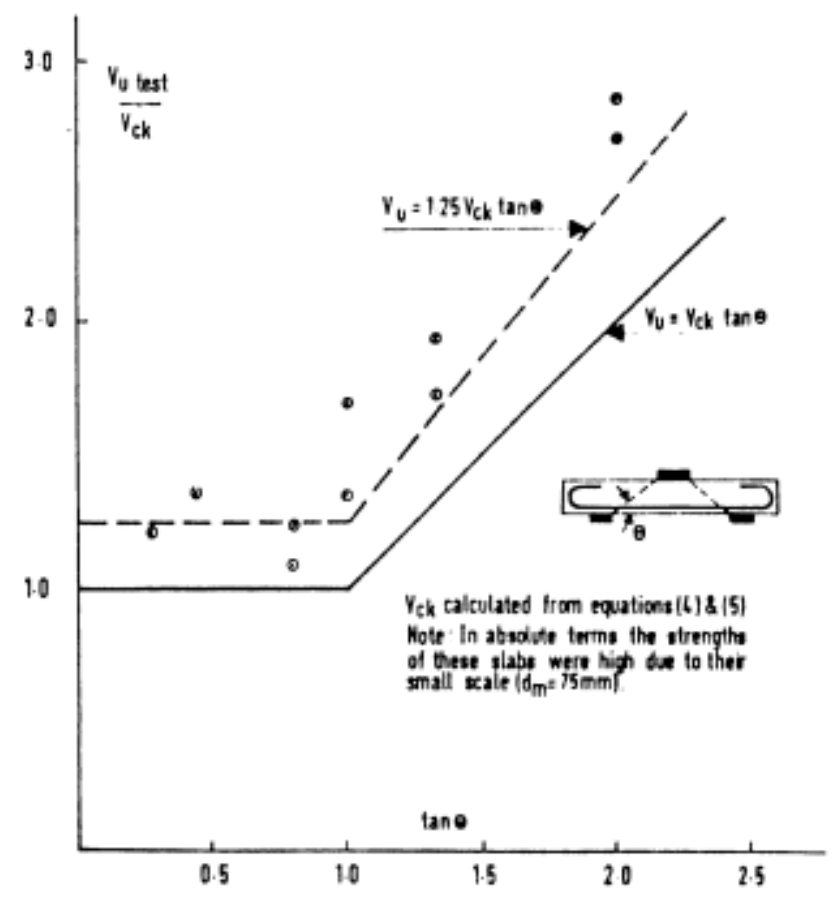

Figura 2.27 - Força de ruptura versus inclinação da superfície de ruína (REGAN, 1985)

No entanto, REGAN (1984) menciona que, para lajes com vãos muito pequenos, onde a inclinação chegou em torno de $70^{\circ}$, a forma de ruína se modificou, envolvendo uma destruição generalizada do elemento.

Esta forma de ruína parece ser semelhante àquela menc ionada por FUSCO (1995), estando relacionada ao esmagamento do concreto através de bielas inclinadas fissuradas. 


\section{b) Superfície de ruptura que atravessa a região armada à punção}

Segundo REGAN (1985), nesta região, a resistência à punção é dada pela contribuição do concreto, que depende principalmente da resistência do concreto e da taxa de armadura longitudinal, e pela contribuição da armadura de punção.

Dados de ensaios experimentais mostram que as fissuras inclinadas de cisalhamento geralmente ocorrem sob um carregamento de aproximadamente $70 \%$ da resistência à punção de uma laje sem armadura de cisalhamento, e, mesmo assim, a estrutura permanece estável durante os próximos $30 \%$ do carregamento de ruptura.

Este fato fornece suporte à constatação de que o concreto pode continuar a oferecer resistência ao cisalhamento na laje fissurada e que esta resistência pode ser adicionada à contribuição dada pela armadura de cisalhamento.

Essa contribuição dada pelo concreto, no entanto, deve ser inferior quando comparada a uma laje similar sem armadura de punção, em consequiência de um aumento nas deformações e nas aberturas de fissuras, necessárias para iniciar a solicitação na armadura de cisalhamento.

Há evidências de que se a armadura de cisalhamento estiver muito distante na direção tangencial, a resistência do concreto pode ser severamente reduzida nas zonas afastadas dessa armadura, resultando um aumento significativo na solicitação da armadura à punção.

Este efeito é similar ao que ocorre quando a ancoragem da armadura de cisalhamento sofre um deslizamento durante o desenvolvimento das tensões na armadura.

\section{c) Superfície de ruptura além da região armada à punção}

REGAN (1985) menciona que é razoável considerar que a resistência a este tipo de ruína seja calculada tomando-se como base o mesmo mecanismo adotado para lajes sem armadura de punção, só que fazendo-se a seguinte adaptação. 
Tomando-se algumas providências com relação ao espaçamento e à disposição dos conectores, pode-se considerar o perímetro da linha que une a armadura mais afastada do pilar com sendo o perímetro de um pilar fictício, no qual deva ser verificada a punção de uma ligação sem armadura de punção.

Analisando-se os possíveis modos de ruptura, pode-se chegar então à seguinte conclusão: considerando-se uma determinada reação no pilar, calculada em função das ações que atuam na laje, desde que se arme a laje para que ela não rompa na região transversalmente armada, desde que se arme uma extensa região da laje próxima ao pilar, de modo que a ruptura não se dê além da região transversalmente armada, e desde que se respeite uma distância máxima entre a face do pilar a armadura de punção mais próxima a ele, tem-se ainda uma última verificação a ser feita. Em face da eficiência da armadura de punção em absorver esforços transversais de tração e em face do alto grau de fissuração da laje nessa região, seria importante que se fizesse uma verificação da biela de compressão que chega ao pilar, analogamente ao que se faz nas vigas com armadura transversal.

\subsection{PARÂMETROS ENVOLVIDOS}

Em virtude de sua complexidade, são diversos os parâmetros que influenciam o fenômeno da punção.

\subsubsection{ESPESSURA OU ALTURA ÚTIL DA LAJE}

Conforme BRAESTRUP \& REGAN (1985), ensaios mostram que o aumento da resistência da ligação é proporcional ao quadrado da altura útil. No entanto, ao se modificar a altura útil para toda a laje, as ações permanentes também aumentam, fazendo com que a relação resistência/altura útil passe a ser linear. Uma outra opção é aumentar a espessura da laje apenas na região de sua ligação com o pilar, utilizando-se "drop panels" ou capitéis. Como opção de um "drop panel”, pode-se ter a utilização de uma placa de aço ilustrada na figura 2.28 . 
A utilização de capitéis e de "drop panels" apresenta alguns inconvenientes: perdem-se as vantagens oferecidas pelo teto liso, embora a resistência da ligação seja aumentada; a utilização destes elementos estruturais não fornece ductilidade à ligação; alguns aspectos arquitetônicos são prejudicados, além de aumentarem a distância

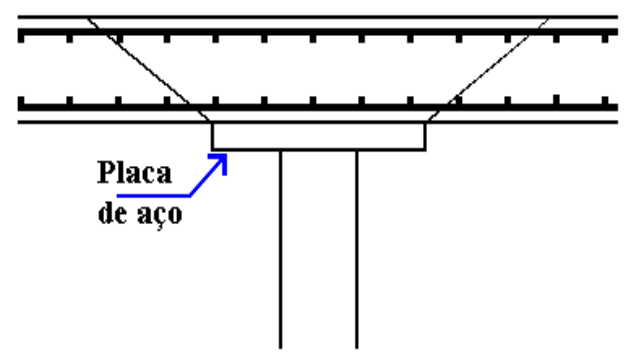

Figura 2.28 - Placa metálica funcionando como um "drop panel” entre pisos.

\subsubsection{DIMENSÕES, FORMATO E POSIÇÃO DO PILAR}

Segundo BRAESTRUP \& REGAN (1985), com relação ao formato dos pilares, pode-se observar que, para pilares circulares, a resistência foi cerca de $15 \%$ maior quando comparada à resistência de pilares quadrados com área equivalente. Isto se deve ao fato de que nos pilares retangulares existe uma concentração de tensões nos cantos.

Com relação à dimensão dos pilares, pode-se observar que para pilares alongados, onde a relação entre lado maior e lado menor é superior a 2, a ruína é mais abrupta, o tamanho do cone de punção é menor e a resistência da ligação também é menor, quando comparados com pilares de seções quadradas. Isto também se deve ao fato de que as tensões se concentram nos cantos e nos menores lados do pilar (figura 2.29).

Por fim, com relação à posição do pilar, tem-se que pilares internos resistem mais que pilares de borda, que, por sua vez, resistem mais que pilares de canto. 


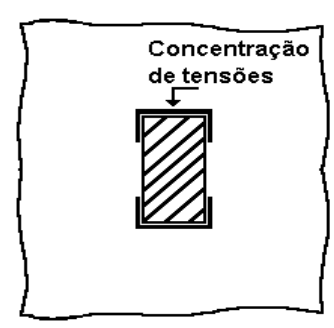

Figura 2.29 - Concentração de tensões nos cantos e no menor lado de pilares alongados

\subsubsection{RESISTÊNCIA DO CONCRETO}

FUSCO (1984) menciona que a resistência da ligação está relacionada à resistência do concreto à tração. Algumas normas admitem que essa resistência seja proporcional ao valor da raiz quadrada da resistência à compressão. No entanto, o aumento da resistência da ligação, em função do aumento da resistência do concreto, não confere à laje uma melhor ductilidade com relação à ruína.

\subsubsection{RELAÇÃO MOMENTO FLETOR / FORÇA CORTANTE}

Ensaios experimentais têm mostrado que, quanto maior a excentricidade do carregamento, menor a resistência da ligação.

\subsubsection{TAXA DE ARMADURA DE FLEXÃO}

Segundo FUSCO (1984), a importância da taxa de armadura decorre de sua influência sobre o efeito de pino da armadura longitudinal de tração, após a fissuração da borda tracionada da peça, e de sua influência sobre a manutenção do engrenamento dos agregados. Conforme resultados experimentais mostrados por FUSCO (1984), observase que taxas acima de $2 \%$ não aumentam a resistência da laje ao cisalhamento. 


\subsubsection{EFEITO DE ESCALA (“SIZE EFFECT")}

Segundo FUSCO (1984), a influência do efeito de escala geralmente é dada em função da altura útil da laje. Este efeito refere-se ao fato de que, em igualdade de outras condições, as lajes de menor altura útil são mais resistentes que as lajes mais espessas. Este fato é em princípio justificável pela possibilidade de maior heterogeneidade do concreto das lajes mais espessas. Além disso, mesmo com uma mesma taxa de armadura longitudinal, nas lajes de maior espessura, a armadura de tração perde sua capacidade de controlar a abertura das fissuras ao longo de toda a altura da seção fissurada. Deste modo, a espessura da peça condiciona o engrenamento dos agregados, fazendo com que a altura útil também seja um fator que controla a resistência das lajes ao cisalhamento. Resultados experimentais mostram, no entanto, que a partir de uma determinada espessura, a influência da variação da altura útil deixa de ser significativa. Essa limitação da influência da espessura a um determinado valor decorre de um efeito de escala entre a altura útil da peça e o diâmetro máximo dos agregados empregados na fabricação do concreto.

O engrenamento dos agregados depende de maneira significativa da porcentagem de grãos de maior diâmetro empregados no concreto e, até um certo limite, da relação entre a altura útil da peça e o diâmetro máximo dos agregados empregados. Deste modo, nas peças usuais de concreto estrutural, com diâmetros máximos do agregado da ordem de $30 \mathrm{~mm}$, o engrenamento dos agregados é mais eficiente em lajes delgadas do que em peças de grande espessura.

Todavia, conforme resultados experimentais, a diminuição do efeito do engrenamento dos agregados fica realmente estabilizada ao redor de um determinado valor da altura útil.

\subsubsection{INFLUENNCIA DO TIPO DE CARREGAMENTO}

Segundo FUSCO (1984), no caso das cargas concentradas aplicadas nas lajes, afastadas dos apoios, a resistência média ao cisalhamento não é mais influenciada por um eventual arqueamento dos esforços. 
Sendo assim, a resistência passa a depender apenas do engrenamento dos agregados, do efeito de pino da armadura de flexão e da própria resistência do concreto à tração. Esta situação também pode ser relacionada à reação de um pilar sobre uma laje diretamente apoiada nele.

\subsubsection{ARMADURA DE PUNÇÃO}

Segundo PILAKOUTAS \& LI (1997), existem diversas maneiras de se evitar o problema da punção:

a) reduzir o carregamento a ser aplicado;

b) reduzir os vãos da laje;

c) aumentar a espessura total da laje;

d) aumentar a espessura do pilar ou da laje apenas na região da ligação, através de capitéis e de "drop panels", respectivamente;

e) aumentar o tamanho do pilar;

f) usar armadura de cisalhamento.

As soluções a) a e) são geralmente impraticáveis, inaceitáveis do ponto de vista arquitetônico, aumentam a altura total do edifício ou não são economicamente viáveis. Portanto, a solução mais adequada é o uso de armaduras de punção. A utilização dessas armaduras proporciona um aumento na resistência da ligação, uma vez que ela "costura" as partes separadas pela fissuração diagonal. Alguns tipos são ilustrados a seguir.

\subsection{TIPOS DE ARMADURA DE PUNÇÃO}

Além de aumentar a resistência da ligação, alguns tipos de armadura de punção fornecem uma maior ductilidade à ligação, ou seja, uma maior capacidade da ligação em se deformar. 
Deve-se, no entanto, estudar cuidadosamente o detalhamento da ancoragem dessa armadura de punção, principalmente para lajes mais esbeltas.

\subsubsection{ESTRIBOS}

Os estribos podem ser abertos em forma de ganchos ou fechados em forma de retângulos. Os estribos retangulares podem estar associados entre si (figura 2.30). Eles podem ainda estar inclinados ou não (figura 2.31).

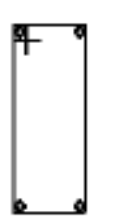

Simples

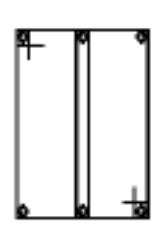

Duplo

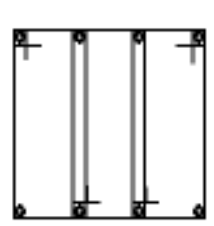

Triplo

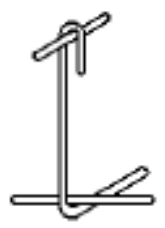

Gancho isolado

Figura 2.30 - Tipos de estribos

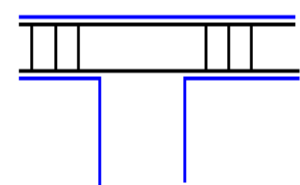

Estribos verticais

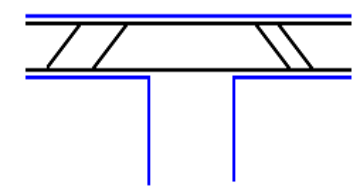

Estribos inclinados

Figura 2.31 - Inclinação dos estribos

Os estribos são apenas parcialmente efetivos nas lajes delgadas, por causa do "escorregamento" da ancoragem do estribo. Este escorregamento ocorre nas dobras de todos os estribos e proporcionam grandes aberturas às fissuras de cisalhamento, a menos que barras longitudinais de grande bitola sejam usadas. Sendo assim, a ruína por cisalhamento se dá antes que a tensão de escoamento dos estribos seja atingida. $(\mathrm{DECON} \circledast, 1998)$.

O desempenho dos ganchos foi considerado satisfatório em ensaios realizados por TAKEYA (1981) e MARTINELLI (1974). Os ganchos possuem a vantagem de não interferir nas armaduras de flexão da laje e nem na dos pilares, sendo de fácil montagem e execução. No entanto, os ensaios confirmaram que, para este tipo de armadura de punção, deve-se garantir que não haja folga entre o gancho e as faces superiores da armadura de flexão (figura 2.32). A importância desse contato deve-se ao fato da armadura de flexão servir de apoio para ancoragem do gancho. 
Caso esta situação não ocorra, toda a contribuição dos ganchos na resistência da ligação estará comprometida, bem como a sua segurança.

Destaca-se que a garantia da não existência de folga entre a armadura de flexão e os ganchos é algo difícil de ser obtida na obra, uma vez que os operários freqüentemente pisam na armadura de flexão, deslocando-a o suficiente para eliminar o contato entre as armaduras mencionadas.

Nos modelos ensaiados por MARTINELLI (1974) e TAKEYA (1981), como não existia uma armadura inferior, os estribos foram ancorados no prolongamento da armadura negativa (Figura 2.32).

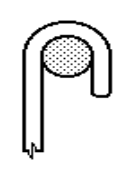

a) Correta

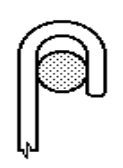

b) Incorreta

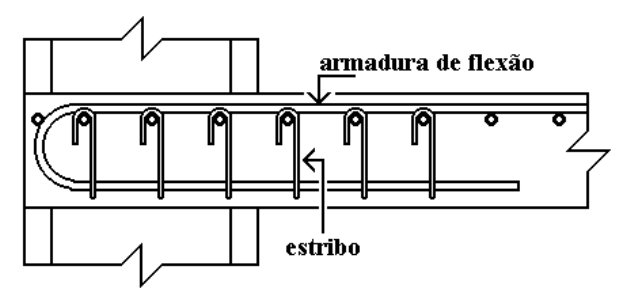

Figura 2.32 - Ancoragem dos ganchos e posicionamento dos estribos

OLIVEIRA (1998), através de ensaios experimentais, comprovou uma grande eficiência de estribos inclinados, em ligações do tipo laje-pilar interno, usando concreto com resistência de $60 \mathrm{MPa}$ (figura 2.33).
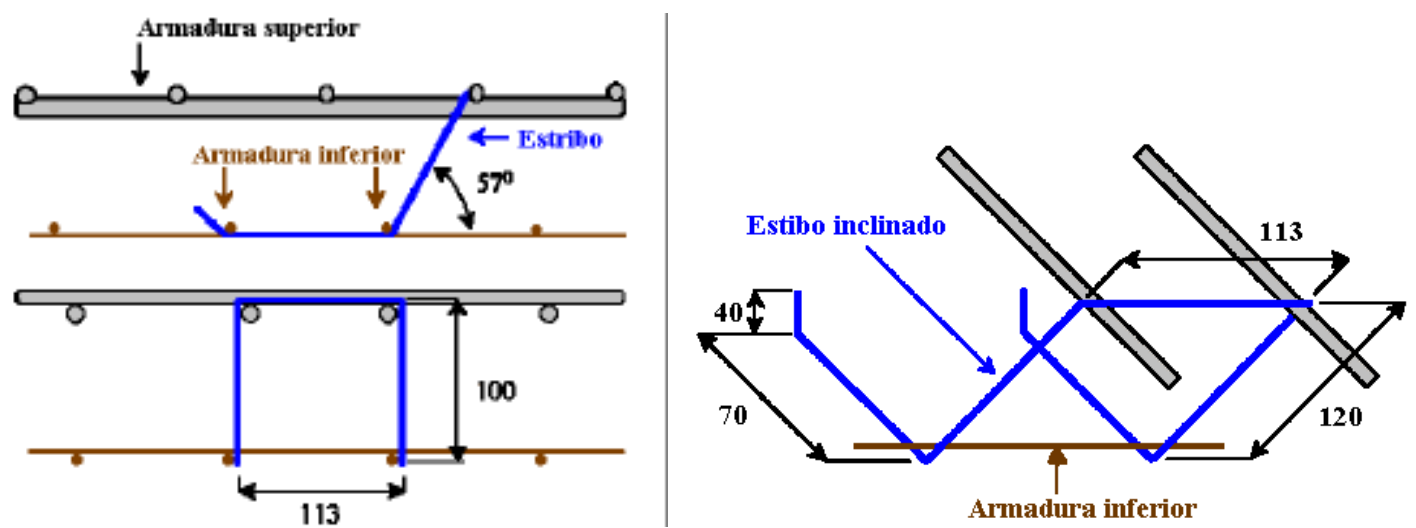

Figura 2.33 - Esquema dos estribos inclinados, usados por OLIVEIRA (1997) 


\subsubsection{BARRAS DOBRADAS}

No exemplo da figura 2.34, as barras estão representadas como sendo o prolongamento da armadura negativa de flexão, estando ancoradas na face inferior da laje.

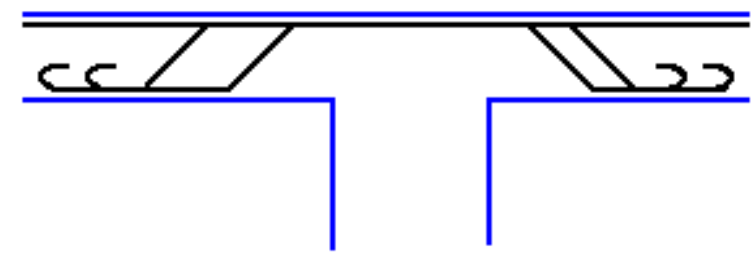

Figura 2.34 - Barras dobradas

PARK \& ISLAM (1976), através da análise de lajes carregadas simetricamente, com e sem armadura de punção, chegaram às seguintes conclusões: o uso de barras dobradas aumenta a resistência da laje, não aumentando, no entanto, a sua ductilidade; já o uso de estribos fechados ancorados nas barras de flexão proporciona, além de um aumento na resistência da ligação, um considerável aumento na sua ductilidade. Uma crítica à barra dobrada é que, como ela também acaba absorvendo parte dos esforços de flexão, não sobra muita capacidade para resistir aos esforços de cisalhamento. Além da ancoragem dessas barras ser problemática em lajes com pouca espessura, MARTINELLI (1974) e TAKEYA (1981) mencionam que o seu uso é inadequado para ligações da laje com pilares de borda e de canto. Estudos realizados por eles mencionam que a disposição das barras dobradas é paralela à superfície de ruína junto às bordas da laje. Sendo assim, esta armadura não apresenta um efeito de "costura" entre as superfícies separadas pela fissuração diagonal.

\subsection{3 "SHEARHEADS"}

"Shearheads" são perfis metálicos embutidos na laje e posicionados na região da ligação da laje com o pilar. 
Geralmente os perfis metálicos tipo U são posicionados na região adjacente ao pilar, enquanto os perfis tipo I atravessam cabeça do pilar (figura 2.35).

PARK \& ISLAM (1976) ressaltam que o uso deste tipo de reforço aumenta a resistência da ligação laje-pilar e também, dentro de certos limites, a sua ductilidade.

Ensaios feitos por CORLEY \& HAWKINS (1968) constataram que modelos com "shearhead" tiveram um aumento na resistência da ligação da ordem de 75\% em relação a corpos-de-prova sem este tipo de reforço. A situação por eles analisada foi a de ligações da laje com pilares internos, com carregamento simétrico.

GODYCKI \&KOZICKI ${ }^{2}$ apud LIBÓRIO (1985) observaram que houve um acréscimo de $40 \%$ a $70 \%$ na capacidade resistente das ligações laje-pilar interno, excentricamente carregadas, em função da presença de "shearheads".

No entanto, GONÇALVES ${ }^{3}$ apud FIGUEIREDO FILHO (1989) constatou, através de ensaios, que a carga de ruína observada para pilares de borda com "shearheads" foi menor que a dos modelos sem qualquer tipo de armadura transversal.

PILAKOUTAS \& LI (1997) mencionam que os sistemas que usam perfis metálicos como armadura de punção tendem a ser pesados, caros, necessitando de operações de soldagem para unir os perfis e geralmente obstruem a passagem da armadura longitudinal do pilar, na região da ligação. Entretanto, este tipo de armadura é particularmente útil como reforço para lajes com grandes aberturas próximas ao pilar.

Os "shearheads" também proporcionam um aumento da resistência da ligação com relação à flexão.

Este aumento, no entanto, pode ser indesejável, uma vez que ele pode modificar o tipo de ruína, que pode então se dar de maneira frágil.

Convém destacar que o uso de "shearheads" é muito comum nos Estados Unidos.

${ }^{2}$ GODYCKI, T.; KOZICKI, J. (1984) Eccentrically loaded interior slab column conections with shearhead reinforcement. Materiaux et Constructions, v.17, n.98, p.145-148 apud LIBÓRIO, J. B. L. (1985) Estudo experimental da ruína de ligações laje-pilar em bordas com pilares de seção retangular. São Carlos. Dissertação (mestrado), EESC-USP

${ }^{3}$ GONÇALVES, R.M. (1986) Estudo experimental da ruína de ligações laje-pilar em bordas de lajescogumelo com reforço transversal constituído de perfis metálicos. São Carlos. Dissertação (mestrado), EESC-USP apud FIGUEIREDO FILHO, J.R. (1989) Sistemas estruturais de 


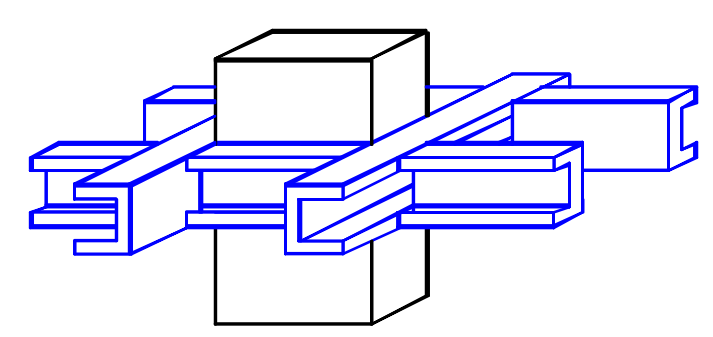

Vista

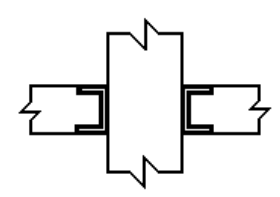

Corte A-A

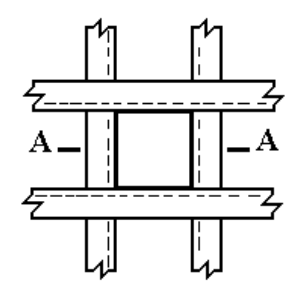

Planta

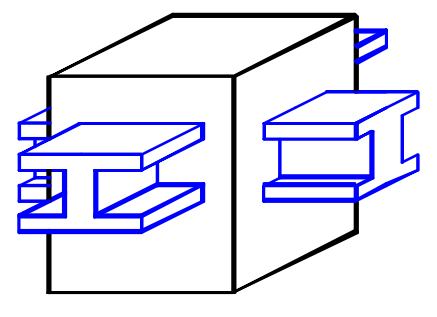

Vista

a) perfis metálicos tipo "U"

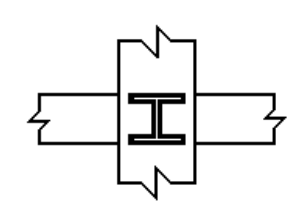

Corte A-A

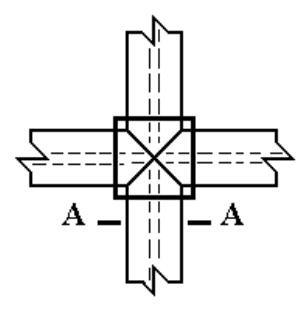

Planta

Figura 2.35 - "Shearheads"

\subsubsection{FIBRAS}

Conforme GIONGO et al. (1997), a introdução de fibras no concreto não visa diretamente o aumento da resistência, embora em algumas situações ela ocorra, mas sim o melhor controle da fissuração e o aumento da ductilidade na etapa posterior à fissuração.

Por ser descontínua, a fibra é menos eficiente que a armadura contínua de fios e barras para resistir aos esforços de tração. No entanto, em função do espaçamento reduzido entre as fibras, a sua atuação como obstáculo ao desenvolvimento das fissuras é superior. Quando combinadas com uma armadura contínua, ambas se tornam mais eficientes, pois, além de "costurar" as fissuras, as fibras melhoram a aderência do concreto com a armadura, inibindo a fissuração na região de transferência de esforços. 
O aumento de tenacidade proporcionado pelas fibras é significativo, uma vez que a energia para a ruptura é dissipada pela deformação da fibra, pela separação da interface fibra-matriz e pelo atrito provocado pelo escorregamento da fibra. Portanto, o aumento de ductilidade está associado à fissuração múltipla da matriz, à ruptura da interface fibra -matriz e ao seu posterior arrancamento.

Existem algumas dificuldades para uniformizar a distribuição de fibras na matriz em consequiência do embolamento e do agrupamento das fibras, formando os "ouriços" (figura 2.36).

Outro problema comum do uso de fibras é a sua tendência de inibir a fluidez do concreto. $\mathrm{O}$ uso de aditivos superplastificantes e a substituição de parte do cimento por pozolanas são as alternativas usuais para melhorar a trabalhabilidade. $\mathrm{O}$ aumento da relação água/cimento também pode ajudar, embora, neste caso, ocorra uma diminuição da resistência do concreto.

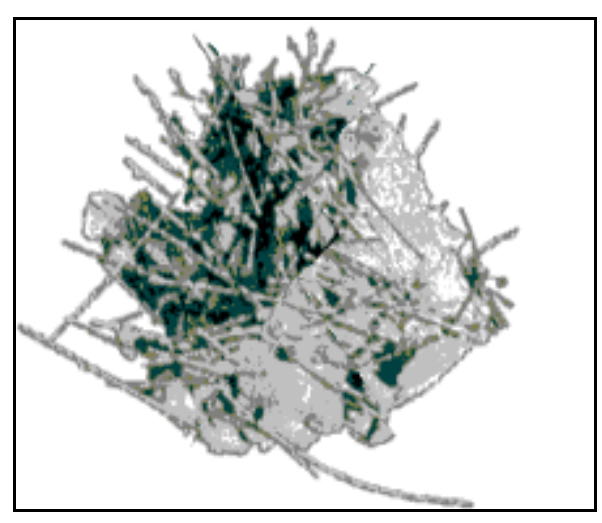

Figura 2.36 - Embolamento das fibras (BEKAERT, s.d.)

Como exemplos de fibras têm-se as fibras de aço, de polipropileno, de vidro, de fibras vegetais e de cimento amianto. Na figura 2.37 tem-se um exemplo de fibras de aço, comercializadas pela empresa Bekaert. Essas fibras podem ser vendidas em feixes ou soltas. Na figura 2.38 tem-se um exemplo das fibras misturadas junto à massa de concreto.

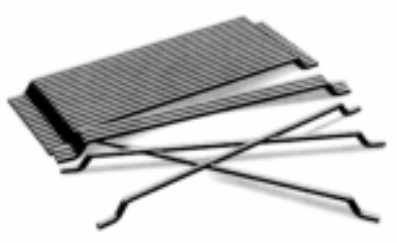

a) Fibra de aço

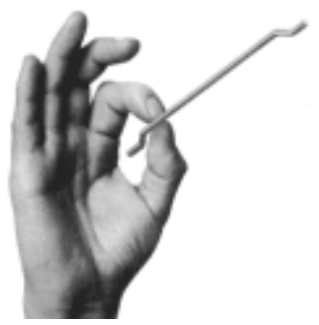

b) Solta

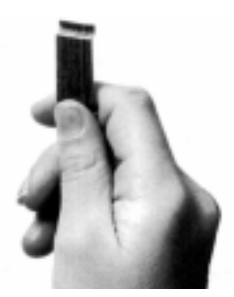

c) Coladas em feixe

Figura 2.37 - Fibras de aço na forma solta ou coladas em feixe (BEKAERT, s.d.) 


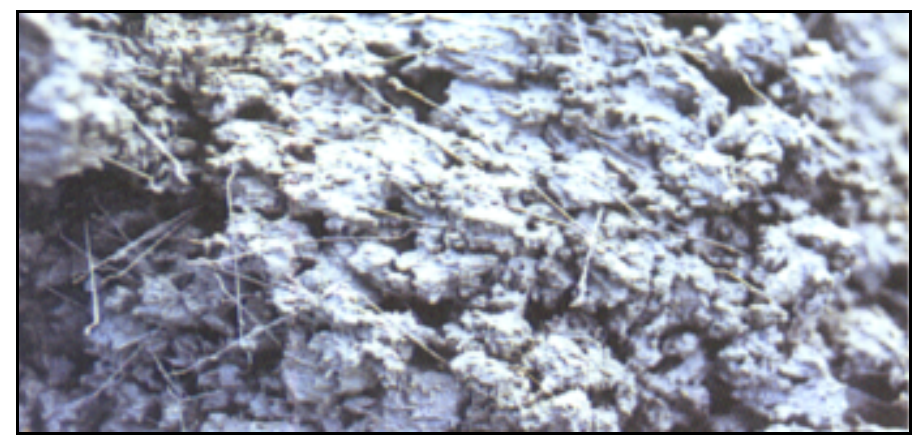

Figura 2.38 - Fibras de aço misturadas junto ao concreto (BEKAERT, s.d.)

As fibras de aço podem ser retas, em forma de gancho ou ainda plissadas, sendo que suas dimensões variam em torno de $50 \mathrm{~mm}$ de comprimento e de $0,5 \mathrm{~mm}$ de espessura.

SWAMY \& ALI (1982) mencionam que, apesar do uso de armaduras de cisalhamento ser mais eficiente que o uso de fibras, o tempo para realizar a montagem e a execução da armadura m laje é significativamente maior que o tempo para preparar o concreto com fibras, além das fibras proporcionarem uma maior ductilidade àligação. Com base em ensaios experimentais, SWAMY \& ALI (1982) observaram que o aumento da resistência de ligações com fibras em relação a ligações sem armadura de cisalhamento e sem fibras pode chegar até a ordem de $40 \%$. É importante frisar que os ensaios realizados foram feitos apenas para a situação de pilares internos, submetidos a carregamentos simétricos.

\subsubsection{CONECTORES TIPO PINO}

O uso de conectores tipo pino (figura 2.39), com extremidades alargadas, é recomendado pela revisão da NB-1 (2000), e apresenta as seguintes vantagens, mencionadas em FIGUEIREDO FILHO (1989) e aqui transcritas:

- são fáceis de instalar, mesmo em lajes esbeltas;

- não interferem na colocação e no posicionamento das armaduras dos pilares e de flexão das lajes; 
- possibilitam ancoragem mecânica satisfatória nas duas extremidades do pino, possibilitando que a armadura atinja toda a sua capacidade resistente antes da ruptura;

- aumentam a resistência e a ductilidade da ligação.

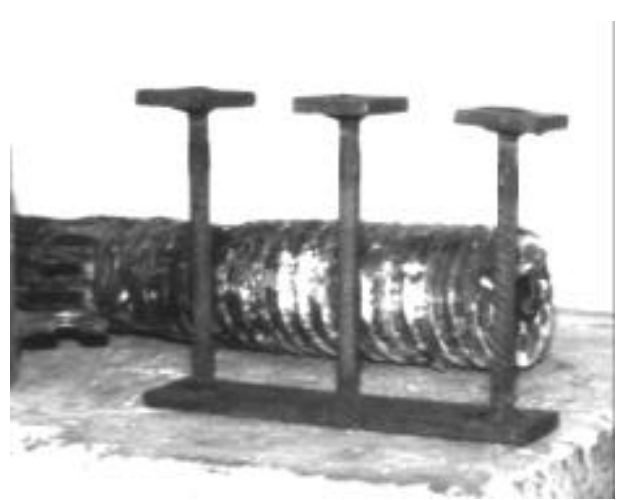

a) Conector feito de forma artesanal, com

barras de aço e chapas metálicas

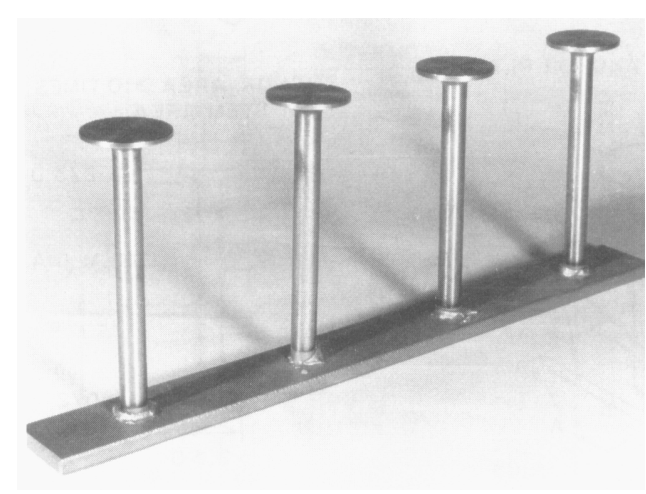

b) Conector industrializado

( ELGABRY \& GHALI, 1990)
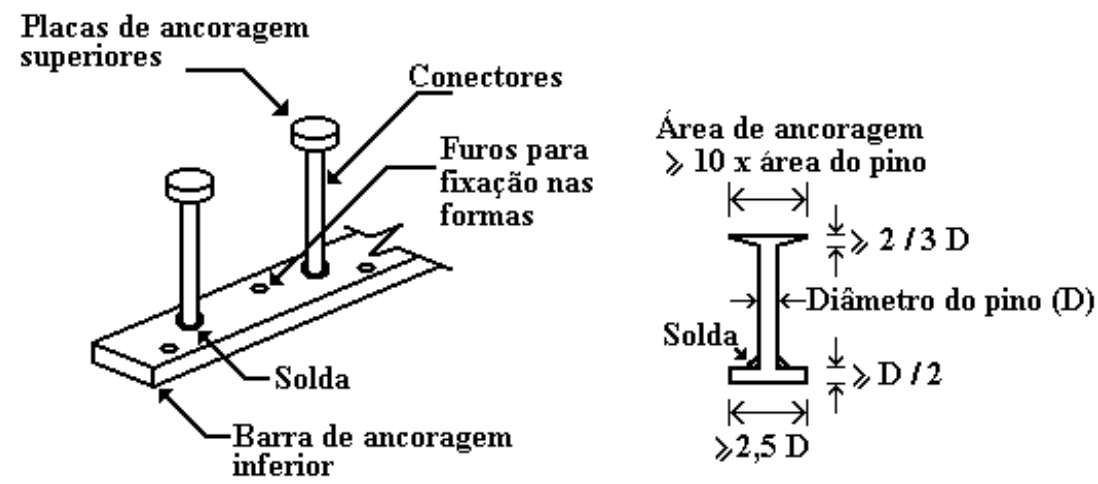

c) Detalhe dos conectores (revisão da NB-1, 2000)

Figura 2.39 - Conectores tipo pino

Os conectores devem possuir as extremidades alargadas, sendo que cada uma dessas extremidades deve estar ancorada além do plano definido pelas barras tracionadas da armadura de flexão e além do centro de gravidade da região comprimida, provocada pela flexão da laje (figura 2.40)
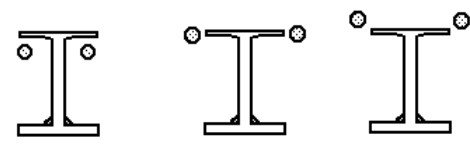

(certo)

(errado)

(errado)

Figura 2.40 - Ancoragem dos conectores 
Segundo a empresa DECON® (1998), a chapa metálica inferior apresenta a vantagem de posicionar corretamente os conectores na obra, além de servir de ancoragem para os pinos. Esta chapa é encaixada a um suporte plástico que, por sua vez, é pregado à fôrma, garantindo o cobrimento adequado (figura 2.41). Esta firma comercializa os suportes plásticos e os conectores tipo pino através da marca Studrails ${ }^{\circledR}$, que é protegida por patentes americana e canadense.
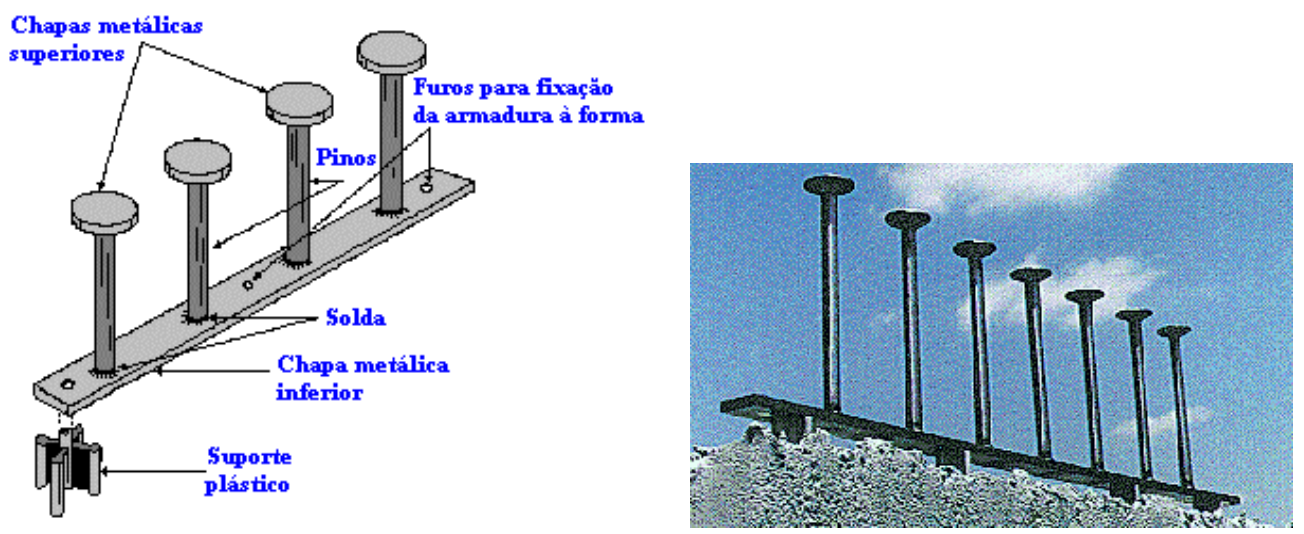

Figura 2.41 - Detalhe da fixação dos Studs à fôrma

Na figura 2.42 tem-se um exemplo de aplicação dos conectores tipo pino em uma laje plana protendida.

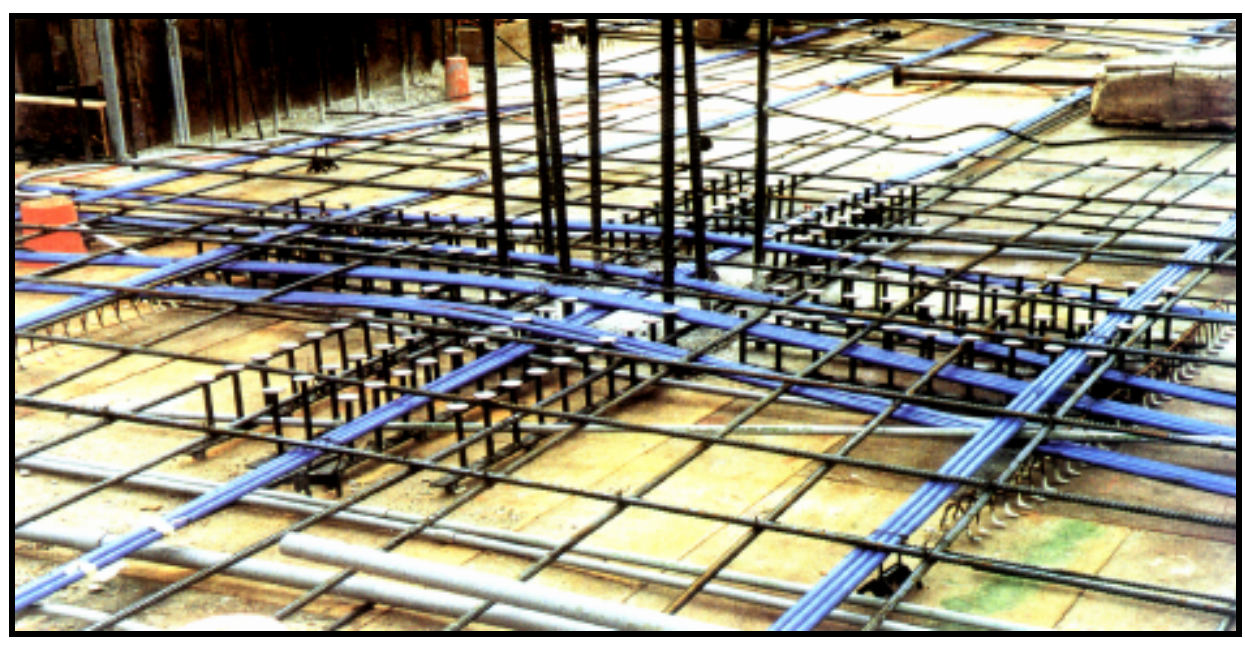

Figura 2.42 - Aplicação de conectores tipo pino em laje plana protendida (DILGER, 1990) 


\subsubsection{SEGMENTOS DE PERFIS METÁLICOS}

Podem ser utilizados, ao invés de conectores tipo pino, pequenos segmentos de perfis metálicos de seção transversal tipo "I", conforme mostrado em FIGUEIREDO FILHO (1989). Este tipo de armadura, apesar de ser adequado segundo o ponto de vista da ancoragem do elemento na laje, não é recomendado segundo o ponto de vista de produção e de economia (figura 2.43).

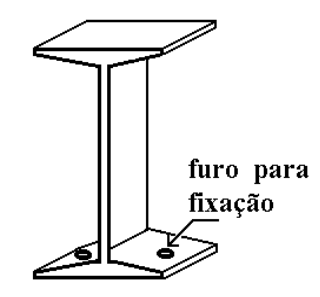

Figura 2.43 - Segmentos de perfis metálicos "I"

\subsubsection{SISTEMA "SHEARBAND"}

Este sistema, testado por PILAKOUTAS \& LI (1997), compõe-se de uma fina faixa metálica, de altas resistência e ductilidade, que pode ser dobrada em uma grande variedade de formas. Essas faixas apresentam furos, que visam melhorar as suas características de ancoragem. Em função de sua pequena espessura, esta chapa pode ser colocada por cima da armadura tracionada de flexão, com perdas mínimas de cobrimento. Segundo os autores, este sistema apresenta a vantagem da simplificar o seu posicionamento na ligação, podendo também ser detalhado com base nos códigos existentes (figura 2.44).

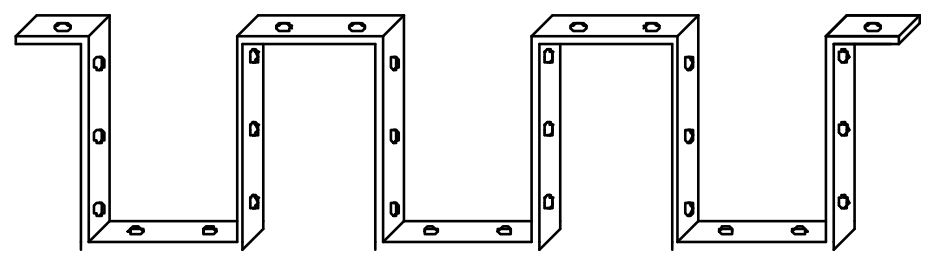

Figura 2.44 - Sistema "shearband" 


\subsection{MODELOS DE CÁLCULO}

Existem alguns métodos desenvolvidos para verificar a resistência de uma ligação laje-pilar com relação à punção, apresentados a seguir.

\subsubsection{MÉTODO DA SUPERFÍCIE DE CONTROLE}

O Método da Superfície de Controle consiste em se calcular uma tensão uniforme de cisalhamento atuante em uma superfície de controle (ou crítica), perpendicular ao plano médio da laje, localizada a uma determinada distância da face do pilar ou da área carregada.

A área desta superfície é dada pela multiplicação do perímetro pela altura da superfície de controle.

Essa altura pode ser dada pela espessura da laje (h), altura útil (d) ou braço de alavanca dos momentos internos (z), dependendo de qual o regulamento a ser adotado (figura 2.45).

Esta tensão atuante, geralmente calculada em função da posição do pilar, da força concentrada e da presença ou não de momentos fletores, é então comparada com uma tensão resistente, geralmente calculada em função da resistência do concreto, da taxa de armadura à flexão e da presença ou não de armadura de punção. Embora este método de cálculo pouco ou nada tenha a haver com a realidade do fenômeno físico, sendo puramente empírico, ele é bastante simples e, quando bem calibrado, conduz a consistentes e razoáveis predições.

Além disso, ele é a base de vários códigos e normas, tais como, por exemplo, a NBR 6118/82 e NBR 7197/89, a revisão da NB-1/2000, o CEB 90/1991, o fib/1999, o FIP/1999, o Eurocode 2 (1991) e o ACI 318-95. 


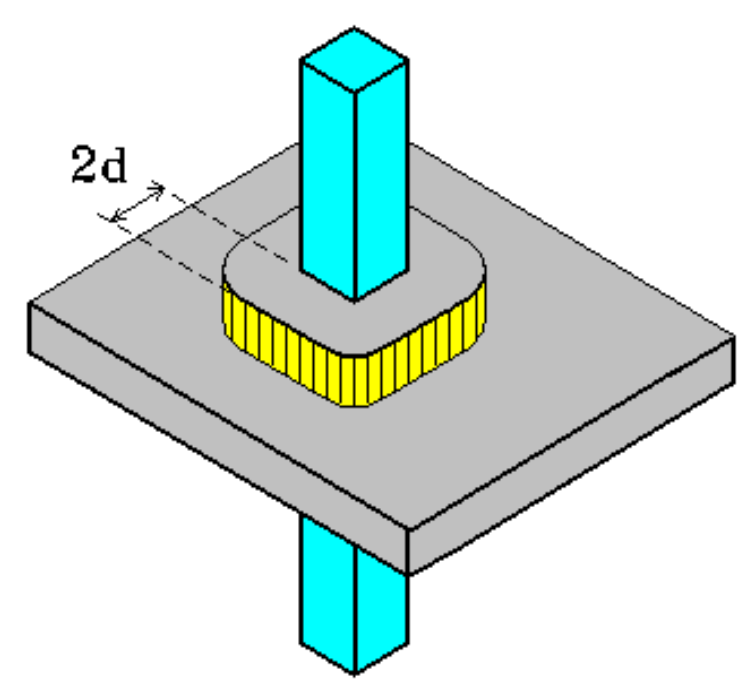

a) Superfície de controle

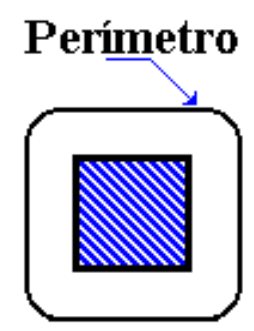

b) Perímetro da superfície de controle

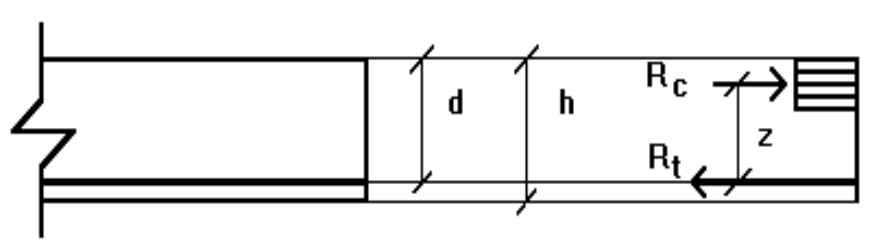

c) Altura da superfície de controle

Figura 2.45 - Definição da superfície de controle

\subsubsection{MÉTODO DE BIELAS E TIRANTES}

Segundo SILVA (1991), os elementos comprimidos (bielas) representam campos de tensão de compressão no concreto, e os elementos tracionados (tirantes), os campos de tração que são usualmente absorvidos pelas barras da armadura. Este modelo concentra as tensões em barras comprimidas e tracionadas, ligando-as através de nós. Conhecendo-se um modelo adequado para uma determinada região da estrutura, as forças nas bielas e nos tirantes são calculadas através do equilíbrio entre as forças internas e externas. Na Figura 2.46 está ilustrado o modelo proposto por Alexander \& Simmonds, em 1987, mencionado por PINTO (1993). 


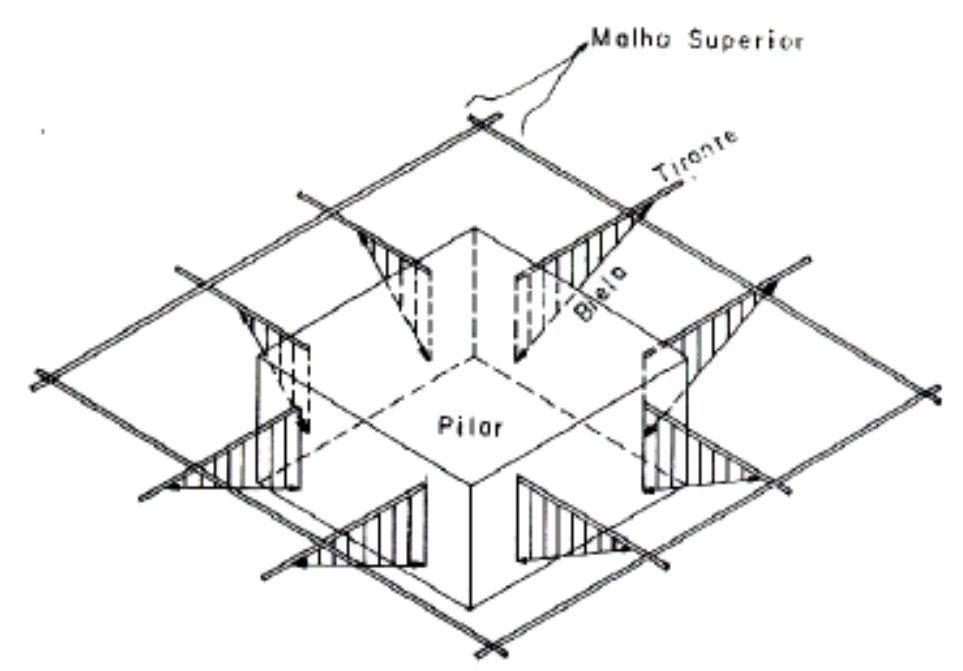

Figura 2.46 - Modelo de bielas e tirantes

\subsubsection{MODELOS MECÂNICOS}

Os modelos mecânicos, também ditos "racionais", são fundamentados pelos modelos constitutivos do concreto e do aço e se baseiam no comportamento da ligação, observado em ensaios.

A resistência da ligação, nesse caso, é obtida através do equilíbrio entre as ações aplicadas e os esforços internos.

Tem-se, como exemplo ilustrado na figura 2.47, o modelo desenvolvido por Kinnunen e Nylander.

Estes modelos, embora complexos, apresentam a grande vantagem de se poder visualizar o comportamento real da ligação laje-pilar. Atualmente, diversas pesquisas têm sido feitas visando o aperfeiçoamento destes modelos, tendo-se, como exemplo, os trabalhos de SHEHATA (1985) e de GOMES (1991). 


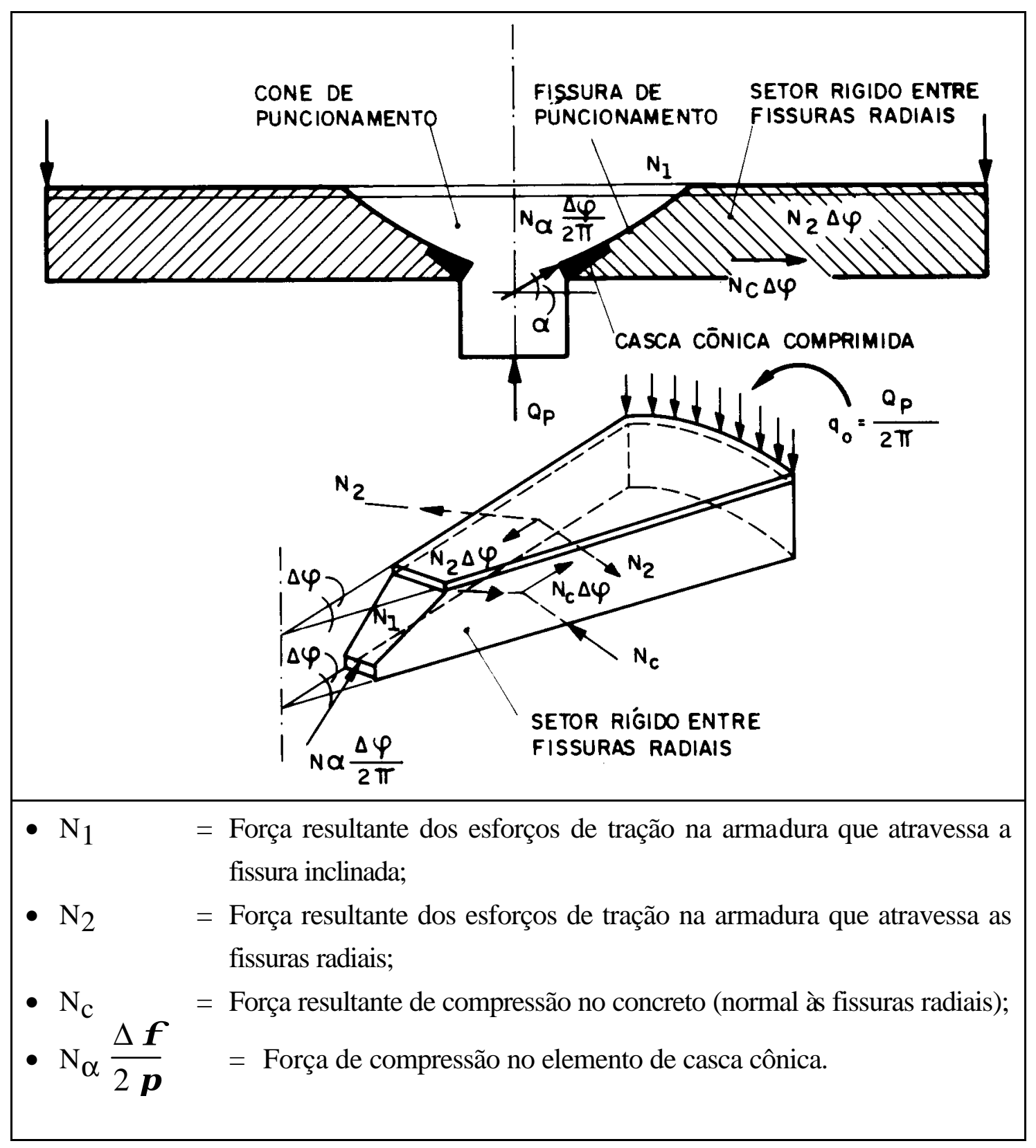

Figura 2.47- Exemplo de modelo mecânico 


\section{INVESTIGAÇÃO EXPERIMENTAL}

São apresentados os materiais, os equipamentos e os procedimentos usados no desenvolvimento deste trabalho. Foram ensaiados "elementos-de-laje", cujas vantagens e desvantagens já foram mencionadas no item 2.4.1 do capítulo 2 .

\subsection{DIMENSÕES DOS MODELOS E ESQUEMA DO ENSAIO}

Foram ensaiados modelos de concreto armado e de concreto protendido, com e sem armadura de punção.

Para aplicar a protensão, foram usadas cordoalhas engraxadas tipo CP-190 RB 7, com diâmetro nominal de $12,7 \mathrm{~mm}$, gentilmente cedidas pela Companhia Siderúrgica Belgo-Mineira.

Nos modelos com armadura de punção, foram usados conectores tipo pino, dispostos radialmente com relação à chapa usada para a aplicar a força concentrada aos modelos. Foram usadas duas e três linhas de conectores.

Todos os modelos ensaiados, mostrados na tabela 3.1, foram constituídos por lajes quadradas que apresentavam recortes na região dos cantos. Esses recortes foram feitos de modo a possibilitar uma determinada inclinação da face lateral da laje.

Essa inclinação teve como objetivo diminuir a magnitude da componente vertical da força de protensão aplicada na extremidade da cordoalha. A espessura da laje foi de $160 \mathrm{~mm}$. 
Tabela 3.1 - Características dos modelos

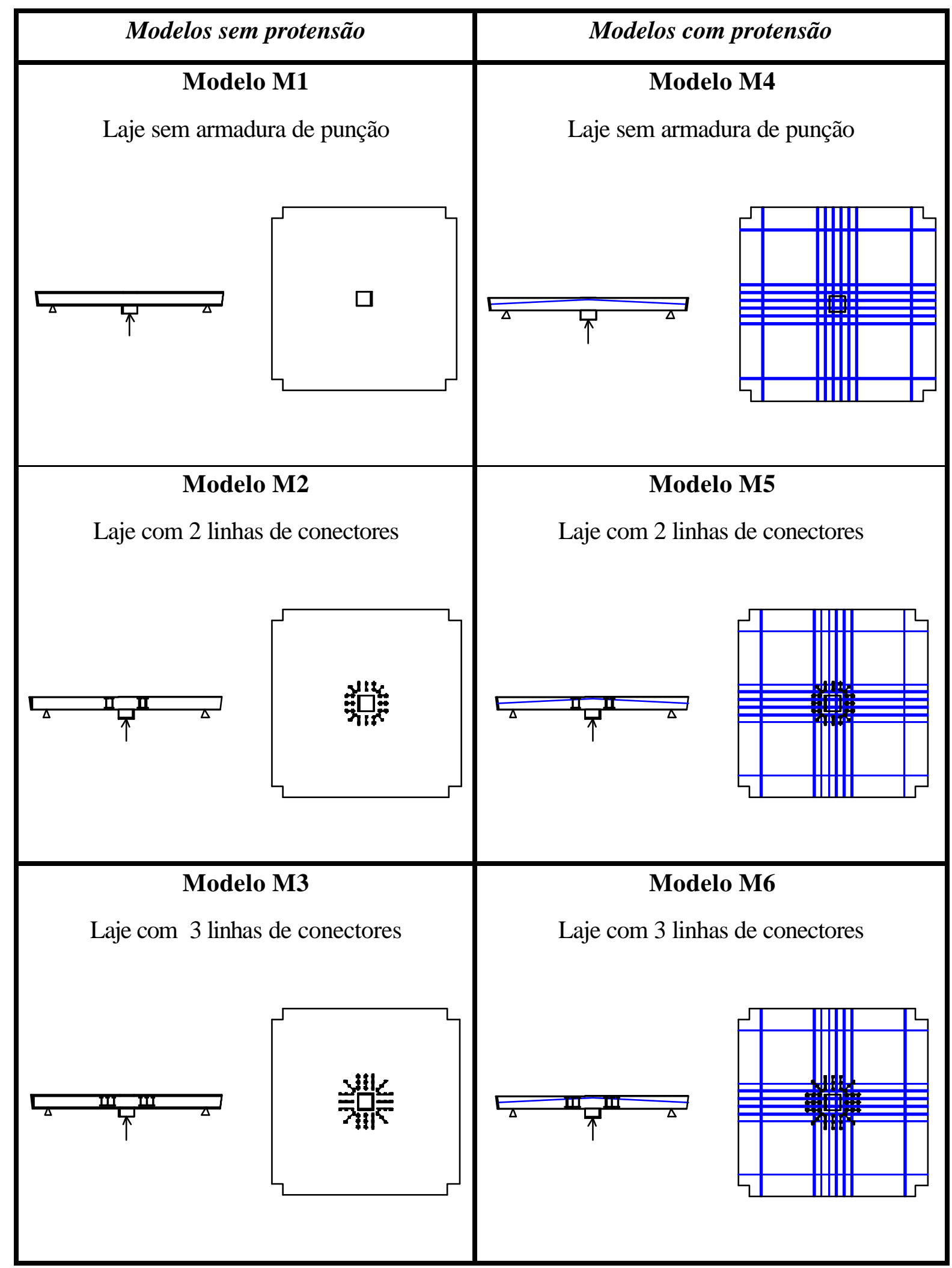


As bordas estavam atirantadas à laje de reação através de um sistema de tirantes e vigas metálicas. O vãa entre as linhas de apoio foi considerado como sendo de aproximadamente $\mathbf{2 1 0 0} \mathbf{~ m m}$, para cada direção (figura 3.1). A força concentrada foi aplicada através de uma chapa de aço, quadrada, com $180 \mathrm{~mm}$ de lado e $120 \mathrm{~mm}$ de espessura. Estas dimensões são válidas para todos os modelos.

A resistência média do concreto foi de aproximadamente $50 \mathrm{MPa}$. No entanto, o concreto usado no primeiro modelo não atingiu este valor, devido a um problema no superplastificante usado pela empresa fornecedora de concreto.

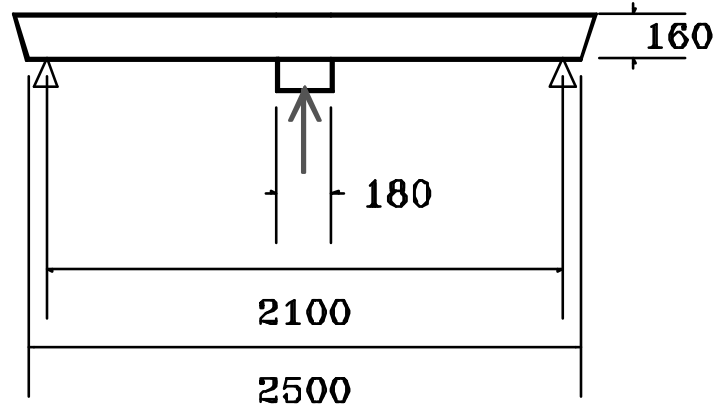

a) Corte no meio do vão

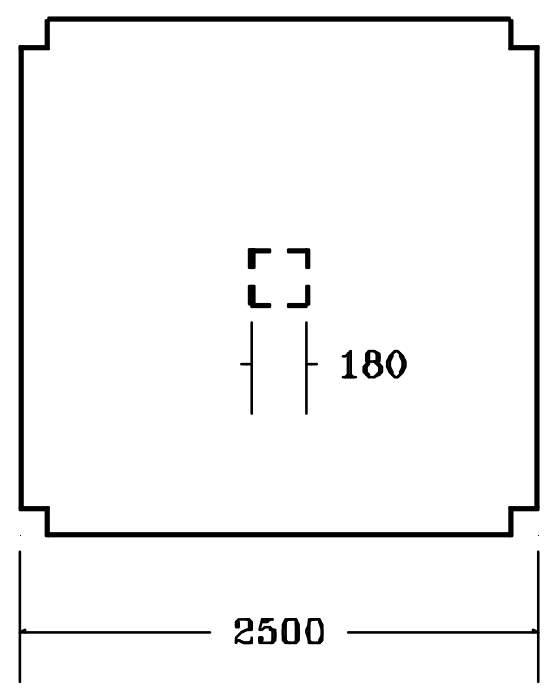

b) Planta

Figura 3.1 - Dimensões gerais do "elemento-de-laje" (em mm)

BORGES \& LIMA* apud MARTINELLI (1974) mencionam que uma redução do protótipo até $1 / 4$ assegura muito boa reprodução dos fenômenos fortemente dependentes da fissuração. Como exemplo, algumas correlações entre as dimensões adotadas no modelo e valores reais são apresentadas na tabela 3.2.

\footnotetext{
* BORGES, J.F.; LIMA, J.A. (1961) Crack and deformation similitude in reinforced concrete. Laboratório Nacional de Engenharia Civil, LNEC, Lisboa, Memória no. 162, p.1-12 apud MARTINELLI, D.A. et al. (1974). Sobre a ruína das ligações laje-pilar nos cantos de lajescogumelo. São Carlos. Tese (Livre-Docência), Escola de Engenharia de São Carlos, Universidade de São Paulo.
} 
Tabela 3.2 - Dimensões adotadas nos modelos e algumas das proporções usadas para a sua correlação com estruturas reais

\begin{tabular}{|c|c|c|c|c|}
\hline $\begin{array}{c}\text { Dimensões } \\
(\mathrm{cm})\end{array}$ & Modelo & $\begin{array}{c}\text { Proporção } \\
\mathbf{1 : 1 , 5}\end{array}$ & Proporção 1:2 & $\begin{array}{c}\text { Proporção } \\
\mathbf{1 : 2 , 5}\end{array}$ \\
\hline Lado do pilar & 18 & 27 & 36 & 45 \\
\hline Espess. da laje & 16 & 24 & 32 & 40 \\
\hline Vão - pilares & 477 & 716 & 954 & 1193 \\
\hline
\end{tabular}

Nos modelos de concreto armado, após a ruptura por punção, os macacos continuaram aplicando carga, visando avaliar o comportamento do modelo após a ruptura. Nos modelos protendidos, imediatamente após a ruptura do modelo M4, o carregamento foi interrompido. Nos modelos M5 e M6, o carregamento permaneceu sendo aplicado após a ruptura. No modelo M5, as cordoalhas foram desprotendidas antes que fosse dada continuidade ao carregamento. Já no modelo M6, as cordoalhas permaneceram protendidas durante o carregamento pós-ruptura.

Nas figuras 3.2 a 3.8, têm-se os esquemas e as fotos que ilustram como foram realizados os ensaios.

Inicialmente, as porcas que fixavam as vigas inferiores à laje de reação foram bem apertadas, de modo a se eliminar qualquer folga entre a laje de reação e as vigas mencionadas.

Também foram eliminadas as folgas entre os tirantes que transferiam o carregamento das vigas superiores às inferiores, através do aperto de porcas localizadas entre as vigas inferiores e a laje de reação (este procedimento também foi feito após a colocação do modelo no sistema de reação).

Estes procedimentos tiveram como objetivo eliminar o problema do peso próprio das vigas inferiores, de modo que, quando o carregamento fosse aplicado ao modelo, esta ação estaria sendo imediatamente transferida à laje de reação.

A seguir, foram posicionadas chapas metálicas, através de porcas, que tiveram a função de apoiar o modelo nos tirantes.

Após colocar o modelo em cima dessas chapas, foram posicionadas as vigas superiores, sem, no entanto, apertar as porcas, permitindo que o modelo se movimentasse verticalmente quando o carregamento fosse aplicado. 
Para uma melhor distribuição dos esforços, essas vigas foram assentadas sobre uma camada de groute, feita com o Eucogrout-49, do grupo Holdercim.

O carregamento, de baixo para cima, foi aplicado através de dois macacos hidráulicos, com capacidade para 100 toneladas cada um, até que a força aplicada pelos macacos se igualasse à soma dos pesos próprios da laje e das vigas superiores.

Para que o modelo ficasse apoiado apenas nos macacos, foram soltas as porcas que o fixavam nas chapas metálicas.

A seguir, as leituras relacionadas aos extensômetros, aos defletômetros e às células de carga foram zeradas. Por fim, foram apertadas as porcas das vigas superiores, de modo gradual e seqüencial, sem o auxílio de instrumentos, visando apenas a eliminação de folgas. Após este procedimento, teve-se o início do ensaio propriamente dito.

As vigas superiores proporcionaram aos modelos um vão livre (distância de face à face da viga) de $1898 \mathbf{~ m m}$.

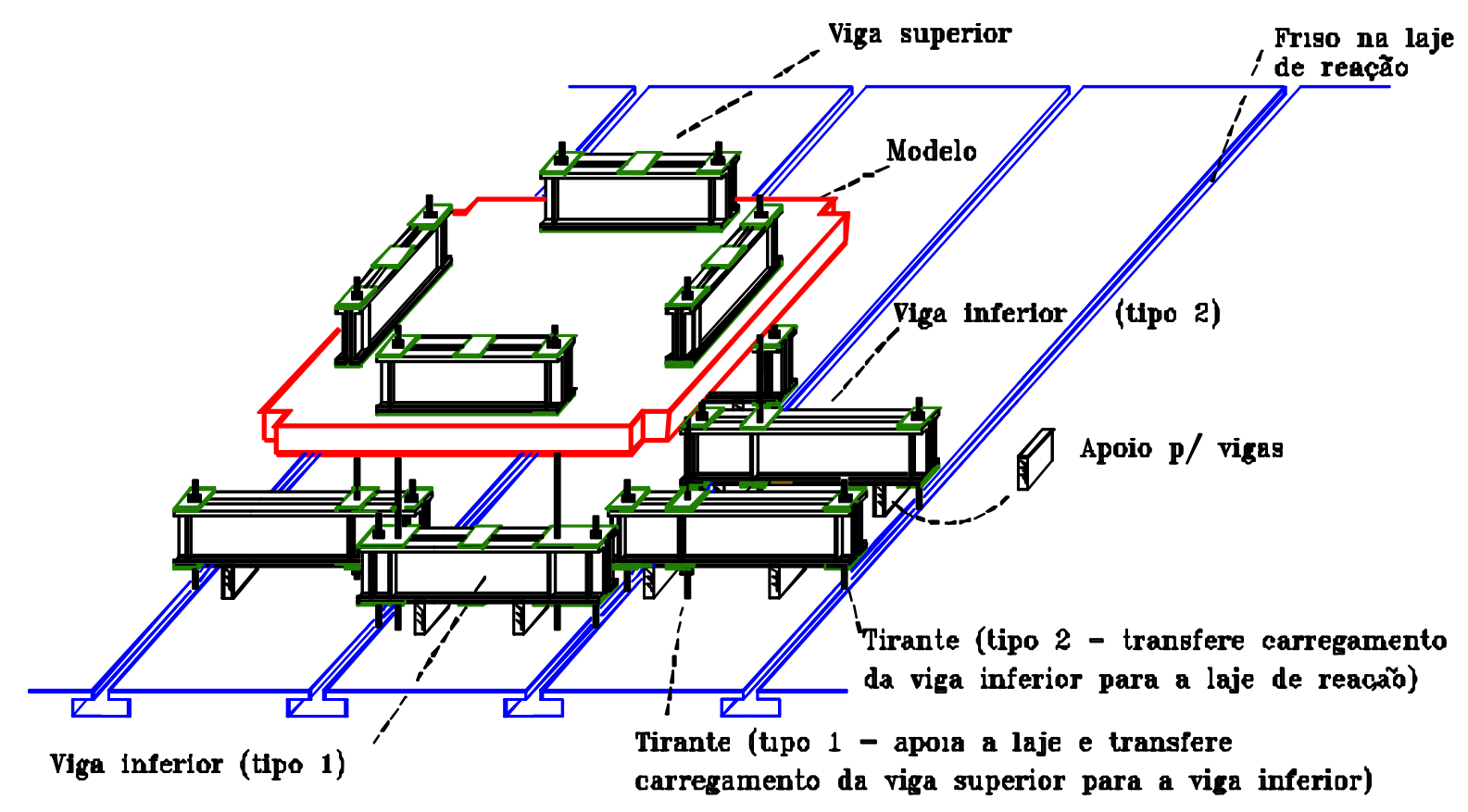

Figura 3.2 - Esquema geral do ensaio 


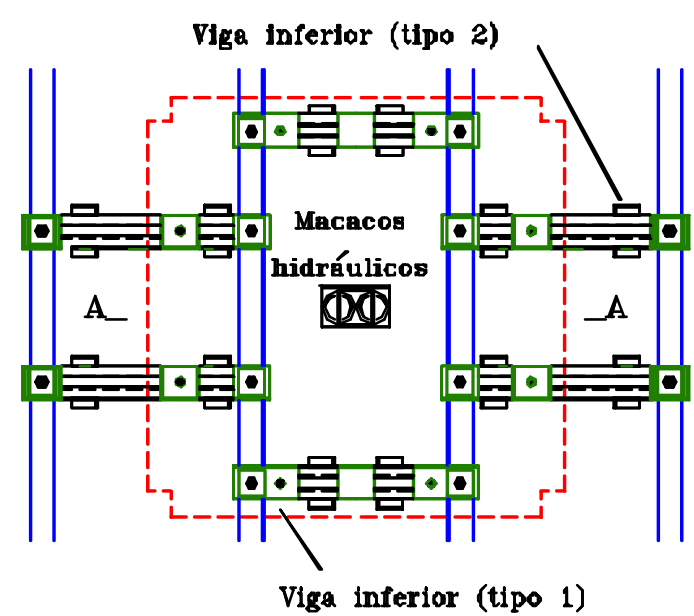

Figura 3.3 - Planta

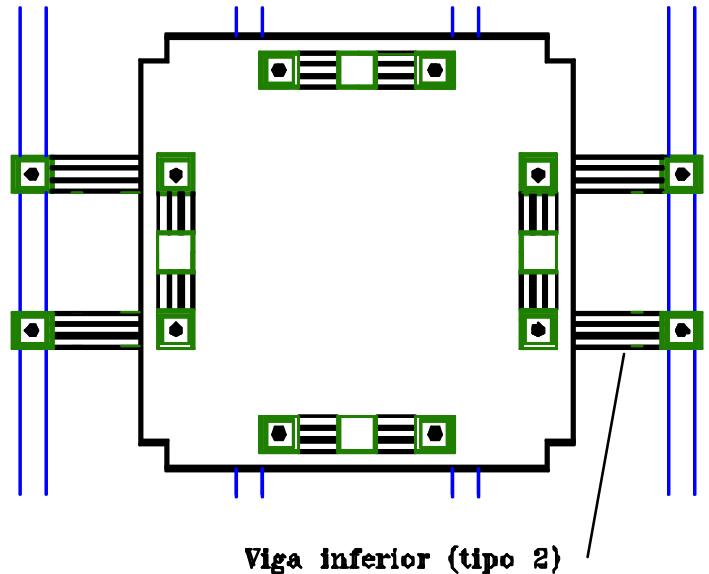

Figura 3.4 - Vista superior

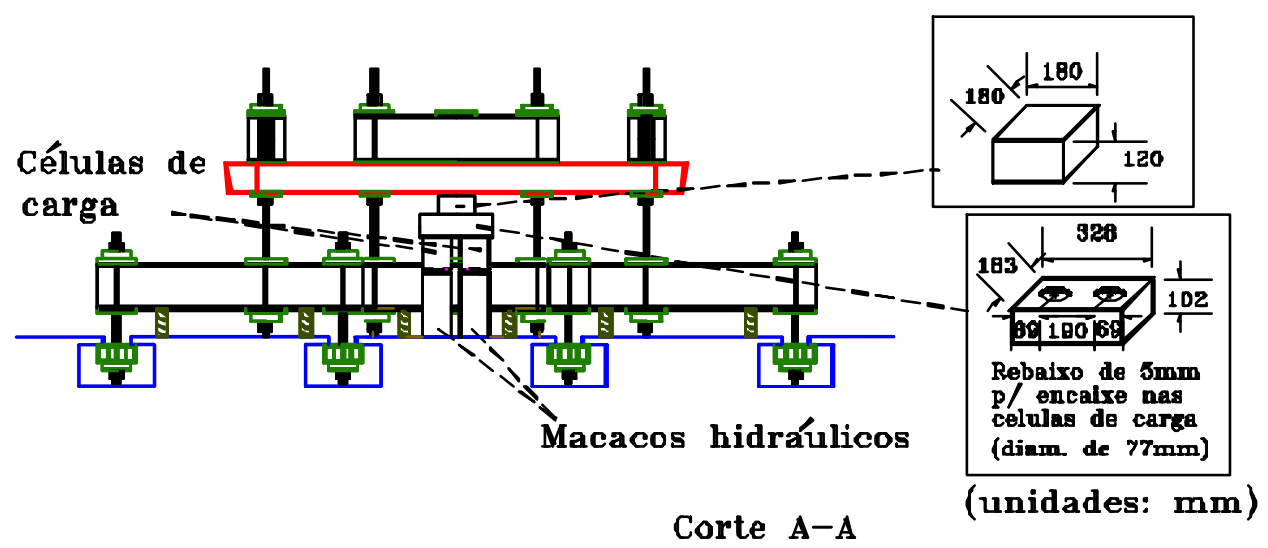

Figura 3.5 - Corte A-A e detalhamento das chapas metálicas usadas para a aplicação do carregamento

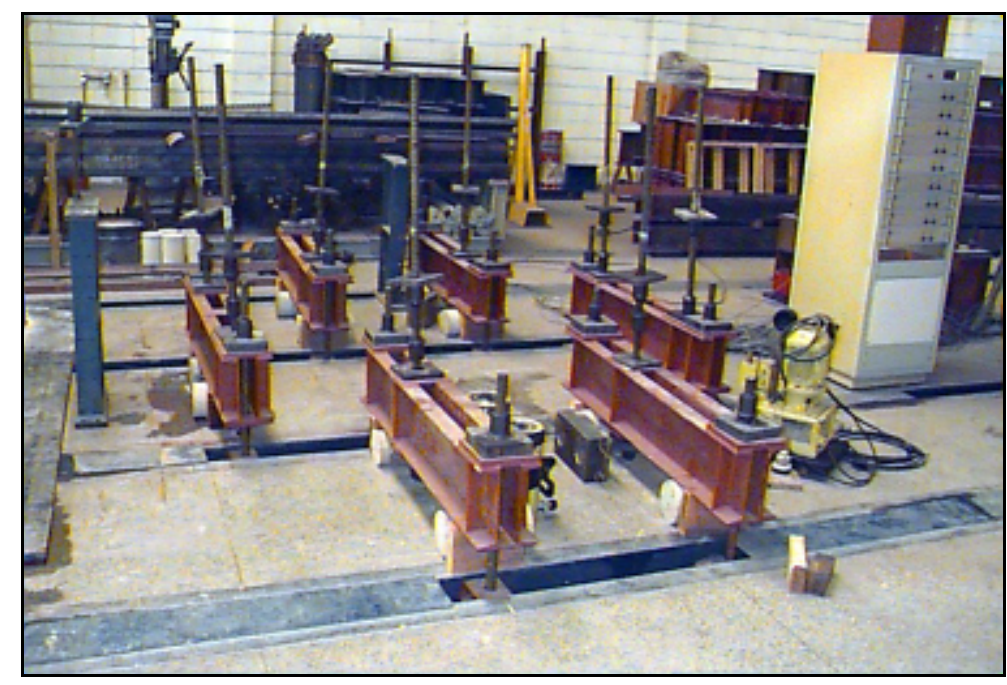

Figura 3.6 - Vista em perspectiva do sistema de reação 


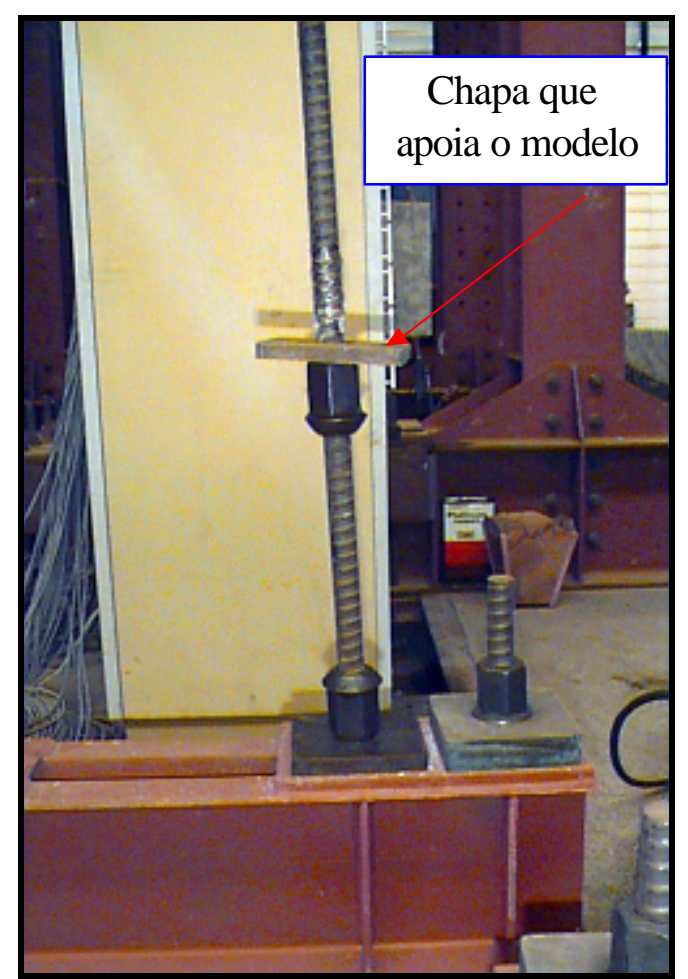

a) Chapas usadas para apoiar o modelo nos tirantes

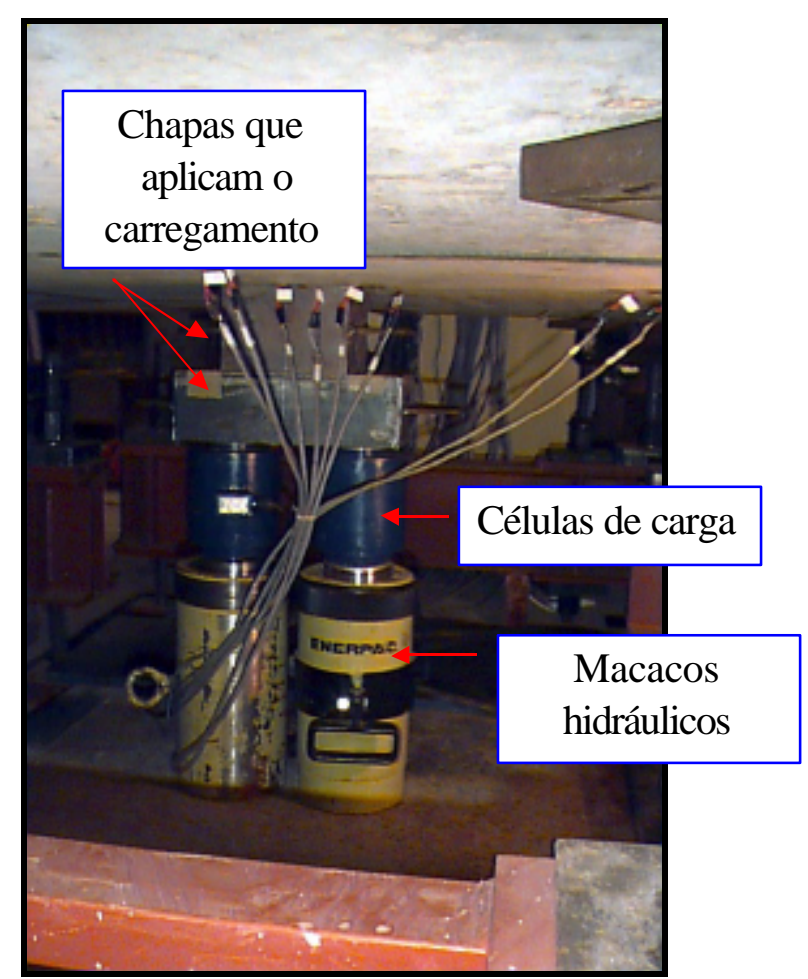

b) Chapas usadas para aplicar o carregamento no modelo

Figura 3.7 - Detalhes das chapas metálicas usadas no ensaio

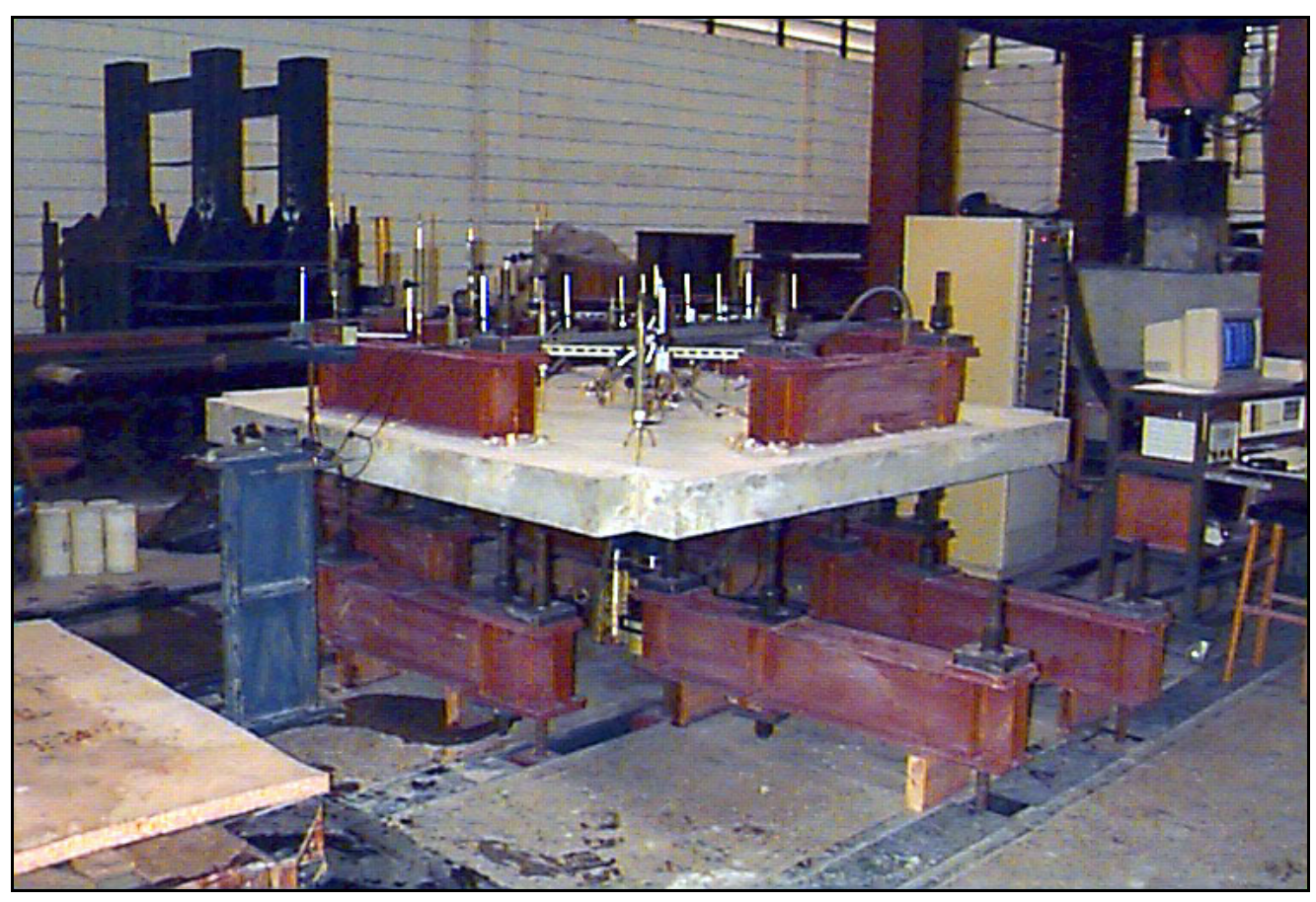

Figura 3.8 - Sistema de reação montado, com modelo de concreto armado pronto para ser ensaiado 
As vigas metálicas foram feitas com perfis metálicos tipo " $C$ " de 10 polegadas $(22,8$ $\mathrm{kg} / \mathrm{m}$ ) e o seu dimensionamento foi feito com o auxílio do Prof. Dr. Maximiliano Malite, do Departamento de Engenharia de Estruturas. No Anexo A são apresentados maiores detalhes sobre o sistema de reação.

Para medir as deformações nas armaduras de flexão e de cisalhamento, e também no concreto, foram usados extensômetros ("strain gauges") com comprimentos iguais a, respectivamente, $5 \mathrm{~mm}, 5 \mathrm{~mm}, 10 \mathrm{~mm}$. Para a medição da força aplicada pelos macacos hidráulicos ao modelo, foram usadas células de carga, já mostradas na figura 3.7b.

Já para medir a força aplicada no concreto pela cordoalha de protensão, foi usada a célula de carga mostrada na figura 3.9. Esta célula foi colocada entre o porta-cunhas e a chapa metálica usada para distribuir a força de protensão no concreto (figura 3.10).

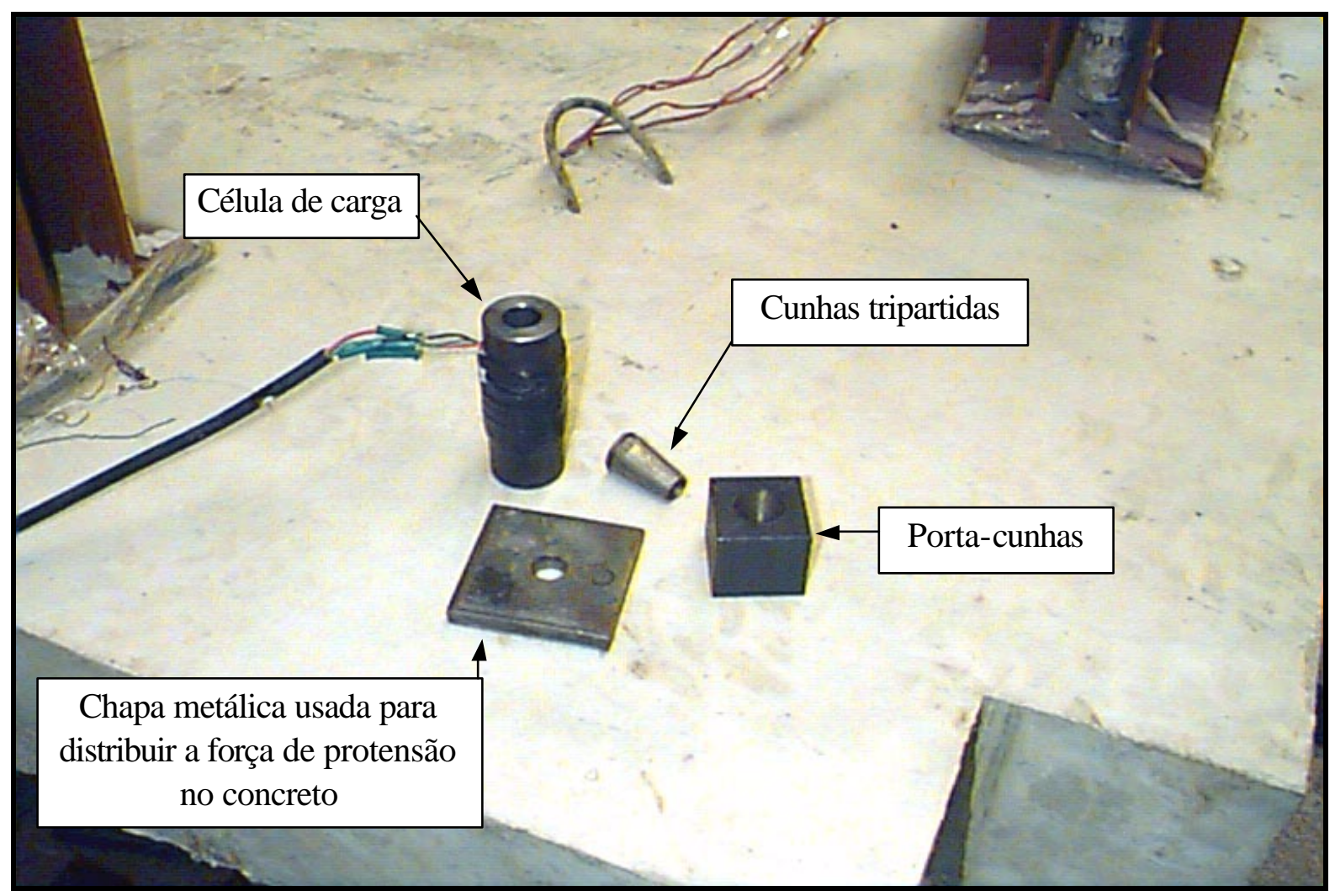

Figura 3.9 - Célula de carga, cunhas, porta-cunhas e chapa metálica usada para distribuir a força de protensão no concreto 
A ancoragem nesta extremidade da cordoalha foi considerada como sendo passiva, já que a força de protensão aplicada pelo macaco foi feita na outra extremidade (figura 3.11).

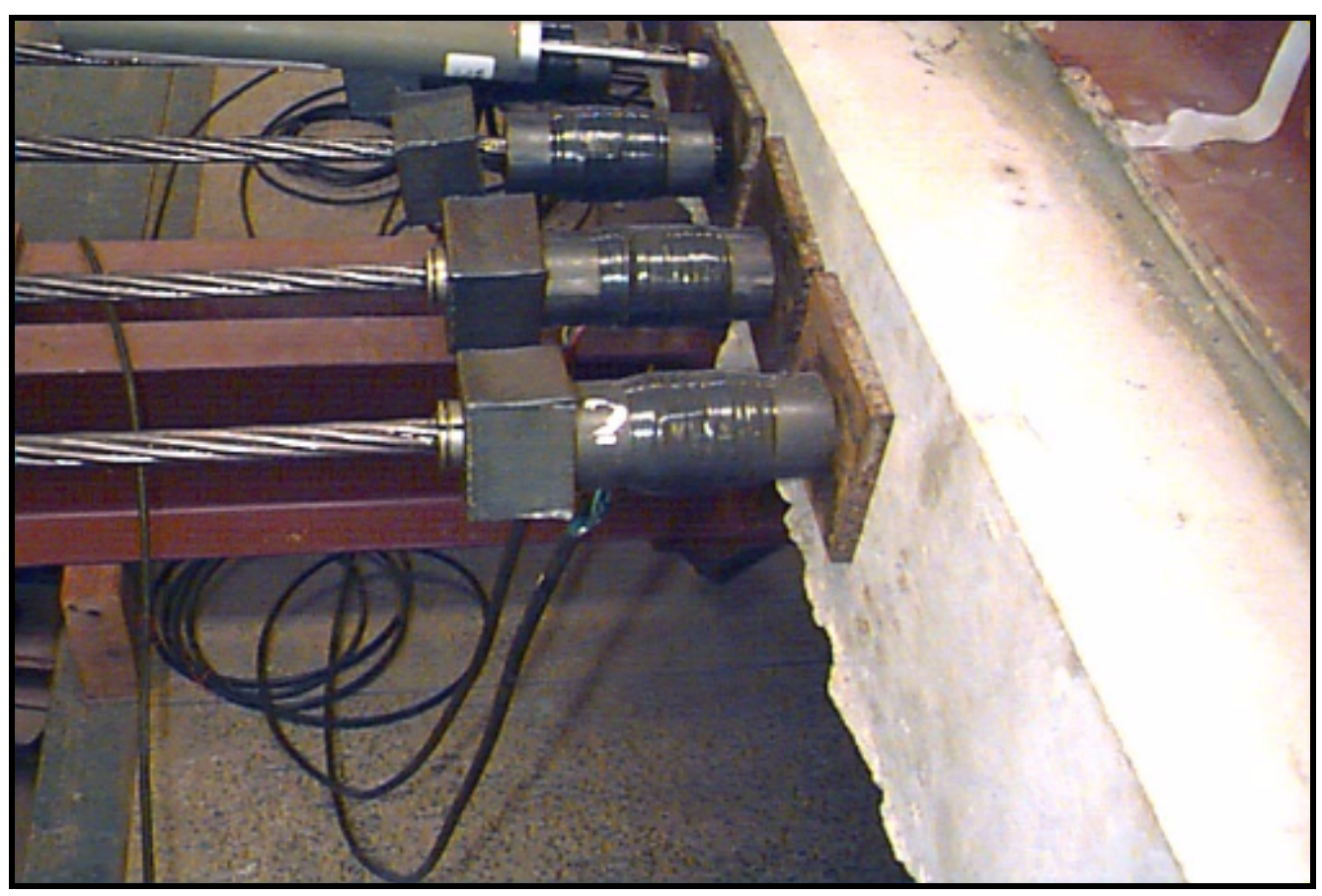

Figura 3.10 - Detalhe da montagem do sistema de ancoragem passiva

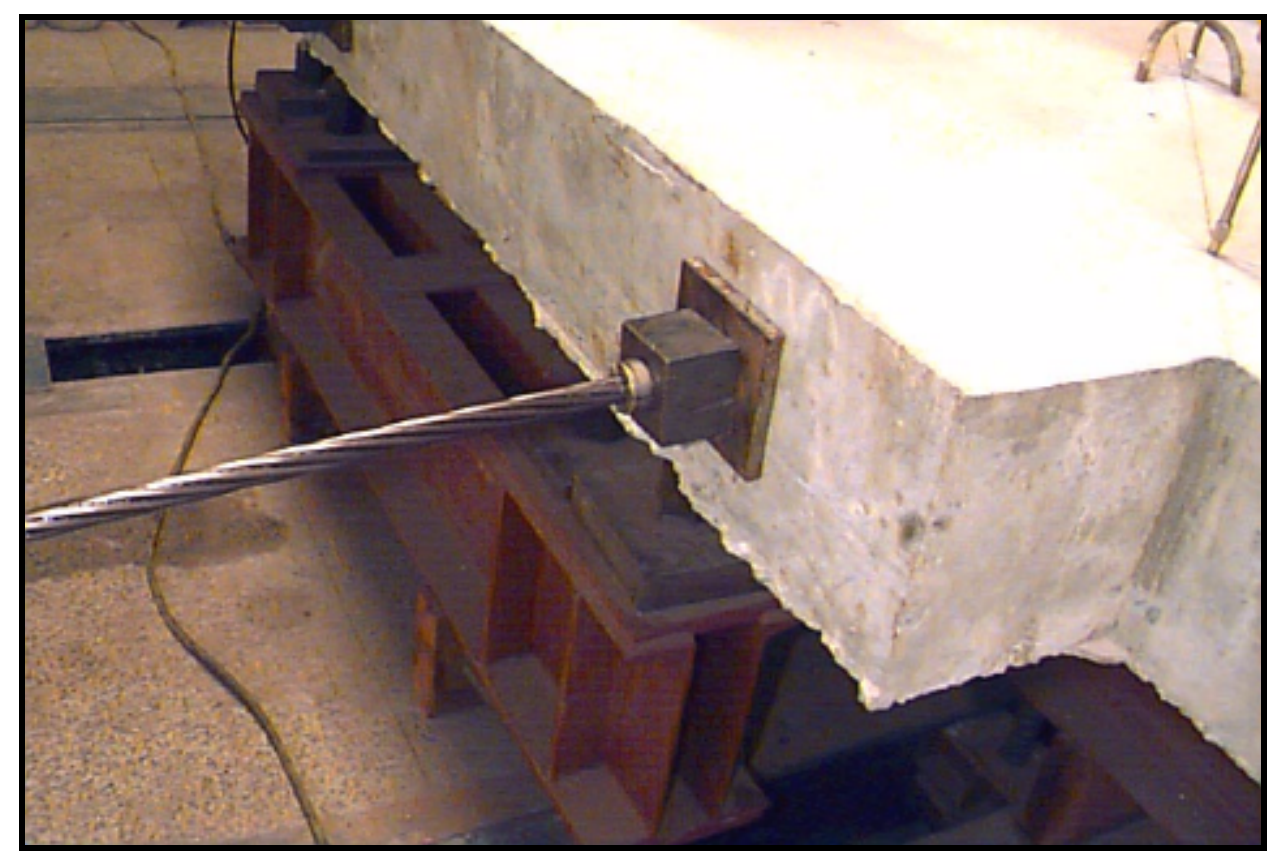

Figura 3.11 - Detalhe da montagem do sistema de ancoragem ativa 
Todos os extensômetros usados foram da marca Kyowa.

Para a medição dos deslocamentos, foram usados transdutores com curso de $100 \mathrm{~mm}$ e sensibilidade da ordem de 0,05 mm, também da marca Kyowa.

O sistema de aquisição de dados foi o System 4000, da Measurements Group. Este sistema bem como a bomba elétrica com acionador manual estão mostradas na figura 3.12 .

Todos os equipamentos usados para a protensão dos modelos, bem como a valiosa orientação técnica, foram gentilmente cedidos pela empresa MAC-Sistema Brasileiro de Protensão Ltda.

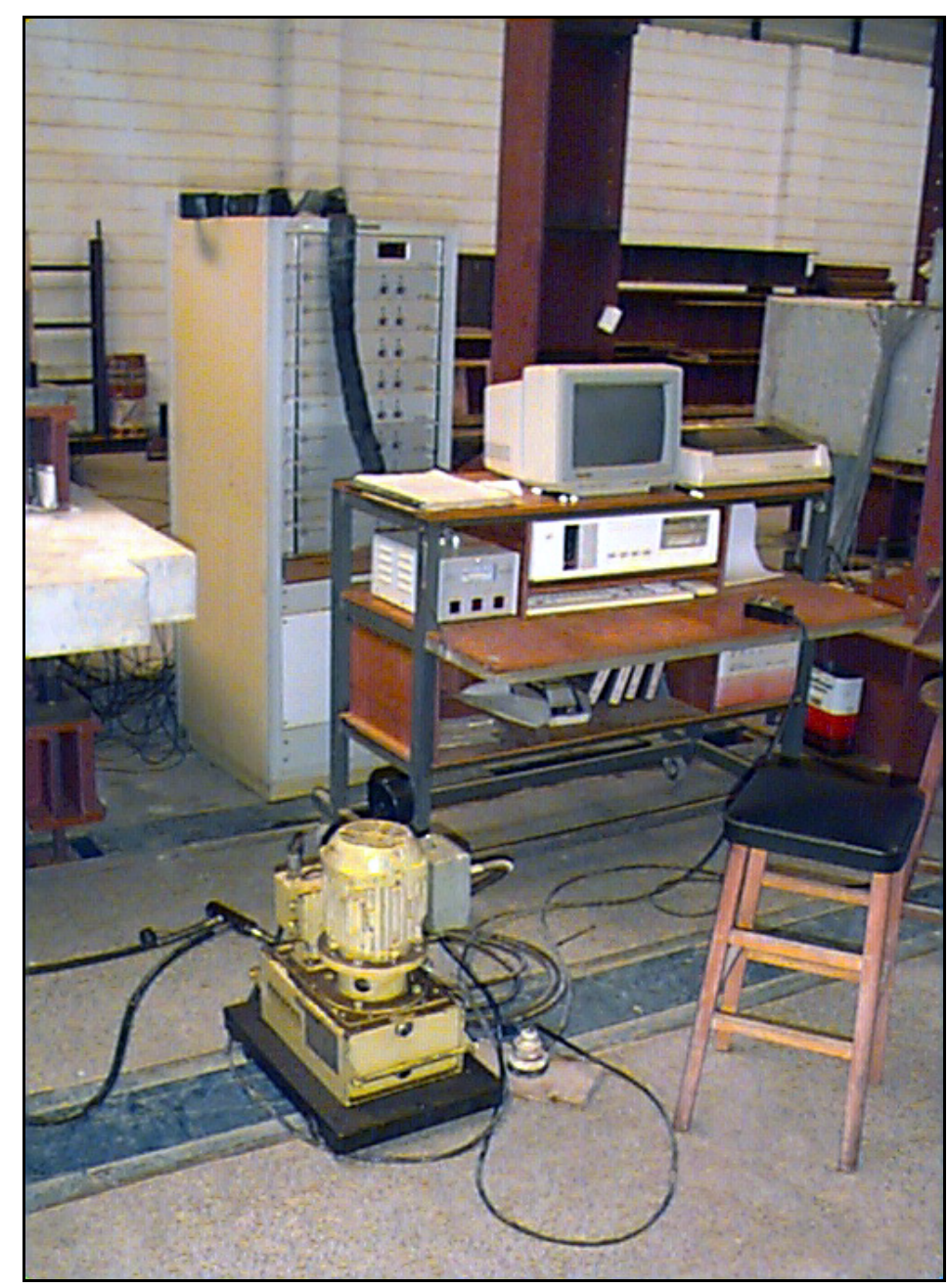

Figura 3.12 - Sistema de aquisição de dados e bomba elétrica 
A força total foi aplicada nos modelos em etapas de $10 \mathrm{kN}$, até que se observasse a primeira fissura. A partir deste instante, o incremento passou a ser de $50 \mathrm{kN}$. Após cada etapa de carregamento, foi feito um período de espera de 5 minutos, tempo este usado para a estabilização do carregamento e também para a marcação das fissuras.

Nos modelos protendidos (figura 3.13), antes que se fizesse a protensão, foi aplicada uma força ao modelo. Este procedimento teve, como finalidade, evitar que o efeito da protensão fissurasse o modelo na região a ser posteriormente comprimida pela ação do carregamento. Para o modelo M4, esta força, descontando-se o valor do peso próprio, foi de $80 \mathrm{kN}$. Já para os modelos M5 e M6, esta força foi aumentada para $150 \mathrm{kN}$, descontando-se o valor do peso próprio.

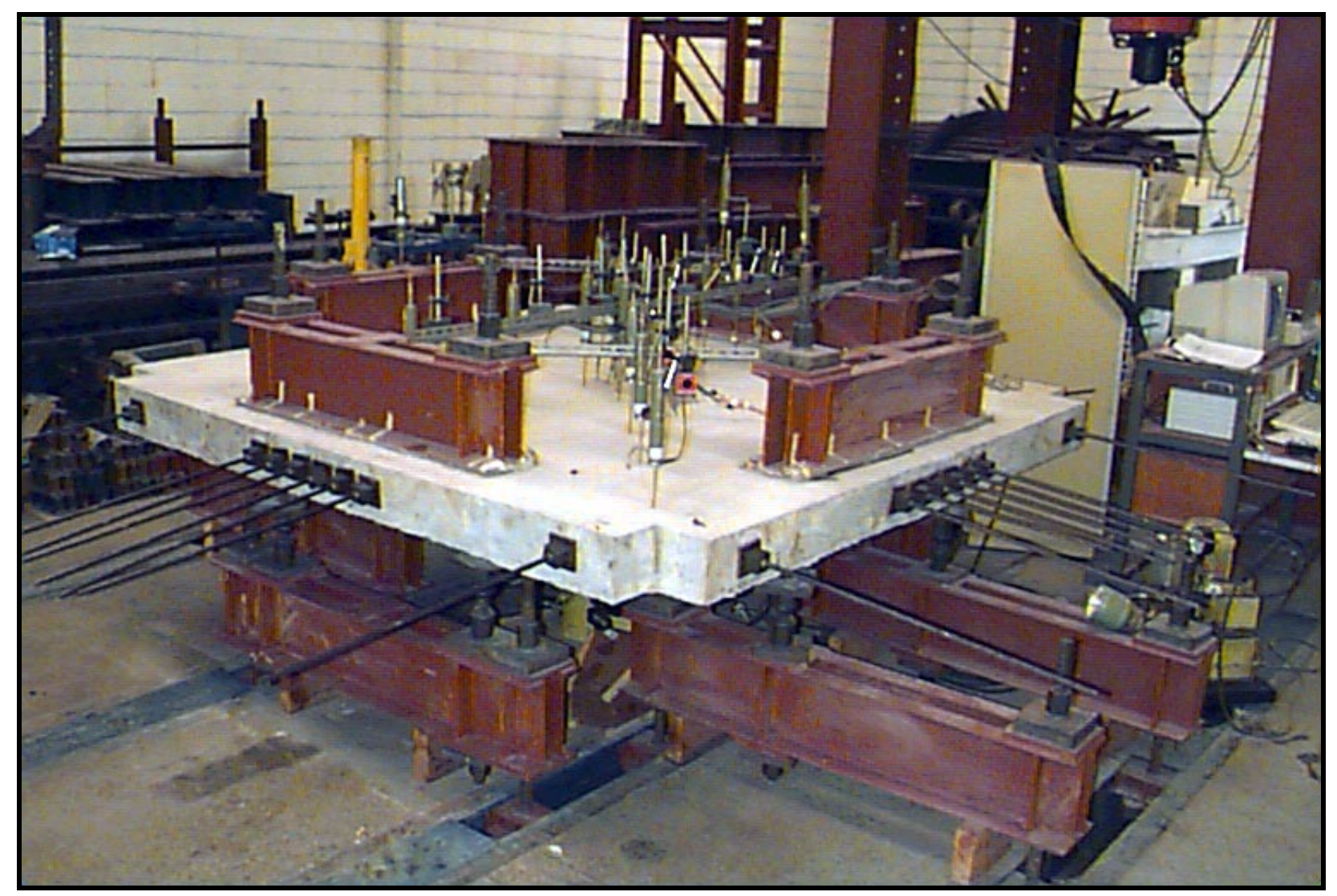

Figura 3.13 - Modelo de concreto protendido 
O ensaio teve uma duração média de dois dias. No primeiro dia, realizavam-se o pré-carregamento no modelo e a protensão das cordoalhas. No segundo dia, recuperavam-se as perdas de protensão e dava-se prosseguimento ao carregamento. Inicialmente foram protendidas as cordoalhas posicionadas na região central do modelo e, a seguir, as cordoalhas mais próximas da borda. Fez-se a protensão em uma direção e depois na outra.

O procedimento da protensão das cordoalhas é descrito a seguir:

a) posicionamento das cunhas dentro do porta-cunhas, tanto na extremidade ativa como na extremidade passiva (figura 3.14);

b) aplicação da protensão junto à ancoragem ativa (figura 3.15). Neste caso, a cravação das cunhas no dispositivo de ancoragem se dá através do alívio da força de protensão na cordoalha;

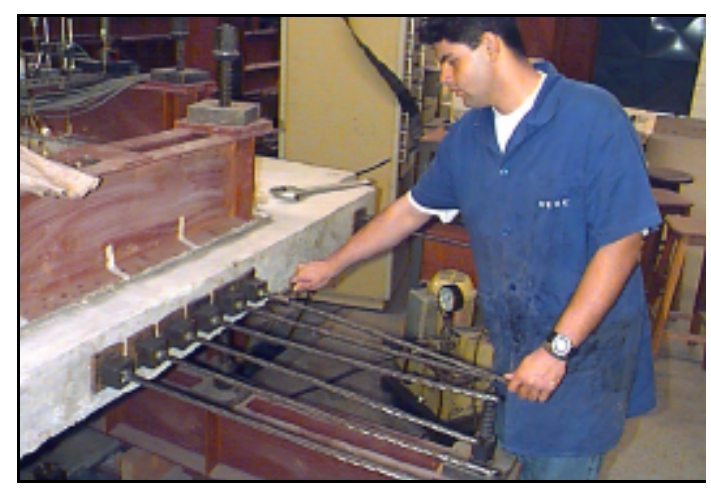

Figura 3.14 - Posicionamento das cunhas

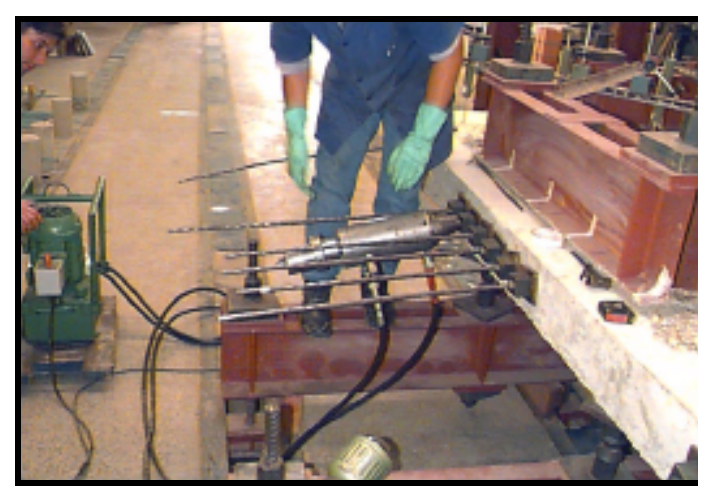

Figura 3.15 - Aplicação da protensão na extremidade com ancoragem ativa

c) em função do pequeno comprimento da cordoalha (aproximadamente 2,5 m), é significativa a perda de protensão provocada pela penetração das cunhas no dispositivo de ancoragem. Sendo assim, para recuperar parte da perda de protensão, reprotendeu-se a cordoalha utilizando-se uma "mesa", mostrada na figura 3.16. Na figura 3.17, pode-se observar a folga entre o porta-cunhas e a chapa metálica usada para distribuir a força de protensão no concreto; 


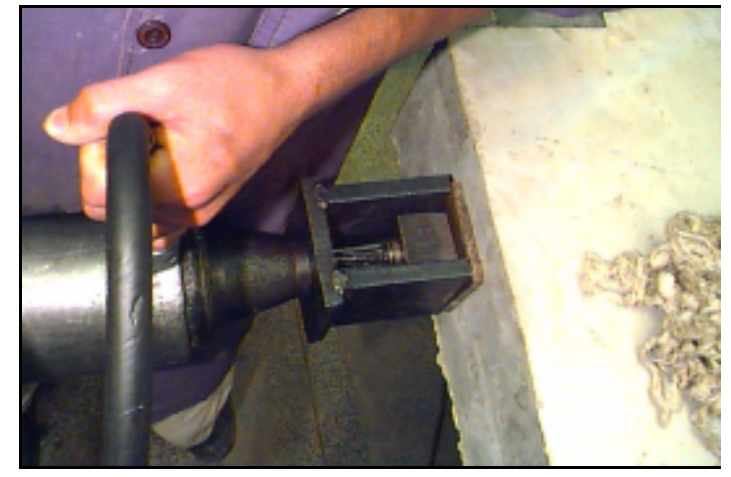

Figura 3.16 - Detalhe da "mesa" de protensão

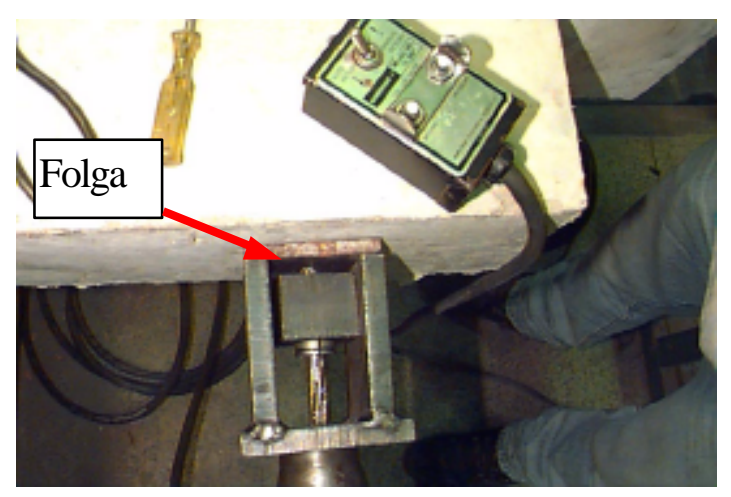

Figura 3.17 - Folga no dispositivo de ancoragem ativa

d) Preencheu-se, então, esta folga com pequenas chapas metálicas (figura 3.18). Na figura 3.19, tem-se a ancoragem ativa, já recuperada da perda de protensão. Após a aplicação da protensão, reiniciou-se o carregamento no modelo até a sua ruptura.

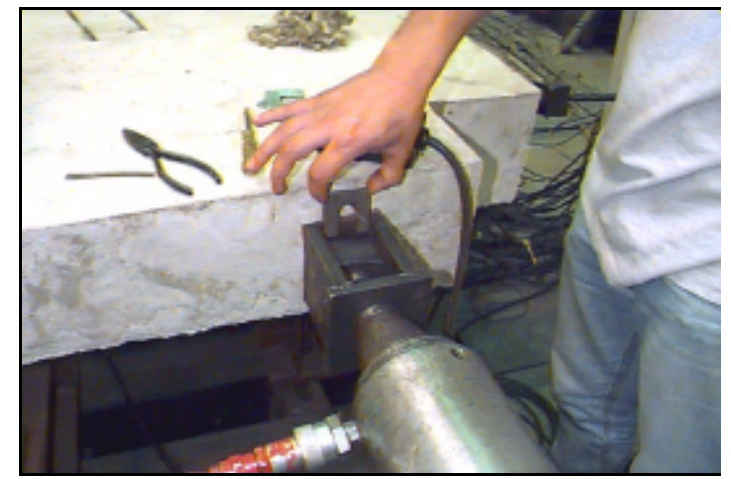

Figura 3.18 - Preenchimento da folga com chapas metálicas

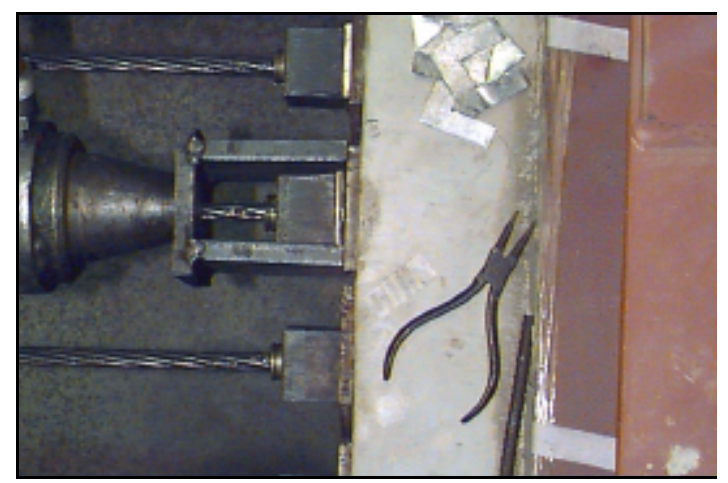

Figura 3.19 - Ancoragem ativa com chapas metálicas

Para a reutilização das células de carga relativas às cordoalhas, foi necessário descravar as cunhas do porta-cunhas. Este procedimento é descrito a seguir:

a) aplicação da protensão na cordoalha através da "mesa" para a retirada das chapas metálicas usadas para recuperar a perda de protensão; 
b) com o auxílio de um "descravador" (figura 3.20), faz-se novamente a protensão da cordoalha e, com uma pequena chave-de-fenda, retiram-se as cunhas de dentro do porta-cunhas (figura 3.21);

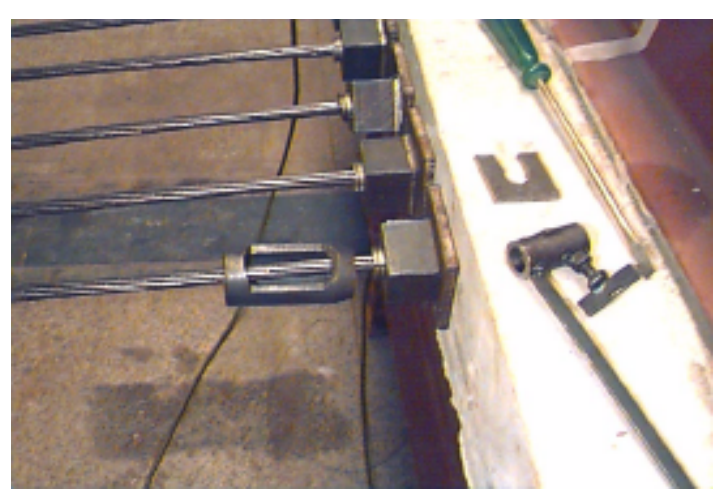

Figura 3.20 - "Descravador"

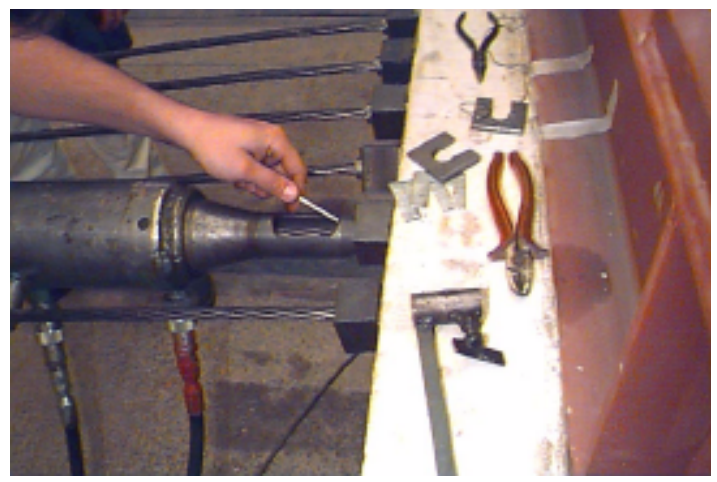

Figura 3.21 - Retirada das cunhas

c) para liberar a célula de carga sem ter que retirar a cordoalha de dentro da laje, posiciona-se o macaco junto à extremidade passiva e puxa-se a cordoalha. Com isso, as cunhas são arrancadas do porta-cunhas, liberando também esta extremidade da cordoalha. É necessário, no entanto, que, nesta extremidade, o comprimento da cordoalha seja suficiente para a ancoragem do macaco.

Durante a etapa de protensão, algumas cordoalhas romperam, provavelmente em função da elevada força aplicada à cordoalha e do pequeno alongamento desta. Geralmente a ruptura da cordoalha era caracterizada pela ruptura de um dos fios, provocando uma defasagem entre eles (figura 3.22).

A ruptura ora se localizou na extremidade ativa (na posição onde o macaco realizava a protensão), ora se localizou na extremidade passiva (posição onde a cordoalha foi instrumentada com uma célula de carga). Para a liberação do macaco, foi necessário cortar as cordoalhas rompidas (figura 3.23) e substituí-las (figura 3.24). 


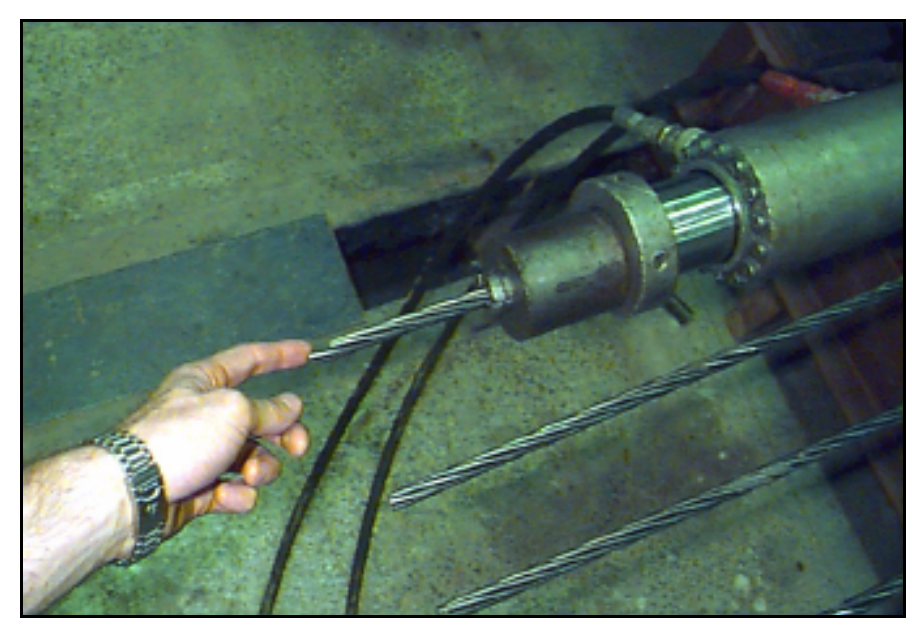

Figura 3.22 - Ruptura da cordoalha, provocando uma defasagem entre os fios

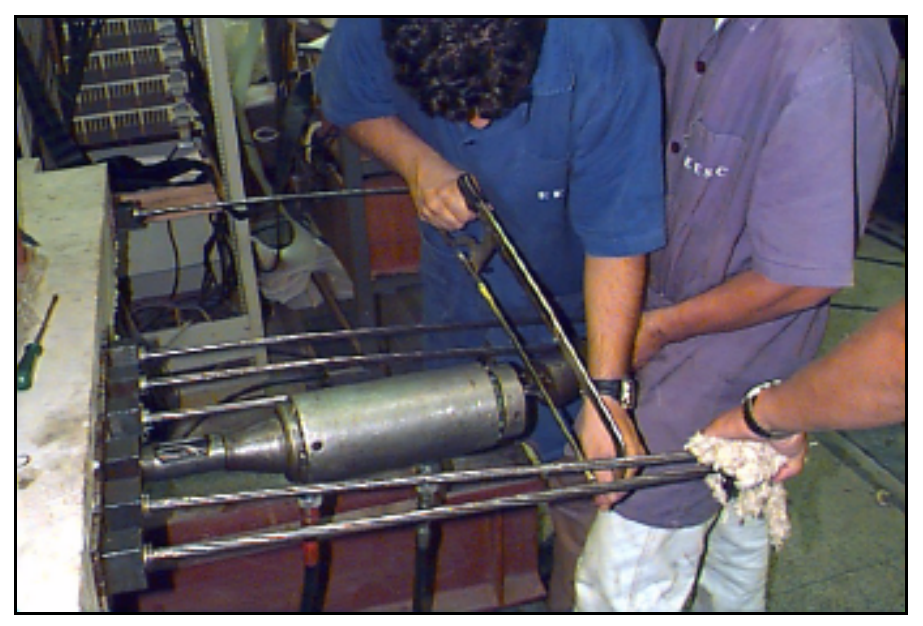

Figura 3.23 - Corte de uma cordoalha rompida, visando liberar o macaco

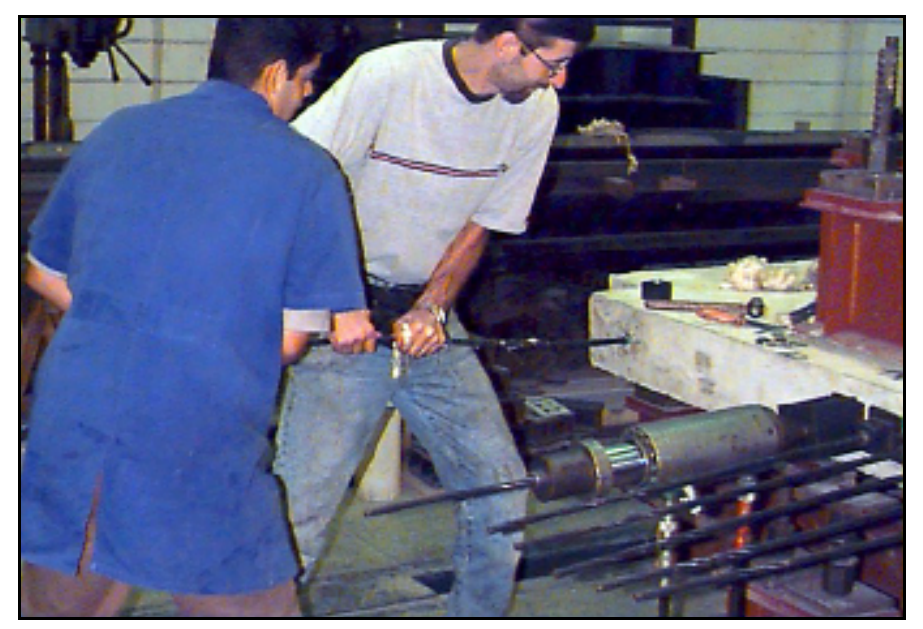

Figura 3.24 - Substituição da cordoalha rompida 


\subsection{FôRMA}

As lajes foram moldadas em fôrmas de madeira plastificada, devidamente untadas com uma camada de óleo desmoldante.

As laterais da laje foram projetadas inclinadas, de modo a não produzir forças verticais significativas na extremidade da cordoalha.

Foi adotada a mesma inclinação tanto com relação à direção x, como com relação à direção y, sendo esta igual a $1,79^{\circ}$. O esquema geral está mostrado na figura 3.25.

$\mathrm{Na}$ figura 3.26, tem-se o esquema utilizado para a fixação dos tubos de PVC, usados como fôrma para os furos que serviram para a passagem dos tirantes. Neste caso, "arruelas" feitas com madeira compensada foram fixadas ao estrado de madeira e à face da fôrma, de modo que os tubos de PVC ficaram perfeitamente encaixados (figura 3.27). Na figura 3.28, tem-se uma foto da fôrma já pronta. Outros detalhes sobre a execução da fôrma podem ser vistos no Anexo B.

Após a concretagem dos modelos de concreto armado, para que se pudesse concretar os modelos protendidos, foi necessário realizar algumas modificações na fôrma. Para facilitar a desforma, a primeira modificação foi fixar as peças dos cantos na face inferior da fôrma, utilizando-se cantoneiras metálicas (figura 3.29).
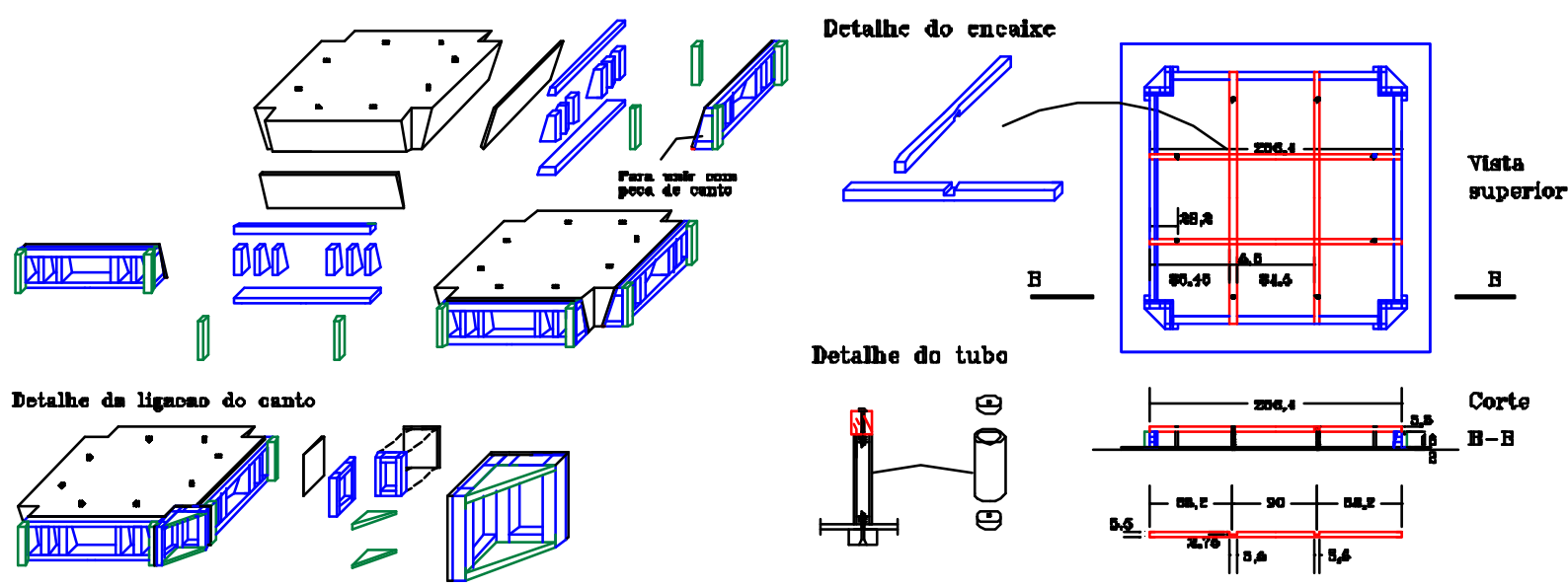

Figura 3.25 - Desenho esquemático sem escala

Figura 3.26 - Posição dos furos 

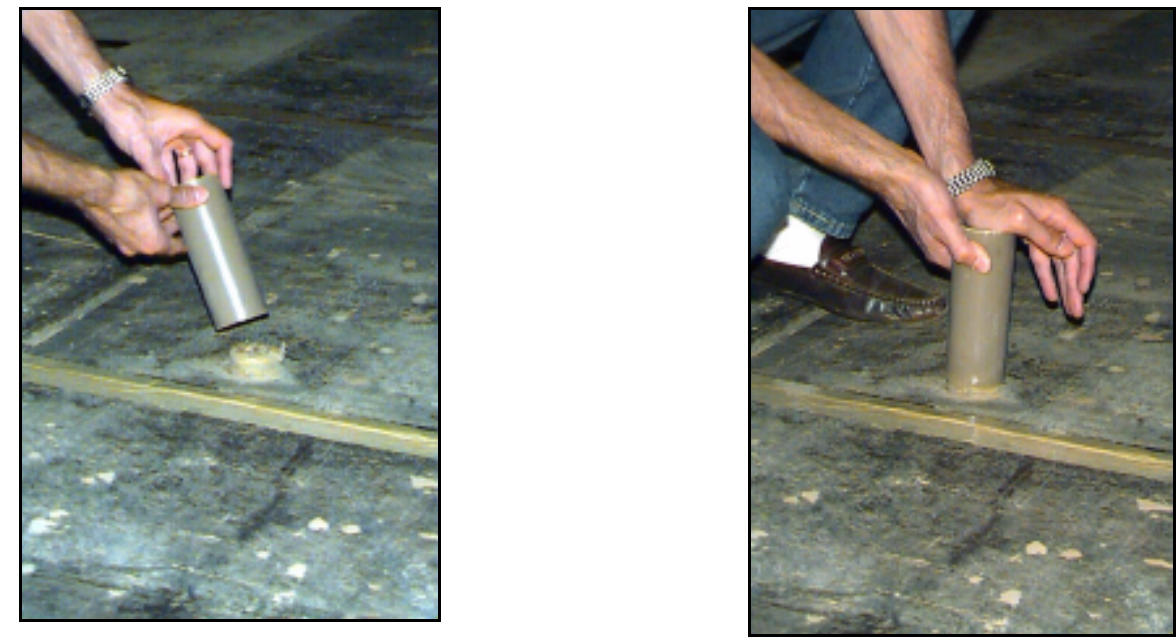

Figura 3.27 - Encaixe do tubo de PVC

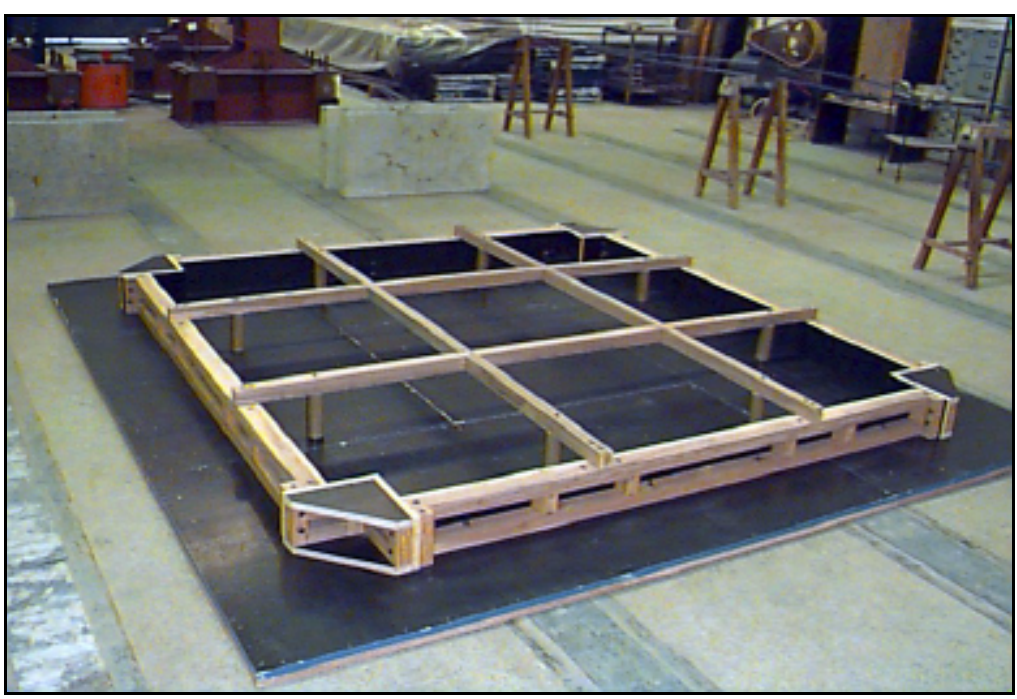

Figura 3.28 - Vista geral da fôrma, para os modelos de concreto armado

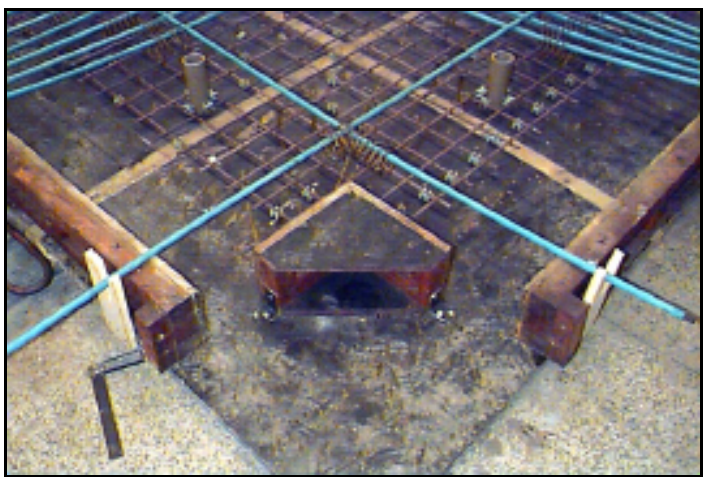

a) Peça de canto parafusada

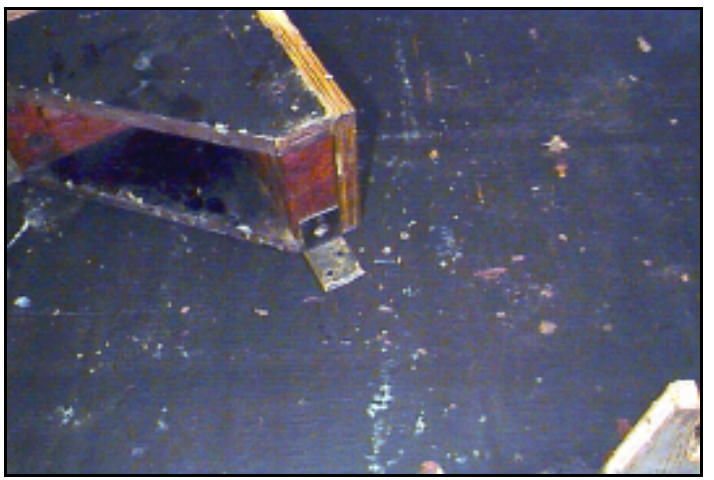

b) Detalhe da fixação

Figura 3.29 - Fixação da peça de canto na face inferior da fôrma 
Para não deixar a face lateral muito solta, inverteram-se os parafusos que prendiam as faces laterais à face inferior da fôrma. Em seguida, as faces laterais foram furadas, visando a passagem das cordoalhas (figura 3.30). Visando facilitar a concretagem, foram retiradas as traves de madeira superiores. Para que os tubos de PVC fossem impedidos de se movimentar, eles foram fixados junto às suas extremidades inferior e superior, respectivamente, a uma "arruela" de madeira (figura 3.27) e à armadura passiva, através de arames (figura 3.31). Para que os tubos não fossem preenchidos com concreto, foram utilizadas folhas de jornais amassadas e molhadas. Para auxiliar o posicionamento das cordoalhas, foram usadas guias de madeira, presas na face inferior da fôrma, conforme mostrado na figura 3.32 .
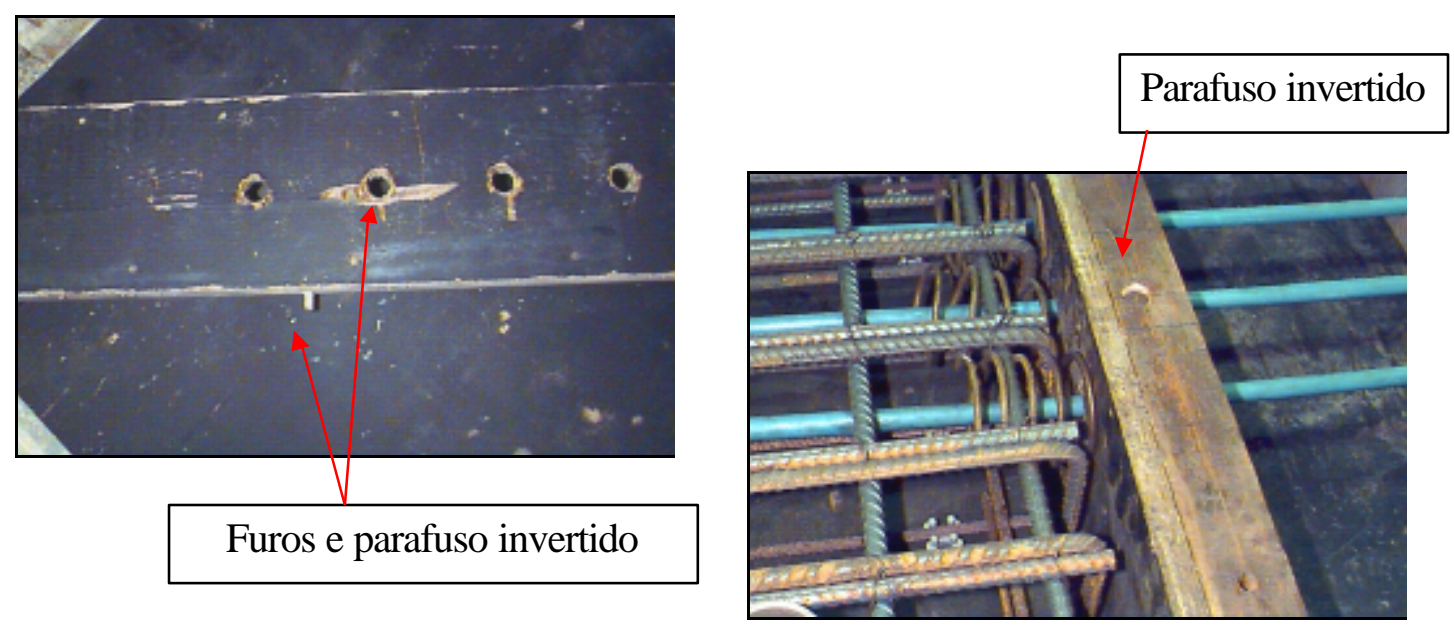

Figura 3.30 - Detalhe dos furos e da inversão do parafuso usado para fixar a face lateral à face inferior do modelo

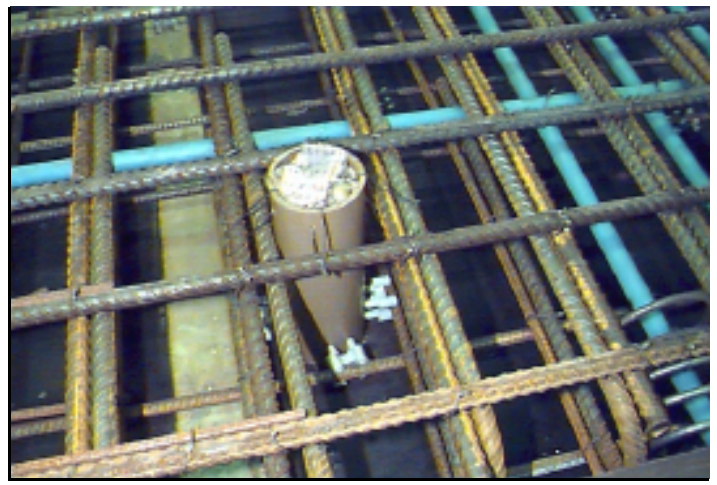

Figura 3.31 - Detalhe do tubo de PVC

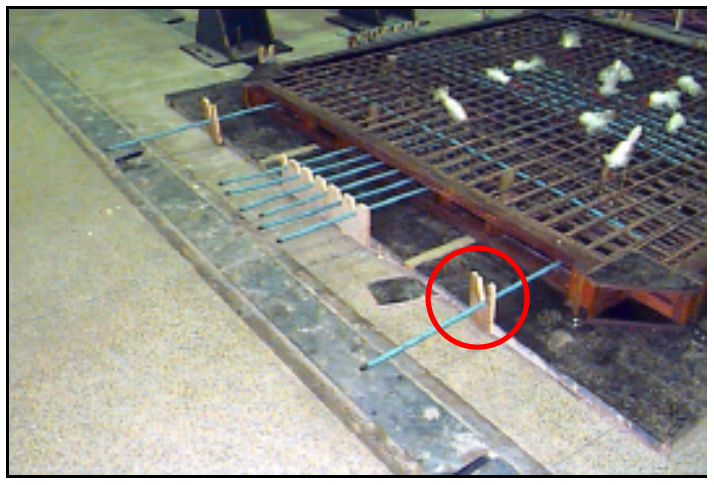

Figura 3.32 - Detalhe das guias usadas para posicionar as cordoalhas 


\subsection{CONCRETO}

Em vista do volume necessário para concretar a laje ser da ordem de $1 \mathrm{~m}^{3}$, optouse pela compra de concreto usinado. HELENE \& TERZIAN (1992) mencionam que, quando o concreto é usinado, pode-se especificar apenas o valor da resistência do concreto, a consistência e a dimensão máxima característica do agregado graúdo, ficando, a cargo da empresa, a escolha da resistência média de dosagem e a determinação do traço. A empresa fornecedora de concreto foi a CONCREBAND Engenharia de Concreto Ltda.

Em vista da alta taxa de armadura adotada, principalmente nos modelos protendidos, adotou-se uma dimensão máxima do agregado graúdo de $19 \mathrm{~mm}$.

Com relação à escolha da consistência do concreto, medida através do ensaio de abatimento do tronco de cone, HELENE \& TERZIAN (1992) apresentam a tabela 3.3, que relaciona o tipo de elemento estrutural com o abatimento, e a tabela 3.4, que relaciona a consistência, o abatimento e a sua tolerância. Eles mencionam ainda que o teste da consistência pelo abatimento do tronco de cone, dado pela NBR 7223, deve ser feito duas vezes: uma no começo da concretagem, para ver se está dentro da faixa de tolerância estipulada, e a outra com o concreto do "meio" do caminhão, quando então é anotado o valor do abatimento e se moldam os corpos-de-prova. Em função do pequeno espaçamento entre as barras da armadura de flexão, especificou-se o limite da consistência plástica em torno de $80 \pm 10 \mathrm{~mm}$.

Na tabela 3.5 apresenta-se a medida do abatimento para cada um dos modelos ensaiados.

Para a obtenção dos corpos-de-prova, seguiu-se a tendência mencionada por HELENE \& TERZIAN (1992), de se retirar, de uma só vez, e do volume intermediário, a porção necessária para a moldagem dos corpos-de-prova.

$\mathrm{O}$ adensamento dos modelos foi feito por meio de um cabo vibrador de $50 \mathrm{~mm}$ de diâmetro. Os corpos-de-prova foram vibrados através de uma mesa vibratória. Nas figuras 3.33 a 3.35 têm-se ilustrados os procedimentos mencionados. 
Tabela 3.3 - Escolha da consistência do concreto em função do tipo do elemento estrutural, para adensamento mecânico (HELENE \& TERZIAN, 1992)

\begin{tabular}{|c|c|c|}
\hline \multirow{2}{*}{ Elemento Estrutural } & \multicolumn{2}{|c|}{ Abatimento (mm) } \\
\cline { 2 - 3 } & Pouco armada & Muito armada \\
\hline \hline Laje & $\leq 60 \pm 10$ & $\leq 70 \pm 10$ \\
\hline Viga e parede armada & $\leq 60 \pm 10$ & $\leq 80 \pm 10$ \\
\hline Pilar de edifício & $\leq 60 \pm 10$ & $\leq 70 \pm 10$ \\
\hline $\begin{array}{c}\text { Paredes de fundação, } \\
\text { sapatas, tubulões }\end{array}$ & $\leq 60 \pm 10$ & \\
\hline $\begin{array}{l}\text { Obs.: quando o concreto for bombeado, a consistência deve estar entre } 70 \text { e } 100 \text { mm, no } \\
\text { máximo. Quando a altura para bombeamento for acima de } 30 \mathrm{~m}, \text { considerar o limite para a } \\
\text { consistência na saída da tubulação. }\end{array}$ \\
\hline
\end{tabular}

Tabela 3.4 - Tolerâncias admitidas para consistência do concreto através do abatimento do tronco de cone - NBR 7223

\begin{tabular}{|c|c|c|}
\hline Consistência & Abatimento $(\mathrm{mm})$ & Tolerância $(\mathrm{mm})$ \\
\hline \hline Seca & 0 a 20 & \pm 5 \\
Medianamente plástica & 30 a 50 & \pm 10 \\
Plástica & 60 a 90 & \pm 10 \\
Fluida & 100 a 150 & \pm 20 \\
Líquida & $\geq 160$ & \pm 30 \\
\hline
\end{tabular}

Tabela 3.5 - Ensaio do abatimento do tronco de cone

\begin{tabular}{|c|c|c|}
\hline \multirow{2}{*}{ Modelo } & \multicolumn{2}{|c|}{ Abatimento - valor médio - mm } \\
\cline { 2 - 3 } & a) No início da concretagem & b) No meio da concretagem \\
\hline M1 & $93(83,102,95)$ & $108(106,87,132)$ \\
\hline M2 & $98(87,109,98)$ & $99(95,107,95)$ \\
\hline M3 & $102(95,112,98)$ & $83(80,85,83)$ \\
\hline M4 & $116(130,120,100)$ & $118(120,125,110)$ \\
\hline M5 & $54(56,50,56)$ & $52(53,52,52)$ \\
\hline M6 & $95(90,95,100)$ & $74(75,75,73)$ \\
\hline
\end{tabular}




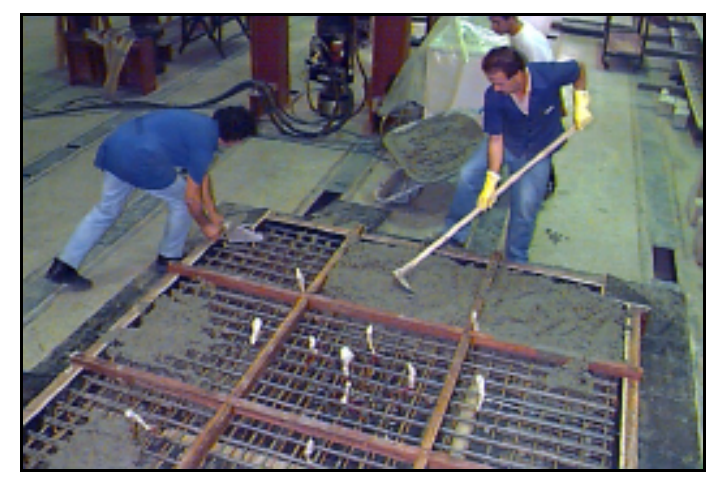

a) Laje de concreto armado

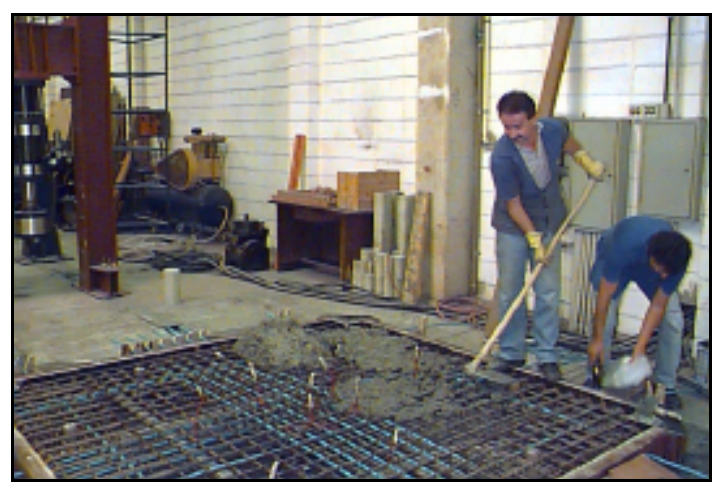

b) Laje de concreto protendido

Figura 3.33 - Concretagem dos modelos

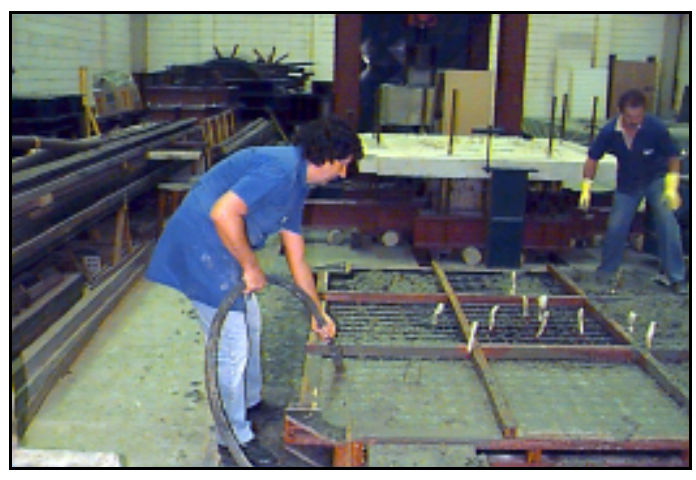

a) Laje de concreto armado

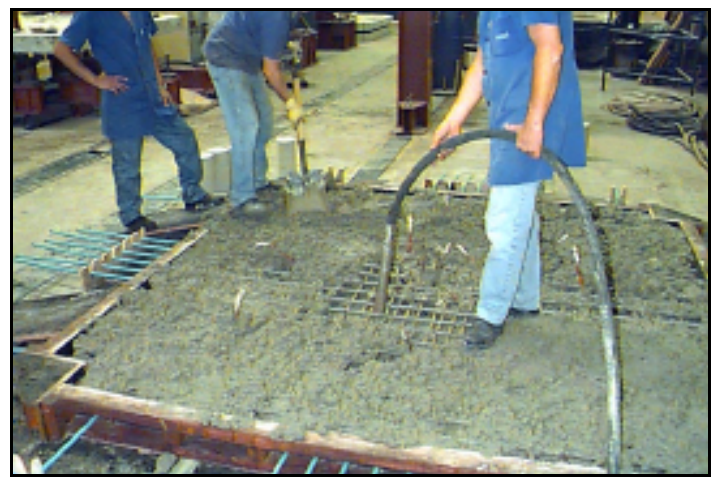

b) Laje de concreto protendido

Figura 3.34 - Vibração dos modelos

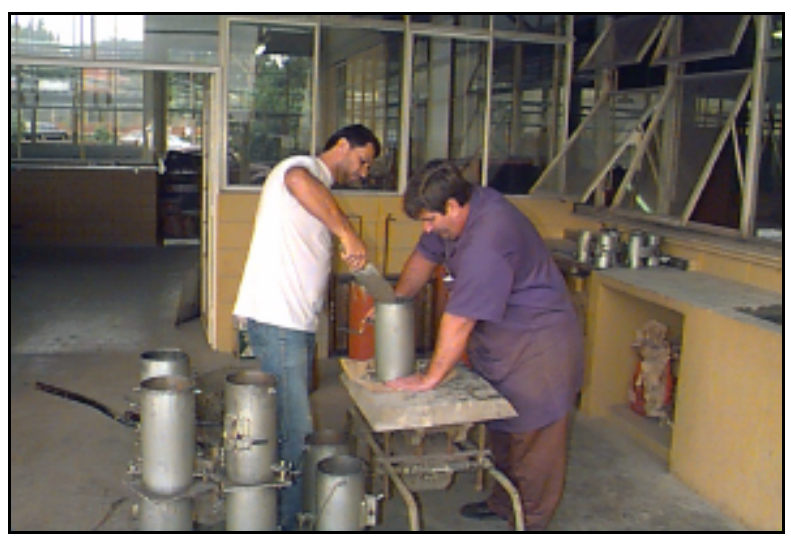

Figura 3.35 - Vibração dos corpos-de-prova

Para o acabamento na face superior do modelo, foi usada uma régua de madeira, conforme a figura 3.36 . 


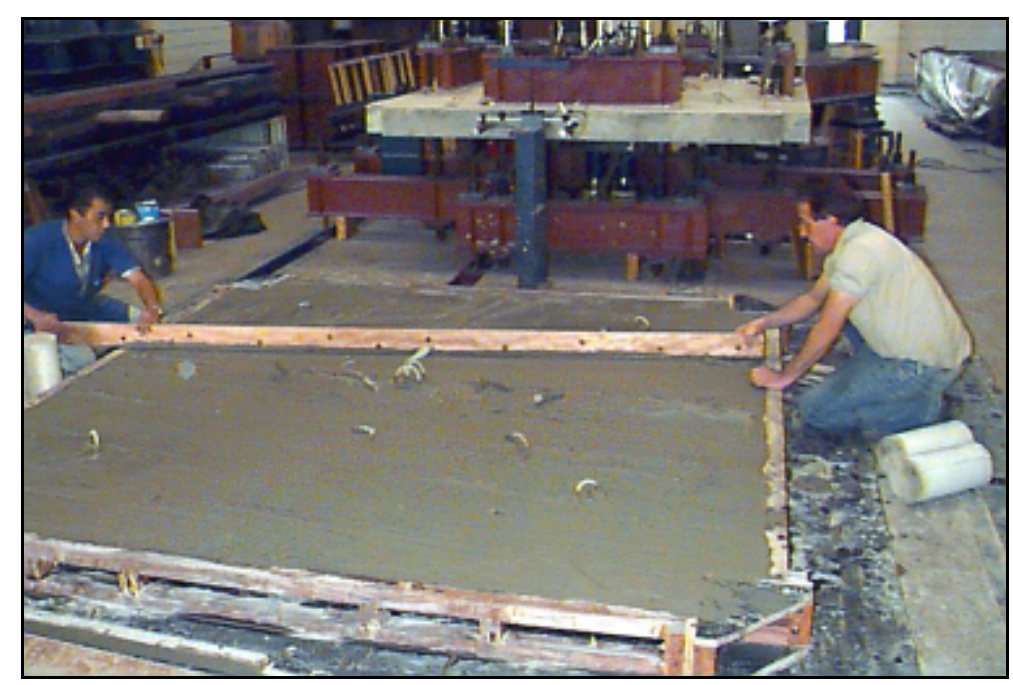

Figura 3.36 - Ajuste do nível do concreto com o auxílio de uma régua de madeira

Ressalta-se ainda que, na chegada do concreto ao laboratório, a betoneira foi girada na rotação máxima durante aproximadamente 5 minutos. A concretagem dos modelos durou, em média, uma hora e quarenta e cinco minutos.

$\mathrm{O}$ procedimento de cura adotado para as lajes consistiu em se manter a sua superfície umedecida com espumas, durante sete dias após o lançamento do concreto (figura 3.37).

A desforma foi realizada a partir do oitavo dia. Para desformar os modelos de concreto armado, soltavam-se as peças dos cantos e içava-se a laje (figura 3.38).

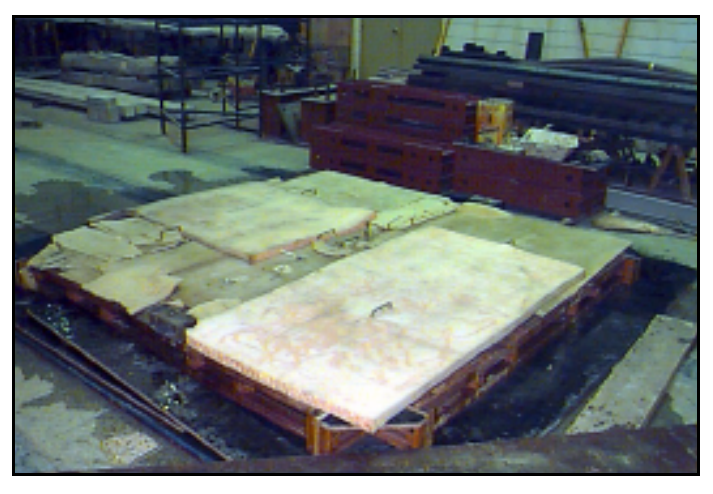

a) Laje de concreto armado

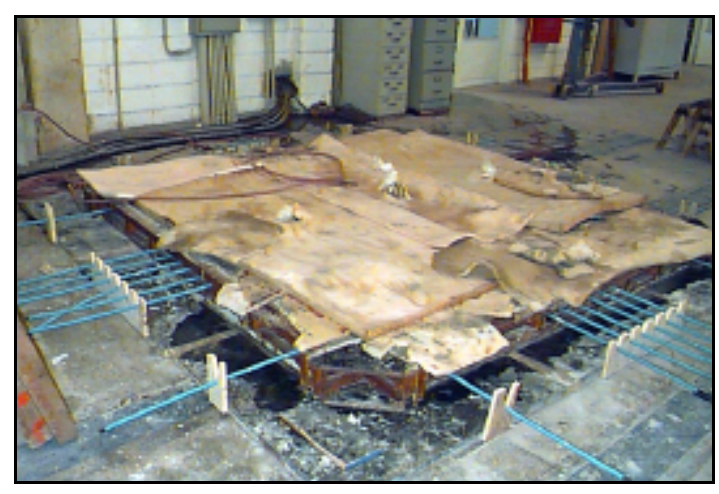

b) Laje de concreto protendido

Figura 3.37 - Cura dos modelos 

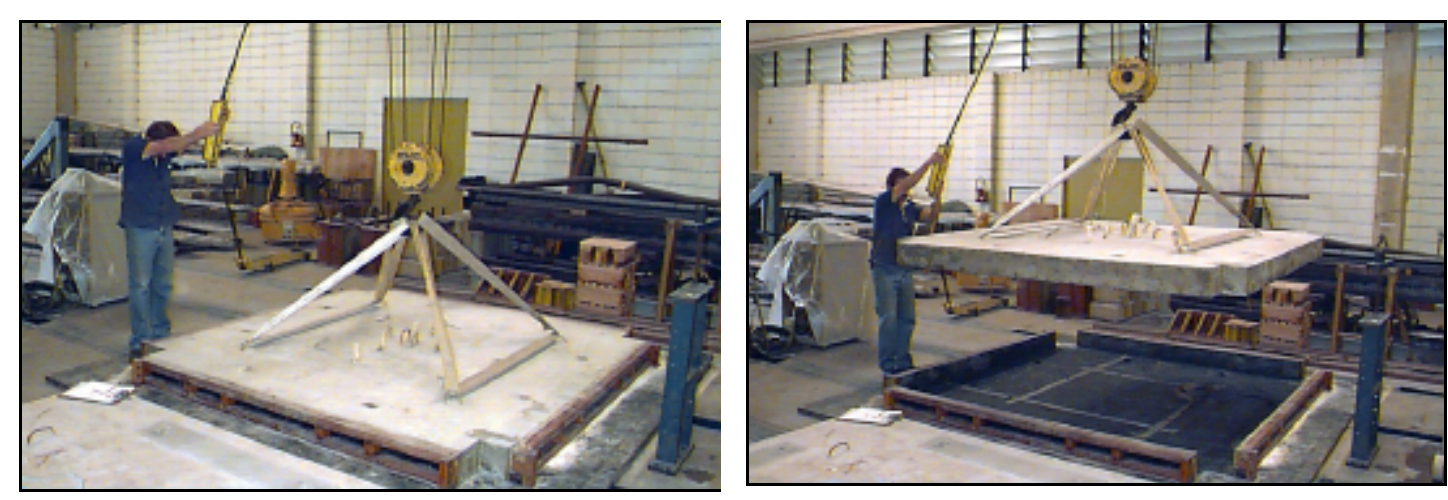

Figura 3.38 - Desforma dos modelos de concreto armado

Já nos modelos de concreto protendido, o procedimento foi outro. Inicialmente, soltavam-se as peças dos cantos e o modelo era içado e colocado sobre calços. A seguir, com o auxílio de um martelo de borracha e de uma cunha de madeira, afastava-se a face lateral da fôrma o suficiente para passar uma faixa entre a face lateral e o modelo (figura 3.39). Por fim, com o auxílio de uma roldana, uma corrente e da ponte rolante, a face lateral era retirada (figura 3.40).

Com relação aos corpos-de-prova, a moldagem e a cura foram feitas com base na NBR 5738.

As diferenças entre os procedimentos recomendados e os executados foram que, no período inicial da cura dos corpos-de-prova, estes não foram cobertos com material não reativo e não absorvente, ficando expostos ao ar livre, porém à sombra de um galpão (figura 3.41).

No período final da cura, os corpos-de-prova de todos os modelos ficaram em um tanque com água sem esta estar saturada de cal (figura 3.42), durante apenas sete dias, em função do elevado número de trabalhos desenvolvidos no laboratório. Após este período, os corpos-de-prova foram colocados dentro do laboratório, nas mesmas condições climáticas dos modelos. 


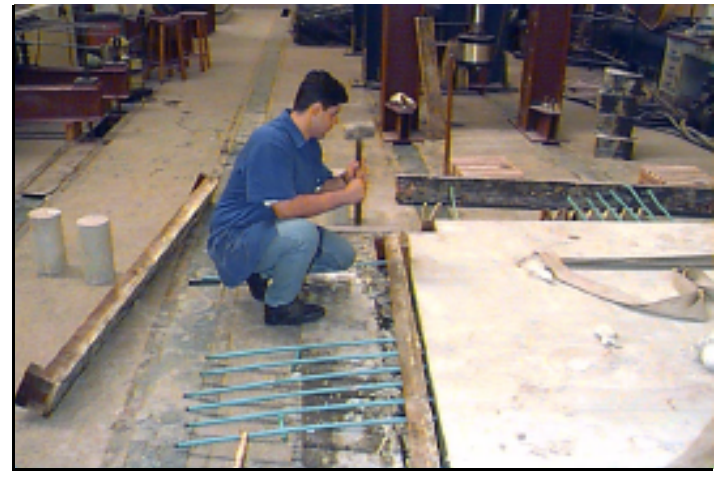

Figura 3.39 - Passagem da faixa entre a fôrma lateral e o modelo

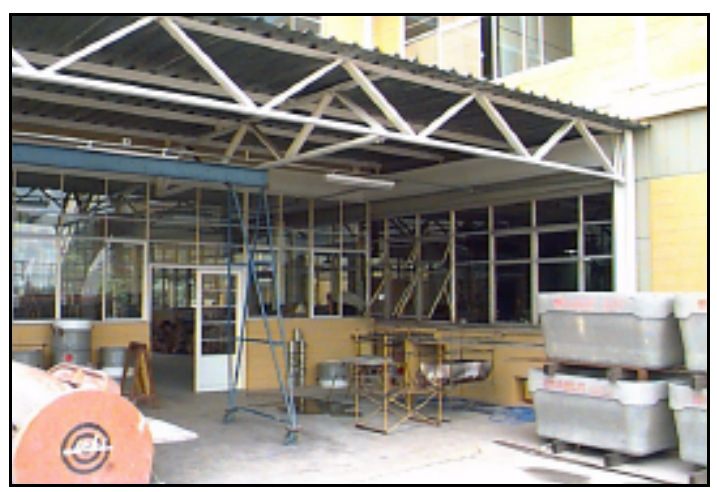

Figura 3.41 - Galpão

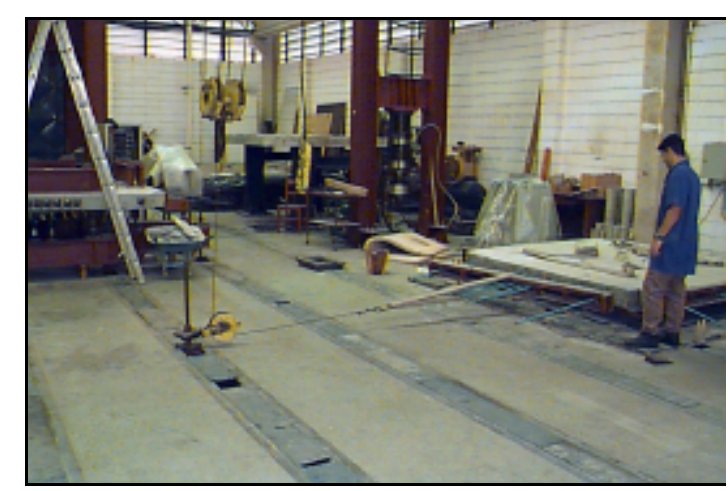

Figura 3.40 - Retirada da face lateral da fôrma

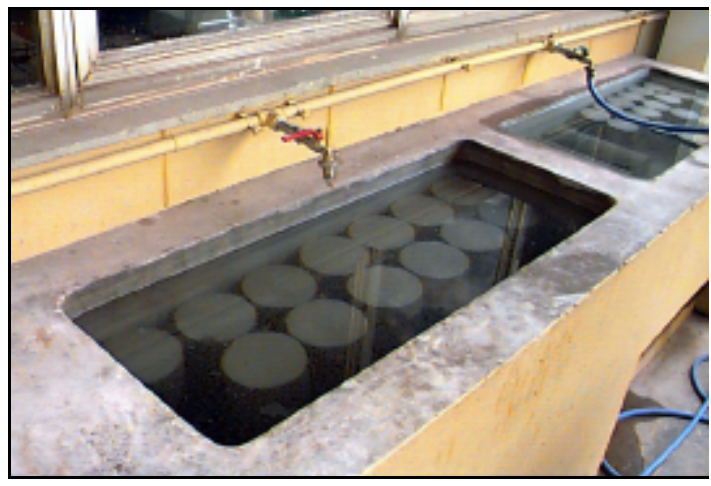

Figura 3.42 - Período final da cura dos corpos-de-prova

Especificou-se para a empresa fornecedora de concreto uma resistência característica de $50 \mathrm{MPa}$ aos 28 dias.

O ensaio de resistência à compressão foi feito com base na NBR 5739, para corpos-de-prova cilíndricos, de dimensões $150 \mathrm{~mm}$ x $300 \mathrm{~mm}$. As diferenças foram que os corpos-de-prova não tiveram capeamento, tendo sido as suas extremidades encaixadas em um dispositivo metálico cujo contato com o corpo-de- prova se dava através de uma camada de neoprene (figura 3.43), e que o ensaio foi realizado com o corpo-de-prova seco. Nos modelos M3 a M6, a medida da resistência à compressão foi feita através de máquina hidráulica para ensaio de corpos-de-prova de concreto, marca ELE, com capacidade de $2000 \mathrm{kN}$. A velocidade de carregamento foi de 5,3 kN/s (figura 3.44). 
Já para os modelos M1 e M2, em função de problemas técnicos na máquina ELE, os corpos-de-prova foram ensaiados na máquina universal de ensaios mecânicos, hidráulica, servo-controlada e computadorizada, com capacidade de $2.500 \mathrm{kN}$ (dinâmico), marca INSTRON (figura 3.45).

Com relação ao módulo de deformação longitudinal do concreto, foram ensaiados corpos-de-prova na máquina INSTRON, com base nas recomendações da NBR 8522. A velocidade de carregamento foi de $5,3 \mathrm{kN} / \mathrm{s}$.

Nesta velocidade de carregamento, permite-se obter não só o diagrama tensãodeformação, como também a resistência à compress ão do corpo-de-prova, respeitando-se tanto a NBR 8522 como a NBR 5739.

Para a obtenção do módulo, foi usado um dispositivo com dois transdutores de deslocamento, mostrado na figura 3.46 .

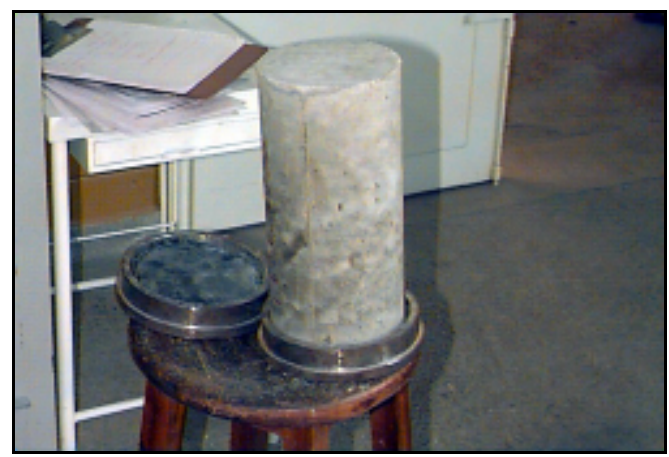

Figura 3.43 - Dispositivo de Neoprene

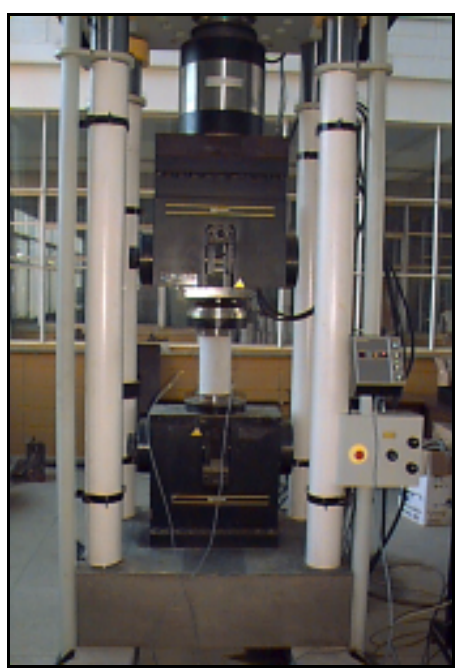

Figura 3.45 - Máquina Instron

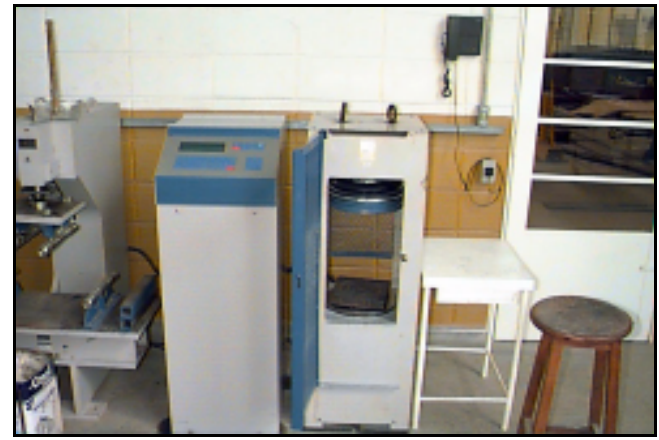

Figura 3.44 - Máquina de Ensaio ELE

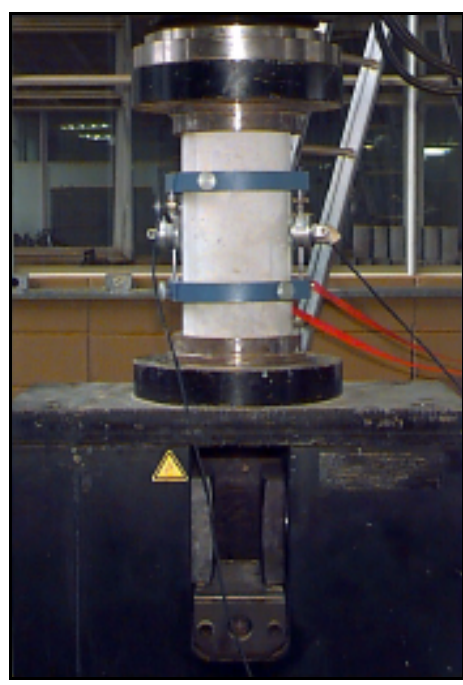

Figura 3.46 - Detalhe do dispositivo usado 
Para efeito de cálculo, considerou-se o Módulo de Deformação Tangente Inicial (E) como sendo dado pela expressão:

$$
\begin{aligned}
& \mathrm{E}=\frac{\sigma_{\mathrm{f}}-\sigma_{\mathrm{a}}}{\varepsilon_{\mathrm{f}}-\varepsilon_{\mathrm{a}}}, \quad \text { onde: } \\
& \sigma_{\mathrm{f}}=\text { tensão correspondente a } 30 \% \text { da carga de ruptura; } \\
& \sigma_{\mathrm{a}}=\text { tensão correspondente a } 0,5 \mathrm{MPa} ; \\
& \varepsilon_{\mathrm{f}}=\text { deformação específica correspondente a } \sigma_{\mathrm{f}}, \\
& \varepsilon_{\mathrm{a}}=\text { deformação específica correspondente a } \sigma_{\mathrm{a}} .
\end{aligned}
$$

Na figura 3.47 tem-se um diagrama tensão-deformação representativo dos corposde-prova ensaiados. Para que o dispositivo não fosse danificado, este foi retirado antes da ruptura do corpo-de-prova.

Conforme a EQUIPE DE FURNAS, LABORATÓRIO DE CONCRETO (1997), o módulo tangente inicial (na origem) é superior ao módulo secante, podendo ser adotado um percentual de $10 \%$. Nos cálculos relacionados aos deslocamentos dos modelos, foi usado o valor do módulo secante, ao invés do módulo tangente.

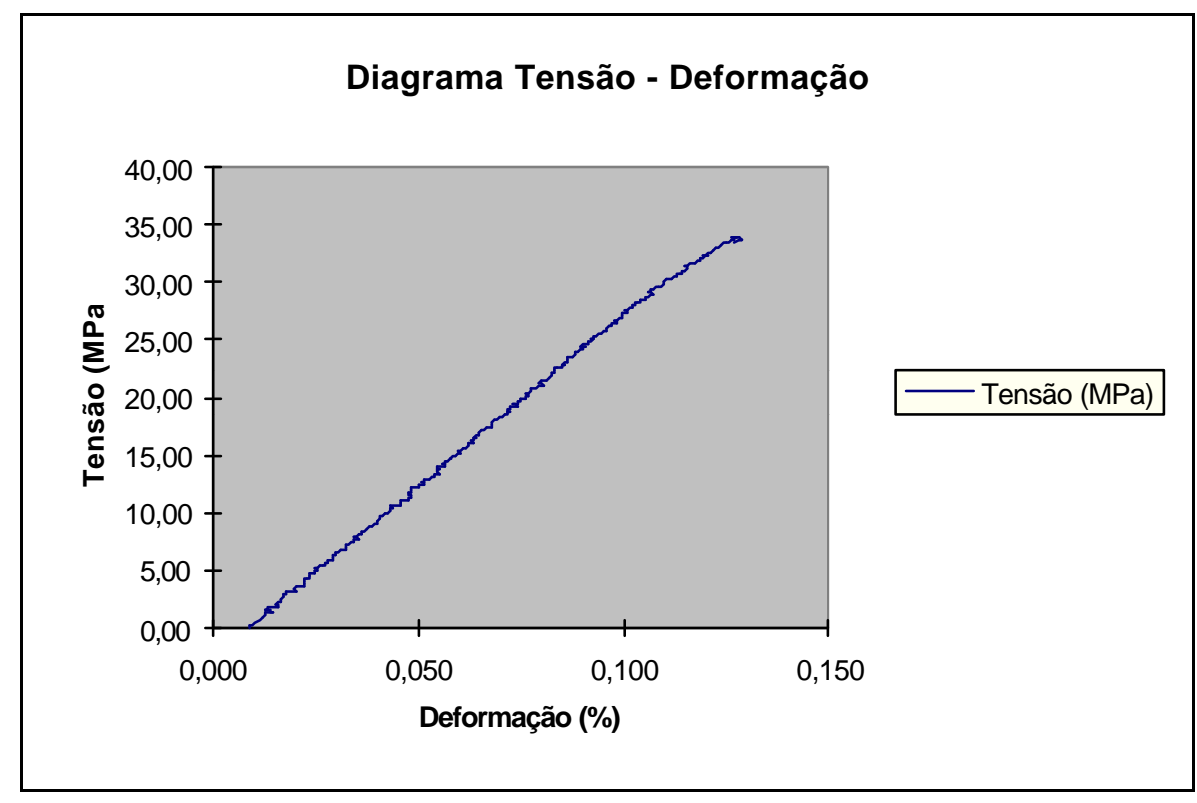

Figura 3.47 - Diagrama tensão-deformação do concreto 
O ensaio de tração por compressão diametral foi feito com base na NBR 7222. A velocidade de carregamento adotada foi de $2,1 \mathrm{kN} / \mathrm{s}$.

Na tabela 3.6, têm-se os resultados da resistência à compressão, da resistência da tração por compressão diagonal e do módulo de deformação longitudinal do concreto para cada um dos modelos. Esses resultados são relativos ao dia do ensaio do modelo. Os valores das resistências dos corpos-de-prova ensaiados estão mostrados no Anexo C.

Tabela 3.6 - Dados relacionados ao concreto usado nos modelos

\begin{tabular}{|c|c|c|c|c|}
\hline Modelo & $\begin{array}{c}f_{c j} \\
(M P a)\end{array}$ & $\begin{array}{c}f_{t j} \\
(M P a)\end{array}$ & $\begin{array}{c}E \\
(G P a)\end{array}$ & $\begin{array}{l}\text { Idade } \\
\text { (dias) }\end{array}$ \\
\hline M1 & $26,60 \pm 0,94$ & $2,71 \pm 0,07$ & $26,125 \pm 0,974$ & $36^{*}$ \\
\hline M2 & $49,90 \pm 0,74$ & $3,50 \pm 0,485$ & $28,878 \pm 1,641$ & 22 \\
\hline M3 & $48,47 \pm 1,11$ & $3,77 \pm 0,17$ & $30,255 \pm 0,367$ & 22 \\
\hline M4 & $51,92 \pm 1,06$ & $3,87 \pm 0,12$ & $30,457 \pm 1,206$ & 56 \\
\hline M5 & $59,40 \pm 1,76$ & $4,30 \pm 0,315$ & $33,704 \pm 1,478$ & 69 \\
\hline M6 & $51,56 \pm 0,48$ & $3,68 \pm 0,43$ & $28,812 \pm 0,350$ & 92 \\
\hline \multicolumn{5}{|c|}{$\begin{array}{l}\mathrm{f}_{\mathrm{cj}}, \mathrm{f}_{\mathrm{tj}} \text { - resistência à compressão e à tração por compressão diametral, resp } \\
\mathrm{E} \text { - módulo de elasticidade secante dos corpos-de-prova } \\
\text { * Idade de ensaio não foi de } 28 \text { dias, conforme recomendada pela norma }\end{array}$} \\
\hline
\end{tabular}

No modelo M1, teve-se como problema a baixa resistência do concreto. Isto se deu função de em problema no aditivo usado pela empresa. Medidas corretivas foram tomadas, para que este problema não ocorresse com a resistência dos outros modelos.

Deve-se ressaltar que, na tabela 3.6, estão apresentados os valores do módulo secante, que corresponde a $90 \%$ do valor obtido para o módulo tangente. 


\subsection{PROJETO, EXECUÇÃO E CARACTERIZAÇÃO DOS MATERIAIS USADOS NA ARMADURA DE FLEX $\tilde{A} O$}

A armadura de flexão usada nos modelos de concreto armado não foi a mesma que a usada para os modelos de concreto protendido.

\subsubsection{MODELOS DE CONCRETO ARMADO}

Para as lajes de concreto armado, foram adotadas duas malhas, uma superior, a ser tracionada, e outra inferior, a ser comprimida, composta por barras de, respectivamente, $16 \mathrm{~mm}$ e $8 \mathrm{~mm}$ de diâmetro. Em cada direção, tanto a malha superior, de $16 \mathrm{~mm}$, como a malha inferior, de $8 \mathrm{~mm}$, apresentaram 21 e 4 barras com, respectivamente $247 \mathrm{~cm} \mathrm{e}$ $212 \mathrm{~cm}$. As barras foram amarradas entre si com arame recozido. Também foi adotada uma armadura em forma de $\mathrm{U}$, junto às bordas da laje, com diâmetro igual a 12,5 mm. Nas figuras 3.48 a 3.52, têm-se ilustrado o detalhamento dessas armaduras.

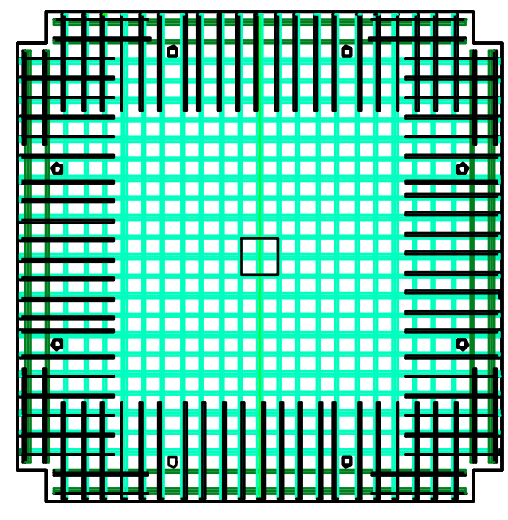

a) Vista superior

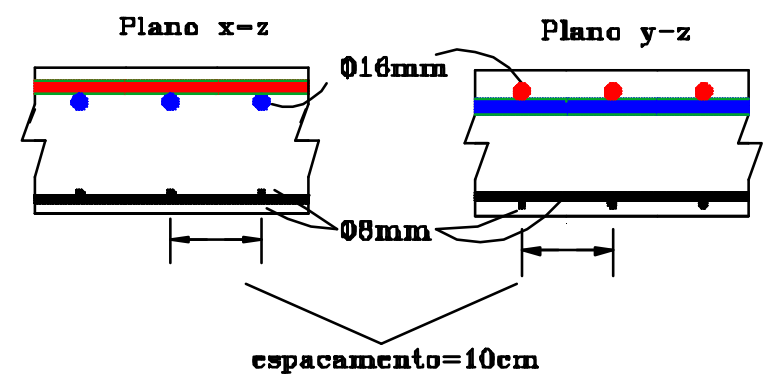

b) Posicionamento das barras

Figura 3.48 - Esquema da laje de concreto armado 


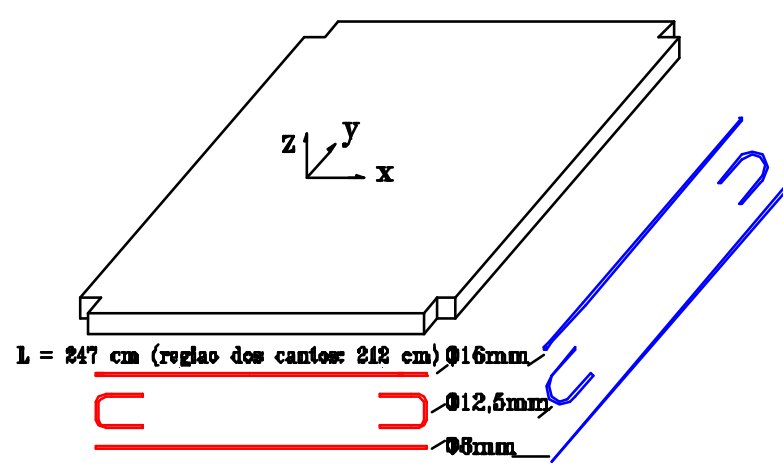

Figura 3.49 - Perspectiva da laje de concreto armado

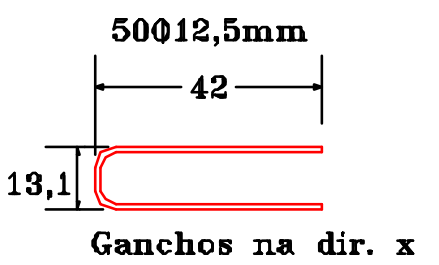

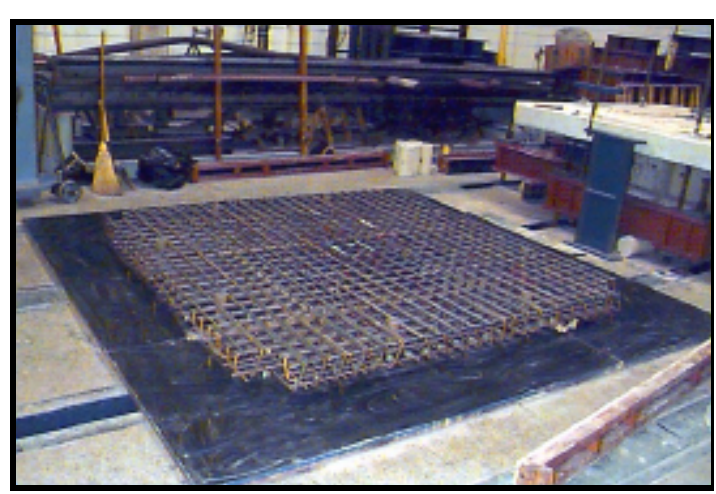

Figura 3.50 - Vista do modelo com a armadura já montada

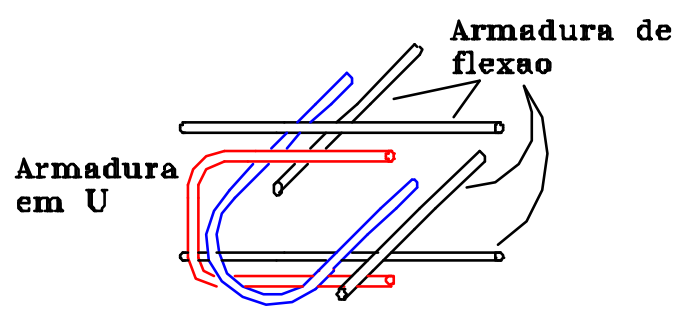

Figura 3.51 - Detalhamento dos ganchos
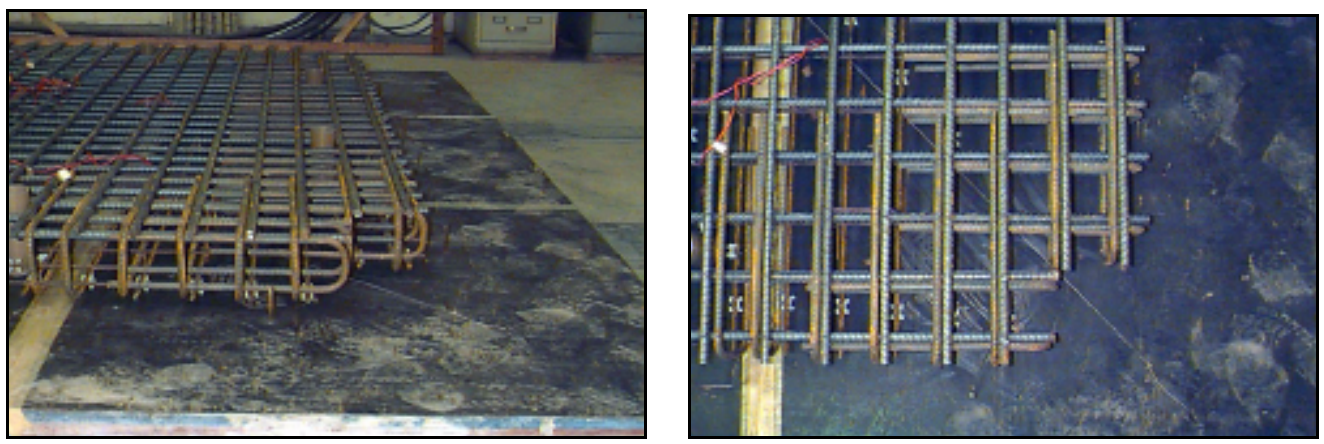

Figura 3.52 - Detalhe da armadura em U

Todas as barras das duas malhas foram igualmente espaçadas $\mathbf{d e} 10 \mathrm{~cm}$, tanto com relação à direção x como com relação à direção y. As malhas foram montadas com o auxílio de um gabarito de madeira (figura 3.53), para que o espaçamento das barras não tivesse uma variação significativa. 
Para a verificação do posicionamento da malha nferior na fôrma, foram usadas linhas de cordonê (figura 3.54).

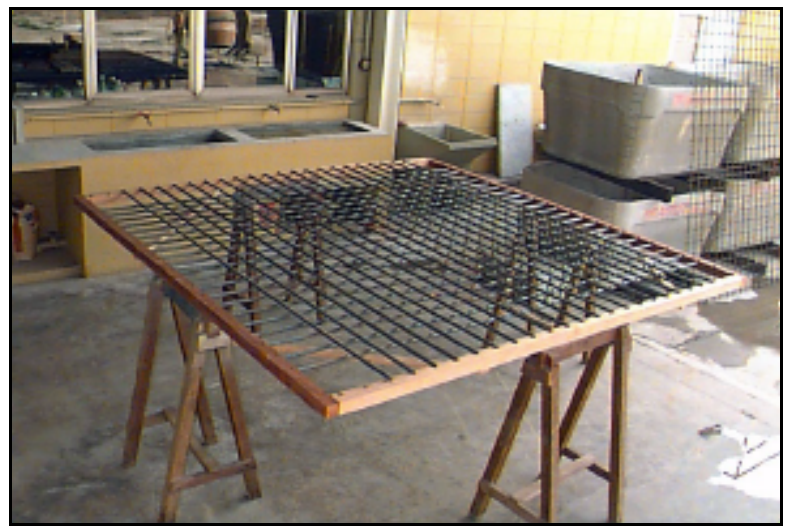

a) Vista geral

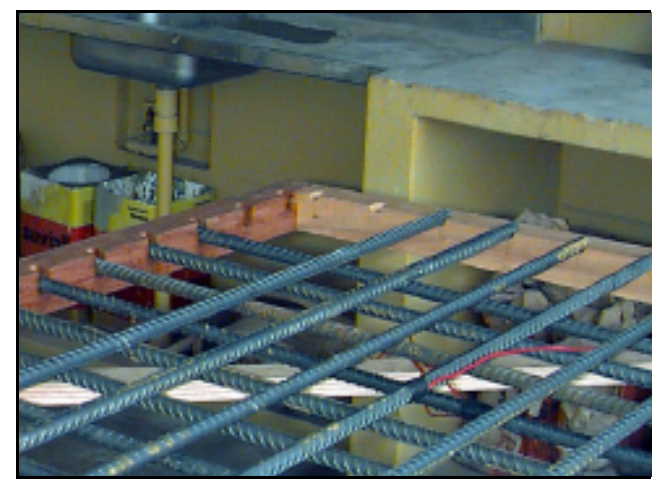

b) Detalhe do canto

Figura 3.53 - Gabarito usado para o posicionamento das barras

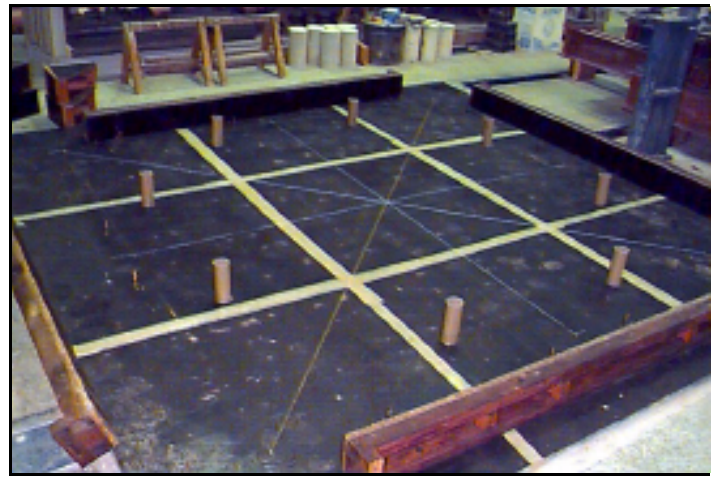

a) Vista geral

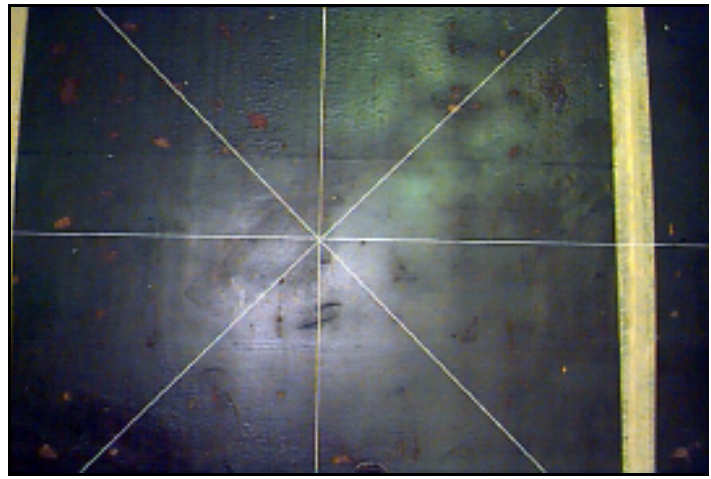

b) Vista superior

Figura 3.54 - Linhas de referência para o posicionamento da malha inferior na fôrma

Tanto o cobrimento da malha inferior quanto o da malha superior foram fixados em $1,5 \mathrm{~cm}$. Para garantir o cobrimento da armadura inferior, foram usados espaçadores plásticos, modelo ETP 15 - 8, tipo cadeira, da empresa JERUELPLAST. Já o cobrimento da armadura superior foi garantido com "caranguejos", feitos com barras de $6,3 \mathrm{~mm}$ de diâmetro. 
Cada "caranguejo" foi projetado para ter uma altura de $12,9 \mathrm{~cm}$, servindo de apoio para duas barras dispostas na direção x, excetuando-se o "caranguejo" posicionado no meio do modelo, cuja altura foi de $11,3 \mathrm{~cm}$, e que serviu de apoio para a barra central disposta na direção y. O espaçador e o "caranguejo" estão mostrados na figura 3.55.

Para os modelos M1 e M2, a disposição dos espaçadores plásticos foi aleatória. Somente a partir do modelo M3 é que se adotou um padrão, mostrado nas figuras 3.56 e 3.57 .

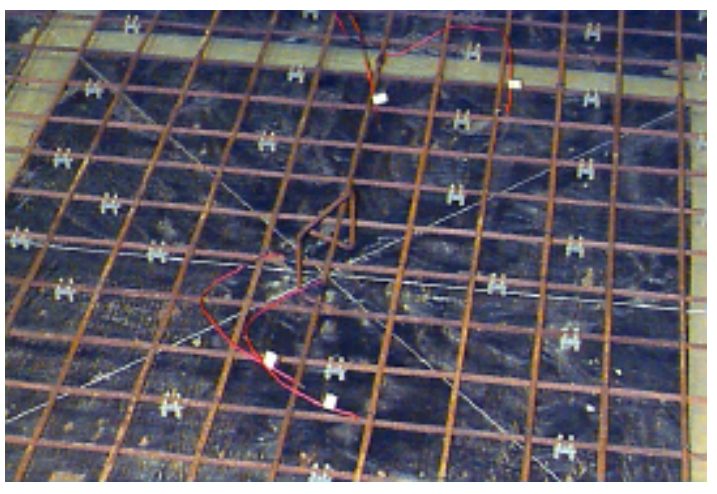

Figura 3.55 - Espaçadores plásticos e "caranguejo"

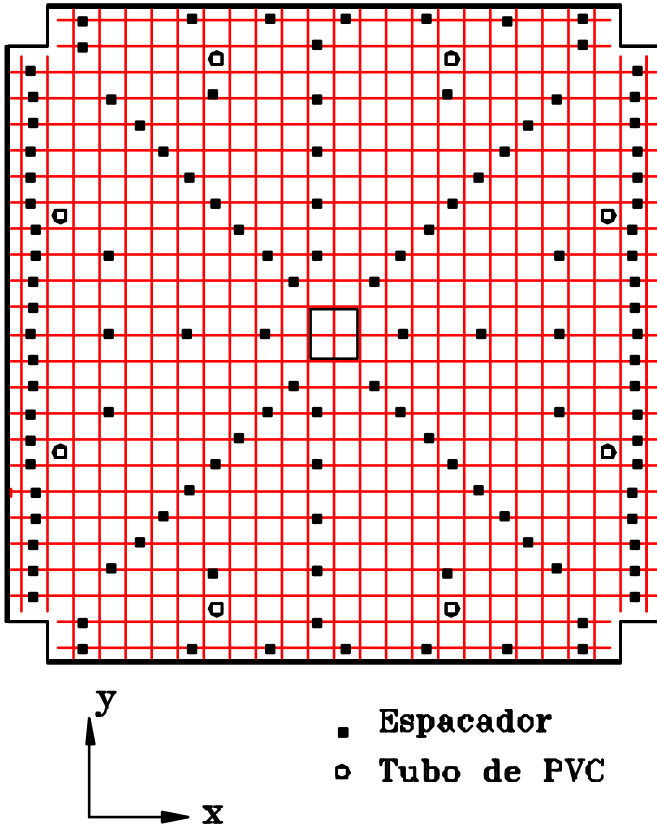

Figura 3.56 - Posicionamento dos espaçadores

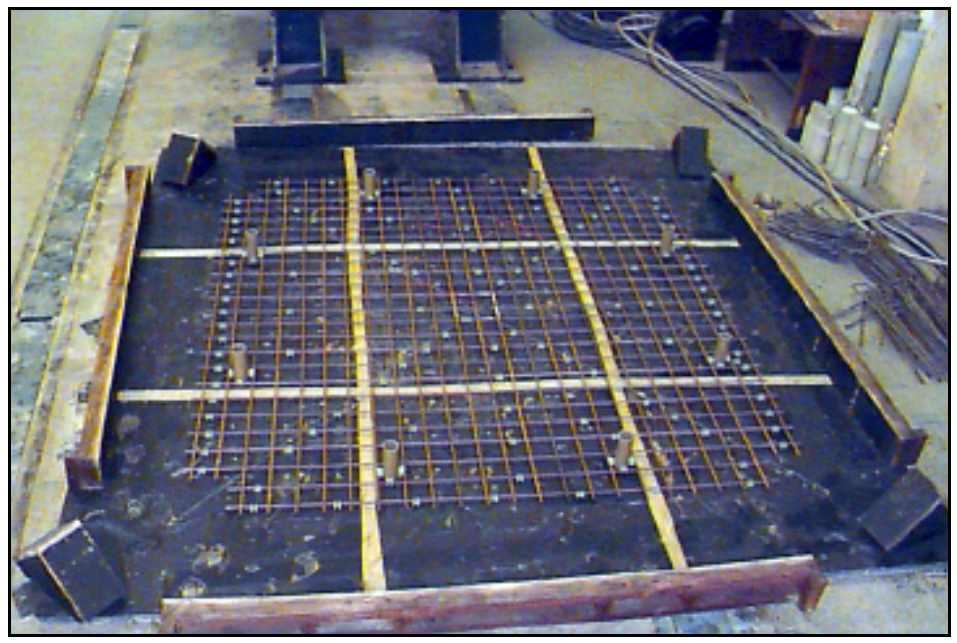

Figura 3.57 - Vista geral da disposição dos espaçadores plásticos 
Para que a malha inferior não se movimentasse durante a concretagem do modelo, foram usados espaçadores para fixar a malha ao tubo de PVC, conforme a figura 3.58, que, por sua vez, está fixado à forma pelo seu encaixe em uma "pastilha" de madeira parafusada à fôrma.

Para a desforma e o transporte do modelo, foram posicionadas "alças" de levantamento, feitas com barras de $8 \mathrm{~mm}$ de diâmetro (figura 3.59).

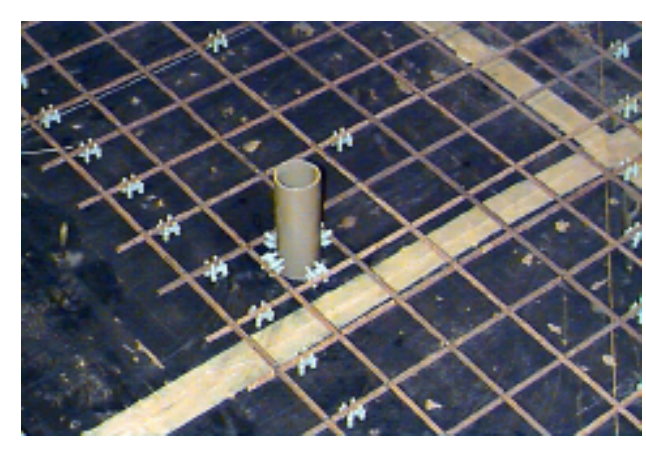

Figura 3.58 - Fixação da malha inferior ao tubo de PVC

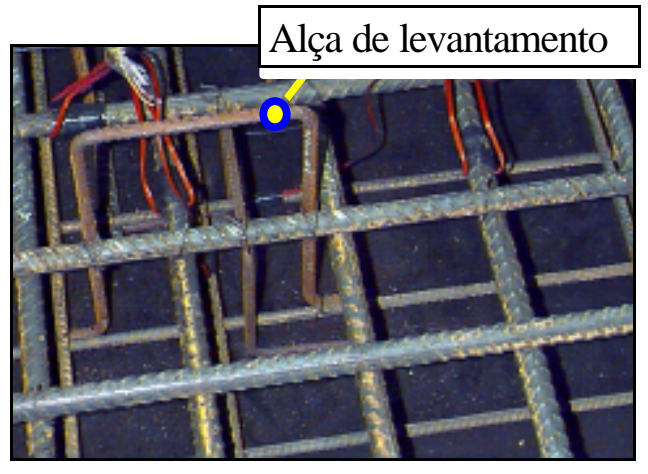

Figura 3.59 - Alça de levantamento

Nas figuras 3.60 e 3.61, têm-se, respectivamente, as disposições dos "caranguejos" e das alças de levantamento.

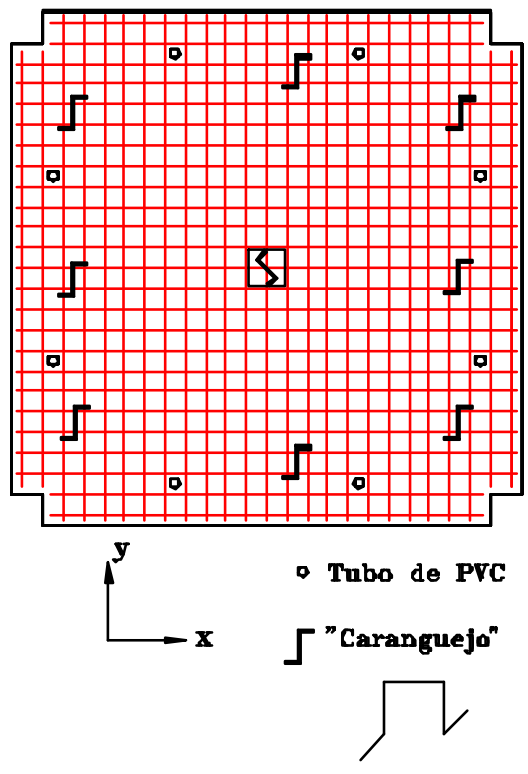

Figura 3.60 - Posição dos “caranguejos"

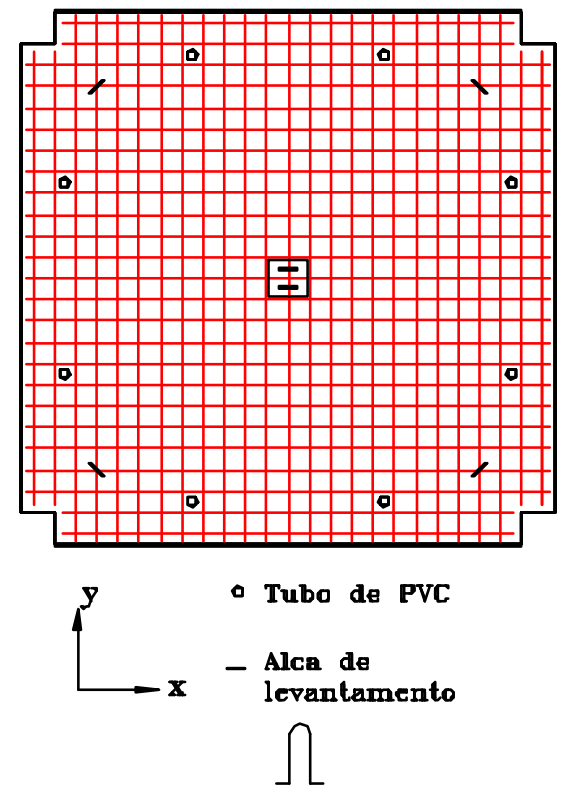

Figura 3.61 - Posição das alças 
Tomou-se o cuidado de posicionar as alças, na região central da laje, de modo que ela ficasse dentro da região onde a força concentrada seria aplicada por uma chapa, de modo a não permitir que essas alças funcionassem como uma armadura transversal.

O cobrimento da malha superior foi verificado após a montagem da armadura na fôrma, para cada uma das lajes. Na tabela 3.7, tem-se o valor do cobrimento medido nos diversos pontos mostrados na figura 3.62. Estes cobrimentos foram obtidos subtraindo-se o valor da distância entre a fôrma e a face superior da armadura de flexão mais distante desta, com relação ao valor da espessura da laje, igual a $16 \mathrm{~cm}$.

Tabela 4.8- Valores dos cobrimentos observados nos modelos em concreto armado, em cm

\begin{tabular}{|c|c|c|c|c|}
\hline \multicolumn{2}{|c|}{ Modelos } & M1 & M2 & M3 \\
\hline \multirow{4}{*}{} & Ponto 1 & 1,6 & 1,7 & 2,1 \\
& Ponto 2 & 1,6 & 1,9 & 2,0 \\
Posição & Ponto 3 & 1,8 & 1.9 & 2,1 \\
dos pontos & Ponto 4 & 1,6 & 1,8 & 2,0 \\
Medidos & Ponto 5 & 1,5 & 1,7 & 1,6 \\
& Ponto 6 & 1,9 & 2,0 & 1,9 \\
& Ponto 7 & 1,5 & 1,9 & 2,0 \\
& Ponto 8 & 1,5 & 2,0 & 1,8 \\
& Ponto 9 & 1,9 & 1,7 & 1,9 \\
\cline { 2 - 5 } & Média & $1,66 \pm 0,17$ & $1,84 \pm 0,12$ & $1,93 \pm 0,16$ \\
\hline
\end{tabular}
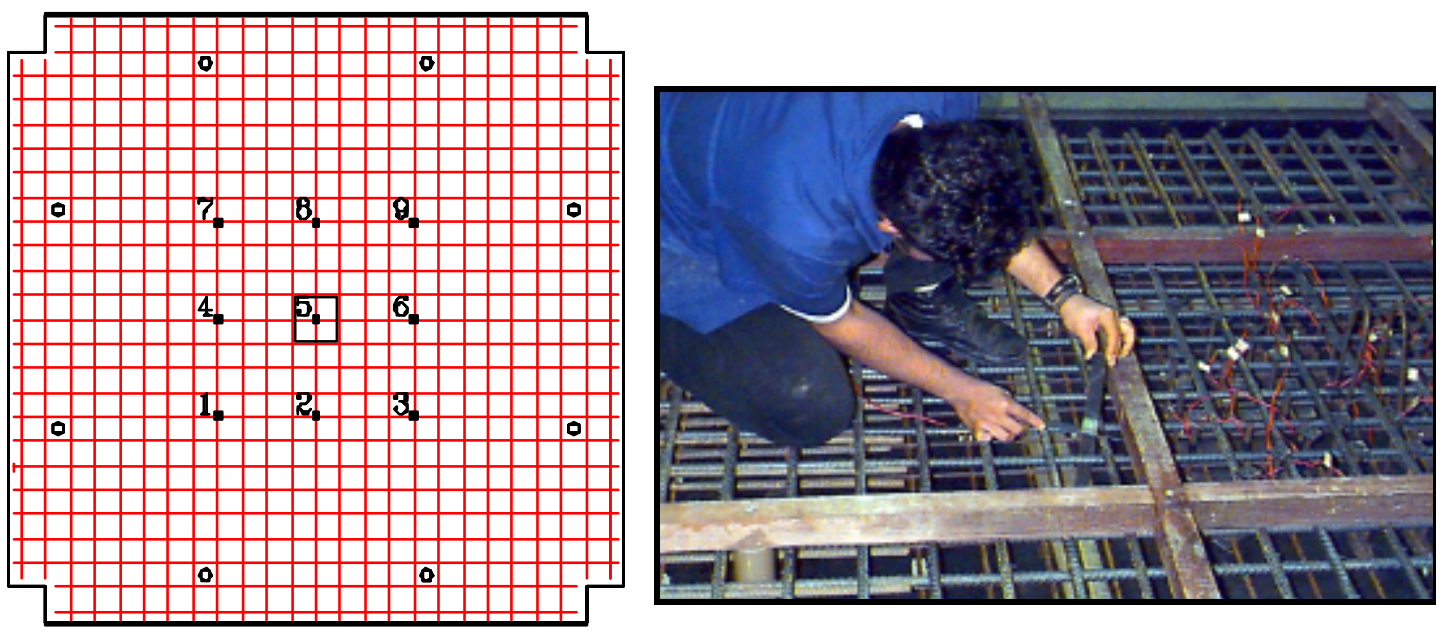

Figura 3.62 - Posição e modo como foram medidos os cobrimentos 


\subsubsection{MODELOS DE CONCRETO PROTENDIDO}

Nos modelos de concreto protendido, foram usados os seguintes tipos de armadura: armadura passiva de flexão, armadura ativa de flexão, armadura de fretagem, armadura dos cantos. Estas armaduras são detalhadas a seguir.

\section{a) Armadura passiva de flexão}

Como armadura passiva, foram adotadas duas malhas, uma superior, a ser tracionada, e uma inferior, a ser comprimida, composta por barras de, respectivamente, $12,5 \mathrm{~mm}$ e $8 \mathrm{~mm}$ de diâmetro. A malha inferior de $8 \mathrm{~mm}$ é idêntica à adotada para os modelos de concreto armado. Já a única diferença entre a malha superior de $12,5 \mathrm{~mm}$ e a adotada para os modelos de concreto armado foi a mudança do diâmetro da barra, de $16 \mathrm{~mm}$ para $12,5 \mathrm{~mm}$.

$\mathrm{O}$ espaçamento entre as barras foi mantido igual a $10 \mathrm{~cm}$, tanto em relação à direção $\mathrm{x}$ como em relação à direção $\mathrm{y}$.

O procedimento para a execução e o posicionamento destas malhas na fôrma foi similar ao adotado para os modelos de concreto armado.

Analogamente aos modelos de concreto armado, foi adotada uma armadura em forma de $\mathrm{U}$, junto às bordas da laje, com diâmetro igual a 12,5 mm.

Tanto o cobrimento da malha inferior, garantido por espaçadores plásticos (modelo ETP 15 - 8, tipo cadeira, da empresa JERUELPLAST), quanto o da malha superior, garantido por "caranguejos" com 6,3 mm de diâmetro, altura de $12,0 \mathrm{~cm}$, e servindo de apoio para duas barras dispostas na direção y (figuras 3.63 e 3.64), foram mantidos em $1,5 \mathrm{~cm}$.

Para os modelos de concreto protendido, também foi verificado o cobrimento da malha superior, após a montagem das armaduras na fôrma. Na tabela 3.8, tem-se o cobrimento medido nos diversos pontos já mostrados na figura 3.62.

A posição das alças não foi modificada, nos modelos protendidos, estando mostrada na figura 3.61. 


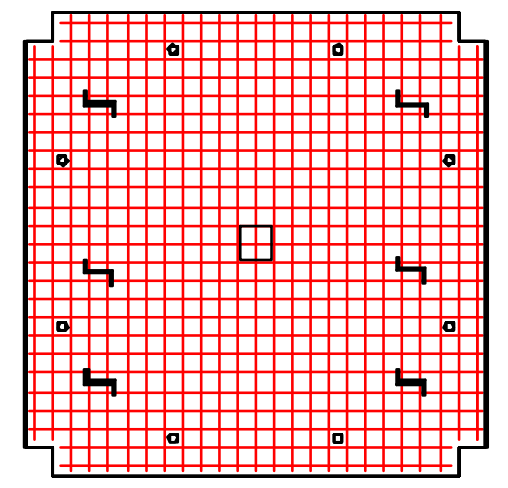

- Tubo de PVC
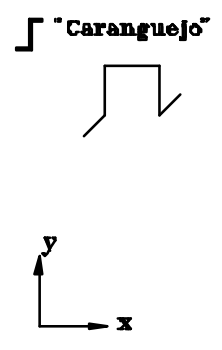

Figura 3.63 - Posição dos “caranguejos” (armadura passiva de flexão)

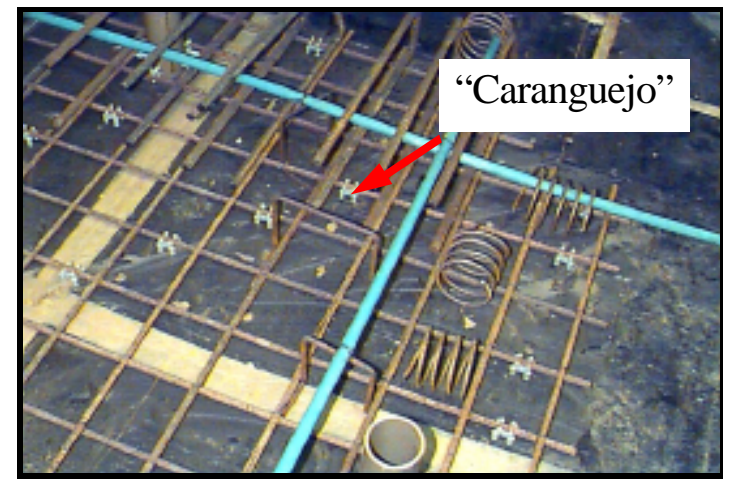

Figura 3.64 - "Caranguejo" usado para apoiar a malha superior

Tabela 3.8- Valores do cobrimento nos modelos protendidos, em $\mathrm{cm}$

\begin{tabular}{|c|c|c|c|c|}
\hline \multicolumn{2}{|c|}{ Modelos } & M4 & M5 & M6 \\
\hline \multirow{4}{*}{} & Ponto 1 & 1,5 & 1,4 & 1,8 \\
& Ponto 2 & 1,2 & 1,3 & 1,6 \\
Posição & Ponto 3 & 1,4 & 1,5 & 1,5 \\
dos pontos & Ponto 4 & 1,4 & 1,5 & 2,0 \\
medidos & Ponto 5 & 1,2 & 1,3 & 1,3 \\
& Ponto 6 & 1,4 & 1,5 & 1,5 \\
& Ponto 7 & 1,3 & 1,5 & 1,7 \\
& Ponto 8 & 1,0 & 1,7 & 1,4 \\
& Ponto 9 & 1,1 & 1,7 & 1,5 \\
\cline { 2 - 5 } & Média & $1,28 \pm 0,16$ & $1,49 \pm 0,15$ & $1,59 \pm 0,21$ \\
\hline
\end{tabular}

\section{b) Armadura ativa de flexão}

Adotou-se o traçado das cordoalhas como sendo parabólico. Considerou-se o diâmetro das cordoalhas como sendo igual a 12,85 mm (valor médio definido pelo fabricante).

A disposição das cordoalhas está representada na figura 3.65.

As equações das parábolas são dadas no Anexo D.

Na direção x, a excentricidade adotada foi igual a $\mathbf{3 , 3 6} \mathbf{c m}$, enquanto que, na direção y, adotou-se um valor igual a $4,61 \mathrm{~cm}$. 
- Cabos 1' a 8' (direcao x - numeracao de baixo p/ cima)

- Cabos 1 a 8 (direcao y - numeracao: da direita para esquerda)
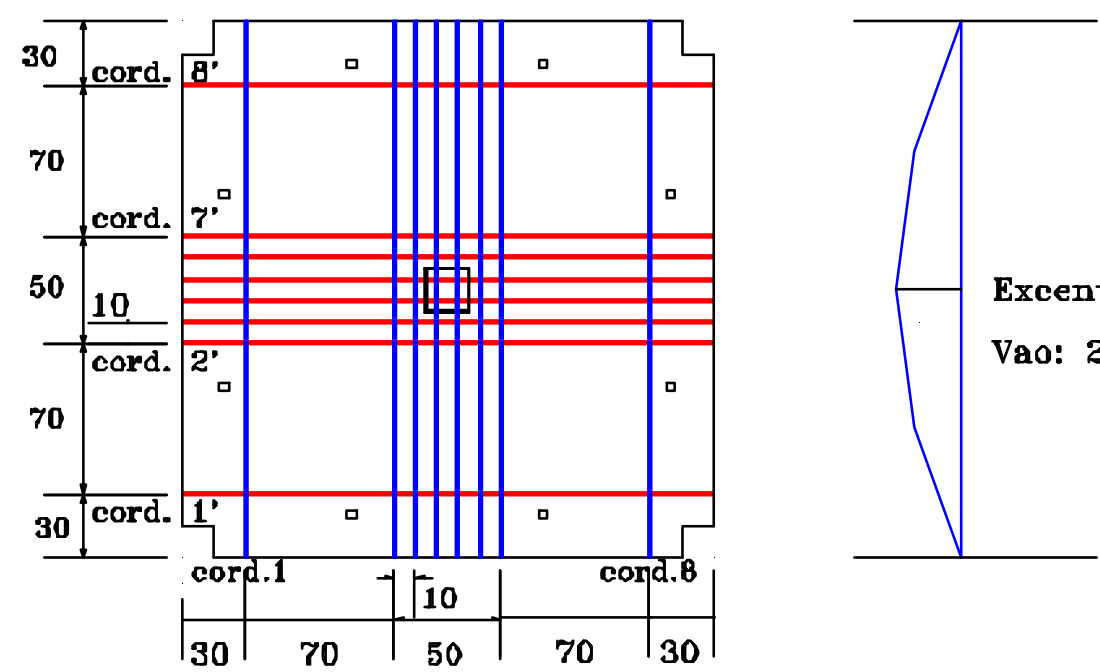

Excentr.: 4,61 cm

Vao: $250 \mathrm{~cm}$
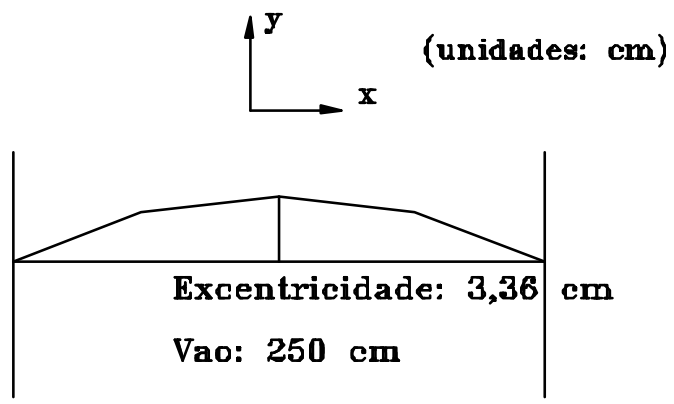

Diametro da cordoalha: 1,285 $\mathrm{cm}$
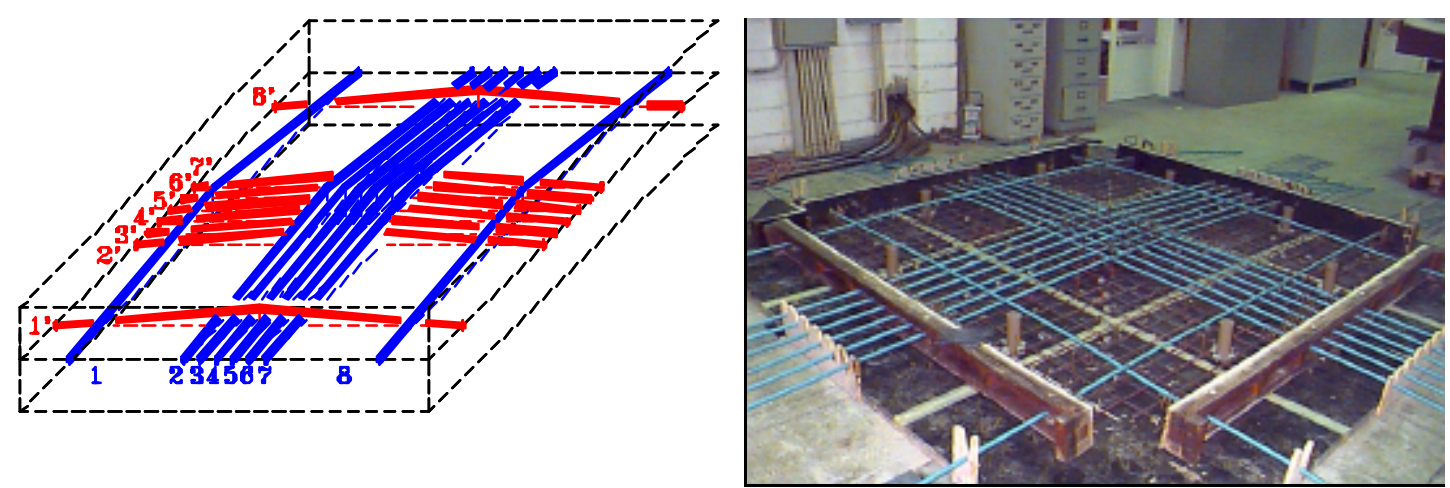

Figura 3.65 - Posição das cordoalhas 
$\mathrm{Na}$ região central, as cordoalhas dispostas na direção y foram intercaladas com a armadura passiva; já as cordoalhas dispostas na direção x foram posicionadas abaixo da armadura passiva disposta nesta mesma direção (figura 3.66). Na figuras 3.67, tem-se o modelo protendido pronto para ser concretado.

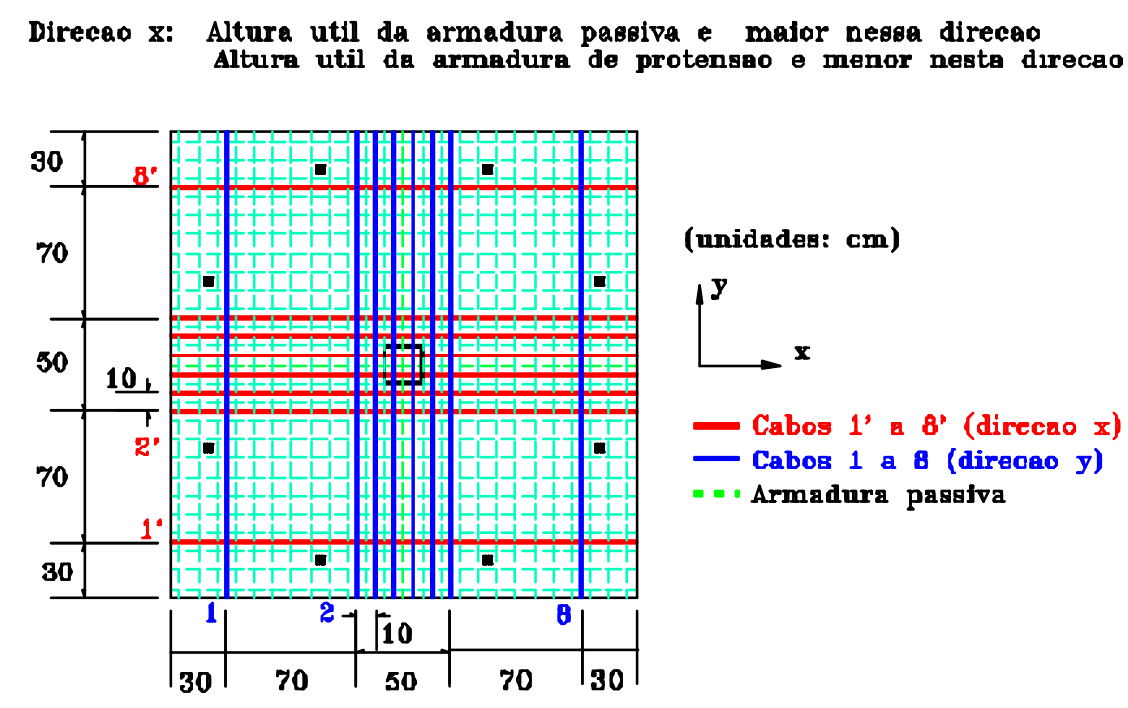

a) Esquema geral

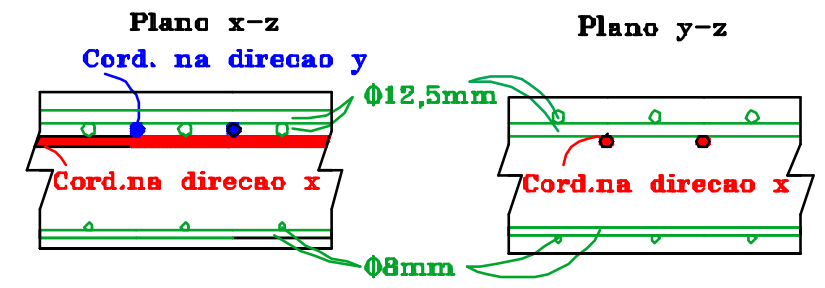

b) Seções transversais relativas ao meio do vão

Figura 3.66 - Disposição das cordoalhas com relação à armadura passiva

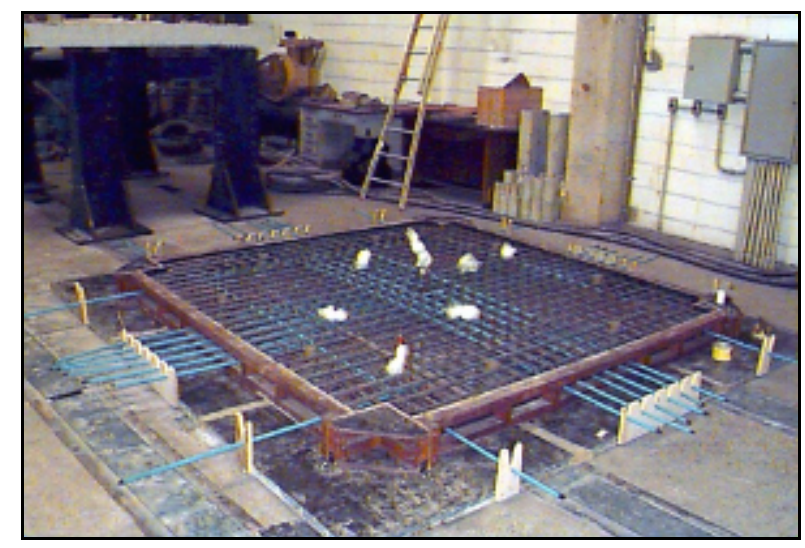

Figura 3.67 - Modelo pronto para ser concretado 
Com relação à regularização de tensões, FUSCO (1995) menciona que, em princípio, a difusão da força deve ser considerada a partir da ancoragem, segundo um ângulo limitado por duas retas inclinadas de $\theta$ em relação à direção da força, sendo $\operatorname{tg} \theta=2 / 3$. Essa regra de difusão, que é empregada para a localização das seções onde as tensões de protensão já estão totalmente regularizadas, serve de guia geral para o estudo das zonas de regularização. Na figura 3.68, define-se esta zona, considerando-se que a placa de ancoragem é quadrada, com lado igual a $8 \mathrm{~cm}$.
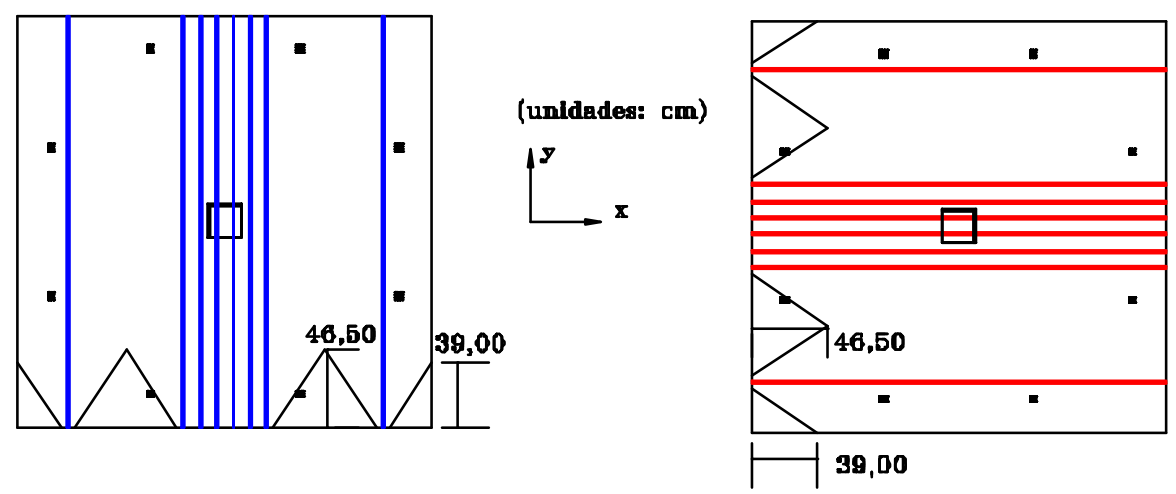

Figura 3.68 - Zona de regularização das tensões

Para o correto posicionamento do traçado das cordoalhas, foram usados "caranguejos". Cumpre destacar que todos os "caranguejos" foram feitos usando-se aço de bitola igual a 6,3 mm. Nas figuras 3.69 e 3.70, têm-se a posição e o detalhe de um dos "caranguejos" usados para posicionar as cordoalhas dispostas na direção x.
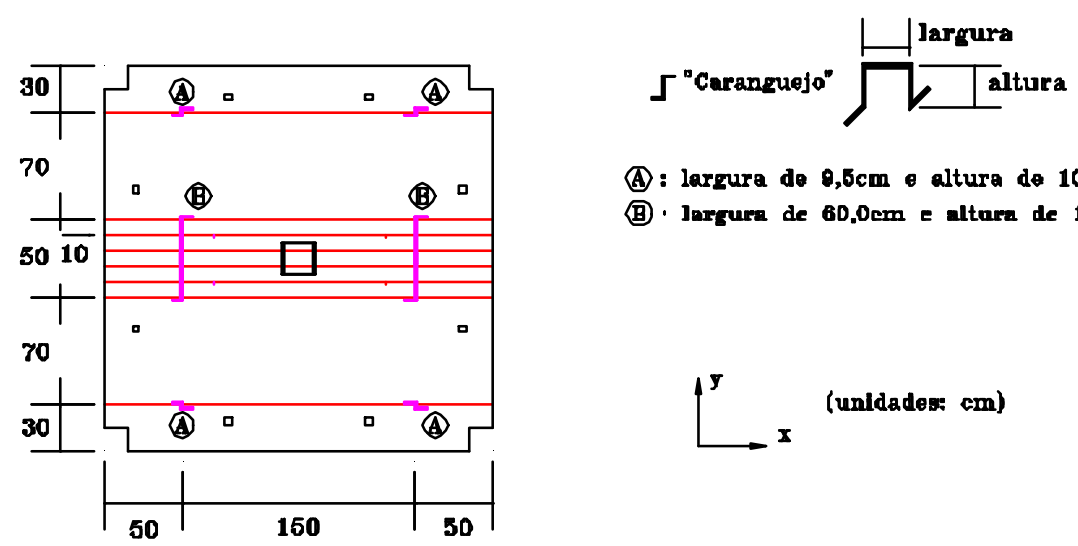

(A) : largura de $0,5 \mathrm{~cm}$ e altura de $10,1 \mathrm{~cm}$

(B): Jargura de 60.0em e altura de $10.1 \mathrm{~cm}$

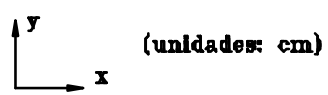

Figura 3.69 - "Caranguejos" usados para posicionar as cordoalhas na direção x 


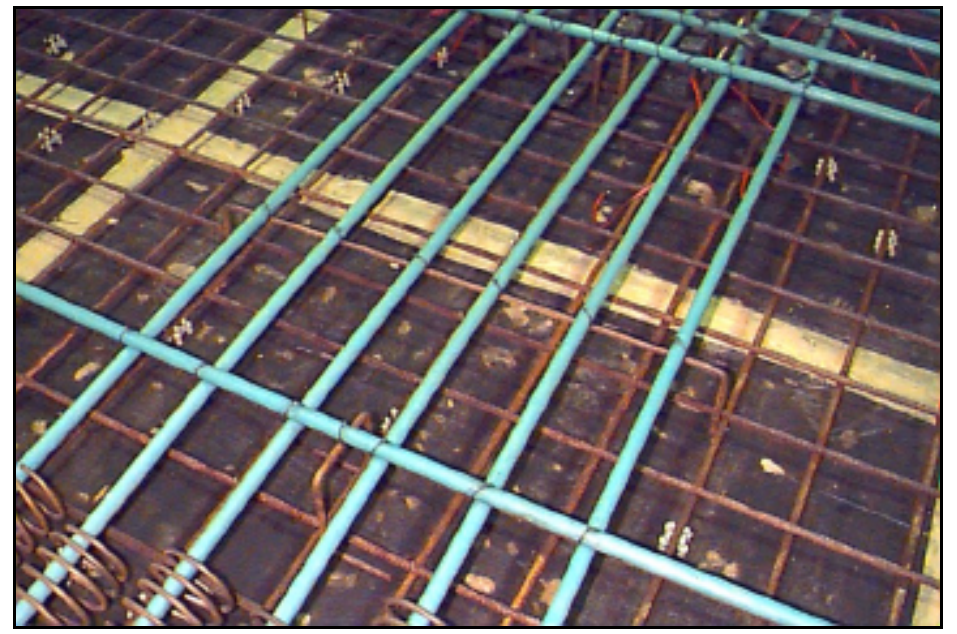

Figura 3.70 - Detalhe do "caranguejo" tipo B

Nas figuras 3.71 a 3.73, têm-se a posição e os detalhes de "caranguejos" usados para posicionar as cordoalhas dispostas na direção y.

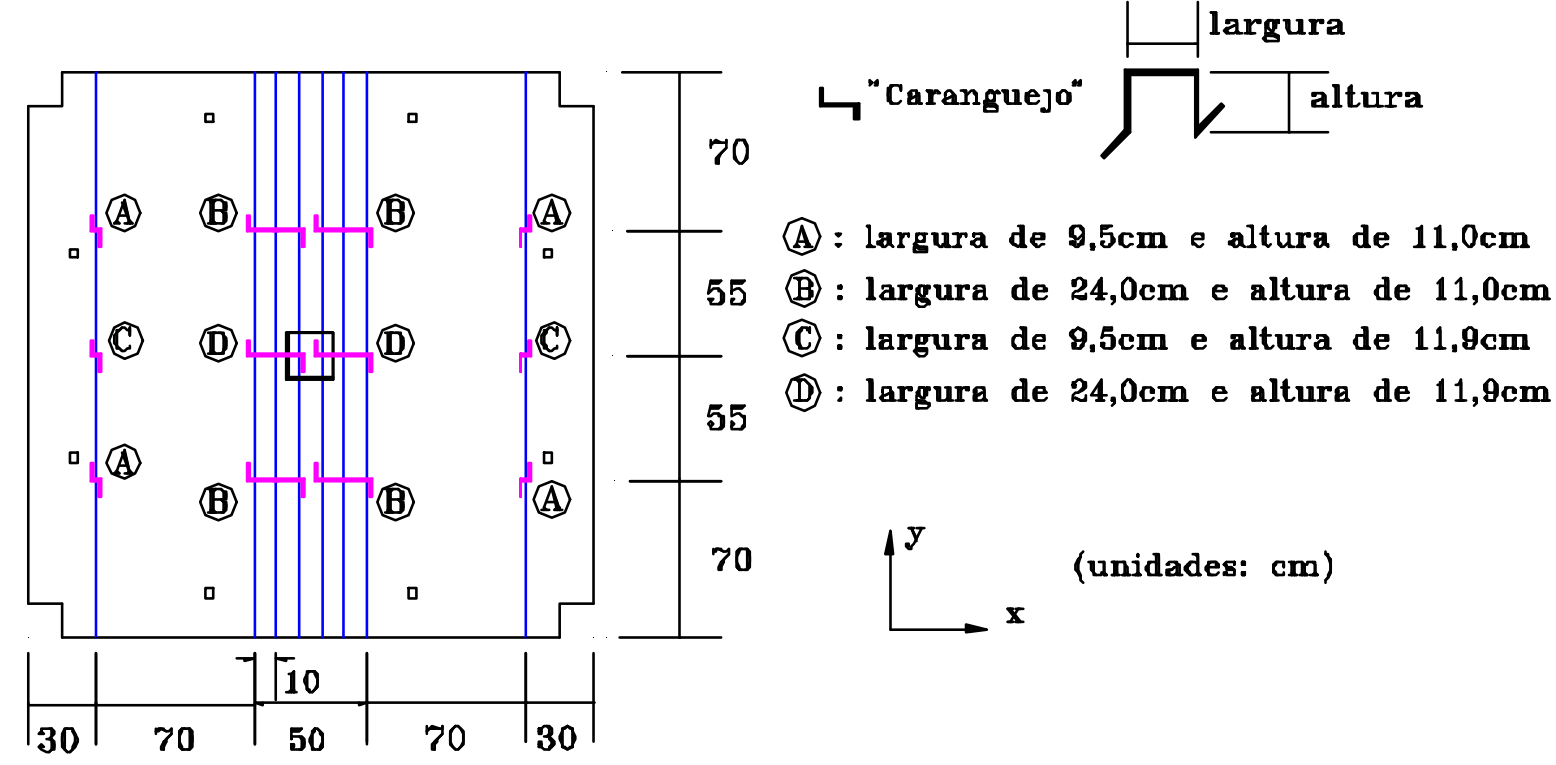

Figura 3.71 - "Caranguejos" usados para posicionar as cordoalhas na direção y 


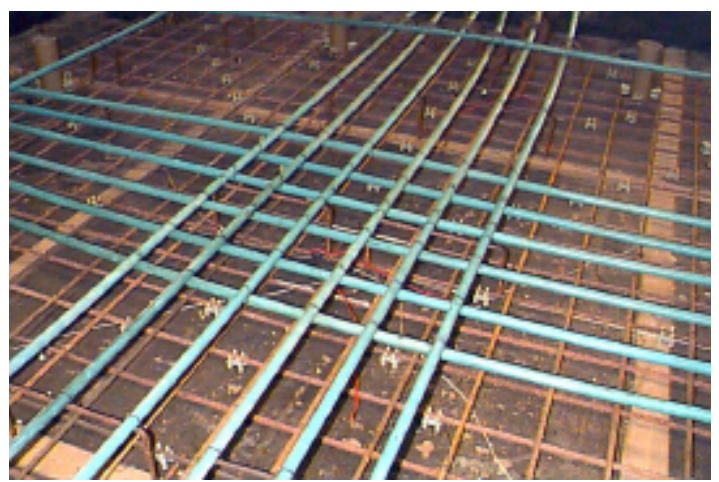

Figura 3.72 - Detalhe dos "caranguejos" tipo D

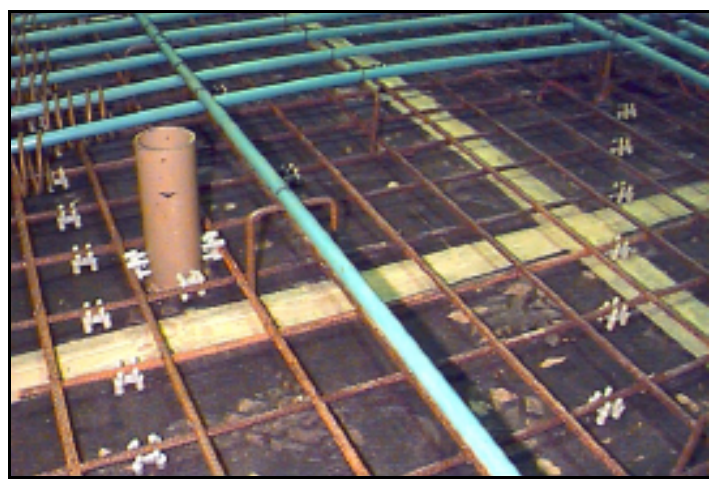

Figura 3.73 - Detalhe do “caranguejo” tipo

A

\section{c) Armadura de fretagem}

Como armadura de fretagem, foram usadas molas, mostradas na figura 3.74. Estas molas foram posicionadas de modo a encostarem na face lateral da fôrma.

\section{FRETAGEM}
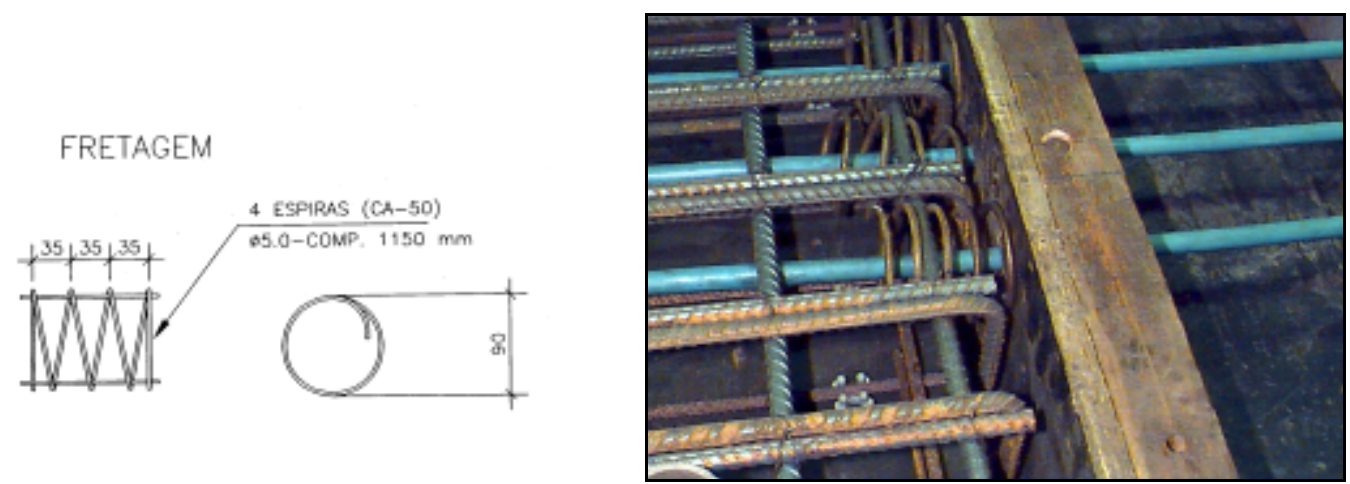

a) Esquema geral

b) Posicionamento

Figura 3.74 - Detalhe do projeto da armadura de fretagem

\section{d) Armadura dos cantos}

Para cada canto do modelo, foram usadas quatro barras de $6,3 \mathrm{~mm}$, em forma de $\mathrm{L}$, estando duas próximas à face inferior do modelo e duas próximas à face superior. $\mathrm{O}$ detalhamento desta armadura está mostrado na figura 3.75. 

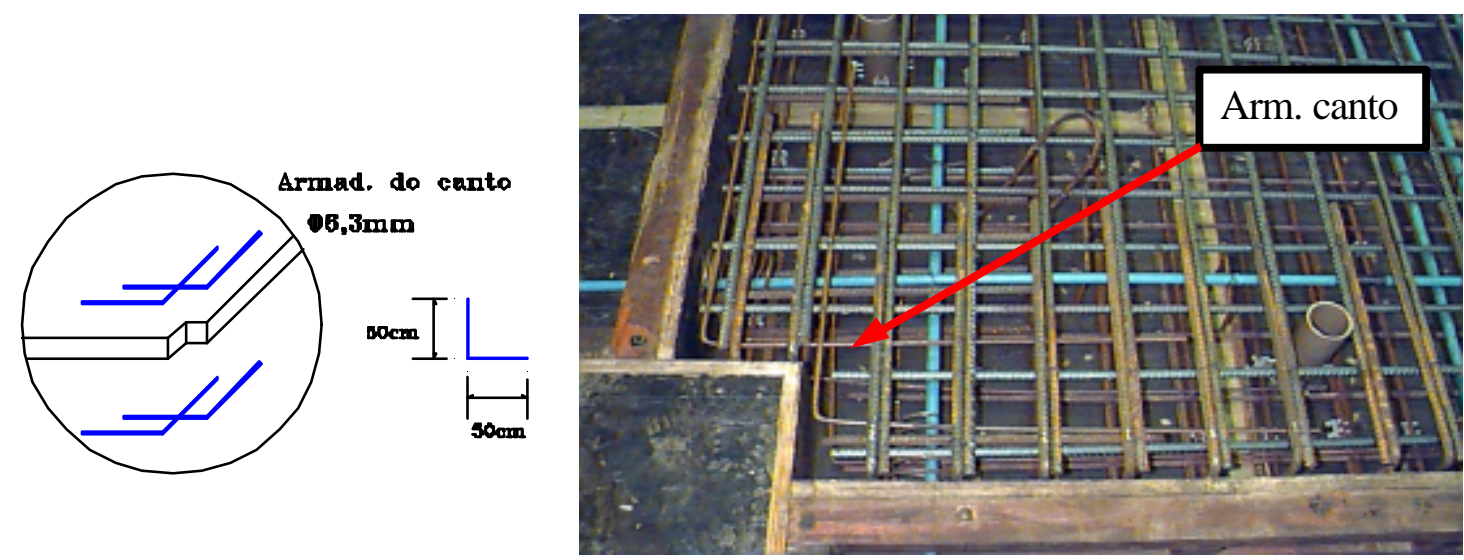

Figura 3.75 - Detalhamento da armadura do canto

\subsubsection{CARACTERIZAÇÃO DOS MATERIAIS}

O aço especificado para as malhas foi o CA $50\left(f_{y}=500 \mathrm{MPa}\right)$. Amostras das armaduras foram ensaiadas de modo a confirmar a resistência e o módulo de elasticidade das barras das malhas superior e inferior.

Com relação à armadura, os termos $f_{y}$ e $f_{r}$ são, respectivamente, as tensões de escoamento e de ruptura da barra. Estas tensões foram calculadas, respectivamente, dividindo-se as forças de escoamento e de ruptura pela área das barras. A área de cada barra foi calculada multiplicando-se a densidade do aço $\left(7850 \mathrm{~kg} / \mathrm{m}^{3}\right)$ pelo comprimento da barra e dividindo-se o peso da barra por este produto.

Nas tabelas 3.9 a 3.12, estão apresentadas as características das barras usadas nos modelos. Os procedimentos usados na obtenção destes valores estão mostrados no Anexo E.

Para o modelo M3, algumas das barras de $8 \mathrm{~mm}$ de diâmetro, pertencentes a um mesmo lote, apresentaram um comportamento mecânico diferenciado, tendo sido classificadas como sendo da classe B. No entanto, como outras barras deste mesmo lote foram classificadas como sendo da classe A, adotou-se o aço como sendo da classe A, com as características mecânicas dadas na tabela 3.10.

As características da cordoalha foram fornecidas pela Companhia Siderúrgica BelgoMineira, através de um certificado de qualidade. As propriedades geométricas e mecânicas da cordoalha estão mostradas na tabela 3.13 
Tabela 3.9 - Características geométricas e mecânicas das barras usadas nos modelos $\boldsymbol{M 1}$ e $\mathbf{M} \boldsymbol{2}$

\begin{tabular}{|c|c|c|c|c|c|}
\hline Diâm. $(\mathbf{m m})$ & Área $\left(\mathbf{c m}^{2}\right)$ & $f_{\boldsymbol{y}}(\mathbf{M P a})$ & $\boldsymbol{f}_{\boldsymbol{r}}(\mathbf{M P a})$ & $\boldsymbol{E}_{\boldsymbol{S}}(\mathbf{M P a})$ & Classe do aço \\
\hline 16 & 2,001 & 590,4 & 722,1 & 190209 & $\mathrm{~A}$ \\
\hline 8 & 0,496 & 597,9 & 711,1 & 214156 & $\mathrm{~A}$ \\
\hline
\end{tabular}

Tabela 3.10- Características geométricas e mecânicas das barras usadas no modelo $\mathbf{M 3}$

\begin{tabular}{|c|c|c|c|c|c|}
\hline Diâm. $(\mathbf{m m})$ & Área $\left(\mathbf{c m}^{2}\right)$ & $f_{\boldsymbol{y}}(\mathbf{M P a})$ & $\boldsymbol{f}_{\boldsymbol{r}}(\mathbf{M P a})$ & $\boldsymbol{E}_{\boldsymbol{S}}(\mathbf{M P a})$ & Classe do aço \\
\hline 16 & 1,919 & 508,3 & 814,9 & 190209 & $\mathrm{~A}$ \\
\hline 8 & 0,497 & 601,8 & 711,9 & 206900 & $\mathrm{~A}$ \\
\hline
\end{tabular}

Tabela 3.11 - Características geométricas e mecânicas das barras usadas no modelo $\mathbf{M 4}$

\begin{tabular}{|c|c|c|c|c|c|}
\hline Diâm. $(\mathbf{m m})$ & Área $\left(\mathrm{cm}^{2}\right)$ & $f_{\boldsymbol{y}}(\mathbf{M P a})$ & $f_{\boldsymbol{r}}(\mathbf{M P a})$ & $\boldsymbol{E}_{\boldsymbol{S}}(\mathbf{M P a})$ & Classe do aço \\
\hline 12,5 & 1,188 & 651,4 & 792,3 & 201541 & $\mathrm{~A}$ \\
\hline 8 & 0,497 & 601,8 & 711,9 & 206900 & $\mathrm{~A}$ \\
\hline
\end{tabular}

Tabela 3.12 - Características geométricas e mecânicas das barras usadas nos modelos M5 e M6

\begin{tabular}{|c|c|c|c|c|c|}
\hline Diâm. $(\mathbf{m m})$ & Área $\left(\mathrm{cm}^{2}\right)$ & $f_{\boldsymbol{y}}(\mathbf{M P a})$ & $f_{\boldsymbol{r}}(\mathbf{M P a})$ & $\boldsymbol{E}_{\boldsymbol{S}}(\mathbf{M P a})$ & Classe do aço \\
\hline 12,5 & 1,188 & 651,4 & 792,3 & 201541 & $\mathrm{~A}$ \\
\hline 8 & 0,491 & 636,8 & 730,9 & 198865 & $\mathrm{~A}$ \\
\hline
\end{tabular}

Tabela 3.13 - Características geométricas e mecânicas da cordoalha de protensão usada nos modelos M4, M5 e M6

\begin{tabular}{|c|c|c|c|c|c|}
\hline $\begin{array}{c}\text { Diâm. da } \\
\text { cordoalha } \\
(\mathbf{m m})\end{array}$ & $\begin{array}{c}\text { Área } \\
\left(\mathbf{m m}^{2}\right)\end{array}$ & $\begin{array}{c}\text { Carga 1\% } \\
(\boldsymbol{k N})\end{array}$ & $\begin{array}{c}\text { Carga ruptura } \\
(\mathbf{k N})\end{array}$ & $\begin{array}{c}\text { Módulo de } \\
\text { Elasticidade } \\
\left(\mathbf{k N}_{\left.\mathbf{m} \mathbf{m m}^{2}\right)}\right.\end{array}$ & $\begin{array}{c}\text { Alongamentto } \\
\mathbf{6 0 0} \mathbf{m m} \\
(\boldsymbol{\%})\end{array}$ \\
\hline 12,85 & 99,9 & 182 & 200 & 208 & 6,4 \\
\hline
\end{tabular}




\subsection{PROJETO, EXECUÇÃO E CARACTERIZAÇÃO DOS MATERIAIS USADOS NA ARMADURA DE PUNÇÃO}

Como armadura de punção, optou-se pelo uso dos conectores tipo-pino (figura 3.76). Estes conectores foram usados nos modelos de concreto armado M2 e M3, e nos modelos de concreto protendido M5 e M6. Nos modelos M2 e M5, foram usadas duas linhas de conectores (figura 3.77), e, nos modelos M3 e M6, três linhas (figura 3.78).

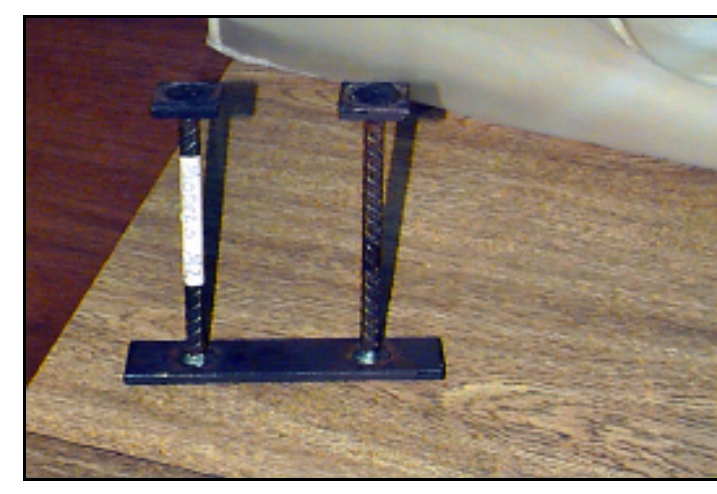

a) Com dois pinos

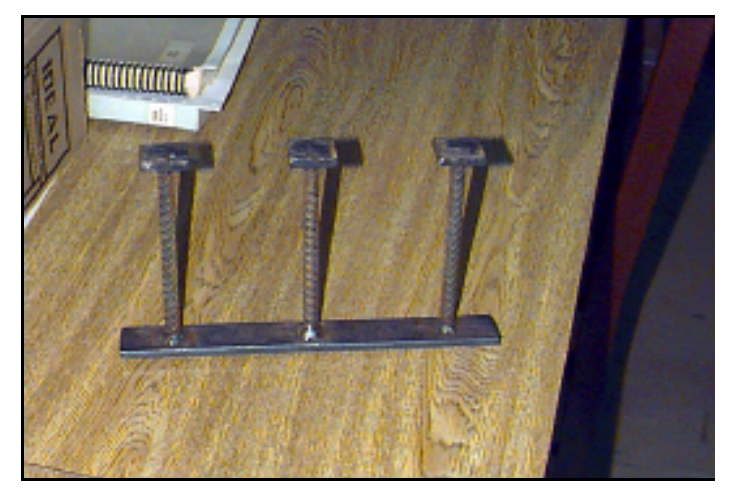

b) Com três pinos

Figura 3.76 - Conectores usados nos modelos
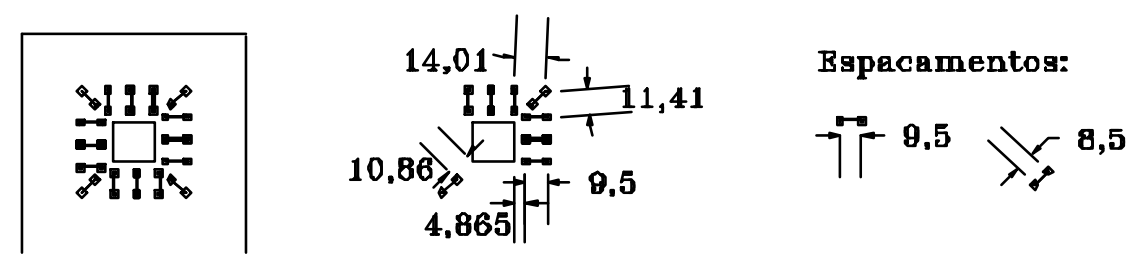

Figura 3.77 - Disposição adotada para duas linhas de conectores
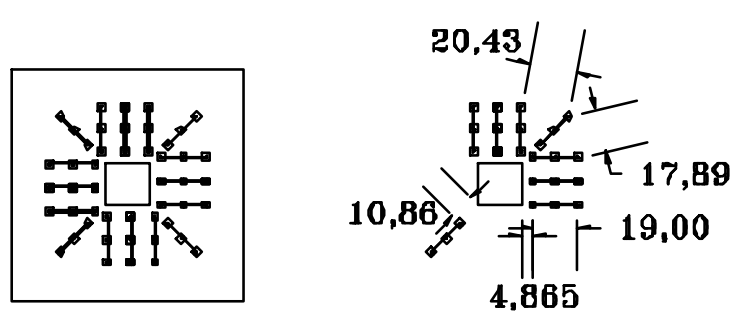

Espacamentos:

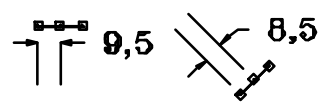

Figura 3.78 - Disposição adotada para três linhas de conectores 
Nas figuras 3.79 a 3.82, tem-se a disposição dos pinos adotada para os modelos M2, M3, M5 e M6, respectivamente.

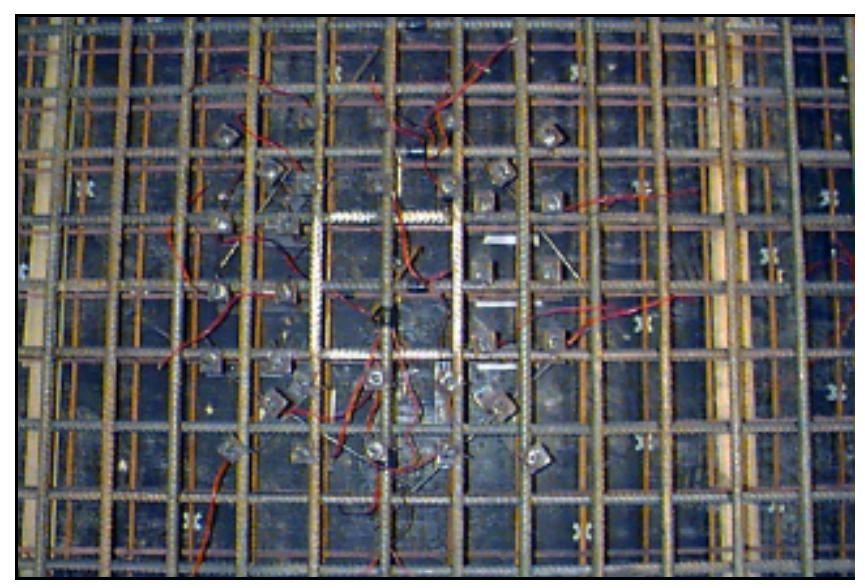

a) Vista superior

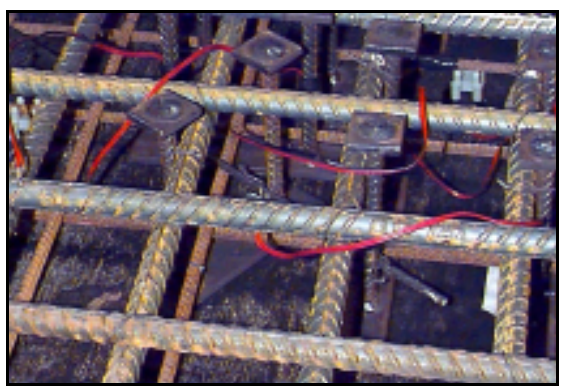

b) Detalhe

Figura 3.79 - Disposição de conectores adotada para o modelo M2

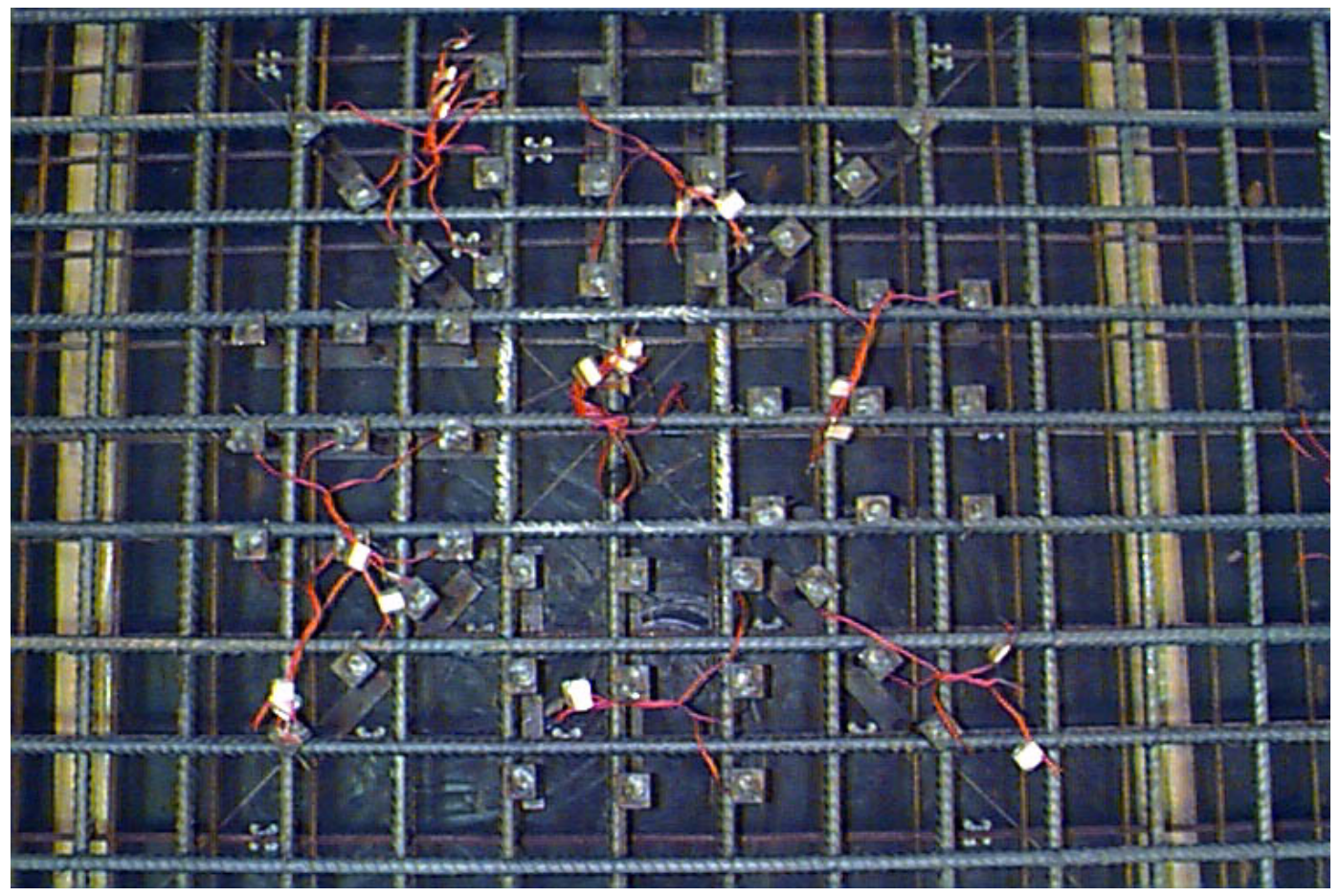

Figura 3.80 - Disposição de conectores adotada para o modelo M3 


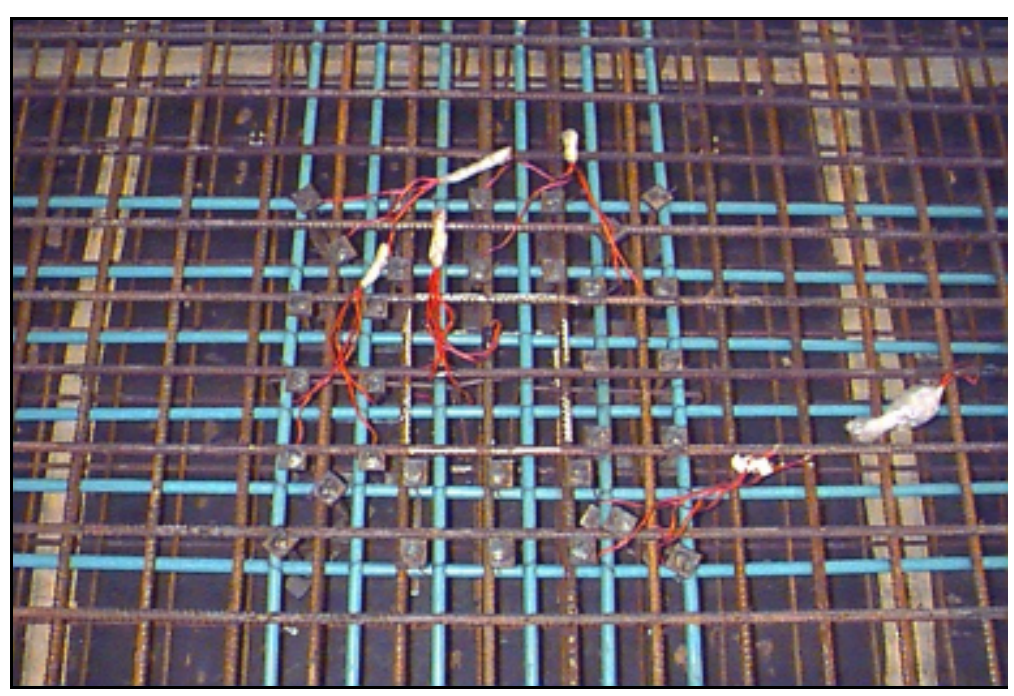

a) Vista superior

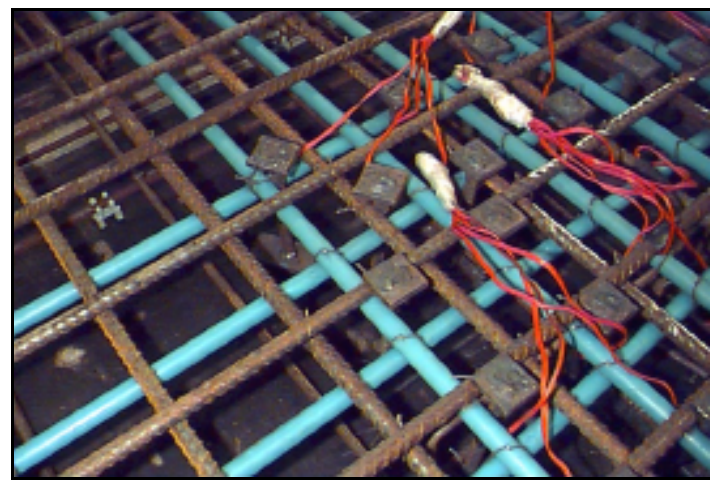

b) Detalhe

Figura 3.81 - Disposição de conectores adotada para o modelo M5

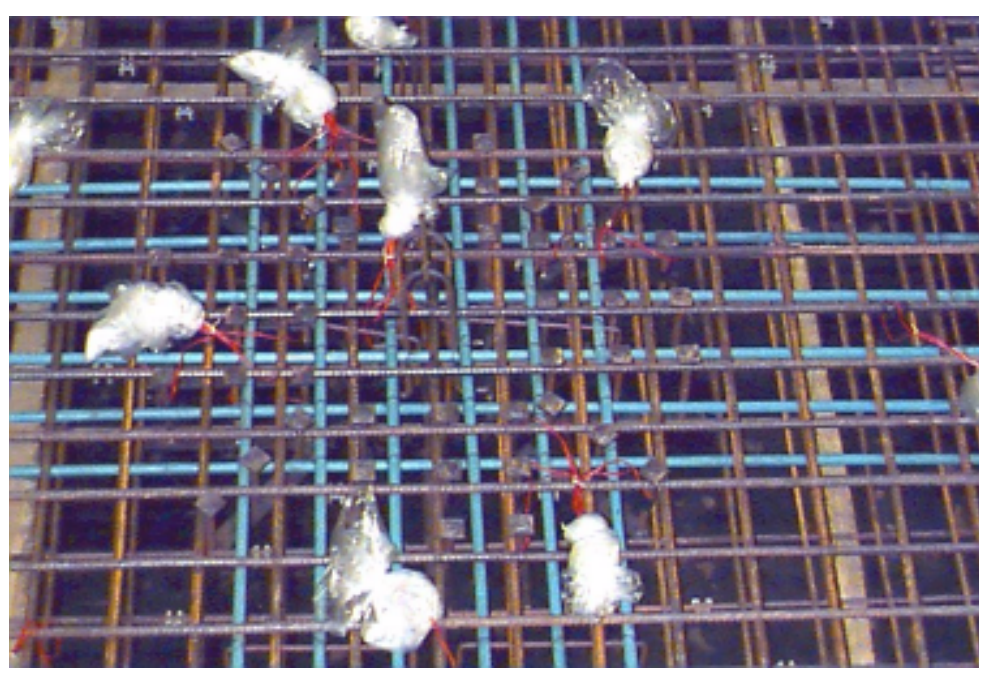

a) Vista superior

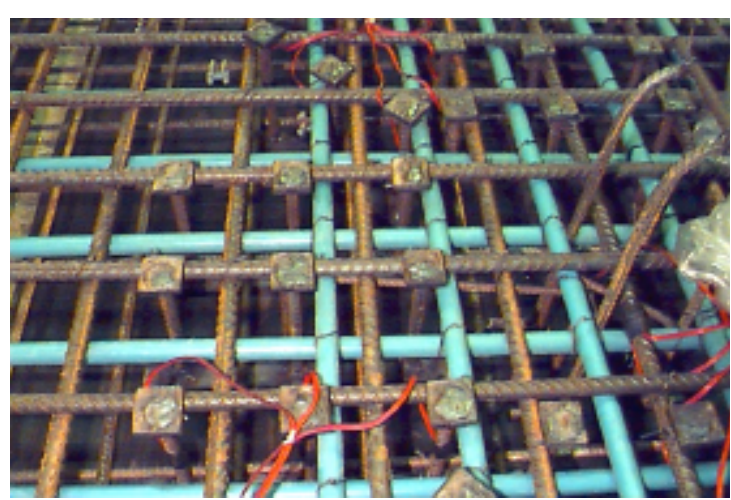

b) Detalhe

Figura 3.82 - Disposição de conectores adotada para o modelo M6

Pode-se observar que, em cada modelo, o espaçamento dos conectores na direção diagonal à malha de armadura de flexão não é igual ao espaçamento dos conectores dispostos nas direções paralelas à essa malha.

O detalhamento dos pinos com 2 e 3 linhas de conectores está mostrado nas figuras 3.83 e 3.84 . 
No Anexo F, estão ilustrados os procedimentos usados para a execução dos conectores.

Foram feitos ensaios de modo a caracterizar tanto o comportamento dos pinos quanto o da armadura usada para fazê-los.

A descrição dos ensaios e os procedimentos usados para a obtenção das características geométricas e mecânicas dos conectores estão mostrados no Anexo F; já o resumo dos resultados obtidos é apresentado a seguir.

A armadura usada para a execução dos pinos foi especificada como sendo do tipo CA 50. Após os ensaios dos pinos, verificou-se que o gráfico da força versus deslocamento apresentou um nítido patamar de escoamento.

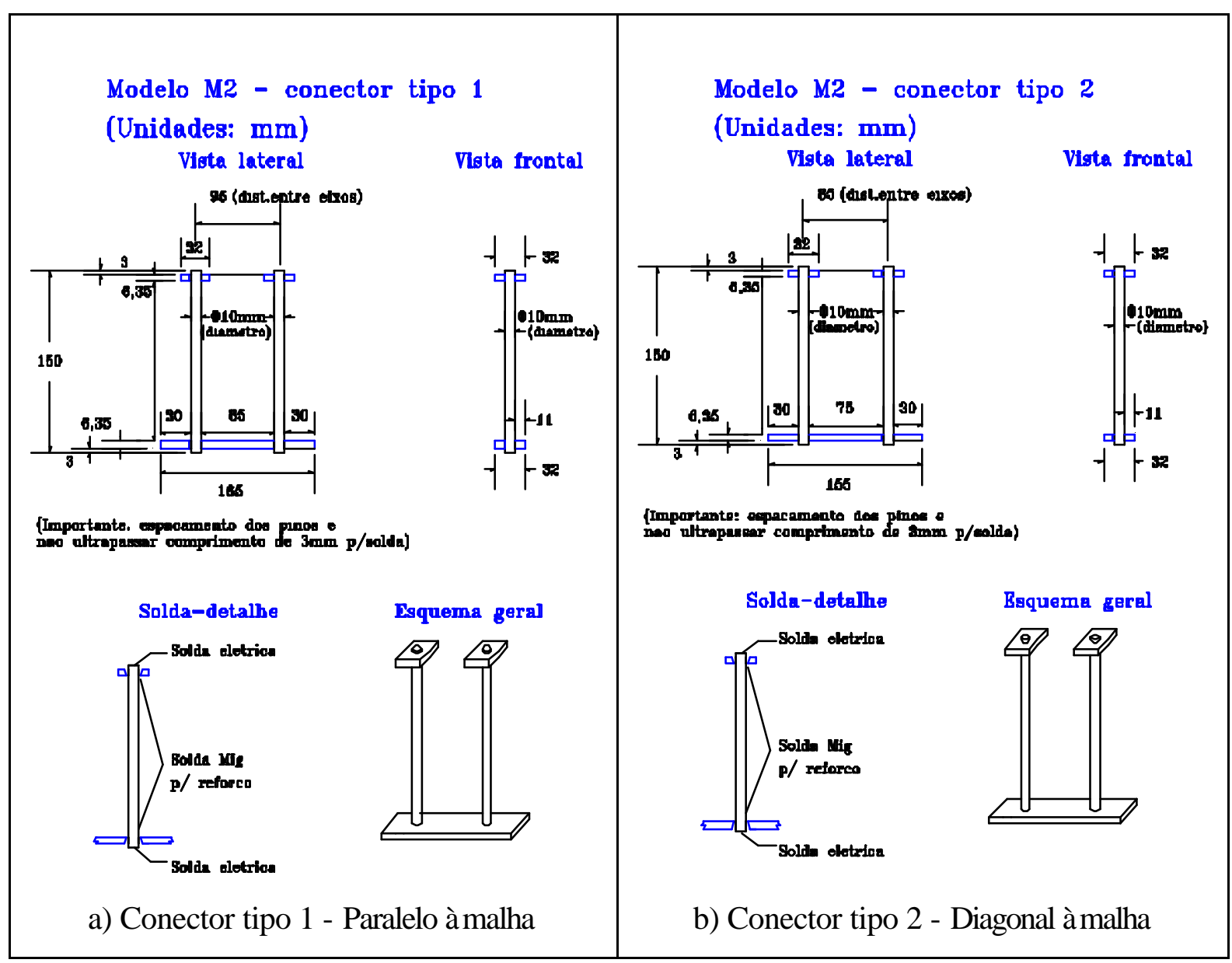

Figura 3.83 - Conectores com duas linhas de pinos 


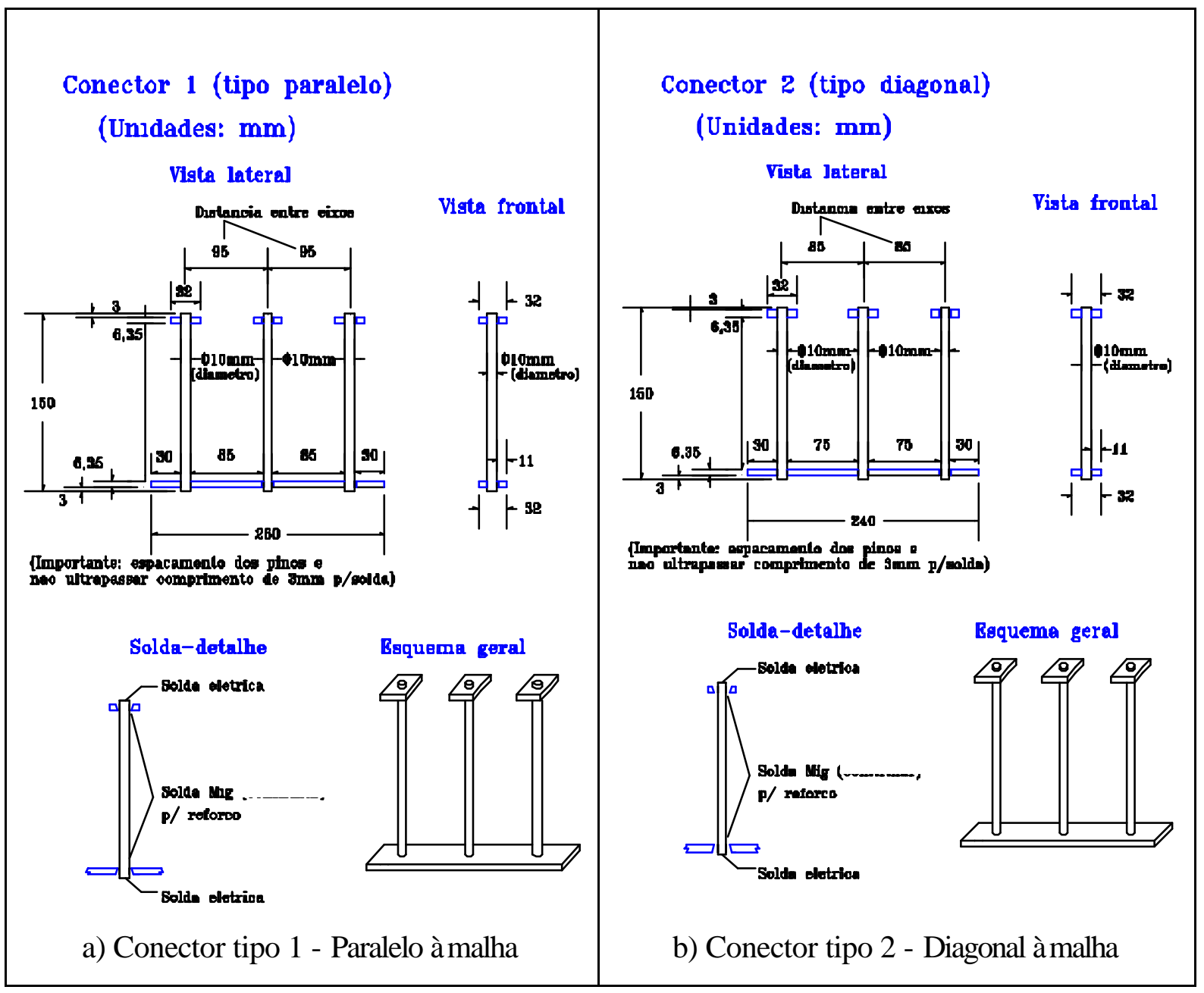

Figura 3.84 - Conectores com três linhas de pinos

\section{a) MODELO M2}

Nas tabelas 3.14 e 3.15, estão apresentados os valores médios relativos às amostras de barras e aos conectores ensaiados.

Tabela 3.14 - Características geométricas e mecânicas da barra

\begin{tabular}{|c|c|c|c|c|}
\hline \multicolumn{5}{|c|}{ Barra - Diâmetro: 10 mm - Aço do tipo A (valores médios) } \\
\hline Área $\left(\mathrm{cm}^{2}\right)$ & $f_{y}(M P a)$ & $f_{r} \quad(M P a)$ & $F_{y}(k N)$ & $F_{r}(k N)$ \\
\hline 0,771 & 598,2 & 718,5 & 46,09 & 55,36 \\
\hline \multicolumn{5}{|c|}{$\begin{array}{l}\text { Obs.: } f_{\boldsymbol{y}} \text { e } \boldsymbol{F}_{\boldsymbol{y}} \text { são, respectivamente, a tensão e a força que provoca o escoamento da barra; } \\
\text { já } \boldsymbol{f}_{\boldsymbol{r}} \text { e } \boldsymbol{F}_{\boldsymbol{r}} \text { são, respectivamente, a tensão e a força que provoca a ruptura da barra }\end{array}$} \\
\hline
\end{tabular}


Tabela 3.15 - Características mecânicas dos conectores

\begin{tabular}{|l|c|c|c|c|}
\hline$f_{\boldsymbol{y}}(\mathbf{M P a})$ & $f_{\boldsymbol{r}}(\mathbf{M P a})$ & $\boldsymbol{F}_{\boldsymbol{y}}(\boldsymbol{k N})$ & $\boldsymbol{F}_{\boldsymbol{r}}(\boldsymbol{k N})$ & $\boldsymbol{E}(\boldsymbol{G P a})$ \\
\hline 568,2 & 696,4 & 43,81 & 53,25 & 166,45 \\
\hline Obs.: \\
• Para o cálculo da tensão, foi adotada a área da seção transversal como sendo de $0,771 \mathrm{~cm}^{2}$. \\
• E é o módulo de elasticidade do conector \\
• $\boldsymbol{f}_{\boldsymbol{y}}$ e $\boldsymbol{F}_{\boldsymbol{y}}$ são, respectivamente, a tensão e a força que provoca o escoamento da barra; já $\boldsymbol{f}_{\boldsymbol{r}}$ e \\
$\boldsymbol{F}_{\boldsymbol{r}}$ são, respectivamente, a tensão e a força que provoca a ruptura da barra \\
\hline
\end{tabular}

Nos cálculos, são adotados os valores relativos às características mecânicas obtidas para os conectores.

\section{b) MODELOS M3, M5 e M6}

Na tabela 3.16 estão apresentadas as características geométricas e mecânicas das barras usadas na execução dos conectores. Já nas tabelas 3.17 a 3.19, estão apresentadas as características dos pinos usados para cada um dos modelos.

Para o modelo M3, alguns conectores romperam na região da ligação dos pinos com uma das chapas metálicas soldadas em suas extremidades. Os detalhes referentes a este assunto estão no Anexo F. No entanto, todos os conectores romperam após o escoamento do pino, possibilitando o seu uso no modelo M3.

Tabela 3.16 - Características geométricas e mecânicas da barra usada para confeccionar os pinos relativos aos modelos M3, M5 e M6

\begin{tabular}{|c|c|c|c|c|}
\hline \multicolumn{5}{|c|}{ Barra - Diâmetro: 10 mm - Aço do tipo A (valores médios) } \\
\hline Área $\left(\mathrm{cm}^{2}\right)$ & $f_{y} \quad(M P a)$ & $f_{r} \quad(M P a)$ & $F_{y}(k N)$ & $F_{r}(k N)$ \\
\hline 0,763 & 633,9 & 759,6 & 48,40 & 58,00 \\
\hline \multicolumn{5}{|c|}{$\begin{array}{l}\text { Obs.: } \boldsymbol{f}_{\boldsymbol{y}} \text { e } \boldsymbol{F}_{\boldsymbol{y}} \text { são, respectivamente, a tensão e a força que provoca o escoamento da barra; já } \\
\boldsymbol{f}_{\boldsymbol{r}} \text { e } \boldsymbol{F}_{\boldsymbol{r}} \text { são, respectivamente, a tensão e a força que provoca a ruptura da barra }\end{array}$} \\
\hline
\end{tabular}


Tabela 3.17 - Características mecânicas dos conectores relativos ao modelo M3

\begin{tabular}{|c|c|c|c|c|}
\hline$f_{y} \quad(M P a)$ & $f_{r} \quad(M P a)$ & $F_{y}(k N)$ & $F_{r}(k N)$ & $E(G P a)$ \\
\hline 625,3 & - & 47,73 & - & 172,42 \\
\hline \multicolumn{5}{|c|}{$\begin{array}{l}\text { Obs.: } \\
\text { - Para o cálculo da tensão, foi adotada a área da seção transversal como sendo de } 0,763 \mathrm{~cm}^{2} \text {. } \\
\text { - Para o modelo M3, parte dos conectores romperam na ligação do pino com a chapa metálica; } \\
\text { deste modo, não foi possível determinar, nem a tensão e nem a força de ruptura }\end{array}$} \\
\hline
\end{tabular}

Tabela 3.18 - Características mecânicas dos conectores relativos ao modelo M5

\begin{tabular}{|c|c|c|c|c|}
\hline$F_{y}(M P a)$ & $f_{r} \quad(M P a)$ & $F_{y} \quad(k N)$ & $F_{r}(k N)$ & $E(G P a)$ \\
\hline 627,7 & 764 & 47,89 & 58,34 & $2 *$ \\
\hline \multicolumn{5}{|c|}{$\begin{array}{l}\text { Obs.: } \\
\text { - Para o cálculo da tensão, foi adotada a área da seção transversal como sendo de } 0,763 \mathrm{~cm}^{2} \text {. } \\
\text { - Para este modelo, todos os conectores romperam fora de região da ligação do pino com a } \\
\text { solda. } \\
\text { - Módulo de deformação longitudinal foi considerado igual ao do modelo M3. }\end{array}$} \\
\hline
\end{tabular}

Tabela 3.19 - Características mecânicas dos conectores relativos ao modelo M6

\begin{tabular}{|c|c|c|c|c|}
\hline$f_{y} \quad(M P a)$ & $f_{r} \quad(M P a)$ & $F_{y} \quad(k N)$ & $F_{r}(k N)$ & $E(G P a)$ \\
\hline 623 & 759 & 47,60 & 57,93 & \\
\hline \multicolumn{5}{|c|}{$\begin{array}{l}\text { Obs.: } \\
\text { - Para o cálculo da tensão, foi adotada a área da seção transversal como sendo de } 0,763 \mathrm{~cm}^{2} \text {. } \\
\text { - Para este modelo, todos os conectores romperam fora de região da ligação do pino com a } \\
\text { solda. } \\
\text { - Módulo de deformação longitudinal foi considerado igual ao do modelo M3. }\end{array}$} \\
\hline
\end{tabular}




\section{INSTRUMENTAÇÃO DOS MODELOS E RESULTADOS OBTIDOS}

São apresentados a instrumentação e os resultados experimentais obtidos, relativos aos modelos mostrados na tabela 3.1 do capítulo 3 .

Para determinar as deformações da armadura e do concreto, foram usados, respectivamente, extensômetros elétricos do tipo KFG-5-C1-11 e KFG-10-C1-11, da marca Kyowa. Os deslocamentos foram medidos através de transdutores de deslocamentos, também de marca Kyowa, com curso máximo de 100 mm, tendo sido posicionados junto às faces superior e lateral do modelo (figura 4.1). Na figura 4.2, tem-se o detalhe da fixação de cantoneiras metálicas nas vigas superiores. Essas cantoneiras foram usadas para apoiar os transdutores que mediram os deslocamentos transversais da laje. Nos modelos protendidos, foram usadas células de carga para quantificar a força de protensão nas cordoalhas. A calibração das células de carga é ilustrada pela figura 4.3.

Os gráficos que relacionam a força aplicada pelos macacos hidráulicos com os deslocamentos, com as deformações e com as forças de protensão nas cordoalhas não saem do zero, mas sim de uma força correspondente ao peso próprio do modelo.

$\mathrm{Na}$ figura 4.4, tem-se a posição dos macacos usados para aplicar a força concentrada ao modelo. Apenas para o modelo M2 é que, após o ensaio, foi constatada uma excentricidade da chapa metálica com relação ao centro da laje, sendo esta da ordem de $1 \mathrm{~cm}$, no sentido do eixo x (figura 4.5). 


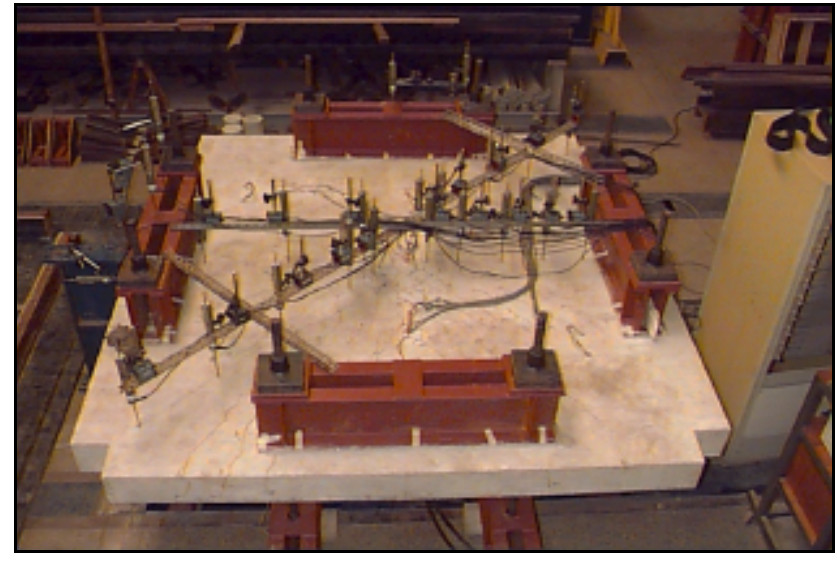

a) Deslocamentos transversais

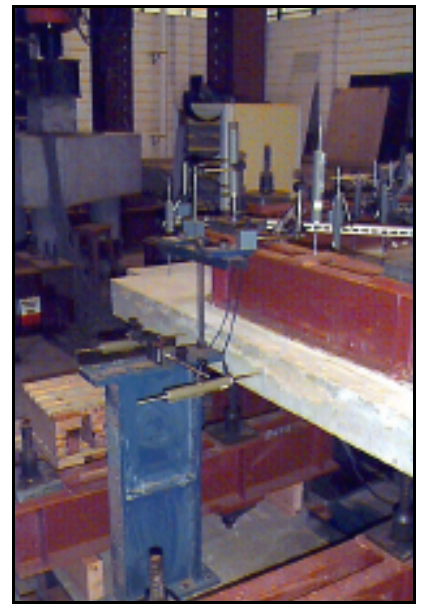

b) Deslocamentos verticais nos apoios e deslocamentos horizontais da laje

Figura 4.1 - Posicionamento dos transdutores

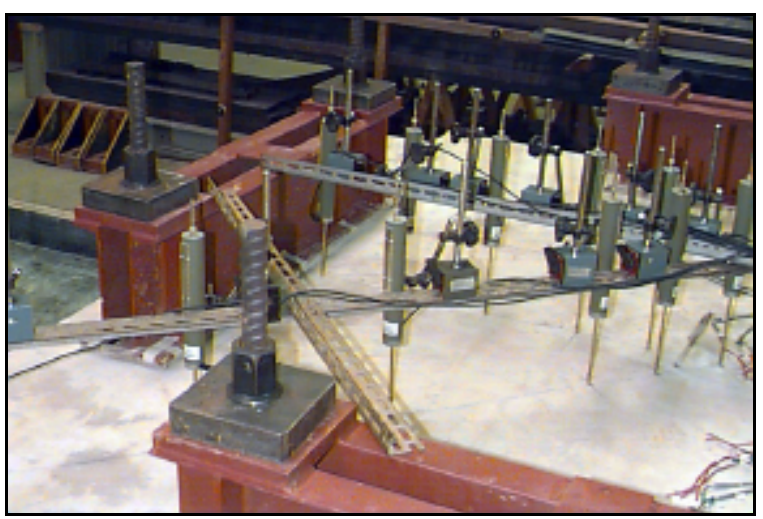

Figura 4.2 - Detalhe da fixação dos transdutores nas cantoneiras metálicas, através de bases magnéticas

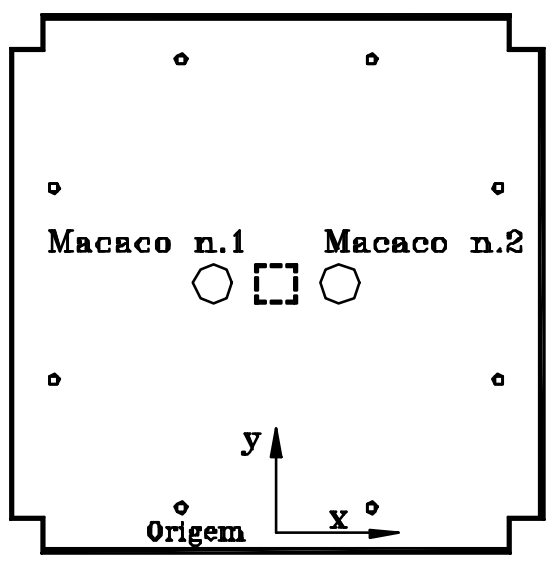

Figura 4.4 - Posição dos macacos hidráulicos

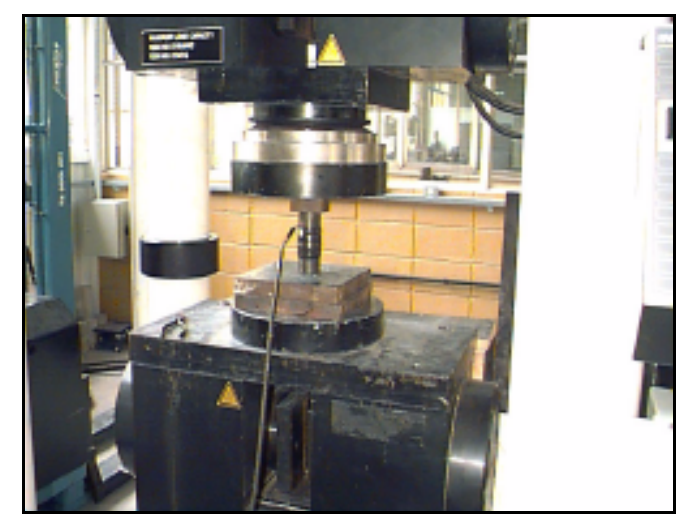

Figura 4.3 - Célula de carga sendo calibrada na máquina Instron

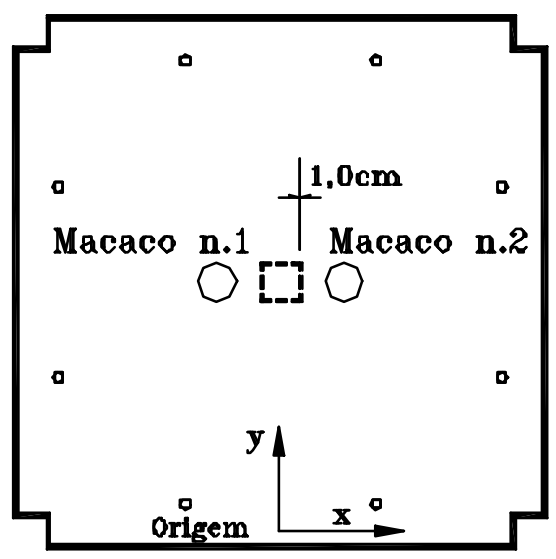

Figura 4.5 - Excentricidade observada no modelo M2 (1 cm na direção $\mathrm{x})$ 
Na tabela 4.1, têm-se algumas informações gerais, obtidas nos ensaios dos modelos.

Na tabela 4.2, estão os valores medidos em cada um dos macacos, para cada um dos modelos, nas seguintes situações: na determinação do peso próprio, na iminência da ruína e na determinação da força residual nos macacos após a ruína do modelo.

Com relação à armadura de flexão tracionada, nos modelos de concreto armado ( $\phi 16 \mathrm{~mm}$ ), e armadura de flexão passiva tracionada, nos modelos de concreto protendido $(\phi 12,5 \mathrm{~mm})$, foram colados extensômetros em duas faces opostas das barras da armadura.

Alguns dos pares de extensômetros foram colados nas faces superior e inferior da barra (figura 4.6); outros, nas faces laterais. Este procedimento teve como objetivo analisar o efeito da flexão localizada das barras, mencionado por CORDOVIL (1995).

Tabela 4.1 - Informações gerais obtidas nos ensaios dos modelos (peso próprio incluído)

\begin{tabular}{|c|c|c|c|c|}
\hline Modelo. & $\begin{array}{c}\text { Força (1) } \\
(k N)\end{array}$ & $\begin{array}{c}\text { Força (2) } \\
(k N)\end{array}$ & $\begin{array}{c}\text { Força (3) } \\
(\boldsymbol{k} N)\end{array}$ & $\begin{array}{c}\text { Força (4) } \\
(\boldsymbol{k} N)\end{array}$ \\
\hline M1 & $\mathbf{4 4 1 , 6}$ & $\mathbf{3 0 , 8}$ & $\mathbf{1 1 0 , 8}$ & $\mathbf{1 6 3 , 8}$ \\
\hline M2 & $\mathbf{8 6 3 , 7}$ & $\mathbf{3 0 , 3}$ & $\mathbf{1 4 1 , 4}$ & $\mathbf{3 0 2 , 8}$ \\
\hline M3 & $\mathbf{9 0 5 , 8}$ & $\mathbf{3 1 , 1}$ & $\mathbf{1 0 1 , 1}$ & $\mathbf{3 2 7 , 8}$ \\
\hline M4 & $\mathbf{7 7 2 , 6}$ & $\mathbf{3 1 , 8}$ & $\mathbf{7 1 , 8}(*)$ & $\mathbf{3 0 0 , 6}$ \\
\hline M5 & $\mathbf{1 1 0 4 , 1}$ & $\mathbf{3 3 , 6}$ & $\mathbf{1 2 6 , 7}(*)$ & $\mathbf{5 0 4 , 6}$ \\
\hline M6 & $\mathbf{1 ~ 0 7 7 , 8}$ & $\mathbf{3 1 , 3}$ & $\mathbf{9 1 , 3}(*)$ & $\mathbf{6 2 3 , 0}$ \\
\hline
\end{tabular}


Tabela 4.2 - Valores das forças aplicadas pelos macacos ao modelo M1 (peso próprio incluído)

\begin{tabular}{|c|c|c|c|c|c|}
\hline Mod. & $\begin{array}{l}\text { Situação } \\
\text { analisada }\end{array}$ & $\begin{array}{c}\text { Macaco } \\
\text { N. } 1 \\
(\mathrm{kN})\end{array}$ & $\begin{array}{c}\text { Macaco } \\
\text { N.2 } \\
(\mathrm{kN})\end{array}$ & $\begin{array}{c}\text { Força total } \\
\text { aplicada pelos } \\
\text { macacos }(\mathrm{kN})\end{array}$ & $\begin{array}{c}\text { Dif. percentual } \\
\text { entre N.2 e N.1 } \\
(\%)\end{array}$ \\
\hline \multirow{3}{*}{ M1 } & Peso próprio & 15,8 & 15,0 & 30,8 & $-5,1$ \\
\hline & Ruína & 223,8 & 217,8 & 441,6 & $-2,7$ \\
\hline & Força residual & 83,8 & 80,0 & 163,8 & $-4,5$ \\
\hline \multirow{3}{*}{ M2 } & Peso próprio & 15,3 & 15,0 & 30,3 & $-2,0$ \\
\hline & Ruína & 433,0 & 430,7 & 863,7 & $-0,5$ \\
\hline & Força residual & 153,0 & 149,7 & 302,8 & $-2,2$ \\
\hline \multirow{3}{*}{ M3 } & Peso próprio & 15,3 & 15,8 & 31,1 & 3,3 \\
\hline & Ruína & 445,5 & 460,3 & 905,8 & 3,3 \\
\hline & Força residual & 161,0 & 166,8 & 327,8 & 3,6 \\
\hline \multirow{3}{*}{ M4 } & Peso próprio & 15,6 & 16,2 & 31,8 & 3,8 \\
\hline & Ruína & 387,5 & 385,0 & 772,5 & $-0,6$ \\
\hline & Força residual & 150,3 & 150,2 & 300,5 & $-0,1$ \\
\hline \multirow{3}{*}{ M5 } & Peso próprio & 16,8 & 16,8 & 33,6 & 0,0 \\
\hline & Ruína & 547,8 & 556,3 & 1104,1 & 1,6 \\
\hline & Força residual & 250,0 & 254,6 & 504,6 & 1,8 \\
\hline \multirow{3}{*}{ M6 } & Peso próprio & 15,5 & 15,8 & 31,3 & 1,9 \\
\hline & Ruína & 539,0 & 538,8 & 1077,8 & $-0,04$ \\
\hline & Força residual & 310,7 & 312,3 & 623,0 & 0,5 \\
\hline
\end{tabular}
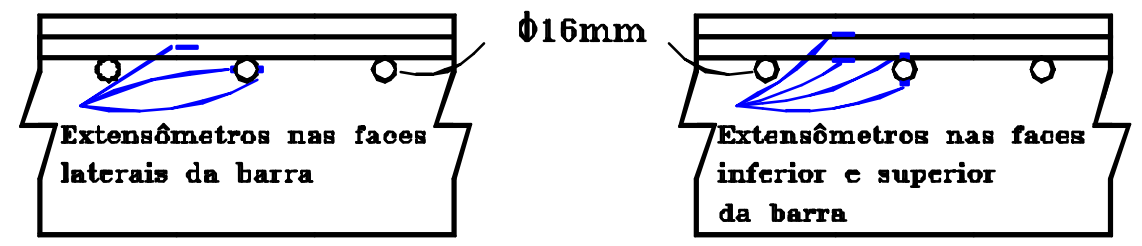

Figura 4.6 - Posição dos extensômetros com relação à barra instrumentada 
Nos itens a seguir, as letras maiúsculas $\underline{\mathrm{E}} \mathrm{e} \underline{\mathrm{D}}$, seguidas de um número, são usadas para designar, respectivamente, um extensômetro e um transdutor nas posições indicadas por este número.

Todos os resultados experimentais obtidos encontram-se em tabelas armazenadas em um disco flexível que acompanha este trabalho.

\subsection{INSTRUMENTAÇÃO DA ARMADURA DE FLEXÃO TRACIONADA}

As posições das barras instrumentadas, para cada um dos modelos, encontram-se nas figuras 4.7 a 4.12. Nestas figuras, o sinal (') indica que são dois os extensômetros colados nesta posição.

Os gráficos que relacionam as deformações de cada par de extensômetros à força total aplicada pelos macacos estão mostrados no Anexo G.

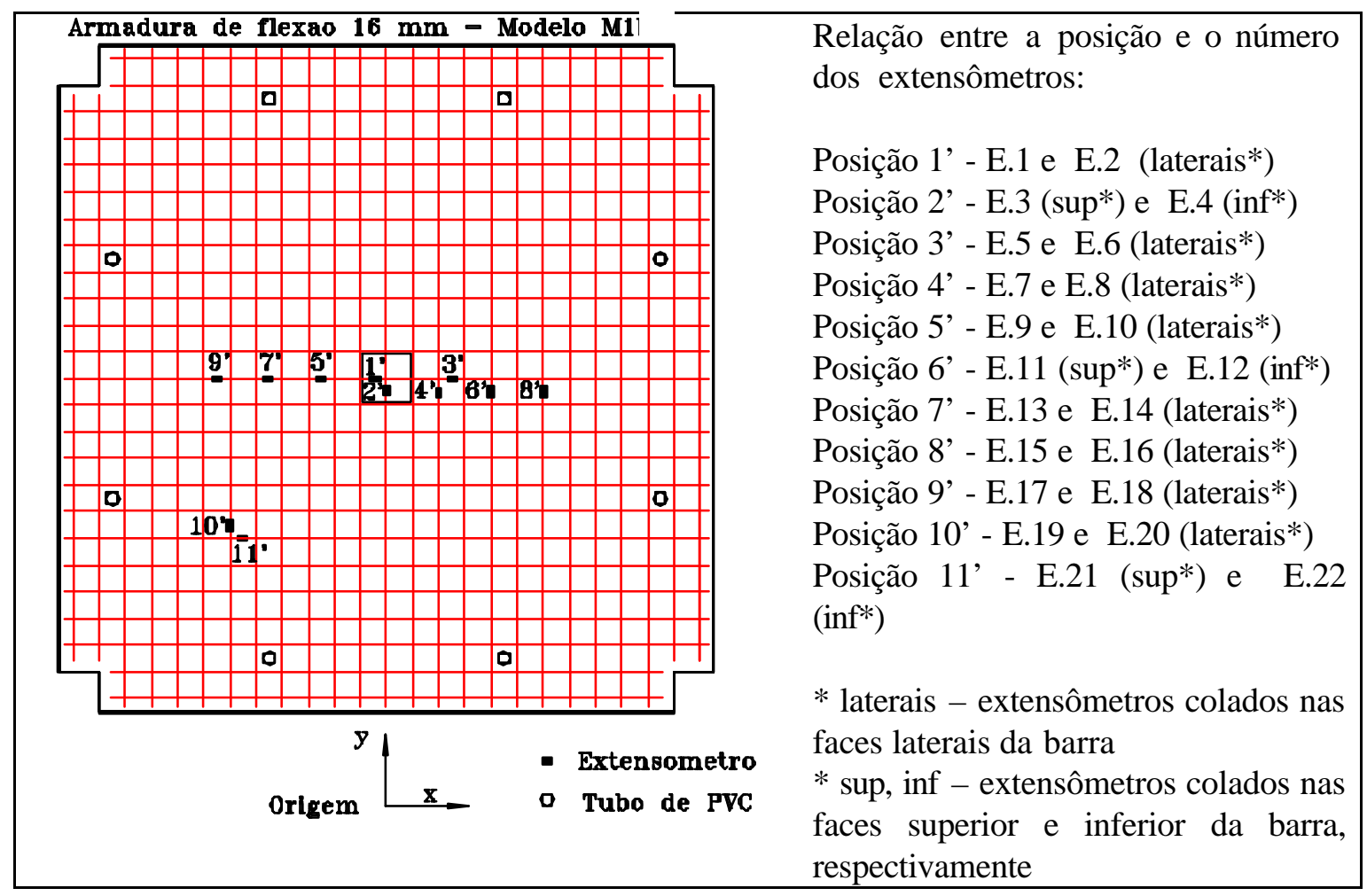

Figura 4.7 - Posição dos extensômetros - malha de 16 mm - Modelo M1 


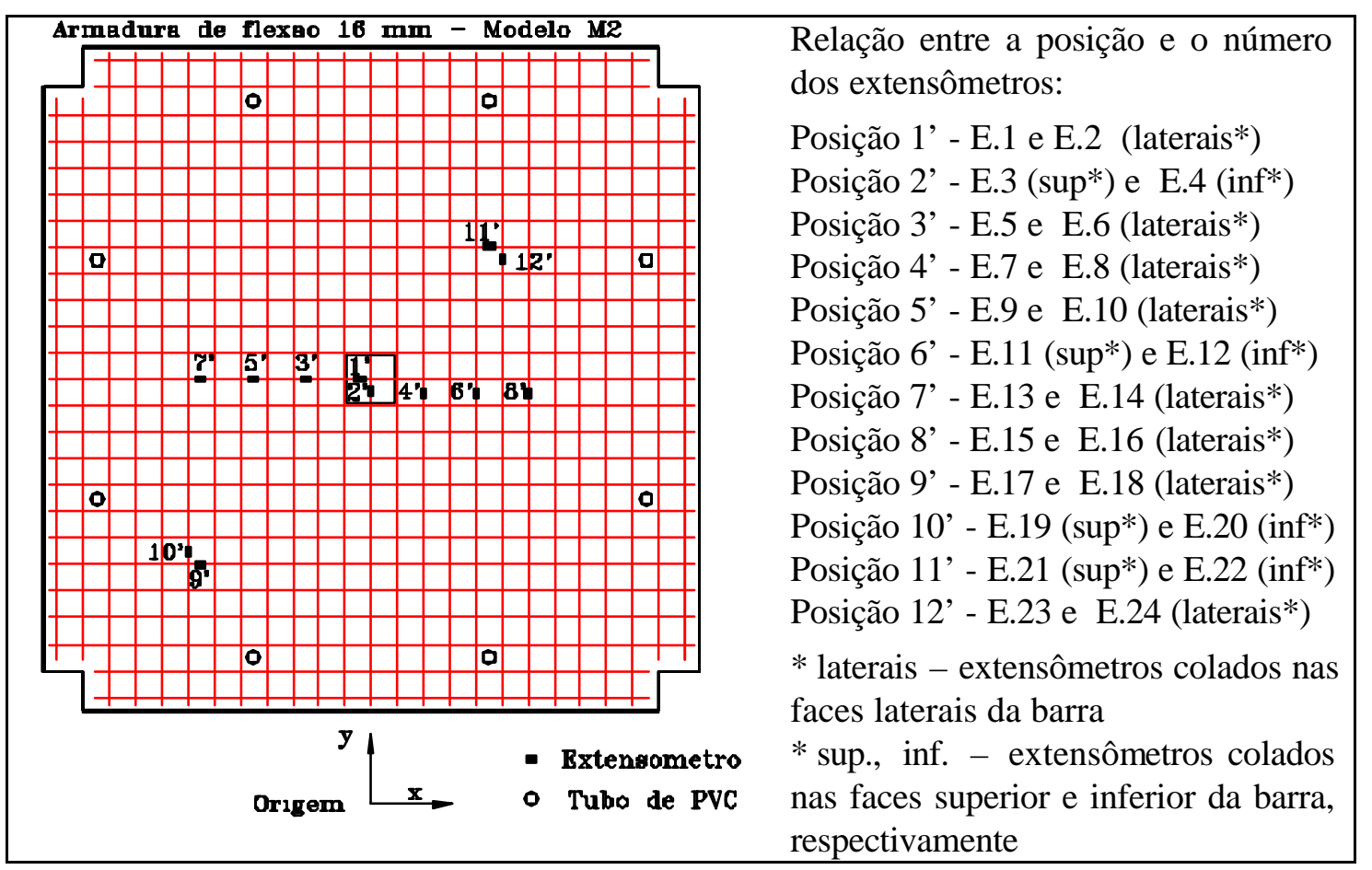

Figura 4.8 - Posição dos extensômetros - malha de 16 mm - Modelo M2

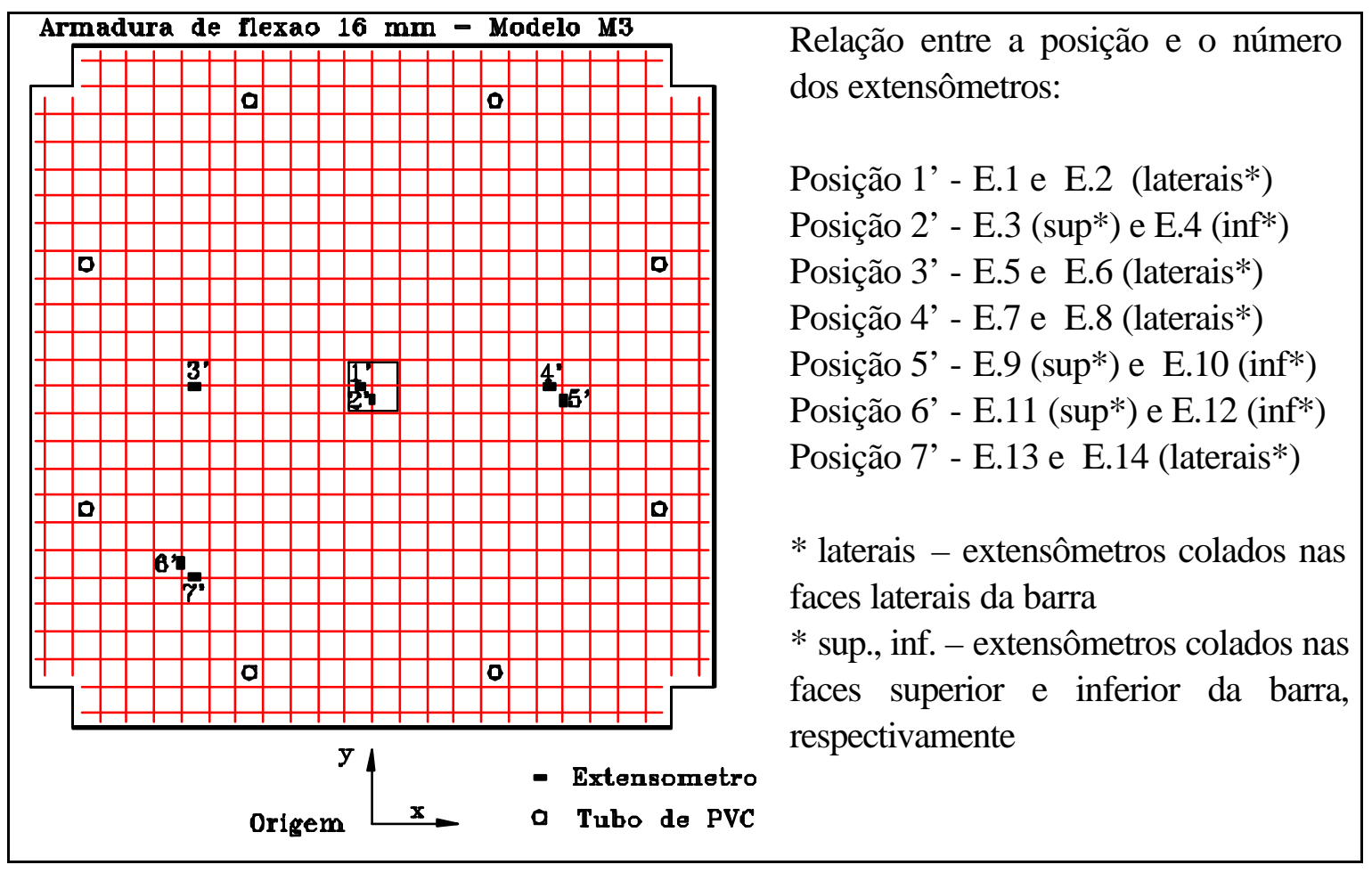

Figura 4.9 - Posição dos extensômetros - malha de 16 mm - Modelo M3 


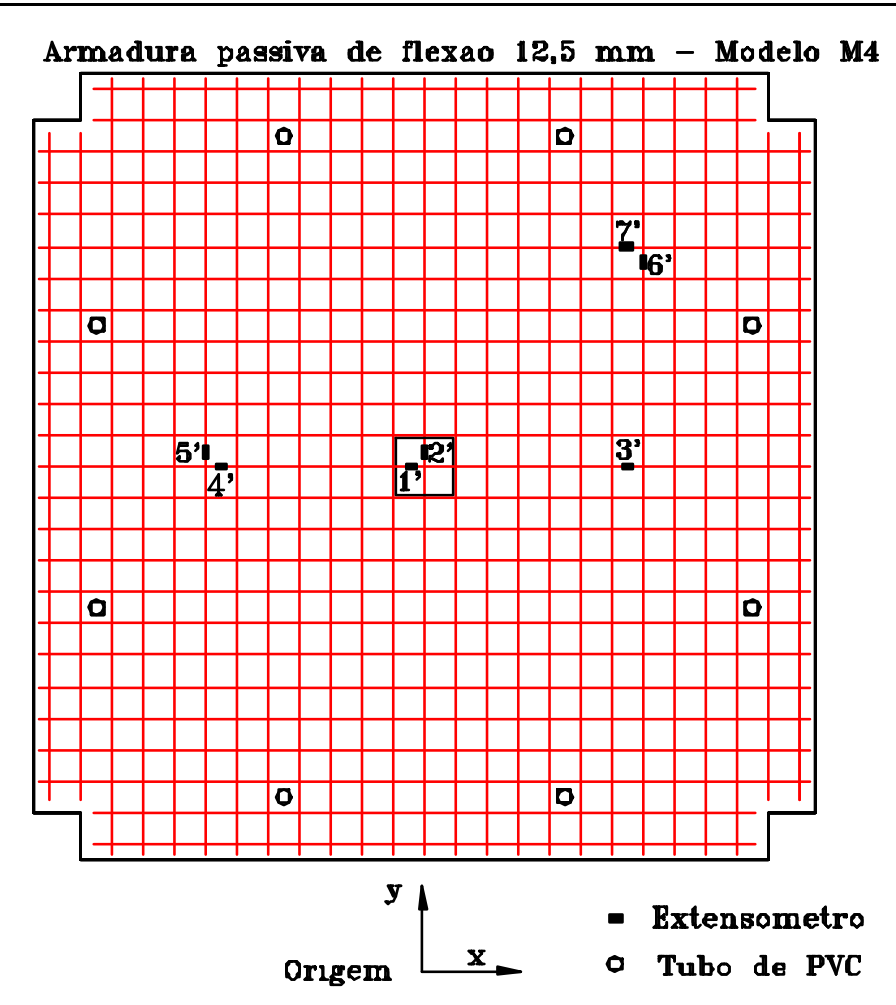

Relação entre a posição e o número dos extensômetros:

Posição 1' - E.1 e E.2 (laterais*)

Posição 2' - E.3 (sup*) e E.4 (inf*)

Posição 3' - E.5 e E.6 (laterais*)

Posição 4' - E.7 e E.8 (laterais*)

Posição 5' - E.9 (sup*) e E.10 (inf*)

Posição 6' - E.11 (sup*) e E.12 (inf*)

Posição 7' - E.13 e E.14 (laterais*)

* laterais - extensômetros colados nas faces laterais da barra

* sup, inf - extensômetros colados nas faces superior e inferior da barra, respectivamente

Figura 4.10 - Posição dos extensômetros - malha de 12,5 mm - Modelo M4

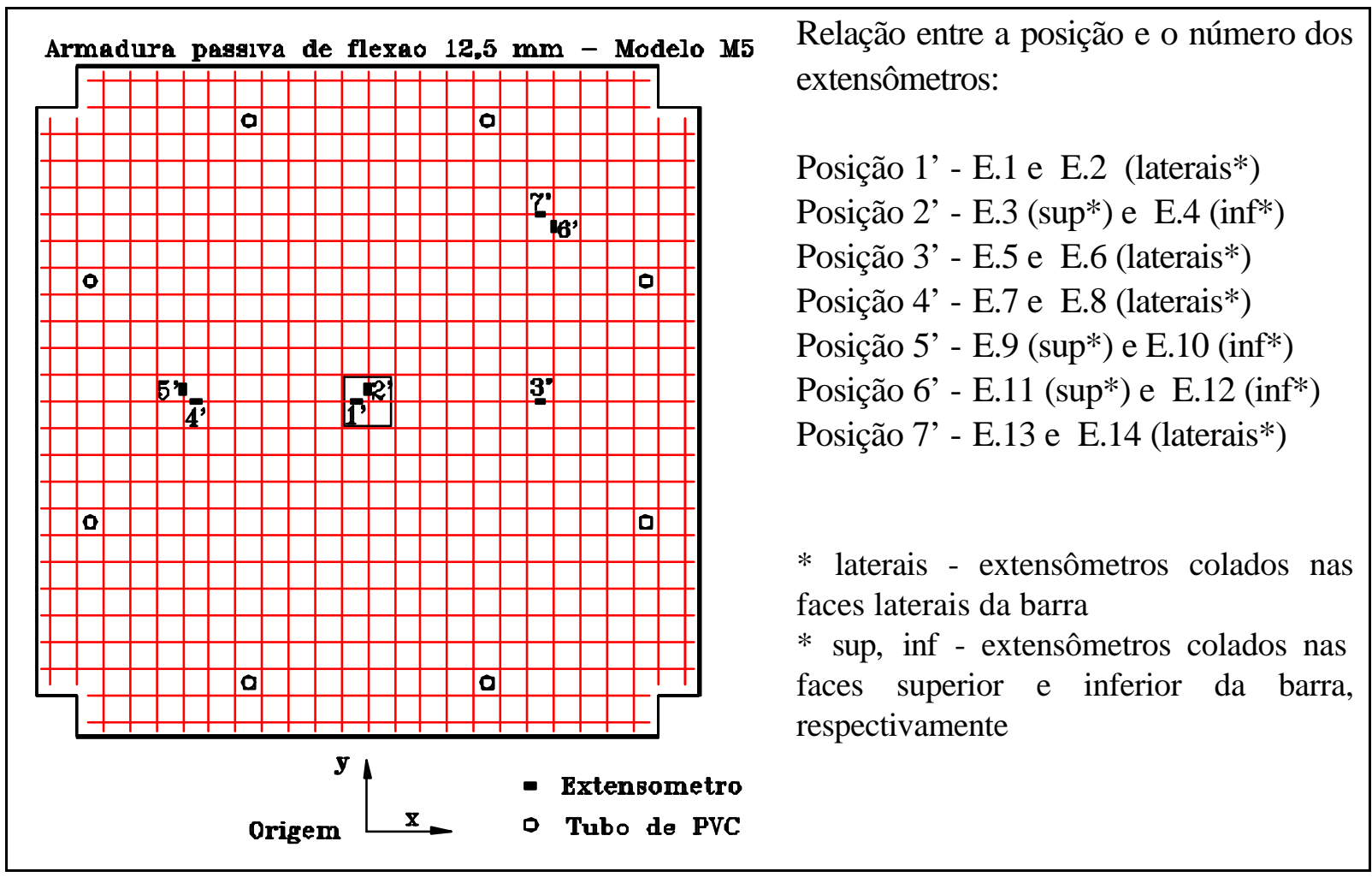

Figura 4.11 - Posição dos extensômetros - malha de 12,5 mm - Modelo M5 


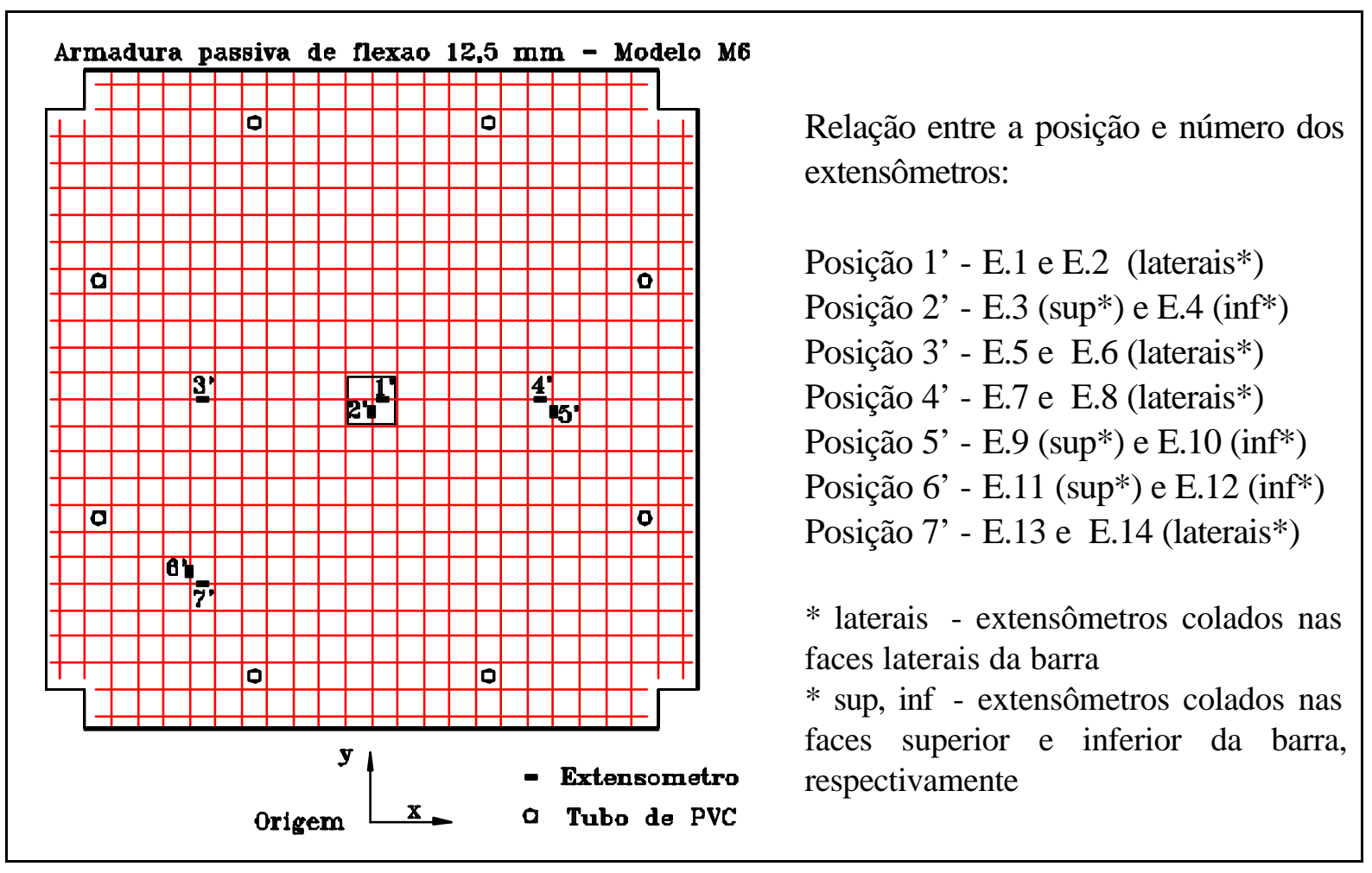

Figura 4.12 - Posição dos extensômetros - malha de 12,5 mm - Modelo M6

Nas figuras 4.13 a 4.17, têm-se a análise da simetria dos modelos M1 e M3 a M6, respectivamente, através das leituras médias dos extensômetros nas posições indicadas. Esta análise não foi feita para o modelo M2 em função da ausência de um posicionamento de extensômetros adequado para tal finalidade. Isto deve-se ao fato do M2 ter sido o primeiro modelo ensaiado, quando a definição da instrumentação ainda estava sendo analisada.

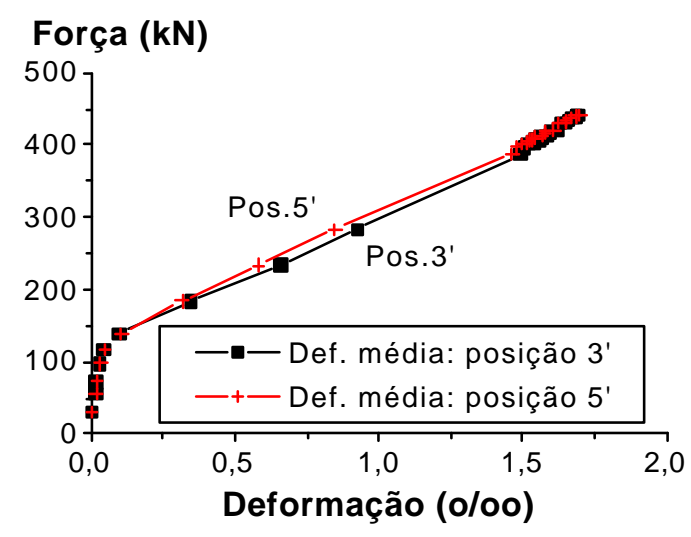

Figura 4.13 - Análise da simetria para o modelo M1: posições 3'e 5' 


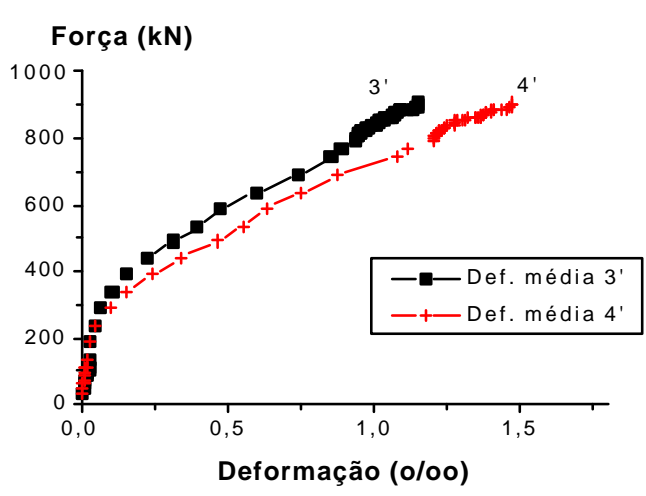

a) usando posições simétricas

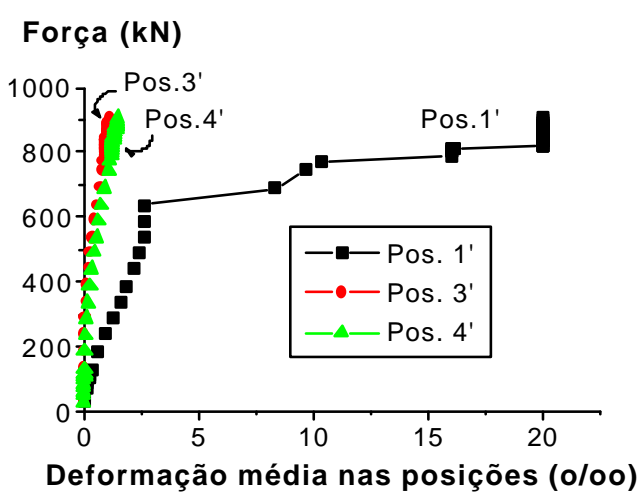

b) usando a deformação ao longo da barra que passa pelo meio da laje

Figura 4.14 - Análise da simetria para o modelo M3

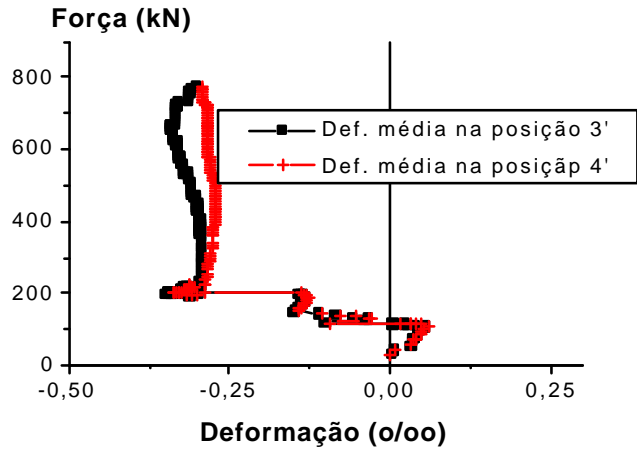

Figura 4.15 - Análise da simetria para o modelo M4: posições 3'e 4'

\section{Força (kN)}

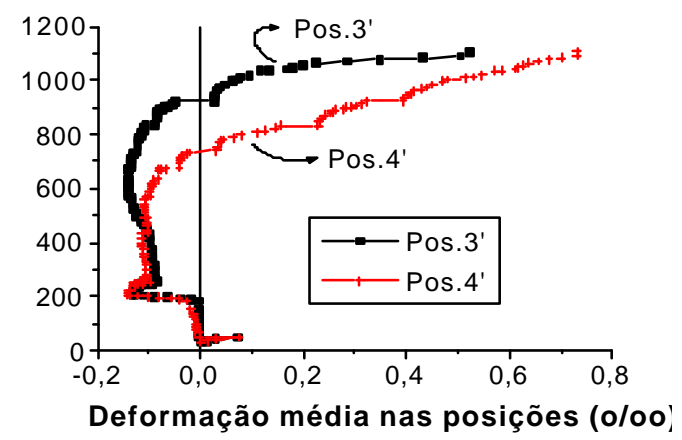

Figura 4.16 - Análise da simetria para o modelo M5: posições 3'e 4'

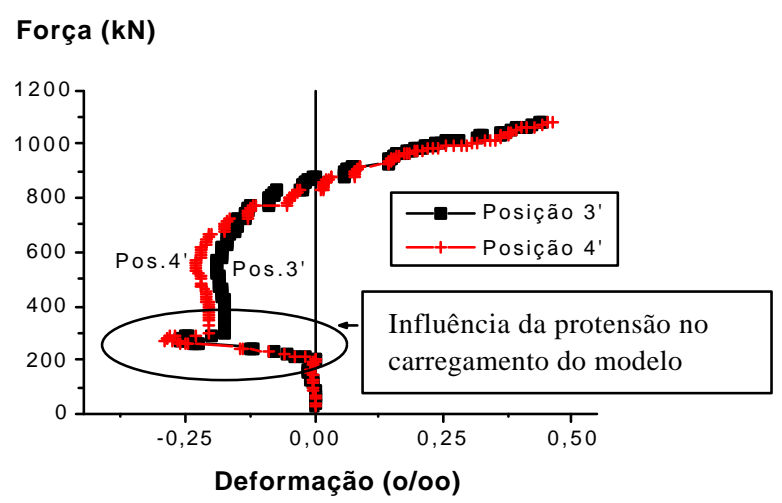

Figura 4.17- Análise da simetria para o modelo M6: posições 3'e 4' 
Nas figuras 4.18 a 4.23, os extensômetros visam mostrar a formação de charneira plástica diagonal para os modelos M1 a M6, através das leituras médias dos extensômetros nas posições indicadas. Para o modelo M6, foi usado apenas o E.14 para determinar a deformação da posição 7', visto o E.13 ter apresentado problemas.

\section{Força $(\mathbf{k N})$}

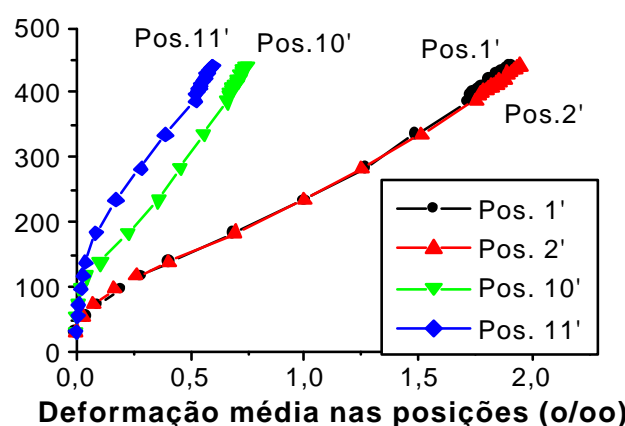

Figura 4.18 - Análise da formação de charneira plástica para o modelo M1

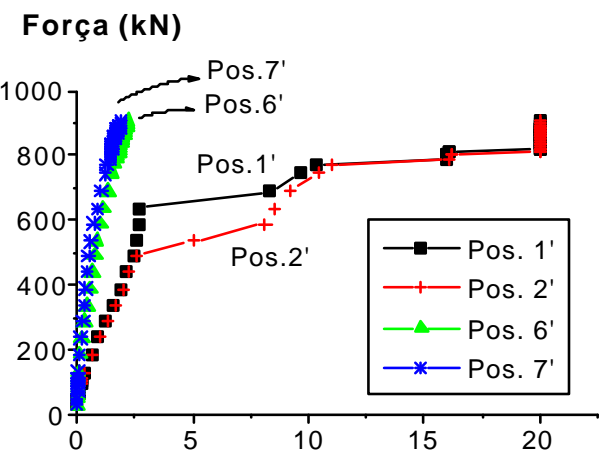

Deformação média nas posições (o/00) Figura 4.20 - Análise da formação de charneira plástica para o modelo M3

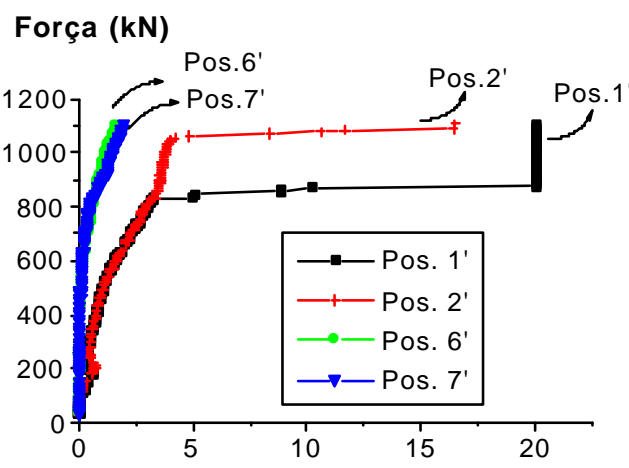

Deformação média nas posições (0/00)

Figura 4.22 - Análise da formação de charneira plástica para o modelo M5

\section{Força (kN)}

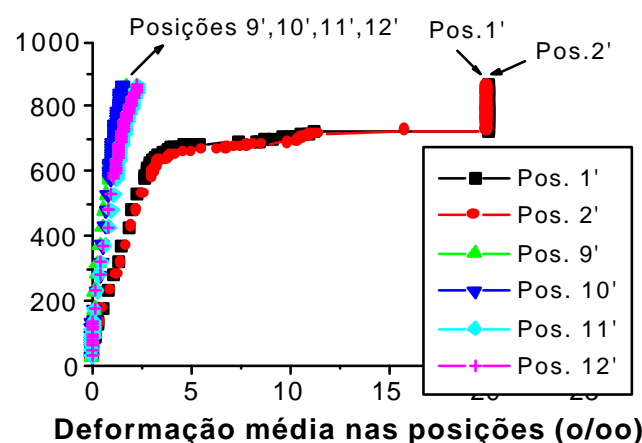

Figura 4.19 - Análise da formação de charneira plástica para o modelo M2

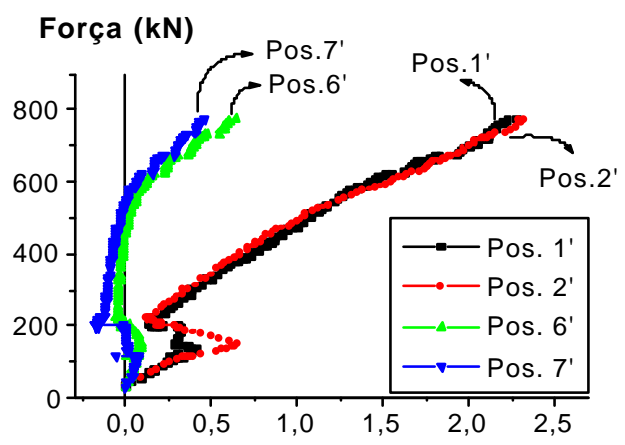

Deformação média nas posições (o/00) Figura 4.21 - Análise da formação de charneira plástica para o modelo M4

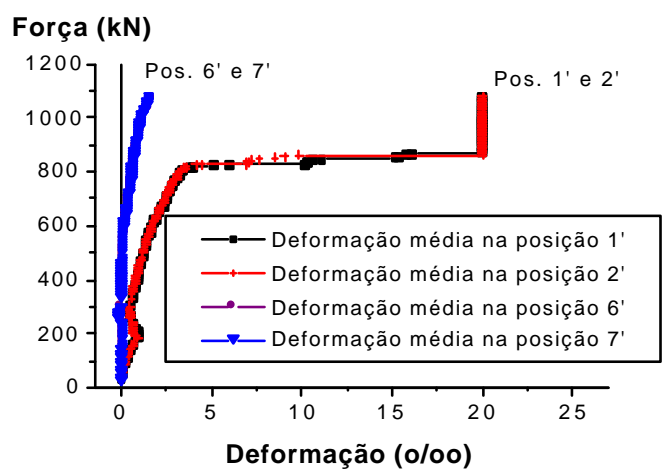

Figura 4.23 - Análise da formação de charneira plástica para o modelo M6 
Nas figuras 4.24 a 4.29, tem-se a deformação da barra que passa pelo meio da laje, ao longo de seu comprimento, para os modelos M1 a M6. O objetivo desta anális foi verificar se a barra analisada não sofreu algum tipo de escorregamento.

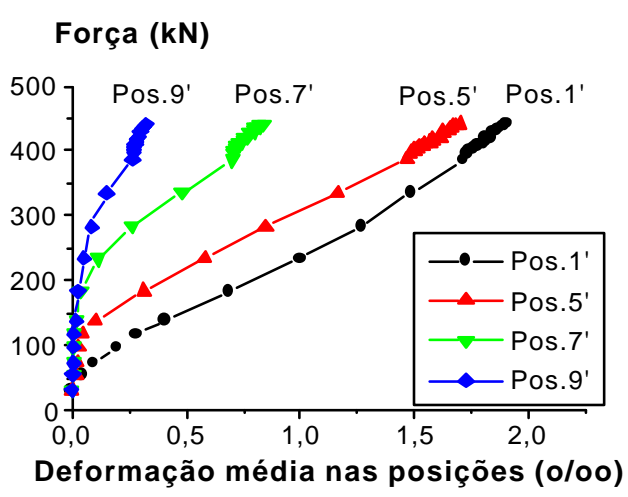

Figura 4.24 - Deformação ao longo da barra central - Modelo M1

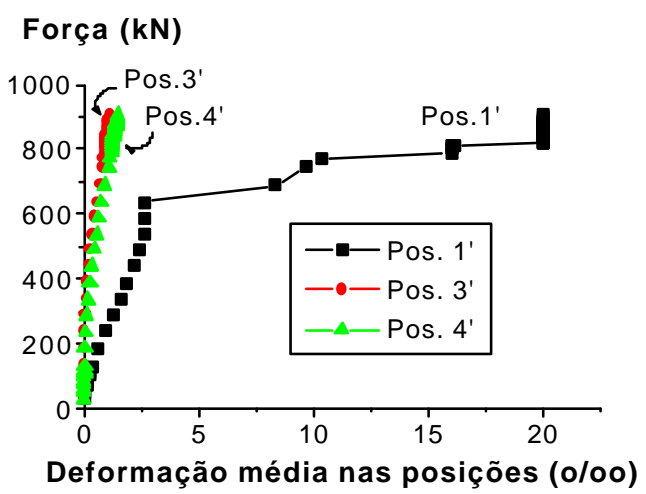

Figura 4.26 - Deformação ao longo da barra central - Modelo M3

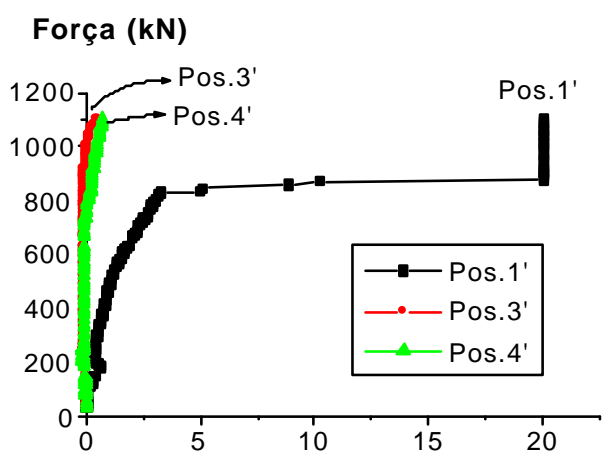

Deformação média nas posições (o/00)

Figura 4.28 - Deformação ao longo da barra central - Modelo M5

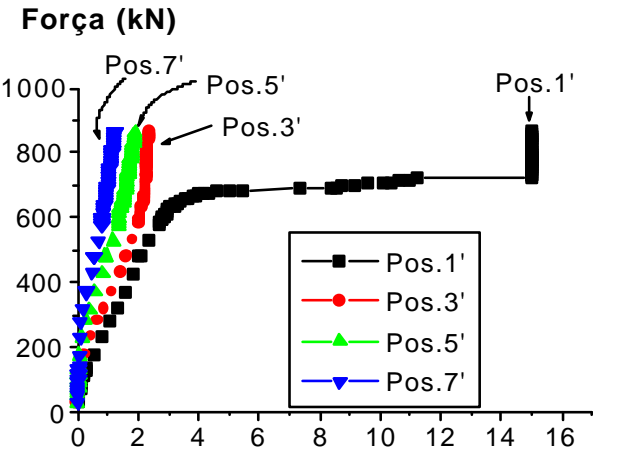

Deformação média nas posições (0/00)

Figura 4.25 - Deformação ao longo da barra central - Modelo M2

\section{Força $(k N)$}

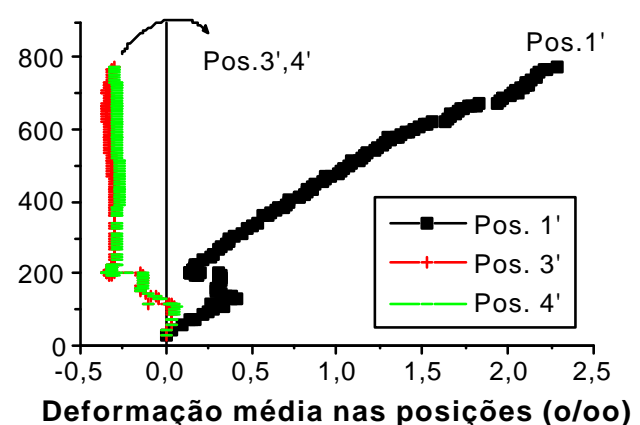

Figura 4.27 - Deformação ao longo da barra central - Modelo M4

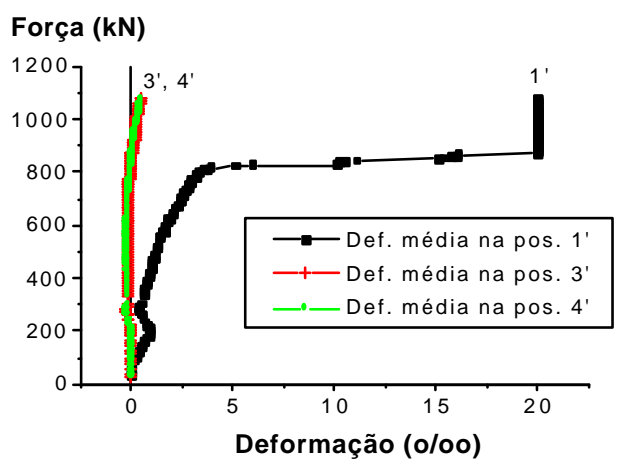

Figura 4.29 - Deformação ao longo da barra central - Modelo M6 
Nas figuras 4.30 a 4.35, têm-se as deformações nas barras paralelas ao eixo de simetria, para todos os modelos.

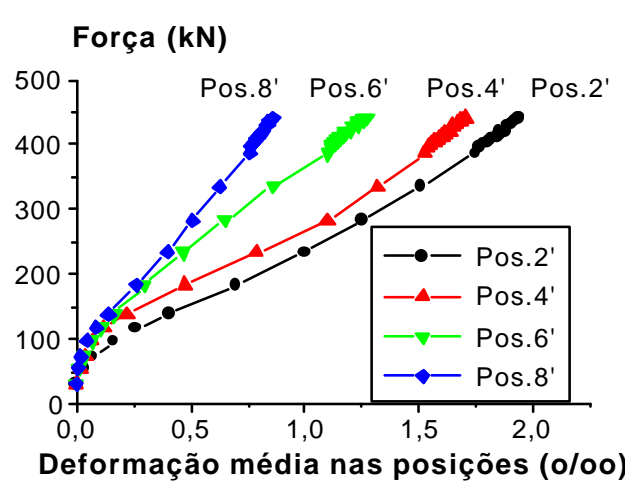

Figura 4.30 - Deformações nas barras paralelas ao eixo y - Modelo M1

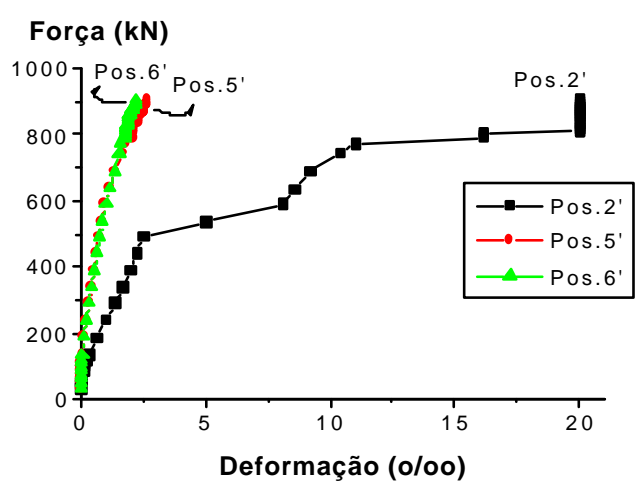

Figura 4.32 - Deformações nas barras paralelas ao eixo y - Modelo M3

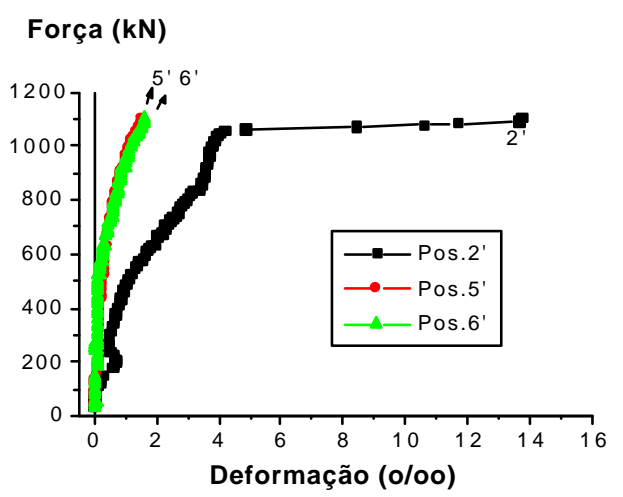

Figura 4.34 - Deformações nas barras paralelas ao eixo y - Modelo M5

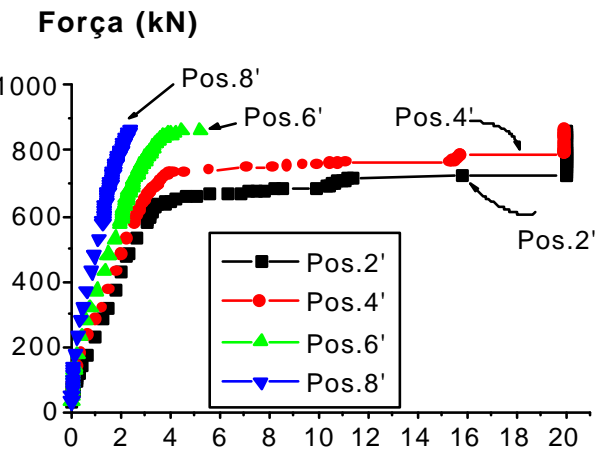

Deformação média nas posições (o/00)

Figura 4.31 - Deformação nas barras paralelas ao eixo y - Modelo M2

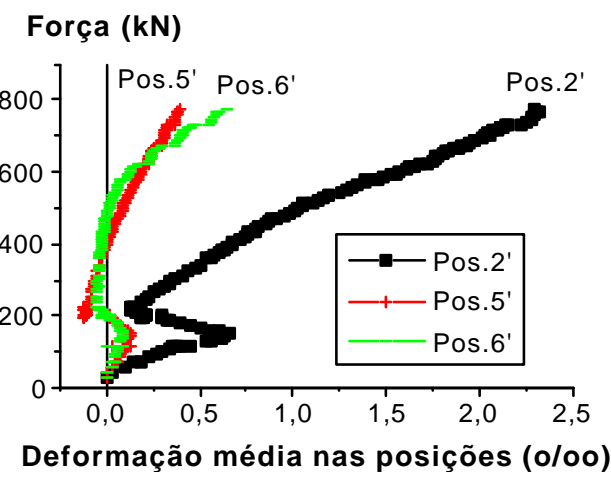

Figura 4.33 - Deformações nas barras paralelas ao eixo y - Modelo M4

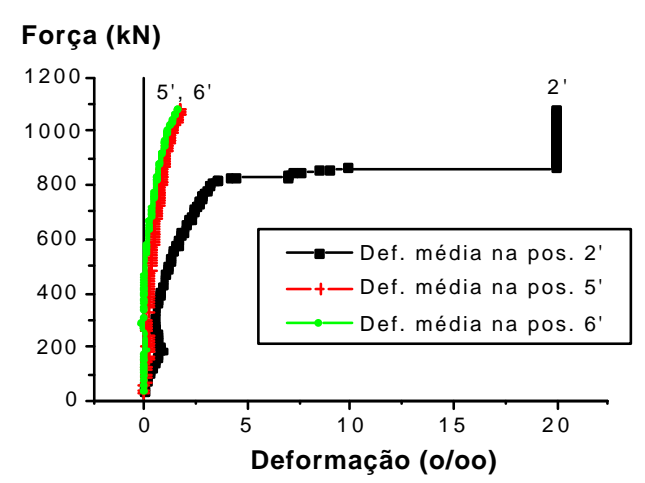

Figura 4.35 - Deformações nas barras paralelas ao eixo y - Modelo M6 


\subsection{INSTRUMENTAÇÃO DA ARMADURA DE FLEXÃO COMPRIMIDA}

As posições das barras instrumentadas, da malha de $8 \mathrm{~mm}$, usadas como armadura de flexão comprimida, encontram-se nas figuras 4.36 a 4.41, relativas a cada um dos modelos ensaiados.

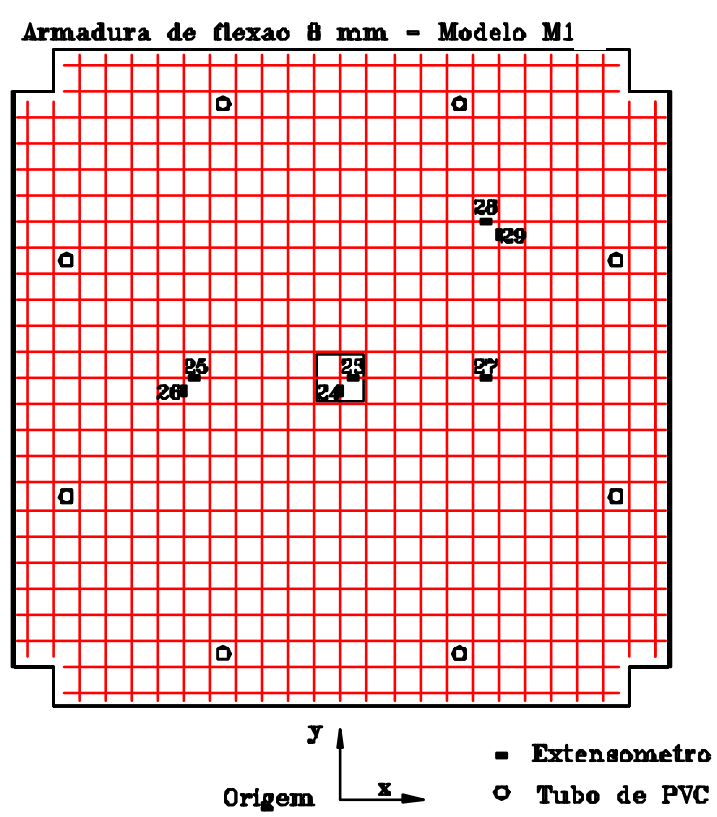

Figura 4.36 - Posição dos extensômetros (M1)

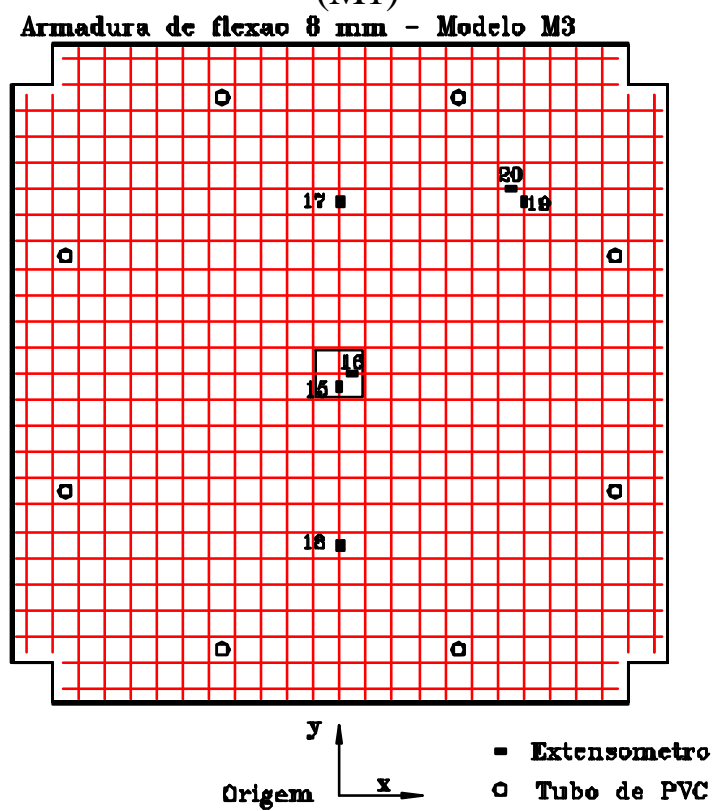

Figura 4.38 - Posição dos extensômetros (M3)

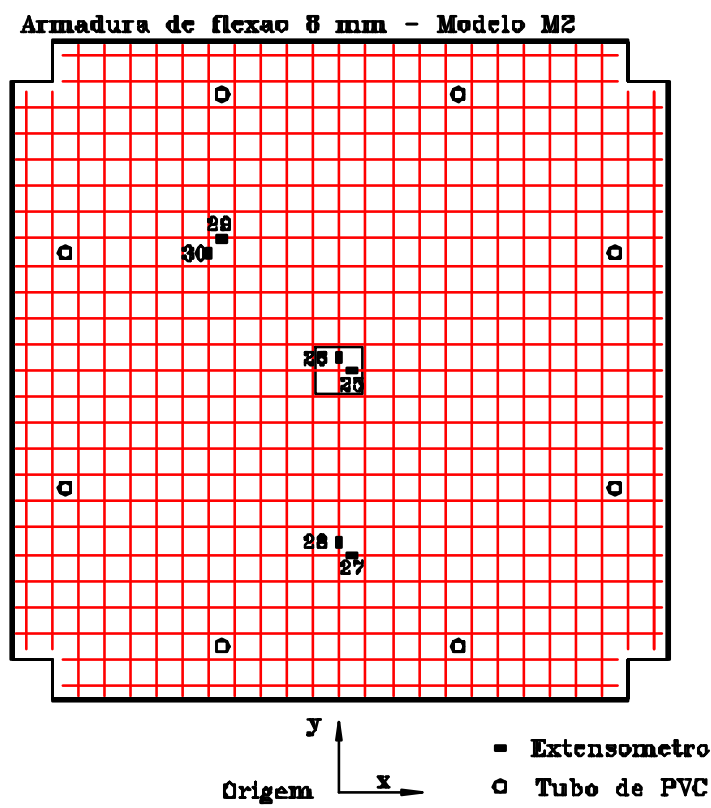

Figura 4.37 - Posição dos extensômetros (M2)

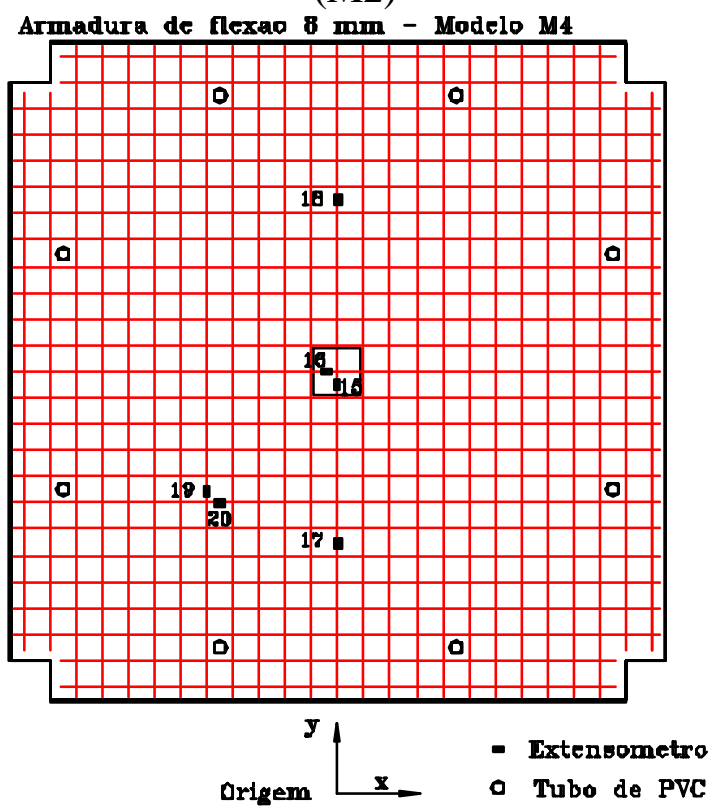

Figura 4.39 - Posição dos extensômetros (M4) 


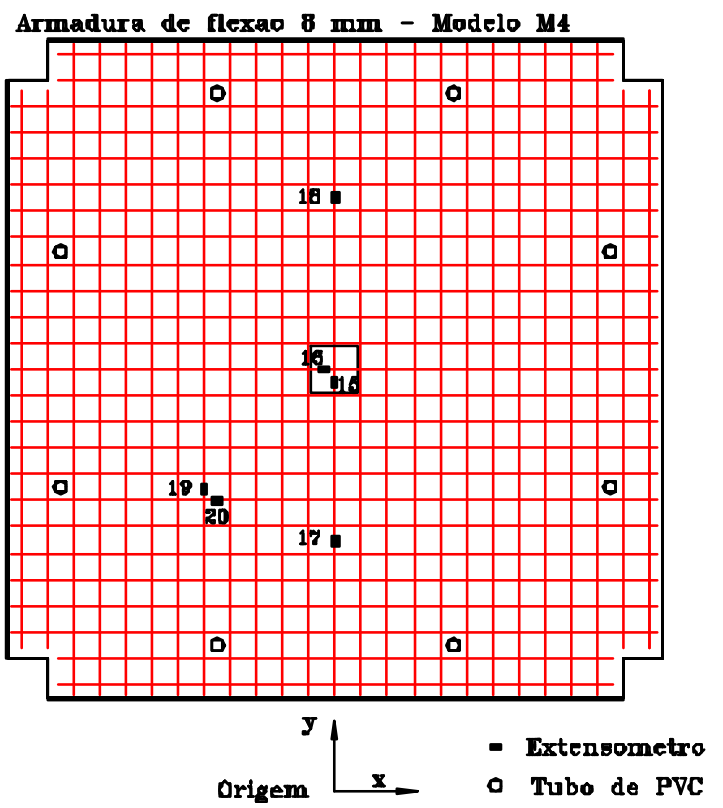

Figura 4.40 - Posição dos extensômetros -

(M5)

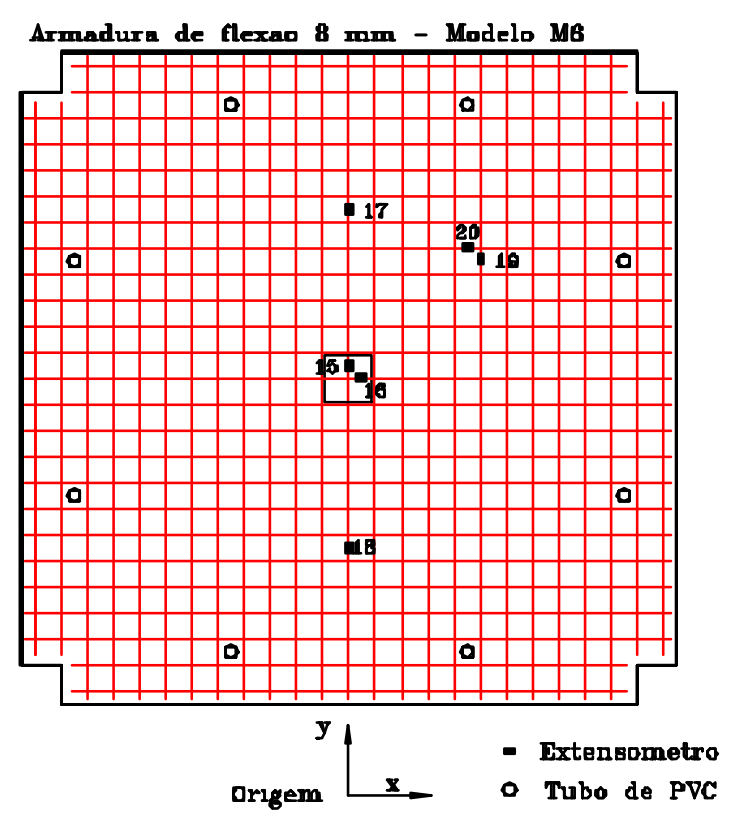

Figura 4.41 - Posição dos extensômetros (M6)

Nas figuras 4.42 a 4.46, tem-se a verificação da simetria para os modelos M1 e M3 a M6. Esta análise não foi feita para o modelo M2 em função da ausência de um posicionamento de extensômetros adequado para tal finalidade. Isto deve-se ao fato do M2 ter sido o primeiro modelo ensaiado, quando a definição da instrumentação ainda estava sendo analisada.

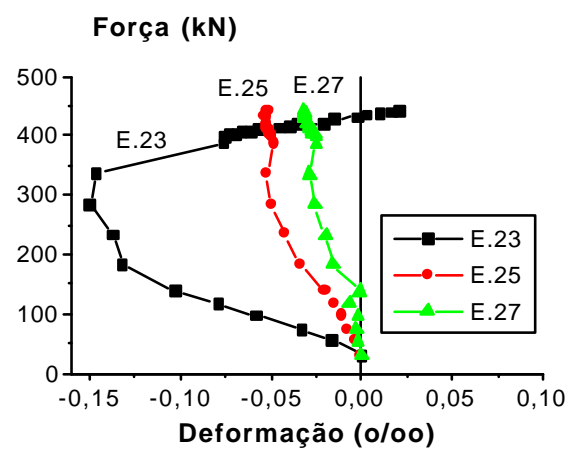

Figura 4.42 - Análise da simetria - Modelo M1

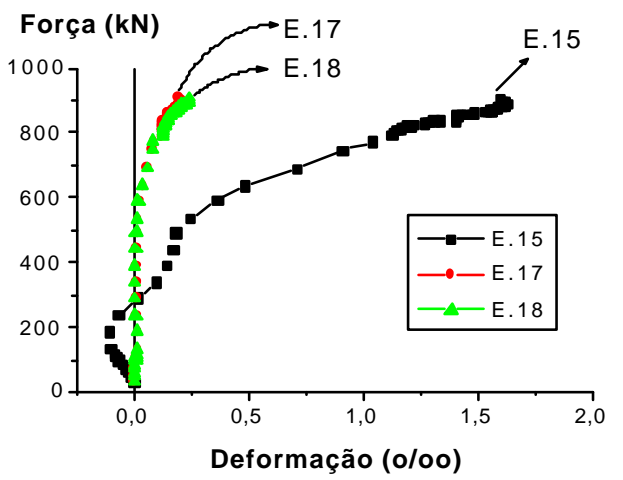

Figura 4.43 - Análise da simetria - Modelo M3 


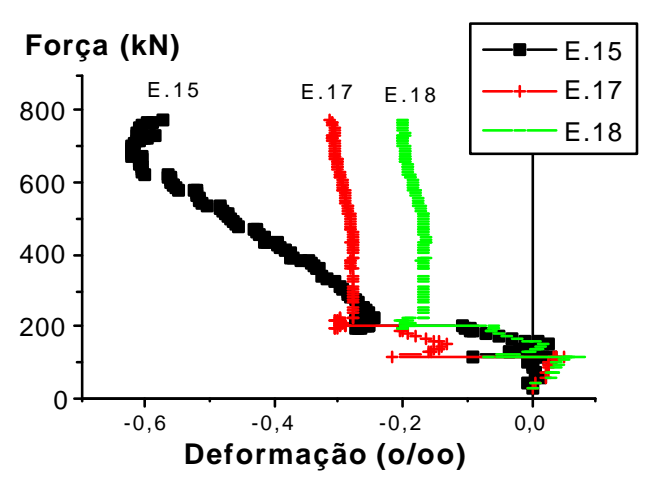

Figura 4.44 - Análise da simetria - Modelo M4

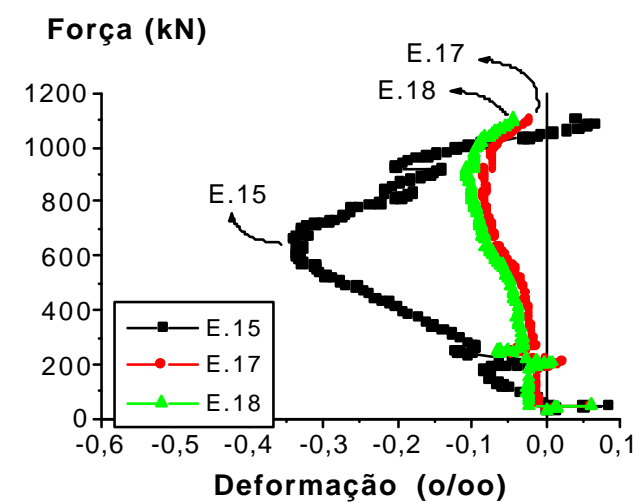

Figura 4.45 - Análise da simetria - Modelo

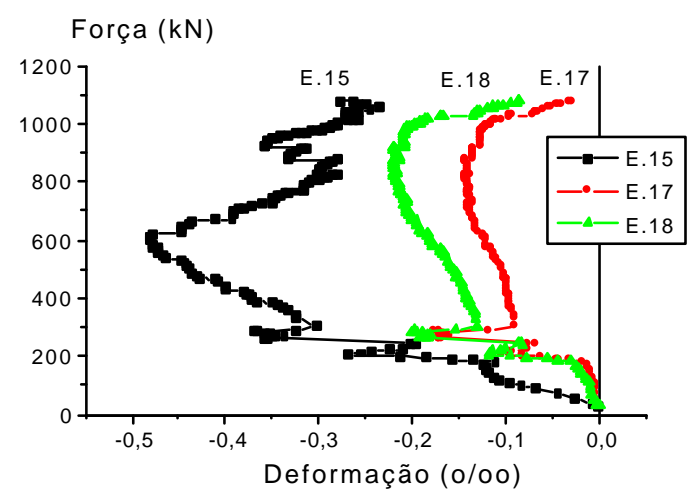

Figura 4.46 - Análise da simetria - Modelo M6

Nas figuras 4.47 a 4.52, tem-se a análise com relação à formação de charneira plástica para todos os modelos. Nos modelos M5 e M6, foi observado um problema no E.20, razão esta pela qual ele não é apresentado nas figuras 4.51 e 4.52 .

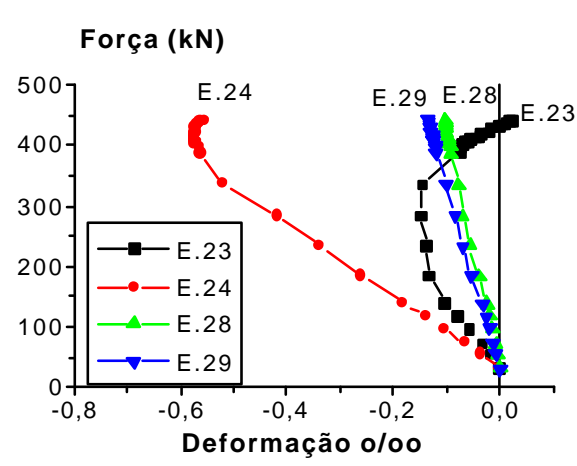

Figura 4.47 - Análise da formação de charneira - Modelo M1

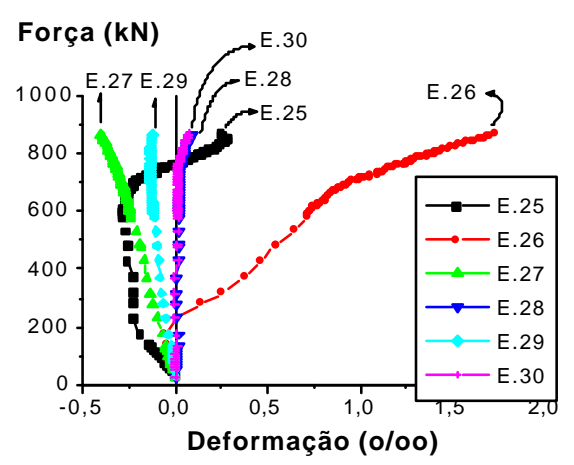

Figura 4.48 - Análise da formação de charneira - Modelo M2 


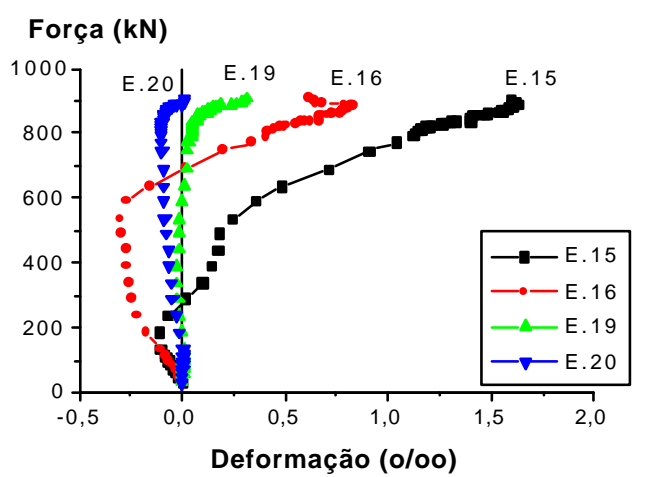

Figura 4.49 - Análise da formação de charneira - Modelo M3

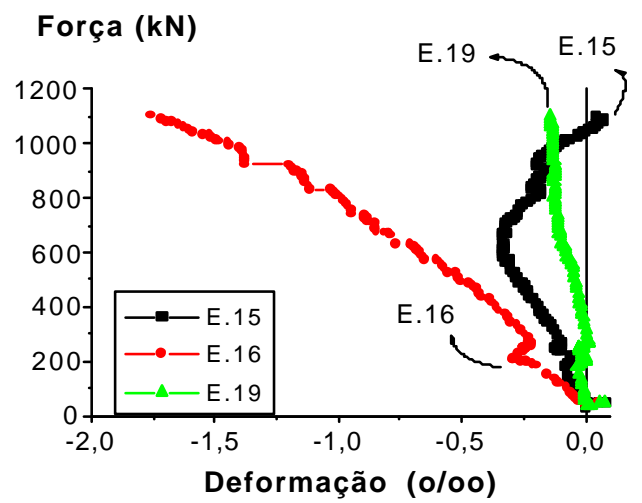

Figura 4.51 - Análise da formação de charneira - Modelo M5

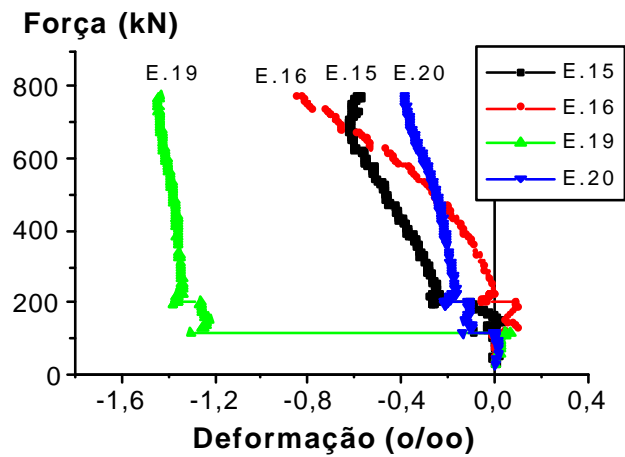

Figura 4.50 - Análise da formação de charneira - Modelo M4

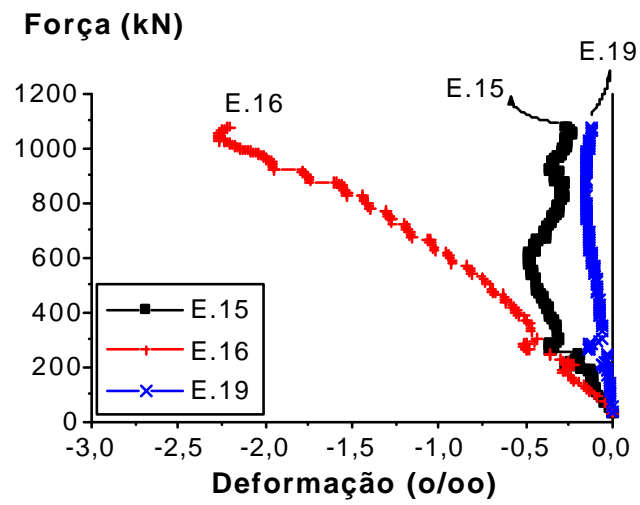

Figura 4.52 - Análise da formação de charneira - Modelo M6

Nas figuras 4.53 a 4.58, têm-se o comportamento das barras após a ruína dos modelos.

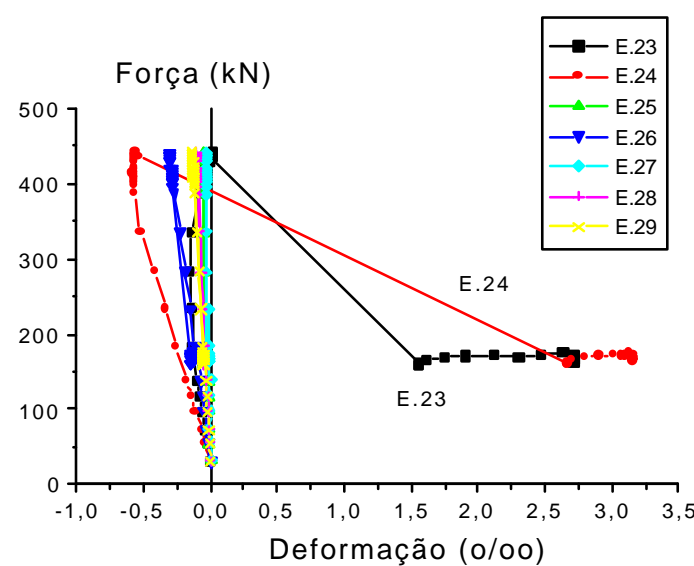

Figura 4.53 - Comportamento das barras após a ruptura (modelo M1)

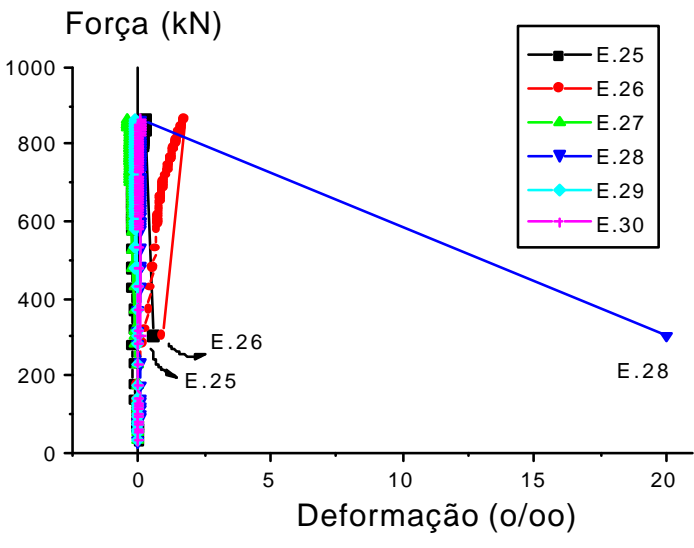

Figura 4.54 - Comportamento das barras após a ruptura (modelo M2) 


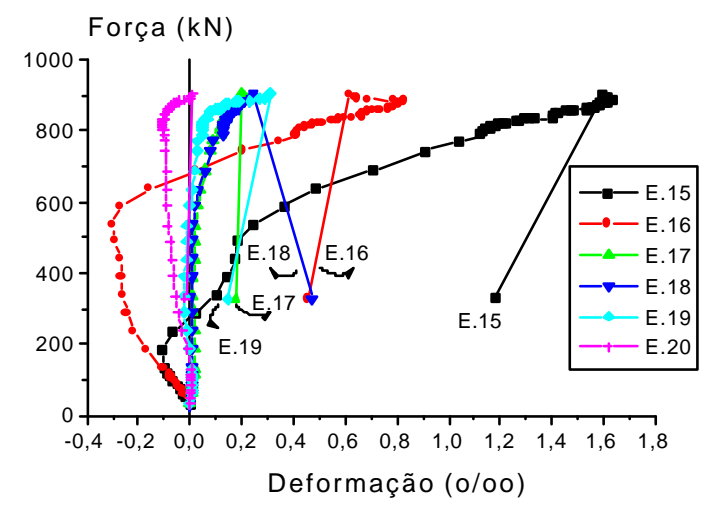

Figura 4.55 - Comportamento das barras após a ruptura (modelo M3)

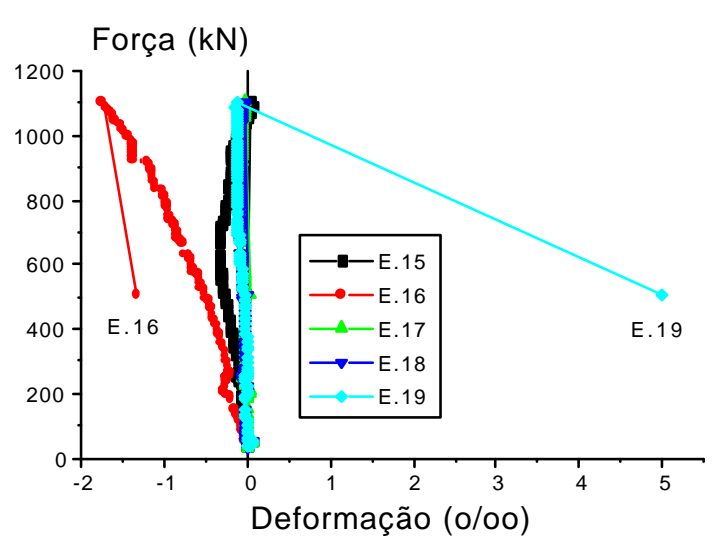

Figura 4.57 - Comportamento das barras após a ruptura (modelo M5)

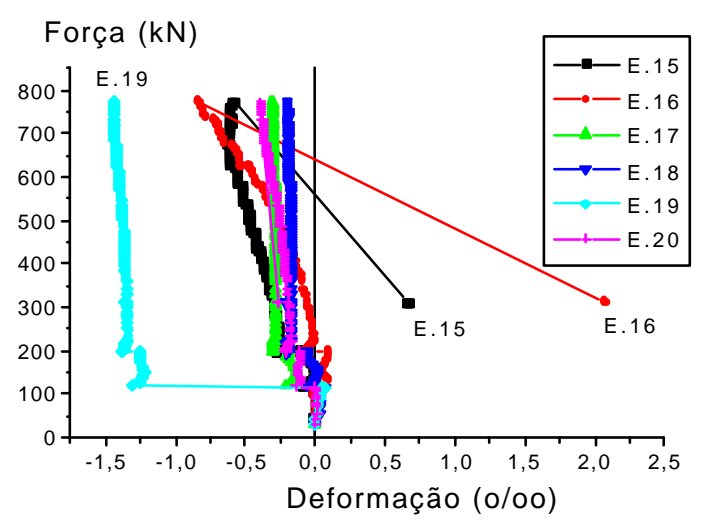

Figura 4.56 - Comportamento das barras após a ruptura (modelo M4)

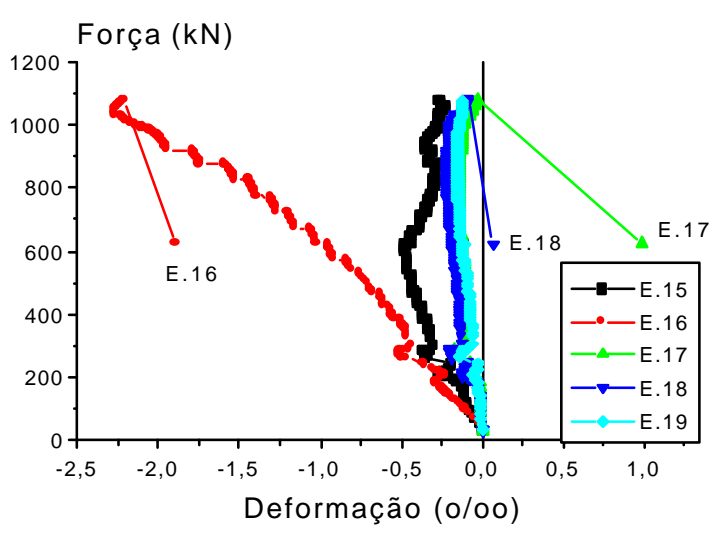

Figura 4.58 - Comportamento das barras após a ruptura (modelo M6)

\subsection{INSTRUMENTAÇÃO DO CONCRETO}

Foram instrumentados alguns pontos na face inferior comprimida dos modelos. $\mathrm{O}$ detalhe da fixação dos extensômetros está mostrado na figura 4.59. Já na figura 4.60, têmse as posições dos extensômetros, com vista da face superior para a face inferior dos modelos ("olhando de cima para baixo"). 


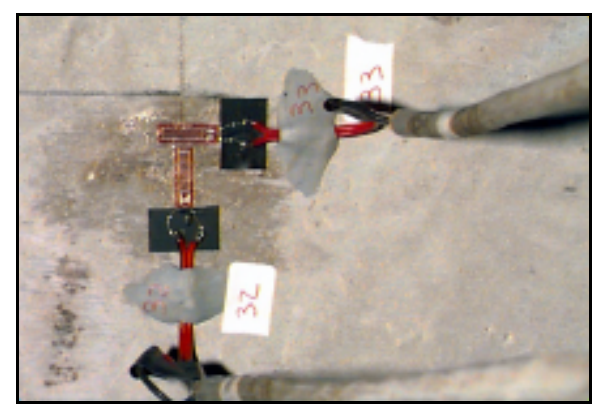

Figura 4.59 - Detalhe da fixação dos extensômetros

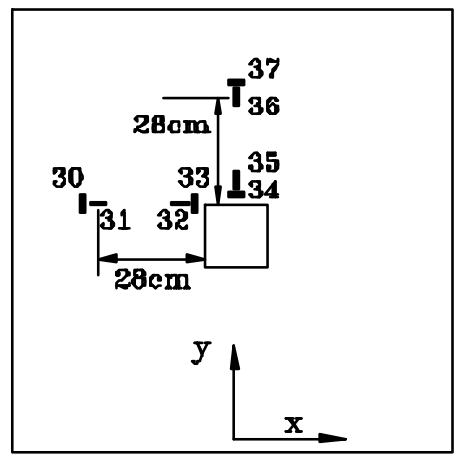

a) Modelo M1

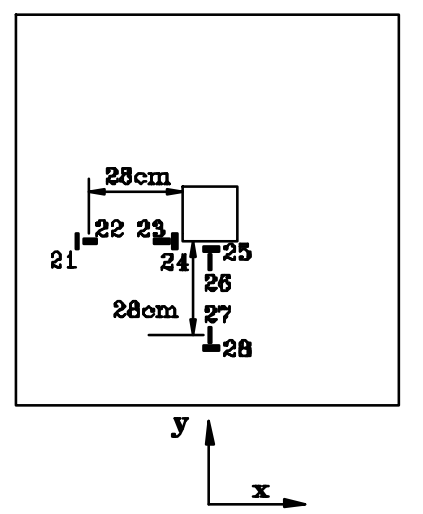

d) Modelo M4

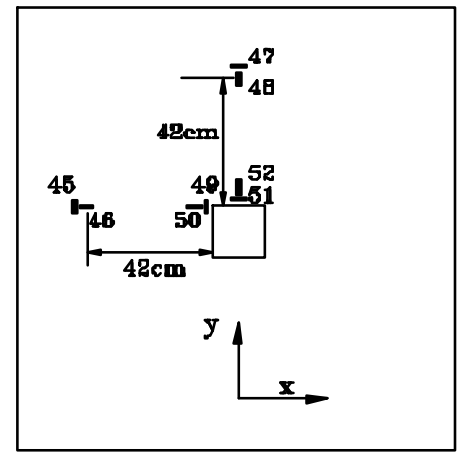

b) Modelo M2

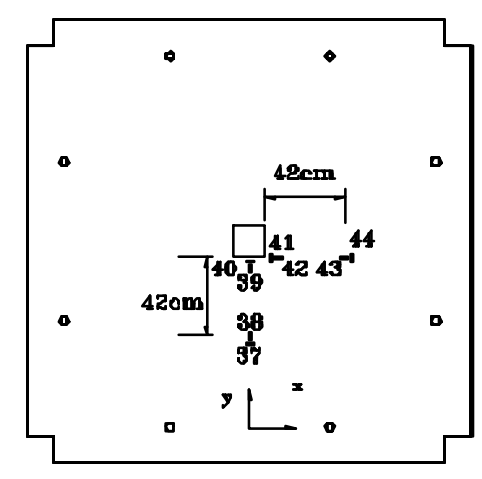

e) Modelo M5

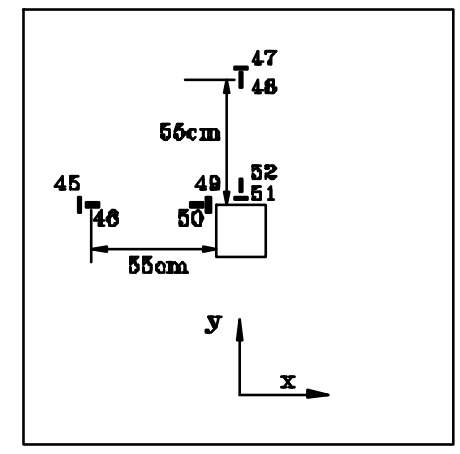

c) Modelo M3

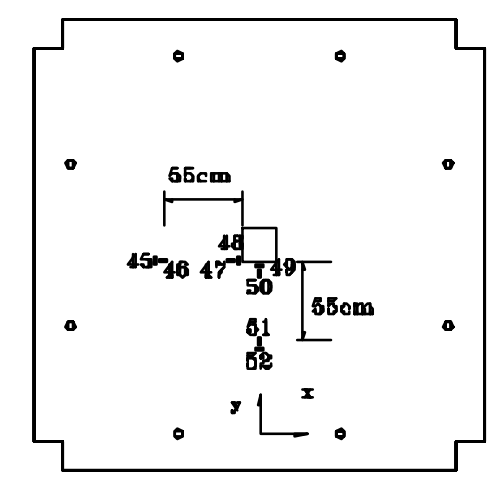

f) Modelo M6

4.60 - Posição dos extensômetros

Nas figuras 4.61 a 4.66, tem-se a comparação das deformações radiais e tangenciais dos pontos instrumentados na região adjacente à chapa de aplicação do carregamento, para todos os modelos. 


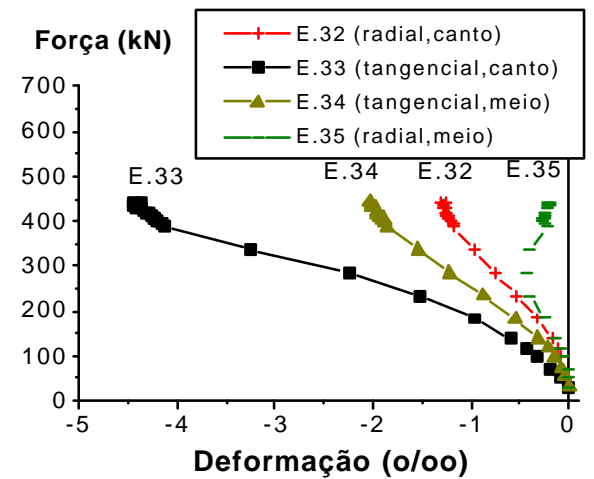

Figura 4.61- Modelo M1 - deformações na região adjacente à chapa metálica

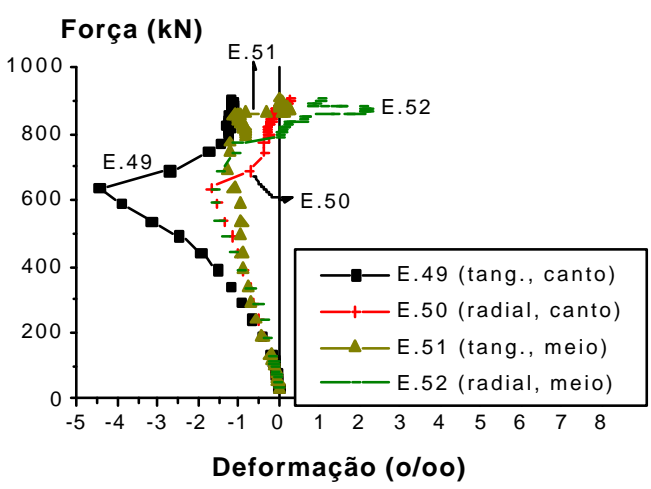

Figura 4.63 - Modelo M3 - deformações na região adjacente à chapa metálica

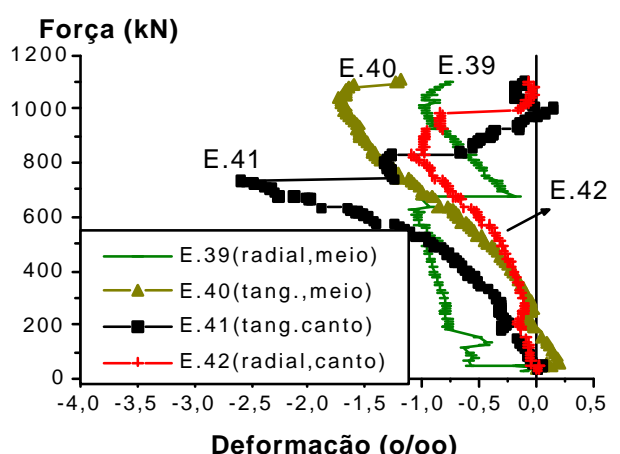

Figura 4.65 - Modelo M5 - deformações na região adjacente à chapa metálica
Força $(k N)$

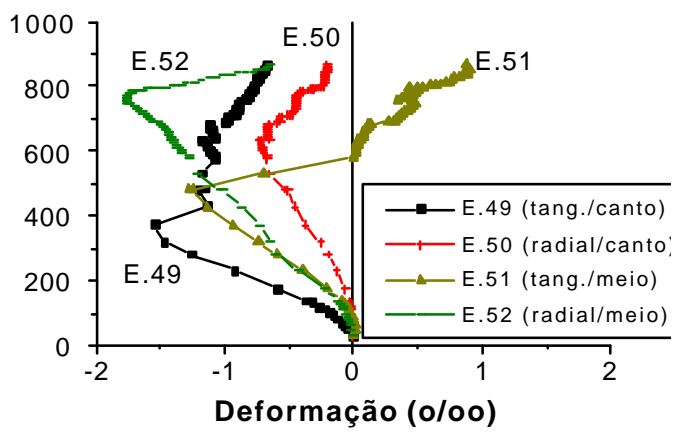

Figura 4.62 - Modelo M2 - deformações na região adjacente à chapa metálica

\section{Força $(k N)$}

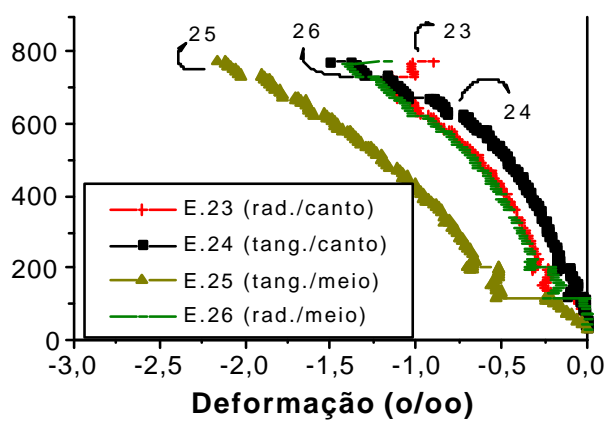

Figura 4.64 - Modelo M4 - deformações na região adjacente à chapa metálica

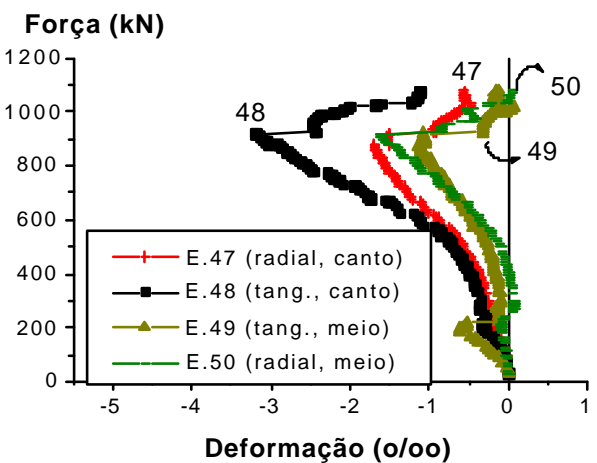

Figura 4.66 - Modelo M6 - deformações na região adjacente à chapa metálica

Nas figuras 4.67 a 4.72, tem-se a comparação das deformações radiais e tangenciais dos pontos instrumentados na região afastada da chapa de aplicação do carregamento, para todos os modelos. 


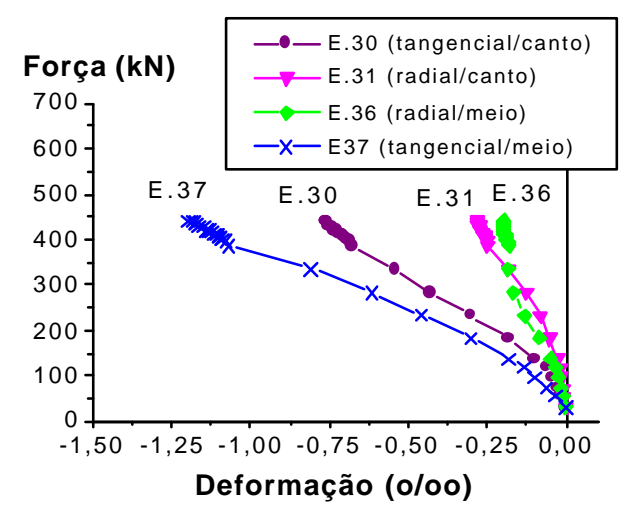

Figura 4.67 - Modelo M1 - deformações na região afastada da chapa metálica

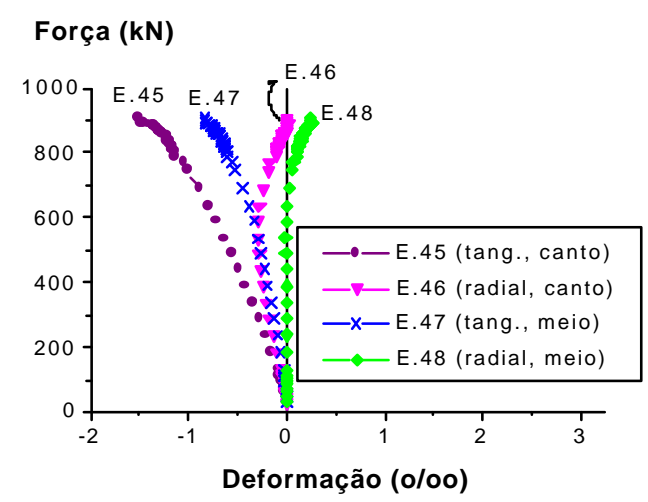

Figura 4.69 - Modelo M3 - deformações na região afastada da chapa metálica

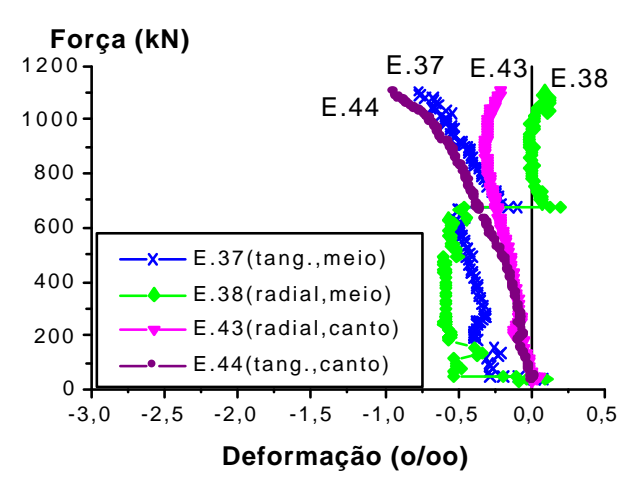

Figura 4.71 - Modelo M5 - deformações na região afastada da chapa metálica

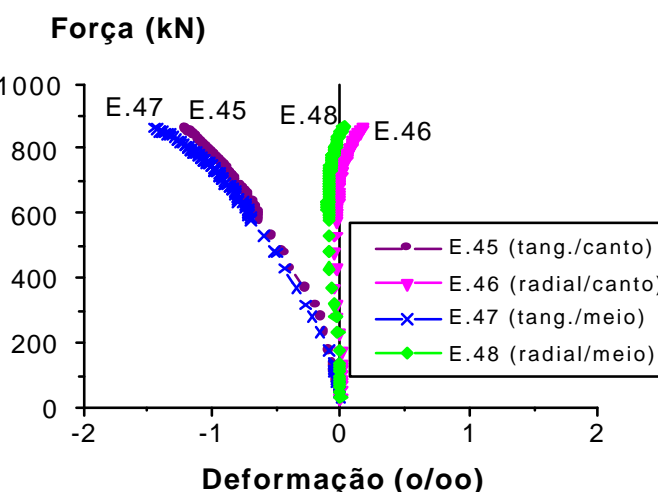

Figura 4.68 - Modelo M2 - deformações na região afastada da chapa metálica

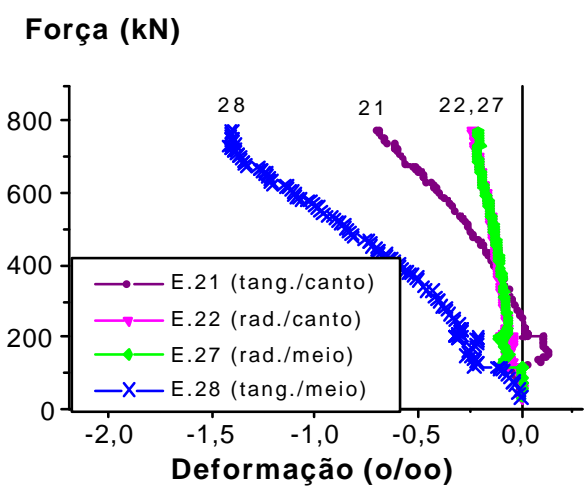

Figura 4.70 - Modelo M4 - deformações na região afastada da chapa metálica

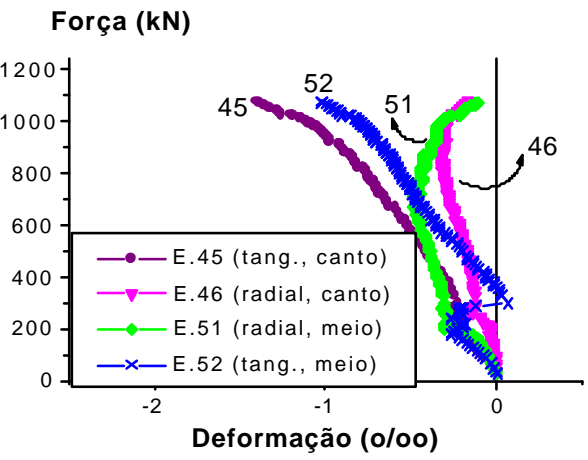

Figura 4.72 - Modelo M6 - deformações na região afastada da chapa metálica

Nas figuras 4.73 a 4.78, têm-se as deformações radiais, com relação ao canto e com relação ao meio da chapa metálica, para todos os modelos. 


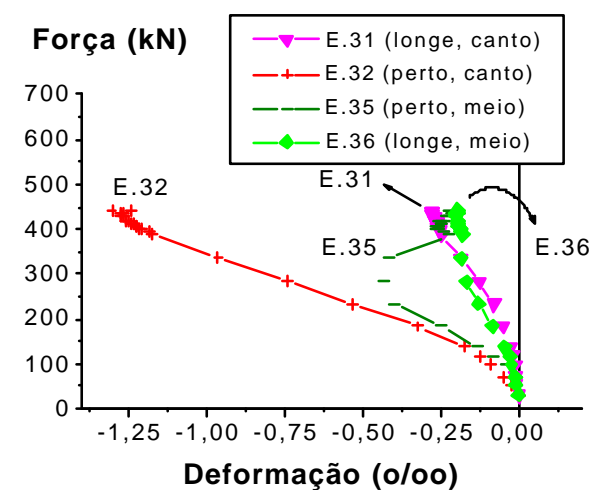

Figura 4.73 - Modelo M1 - deformações radiais

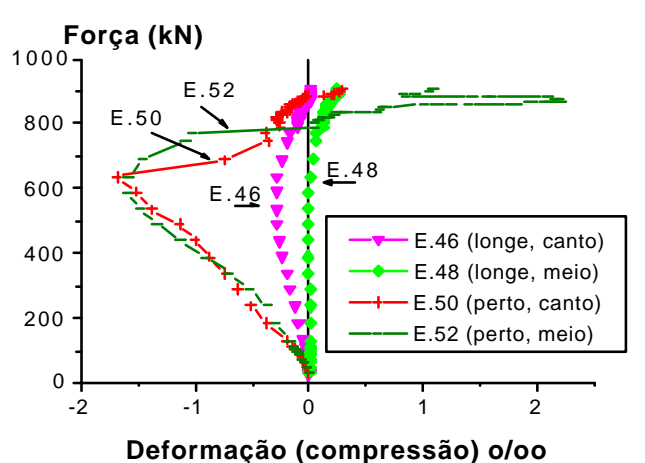

Figura 4.75 - Modelo M3 - deformações radiais

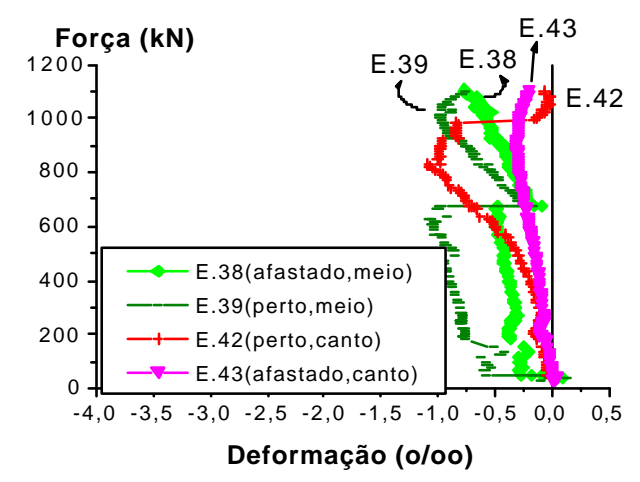

Figura 4.77 - Modelo M5 - deformações radiais

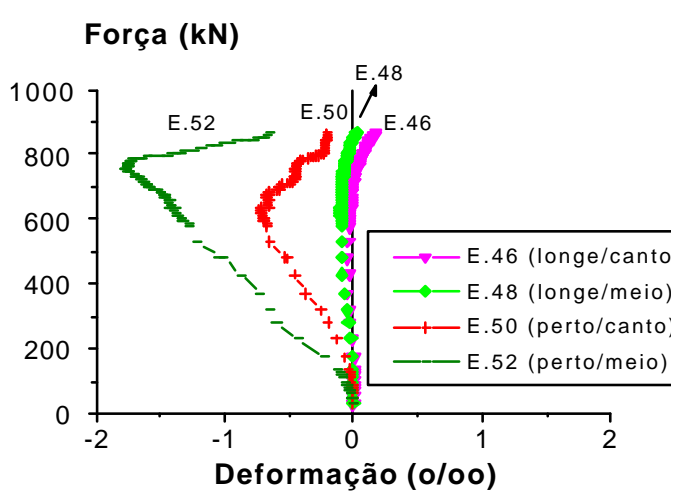

Figura 4.74 - Modelo M2 - deformações radiais

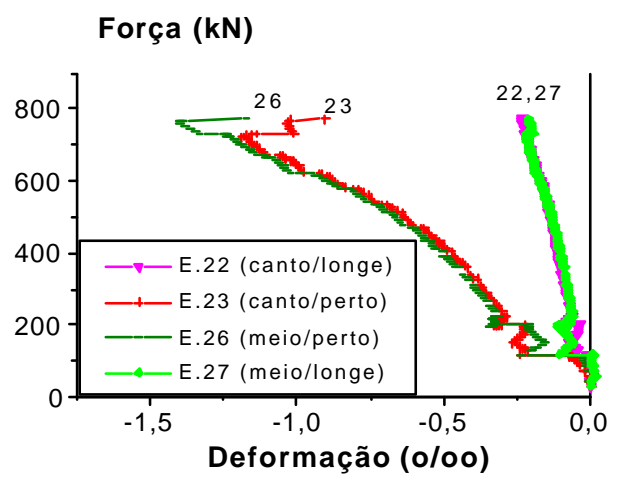

Figura 4.76 - Modelo M4 - deformações radiais

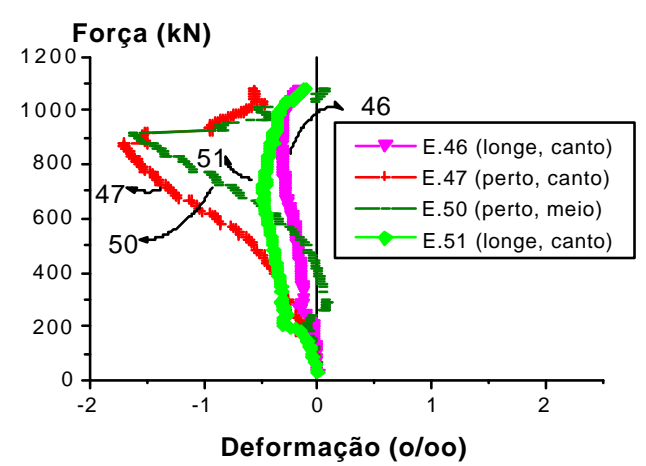

Figura 4.78 - Modelo M6 - deformações radiais

Nas figuras 4.79 a 4.84, têm-se as deformações tangenciais, com relação ao canto e com relação ao meio da chapa metálica, para todos os modelos. 


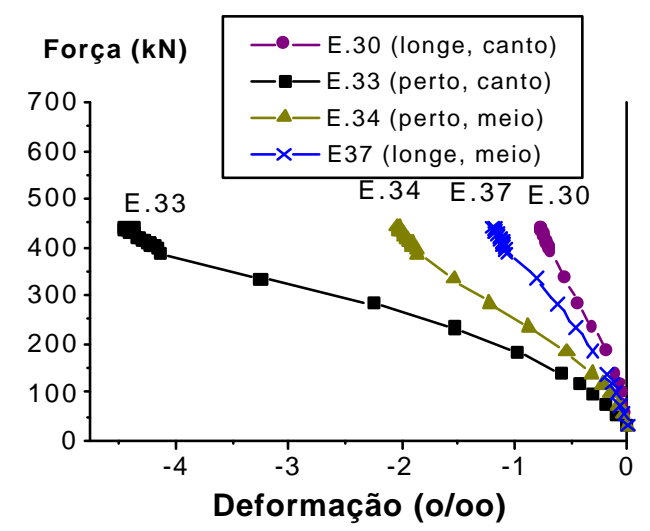

Figura 4.79 - Modelo M1 - deformações tangenciais

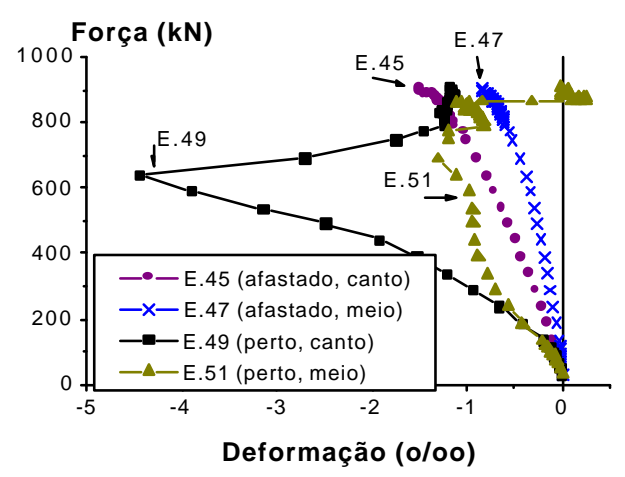

Figura 4.81 - Modelo M3 - deformações tangenciais

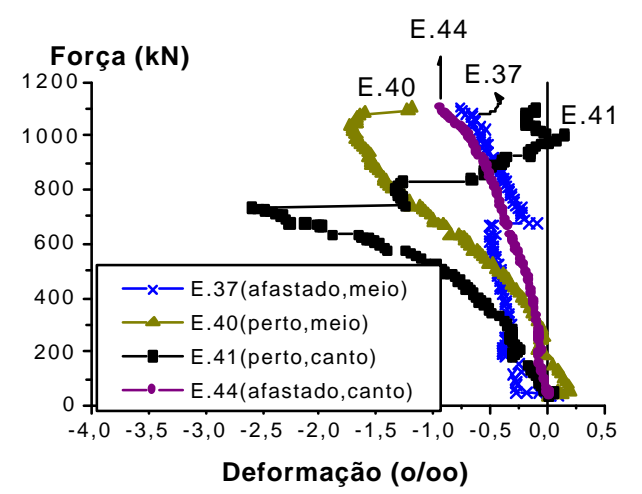

Figura 4.83 - Modelo M5 - deformações tangenciais

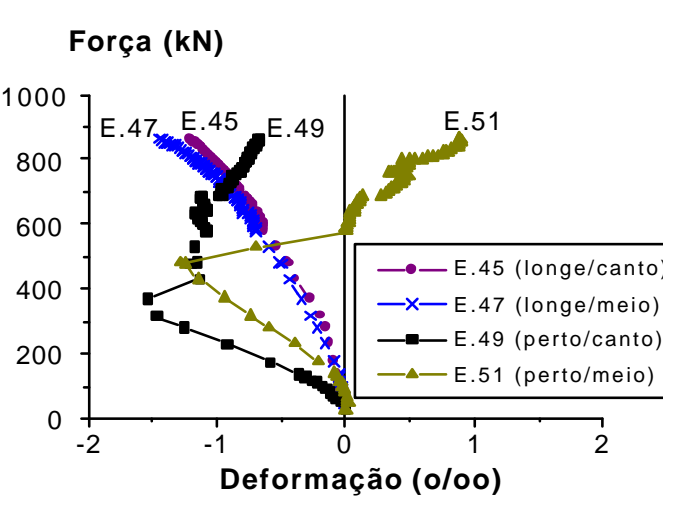

Figura 4.80 - Modelo M2 - deformações tangenciais

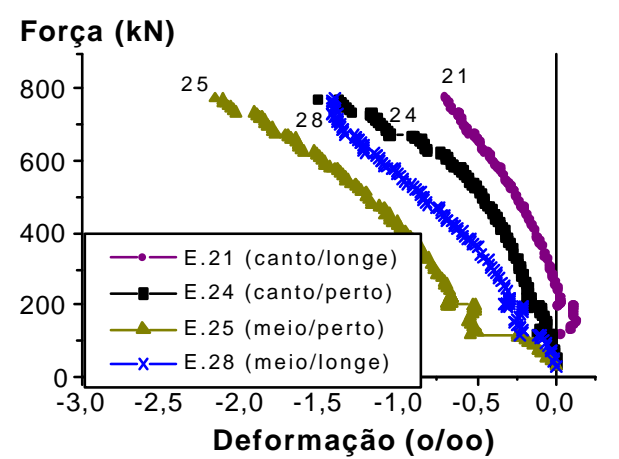

Figura 4.82 - Modelo M4 - deformações tangenciais

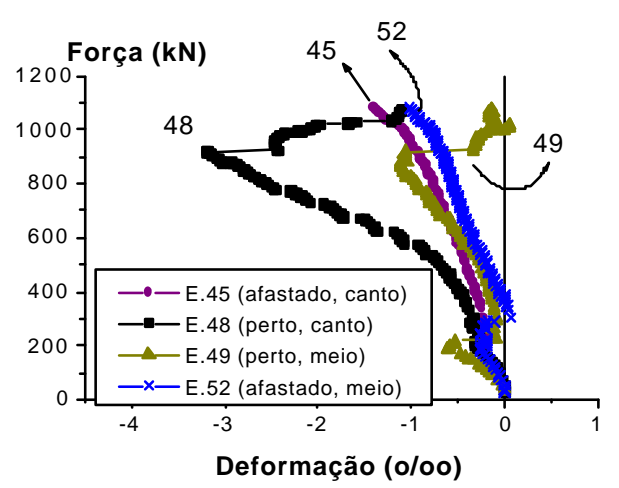

Figura 4.84 - Modelo M6 - deformações tangenciais 


\subsection{INSTRUMENTAÇÃO DOS DESLOCAMENTOS}

Os deslocamentos dos modelos foram medidos através de transdutores de deslocamentos, cujas posições e numerações estão mostradas nas figuras 4.85 a 4.88 . Nessas figuras, as unidades são dadas em $\mathrm{cm}$.

As leituras dos transdutores D.1, D.2, D.3 e D.4, que medem os deslocamentos horizontais do modelo, estão mostradas na tabela 4.3. O sinal positivo indica que o sentido do deslocamento é o mesmo que foi adotado para os eixos $\mathrm{x}$ e $\mathrm{y}$, mostrados na figura 4.85. Em função da necessidade de se trocarem cordoalhas rompidas, durante as operações de protensão, os transdutores relacionados às leituras dos deslocamentos horizontais (D.1 a D.4) foram retirados, não sendo possível apresentar esses resultados para os modelos protendidos.

As leituras dos transdutores D.5, D.6, D.7 e D.8 referem-se aos deslocamentos dos apoios com relação ao piso do laboratório e estão mostrados na tabela 4.4. O sinal positivo na tabela indica um afastamento entre o apoio e o piso; já o sinal negativo indica uma aproximação.

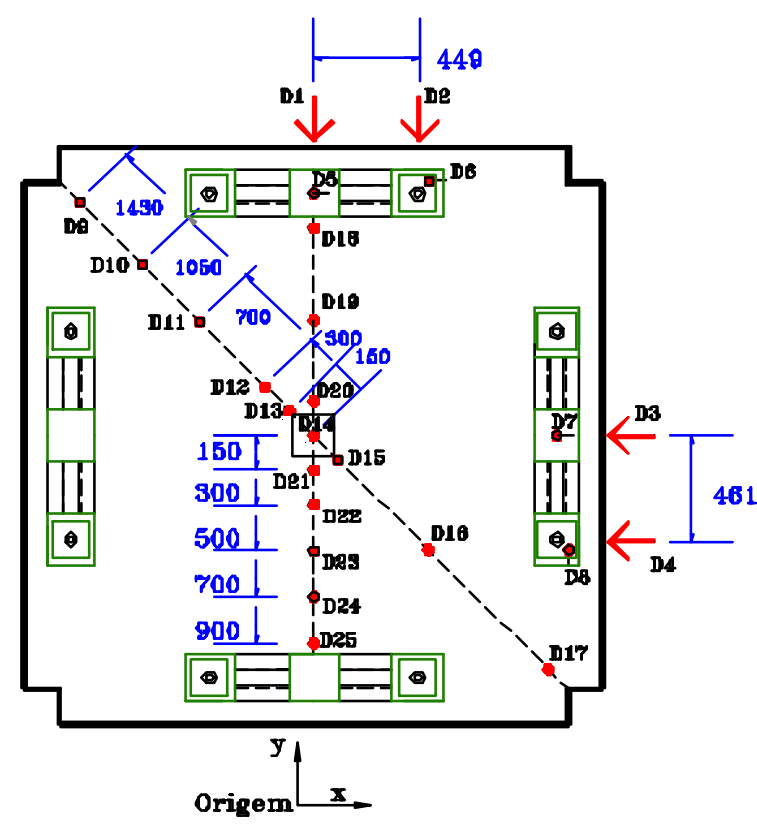

Figura 4.85 - Modelo M1 - posição e numeração dos transdutores

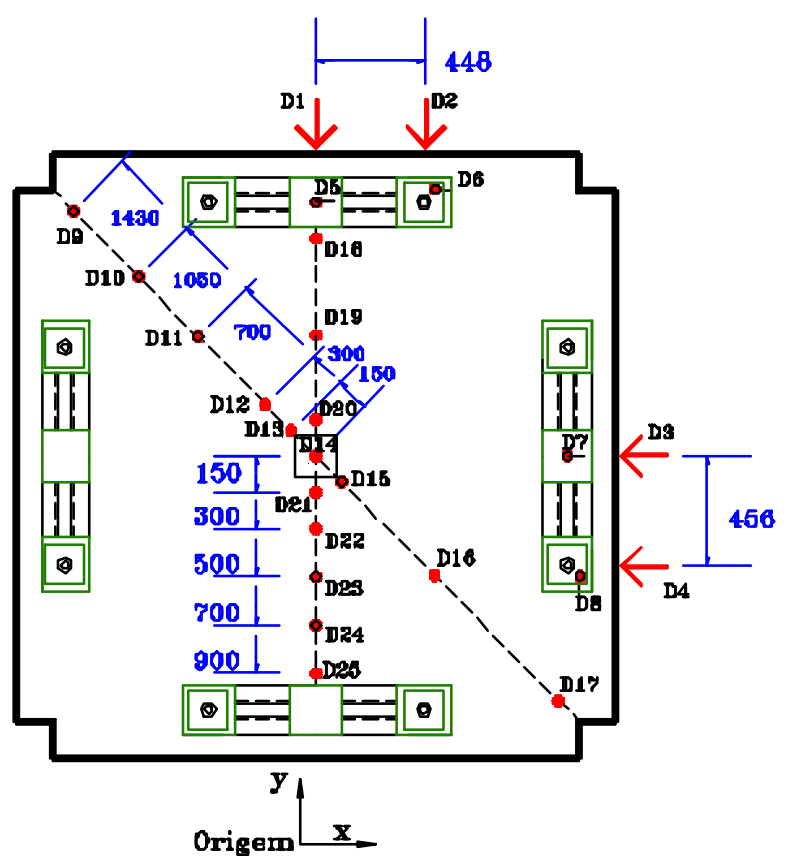

Figura 4.86 - Modelo M2 - posição e numeração dos transdutores 


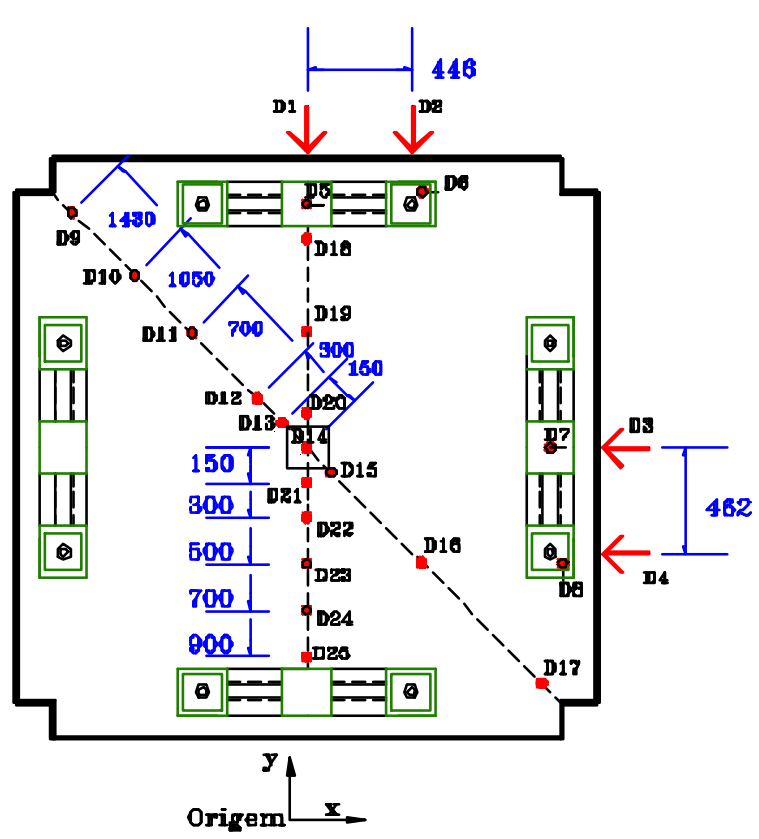

Figura 4.87 - Modelo M3 - posição e numeração dos transdutores

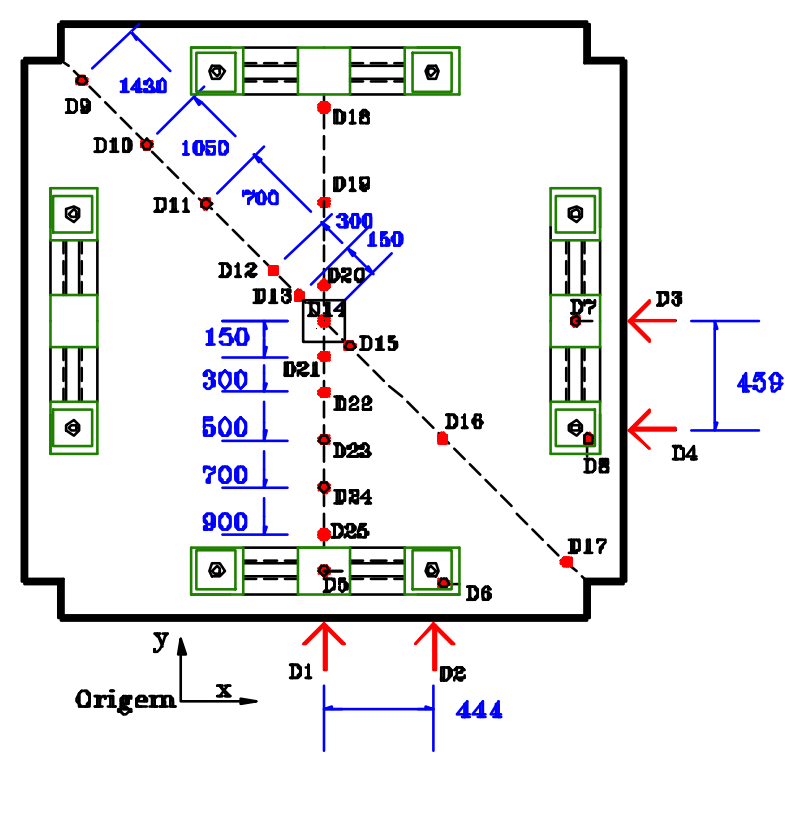

Figura 4.88 - Modelo M4, M5 e M6 - posição e numeração dos transdutores

Tabela 4.3 - Deslocamentos horizontais, medidos pelos transdutores D.1 a D.4

\begin{tabular}{|c|c|c|c|c|}
\hline Modelos & D.1 (mm) & D.2 ( $\mathbf{m m})$ & $\boldsymbol{D . 3}(\mathbf{m m})$ & $\boldsymbol{D . 4}(\mathbf{m m})$ \\
\hline Modelo M1 & 0,11 & 1,43 & 0,71 & 1,82 \\
\hline Modelo M2 & 0,91 & 3,99 & 1,81 & 2,91 \\
\hline Modelo M3 & 0,33 & 2,20 & 0,71 & 4,00 \\
\hline
\end{tabular}

Tabela 4.4 - Deslocamentos verticais dos apoios, dados pelos transdutores D.5 a D.8

\begin{tabular}{|c|c|c|c|c|}
\hline Modelos & D.5 $(\mathbf{m m})$ & $\mathbf{D . 6}(\mathbf{m m})$ & $\mathbf{D . 7}(\mathbf{m m})$ & $\mathbf{D . 8}(\mathbf{m m})$ \\
\hline Modelo M1 & $-0,22$ & $-0,68$ & 1,61 & 1,20 \\
\hline Modelo M2 & 1,73 & 0,22 & 2,90 & 2,44 \\
\hline Modelo M3 & 1,21 & $-0,79$ & 2,26 & 0,90 \\
\hline Modelo M4 & 1,68 & 1,98 & 1,76 & 2,17 \\
\hline Modelo M5 & 1,51 & 0,79 & 2,83 & 1,80 \\
\hline Modelo M6 & 2,61 & 1,22 & 2,76 & 2,17 \\
\hline
\end{tabular}


Já os deslocamentos verticais (ou transversais) das lajes com relação ao seu plano médio são dadas através dos transdutores D.9 a D.25. Nas figuras 4.89 a 4.100, têm-se ilustrados os deslocamentos dos transdutores dispostos na direção inclinada ao eixo y, e na direção deste eixo, para todos os modelos. Para o modelo M3, foram observados problemas nos transdutores D.12 e D.24, razão pela qual seus valores não foram incluídos nas figuras $4.93 \mathrm{~b}$ e $4.94 \mathrm{~b}$, respectivamente.

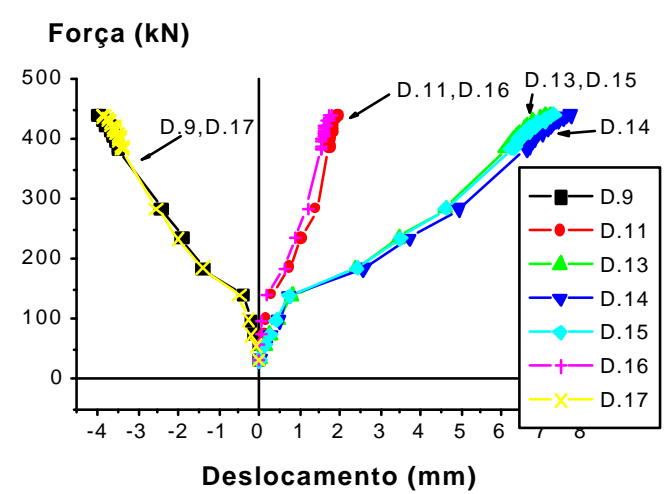

a) Análise do carregamento através dos deslocamentos em pontos simétricos

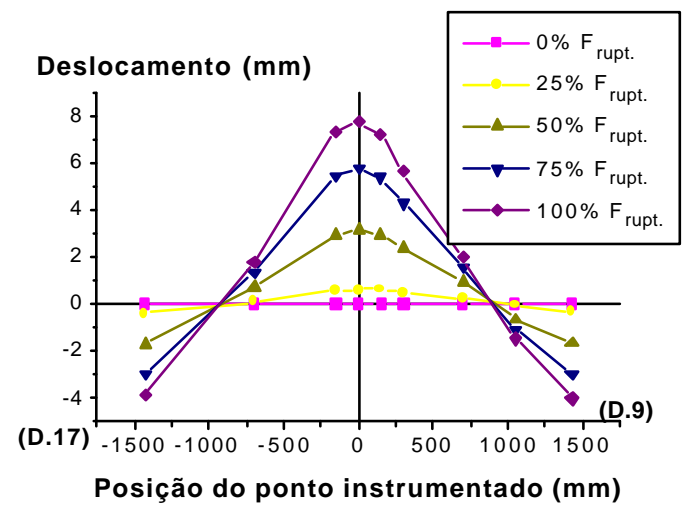

b) Deslocamentos para 4 níveis de carregamento

Figura 4.89 - Deslocamentos transversais do modelo M1, na direção inclinada ao eixo $y$

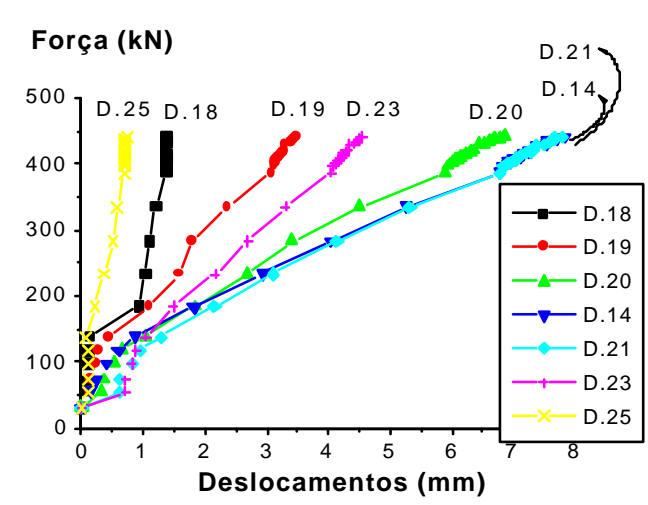

a) Análise do carregamento através dos deslocamentos em pontos simétricos

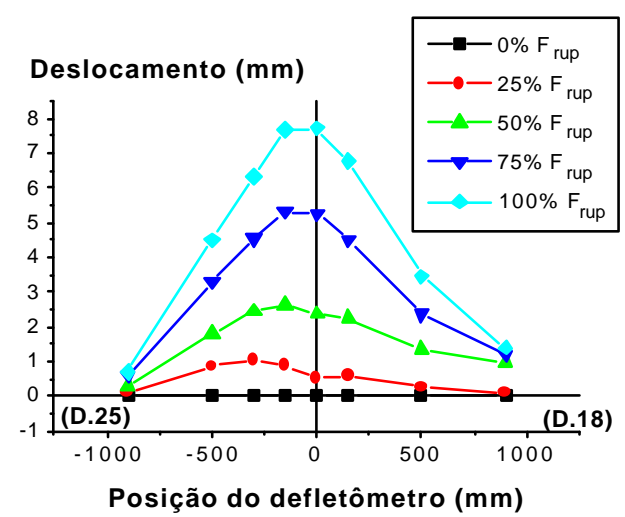

b) Deslocamentos para 4 níveis de carregamento

Figura 4.90 - Deslocamentos transversais do modelo M1, na direção do eixo y 
Força $(\mathbf{k N})$

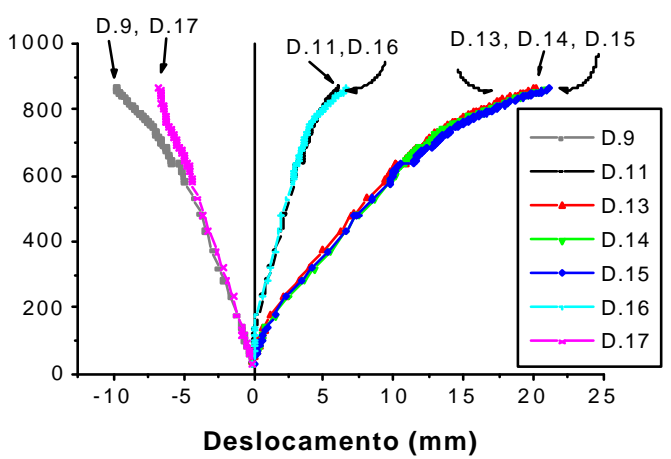

a) Análise do carregamento através dos deslocamentos em pontos simétricos

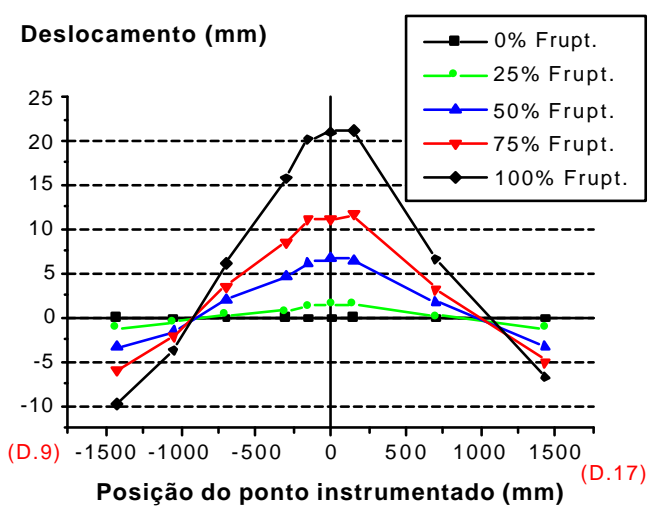

b) Deslocamentos para 4 níveis de carregamento

Figura 4.91 - Deslocamentos transversais do modelo M2, na direção

\section{inclinada ao eixo y}

\section{Força (kN)}

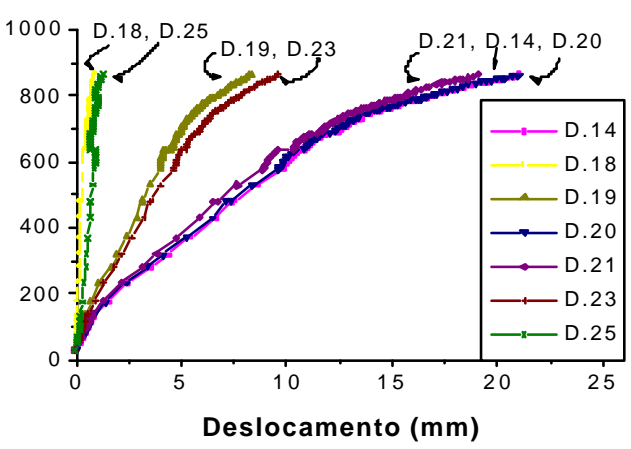

a) Análise do carregamento através dos deslocamentos em pontos simétricos

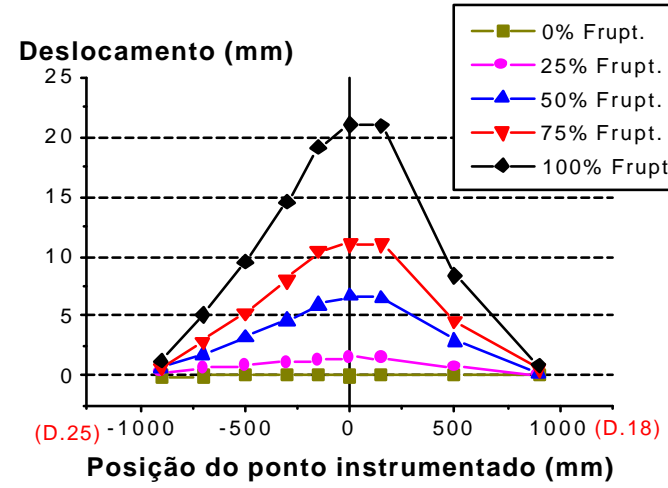

b) Deslocamentos para 4 níveis de carregamento

Figura 4.92 - Deslocamentos transversais do modelo M2, na direção do eixo y

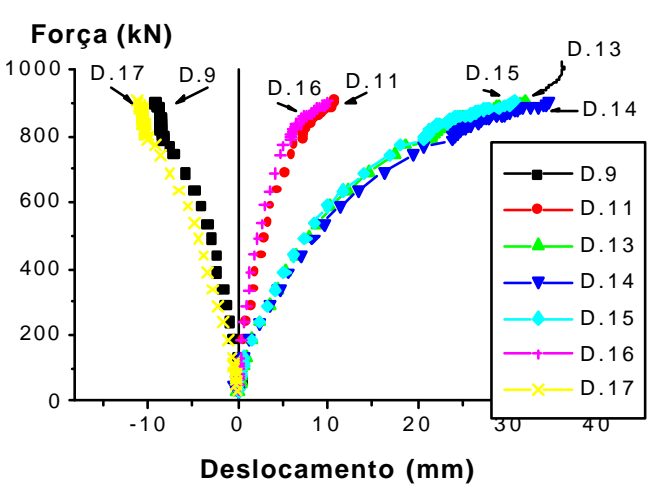

a) Análise do carregamento através dos deslocamentos em pontos simétricos

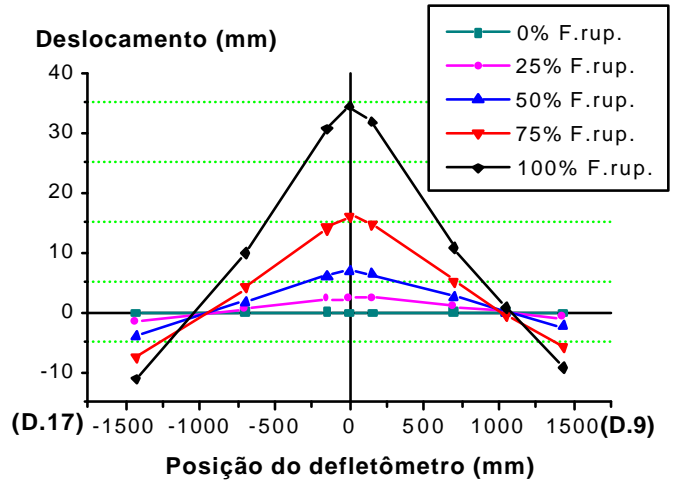

b) Deslocamentos para 4 níveis de carregamento

Figura 4.93 - Deslocamentos transversais do modelo M3, na direção 


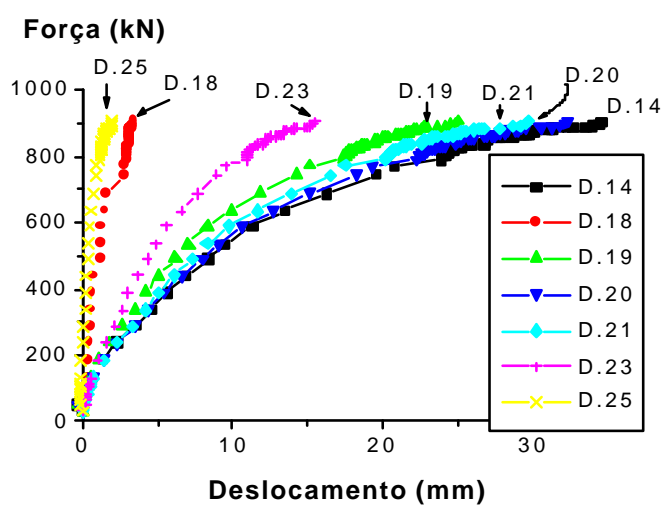

a) Análise do carregamento através dos deslocamentos em pontos simétricos

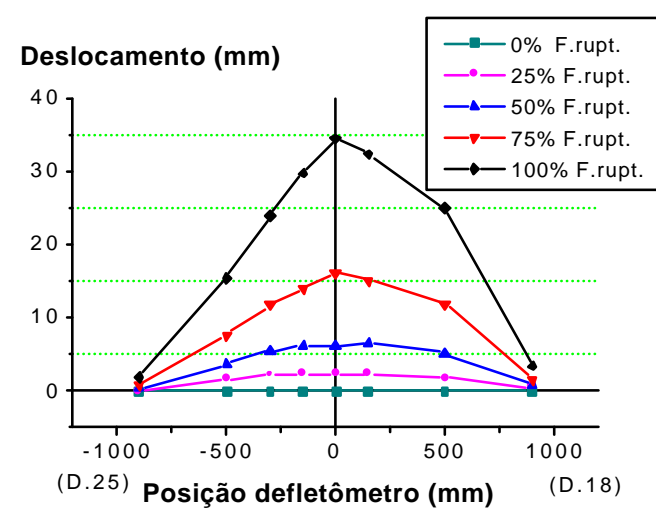

b) Deslocamentos para 4 níveis de carregamento

Figura 4.94 - Deslocamentos transversais do modelo M3, na direção do eixo y

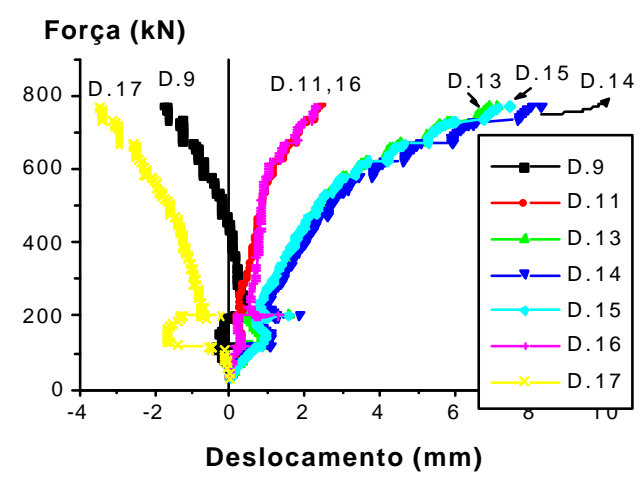

a) Análise do carregamento através dos deslocamentos em pontos simétricos

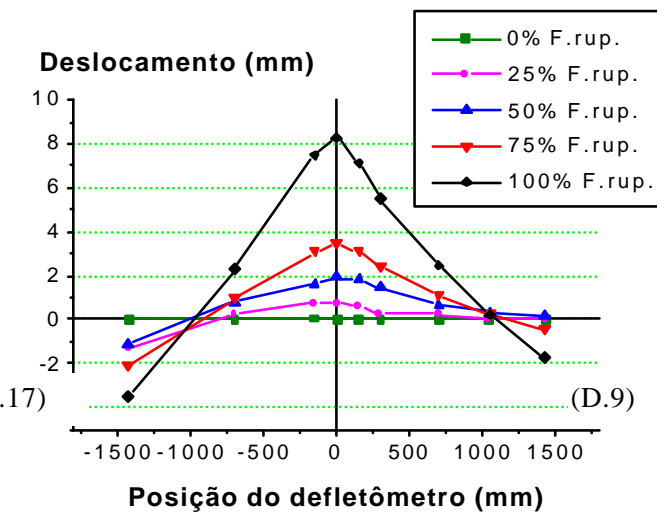

b) Deslocamentos para 4 níveis de carregamento

Figura 4.95 - Deslocamentos transversais do modelo M4, na direção

\section{inclinada ao eixo y}

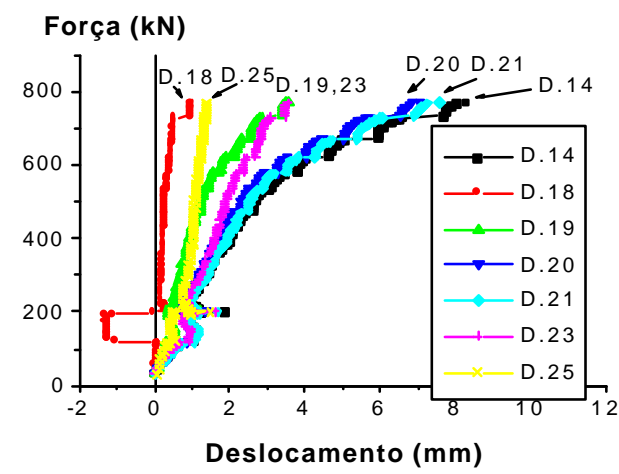

a) Análise do carregamento através dos deslocamentos em pontos simétricos

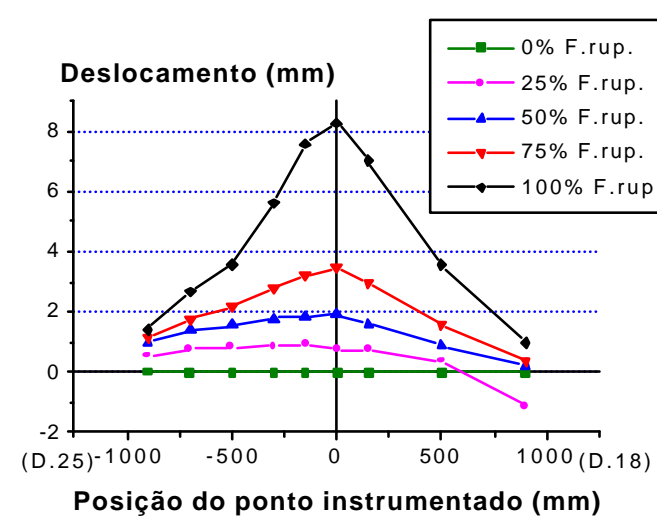

b) Deslocamentos para 4 níveis de carregamento

Figura 4.96 - Deslocamentos transversais do modelo M4, na direção do eixo y 


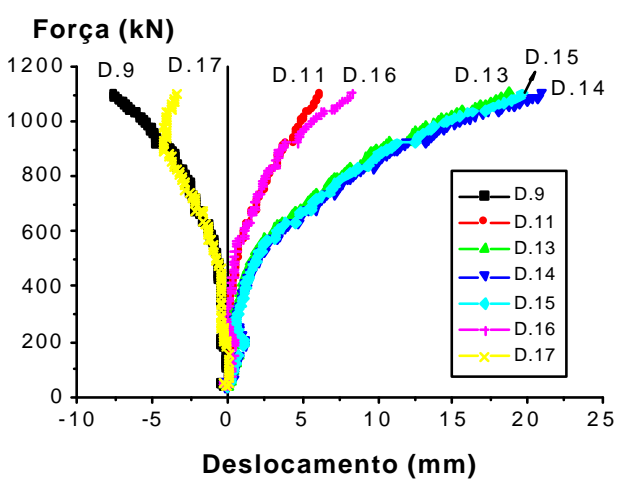

a) Análise do carregamento através dos deslocamentos em pontos simétricos

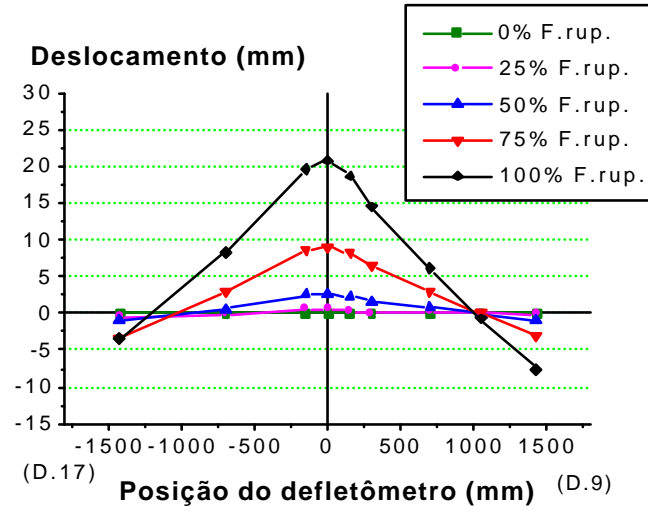

b) Deslocamentos para 4 níveis de carregamento

Figura 4.97 - Deslocamentos transversais do modelo M5, na direção inclinada ao eixo y

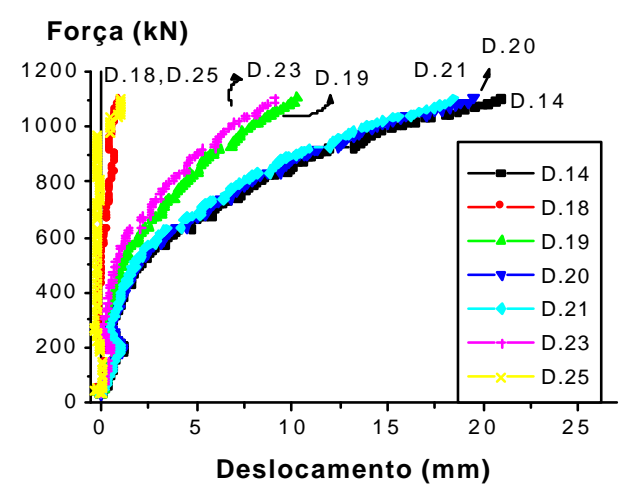

a) Análise do carregamento através dos deslocamentos nos pontos simétricos

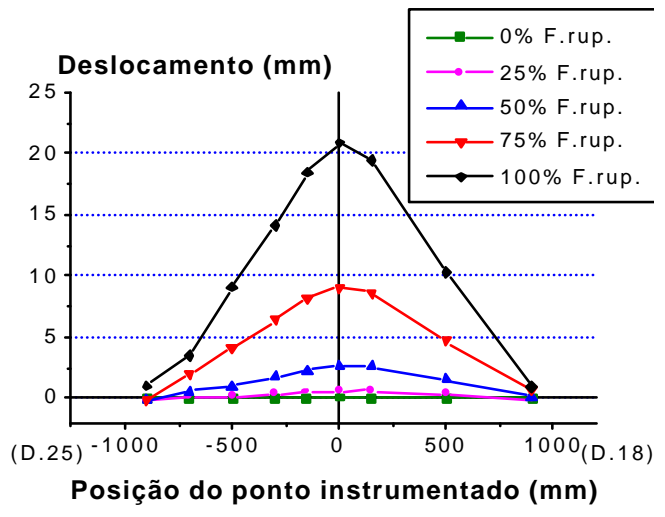

b) Deslocamentos para 4 níveis de carregamento

Figura 4.98 - Deslocamentos transversais do modelo M5, na direção do eixo y

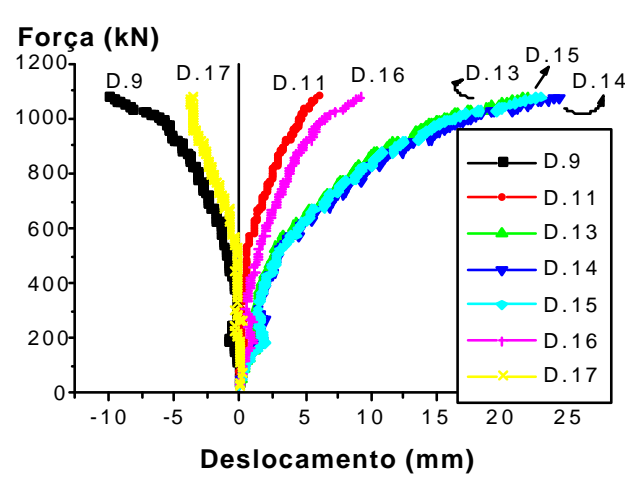

a) Análise do carregamento através dos deslocamentos em pontos simétricos

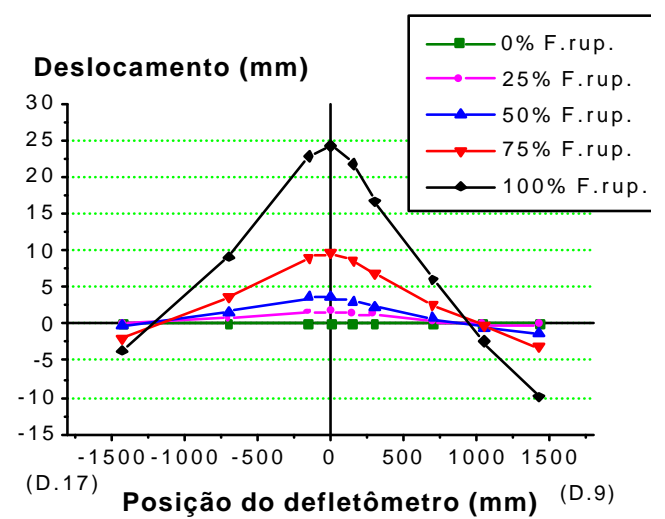

b) Deslocamentos para 4 níveis de carregamento

Figura 4.99 - Deslocamentos transversais do modelo M6, na direção

\section{inclinada ao eixo $y$}




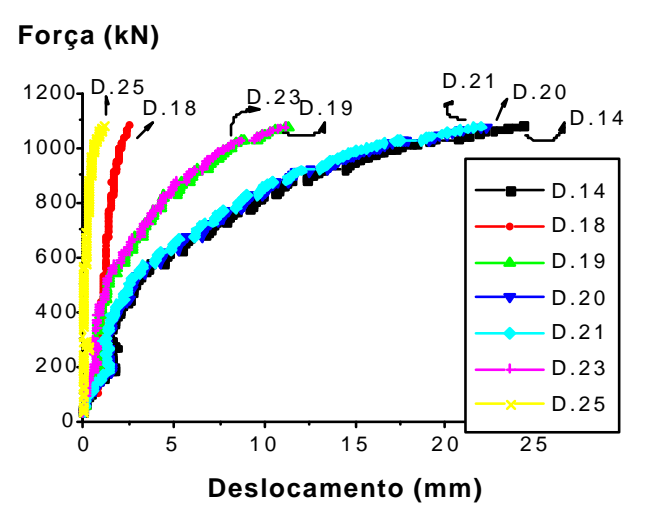

a) Análise do carregamento através dos deslocamentos em pontos simétricos

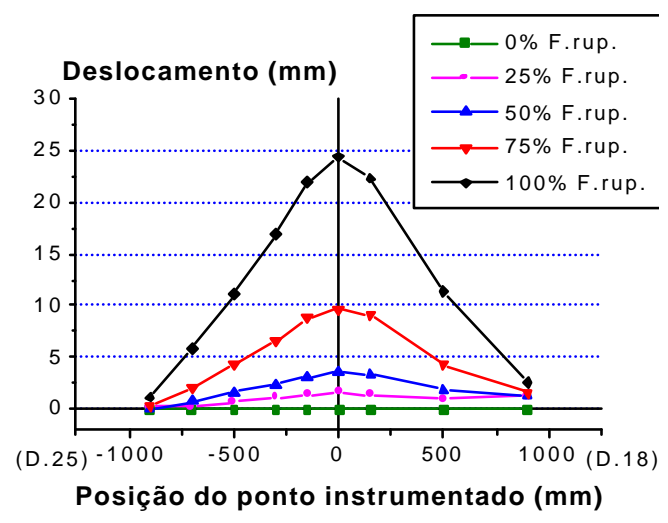

b) Deslocamentos para 4 níveis de carregamento

Figura 4.100 - Deslocamentos transversais do modelo M6, na direção do eixo y

\subsection{INSTRUMENTAÇÃO DA ARMADURA DE PUNÇÃO}

Os gráficos que relacionam a deformação de cada extensômetro à força total aplicada pelos macacos, para os modelos com armadura de punção, estão mostrados no Anexo H. Para facilitar a análise dos resultados, são agrupados os modelos com mesmo número de linhas de conectores: M2 com M5 e M3 com M6.

\subsubsection{COMPARAÇÃO ENTRE OS MODELOS M2 E M5}

Com relação à armadura de punção, os extensômetros foram colados nas posições mostradas na figura $4.101 a$ e $4.101 b$. Os extensômetros foram colocados no meio dos pinos, conforme mostrado na figura $4.101 c$ e posicionados de modo que a superfície de ruína não interceptasse a face da barra onde os extensômetros foram colados.

Os extensômetros com numeração ḿmpar encontram-se mais próximos da região onde foi aplicado o carregamento. 


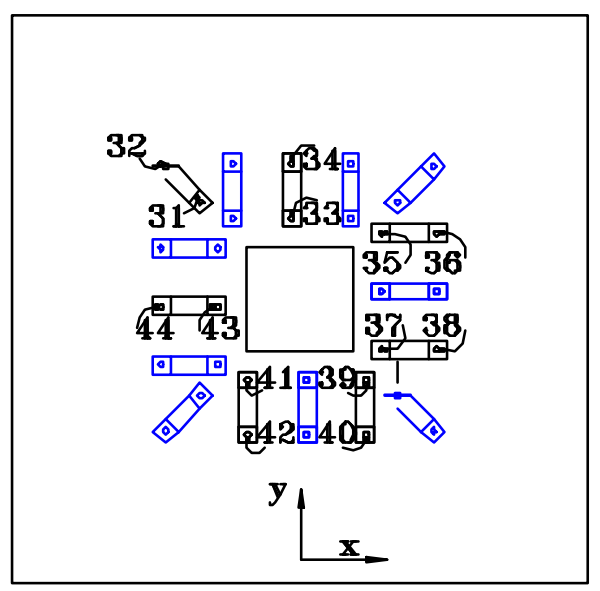

a) Modelo M2

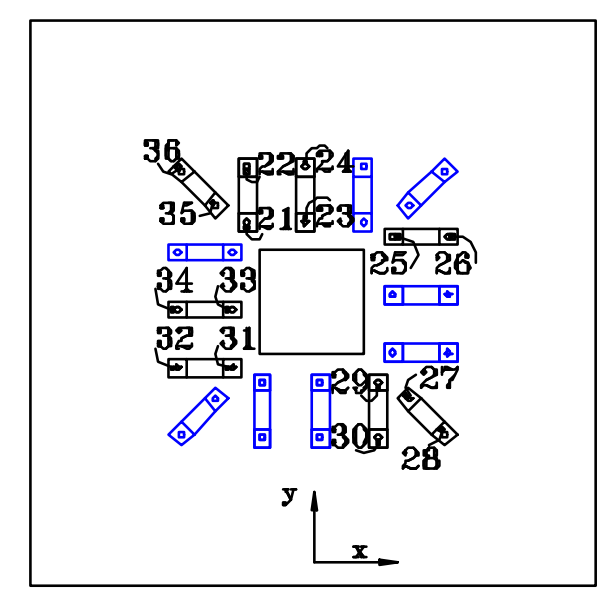

b) Modelo M5

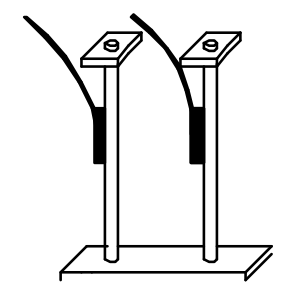

c) Posição dos extensômetros nos pinos dos conectores

Figura 4.101 - Numeração dos extensômetros e sua posição nos pinos instrumentados

Nas fguras 4.102 a 4.110, são apresentados alguns gráficos que relacionam o comportamento dos pinos instrumentados com a sua posição relativa à chapa metálica usada para aplicar o carregamento ao modelo. Na figura 4.102, têm-se ilustrados os conectores dispostos na direção $\mathrm{x}$, colocados no mesmo lado.

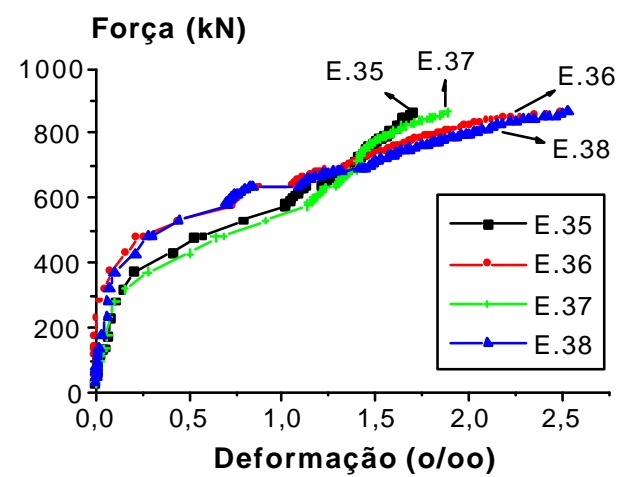

a) Modelo M2 (lado direito do modelo, conectores localizados nos cantos)

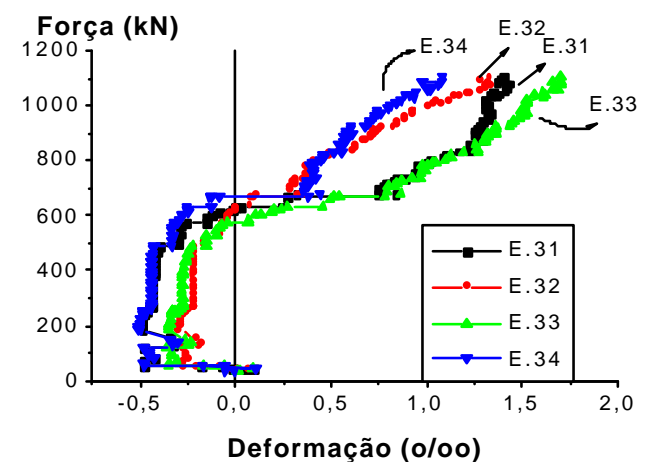

b) Modelo M5 (lado esquerdo do modelo, E.31- E.32 nos cantos, E.33-E.34 no meio)

Figura 4.102 - Conectores dispostos na direção x, estando do mesmo lado 
Na figura 4.103, têm-se os conectores dispostos na direção x, colocados em lados opostos.

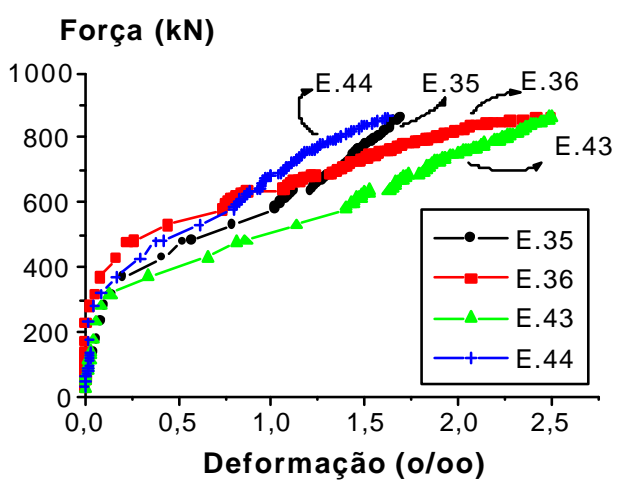

a) Modelo M2 (E.35-E.36 no canto superior direito, E.43-E.44 no meio do lado esquerdo)

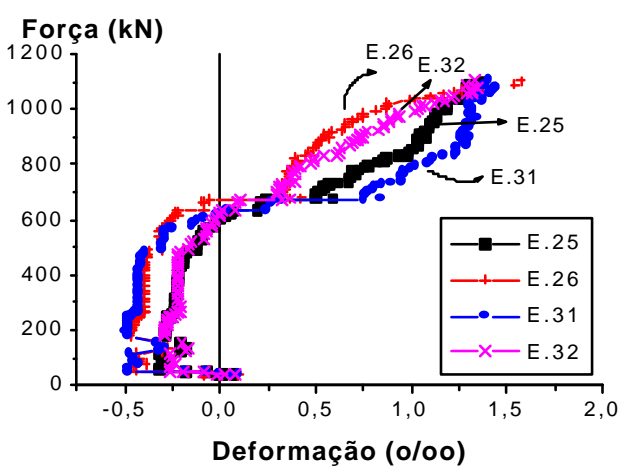

b) Modelo M5 (E.25-E.26 no canto superior direito; E.31-E32 no canto inferior esquerdo)

Figura 4.103 - Conectores dispostos na direção x, estando em lados opostos

Na figura 4.104, têm-se ilustrados os conectores dispostos na direção y, colocados no mesmo lado, apenas para o modelo M2. Para o modelo M5, devido ao problema ocorrido no E.23 e no E.24, não foi possível analisar os conectores dispostos na direção y, do mesmo lado.

Na figura 4.105, têm-se ilustrados os conectores dispostos na direção y, colocados em lados opostos.

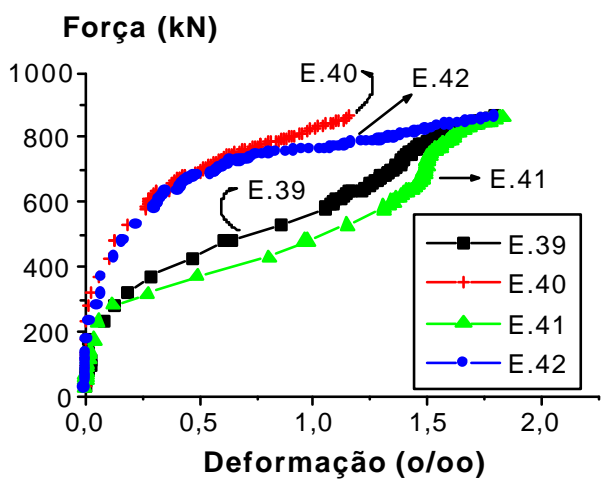

Figura 4.104 - Modelo M2: Conectores dispostos na direção y, no mesmo lado (lado inferior) 


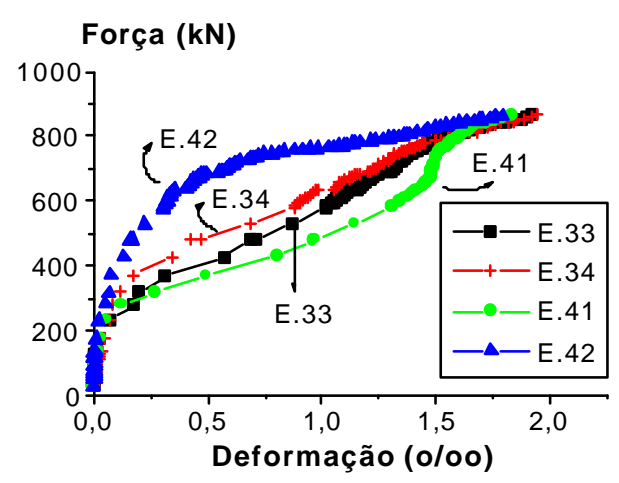

a) Modelo M2 (E.33-E.34, lado superior, no meio; E.41-E.42, canto inferior esquerdo

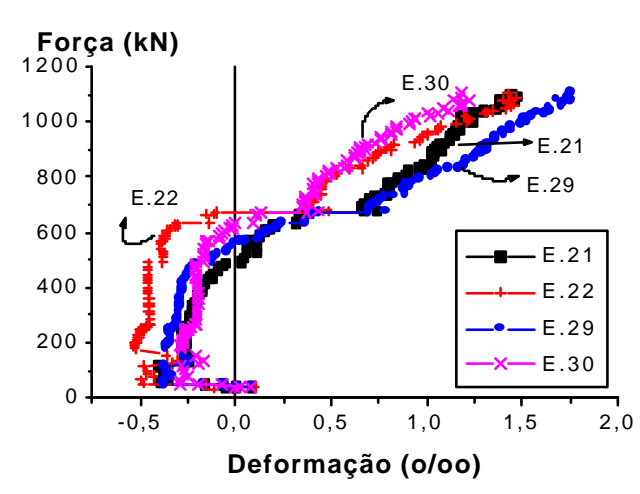

b) Modelo M5 (E.21-E.22, canto superior esquerdo; E.29-E.30, canto inferior direito)

Figura 4.105 - Conectores dispostos na direção y, estando em lados opostos

Para o modelo M2, nas figuras 4.106 e 4.107, têm-se, respectivamente, comparações entre conectores dispostos na direção x e na direção inclinada, e na direção y e na direção inclinada. Para o modelo M5, na figura 4.108, têm-se as deformações dos pinos de conectores inclinados.

Na figura 4.109, têm-se ilustrados os pinos dos conectores mais próximos da chapa de aplicação da carga. Na figura 4.110, têm-se ilustrados os pinos dos conectores mais afastados da chapa de aplicação da carga.

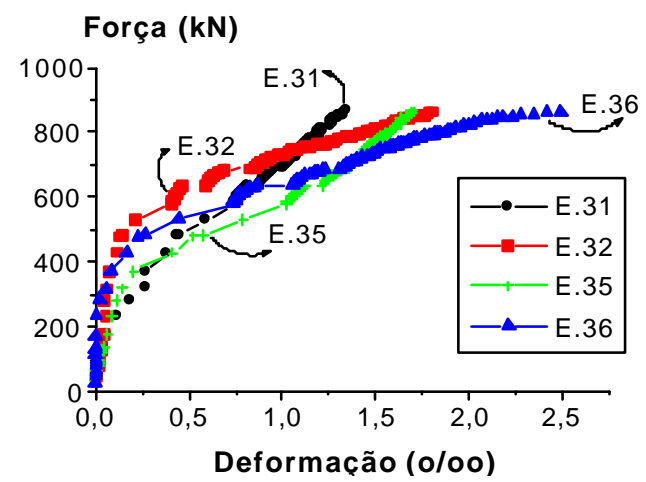

Figura 4.106 - Modelo M2: disposição dos conectores: um na direção x (lado direito, superior) e o outro inclinado (canto superior esquerdo)

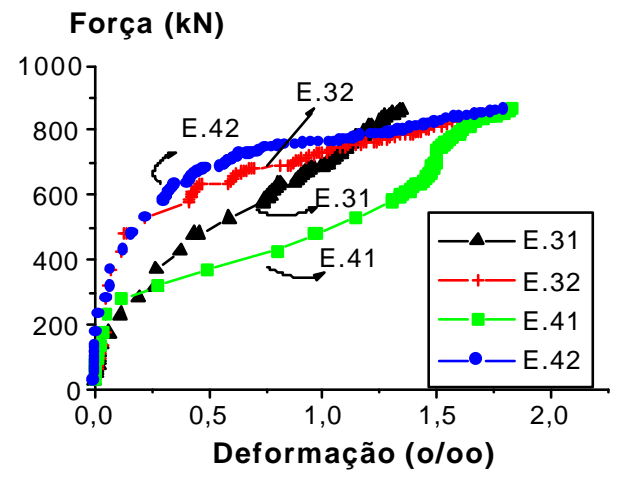

Figura 4.107 - Modelo M2: disposição dos conectores: um na direção y (canto inferior esquerdo)e o outro inclinado (canto superior esquerdo) 


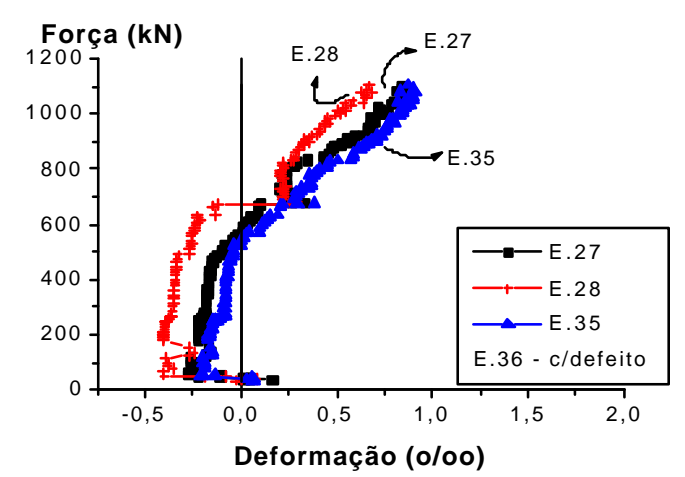

Figura 4.108 - Modelo M5: comparação da disposição de dois conectores inclinados (E.27-E.28, no canto inferior direito; E.35-E.36, canto superior esquerdo)

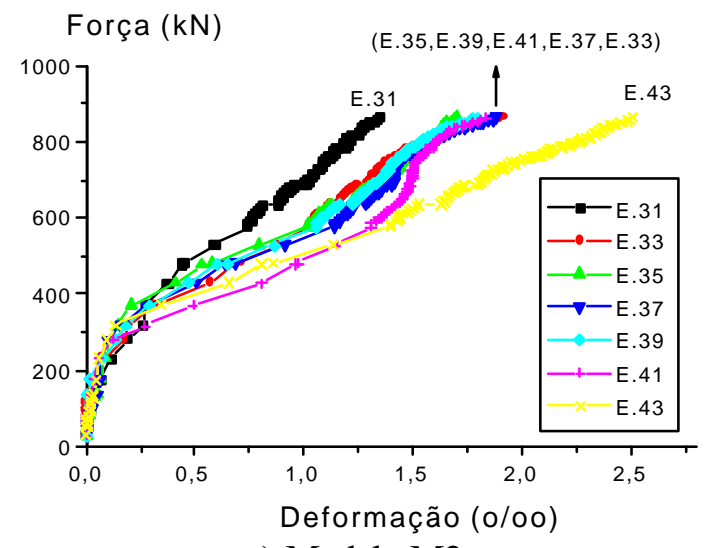

a) Modelo M2

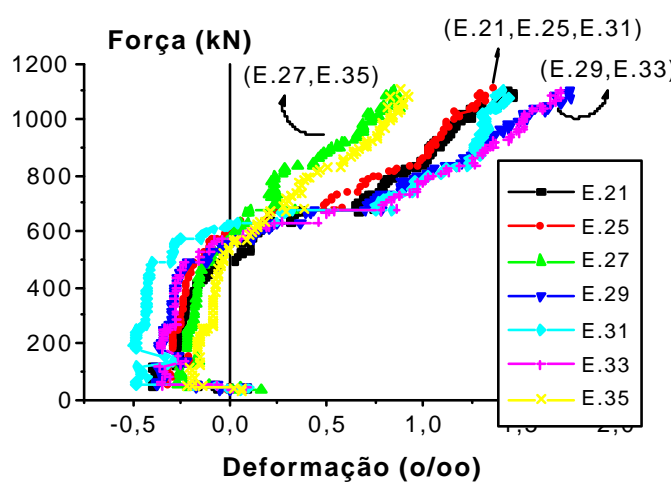

b) Modelo M5

Figura 4.109 - Deformações nos pinos mais próximos à chapa metálica

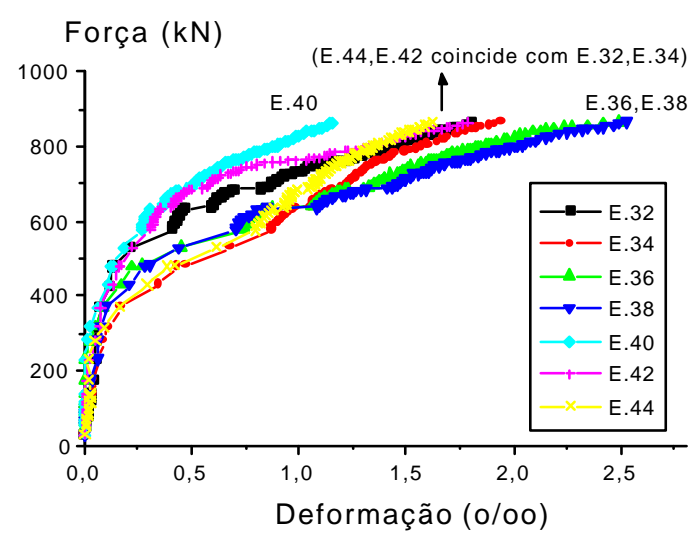

a) Modelo M2

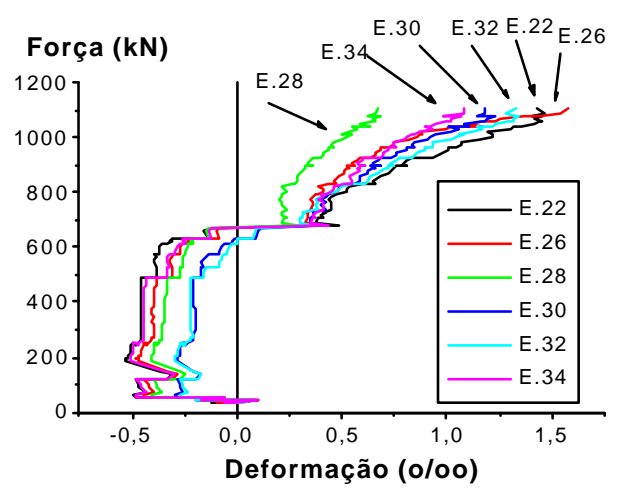

b) Modelo M5

Figura 4.110 - Deformações nos pinos mais afastados da chapa metálica 


\subsubsection{COMPARAÇÃO ENTRE OS MODELOS M3 E M6}

Os extensômetros foram colados nas posições mostradas na figura 4.111 e no meio dos pinos, para que a superfície de ruína não interceptasse a face da barra onde os extensômetros foram colados.

Os extensômetros com números ímpares menores encontram-se mais próximos da região onde foi aplicado o carregamento. Já os números pares intermediários estão relacionados aos pinos posicionados no meio das chapas de ancoragem inferiores.

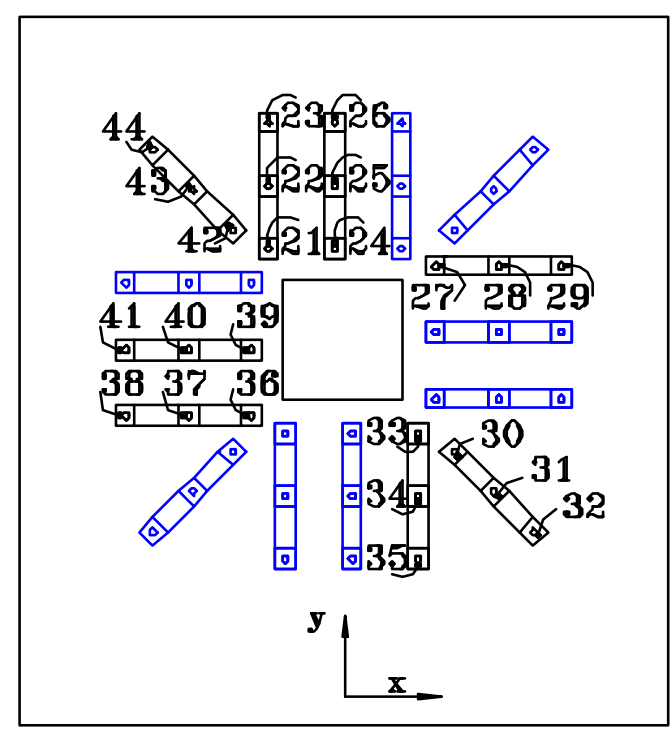

a) Numeração

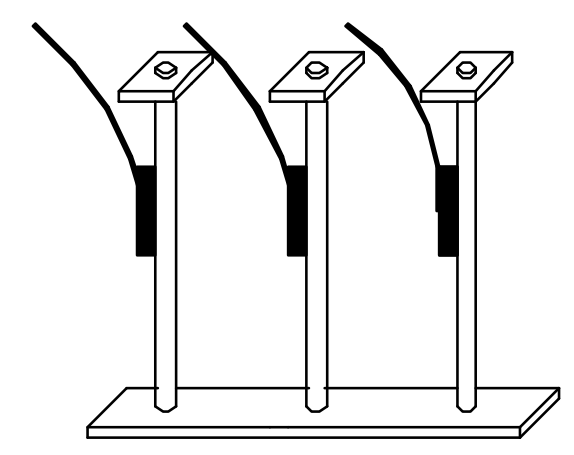

b) Posição

Figura 4.111 - Posição dos pinos instrumentados, para os modelos M3 e M6

Como a maioria dos extensômetros do modelo M6 não apresentou boas condições de funcionamento, faz-se uma análise mais detalhada apenas para o modelo M3. Para este modelo, as figuras 4.112 e 4.113 mostram o comportamento das armaduras dispostas nas direções y e $\mathrm{x}$, respectivamente. 


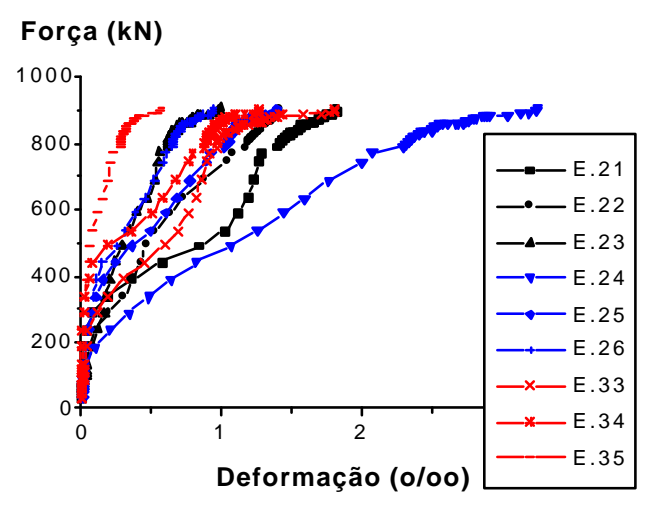

Figura 4.112 - Comportamento dos conectores dispostos na direção y (modelo M3)

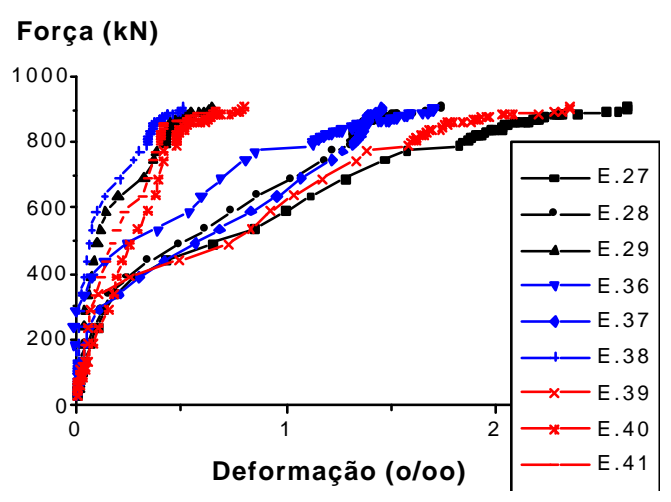

Figura 4.113- Comportamento dos conectores dispostos na direção $\mathrm{x}$ (modelo M3)

Para o modelo M3, na figura 4.114, tem-se ilustrado o comportamento da armadura disposta diagonalmente à chapa usada para aplicar o carregamento ao modelo.

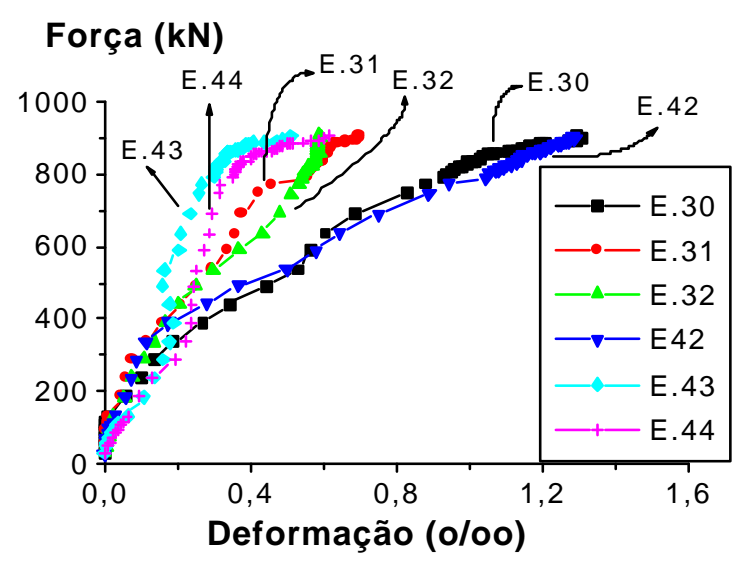

Figura 4.114 - Comportamento dos conectores dispostos na direção diagonal (modelo M3)

Na figura 4.115 tem-se a única comparação entre os modelos M3 e M6, com relação a conectores diagonais, no canto superior esquerdo. 


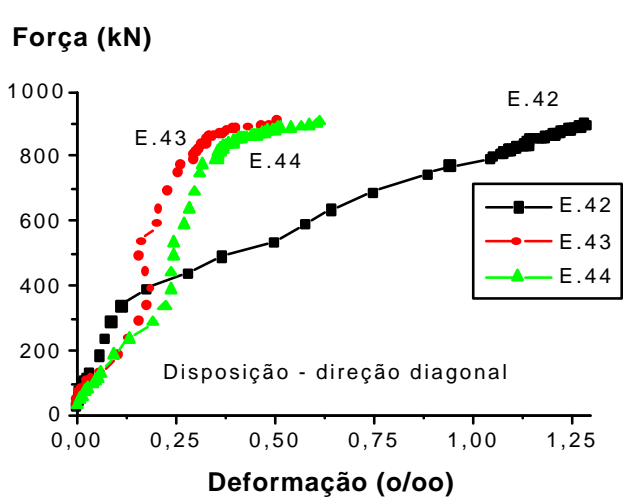

a) Modelo M3
Força (kN)

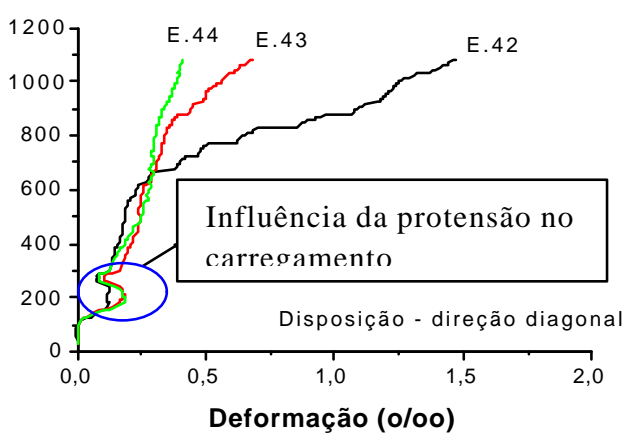

b) Modelo M6

Figura 4.115 - Conectores dispostos diagonalmente à chapa metálica usada para aplicar o carregamento ao modelo

\subsection{INSTRUMENTAÇÃO DAS CORDOALHAS DE PROTENSÃO}

As cordoalhas foram instrumentadas com base na numeração dada na figura 4.116.

Todas as cordoalhas foram protendidas com uma força padrão de $147 \mathrm{kN}$ (aproximadamente 15 toneladas-força).

Em função da excentricidade do traçado das cordoalhas, a protensão das cordoalhas provocou um acréscimo da carga aplicada pelos macacos, em função destes funcionarem como um apoio intermediário.

Portanto, antes do início da protensão, a força aplicada ao modelo estava em torno de um determinado valor e, no final da fase de protensão, a força total medida nos macacos estava maior.

$\mathrm{Na}$ tabela 4.5, têm-se as forças medidas nos macacos, para cada um dos modelos protendidos.

Nas tabelas 4.6 a 4.11, apresenta-se a força de protensão nas cordoalhas nas seguintes situações: na primeira protensão, após a recuperação das perdas, no instante de ruptura e imediatamente após a ruptura. 

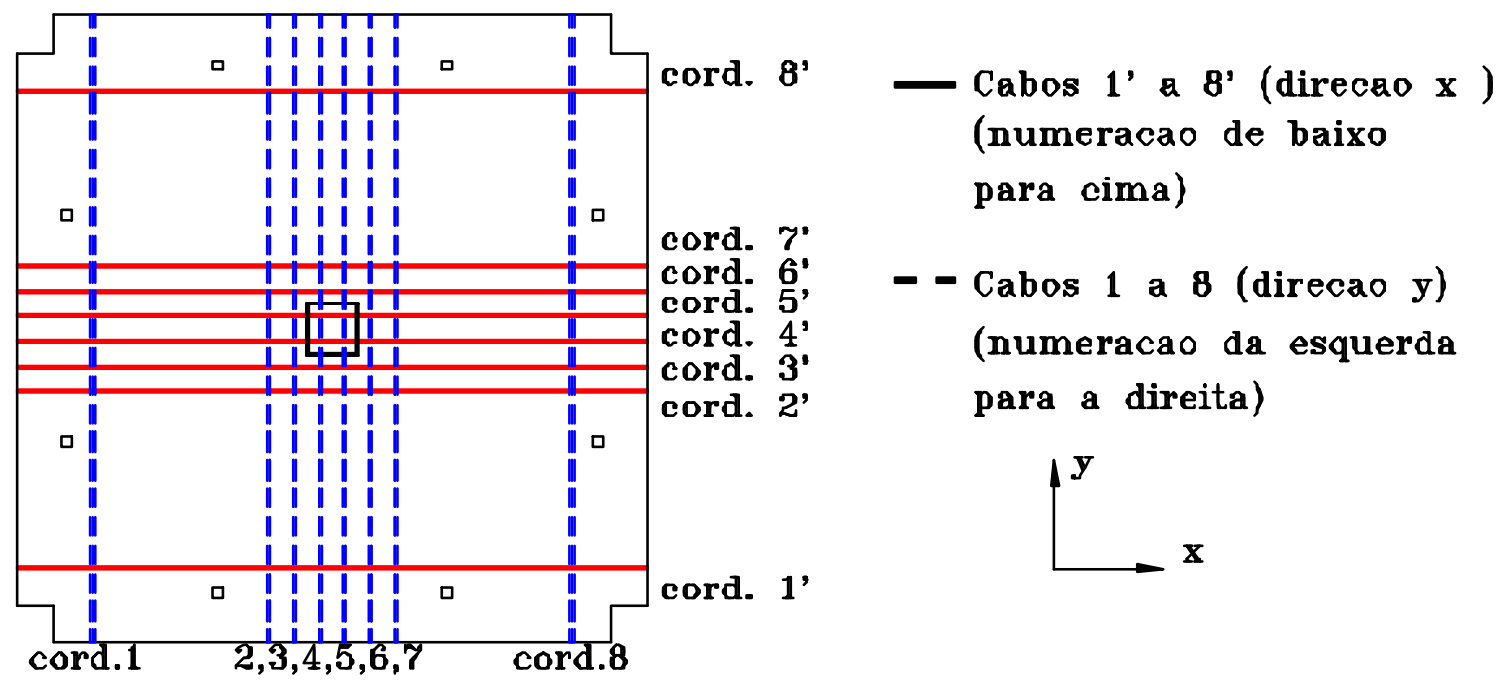

Figura 4.116 - Numeração das cordoalhas.

Tabela 4.5 - Forças medidas nos macacos, antes e após as operações de protensão

\begin{tabular}{|c|c|c|}
\hline Modelo & $\begin{array}{c}\text { Força medida nos macacos } \\
\text { antes das operações de } \\
\text { protensão }(\mathrm{kN})\end{array}$ & $\begin{array}{c}\text { Força medida nos macacos } \\
\text { após as operações de } \\
\text { protensão }(\mathrm{kN})\end{array}$ \\
\hline Modelo M4 & 109,8 & 221,3 \\
\hline Modelo M5 & 182,3 & 269,1 \\
\hline Modelo M6 & 186,8 & 289,8 \\
\hline
\end{tabular}

Tabela 4.6 - Modelo M4: protensão nas cordoalhas dispostas na direção y (kN)

\begin{tabular}{|c|c|c|c|c|c|c|c|c|}
\hline \multirow{2}{*}{ Situação } & \multicolumn{8}{|c|}{ Força de protensão nas cordoalhas dipostas na direção y $(k N)$} \\
\hline & C.1 & C.2 & C.3 & $\begin{array}{l}\text { C.4 } \\
\end{array}$ & C.5 & $\begin{array}{l}\text { C.6 } \\
\end{array}$ & 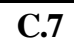 & C.8 \\
\hline $1^{\text {a }}$.Prot. & 92,0 & 102,6 & 98,9 & 98,7 & 93,5 & 97,6 & 85,8 & 98,2 \\
\hline $\begin{array}{c}\text { Após } \\
\text { recuperação } \\
\text { das perdas }\end{array}$ & 127,6 & 131,9 & 131,9 & 133,9 & 128,7 & 132,3 & 127,5 & 131,9 \\
\hline Na ruptura & 131,3 & 139,9 & 140,6 & 142,3 & 137,2 & 141,0 & 134,9 & 135,5 \\
\hline $\begin{array}{l}\text { Após } \\
\text { ruptura }\end{array}$ & 129,0 & 136,5 & 137,4 & 139,3 & 135,5 & 138,3 & 131,1 & 133,1 \\
\hline
\end{tabular}


Tabela 4.7 - Modelo M4: protensão nas cordoalhas dispostas na direção x (kN)

\begin{tabular}{|c|c|c|c|c|c|c|c|c|}
\hline \multirow{2}{*}{ Situação } & \multicolumn{8}{|c|}{ Força de protensão nas cordoalhas dipostas na direção $x(k N)$} \\
\hline & C. $1^{\prime}$ & C. $2^{\prime}$ & C. $3^{\prime}$ & C. $4^{\prime}$ & C. $5^{\prime}$ & C.6' & C.7' & C. 8 \\
\hline $1^{a}$.Prot. & 97,9 & 98,1 & 94,7 & 94,1 & 97,1 & 94,4 & 121,1 & 95,2 \\
\hline $\begin{array}{c}\text { Após } \\
\text { recuperação } \\
\text { das perdas }\end{array}$ & 132,4 & 129,7 & 131,2 & 128,5 & 128,8 & 129,6 & 133,2 & 130,6 \\
\hline Ruptura & 135,0 & 136,1 & 138,3 & 136,0 & 136,0 & 137,9 & 140,1 & 134,1 \\
\hline $\begin{array}{c}\text { Após } \\
\text { ruptura }\end{array}$ & 133,6 & 132,5 & 136,0 & 133,1 & 134,1 & 137,1 & 136,3 & 132,0 \\
\hline
\end{tabular}

Tabela 4.8 - Modelo M5: protensão nas cordoalhas dipostas na direção y $(\mathrm{kN})$

\begin{tabular}{|c|c|c|c|c|c|c|c|c|}
\hline \multirow{2}{*}{ Situação } & \multicolumn{7}{|c|}{ Força de protensão nas cordoalhas dipostas na direção y (kN) } \\
\cline { 2 - 9 } & C.1 & C.2 & C.3 & C.4 & C.5 & C.6 & C.7 & C.8 \\
\hline $1^{\text {a } . P r o t . ~}$ & 96,6 & 102,8 & 85,5 & 100,6 & 96,3 & 107,6 & 98,9 & 102,4 \\
\hline $\begin{array}{c}\text { Após } \\
\text { recuperação } \\
\text { das perdas }\end{array}$ & 124,7 & 123,7 & 127,2 & 126,5 & 117,3 & 128,9 & 122,5 & 129,9 \\
\hline $\begin{array}{c}\text { Na ruptura } \\
\text { Após }\end{array}$ & 138,4 & 146,3 & 152,3 & 149,4 & 140,2 & 152,7 & 144,4 & 145,4 \\
\hline ruptura & 126,9 & 144,8 & 148,8 & 145,6 & 135,4 & 146,3 & 138,0 & 135,2 \\
\hline
\end{tabular}

Tabela 4.9 - Modelo M5: protensão nas cordoalhas dipostas na direção x $(\mathrm{kN})$

\begin{tabular}{|c|c|c|c|c|c|c|c|c|}
\hline \multirow{2}{*}{ Situação } & \multicolumn{7}{|c|}{ Força de protensão nas cordoalhas dipostas na direção $\boldsymbol{x}(\boldsymbol{k} N)$} \\
\cline { 2 - 10 } & C.1' & C.2' & C.3' & C.4' & C.5' & C.6' & C.7' & C.8' \\
\hline $1^{\text {a } . P r o t . ~}$ & 94,9 & 102,6 & 89,5 & 98,9 & 102,2 & 104,8 & 100,8 & 90,0 \\
\hline $\begin{array}{c}\text { Após } \\
\text { recuperação } \\
\text { das perdas }\end{array}$ & 118,9 & 116,8 & 117,2 & 123,9 & 123,2 & 126,0 & 131,8 & 124,7 \\
\hline $\begin{array}{c}\text { Ruptura } \\
\text { Appós } \\
\text { ruptura }\end{array}$ & 131,2 & 135,1 & 134,4 & 119,2 & 141,6 & 144,4 & 150,5 & 137,5 \\
\hline
\end{tabular}


Tabela 4.10 - Modelo M6: protensão nas cordoalhas dipostas na direção y $(\mathrm{kN})$

\begin{tabular}{|c|c|c|c|c|c|c|c|c|}
\hline \multirow{2}{*}{ Situação } & \multicolumn{7}{|c|}{ Força de protensão nas cordoalhas dipostas na direção y $(\boldsymbol{k N})$} \\
\cline { 2 - 9 } & C.1 & C.2 & C.3 & C.4 & C.5 & C.6 & C.7 & C.8 \\
\hline $1^{\text {a } . \text { Prot. }}$ & 95,5 & 94,0 & 86,6 & 102,0 & 95,4 & 106,7 & 106,5 & 123,8 \\
\hline $\begin{array}{c}\text { Após } \\
\text { recuperação } \\
\text { das perdas }\end{array}$ & 127,7 & 130,6 & 127,8 & 133,9 & 127,3 & 135,0 & 134,8 & 123,9 \\
\hline $\begin{array}{c}\text { Na ruptura } \\
\text { Após }\end{array}$ & 143,7 & 154,6 & 154,6 & 160,2 & 124,2 & 160,6 & 157,3 & 140,3 \\
\hline \begin{tabular}{c} 
ruptura \\
\hline
\end{tabular} & 135,7 & 155,0 & 154,1 & 129,0 & 124,7 & 130,2 & 154,1 & 133,5 \\
\hline
\end{tabular}

Tabela 4.11 - Modelo M6: protensão nas cordoalhas dipostas na direção x (kN)

\begin{tabular}{|c|c|c|c|c|c|c|c|c|}
\hline \multirow{2}{*}{ Situação } & \multicolumn{8}{|c|}{ Força de protensão nas cordoalhas dipostas na direção $x(k N)$} \\
\hline & C.1' & C.2' & C.3' & C.4' & C.5' & C.6' & C.7' & C.8' \\
\hline $1^{\mathrm{a}}$.Prot. & 87,2 & 97,9 & 102,1 & 98,6 & 103,7 & 95,5 & 107,5 & 103,2 \\
\hline $\begin{array}{c}\text { Após } \\
\text { recuperação } \\
\text { das perdas }\end{array}$ & 122,2 & 130,7 & 131,0 & 130,5 & 132,6 & 128,9 & 136,8 & 130,5 \\
\hline Ruptura & 133,7 & 151,3 & 151,5 & 126,5 & 153,4 & 146,2 & 157,4 & 144,0 \\
\hline $\begin{array}{c}\text { Após } \\
\text { ruptura }\end{array}$ & 127,1 & 152,2 & 152,1 & 127,7 & 128,9 & 144,0 & 153,8 & 139,7 \\
\hline
\end{tabular}

\subsection{FOTOS DA RUPTURA DOS MODELOS}

São apresentadas as fotos da ruptura dos modelos. 


\subsubsection{MODELO M1}

Nas figuras 4.117 a 4.121, têm-se ilustradas algumas fotos do modelo M1, após a sua ruptura.

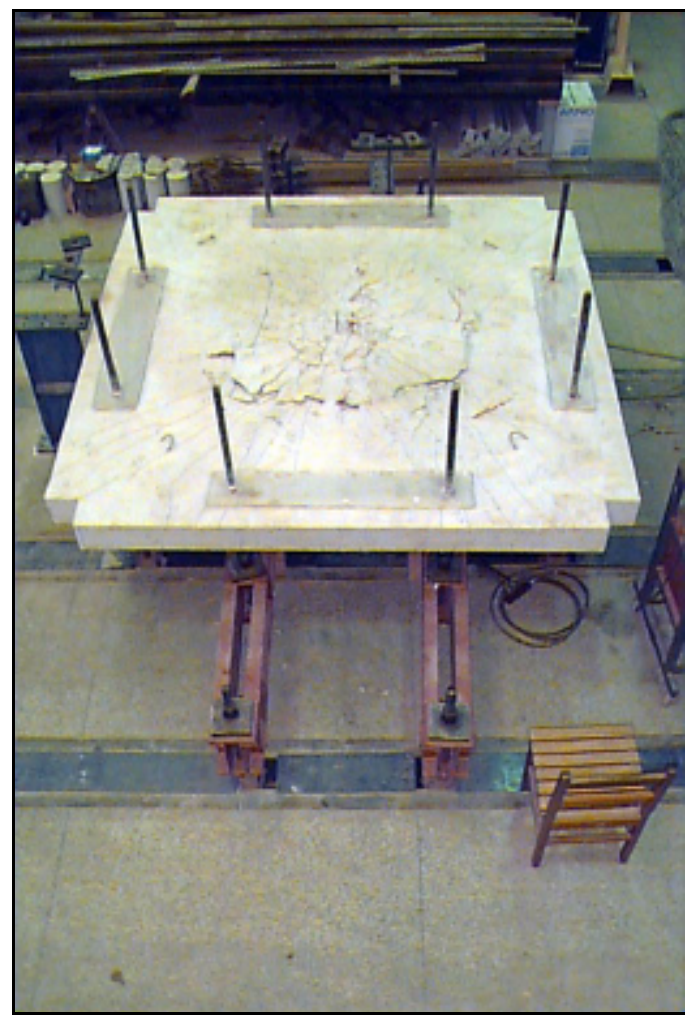

Figura 4.117 - Ruptura do modelo

(vista de cima)

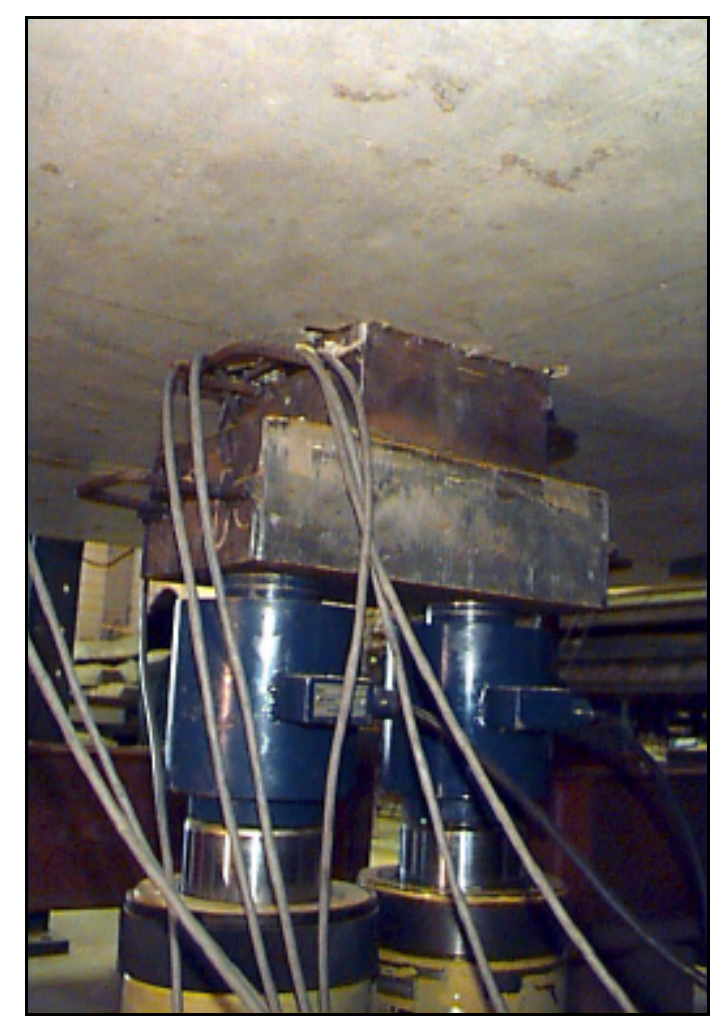

Figura 4.118 - Ruptura do modelo (vista do plano de carregamento)

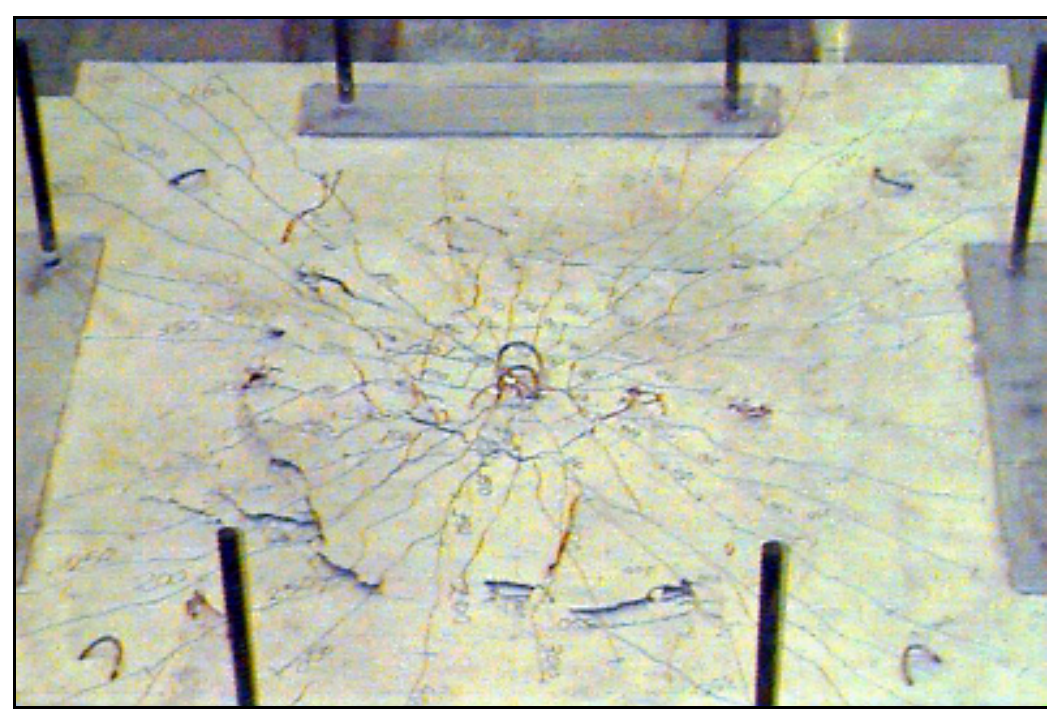

Figura 4.119 - Detalhe da superfície de ruptura vista de cima 


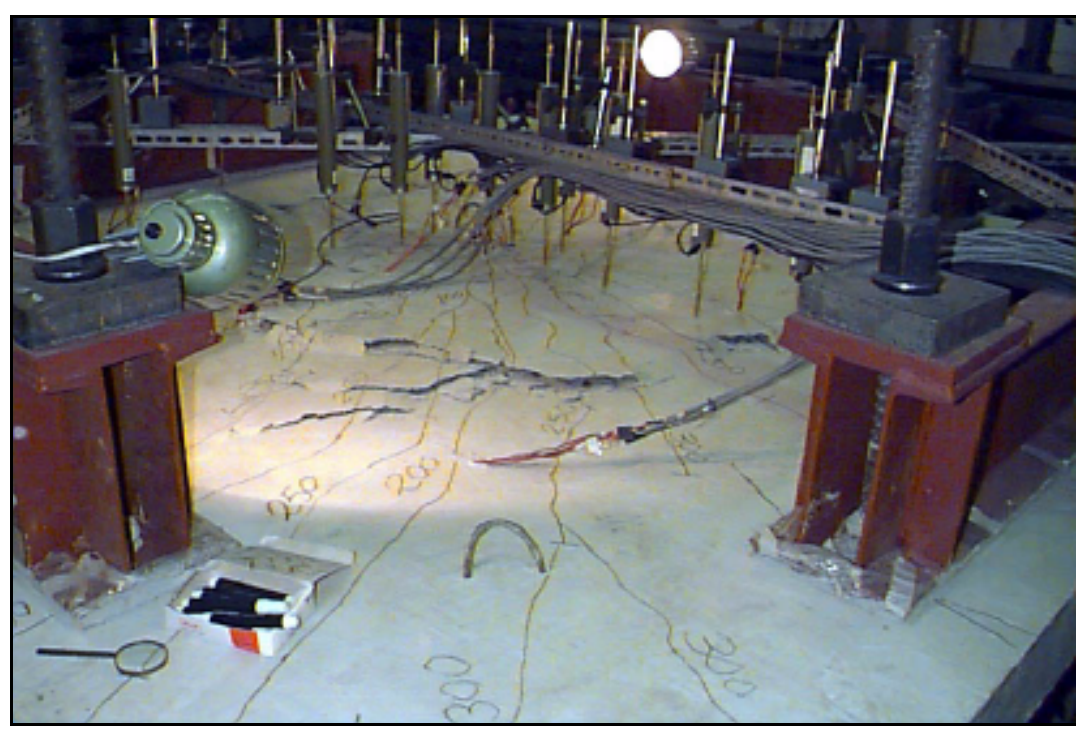

Figura 4.120 - Detalhe de uma região mais danificada

A chapa responsável pela aplicação do carregamento ficou centrada, constatação essa feita após o descarregamento.

Com base na figura 4.121, observa-se uma grande penetração da chapa metálica em direção ao interior do modelo.

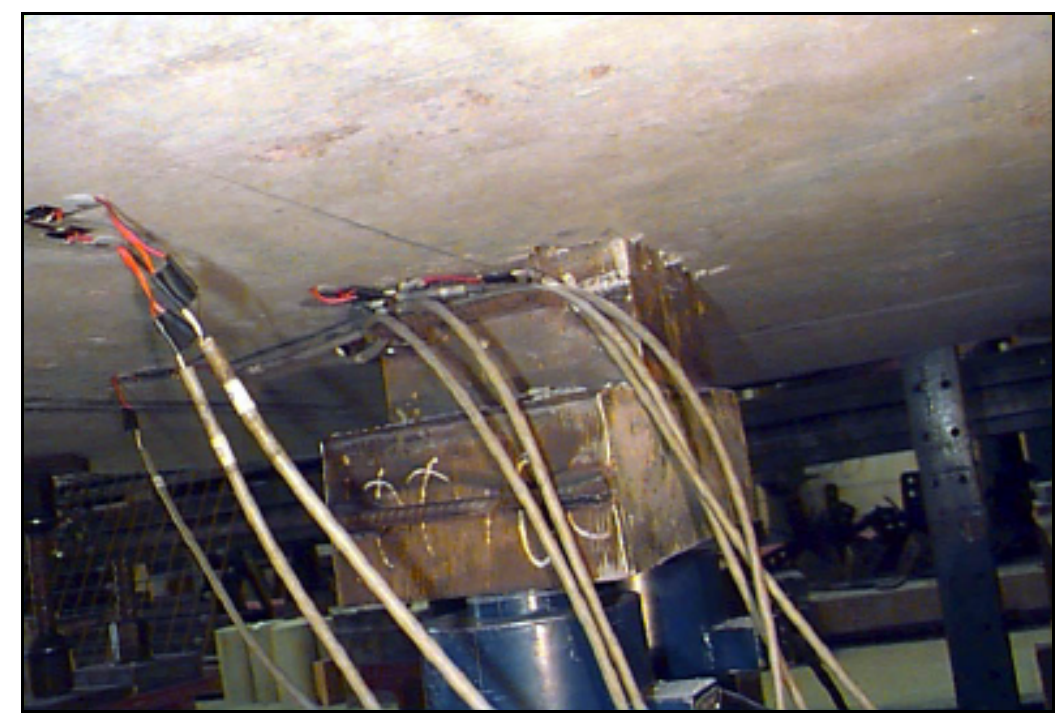

Figura 4.121 - Detalhe da penetração da chapa metálica no modelo ensaiado 
4.7.2 MODELO M2

Nas figuras 4.122 a 4.129, têm-se ilustradas algumas fotos do modelo M2, após a sua ruptura.

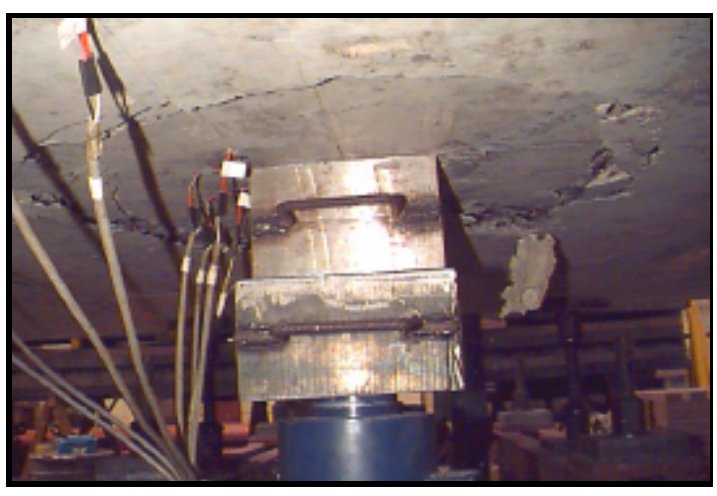

a) Vista do carregamento na face inferior da laje

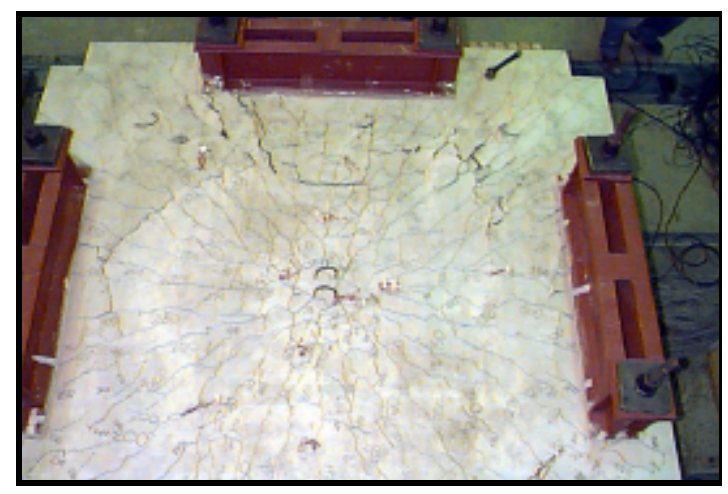

b) Vista da fissuração na face superior da laje

Figura 4.122 - Vista do modelo, imediatamente após a sua ruptura

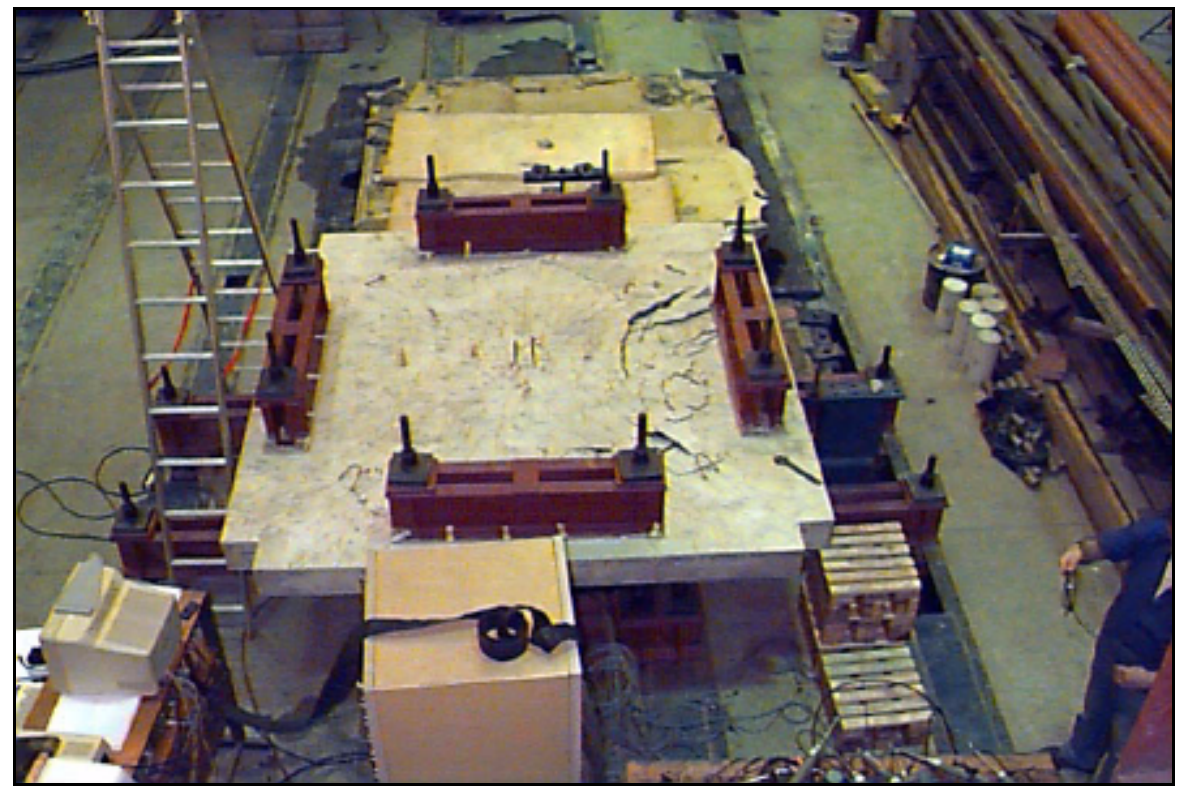

Figura 4.123 - Ruptura do modelo

$\mathrm{Na}$ figura 4.124, tem-se ilustrado o comportamento das barras que passam por dentro da região transversalmente armada. Pode-se observar que essas barras colaboram efetivamente com relação ao carregamento pós-ruptura do modelo, em função das deformações ilustradas na figura 4.124b. 


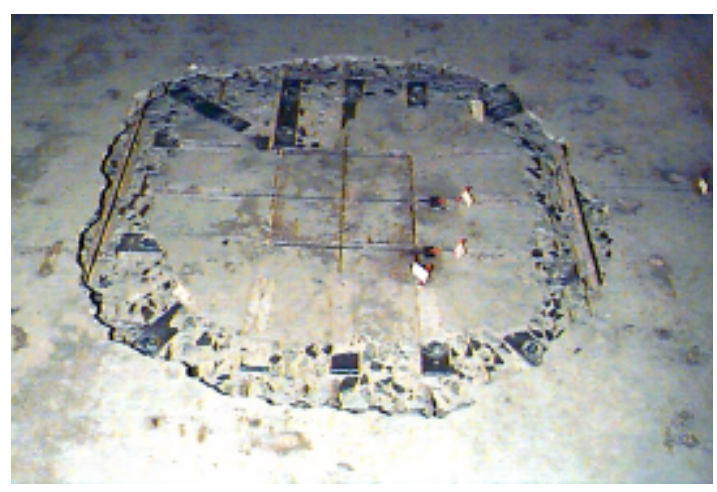

a) Detalhe da região rompida, além da região transversalmente armada

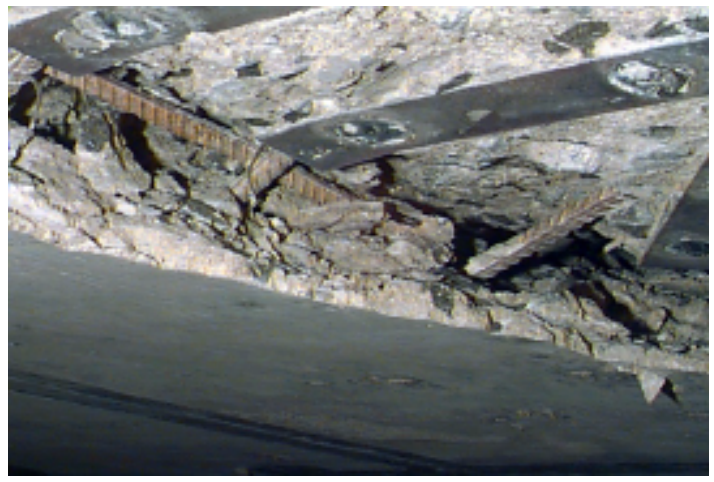

b) Detalhe do comportamento da armadura de flexão negativa, que passa por dentro da região transversalmente armada

Figura 4.124 - Vista da face inferior após a retirada de material solto

$\mathrm{Na}$ figura 4.125, pode-se observar que, retirando-se o material solto da face superior da laje, não houve uma simetria completa com relação à ruptura. Para confirmar a completa separação entre o cone de punção e o modelo é que se procedeu a retirada do cone de punção. Para isso, primeiramente cortaram-se as barras junto à face inferior do modelo (figura 4.126). A seguir, cortaram-se as barras expostas junto à face superior (figura 4.127). Com uma máquina de serra, gentilmente emprestada pela SABESP, foi possível cortar as barras embutidas no concreto (figura 4.128). Por fim, com o auxílio de um pórtico móvel, o cone de punção foi içado (figura 4.129).

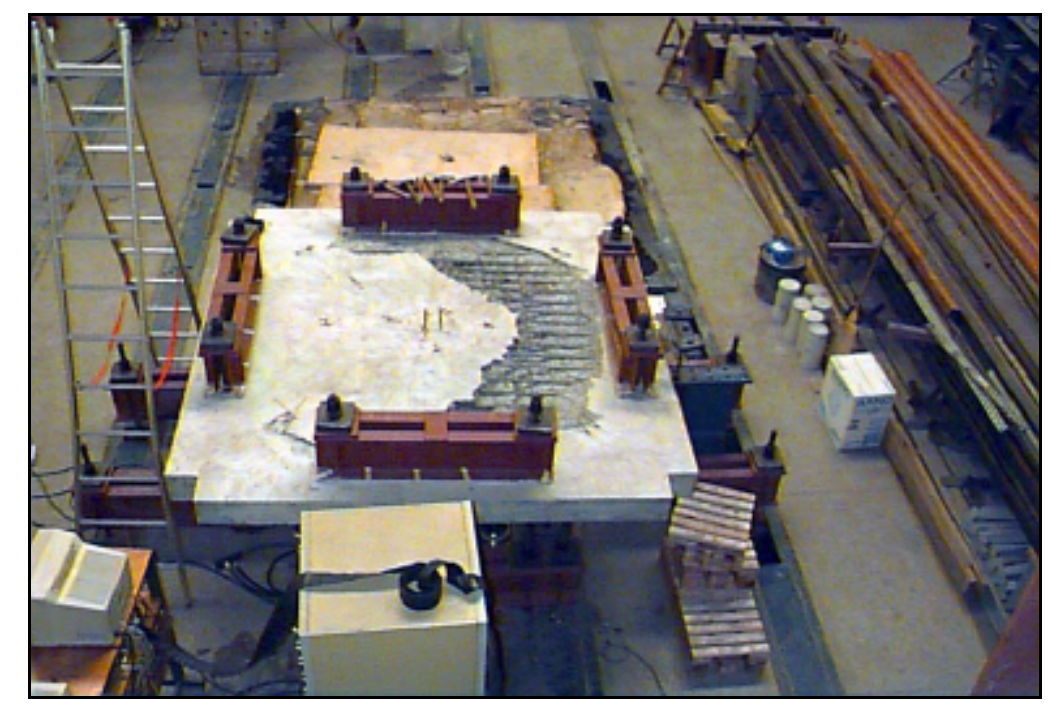

Figura 4.125 - Vista da face superior do modelo após a retirada do material solto 


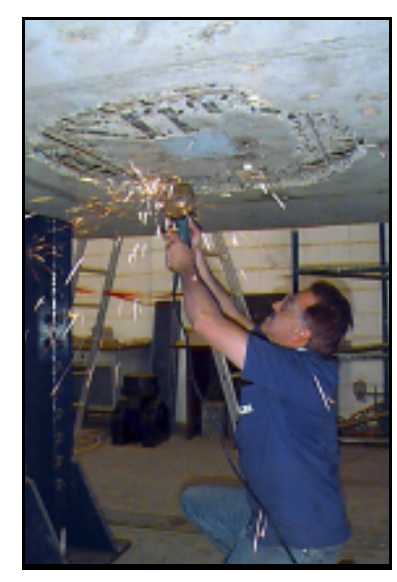

Figura 4.126- Corte das barras

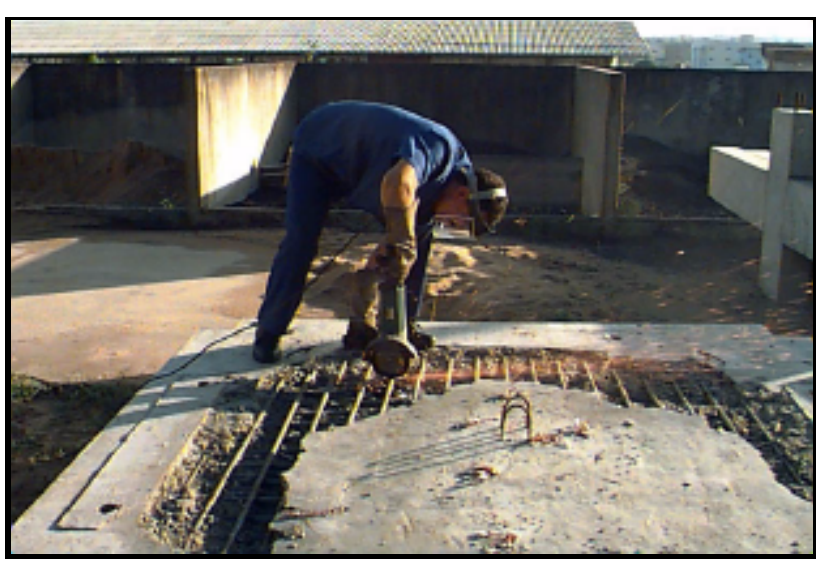

Figura 4.127- Corte das barras junto à face superior junto àface inferior

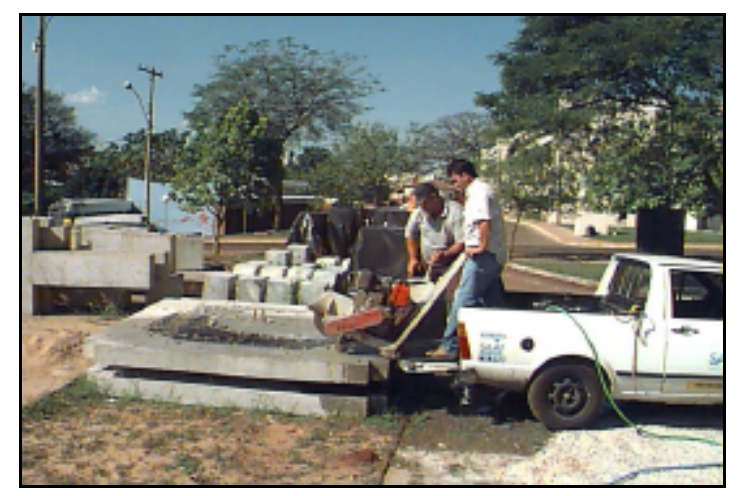

a) Vista geral do corte

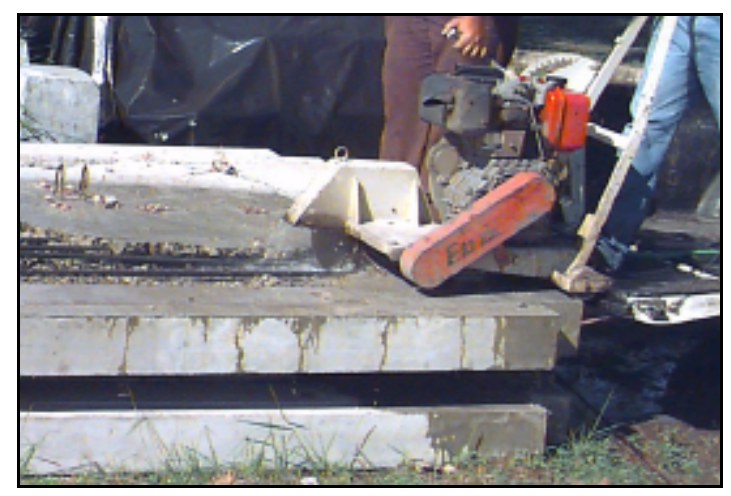

b) Detalhe da máquina

Figura 4.128 - Corte das barras embutidas
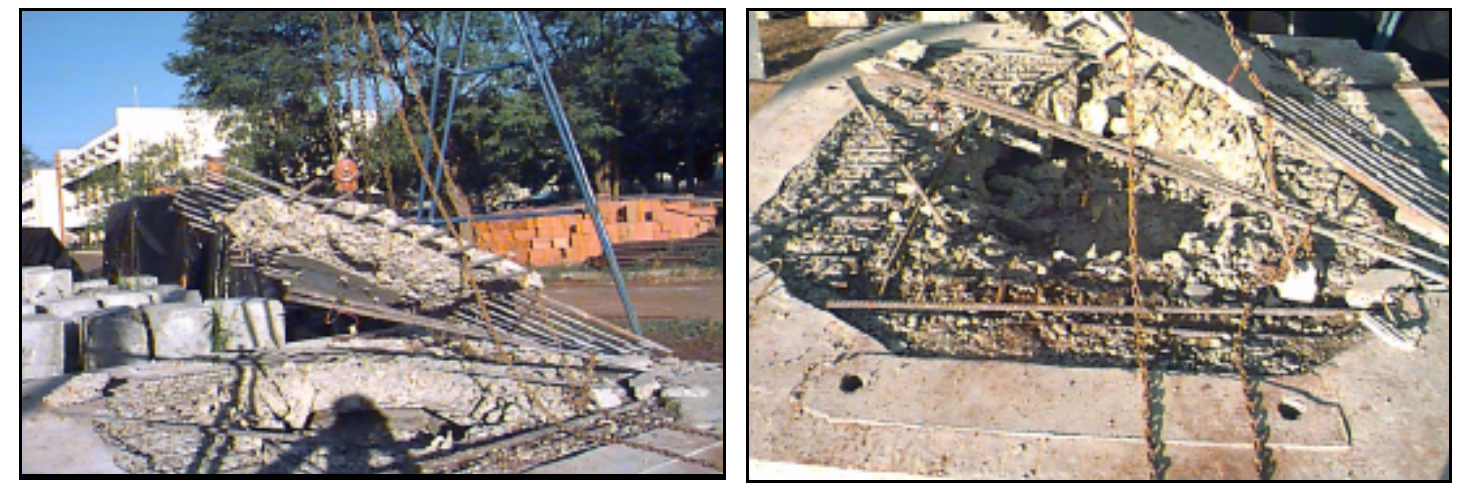

Figura 4.129 - Içamento do cone de punção 


\subsubsection{MODELO M3}

Nas figuras 4.130 a 4.134, têm-se algumas fotos da ruptura do modelo M3. O comportamento deste modelo foi análogo ao do modelo M2.

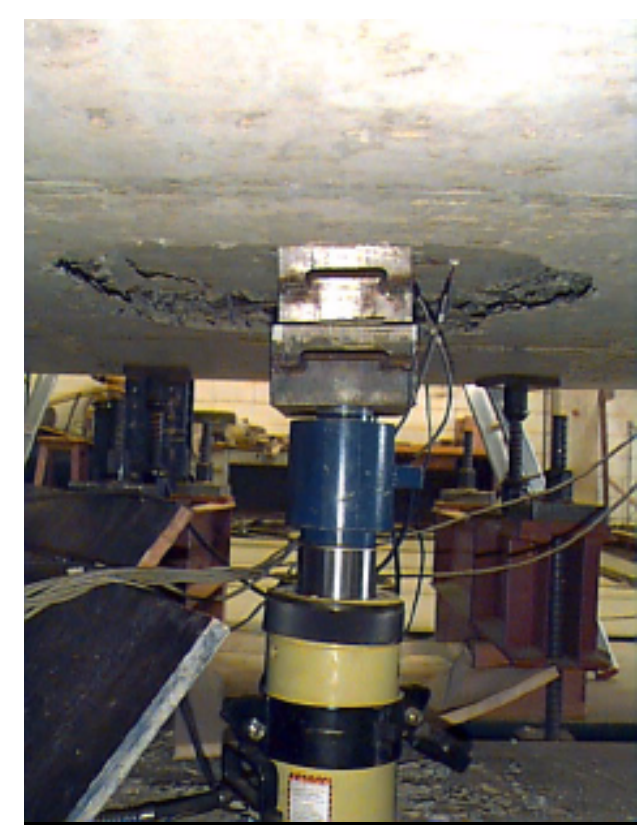

Figura 4.130 - Detalhe da ruptura além da região armada

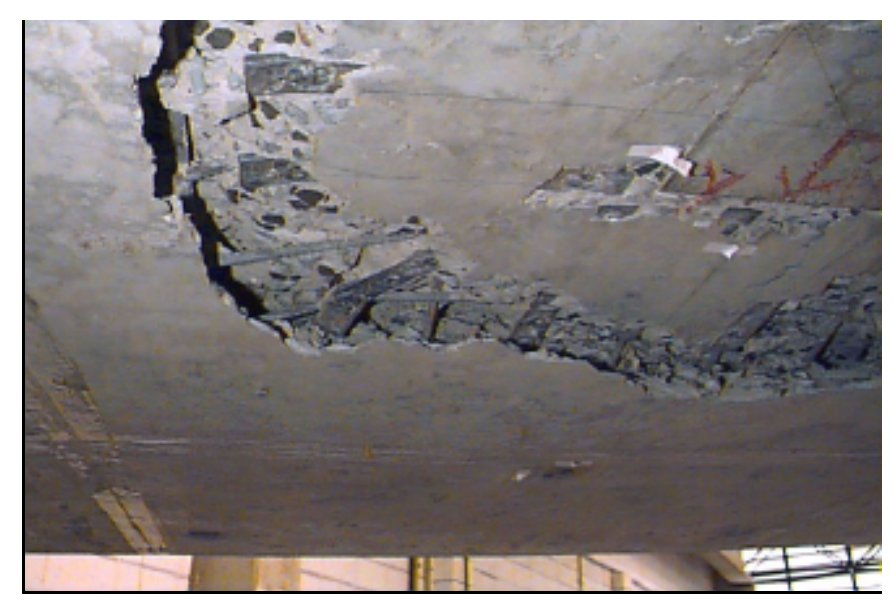

Figura 4.131 - Detalhe da ruptura na face inferior 


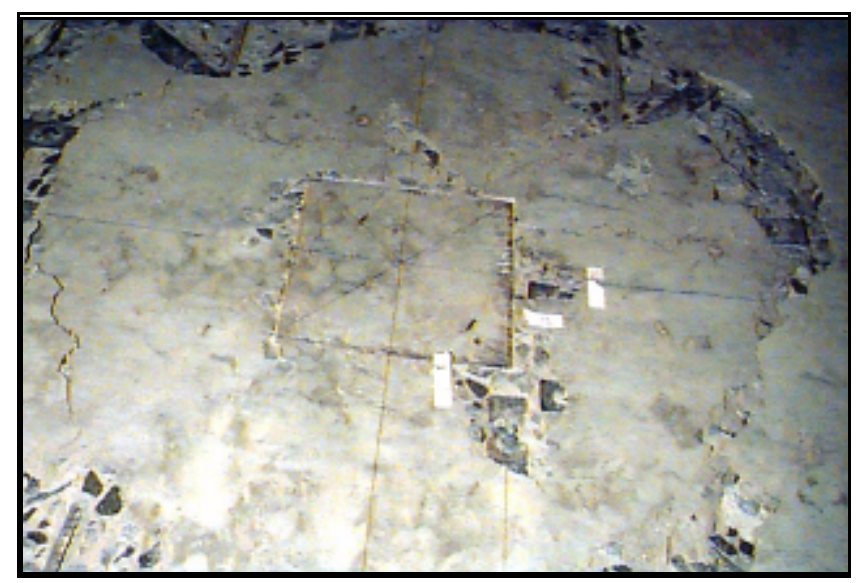

Figura 4.132 - Face inferior do modelo

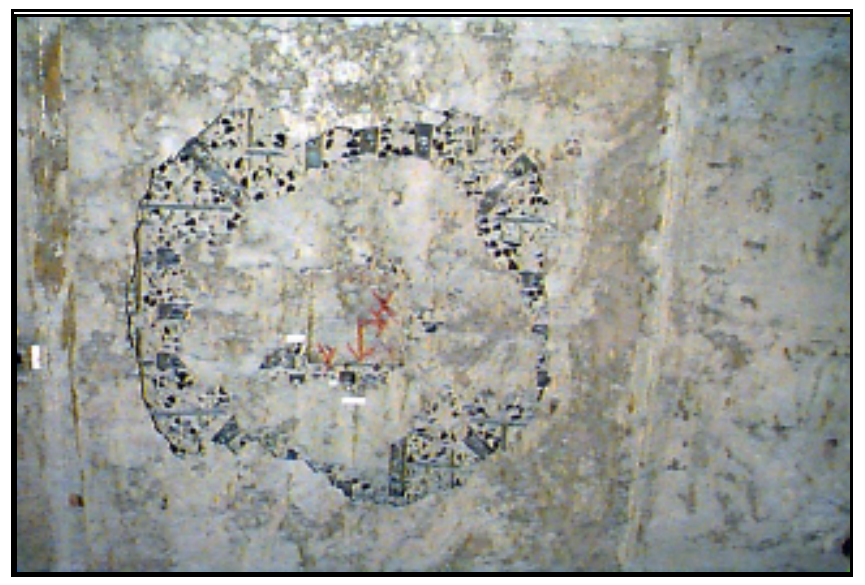

Figura 4.133 - Vista da face inferior

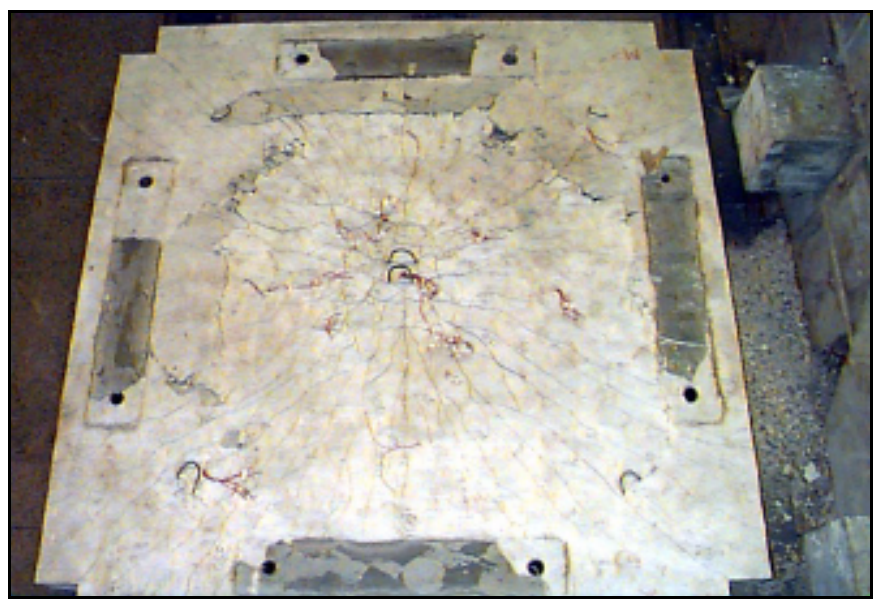

Figura 4.134 - Vista da face superior do modelo 


\subsubsection{MODELO M4}

Após a ruptura do modelo, o carregamento foi interrompido.

$\mathrm{Na}$ figura 4.135, pode-se observar, na face inferior do modelo, que a superfície de ruptura se inicia no contorno da chapa que aplica o carregamento.

Na figura 4.136, pode-se observar a fissuração na face superior do modelo.

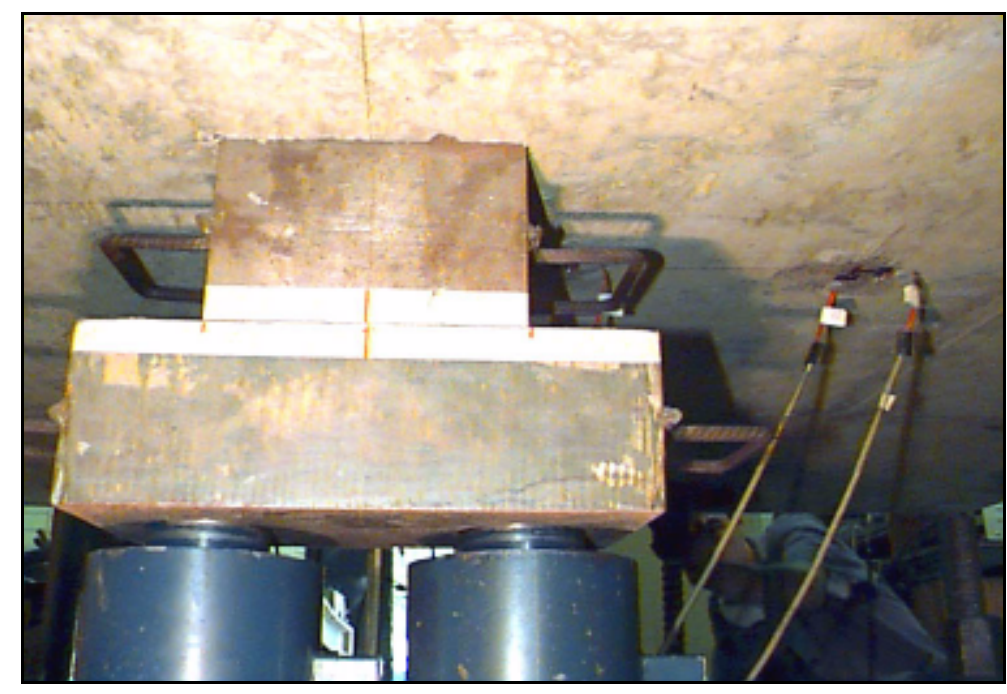

Figura 4.135 - Aspecto da ruptura na face inferior do modelo

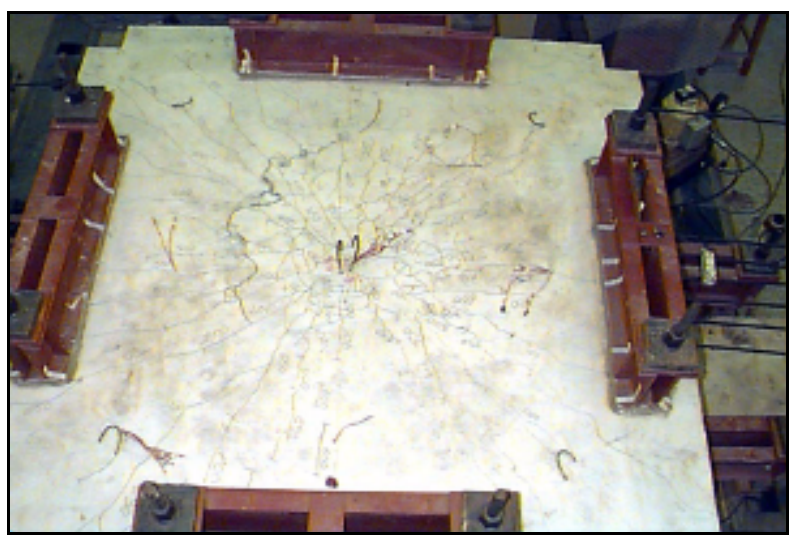

a) Fissuração na face superior do modelo

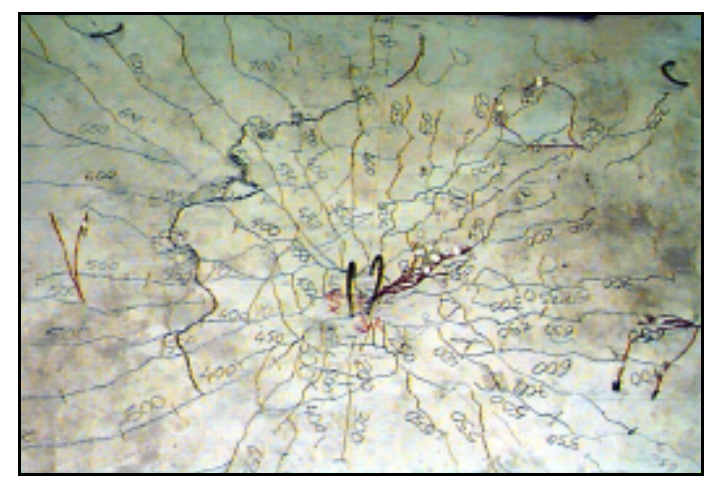

b) Ampliação da foto anterior na região central do modelo

Figura 4.136 - Aspecto da ruptura na face superior do modelo 


\subsubsection{MODELO M5}

Após a ruptura e a desprotensão das cordoalhas, o carregamento permaneceu sendo aplicado.

O comportamento observado foi o destacamento do cobrimento, em função do levantamento da armadura de flexão positiva (figura 4.137).

Na figura 4.138, pode-se observar, na face inferior do modelo, que a superfície de ruptura se inicia além do contorno da chapa que aplica o carregamento, mais propriamente além da região transversalmente armada.

Na figura 4.139, tem-se a vista da face inferior, após a retirada dos macacos.

Nas figuras 4.140 e 4.141, tem-se a vista da fissuração na face superior da laje.

$\mathrm{Na}$ figura 4.142, tem-se uma vista da face superior, após a retirada do material completamente solto.

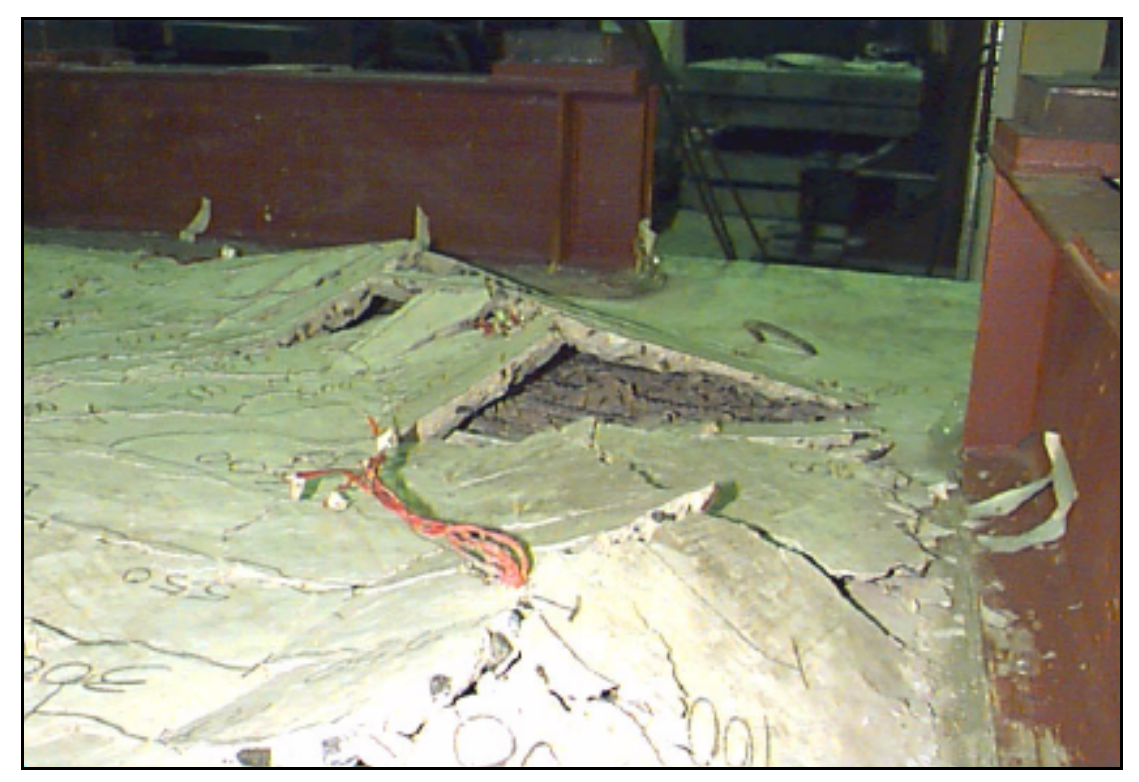

Figura 4.137 - Destacamento do cobrimento durante o carregamento pós-ruptura 


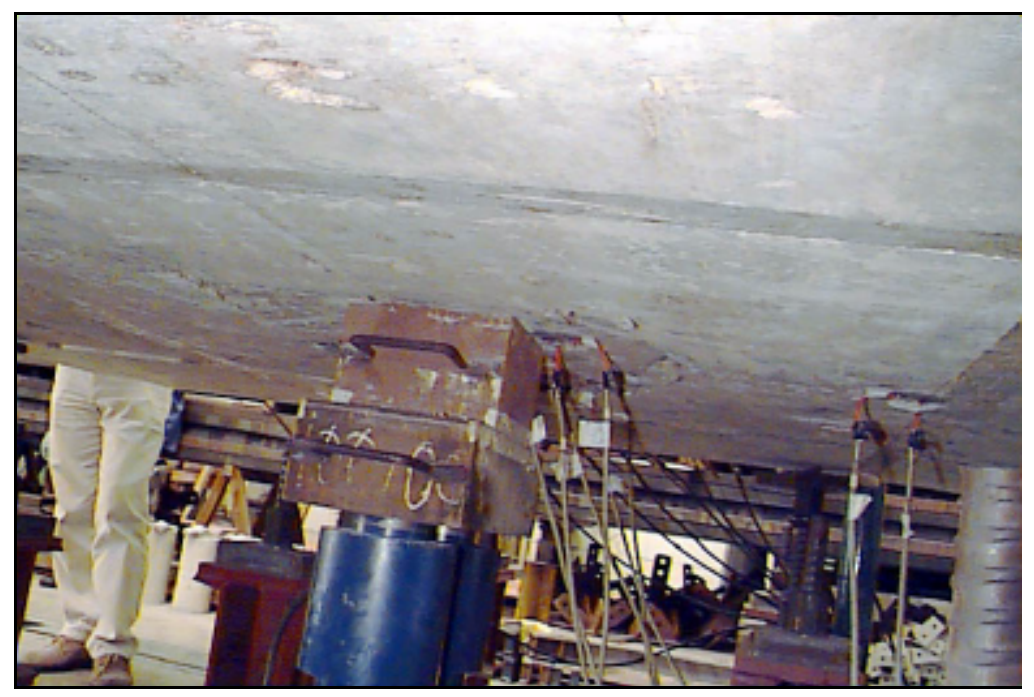

a) $\mathrm{Na}$ situação de ruptura do modelo

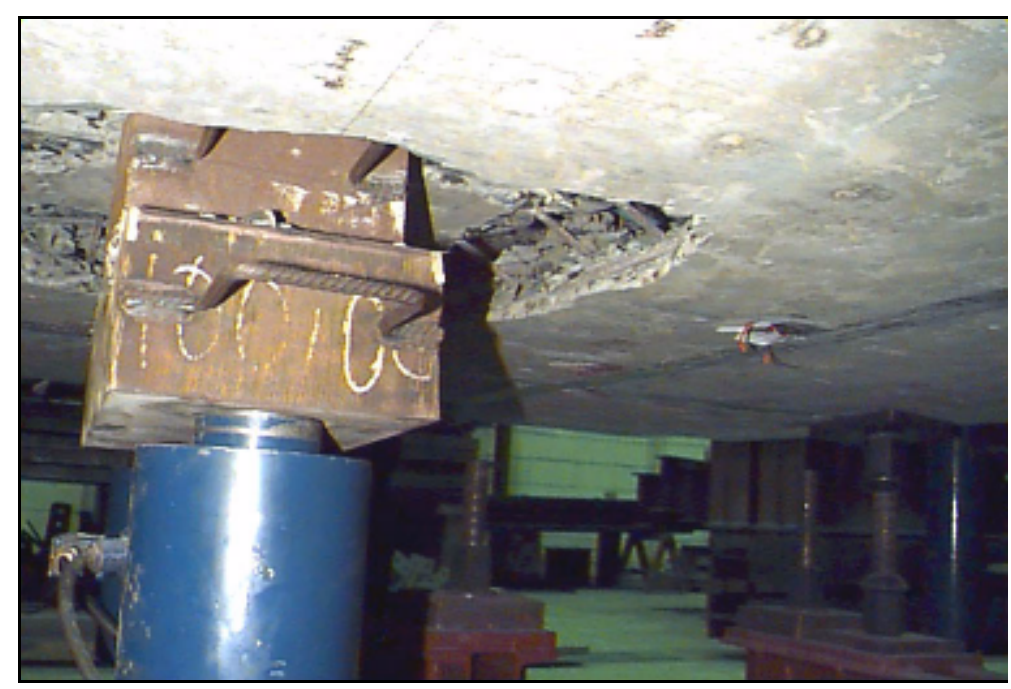

b) Após o carregamento pós-ruptura

Figuras 4.138 - Ruptura na face inferior do modelo
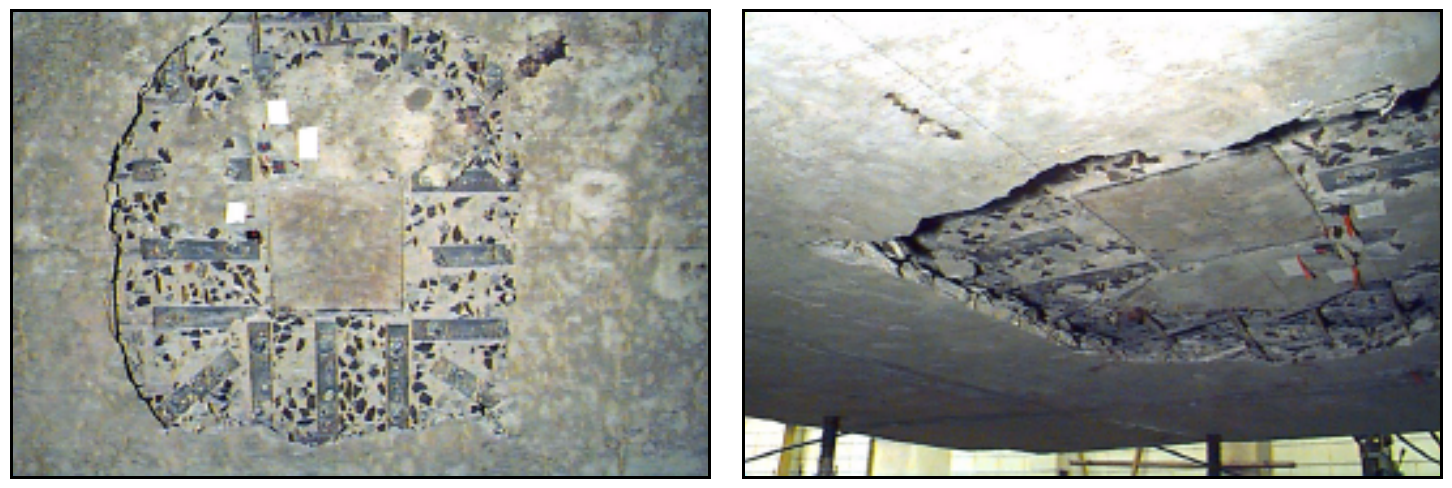

Figuras 4.139 - Vista da face inferior após a retirada dos macacos 


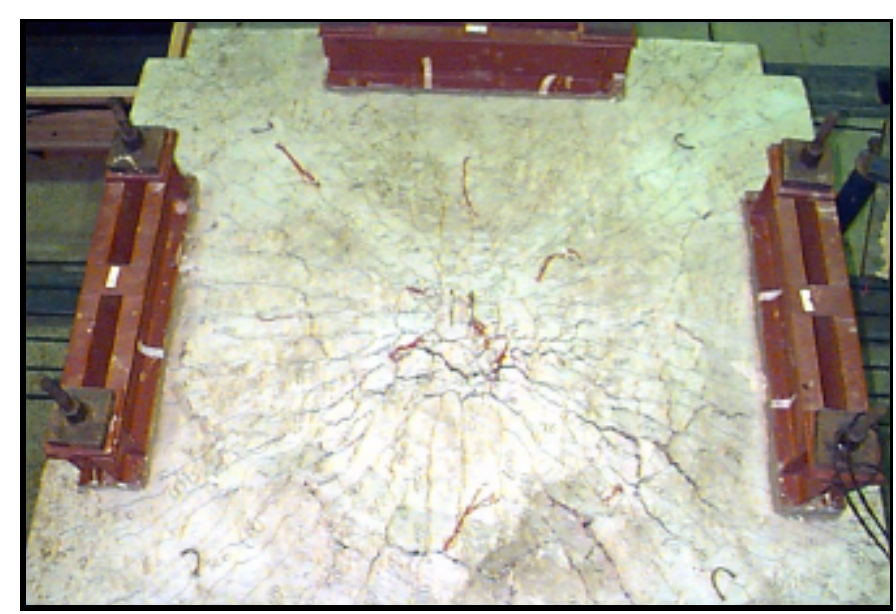

Figuras 4.140 - Vista da face superior

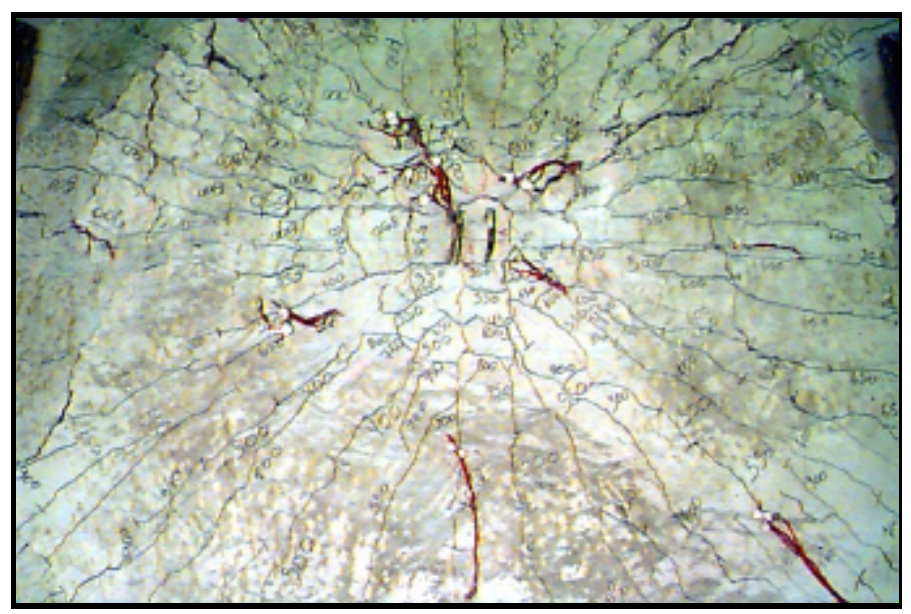

Figuras 4.141 - Vista da fissuração, na face superior, na região central do modelo

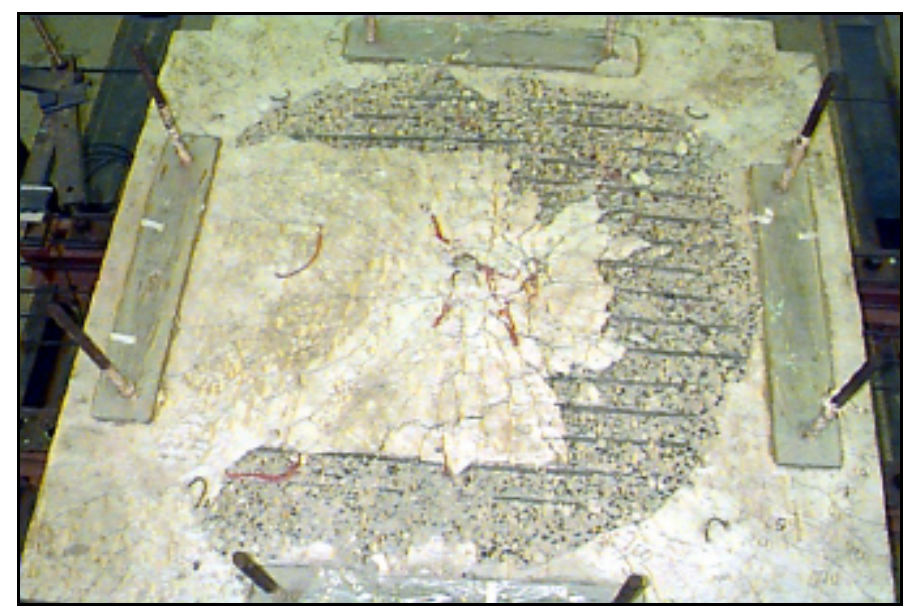

Figuras 4.142 - Vista da face superior, após a retirada do material completamente solto 


\subsubsection{MODELO M6}

Na figura 4.143, tem-se ilustração da face inferior do modelo no instante da ruptura.

$\mathrm{Na}$ figura 4.144, pode-se observar, na face inferior do modelo, que a superfície de ruptura se inicia além do contorno da chapa que aplica o carregamento, mais propriamente além da região transversalmente armada.

Nas figuras 4.145 e 4.146, tem-se a vista da fissuração na face superior da laje.

$\mathrm{Na}$ figura 4.147, tem-se uma vista da face superior, após a retirada do material completamente solto.

Neste modelo, foi feito um carregamento após a sua ruptura, com as cordoalhas ainda protendidas.

O comportamento observado foi que, após a ruptura do modelo, definida por uma superfície de ruína além da região transversalmente armada, a continuidade do carregamento provocou uma outra ruptura, através da penetração da chapa metálica no cone de punção, vista nas figuras 4.148 e 4.149 .

Nas figuras 4.150 e 4.151 , tem-se o aparecimento de uma nova superfície de ruptura na face superior do modelo.

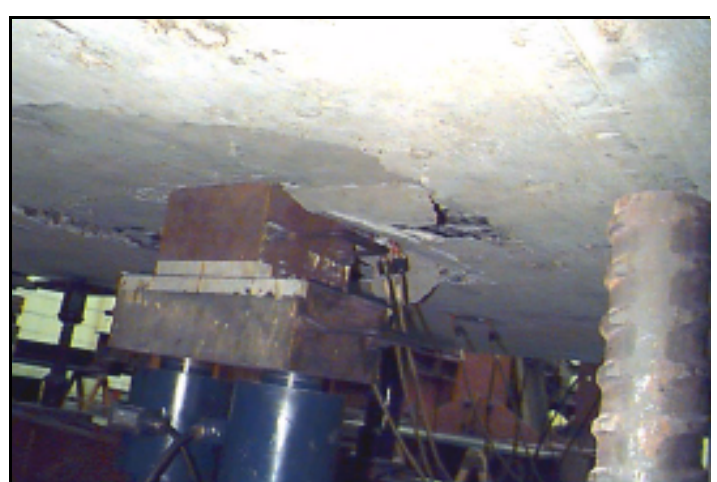

Figuras 4.143 - Ruptura na face inferior do modelo

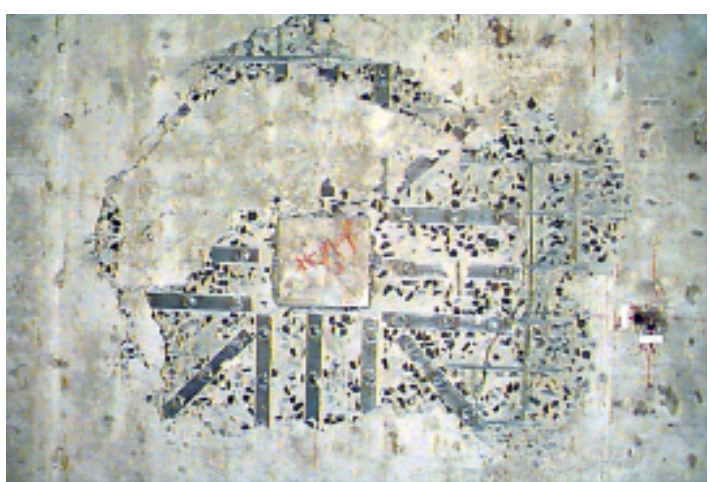

Figuras 4.144 - Detalhe da ruptura na face inferior do modelo (superfície de ruptura além da região transversalmente armada) 


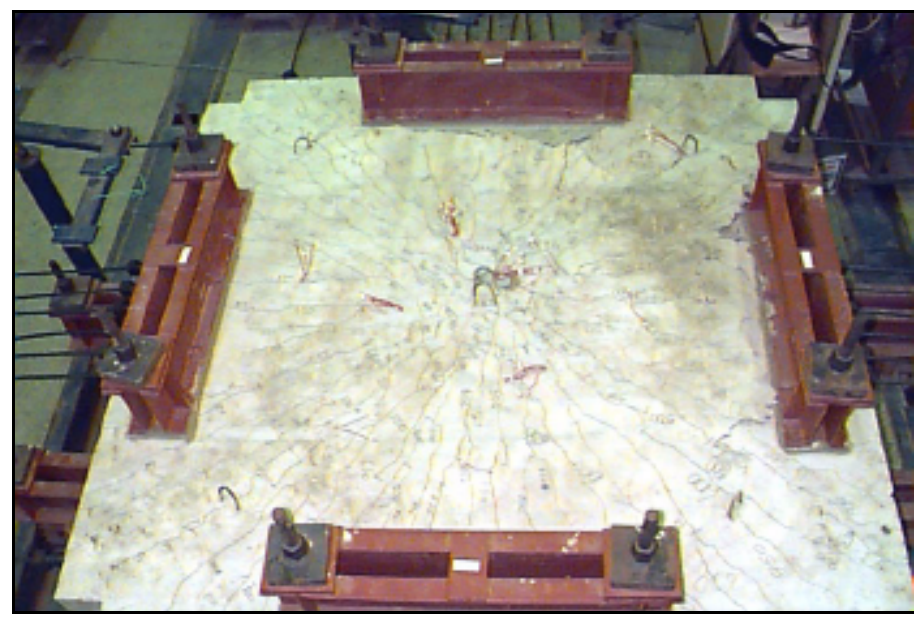

Figuras 4.145 - Vista da face superior, após a ruptura do modelo, mas em fase anterior ao carregamento pós-ruptura.

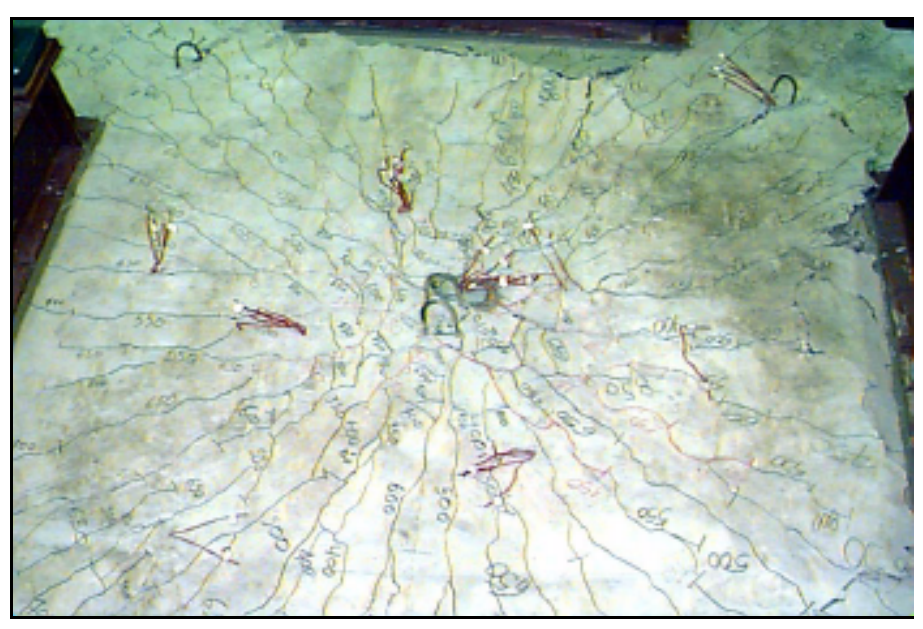

Figuras 4.146 - Vista da fissuração, na face superior, na região central do modelo, anterior ao carregamento pós-ruptura

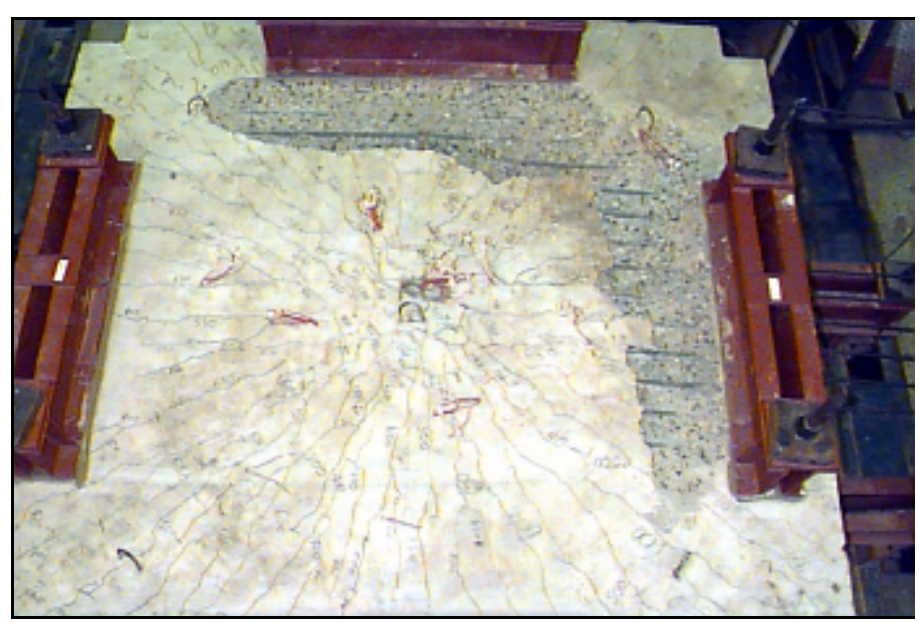

Figuras 4.147 - Vista da face superior, após a retirada do material completamente solto, em fase anterior ao carregamento pós-ruptura 


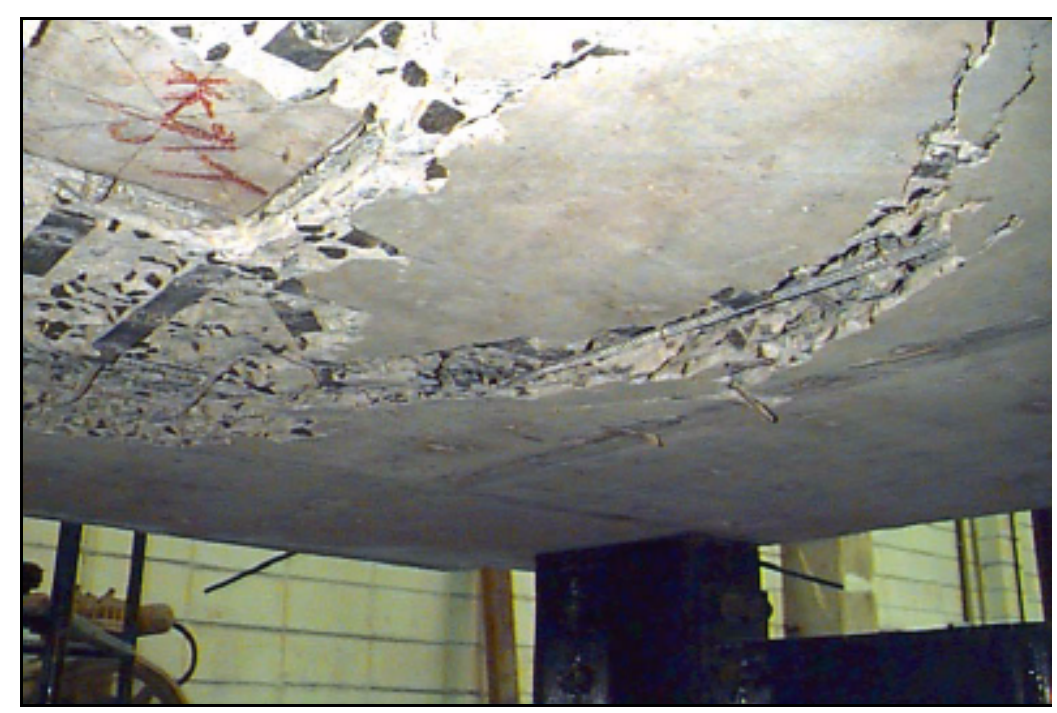

Figuras 4.148 - Vista das superfícies de ruptura, anterior e após o carregamento pós-ruptura

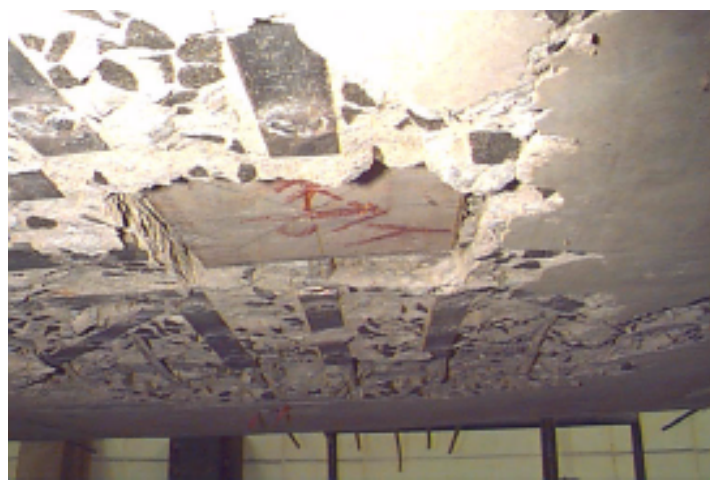

Figura 4.149 - Detalhe da superfície de ruptura formada após o carregamento pósruptura

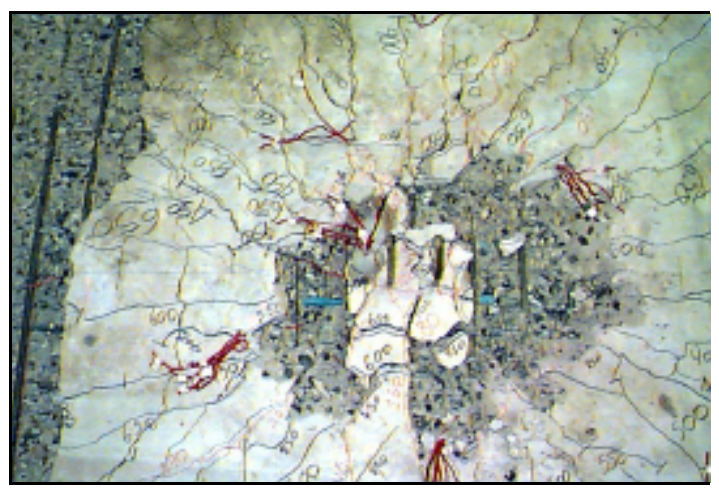

a) Vista geral

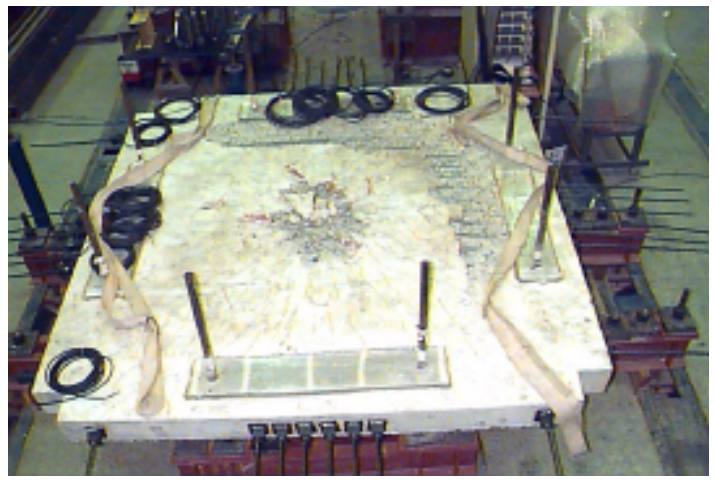

Figura 4.150 - Superfície de ruptura formada após o carregamento pós-ruptura, na face superior do modelo

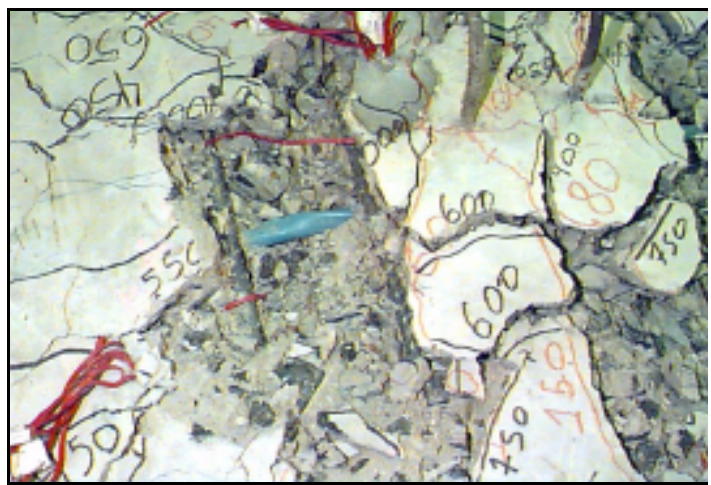

b) Detalhe do cabo de protensão

Figura 4.151 - Detalhe da superfície de ruptura formada após o carregamento pós-ruptura, na face superior do modelo 


\section{ANÁLISE DOS RESULTADOS}

Para facilitar a interpretação dos resultados, estes foram analisados através dos seguintes modos: inicialmente faz-se uma análise dos resultados obtidos para cada um dos modelos; apresentam-se algumas análises específicas com relação à protensão aplicada ao modelo e, a seguir, apresenta-se uma comparação entre os resultados obtidos e a previsão da carga de ruína dada por algumas normas e códigos.

\subsection{ANÁLISE DOS RESULTADOS EXPERIMENTAIS OBTIDOS}

Apresentam-se alguns comentários sobre os resultados obtidos para cada um dos modelos.

\subsubsection{MODELO M1}

a) Instrumentação dos macacos hidráulicos (M1)

A diferença percentual entre as forças aplicadas pelos macacos, no instante da ruína, foi de 2,8\% (tabela 4.2). Considerando-se que a distância entre os eixos dos macacos hidráulicos era de $19 \mathrm{~cm}$ (figura 3.5), esta diferença é equivalente a uma excentricidade do carregamento de $1,3 \mathrm{~mm}$ e foi considerada pequena. 
Pode ser constatado que não houve nenhuma excentricidade da posição da chapa metálica, usada para transferir o carregamento dos macacos hidráulicos ao modelo, com relação ao centro da laje.

\section{b) Instrumentação da armadura de flexão tracionada (M1)}

Com base na tabela 5.1 e excluindo-se as posições 5' e 9', observa-se uma grande proximidade de valores dos extensômetros dispostos lateralmente à armadura, ao contrário do que é observado na tabela 5.2, relativa a extensômetros posicionados nas faces superior e inferior da barra.

Com relação aos extensômetros relativos às posições 2', 6' e 11', localizados nas faces superior e inferior da barra, as deformações médias foram 1,94\% \% 1,27\% \% e 0,60\% \% . Com exceção da posição 11', os extensômetros colocados na face superior da barra tiveram deformações maiores que os colocados na face inferior, indicando o efeito de flexão localizada da armadura. Além disso, quanto maior a deformação do extensômetro, maior a diferença entre as leituras. Nas posições 2', 6' e 11', as diferenças entre as leituras nas faces superior e inferior foram de, respectivamente, $44 \%, 22,9 \%$ e $8,5 \%$.

Outro fator que confirma a influência do efeito de flexão localizada na barra é que, embora a diferença percentual entre os extensômetros colocados na posição 2' (faces superior e inferior da barra) seja igual a 44\%, a média desses valores difere apenas de 1,8\% da média dos extensômetros colocados na posição 1' (faces laterais das barras).

Mesmo para extensômetros posicionados lateralmente à barra, justifica-se o uso de dois extensômetros, baseados na observação de que, embora a diferença percentual entre os extensômetros colocados na posição 5' (faces laterais) seja igual a 11,2\%, a média desses valores difere apenas de $-0,6 \%$ da média dos extensômetros colocados na posição 3' (faces laterais das barras). 
Ainda com relação aos extensômetros posicionados nas laterais, as diferenças variaram de $-0,1 \%$ a $60 \%$. Observa-se, nesses casos, a tendência de diferenças maiores para solicitações menores, ao contrário do que foi observado para os extensômetros posicionados nas faces superior e inferior da barra.

Tabela 5.1 - Leituras dos extensômetros posicionados lateralmente à barra (valores mostrados relacionados ao instante anterior àruína)

\begin{tabular}{|c|c|}
\hline Posição lateral & Diferença percentual \\
\hline $1^{\prime}$ - E.1 e E.2 $\left(1,86^{\circ} \%, 1,95 \%\right)$ & $-4,8 \%$ \\
\hline $3^{\prime}$ - E.5 e E.6 $(1,65 \%$ \%o, $1,73 \%)$ & $-4,6 \%$ \\
\hline 4' - E.7 e E.8 $(1,69 \%$ \%o, $1,72 \%)$ & $-1,5 \%$ \\
\hline $5^{\prime}-$ E.9 e E.10 $(1,79 \%$ oo, $1,61 \%$ \%o & $+11,2 \%$ \\
\hline $7^{\prime}$ - E.13 е E.14 (0,81\%oo, 0,86\%oo $)$ & $-5,6 \%$ \\
\hline $8^{\prime}$ - E. 15 e E. $16\left(0,86^{\circ} \%, 0,86^{\circ} \%\right)$ & $-0,1 \%$ \\
\hline $9^{\prime}$ - E.17 e E.18 $(0,40 \%$ oo, 0,25\% \% $)$ & $+60 \%$ \\
\hline $10^{\prime}-$ E.19 e E.20 $\left(0,80 \%\right.$ \%о, $\left.0,69^{\circ} \%\right)$ & $-0,1 \%$ \\
\hline
\end{tabular}

Tabela 5.2 - Leituras dos extensômetros colados nas faces superior e inferior da armadura (valores relacionados ao instante anterior à ruína)

\begin{tabular}{|c|c|}
\hline Posição superior/inferior & Diferença percentual \\
\hline 2' - E.3 e E.4 $(2,29 \%$ \%o, $1,59 \%)$ & $+44,0 \%$ \\
\hline 6' - E.11 e E.12 $(1,40 \%$ \%o, $1,14 \%)$ & $+22,9 \%$ \\
\hline $11^{\prime}-$ E.21 e E.22 $\left(0,57^{\circ} \%, 0,63 \%\right)$ & $-8,5 \%$ \\
\hline
\end{tabular}

Não foi observado nenhum indício de escoamento na armadura.

$\mathrm{Na}$ figura 4.13, tem-se a análise da simetria através das leituras médias dos extensômetros nas posições 5' e 3'. Nota-se que houve simetria no carregamento, sendo que, na situação de máxima força aplicada, a média das leituras na posição 5' foi apenas 0,4\% superior à média das leituras dos extensômetros na posição 3'.

$\mathrm{Na}$ figura 4.18, nota-se que não houve a formação de charneira triangular, uma vez que as deformações nas posições 1'-2' são diferentes das medidas nas posições 10'-11'. 
$\mathrm{Na}$ figura 4.24, tem-se a deformação da barra ao longo de seu comprimento, com relação à aplicação do carregamento. Diferentes níveis de deformações ao longo da barra indicam que esta não sofreu escorregamento.

$\mathrm{Na}$ figura 4.30, têm-se as deformações nas barras paralelas ao eixo y. Pode-se observar que este gráfico está perfeitamente coerente com o anterior: barras mais próximas à região onde se dá o carregamento apresentam deformações maiores.

Compararam-se as leituras nas posições 4', 6', 8' (direção transversal), com as verificadas nas posições 5', 7' e 9' (direção radial). Estas leituras estão mostradas na tabela 5.3. Observa-se que, na região mais afastada do carregamento, a deformação na barra disposta na direção transversal é maior do que a deformação da barra disposta na direção radial.

Tabela 5.3 - Leituras dos extensômetros nas direções radial e tangencial, no instante anterior à ruína

\begin{tabular}{|c|c|}
\hline Posição & Deformação ( \%oo ) \\
\hline 4' (tangencial) & 1,70 \\
5' (radial) & 1,70 \\
\hline 6' (tangencial) & 1,27 \\
7' (radial) & 0,84 \\
\hline 8' (tangencial) & 0,86 \\
9' (radial) & 0,33 \\
\hline
\end{tabular}

\section{c) Instrumentação da armadura de flexão comprimida (M1)}

Na figura 4.42, tem-se a verificação da simetria através do E.25 e do E.27. Embora ambos apresentem um comportamento similar, a diferença entre as leituras foi grande, igual a 58,6\%. Ressalta-se, no entanto, que as deformações apresentaram valores pequenos, da ordem de $-0,05 \%$ e $-0,03 \%$ o, para o E. 25 e o E. 27 , respectivamente.

Com relação à formação de charneira plástica, nota-se que o E.23 deixa de ser comprimido e começa a sofrer um alívio na sua solicitação, a partir de um determinado nível do carregamento, conforme mostrado na figura 4.47 . 
Este comportamento também é observado para o E.24, mas apenas quando o carregamento estava próximo da ruína. Já as outras barras permanecem comprimidas durante todo o carregamento.

Ainda com base na figura 4.47, observa-se que, na região central do modelo, o E.23 e o E.24 apresentam comportamentos bem diferenciados. Já na região mais afastada do ponto de aplicação do carregamento, observa-se que os valores medidos pelos extensômetros E.28 e E.29 estão próximos. Na tabela 5.4, apresentam-se os valores medidos no instante anterior àruína.

Não há uma tendência de escoamento das barras nas regiões dos extensômetros.

O E.28 e o E.29 parecem estar bem coerentes com o carregamento aplicado: quanto maior o carregamento, maior a compressão nas barras.

$\mathrm{Na}$ figura 4.53, têm-se as leituras dadas pelo E.23 e pelo E.24, indicando que as barras, nessas posições, foram bruscamente tracionadas após a ruptura do modelo. As barras, nas outras posições, embora tenham sofrido um alívio, não chegaram a ser tracionadas.

Com base na tabela 5.4, observa-se que a deformação radial (E.25) foi menor que a deformação tangencial (E.26).

Tabela 5.4 - Leituras dos extensômetros no instante anterior à ruína

\begin{tabular}{|c|c|c|c|c|c|c|}
\hline \multicolumn{7}{|c|}{ Posição dos Extensômetros } \\
\hline E.23 $(\%)$ & E.24 $(\%$ \%o & E.25 $(\%$ \%o $)$ & E.26 $(\%$ \% $)$ & E.27 $(\%$ \%o $)$ & E.28 $(\%$ \%o $)$ & E.29 $(\%)$ \\
\hline $\mathbf{0 , 0 2 1}$ & $\mathbf{- 0 , 5 5 5}$ & $\mathbf{- 0 , 0 5 1}$ & $\mathbf{- 0 , 3 0 6}$ & $\mathbf{- 0 , 0 3 2}$ & $\mathbf{- 0 , 1 0 2}$ & $\mathbf{- 0 , 1 3 5}$ \\
\hline
\end{tabular}

\section{d) Instrumentação do concreto (M1)}

Com base nos dados mostrados na tabela 5.5, apresentam-se as seguintes considerações.

Observa-se que o E.35 não teve um funcionamento adequado. Por medir a deformação radial próxima à região onde é aplicado o carregamento, era de se esperar que a deformação aumentasse com o aumento do carregamento. 
Este fato, no entanto, somente se confirmou até a carga de $335 \mathrm{kN}$, conforme mostrado na figura 4.61. A partir deste ponto, o desempenho deste extensômetro foi considerado insatisfatório.

$\mathrm{Na}$ região adjacente ao carregamento (figura 4.61), as deformações tangenciais são maiores que as deformações radiais. Nessa região, as deformações que ocorrem nos cantos são maiores que as deformações que ocorrem no meio da chapa metálica. Confirma-se, portanto, a tendência da concentração das tensões nos cantos dos pilares.

$\mathrm{Na}$ região afastada da chapa metálica (figura 4.67), pode-se observar que as deformações tangenciais também são maiores que as deformações radiais. Nesse caso, a maior deformação tangencial ocorre no meio da chapa metálica e a maior deformação radial no canto da chapa metálica.

Na figura 4.73, têm-se as deformações radiais, com relação ao canto e com relação ao meio da chapa metálica. Tanto próximo quanto afastado da chapa metálica, as maiores deformações referem-se ao canto. Verifica-se que, a partir de um determinado nível de solicitação, o E.35 parece apresentar um defeito.

Na figura 4.79, enquanto a deformação tangencial no canto é maior para a região próxima ao carregamento, já para a região afastada, a deformação tangencial no canto é menor.

Tabela 5.5 - Leituras dos extensômetros no instante anterior à ruptura

\begin{tabular}{|c|c|c|c|c|c|c|c|}
\hline E.30 (\%oo) & E.31 (\%o) & E.32 (\%oo) & E.33 (\%o) & E.34 (\%oo) & E.35 (\%oo) & E.36 (\%oo) & E.37 (\%oo) \\
\hline$-0,77$ & $-0,28$ & $-1,31$ & $-4,37$ & $-2,04$ & $-0,23$ & $-0,20$ & $-1,20$ \\
\hline \multicolumn{8}{|c|}{$\begin{array}{l}\text { Obs.: } \\
\text { E.30 - direção tangencial, afastado da chapa metálica, no canto } \\
\text { E.31 -direção radial, afastado da chapa metálica, no canto } \\
\text { E.32 -direção radial, perto da chapa metálica, no canto } \\
\text { E.33 - direção tangencial, perto da chapa metálica, no canto } \\
\text { E.34 -direção tangencial, perto da chapa metálica, no meio } \\
\text { E.35 - direção radial, perto da chapa metálica, no meio } \\
\text { E.36 - direção radial, afastado da chapa metálica, no meio } \\
\text { E.37 - direção tangencial, afastado da chapa metálica, no meio }\end{array}$} \\
\hline
\end{tabular}




\section{e) Instrumentação dos deslocamentos do modelo (M1)}

As leituras dos transdutores D.1 a D.4 mostram que o modelo sofreu uma rotação média, em seu próprio plano, como um corpo rígido, de $0,15^{\circ}$ no sentido antihorário, e deslocamentos de $+0,71 \mathrm{~mm}$ e $+0,11 \mathrm{~mm}$, com relação aos eixos x e y, respectivamente, mostrados na tabela 4.3.

As leituras dos transdutores D.5 a D.8 referem-se aos deslocamentos dos apoios com relação ao piso do laboratório. Estes valores estão mostrados na tabela 4.4, sendo considerados pequenos para interferir nos resultados.

$\mathrm{Na}$ figura 4.89, têm-se ilustrados os deslocamentos dos transdutores dispostos na direção inclinada ao eixo y. Pode-se observar que o carregamento não parece apresentar excentricidade significativa, em função da proximidade dos valores dados pelos transdutores dispostos simetricamente em relação ao ponto central do modelo. Próximo à ruptura, as diferenças percentuais entre os transdutores D.9 e D.17, D.11 e D.16, D.13 e D.15 foram de, respectivamente, 3,5\%; 10,6\% e -1,4\%. O mesmo comportamento já não é observado para os transdutores dispostos ao longo da direção y, ilustrado na figura 4.90. Nesse caso, parece haver um levantamento na região próxima do D.18. Foram observados problemas no D.24, razão esta pela qual ele não foi incluído na figura 4.90 .

\subsubsection{MODELO M2}

a) Instrumentação dos macacos hidráulicos (M2)

A diferença percentual entre as forças aplicadas pelos macacos, no instante da ruína, foi de $-0,5 \%$ (tabela 4.2). Pode ser constatado que houve uma excentricidade da chapa metálica com relação ao centro da laje. Esta excentricidade foi da ordem de $1 \mathrm{~cm}$, no sentido do eixo x, conforme mostrado na figura 4.5 . 
Considerando-se que a distância entre os eixos dos macacos hidráulicos era de $19 \mathrm{~cm}$ (figura 3.5), bem como a excentricidade geométrica de $1 \mathrm{~cm}$, calcula-se que a excentricidade real do carregamento foi igual a $\mathbf{9 , 7} \mathbf{~ m m}$. Portanto, esta diferença foi considerada pequena.

\section{b) Instrumentação da armadura de flexão tracionada (M2)}

Observou-se o escoamento da armadura nos pontos 1', 2', 4' e 6'. Nas figuras $4.19,4.25$ e 4.31, o escoamento é caracterizado pelo trecho horizontal dos gráficos. O trecho vertical, no final do gráfico, indica que, apesar da barra ter escoado, a ruptura ocorreu com uma força acima do valor relacionado ao escoamento da barra.

Na figura 4.31, observa-se que o escoamento da barra na posição 4' ocorre com uma força superior à que provoca o escoamento na posição 2'.

Com base nas tabelas 5.6 e 5.7, observa-se uma proximidade maior de valores dos extensômetros dispostos lateralmente à armadura do que os dispostos nas faces superior e inferior da barra, excetuando-se a posição 9'. No entanto, com base na figura G.20 do Anexo G, observa-se que o E.17 e o E.18, relacionados à posição 9', apresentam uma diferença grande somente quando o carregamento já estava bastante avançado.

Na tabela 5.7, observa-se a influência do efeito de flexão localizada da armadura. Para os extensômetros relativos às posições 6', 10' e 11', posicionados nas faces superior e inferior da barra, as deformações médias foram 5,20\% $1,62 \%$ e 2,34\%. Os extensômetros colocados na face superior da barra tiveram deformações maiores que os colocados na face inferior, indicando o efeito de flexão localizada da armadura. Além disso, quanto maiores as deformações dos extensômetros, maior a diferença entre as leituras. Nas posições 6', 10' e 11', as diferenças entre as leituras nas faces superior e inferior foram de, respectivamente, $51 \%, 36,2 \%$ e $38,8 \%$. 
Outro fator que confirma o efeito de flexão localizada é que, embora a diferença percentual entre os extensômetros colocados na posição 11' seja igual a 38,8\%, a média desses valores difere apenas de $+0,2 \%$ da média dos extensômetros colocados na posição 12'. O mesmo acontece para os extensômetros colocados nas posições 9' e 10', cujas médias apresentam uma diferença percentual de apenas 6,5\%, ao contrário de suas leituras individuais, que apresentam uma diferença de 45,2\% e 36,2\%, respectivamente.

$\mathrm{Na}$ figura 4.19, pode-se ver que não houve a formação de charneira diagonal, uma vez que as deformações nas posições 1'-2' são bem maiores do que as que ocorrem nas posições 9'-10' e 11'-12'. Como o E.1 apresentou problemas, apenas o E.2 foi considerado na determinação da deformação relativa à posição 1 '.

Na figura 4.25, pode-se observar a deformação ao longo da barra, com relação à aplicação do carregamento. Diferentes deformações ao longo da barra indicam que a barra não sofreu escorregamento.

$\mathrm{Na}$ figura 4.31, têm-se as deformações das barras paralelas ao eixo y. Estes valores estão coerentes com a posição da barra: barras mais próximas do carregamento apresentam deformações maiores.

Compararam-se as leituras nas posições 4', 6', 8' (direção transversal), com as medidas nas posições 3', 5' e 7' (direção radial). Estas leituras estão mostradas na tabela 5.8. Assim como no modelo M1, observa-se que, na região mais afastada do carregamento, a deformação na barra disposta na direção transversal é maior do que a deformação da barra disposta na direção radial.

Tabela 5.6 - Leituras dos extensômetros posicionados lateralmente à barra, no instante anterior àruína

\begin{tabular}{|c|c|}
\hline Posição lateral & Diferença percentual \\
\hline $3^{\prime}-$ E.5 e E.6 $\left(2,37^{\circ} \%, 2,40 \%\right)$ & $-1,4 \%$ \\
\hline $5^{\prime}-$ E.9 e E.10 $\left(1,98^{\circ} \%, 1,82^{\circ} \%\right)$ & $+8,7 \%$ \\
\hline $7^{\prime}$ - E.13 e E.14 (1,27\%o, $1,21 \%$ \%o & $+4,9 \%$ \\
\hline $8^{\prime}-$ E.15 e E.16 $(2,27 \%$ oo, $2,45 \%$ \%o & $-7,4 \%$ \\
\hline $9^{\prime}$ - E.17 e E.18 (2,04\%o, $1,41 \%$ \%o $)$ & $+45,2 \%$ \\
\hline $12{ }^{\prime}-$ E. 23 e E. $24(2,40 \%$ oo, $2,27 \%$ \%o $)$ & $+5,8 \%$ \\
\hline
\end{tabular}


Tabela 5.7 - Leituras dos extensômetros colados nas faces superior e inferior da armadura, no instante anterior à ruína

\begin{tabular}{|c|c|}
\hline Posição superior/inferior & Diferença percentual \\
\hline 6' - E.11 e E.12 $\left(6,25 \%\right.$ \%o, $\left.4,14^{\circ} \%\right)$ & $+51,0 \%$ \\
\hline $10^{\prime}-$ E.19 e E.20 $\left(1,87^{\circ} \%, 1,37^{\circ} \%\right)$ & $+36,2 \%$ \\
\hline $11^{\prime}-$ E.21 e E.22 $(2,72 \%, 1,96 \%)$ & $+38,8 \%$ \\
\hline
\end{tabular}

Tabela 5.8 - Leituras dos extensômetros nas direções radial e tangencial, no instante anterior à ruína

\begin{tabular}{|c|c|}
\hline Posição & Deformação ( $\%$ oo $)$ \\
\hline 3' (radial) & 2,38 \\
4' (tangencial) & escoamento \\
\hline 5' (radial) & 1,90 \\
6' (tangencial) & 5,20 \\
\hline 7' (radial) & 1,24 \\
8' (tangencial) & 2,36 \\
\hline
\end{tabular}

\section{c) Instrumentação da armadura de flexão comprimida (M2)}

Na figura 4.48, têm-se os valores medidos para a malha comprimida. Embora tracionadas, as barras nas posições E28 e E.30, dispostas na direção y, tiveram uma deformação muito baixa. Observa-se que o E.25 e o E.26, que deveriam ter tido um comportamento semelhante, foram bem diferentes. Este comportamento, no entanto, é semelhante ao observado no modelo M1, relacionando-se o E.25 (disposto na direção x) do modelo M2 ao E.24 (disposto na direção y) do modelo M2, e o E.26 (disposto na direção y) do modelo M2 ao E.23 (disposto na direção x) do modelo M1.

A curva relativa ao E.26 do modelo M2, mostrada na figura 4.48, indica que a barra começou sendo comprimida, como era de se esperar, mas em seguida inverteu o tipo de esforço, terminando por vir a ser tracionada, tal qual aconteceu para o E.23 do modelo M1.

Este tipo de comportamento também ocorreu para o E.25 do modelo M2 e para o E.24 do modelo M1, mas somente quando o carregamento estava próximo da ruína. 
Para o modelo M2, parece ter havido uma diferença no tipo de comportamento entre as barras dispostas na direção x (E.25, E.27 e E.29), estando estas barras comprimidas durante a maior parte do carregamento, e as barras dispostas na direção y (E.26, E.28 e E.30), estando estas barras tracionadas. No entanto, pode-se observar que, excetuando-se os extensômetros E.28 e E.30, até uma força de 175,3 kN, todos os extensômetros indicavam deformações de compressão.

Na tabela 5.9, apresentam-se os valores medidos no instante anterior àruína.

Após a ruína, conforme mostrado na figura 4.54, observa-se que apenas o E.28 indicou uma súbita deformação de tração.

Também neste caso, observa-se que a deformação radial (E.28) foi menor que a deformação tangencial (E.27), em módulo.

Tabela 5.9 - Leituras dos extensômetros no instante anterior à ruína

\begin{tabular}{|c|c|c|c|c|c|}
\hline \multicolumn{7}{|c|}{ Posição dos Extensômetros } \\
\hline E.25 $(\%)$ & E.26 $(\%$ \%o $)$ & E.27 $(\%)$ & E.28 $(\%$ \%o $)$ & E.29 $(\%)$ & E.30 $(\%)$ \\
\hline $\mathbf{0 , 2 4 4}$ & $\mathbf{1 , 7 3 2}$ & $\mathbf{- 0 , 4 0 4}$ & $\mathbf{0 , 0 9 4}$ & $\mathbf{- 0 , 1 2 2}$ & $\mathbf{0 , 0 7 1}$ \\
\hline
\end{tabular}

\section{d) Instrumentação do concreto (M2)}

Com relação à região adjacente ao carregamento (figura 4.62), observa-se que, após determinados níveis de carregamento, as tensões começam a diminuir, mesmo aumentando-se o carregamento.

Antes que estes picos de deformações fossem atingidos, o comportamento observado para o modelo M2 foi bem semelhante ao observado para o modelo M1, com exceção da deformação radial no meio, que, para o M1, não apresentou resultado satisfatório.

$\mathrm{Na}$ região afastada (figura 4.68), novamente observa-se uma grande semelhança de comportamento das deformações. A diferença é que, para o modelo M2, as deformações radiais apresentaram pequenas deformações relacionadas à tração . 
Com relação às deformações radiais e tangenciais deste modelo, tem-se uma grande semelhança com as obtidas para o modelo M1, antes que os picos de deformações fossem atingidos, conforme mostram as figuras 4.74 e 4.80, quando comparadas com as figuras 4.73 e 4.79 , respectivamente.

\section{e) Instrumentação dos deslocamentos do modelo (M2)}

As leituras dos transdutores D.1 a D.4 mostram que o modelo sofreu uma rotação média, em seu próprio plano, como um corpo rígido, de $0,27^{\circ}$ no sentido anti-horário, e deslocamentos de $+1,81 \mathrm{~mm}$ e $+0,91 \mathrm{~mm}$, com relação aos eixos x e y, respectivamente. Os valores medidos pelos transdutores encontram-se na tabela 4.3.

$\mathrm{Na}$ figura 4.91, têm-se ilustrados os deslocamentos dos transdutores dispostos na direção inclinada ao eixo y. Pode-se observar que o carregamento não parece apresentar excentricidades significativas, em função da proximidade dos valores dados pelos transdutores dispostos simetricamente em relação ao ponto central do modelo. Próximo à ruptura, as diferenças percentuais entre os transdutores D.9 e D.17, D.11 e D16, D.13 e D.15 foram, respectivamente, de $-31,44 \% ; 8,5 \%$ e 4,8\%. Embora seja grande a diferença entre o D.9 e o D.17, percebe-se que, antes da proximidade da ruína, o comportamento destes pontos estava semelhante.

O mesmo comportamento é observado para os transdutores dispostos ao longo da direção y, ilustrado na figura 4.92 .

Próximo à ruptura, as diferenças percentuais entre os transdutores D.18 e D.25, D.19 e D.23, D.20 e D.21 foram, respectivamente, de 38,0\%; 14,4\% e -9,0\%.

$\mathrm{Na}$ figura 4.92b, pode-se observar uma certa simetria com relação ao carregamento. Para 75\% da força de ruptura, o desnivelamento não foi significativo.

Já para $100 \%$ da força de ruptura, embora o desnivelamento pareça bem maior, deve-se levar em conta a intensa fissuração, que não é uniforme, e o valor dos deslocamentos, que é pequeno em relação ao tamanho do modelo. Conclui-se que somente próximo àruptura é que parece ter havido um desnivelamento da laje 


\section{f) Instrumentação da armadura de punção (M2)}

Na figura 4.102a, têm-se ilustrados os conectores dispostos na direção x, colocados no mesmo lado. Pode-se observar que os extensômetros E.35-E.36 apresentam comportamento semelhante aos extensômetros E.37-E.38.

Na figura 4.103a, têm-se os conectores dispostos na direção x, colocados em lados opostos. Pode-se observar que o conjunto E.35-E.36 apresenta comportamento semelhante ao E.43-E.44. No entanto, este comportamento não coincide com a posição dos extensômetros. O E.35 deveria estar relacionado com o E.43 e o E.36 deveria estar relacionado ao E.44.

Na figura 4.104, têm-se ilustrados os conectores dispostos na direção y, colocados no mesmo lado. Era de se esperar que o E.42 ficasse próximo do E.40, não sendo isso o que ocorreu.

$\mathrm{Na}$ figura 4.105a, têm-se ilustrados os conectores dispostos na direção y, colocados em lados opostos. Pode-se observar que o E.33-E.34 apresenta comportamento semelhante ao E.41-E.42. Deste modo, embora possa parecer estranho que conectores em pontos diferentes tenham uma solicitação tão próxima, este fato é confirmado pela instrumentação dos pinos nas posições mencionadas.

Na figura 4.106, tem-se uma comparação entre conectores dispostos na direção x e na direção inclinada. Pode-se observar uma certa semelhança no comportamento, embora o conector disposto na direção x (E.35-E.36) esteja sendo mais solicitado que o da direção inclinada (E.31-E.32).

Na figura 4.107, tem-se uma comparação entre conectores dispostos na direção y e na direção inclinada.

Pode-se observar que não existe uma semelhança no comportamento, embora os extensômetros E.41, E.42 e E.32 apresentem valores bem próximos uns dos outros. $\mathrm{Na}$ figura 4.109a, têm-se ilustrados os pinos dos conectores mais próximos da chapa de aplicação da carga. A maior solicitação ocorre no pino do conector colocado na direção $\mathrm{x}$ (E.43); já a menor, na direção inclinada (E.31). 
Na figura 4.110a, têm-se ilustrados os pinos dos conectores mais afastados da chapa de aplicação da carga. As maiores solicitações ocorrem nos pinos dos conectores colocados na direção x (E.36, E.38) e a menor, na direção y (E.40).

Com base nas informações apresentadas no Anexo H, pode-se observar as regiões que definem o tipo de comportamento dos pinos dos conectores por meio da figura 5.1. As regiões I definem o seguinte comportamento: no início do carregamento, o pino do conector mais próximo da área de carregamento está sendo mais solicitado que o pino do conector mais afastado; já no final do carregamento, esta situação é invertida, passando o pino mais afastado, a ser mais solicitado. As regiões II definem o seguinte comportamento: no início do carregamento, pino do conector mais próximo está sendo mais solicitado que o mais afastado; já no final do carregamento, os dois pinos do conector apresentam praticamente a mesma solicitação. As regiões III definem o seguinte comportamento: tanto no início, como no final, a solicitação do pino mais próximo à área de carregamento sempre será maior que a solicitação do pino do conector mais afastado.

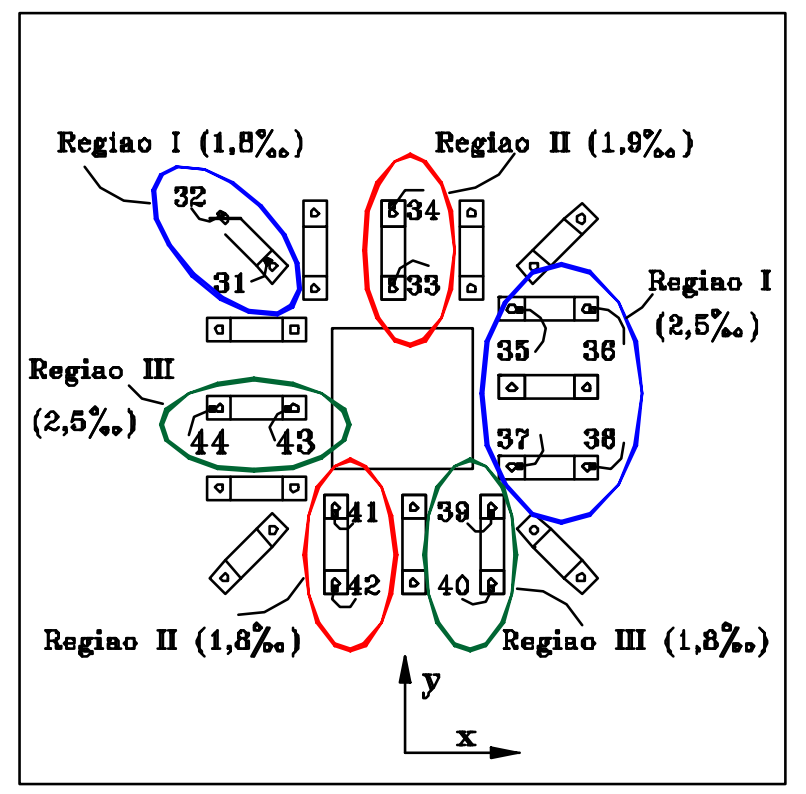

Figura 5.1 - Regiões que definem o tipo de comportamento dos conectores 
Na figura 5.1, a deformação entre parênteses refere-se ao pino do conector mais solicitado. Na direção $\mathrm{x}$, embora os conectores da região I tenham um comportamento diferente dos da região III, o nível de solicitação no pino mais solicitado é praticamente o mesmo para as duas regiões. Tal comportamento também é observado na direção y, embora o nível de solicitação nessa região seja menor.

Portanto, embora o comportamento dos pinos seja diferente, e o nível de solicitação na direção x seja maior que o nível de solicitação na direção y, pode-se observar uma simetria no nível de solicitações, tanto na direção x como na direção y.

Destaca-se que, na direção $\mathrm{x}$, as chapas superiores dos conectores estavam diretamente encostadas na armadura de flexão. Já os conectores dispostos na direção y, embora o pino estivesse encostado na armadura de flexão, havia uma "folga" entre a face inferior da chapa superior do conector e a face superior da armadura de flexão.

Observa-se nitidamente nas figuras H.1 a H.7, do Anexo H, o momento em que a armadura começa a ser solicitada. Como conclusão, tem-se que a armadura trabalhou satisfatoriamente.

\subsubsection{MODELO M3}

\section{a) Instrumentação dos macacos hidráulicos (M3)}

A diferença percentual entre as forças aplicadas pelos macacos, no instante da ruína, foi de 3,3\% (tabela 4.2). Considerando-se que a distância entre os eixos dos macacos hidráulicos era de $19 \mathrm{~cm}$ (figura 3.5), esta diferença é equivalente a uma excentricidade do carregamento de $\mathbf{1 , 6} \mathbf{~ m m}$. e foi considerada pequena.

Pode ser constatado que não houve nenhuma excentricidade da posição da chapa metálica, usada para transferir o carregamento dos macacos hidráulicos ao modelo, com relação ao centro da laje. 


\section{b) Instrumentação da armadura de flexão tracionada (M3)}

Observou-se o escoamento da armadura nos pontos 1' e 2'. Nas figuras 4.14b, 4.20 e 4.26, o escoamento é caracterizado pelo trecho horizontal dos gráficos. O trecho vertical, no final do gráfico, indica que, apesar da barra ter escoado, a ruptura ocorreu com uma força acima do valor relacionado ao escoamento da barra.

Com base nas tabelas 5.10 e 5.11, não se pode afirmar que os resultados dos extensômetros colocados lateralmente à barra apresentem valores mais próximos entre si do que os colocados nas faces superior e inferior da armadura. Conclui-se apenas que é importante que a barra esteja instrumentada com 2 extensômetros em cada ponto, ao invés de 1 .

Observa-se que a diferença percentual entre as médias dos extensômetros colocados nas posições 6’ $(2,198$ \%oo e 7 ' (1,876 \%o ), que deveriam ser próximas, apresenta uma diferença de $17,2 \%$.

Tabela 5.10 - Leituras dos extensômetros posicionados lateralmente à barra, no instante anterior à ruína

\begin{tabular}{|c|c|}
\hline Posição lateral & Diferença percentual \\
\hline 3' - E.5 e E.6 $(1,12 \%, 1,18 \%)$ & $-4,8 \%$ \\
\hline 4' - E.7 e E.8 $(1,49 \%$ \%o, $1,46 \%)$ & $+1,8 \%$ \\
\hline 7' - E.13 e E.14 $(1,63 \%, 2,12 \%)$ & $-23,1 \%$ \\
\hline
\end{tabular}

Tabela 5.11 - Leituras dos extensômetros colados nas faces superior e inferior da armadura, no instante anterior à ruína

\begin{tabular}{|c|c|}
\hline Posição superior/inferior & Diferença percentual \\
\hline 5' - E.9 e E.10 $(2,7 \%$ \%o, 2,6\%o $)$ & $4,1 \%$ \\
\hline 6' - E.11 e E.12 $(2,4 \%$ \% $2,0 \%$ oo & $19,9 \%$ \\
\hline
\end{tabular}

Com relação à simetria, a média dos extensômetros na posição 3' diferiu de 21,8\% da média dos extensômetros colocados na posição 4' (figura 4.14). 
Embora essa diferença seja grande, estas medidas têm com a mesma ordem de grandeza, quando comparadas com a deformação média na posição 1'.

Na figura 4.20, pode-se ver que não houve a formação de charneira diagonal, uma vez que as deformações nas posições 1'-2' são bem maiores que as que ocorrem nas posições 6'-7'.

Na figura 4.26, pode-se observar a solicitação ao longo da barra, com relação à aplicação do carregamento. Diferentes solicitações ao longo da barra indicam que a barra não sofreu escorregamento.

$\mathrm{Na}$ figura 4.32, têm-se as deformações nas barras paralelas ao eixo y. Pode-se observar que este gráfico está perfeitamente coerente com o anterior: barras mais próximas à região onde se dá o carregamento apresentam deformações maiores.

Comparou-se a leitura na posição 4' (direção radial), igual a 1,47\% \%o com a medida na posição 5' (direção transversal), igual a 2,68\% \%

Assim como nos modelos M1 e M2, observa-se que, na região mais afastada do carregamento, a deformação na barra disposta na direção transversal é maior do que a deformação da barra disposta na direção radial.

\section{c) Instrumentação da armadura de flexão comprimida (M3)}

$\mathrm{Na}$ figura 4.43, tem-se a verificação da simetria através dos extensômetros E.17 e E.18. São incluídos, neste gráfico, os valores relativos ao E.15, de modo a verificar também a diferença de solicitação ao longo da barra. Observa-se que, embora o E.15 esteja tracionado a partir de um determinado carregamento, o gráfico está coerente, estando o E.15 mais solicitado que os outros extensômetros. Embora E.18 tenha uma deformação 23\% maior que o E.17, quando comparados com o E.15, estas deformações apresentam a mesma ordem de grandeza, indicando uma simetria com relação ao carregamento.

Cumpre destacar que, desde o início do carregamento, tanto o E.17 como o E.18 apresentaram, embora pequenas, deformações de tração. 
Na figura 4.49, apresenta-se a verificação de uma charneira. Observam-se que as deformações medidas pelos extensômetros E.15 e E.16 são bem superiores às deformações medidas pelos E.19 e E.20.

Embora com valores diferentes, tanto o E.15 e o E.16, como o E.19 e o E.20, apresentam um comportamento semelhante entre si. No entanto, observam-se que os extensômetros E.15 e E.19, posicionados em barras paralelas ao eixo y, apresentaram, respectivamente, deformações de tração maiores que os extensômetros E.16 e E.20, posicionados em barras paralelas ao eixo $\mathrm{x}$.

Na figura 4.55, tem-se a verificação do comportamento das barras após a ruína do modelo, com relação às barras dispostas nas direções x e y, respectivamente. Pode-se observar que, bem no início do carregamento, apenas o E.15 e o E.16 apresentavam deformações de compressão. Com o aumento do carregamento, todos os extensômetros passam a indicar deformações de tração. Após a ruína, ao contrário do modelo M2, não se observou nenhuma barra que tenha sofrido uma mudança extremamente brusca, com relação a um aumento da deformação de tração.

Para relacionar o comportamento dos extensômetros deste modelo com os outros já analisados, é apresentada a tabela 5.12.

Embora o M3 apresente um comportamento semelhante aos modelos anteriores, este comportamento não parece estar relacionado à direção, uma vez que, relacionam-se extensômetros colocados na direção x, para o modelo M1, com extensômetros colocados na direção y, para os modelos M2 e M3.

Tabela 5.12 - Padrão de comportamento da armadura comprimida, através da correlação de extensômetros nos três modelos

E.23 (M1, direção x) - corresponde a E.26 (M2, direção y) - corresponde a E.15 (M3, direção y)

E.24 (M1, direção y) - corresponde a E.25 (M2, direção x) - corresponde a E.16 (M3, direção x)

E.29 (M1, direção y) - corresponde a E.29 (M2, direção x) - corresponde a E.20 (M3, direção x)

E.28 (M1, direção x) - corresponde a E.30 (M2, direção y) - corresponde a E.19 (M3, direção y) 
Na tabela 5.13 apresentam-se os valores medidos no instante anterior à ruína. Observa-se que, na situação próxima à ruína, nenhuma das barras apresentava deformações de compressão, como era de se esperar.

Tabela 5.13 - Leituras dos extensômetros na situação anterior à ruína

\begin{tabular}{|c|c|c|c|c|c|}
\hline \multicolumn{7}{|c|}{ Posição dos Extensômetros } \\
\hline E.15 $(\%)$ & E.16 $(\%$ \%o $)$ & E.17 $(\%)$ & E.18 $(\%)$ & E.19 $(\%)$ & E.20 $(\%)$ \\
\hline $\mathbf{1 , 6 0}$ & $\mathbf{0 , 6 2}$ & $\mathbf{0 , 2 0}$ & $\mathbf{0 , 2 4}$ & $\mathbf{0 , 3 1}$ & $\mathbf{0 , 0 1}$ \\
\hline
\end{tabular}

\section{d) Instrumentação do concreto (M3)}

De um modo geral, observa-se uma certa semelhança do comportamento deste modelo com o do modelo M2.

Na figura 4.63, tem-se a comparação das deformações radiais e tangenciais dos pontos instrumentados na região adjacente à chapa de aplicação da força concentrada. Pode-se observar que, para os estágios iniciais de carregamento, os extensômetros indicavam leituras semelhantes. Com o aumento do carregamento, o E.49 (tangencial, canto) indica uma maior deformação. A partir de uma força da ordem de $650 \mathrm{kN}$ (aproximadamente $72 \%$ da força de ruína) observa-se um alívio nas deformações do concreto nesta região.

Na figura 4.69, tem-se a comparação das deformações radiais e tangenciais dos pontos posicionados longe da chapa de aplicação da força concentrada. Nesta figura, relativa a extensômetros colados a uma certa distância da área de carregamento, pode-se observar que, embora com valores diferentes, os extensômetros dispostos na direção radial seguem um mesmo padrão de comportamento. Esta observação também é válida para os extensômetros colados na direção tangencial.

Na figura 4.75, têm-se as deformações radiais, com relação ao canto e com relação ao meio da chapa metálica. Pode-se observar uma semelhança no comportamento dos conectores com relação à direção radial. 
Com base na figura 4.75, é importante destacar que, na região próxima ao carregamento, a partir de um determinado valor do carregamento, o concreto passou a sofrer um alívio na sua solicitação.

Na figura 4.81, têm-se as deformações tangenciais, com relação ao canto e com relação ao meio da chapa metálica. Observa-se que, com relação aos valores dados pelos extensômetros colados perto da área de carregamento, existe uma grande diferença entre o colado no meio e o colado no canto da área de carregamento.

Observa-se, ainda, que, o E.45 e o E.47 do modelo M3 (figura 4.81), embora pareçam estar invertidos no modelo M3, quando comparados com o E.45 e o E.47 do modelo M2 (figura 4.80), estão perfeitamente coerentes se comparados com o E.37 e o E.30 do modelo M1 (figura 4.79).

\section{e) Instrumentação dos deslocamentos do modelo (M3)}

Foram observados problemas nos transdutores D.12 e D.24, razão pela qual seus valores não foram incluídos nesta análise.

As leituras dos transdutores D.1 a D.4 mostram que o modelo sofreu uma rotação média, em seu próprio plano, como corpo rígido, de $0,32^{\circ}$ no sentido anti-horário, e deslocamentos de $+0,71 \mathrm{~mm}$ e $+0,33 \mathrm{~mm}$, com relação aos eixos x e y.

As leituras dos transdutores D.5 a D.8 referem-se aos deslocamentos dos apoios com relação ao piso do laboratório. Estes valores estão mostrados na tabela 4.4, e foram considerados pequenos para interferir nos resultados obtidos nos ensaios.

Na figura 4.93, têm-se ilustrados os deslocamentos dos transdutores dispostos na direção inclinada ao eixo y. Pode-se observar que o carregamento não parece apresentar excentricidades significativas, em função da proximidade dos valores dados pelos transdutores dispostos simetricamente em relação ao ponto central do modelo.

Próximo à ruptura, as diferenças percentuais entre os transdutores D.9 e D.17, D.11 e D16, D.13 e D.15 foram, respectivamente, de $\mathbf{- 1 7 , 6 \% ; ~ 9 , 6 \% ~ e ~ 4 , 1 \% . ~}$ 
Embora a diferença percentual possa parecer grande, graficamente pode-se observar que o comportamento do modelo nesta direção tende a ser simétrico.

Com relação ao comportamento observado para os transdutores dispostos ao longo da direção y, ilustrado na figura 4.94, nota-se uma tendência de levantamento da região do D.18. Próximo à ruptura, as diferenças percentuais entre os transdutores D.18 e D.25, D.19 e D.23, D.20 e D.21 foram, respectivamente, de $\mathbf{- 4 4 , 1 \% ; - 3 8 , 1 \% ~ e ~} \mathbf{- 8 , 1 \%}$. No entanto, observando os gráficos, pode-se considerar uma certa simetria com relação ao carregamento.

Observa-se, portanto, que parece ter havido um pequeno desnivelamento da laje com a aplicação do carregamento, significativo apenas quando foi atingida a ruptura.

\section{f) Instrumentação da armadura de punção (M3)}

Nas figuras H.15 a H.22, do Anexo H, têm-se os gráficos relativos a cada um dos conectores instrumentados. Os extensômetros com números menores encontram-se mais próximos da região onde foi aplicado o carregamento. Já os com números intermediários estão relacionados aos pinos posicionados no meio das chapas de ancoragem.

Com relação às armaduras dispostas na direção y (figura 4.112), pode-se observar que todas têm um comportamento semelhante, com o extensômetro mais perto da área carregada estando mais solicitado, e o extensômetro mais afastado estando menos solicitado. Nessa figura, a diferença das linhas de conectores é dada através das cores azul, para as deformações medidas na linha de conectores E.24, E.25 e E.26; preta, para as deformações medidas na linha de conectores E.21, E.22 e E.23, e vermelha, para as deformações medidas na linha de conectores E.33, E.34 e E.35.

Na tabela 5.14, têm-se os valores da deformação dos pinos, no instante anterior à ruína. 
Tabela 5.14 - Deformação dos pinos dispostos na direção y, no instante anterior à ruína do modelo

\begin{tabular}{|c|c|c|c|}
\hline $\begin{array}{c}\text { Posição da linha de } \\
\text { conectores }\end{array}$ & $\begin{array}{c}\text { Pino mais próximo à } \\
\text { carga }\end{array}$ & Pino intermediário & $\begin{array}{c}\text { Pino mais afastado } \\
\text { da carga }\end{array}$ \\
\hline Próximo ao canto & $1,82 \%$ (E.21) & $1,42 \%$ (E.22) & $0,99 \%$ (E.23) \\
\hline No meio & $3,26 \%$ (E.24) & $1,39 \%$ (E.25) & $0,94 \%$ (E.26) \\
\hline Próximo ao canto & $1,81 \%$ (E.33) & $1,26 \%$ (E.34) & $0,57 \%$ (E.35) \\
\hline
\end{tabular}

Pode-se observar que as três linhas de conectores dispostas na direção y apresentam um comportamento semelhante, à exceção dos valores indicados pelos extensômetros E.24 e E.35, sendo estes valores, respectivamente, muito elevado e muito baixo, em comparação com os seus correspondentes.

Com relação às armaduras dispostas na direção x (figura 4.113), pode-se observar que todas têm um comportamento semelhante, com o extensômetro mais perto da área carregada estando mais solicitado, e o extensômetro mais afastado estando menos solicitado. Na tabela 5.15, têm-se os valores da deformação nos conectores no instante da ruptura.

Tabela 5.15 - Deformação dos pinos dispostos na direção x, no instante anterior à ruína do modelo

\begin{tabular}{|c|c|c|c|}
\hline $\begin{array}{c}\text { Posição da linha de } \\
\text { conectores }\end{array}$ & $\begin{array}{c}\text { Pino mais próximo à } \\
\text { carga }\end{array}$ & Pino intermediário & $\begin{array}{c}\text { Pino mais afastado } \\
\text { da carga }\end{array}$ \\
\hline Próximo ao canto & $2,63 \%$ (E.27) & $1,75 \%$ (E.28) & $0,65 \%$ (E.29) \\
\hline Próximo ao canto & $1,70 \%$ (E.36) & $1,46 \%$ (E.37) & $0,51 \%$ (E.38) \\
\hline No meio & $2,36 \%$ (E.39) & $0,80 \%$ (E.40) & $0,66 \%$ (E.41) \\
\hline
\end{tabular}


Tomando-se como referência a linha de conectores E.27, E.28, E.29, pode-se observar que a linha de conectores E.36, E.37, E.38 apresentou valores inferiores. Já a linha de conectores E.39, E.40, E.41 apresentou valores mais próximos, com exceção do E.40. Com relação às armaduras dispostas na diagonal (figura 4.114), pode-se observar uma aproximação entre os valores referentes aos extensômetros mais afastados da área de carregamento e os intermediários. Na tabela 5.16, têm-se os valores da deformação nos conectores no instante anterior à ruína.

Tabela 5.16 - Deformação dos pinos dispostos na direção diagonal, no instante anterior à ruína do modelo

\begin{tabular}{|c|c|c|c|}
\hline $\begin{array}{c}\text { Posição da linha de } \\
\text { conectores }\end{array}$ & $\begin{array}{c}\text { Pino mais próximo à } \\
\text { carga }\end{array}$ & Pino intermediário & $\begin{array}{c}\text { Pino mais afastado } \\
\text { da carga }\end{array}$ \\
\hline Diagonal & $1,29 \%$ (E.30) & $0,70 \%$ (E.31) & $0,59 \%$ (E.32) \\
\hline Diagonal & $1,28 \%$ (E.42) & $0,51 \%$ (E.43) & $0,61 \%$ (E.44) \\
\hline
\end{tabular}

Tomando-se como referência a linha de pinos E.30, E.31, E.32, pode-se observar que apenas o E.43 apresentou um resultado suspeito, uma vez que este valor encontra-se menor que o E.31, seu correspondente, e menor que o valor dado pelo E.44, quando deveria ser maior, uma vez que o E.44 está mais afastado do carregamento aplicado ao modelo.

Na figura 5.2, têm-se os valores medidos pelos extensômetros no instante da ruína do modelo.

Mesmo com alguns valores estando excessivamente altos e outros excessivamente baixos, pode-se considerar uma certa simetria no que diz respeito ao carregamento. No entanto, em virtude da grande variação nos valores, não se pode deduzir que os conectores dispostos na direção x tiveram uma melhor ancoragem que os da direção y. 
Pode-se, no entanto, observar que os valores medidos nos conectores dispostos na direção diagonal foram relativamente menores que os dispostos nas direções x e y. Após a ruptura, as leituras indicaram um alívio em todos os extensômetros.

Conclui-se que o pino mais próximo da área carregada foi o mais solicitado. $\mathrm{Na}$ maior parte das vezes, o conector intermediário apresentou deformação superior à do conector mais afastado da área carregada.

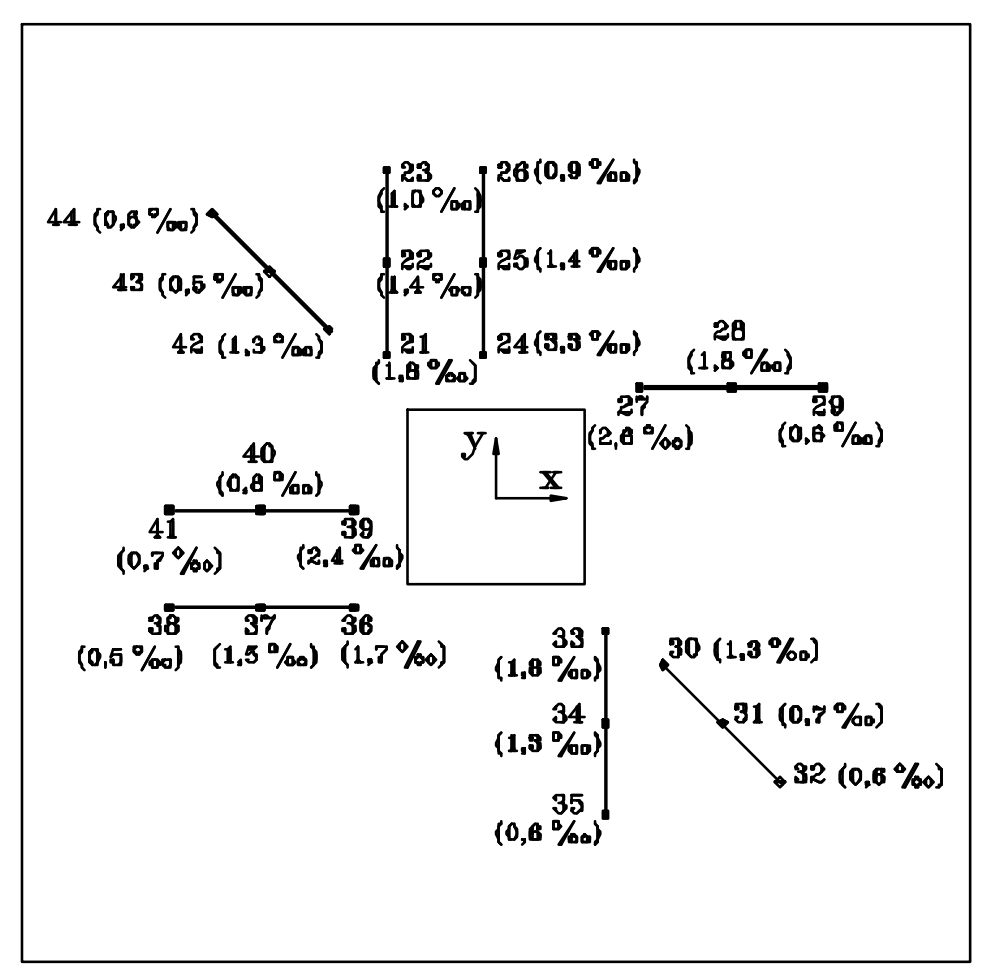

Figura 5.2 - Deformação nos conectores no instante da ruína

\subsubsection{MODELO M4}

a) Instrumentação dos macacos hidráulicos (M4)

A diferença percentual entre as forças aplicadas pelos macacos, no instante da ruína, foi de $-0,6 \%$ (tabela 4.2 ). 
Considerando-se que a distância entre os eixos dos macacos hidráulicos era de $19 \mathrm{~cm}$ (figura 3.5), esta diferença é equivalente a uma excentricidade do carregamento de $\mathbf{0 , 3} \mathbf{~ m m}$ e foi considerada pequena.

Pode ser constatado que não houve nenhuma excentricidade da posição da chapa metálica, usada para transferir o carregamento dos macacos hidráulicos ao modelo, com relação ao centro da laje.

\section{b) Instrumentação da armadura passiva de flexão tracionada (M4)}

Não foi observado nenhum indício de escoamento na armadura. No entanto, observam-se, nas figuras 4.15, 4.21, 4.27 e 4.33, uma descontinuidade nos gráficos, causada pela aplicação da protensão, realizada quando o carregamento estava em aproximadamente 112 kN. Observam-se, nas figuras G.31 a G.37 do Anexo G, a influência da protensão provocando um alívio (ou mesmo compressão) na armadura passiva tracionada.

Com base nas tabelas 5.17 e 5.18, observa-se que fica difícil afirmar que os resultados dos extensômetros colocados lateralmente à barra apresentam valores mais próximos entre si do que os colocados nas faces superior e inferior da armadura. Este fato justifica o uso de dois extensômetros para cada posição adotada. Observa-se que a diferença percentual entre as médias dos extensômetros colocados nas posições 6' (0,64 \% \% e 7 ' $(0,46 \%$ oo), que deveriam ser próximas, apresenta uma diferença de $39 \%$. Esta diferença pode ter sido causada pela diferença da quantidade de protensão aplicada em cada uma das direções.

Tabela 5.17 - Leituras dos extensômetros posicionados lateralmente àbarra, no instante anterior àruína

\begin{tabular}{|c|c|}
\hline Posição lateral & Diferença percentual \\
\hline 1' - E.1 e E.2 $(2,12 \%, 2,44 \%)$ & $-13,2 \%$ \\
\hline 3' - E.5 e E.6 $(-0,38 \%$ \%o, $-0,22 \%)$ & $+72,6 \%$ \\
\hline 4' - E.7 e E.8 $(-0,29 \%,-0,29 \%)$ & $-0,4 \%$ \\
\hline 7' - E.13 e E.14 $(0,55 \%, 0,37 \%)$ & $45,5 \%$ \\
\hline
\end{tabular}


Tabela 5.18 - Leituras dos extensômetros colados nas faces superior e inferior da armadura, imediatamente anteriores à ruína

\begin{tabular}{|c|c|}
\hline Posição superior/inferior & Diferença percentual \\
\hline 2' - E.3 e E.4 $\left(2,56^{\circ} \%, 2,02 \%\right)$ & $27,0 \%$ \\
\hline 5' - E.9 e E.10 $(0,39 \%$ \%o, $0,40 \%)$ & $-3,8 \%$ \\
\hline 6' - E.11 e E.12 $(0,82 \%, 0,45 \%)$ & $81,5 \%$ \\
\hline
\end{tabular}

Com relação à simetria, analisada através da figura 4.15, a média dos extensômetros na posição 3' (-0,302 \%oo) diferiu apenas de 2,7\% da média dos extensômetros colocados na posição 4’ $(-0,294 \%$ oo), indicando um comportamento simétrico com relação a esta direção.

Na figura 4.21, nota-se que não houve a formação de charneira, uma vez que as deformações nas posições 1'-2' são diferentes das medidas nas posições 6'-7'.

Na figura 4.27, observam-se diferentes deformações ao longo da barra, indicando que esta não sofreu escorregamento.

Na figura 4.33, têm-se as deformações das barras paralelas ao eixo y. Estes valores estão coerentes com a posição da barra: barras mais próximas do carregamento apresentam deformações maiores.

Comparou-se a leitura medida na posição 4' (direção radial), igual a -0,29 \%o, com a medida na posição 5' (direção transversal), igual a 0,40 \%. Esta variação pode ser atribuída à diferença entre a força de protensão aplicada em uma direção, com relação à outra.

\section{c) Instrumentação da armadura passiva de flexão comprimida (M4)}

Na figura 4.44, tem-se a verificação da simetria através do E.17 e do E.18. Embora ambos apresentem um comportamento similar, a diferença entre as leituras foi grande, da ordem de $56,4 \%$. Isto pode ser justificado através das diferentes forças de protensão aplicadas nas direções x e y. 
Com relação à análise da formação de charneiras, mostrada na figura 4.50, o E.19 apresenta um comportamento diferenciado, provavelmente devido à aplicação da protensão no modelo.

$\mathrm{Na}$ figura 4.56, é avaliado o comportamento pós-ruptura de todas as barras. Notase que apenas o E.15 e o E.16 são tracionados após a ruína da laje. Este comportamento é semelhante ao observado para o modelo M1, podendo indicar um comportamento característico de modelos sem armadura de punção.

Com a aplicação da protensão, observa-se que ela manteve esta armadura comprimida durante todo o carregamento, ao contrário dos ensaios feitos com modelos de concreto armado.

\section{d) Instrumentação do concreto (M4)}

Comparando-se o modelo M4 com o M1, tem-se que os extensômetros E.30 a E.37 do modelo M1 são correspondentes aos extensômetros E.21 a E.28 do modelo M4. Observa-se que a aplicação da protensão modificou de forma significativa o comportamento do concreto com relação à região adjacente ao carregamento (figuras 4.61 e 4.64), mas não com relação à região afastada do carregamento (figuras 4.67 e 4.70).

Com relação às deformações radiais, caso o E.35 do modelo M1 não tivesse tido um comportamento insatisfatório, haveria uma grande semelhança entre os modelos M1 e M4 (figuras 4.73 e 4.76).

Com relação às deformações tangenciais, caso o E.24 do modelo M4 não tivesse tido um comportamento insatisfatório, também haveria uma grande semelhança entre os modelos M1 e M4 (figuras 4.79 e 4.82).

A influência da aplicação da protensão ao modelo pode ser observada de modo visível nos gráficos. 


\section{e) Instrumentação dos deslocamentos do modelo (M4)}

As leituras dos transdutores D.5 a D.8 referem-se aos deslocamentos dos apoios com relação ao piso do laboratório. Estes valores estão mostrados na tabela 4.4, e foram considerados pequenos para interferir nos resultados obtidos nos ensaios. O sinal positivo na tabela indica um afastamento entre o apoio e o piso; já o sinal negativo indica um aproximação.

Na figuras 4.95, têm-se ilustrados os deslocamentos dos transdutores dispostos na direção inclinada ao eixo y. Na figura 4.95a, pode ser vista a influência da protensão nos deslocamentos. Esta influência afetou a simetria na região dos cantos. Próximo à ruptura, as diferenças percentuais entre os transdutores D.9 e D.17, D.11 e D16, D.13 e D.15 foram, respectivamente, de $-\mathbf{1 0 1 , 5 \%} ;-\mathbf{6 , 8 \%}$ e 4,8\%. Embora a diferença percentual possa parecer grande, pode-se observar, na figura 4.95b, que o comportamento do modelo nesta direção tende a ser simétrico.

O comportamento dos transdutores dispostos ao longo da direção y está ilustrado na figura 4.96. Pode-se observar uma tendência de levantamento da região do transdutor D.25. Próximo à ruptura, as diferenças percentuais entre os transdutores D.18 e D.25, D.19 e D.23, D.20 e D.21 foram, respectivamente, de 41,9\%; $0,1 \%$ e 7,5\%. Observando os gráficos, pode-se considerar uma certa simetria com relação ao carregamento. Na extremidade direita da figura 4.96b, nota-se a influência da aplicação da protensão no modelo, através dos deslocamentos transversais medidos.

\section{f) Instrumentação da força de protensão nas cordoalhas (M4)}

Nas tabelas 5.19 e 5.20, tem-se o valor médio da protensão, em porcentagem, para as cordoalhas dispostas nas direções y e $\mathrm{x}$, respectivamente.

Nessas tabelas, tomou-se, como referência, os valores da protensão após a recuperação das perdas.

De um modo geral, para ambas as direções, as porcentagens foram praticamente as mesmas: após a protensão inicial, ocorria uma perda da ordem $30 \%$. 
$\mathrm{Na}$ iminência de ruptura, observou-se o acréscimo da força de protensão em torno de $5 \%$ e, após a ruína, observou-se uma diminuição da força de protensão, cujo valor ficou cerca de $3 \%$ acima da força de protensão obtida no início do ensaio, após a recuperação das perdas.

Os maiores acréscimos da força de protensão ocorreram nas cordoalhas que atravessavam a região onde o carregamento era aplicado (C2 a C7 e C2' a C7').

Tabela 5.19 - Modelo M4: protensão nas cordoalhas dispostas na direção y (em \%)

\begin{tabular}{|c|c|c|c|c|c|c|c|c|c|}
\hline \multirow{2}{*}{ Situação } & \multicolumn{9}{|c|}{ Força de protensão nas cordoalhas dispostas na direção y (\%) } \\
\hline & C.1 & $\mathbf{C . 2}$ & $\begin{array}{l}\mathbf{C} 3 \\
\end{array}$ & C.4 & C.5 & $\begin{array}{l}\text { C.6 } \\
\end{array}$ & C.7 & C.8 & Média \\
\hline $1^{\mathrm{a}}$.Prot. & 72 & 78 & 75 & 74 & 73 & 74 & 67 & 74 & 73 \\
\hline $\begin{array}{l}\text { Após rec. das } \\
\text { perdas }\end{array}$ & 100 & 100 & 100 & 100 & 100 & 100 & 100 & 100 & 100 \\
\hline Na ruptura & 103 & 106 & 107 & 106 & 107 & 107 & 106 & 103 & 105 \\
\hline Após ruptura & 101 & 103 & 104 & 104 & 105 & 105 & 103 & 101 & 103 \\
\hline
\end{tabular}

Tabela 5.20 - Modelo M4: protensão nas cordoalhas dispostas na direção x (em \%)

\begin{tabular}{|c|c|c|c|c|c|c|c|c|c|}
\hline \multirow{2}{*}{ Situação } & \multicolumn{6}{|c|}{ Força de protensão nas cordoalhas dispostas na direção x (\%) } \\
\cline { 2 - 11 } & C.1' & C.2' & C.3' & C.4' & C.5' & C.6' & C.7' & C.8' & Média \\
\hline $1^{\text {a.Prot. }}$ & 74 & 76 & 72 & 73 & 75 & 73 & 91 & 73 & $\mathbf{7 6}$ \\
\hline $\begin{array}{c}\text { Após rec. } \\
\text { das perdas }\end{array}$ & 100 & 100 & 100 & 100 & 100 & 100 & 100 & 100 & $\mathbf{1 0 0}$ \\
\hline Na ruptura & 102 & 105 & 105 & 106 & 106 & 106 & 105 & 103 & $\mathbf{1 0 5}$ \\
\hline Após ruptura & 101 & 102 & 104 & 104 & 104 & 106 & 102 & 101 & $\mathbf{1 0 3}$ \\
\hline
\end{tabular}

\subsubsection{MODELO M5}

\section{a) Instrumentação dos macacos hidráulicos (M5)}

A diferença percentual entre as forças aplicadas pelos macacos, no instante da ruína, foi de $1,6 \%$. Considerando-se que a distância entre os eixos dos macacos hidráulicos era de $19 \mathrm{~cm}$ (figura 3.5), esta diferença é equivalente a uma excentricidade do carregamento de $\mathbf{0 , 7} \mathbf{~ m m}$. e foi considerada pequena. 
Pode ser constatado que não houve nenhuma excentricidade da posição da chapa metálica, usada para transferir o carregamento dos macacos hidráulicos ao modelo, com relação ao centro da laje.

\section{b) Instrumentação da armadura passiva de flexão tracionada (M5)}

Ocorreu o escoamento das armaduras nas posições 1' e 2'.

Assim como no modelo M4, observam-se, nas figuras 4.16, 4.22, 4.28 e 4.34, uma descontinuidade nos gráficos, causada pela aplicação da protensão, realizada quando o carregamento estava em aproximadamente $184 \mathrm{kN}$. Observam-se, nas figuras G.38 a G.44 do Anexo G, a influência da protensão provocando um alívio (ou mesmo compressão) na armadura passiva tracionada.

Com base nas tabelas 5.21 e 5.22, é difícil afirmar que os resultados dos extensômetros colocados lateralmente à barra apresentam valores mais próximos entre si do que os colocados nas faces superior e inferior da armadura. Conclui-se apenas que é importante que a barra esteja instrumentada com 2 extensômetros em cada ponto, ao invés de 1 .

$\mathrm{Na}$ figura 4.16, tem-se a análise da simetria através das leituras médias dos extensômetros nas posições 3' (0,52 \% \% ) e 4' (0,73 \% \%). Observa-se que, embora com comportamento semelhante, os valores nestas posições foram bem diferentes. Na situação de máxima força aplicada, a média dos extensômetros na posição 3' foi 28,5\% inferior à média dos extensômetros na posição 4'.

Na figura 4.22, nota-se que não houve a formação de charneira, uma vez que o as deformações nas posições 1'-2' são diferentes das medidas nas posições 6'-7'. Pode-se notar que a força que provocou o escoamento na posição 2' foi superior à força que provocou o escoamento na posição 1'.

Observa-se que a diferença entre as médias dos extensômetros colocados nas posições 6' (1,62 \%o) e 7' (1,94\% \%o), estão relativamente próximas, com uma diferença percentual de $-17 \%$. Esta diferença pode ter sido causada pela diferença da quantidade de protensão aplicada em cada uma das direções. 
$\mathrm{Na}$ figura 4.28, observam-se diferentes deformações ao longo da barra, indicando que ela não sofreu escorregamento.

Na figura 4.34, têm-se as deformações nas barras paralelas a um dos eixos de simetria da laje. Pode-se observar que este gráfico está coerente com o anterior: barras mais próximas à região onde se dá o carregamento apresentam deformações maiores.

Tabela 5.21 - Leituras dos extensômetros posicionados lateralmente à barra, no instante anterior àruína

\begin{tabular}{|c|c|}
\hline Posição lateral & Diferença percentual \\
\hline 3' - E.5 e E.6 $(0,57 \%$ \%o, $0,48 \%)$ & $+17,1 \%$ \\
\hline 4' - E.7 e E.8 $(0,81 \%$ \%o, $0,65 \%)$ & $+24,3 \%$ \\
\hline 7' - E.13 e E.14 $(1,95 \%, 1,92 \%)$ & $+1,5 \%$ \\
\hline
\end{tabular}

Tabela 5.22 - Leituras dos extensômetros colados nas faces superior e inferior da armadura, no instante anterior à ruína

\begin{tabular}{|c|c|}
\hline Posição superior/inferior & Diferença percentual \\
\hline 5' - E.9 e E.10 $(1,39 \%, 1,68 \%)$ & $-17,5 \%$ \\
\hline 6 ' E.11 e E.12 $(1,72 \%, 1,51 \%)$ & $+14,3 \%$ \\
\hline
\end{tabular}

A diferença percentual entre a deformação média da armadura na posição 5' $(1,53 \%$ \%o e a deformação média na posição 4' (0,73\% \%o foi da ordem de $110 \%$, indicando uma predominância da deformação tangencial em relação à radial. Esta diferença, no entanto, também pode ser atribuída à diferença entre as forças de protensão aplicadas em cada direção. 


\section{c) Instrumentação da armadura passiva de flexão comprimida (M5)}

Na figura 4.45, tem-se a verificação da simetria através do E.17 e do E.18. Embora a diferença entre as leituras seja grande, da ordem de 95,7\%, ambos apresentam um comportamento similar, quando comparados com o comportamento observado para o E.15. Observa-se, ainda, que o nível das deformações foi baixo, da ordem de $0,02 \%$ o e $0,04 \%$ para o E.17 e E.18, respectivamente. Portanto, considera-se verificada a condição de simetria do carregamento com base nesta instrumentação. Esta discrepância nos valores pode ainda ser justificada através das diferentes forças de protensão aplicadas nas direções $\mathrm{x}$ e $\mathrm{y}$.

Na figura 4.51, pode-se observar uma grande semelhança no comportamento deste modelo com o do modelo M4, com exceção do E.20 do modelo M5, que apresentou defeito, e do E.19 do modelo M4, que parece não ter funcionado bem.

Analogamente aos modelos de concreto armado, o E.15 (disposto na direção y) apresenta um comportamento bem diferenciado do E.16 (disposto na direção x).

Ainda com base na figura 4.51, observa-se que não há a tendência da formação de uma charneira.

Na figura 4.57, observa-se uma certa semelhança do comportamento pós-ruptura do modelo M5 com o comportamento pós-ruptura do modelo M2. Em ambos os casos, apenas um dos extensômetros apresentou um significativo aumento na deformação de tração após a ruína; no entanto, a posição dos extensômetros nos modelos não são coincidentes.

\section{d) Instrumentação do concreto (M5)}

Comparando-se o modelo M5 com os modelos M2 e M3, com relação à região adjacente ao carregamento, a menos da deformação radial no meio (figuras 4.62, 4.63 e 4.65), o comportamento dos extensômetros aparenta ser semelhante. 
$\mathrm{Na}$ região afastada do carregamento (figuras 4.68, 4.69, 4.71), novamente, a menos da deformação radial no meio, do modelo M5, o comportamento dos extensômetros aparenta ser semelhante. Destaca-se, no entanto, que para os modelos M3 e M5, a máxima tensão de compressão ocorre no extensômetro tangencial no canto; já para o modelo M2, a máxima deformação de compressão ocorre no extensômetro tangencial no meio, mas com um valor bem próximo do extensômetro tangencial no canto.

Comparando-se as deformações radiais, observa-se um padrão na distribuição dessas deformações, embora os extensômetros posicionados no meio da chapa não estejam funcionando de modo adequado. A sequiência de cores observada é verde, vermelho, magenta e verde (figuras 4.74, 4.75 e 4.77 ).

Comparando-se as deformações tangenciais, observa-se um padrão na distribuição dessas deformações. A seqüência de cores observada é preto, bege, azul e magenta (figuras 4.80, 4.81 e 4.83).

\section{e) Instrumentação dos deslocamentos do modelo (M5)}

Analisando a direção inclinada ao eixo y, pode ser observado, na figura 4.97b, que somente a partir de um certo carregamento é que houve uma grande variação nos valores relativos aos transdutores simétricos. Esta observação está mostrada na tabela 5.23.

Tabela 5.23 - Comparação entre valores medidos por transdutores simétricos

\begin{tabular}{|c|c|c|}
\hline \multirow{2}{*}{ Transdutores } & \multicolumn{2}{|c|}{ Diferença percentual } \\
\cline { 2 - 3 } & $\begin{array}{c}\text { a) Com 75\% da Força de } \\
\text { Ruptura }(833,1 \mathrm{kN})\end{array}$ & $\begin{array}{c}\text { b) Com } 100 \% \text { da Força de } \\
\text { Ruptura ( } 1104,1 \mathrm{kN})\end{array}$ \\
\hline D.9 e D.17 & $-8,1 \%$ & $124,6 \%$ \\
\hline D.11 e D.16 & $5,3 \%$ & $-25,9 \%$ \\
\hline D.13 e D.15 & $-5,0 \%$ & $-4,7 \%$ \\
\hline
\end{tabular}


Com relação ao comportamento observado para os transdutores dispostos ao longo da direção y, ilustrado na figura 4.98, pode-se observar uma tendência de levantamento da região próxima ao D.25.

Próximo à ruptura, as diferenças percentuais entre os transdutores D.18 e D.25, D.19 e D.23, D.20 e D.21 foram, respectivamente, de $\mathbf{- 5 , 2 \%} ; \mathbf{- 1 3 , 3 \%}$ e $\mathbf{5 , 7 \%}$.

Portanto, observando os gráficos, pode-se considerar uma simetria com relação ao carregamento.

\section{f) Instrumentação da armadura de punção (M5)}

$\mathrm{Na}$ figura 4.102b, têm-se ilustrados os conectores dispostos na direção $\mathrm{x}$, colocados no mesmo lado. Pode-se observar que E.31-E.32 apresenta comportamento semelhante ao indicado pelo E.33-E.34.

Observa-se ainda que os pinos dos conectores posicionados na proximidade do canto apresentaram deformações maiores que os mais afastados da face do pilar. Além disso, a deformação no pino mais próximo à face do pilar é maior que o conjunto de pinos dispostos na região central, mais afastada da chapa metálica usada para aplicar o carregamento.

Como os extensômetros E.23 e E.24 apresentaram defeito, não possível representar o gráfico dos conectores dispostos na direção y, colocados no mesmo lado.

$\mathrm{Na}$ figura 4.103b, têm-se ilustrados os conectores dispostos na direção $\mathrm{x}$, colocados em lados opostos, na região do canto. Pode-se observar que o E.25-E.26 apresenta comportamento semelhante ao E.31-E.32, revelando uma certa simetria no carregamento.

Na figura 4.105b, têm-se os conectores dispostos na direção y, em lados opostos. Devido ao problema ocorrido no E.23 e no E.24, não foi possível analisar os conectores dispostos na direção y, do mesmo lado.

Na figura 4.108, tem-se um exemplo de conector inclinado. Pode-se observar uma semelhança no comportamento do E.27 com o do E.35. 
Na figura 4.109b, têm-se ilustrados os conectores próximos à chapa de aplicação da carga. As maiores solicitações ocorrem nos pinos E.29 e E.33, dispostos, respectivamente, nas direção y e x; já as menores, ocorrem nos pinos E.27 e E.35, dispostos nas direção inclinada. Conectores na direção inclinada parecem ser menos solicitados, mas a direção em que os pinos são mais solicitados não ficou claramente definida.

$\mathrm{Na}$ figura $4.110 \mathrm{~b}$, têm-se a instrumentação dos conectores afastados da chapa de aplicação da carga. A maior solicitação ocorre no E.26, disposto na direção x, mas com valor próximo do E.22, disposto na direção y. A menor solicitação ocorre no E.28, disposto na direção inclinada.

Nas tabelas 5.24 a 5.26, têm-se algumas informações com relação às deformações medidas nos pinos.

Tabela 5.24 - Deformação dos pinos dispostos na direção y, no instante anterior à ruína do modelo

\begin{tabular}{|c|c|c|}
\hline $\begin{array}{c}\text { Posição da linha de } \\
\text { conectores }\end{array}$ & Pino mais próximo à carga & Pino mais afastado da carga \\
\hline Próximo ao canto & $1,44 \%$ \%o (E.21) & $1,43 \%$ \%o (E.22) \\
\hline No meio & Defeito - (E.23) & Defeito - (E.24) \\
\hline Próximo ao canto & $1,76 \%$ \%o (E.29) & $1,18 \%$ (E.30) \\
\hline
\end{tabular}

Tabela 5.25 - Deformação dos pinos dispostos na direção x, no instante anterior à ruína do modelo

\begin{tabular}{|c|c|c|}
\hline $\begin{array}{c}\text { Posição da linha de } \\
\text { conectores }\end{array}$ & Pino mais próximo à carga & Pino mais afastado da carga \\
\hline Próximo ao canto & $1,36 \%$ \%o (E.25) & $1,57 \%$ \%o (E.26) \\
\hline No meio & $1,41 \%$ \%o (E.31) & $1,33 \%$ \%. E.32) \\
\hline Próximo ao canto & $1,71 \%$ \%o (E.33) & $1,08 \%$ (E.34) \\
\hline
\end{tabular}


Tabela 5.26- Deformação dos pinos dispostos na direção inclinada, no instante anterior à ruína do modelo

\begin{tabular}{|c|c|}
\hline Pino mais próximo à carga & Pino mais afastado da carga \\
\hline $0,85 \%(\mathrm{E} .27)$ & $0,67 \%$ (E.28) \\
\hline $0,88 \%(\mathrm{E} .35)$ & Defeito - (E.36) \\
\hline
\end{tabular}

Portanto, as principais diferenças com relação ao comportamento dos conectores são:

- os conectores, para o modelo M5, apresentam deformações de compressão nos estágios iniciais do carregamento;

- as curvas relacionadas aos conectores dos modelos protendidos apresentam basicamente duas descontinuidades: a primeira refere-se à aplicação da protensão e a segunda, à rápida inversão dos esforços solicitantes, quando os conectores deixam de ser comprimidos e passam a ser tracionados.

\section{g) Instrumentação da força de protensão nas cordoalhas (M5)}

Nas tabelas 5.27 e 5.28, tem-se o valor médio da protensão, em porcentagem, para as cordoalhas dispostas nas direções y e $\mathrm{x}$, respectivamente. Nessas tabelas, tomou-se, como referência, os valores da protensão após a recuperação das perdas.

De um modo geral, para ambas as direções, as porcentagens foram praticamente as mesmas: após a protensão inicial, ocorria uma perda da ordem 20\%, inferior à do modelo anterior. Na iminência de ruptura, observou-se o acréscimo da força de protensão em torno de $17 \%$ na direção y e $11 \%$ na direção $x$.

Após a ruína, observou-se uma diminuição da força de protensão, cujo valor ficou cerca de $12 \%$ acima da força de protensão obtida no início do ensaio, após a recuperação das perdas, na direção y, e 5\% na direção x. 
Os maiores acréscimos da força de protensão ocorreram nas cordoalhas que atravessavam a região onde o carregamento era aplicado (C2 a C7 e C2' a C7'). Tem-se como exceção a cordoalha C4', que na iminência da ruptura apresentou uma força inferior àquela obtida após a recuperação das perdas. Este fato pode ser devido a uma acomodação das cunhas durante o ensaio.

Tabela 5.27 - Modelo M5: protensão nas cordoalhas dispostas na direção y (em \%)

\begin{tabular}{|c|c|c|c|c|c|c|c|c|c|}
\hline \multirow{2}{*}{ Situação } & \multicolumn{9}{|c|}{ Força de protensão nas cordoalhas dispostas na direção y (\%) } \\
\hline & 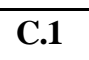 & C.2 & C.3 & C.4 & $\begin{array}{l}\mathbf{C . 5} \\
\end{array}$ & C.6 & C.7 & C.8 & Média \\
\hline $1^{\text {a }}$.Prot. & 77 & 83 & 67 & 80 & 82 & 83 & 81 & 79 & 79 \\
\hline $\begin{array}{l}\text { Após rec. das } \\
\text { perdas }\end{array}$ & 100 & 100 & 100 & 100 & 100 & 100 & 100 & 100 & 100 \\
\hline Na ruptura & 111 & 118 & 120 & 118 & 120 & 118 & 118 & 112 & 117 \\
\hline Após ruptura & 102 & 117 & 117 & 115 & 115 & 113 & 113 & 104 & 112 \\
\hline
\end{tabular}

Tabela 5.28 - Modelo M5: protensão nas cordoalhas dispostas na direção x (em \%)

\begin{tabular}{|c|c|c|c|c|c|c|c|c|c|}
\hline \multirow{2}{*}{ Situação } & \multicolumn{8}{|c|}{ Força de protensão nas cordoalhas dispostas na direção x (\%) } \\
\cline { 2 - 12 } & C.1' & C.2' & C.3' & C.4' & C.5' & C.6' & C.7' & C.8' & Média \\
\hline $1^{\text {a.Prot. }}$ & 80 & 88 & 76 & 80 & 83 & 83 & 76 & 72 & 80 \\
\hline $\begin{array}{c}\text { Após rec. } \\
\text { das perdas }\end{array}$ & 100 & 100 & 100 & 100 & 100 & 100 & 100 & 100 & 100 \\
\hline Na ruptura & 110 & 116 & 115 & 96 & 115 & 115 & 114 & 110 & 111 \\
\hline Após ruptura & 103 & 109 & 109 & 93 & 110 & 109 & 108 & 102 & 105 \\
\hline
\end{tabular}

\subsubsection{MODELO M6}

\section{a) Instrumentação dos macacos hidráulicos (M6)}

A diferença percentual entre as forças aplicadas pelos macacos, no instante da ruína, foi de aproximadamente $0,1 \%$. Considerando-se que a distância entre os eixos dos macacos hidráulicos era de $19 \mathrm{~cm}$ (figura 3.5), esta diferença é equivalente a uma excentricidade do carregamento de $\mathbf{0 , 0 2} \mathbf{~ m m}$ e foi considerada pequena. 
Pode ser constatado que não houve nenhuma excentricidade da posição da chapa metálica, usada para transferir o carregamento dos macacos hidráulicos ao modelo, com relação ao centro da laje.

\section{b) Instrumentação da armadura passiva de flexão tracionada (M6)}

Ocorreu o escoamento das armaduras nas posições 1' e 2'.

Na iminência do escoamento, para a posição 1', a leitura do E.1 (lateral) foi 40,1\% maior que a leitura do E.2 (lateral). Já na posição 2', a leitura do E.3 (sup.) foi 84,4\% maior que a leitura do E.4 (inf.). Estas elevadas diferenças, bem como as mostradas nas tabelas 5.29 e 5.30, mostram ser adequada a disposição de dois extensômetros para a instrumentação da armadura, ficando difícil afirmar que os extensômetros colocados lateralmente à barra apresentam valores mais próximos entre si do que os colocados nas faces superior e inferior da armadura.

Assim como nos modelos M4 e M5, observam-se, nas figuras 4.17, 4.23, 4.29 e 4.35, uma descontinuidade nos gráficos, causada pela aplicação da protensão, realizada quando o carregamento estava em aproximadamente $181 \mathrm{kN}$. Observam-se, nas figuras G.45 a G.51 do Anexo G, a influência da protensão provocando um alívio (ou mesmo compressão) na armadura passiva tracionada.

Tabela 5.29 - Leituras dos extensômetros posicionados lateralmente à barra, no instante anterior à ruína

\begin{tabular}{|c|c|}
\hline Posição lateral & Diferença percentual \\
\hline 3' - E.5 e E.6 $(0,34 \%$ \%o, $0,55 \%$ \%o & $-38,3 \%$ \\
\hline 4' - E.7 e E.8 $(0,50 \%$ \%o, $0,43 \%)$ & $+17,1 \%$ \\
\hline 7' - E.13 (com defeito) e E.14 $(1,55 \%)$ & - \\
\hline
\end{tabular}


Tabela 5.30 - Leituras dos extensômetros colados nas faces superior e inferior da armadura, no instante anterior à ruína

\begin{tabular}{|c|c|}
\hline Posição superior/inferior & Diferença percentual \\
\hline 5' - E.9 (com defeito) e E.10 $(1,79 \%)$ & - \\
\hline 6' - E.11 e E.12 $\left(1,80 \%, 1,47^{\circ} \%\right)$ & $+22,1 \%$ \\
\hline
\end{tabular}

$\mathrm{Na}$ figura 4.17, pode ser observada a simetria do carregamento com base na média das leituras feitas nas posições 3' e 4'. Na situação de máxima força aplicada, a média dos extensômetros na posição 4' foi apenas $4,1 \%$ superior à média dos extensômetros posicionados na posição 3', mesmo com as leituras isoladas dos extensômetros apresentando uma significativa variação.

$\mathrm{Na}$ figura 4.23, pode-se ver que não houve a formação de charneira, uma vez que as deformações nas posições 1'-2' são bem diferentes das deformações observadas nas posições 6'-7'. Para determinar a deformação da posição 7', foi usado apenas o E.14, visto o E.13 ter apresentado problemas durante o ensaio.

Observa-se que a diferença percentual entre as médias dos extensômetros colocados nas posições 6' $(1,63$ \%o ) e 7' (1,55\%oo), estão relativamente próximas, com uma diferença percentual de $-5 \%$.

Na figura 4.29, pode-se observar a solicitação ao longo da barra, com relação à aplicação do carregamento. Diferentes solicitações ao longo da barra indicam que a barra não sofreu escorregamento.

$\mathrm{Na}$ figura 4.35, têm-se as solicitações nas barras paralelas a um dos eixos de simetria da laje. Pode-se observar que este gráfico está perfeitamente coerente com o anterior: barras mais próximas à região onde se dá o carregamento apresentam deformações maiores.

A deformação da armadura na posição 5' $\left(1,79^{\circ} \%\right.$ é quase 4 vezes maior que a deformação na posição 4' $\left(0,46^{\circ}\right.$ \%o $)$, indicando uma predominância do esforço transversal ao esforço radial. Para determinar a deformação da posição 5', foi usado apenas o E.10, uma vez que o E.9 apresentou problemas. 


\section{c) Instrumentação da armadura passiva de flexão comprimida (M6)}

Na figura 4.46, tem-se a verificação da simetria através do E.17 e do E.18. Embora ambos apresentem um comportamento similar, a diferença entre as leituras foi grande, de ordem de 190,3\%. Observa-se, no entanto que o nível das deformações foi baixo, da ordem de $0,03 \%$ e $0,09 \%$ para o E.17 e para o E.18, respectivamente. Esta discrepância entre os valores pode ser justificada através das diferentes forças de protensão aplicadas nas direções x e y.

Foi observado um problema no E.20, razão esta pela qual ele não é apresentado na figura 4.52, relacionada à formação de uma charneira. Pode-se observar que não há uma tendência de escoamento das barras nas posições indicadas, muito embora o E.16 apresente uma solicitação bem maior que E.15 e o E.19.

Na figura 4.58, observa-se que, após a ruptura, os extensômetros E.17 e E.18 sofreram uma brusca deformação de tração.

De um modo geral, o comportamento da armadura comprimida do modelo M6 apresentou uma grande semelhança com o comportamento da armadura comprimida do modelo M5.

\section{d) Instrumentação do concreto (M6)}

Com relação à região adjacente ao carregamento, pode-se observar uma grande semelhança entre o comportamento do modelo M6 com o modelo M3.

Com relação à região afastada do carregamento, observa-se um padrão no comportamento de todos os modelos, com pequenas variações.

Com relação às deformações radiais, observa-se uma grande semelhança entre todos os modelos.

Com relação às deformações tangenciais, observa -se uma semelhança maior entre os modelos M6, M5, M3, M2 e, com algumas restrições, o modelo M1. 


\section{e) Instrumentação dos deslocamentos do modelo (M6)}

As leituras dos transdutores D.5 a D.8 referem-se aos deslocamentos dos apoios com relação ao piso do laboratório. Estes valores estão mostrados na tabela 4.4 e foram considerados pequenos para interferir nos resultados obtidos nos ensaios. O sinal positivo na tabela indica um afastamento entre o apoio e o piso.

$\mathrm{Na}$ figura $4.99 \mathrm{~b}$, pode ser observada a região na qual a protensão provocou algumas distorções com relação ao deslocamento. Próximo à ruptura, as diferenças percentuais entre os transdutores D.9 e D.17, D.11 e D16, D.13 e D.15 foram, respectivamente, de $\mathbf{- 6 3 , 2 \%} ; \mathbf{+ 5 0 , 8 \%}$ e $\mathbf{- 5 , 6 \%}$. Embora a diferença percentual possa parecer grande, graficamente pode-se observar que o comportamento do modelo nesta direção tende a ser simétrico.

Já o comportamento observado para os transdutores dispostos ao longo da direção y está mostrado na figura 4.100. Pode-se observar uma tendência de levantamento da região próxima ao transdutor D.25. Próximo à ruptura, as diferenças percentuais entre os transdutores D.18 e D.25, D.19 e D.23, D.20 e D.21 foram, respectivamente, de $\mathbf{5 6 , 4 \%} ; \mathbf{- 2 , 0 \%}$ e $\mathbf{- 1 , 6 \%}$. No entanto, observando os gráficos, pode-se considerar uma certa simetria com relação ao carregamento. Na extremidade direita da figura $4.100 \mathrm{~b}$, pode-se observar a influência que a protensão provoca no deslocamento transversal.

\section{f) Instrumentação da armadura de punção (M6)}

Conforme pode ser visto nas figuras H.23 a H.30, do Anexo H, apenas do E.40 ao E.44 parecem estar funcionando bem. A explicação provável para o mau funcionamento dos extensômetros pode ter sido a falta de cuidado na execução, o que resultou em baixo isolamento, ou durante o posicionamento da malha passiva de tração superior sobre os caranguejos. O resumo dos resultados obtidos com esta instrumentação está ilustrado na figura 5.3. 
Portanto, é feita uma análise qualitativa entre o comportamento dos modelos M3 e M6, uma vez que a maioria dos extensômetros posicionados nos conectores do modelo M6 apresentou defeitos. É vista, na figura 4.115, que a menos da influência que a protensão provoca no gráfico, quando da sua aplicação, as curvas obtidas para os modelos M3 e M6 são bem parecidas entre si, sugerindo um comportamento análogo entre os modelos.

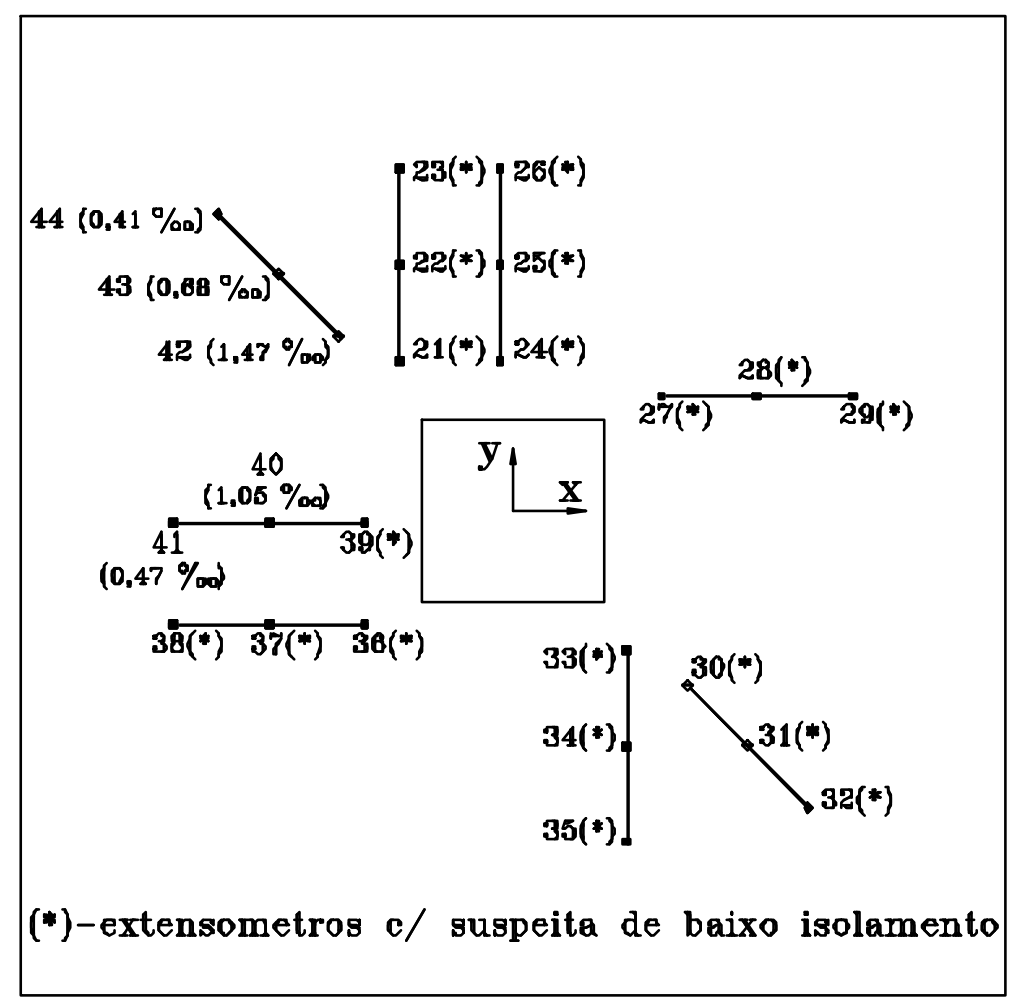

Figura 5.3 - Resultados obtidos e posição dos extensômetros suspeitos de baixo isolamento

g) Instrumentação da força de protensão nas cordoalhas (M6)

Nas tabelas 5.31e 5.32, tem-se o valor médio da protensão, em porcentagem, para as cordoalhas dispostas nas direções y e $\mathrm{x}$, respectivamente. Nessas tabelas, tomou-se, como referência, os valores da protensão após a recuperação das perdas.

De um modo geral, na direção y a perda foi de $22 \%$ e, na direção x, de $24 \%$. 
Observam-se que estes valores estão mais próximos dos do modelo M5, com armadura de punção, do que dos do modelo M4, sem armadura de punção. Na iminência de ruptura, observou-se o acréscimo da força de protensão em torno de $15 \%$ na direção y e $12 \%$ na direção x. Estes valores também estão mais próximos dos do modelo M5 do que dos do modelo M4. Além disso, assim como no modelo M5, o acréscimo de protensão maior foi para as cordoalhas na direção y. Após a ruína, observou-se uma diminuição da força de protensão, cujo valor ficou cerca de $7 \%$ acima da força de protensão obtida no início do ensaio, após a recuperação das perdas, na direção y, e 8\% na direção x. Novamente, observa-se uma proximidade maior de resultados do modelo M6 com o modelo M5 do que com o modelo M4.

Os maiores acréscimos da força de protensão ocorreram nas cordoalhas que atravessavam a região onde o carregamento era aplicado (C2 a C7 e C2' a C7'). Tem-se como exceções as cordoalha C5 e C4', que na iminência da ruptura apresentaram uma força inferior àquela obtida após a recuperação das perdas. Este fa to pode ser explicado através de alguma acomodação das cunhas durante o ensaio.

Tabela 5.31 - Modelo M6: protensão nas cordoalhas dispostas na direção y (em \%)

\begin{tabular}{|c|c|c|c|c|c|c|c|c|c|}
\hline \multirow{2}{*}{ Situação } & \multicolumn{9}{|c|}{ Força de protensão nas cordoalhas dispostas na direção y (\%) } \\
\hline & C.1 & C.2 & C.3 & C.4 & C.5 & C.6 & C.7 & C.8 & Média \\
\hline $1^{a}$.Prot. & 75 & 72 & 68 & 76 & 75 & 79 & 79 & 100 & 78 \\
\hline $\begin{array}{c}\text { Após rec. das } \\
\text { perdas }\end{array}$ & 100 & 100 & 100 & 100 & 100 & 100 & 100 & 100 & 100 \\
\hline Na ruptura & 113 & 118 & 121 & 120 & 98 & 119 & 117 & 113 & 115 \\
\hline Após ruptura & 106 & 119 & 121 & 96 & 98 & 96 & 114 & 108 & 107 \\
\hline
\end{tabular}

Tabela 5.32 - Modelo M6: protensão nas cordoalhas dispostas na direção x (em \%)

\begin{tabular}{|c|c|c|c|c|c|c|c|c|c|}
\hline \multirow{2}{*}{ Situação } & \multicolumn{9}{|c|}{ Força de protensão nas cordoalhas dispostas na direção $x(\%)$} \\
\hline & C.1' & C.2' & C.3' & C.4' & C.5' & C.6' & C.7' & C.8' & Média \\
\hline $1^{\text {a }}$.Prot. & 71 & 75 & 78 & 76 & 78 & 74 & 79 & 79 & 76 \\
\hline $\begin{array}{l}\text { Após rec. } \\
\text { das perdas }\end{array}$ & 100 & 100 & 100 & 100 & 100 & 100 & 100 & 100 & 100 \\
\hline Na ruptura & 109 & 116 & 116 & 97 & 116 & 113 & 115 & 110 & 112 \\
\hline Após ruptura & 104 & 116 & 116 & 98 & 97 & 112 & 112 & 107 & 108 \\
\hline
\end{tabular}




\subsection{ANÁLISE DA PROTENSÃO APLICADA AOS MODELOS}

Nas tabelas 5.33 e 5.34, tem-se os valores médios da protensão aplicada aos modelos, nas direções x e y, em $\mathrm{kN}$ e em porcentagem, respectivamente.

Na tabela 5.33, observa-se, ainda, que a recuperação das perdas não foi tão eficiente para o modelo M5, quanto para os outros modelos. Na tabela 5.34, observa-se que a armadura de punção proporcionou um aumento na força de protensão aplicada ao modelo, no instante da ruptura.

Tabela 5.33 - Valores médios da protensão nas cordoalhas, em kN

\begin{tabular}{|c|c|c|c|c|}
\hline Modelo/Situação & 1'Prot. & $\begin{array}{c}\text { Após recuperação } \\
\text { das perdas }\end{array}$ & Na ruptura & Após ruptura \\
\hline M4 - direção x & 99,1 & 130,5 & 136,7 & 134,3 \\
M4 - direção y & 95,9 & 130,7 & 137,8 & 135,0 \\
\hline M5 - direção x & 98,0 & 122,8 & 136,7 & 129,5 \\
M5 - direção y & 98,8 & 125,1 & 146,1 & 140,1 \\
\hline M6 - direção x & 99,5 & 130,4 & 145,5 & 140,7 \\
M6 - direção y & 101,3 & 130,1 & 149,4 & 139,5 \\
\hline
\end{tabular}

Tabela 5.34 - Valores médios da protensão nas cordoalhas, em termos de porcentagem

\begin{tabular}{|c|c|c|c|c|}
\hline Modelo/Situação & 1'Prot. & $\begin{array}{c}\text { Após recuperação } \\
\text { das perdas }\end{array}$ & Na ruptura & Após ruptura \\
\hline M4 - direção x & 76 & 100 & 105 & 103 \\
M4 - direção y & 73 & 100 & 105 & 103 \\
\hline M5 - direção x & 80 & 100 & 111 & 105 \\
M5 - direção y & 79 & 100 & 117 & 112 \\
\hline M6 - direção x & 76 & 100 & 112 & 108 \\
M6 - direção y & 78 & 100 & 115 & 107 \\
\hline
\end{tabular}




\subsection{PREVISÃO DA FORÇA RESPONSÁVEL PELA RUÍNA DO MODELO}

De modo a melhor caracterizar a ruína da ligação, apresenta-se o dimensionamento das lajes de concreto à flexão, calculada através da teoria das charneiras plásticas, bem como o dimensionamento do modelo com relação à punção, utilizando formulações dadas por alguns códigos e normas, especificados nos itens a seguir.

\subsubsection{DIMENSIONAMENTO DOS MODELOS DE CONCRETO ARMADO À FLEX ̃̃O}

No Brasil, a resistência do concreto à compressão é determinada por meio de ensaios padronizados de corpos-de-prova cilíndricos, com $15 \mathrm{~cm}$ de diâmetro e $30 \mathrm{~cm}$ de altura. No caso de concretos com resistência acima de $50 \mathrm{MPa}$, a limitação imposta pela capacidade das prensas tem levado à adoção de corpos-de-prova cilíndricos com $10 \mathrm{~cm}$ de diâmetro e $20 \mathrm{~cm}$ de altura.

De acordo com as normas brasileiras, a resistência do concreto estrutural é especificada pelo valor de sua resistência característica $\left(\mathrm{f}_{\mathrm{ck}}\right)$ aos 28 dias de idade.

Para a verificação da segurança, em relação a estados limites últimos, considera-se o valor da resistência de cálculo $\left(\mathrm{f}_{\mathrm{cd}}\right)$ igual a :

- $\mathrm{f}_{\mathrm{cd}}=\frac{\mathrm{f}_{\mathrm{ck}}}{\gamma_{\mathrm{c}}} ;$ com $\gamma_{\mathrm{c}}$ sendo o coeficiente de minoração da resistência do concreto, tomado usualmente como sendo igual a 1,4.

O coeficiente de minoração da resistência do concreto $\left(\gamma_{c}\right)$ pode ser considerado como sendo o produto de três outros coeficientes parciais:

$$
\gamma_{c}=\gamma_{c 1} \cdot \gamma_{c 2} \cdot \gamma_{c 3}
$$


O termo $\gamma_{\mathrm{c} 1}$ considera a real variabilidade intrínseca do concreto; o termo $\gamma_{\mathrm{c} 2}$ leva em conta o fato de o processo de produção do concreto da estrutura ser significativamente diferente do processo de fabricação dos corpos-de-prova de controle e o termo $\gamma_{\mathrm{c} 3}$ considera os eventuais defeitos localizados.

FUSCO (1995) menciona que, para a avaliação da segurança das estruturas, especialmente nos problemas de flexão, simples ou composta, no estado limite último de ruptura do concreto comprimido, admite-se que, no plano da seção transversal, possa atuar uma tensão de compressão no máximo igual a $0,85 \mathrm{f}_{\mathrm{cd}}$. Este coeficiente $\mathrm{k}_{\text {mod }}=0,85$, aplicado ao valor de $\mathrm{f}_{\mathrm{cd}}$, representa o produto de três outros coeficientes:

- $\mathrm{k}_{\bmod }=\mathrm{k}_{\bmod , 1} \cdot \mathrm{k}_{\bmod , 2} \cdot \mathrm{k}_{\bmod , 3} ;$ onde:

- $\mathrm{k}_{\text {mod,1 }}=1,2$ (coeficiente que leva em conta o acréscimo de resistência do concreto após os 28 dias de idade);

- $\mathrm{k}_{\bmod , 2}=0,95$ (coeficiente que leva em conta o fato de que a resistência medida nos corpos-de-prova de 15 de diâmetro e $30 \mathrm{~cm}$ de altura é superestimada, devido ao atrito do corpo-de-prova com os pratos da prensa de ensaio);

- $\mathrm{k}_{\text {mod,3 }}=0,75$ (coeficiente que leva em conta o efeito deletério da ação de cargas de longa duração).

Esse efeito destruidor das cargas que permanecem atuando ao longo do tempo já se manifesta de modo importante após algumas semanas de atuação.

Deste modo, nos estados limites últimos de ruptura em que o concreto esteja praticamente submetido a estados de tensão de compressão simples, sua resistência última efetiva vale $0,85 \mathrm{f}_{\mathrm{cd}}$.

Considerando-se que no ensaio experimental ter-se-á apenas a influência do coeficiente $\mathrm{k}_{\text {mod,2 }}$, então a resistência experimental no estado limite último de solicitação normal deverá ser igual a 0,95 €. O dimensionamento dos modelos à flexão foi feito considerando-se o diagrama parábola-retângulo, tendo sido adotada a resistência do concreto obtida no dia do ensaio. 
Com relação à armadura foram usados os valores dados no capítulo 3. As planilhas de cálculo usadas para o dimensionamento dos momentos resistentes dos modelos M1 a M3 foram elaboradas através do "software" Mathcad e estão mostradas no Anexo I.

A força concentrada $(\mathrm{F})$ responsável pela ruína da laje por flexão foi calculada com base na teoria das charneiras plásticas. Para este tipo de carregamento tem-se duas possibilidades: charneiras diagonais ou radiais e circular.

a) Charneiras diagonais (figura 5.4)

$\mathrm{F}=4 \mathrm{~m}_{\mathrm{x}}(1+\mu), \quad$ com $\mu=\mathrm{m}_{\mathrm{y}} / \mathrm{m}_{\mathrm{x}}$, sendo $\mathrm{m}_{\mathrm{x}}$ e $\mathrm{m}_{\mathrm{y}}$ os momentos de plastificação distribuídos nas direções x e y, respectivamente.

b) Charneiras radiais e circular (figura 5.5)

$$
\mathrm{F}=2 \pi\left(\mathrm{m}_{\mathrm{x}}^{\prime}+\mathrm{m}_{\mathrm{x}}\right) \sqrt{\mu} ; \text { com } \mu=\mathrm{m}_{\mathrm{y}} / \mathrm{m}_{\mathrm{x}}=\mathrm{m}_{\mathrm{y}}^{\prime} / \mathrm{m}_{\mathrm{x}}^{\prime} \quad \text { (no caso, }
$$

adotou-se $\left.\mu=\mathrm{m}_{\mathrm{y}} / \mathrm{m}_{\mathrm{x}}\right)$

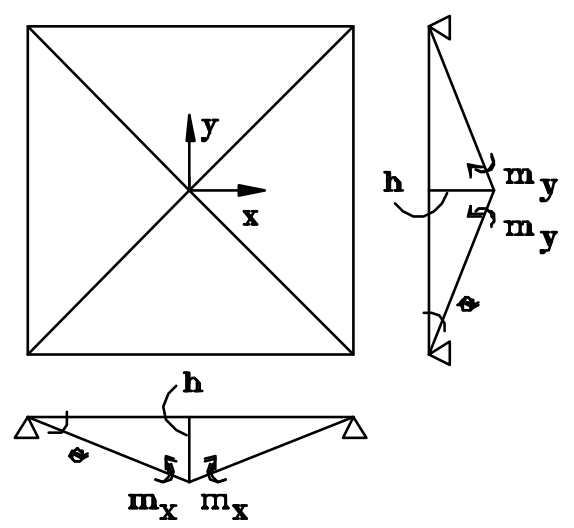

Figura 5.4 - Charneiras diagonais

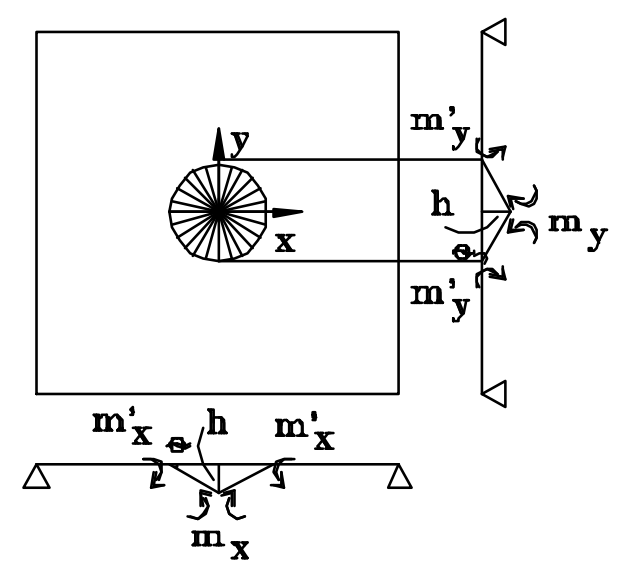

Figura 5.5 - Charneiras radiais e circular

Com relação às charneiras definidas no item a), observa-se que a existência de significativos momentos torçores na região dos cantos dos apoios tenderão a levantá-los, reduzindo, deste modo, o valor da carga máxima que pode ser aplicada à laje. 
No entanto, PARK \& GAMBLE (1980) mencionam que esta redução não será significativa desde que os cantos sejam devidamente armados.

LEONHARDT (1979) apresenta a seguinte explicação com base na teoria das charneiras plásticas: em um canto formado por duas bordas simplesmente apoiadas, representadas pelas linhas $0-1$ e $0-3$, observa-se que a charneira 0-2, entre as partes A e B da laje, dirige-se para o canto onde está situado o ponto de intersecção dos eixos de rotação 0-1 e 0-3 (figura 5.6a). No entanto, para o equilíbrio do nó, as forças nodais $\mathrm{K}_{\mathrm{a}} \mathrm{e}$ $\mathrm{K}_{\mathrm{b}}$ devem ser contrabalançadas por uma força $\mathrm{K}_{\mathrm{O}}=-\left(\mathrm{K}_{\mathrm{a}}+\mathrm{K}_{\mathrm{b}}\right)$, sendo esta condição representada pela figura 5.6a. Sendo assim, o canto deve então ser armado e ancorado para esta força. Não existindo ancoragem, a charneira se bifurca (figura 5.6b), formando uma outra charneira representada pela linha que divide as partes D e C da laje (figura 5.6c). A parte $\mathrm{C}$ da laje é denominada de "báscula" porque ela pode bascular em torno da linha a-b. As básculas reduzem a carga de ruptura da laje.

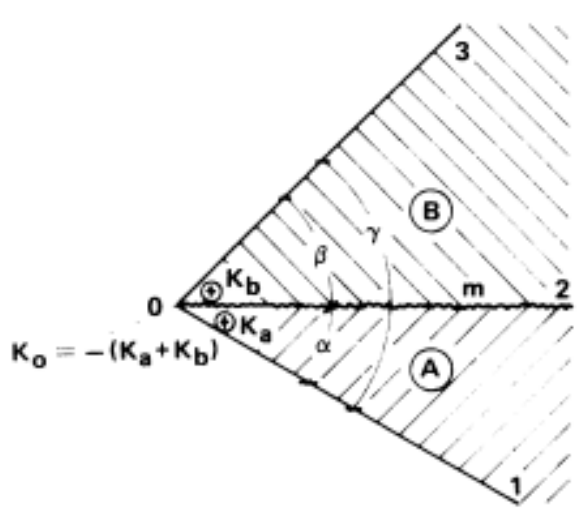

a) Equilíbrio do nó

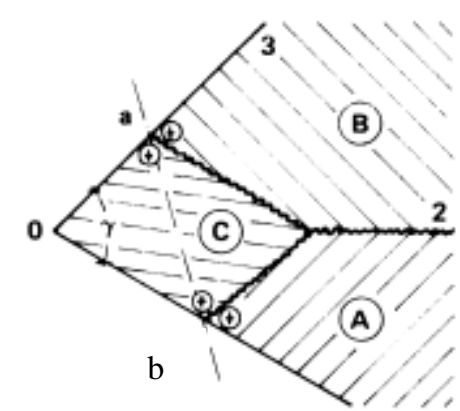

b) Bifurcação da charneira

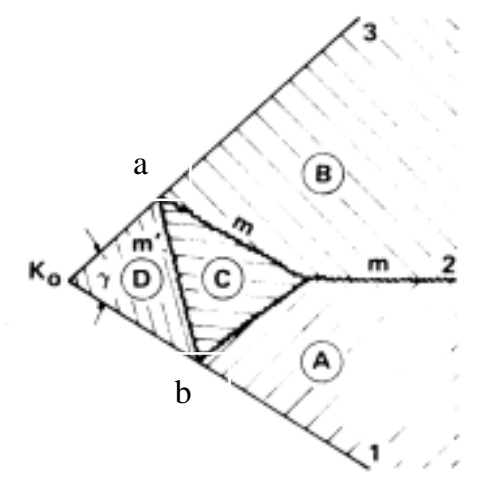

c) Formação da "báscula"

Figura 5.6 - Levantamento dos cantos 
Portanto, determinado-se os momentos $\mathrm{m}_{\mathrm{x}}, \mathrm{m}_{\mathrm{x}}$, $\mathrm{m}_{\mathrm{y}} \mathrm{e} \mathrm{m}_{\mathrm{y}}$, pode-se então determinar a força concentrada máxima (F) que pode ser aplicada à laje.

Os resultados obtidos encontram-se nas tabelas 5.35 e 5.36 .

Tabela 5.35 - Momentos fletores $(\mathrm{kN} . \mathrm{m} / \mathrm{m})$ e coeficiente $\mu$

\begin{tabular}{|c|c|c|c|c|c|}
\hline Modelo & $\mathrm{m}_{\mathrm{x}}$ & $\mathrm{m}_{\mathrm{x}}^{\prime}$ & $\mathrm{M}_{\mathrm{y}}$ & $\mathrm{m}_{\mathrm{y}}$ & $\mu\left(=\mathrm{m}_{\mathrm{y}} / \mathrm{m}_{\mathrm{x}}\right)$ \\
\hline M1 & 137,00 & 40,48 & 115,66 & 44,85 & 0,844 \\
\hline M2 & 143,06 & 44,19 & 123,72 & 55,54 & 0,865 \\
\hline M3 & 118,64 & 44,72 & 103,08 & 55,00 & 0,869 \\
\hline
\end{tabular}

Tabela 5.36 - Força concentrada máxima que pode ser aplicada aos modelos, através da teoria das charneiras plásticas

\begin{tabular}{|c|c|c|c|}
\hline Modelo & $\begin{array}{c}\text { Força dada pela } \\
\text { charneira circular }(\mathrm{kN})\end{array}$ & $\begin{array}{c}\text { Força dada pela } \\
\text { charneira diagonal }(\mathrm{kN})\end{array}$ & $\begin{array}{c}\text { Força que provocou a } \\
\text { ruptura do modelo }(\mathrm{kN})\end{array}$ \\
\hline M1 & 1024,6 & 1010,6 & 441,6 \\
\hline M2 & 1094,1 & 1067,1 & 863,8 \\
\hline M3 & 886,9 & 956,7 & 905,8 \\
\hline
\end{tabular}

\subsubsection{DIMENSIONAMENTO DAS LAJES DE CONCRETO PROTENDIDO $\grave{A}$ FLEXÃO}

Esta análise foi feita de um modo bastante simplificado, utilizando-se a teoria do "Load Balancing". Nesta teoria, a cordoalha é substituída pelos esforços que ela provoca na laje. Estes esforços correspondem a uma força de compressão no plano da laje e a uma força uniformemente distribuída ao longo da cordoalha, perpendicular ao plano médio da laje, provocada pela tendência da cordoalha em se retificar (figura 5.7). 

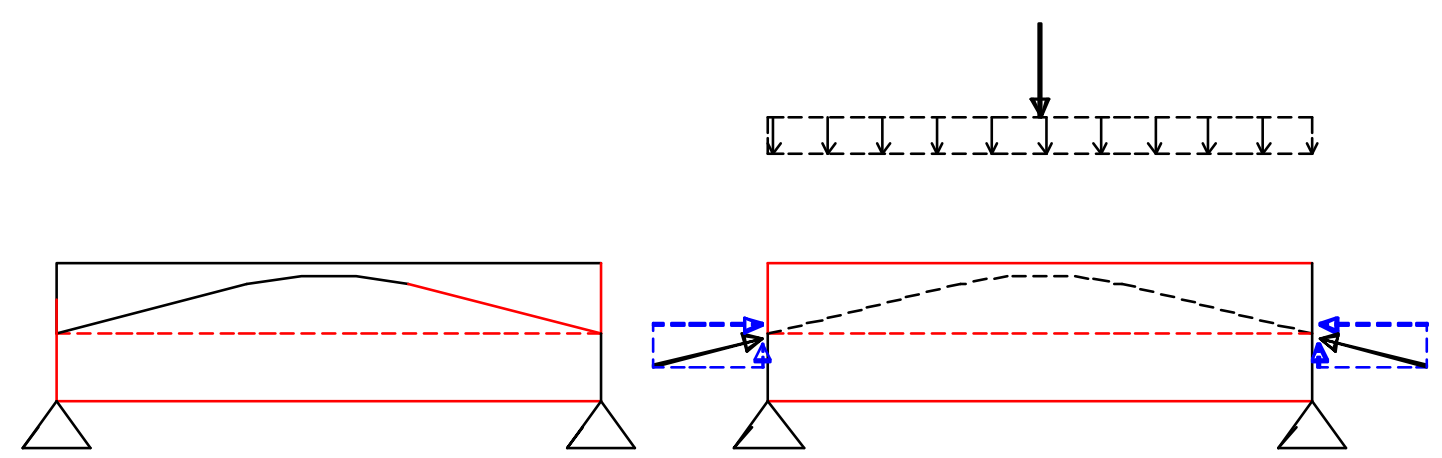

Figura 5.7 - Substituição da cordoalha pelos esforços que ela provoca na laje

Em função do macaco não permitir o deslocamento vertical no ponto central da laje, surge o esforço hiperestático de protensão (figura 5.8).

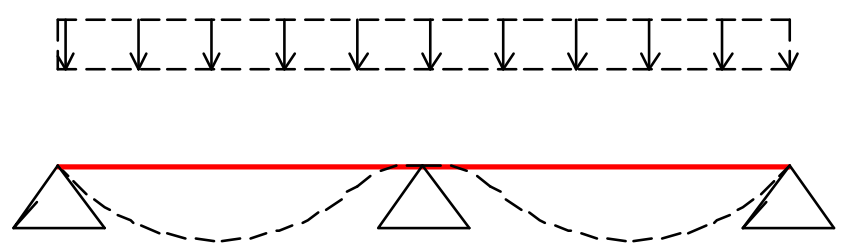

Figura 5.8 - Esforço hiperestático de protensão em função da presença do macaco hidráulico

Este efeito pôde ser comprovado por ocasião da protensão das cordoalhas. Nos modelos M4, M5 e M6, o valor do acréscimo de esforço no macaco, em função do esforço hiperestático de protensão foi de, respectivamente: $111,5 \mathrm{kN}, 86,8 \mathrm{kN}$, e $103 \mathrm{kN}$.

Para o dimensionamento à flexã o dos modelos protendidos, o cálculo dos momentos é feito considerando-se a laje como estando submetida a uma flexo-compressão, decorrente da compressão no plano da laje. 
Em seguida, a força de ruína $\mathrm{F}$ é calculada com a formulação das charneiras plásticas, através dos momentos $\mathrm{m}_{\mathrm{x}}, \mathrm{m}_{\mathrm{x}}{ }^{\prime}, \mathrm{m}_{\mathrm{y}} \mathrm{e} \mathrm{m}_{\mathrm{y}}{ }^{\prime}$, mostrados na tabela 5.37. Pode-se, então determinar a força concentrada máxima $(\mathrm{F})$ que pode ser aplicada à laje. Para se levar em conta o efeito do esforço hiperestático, os valores obtidos experimentalmente foram somados ao valor de F. Os resultados obtidos encontram-se na tabela 5.38.

Tabela 5.37 - Momentos fletores $(\mathrm{kN} . \mathrm{m} / \mathrm{m})$ e coeficiente $\mu$

\begin{tabular}{|c|c|c|c|c|c|}
\hline Modelo & $\mathrm{m}_{\mathrm{x}}$ & $\mathrm{m}^{\prime} \mathrm{x}$ & $\mathrm{m}_{\mathrm{y}}$ & $\mathrm{m}_{\mathrm{y}}$ & $\mu\left(=\mathrm{m}_{\mathrm{y}} / \mathrm{m}_{\mathrm{x}}\right)$ \\
\hline M4 & 128,97 & - & 119,09 & - & 0,923 \\
\hline M5 & 128,78 & - & 120,86 & - & 0,938 \\
\hline M6 & 128,12 & - & 118,73 & - & 0,927 \\
\hline
\end{tabular}

Tabela 5.38 - Força concentrada máxima que pode ser aplicada aos modelos, dada pela teoria das charneiras plásticas, com o esforço hiperestático de protensão

\begin{tabular}{|c|c|c|c|}
\hline Mod. & $\begin{array}{c}\text { Força dada pela } \\
\text { charneira circular }(\mathrm{kN})\end{array}$ & $\begin{array}{c}\text { Força dada pela } \\
\text { charneira diagonal }(\mathrm{kN})\end{array}$ & $\begin{array}{c}\text { Força que provocou a } \\
\text { ruptura do modelo }(\mathrm{kN})\end{array}$ \\
\hline M4 & $778,52+111,5=890,02^{*}$ & $992,0+111,5=1103,5$ & 772,6 \\
\hline M5 & $783,66+86,8=870,46^{*}$ & $998,30+86,8=1085,10$ & 1104,1 \\
\hline M6 & $775,06+103=878,06^{*}$ & $987,54+103=1090,54$ & 1077,8 \\
\hline \multicolumn{3}{|c|}{ *Para a charneira circular, a favor da segurança, não foram calculados $\mathrm{m}_{\mathrm{x}}$ ' e $\mathrm{m}_{\mathrm{y}}{ }^{\prime}$, que } \\
\multicolumn{4}{|c|}{ forneceriam um acréscimo de resistência na ligação } \\
\hline
\end{tabular}

As planilhas usadas para o cálculo dos momentos resistentes dos modelos M4 a M6 foram elaboradas através do "software" Mathcad e estão mostradas no Anexo I. 


\subsubsection{PREVISÃO DO CARREGAMENTO DE RUÍNA DEVIDO À PUNÇÃO}

Para comparar resultados teóricos com experimentais em peças de concreto armado e protendido, alguns aspectos devem ser, primeiramente, abordados.

Segundo CORDOVIL (1995), a comparação de resultados de ensaios com as cargas últimas dadas pelos códigos do ACI 318/89, do CEB/90 e da NB-1/78 é possível quando se estabelecem as condições necessárias para a avaliação das cargas últimas, de cada código, em função das resistências obtidas em laboratório.

De um modo geral, para a determinação da carga característica de ruína dada pelas normas, basta substituir o valor de $f_{\mathrm{ed}}$ pelo valor do $\mathrm{fk}_{\mathrm{k}}$. Essa substituição eliminaria o coeficiente de segurança de minoração da resistência do concreto. No entanto, com relação à punção, algumas expressões não estão diretamente relacionadas ao $\mathrm{f}_{\mathrm{cd}}$. Nesses casos, deve-se utilizar outro procedimento.

Como em um laboratório, as condições para a execução de elementos estruturais são profundamente controladas, pode-se substituir o valor de $\ell_{k}$ pelo de $f_{c}$, visando, deste modo, a transformação de valores característicos em valores médios.

$\mathrm{Na}$ análise dos resultados relativos aos modelos de concreto armado, serão adotadas as recomendações da FIP (1999) e da fib (1999) ao invés das recomendações dadas pelo CEB/90. Na verdade, tanto a FIP (1999) como a fib (1999) representam uma atualização das recomendações do CEB/90. A diferença entre eles está na definição da tensão resistente usada no dimensionamento da região adjacente ao pilar. Supõe-se que a fib (1999) esteja mais coerente com o fenômeno físico, já que considera o valor de $\mathrm{f}_{\mathrm{cd} 2}$ (resistência à compressão do concreto fissurado), ao contrário da FIP (1999), que considera do valor de $\mathrm{f}_{1 \mathrm{~cd}}$. Além disso, existe uma limitação ao valor do termo dado por $(1+\sqrt{20 / d})$, imposta pela FIP (1999).

Em uma das verificações da resistência da ligação laje-pilar, com relação à punção, o CEB/90 apresenta a seguinte expressão de uma tensão resistente de cálculo $\left(\mathrm{f}_{\mathrm{cd}}\right)$, relativa à região adjacente ao pilar: 


$$
\mathrm{f}_{\mathrm{cd} 2}=0,6\left[1-\frac{\mathrm{f}_{\mathrm{ck}}}{250}\right] \mathrm{f}_{\mathrm{cd}}
$$

Pode-se substituir o valor de $\mathrm{f}_{\mathrm{cd}}$ por $\left(\mathrm{f}_{\mathrm{ck}} / \gamma_{\mathrm{c}}\right)$, sem alterar o conceito de tensão resistente de cálculo.

$$
\mathrm{f}_{\mathrm{cd} 2}=0,6\left[1-\frac{\mathrm{f}_{\mathrm{ck}}}{250}\right] \frac{\mathrm{f}_{\mathrm{ck}}}{\gamma_{\mathrm{c}}}
$$

Para obter o valor da tensão resistente característica, multiplica-se $€$ Łd2 pelo coeficiente $\gamma_{c}$.

$$
\mathrm{f}_{\mathrm{ck} 2}=\gamma_{\mathrm{c}} \cdot \mathrm{f}_{\mathrm{cd} 2}=\gamma_{\mathrm{c}} \cdot 0,6\left[1-\frac{\mathrm{f}_{\mathrm{ck}}}{250}\right] \frac{\mathrm{f}_{\mathrm{ck}}}{\gamma_{\mathrm{c}}}
$$

Cancelando-se os coeficientes de segurança obtém-se a seguinte expressão:

$$
\mathrm{f}_{\mathrm{ck} 2}=\gamma_{\mathrm{c}} \cdot \mathrm{f}_{\mathrm{cd} 2}=0,6\left[1-\frac{\mathrm{f}_{\mathrm{ck}}}{250}\right] \mathrm{f}_{\mathrm{ck}}
$$

Portanto, para se obter o valor característico da tensão, neste caso, bastou substituir $\mathrm{f}_{\mathrm{cd}}$ por $\mathrm{f}_{\mathrm{ck}}$, lembrando-se que ao substituir o valor de $\mathrm{f}_{\mathrm{cd}}$ pelo de $\mathrm{f}_{\mathrm{ck}}$, o coeficiente $\gamma_{\mathrm{c}}$ é eliminado. Para análises experimentais, substitui-se, na expressão (2), o valor de $f_{\text {ck }}$ pelo de $f_{c}$.

Já o valor da tensão resistente de cálculo com relação à punção, conforme o CEB/90, para uma região afastada de $2 \mathrm{~d}$ da face do pilar, é dado pela expressão (para ligações sem armadura de punção):

$$
\tau_{\mathrm{rd}}=0,12 \xi(100 \rho)^{(1 / 3)} \sqrt[3]{\mathrm{f}_{\mathrm{ck}}}
$$


Embora $\tau_{\mathrm{rd}}$ seja uma tensão resistente de cálculo, ela não está em função de $\mathrm{f}_{\mathrm{cd}}$. Aplicando o raciocínio anterior, para se transformar a expressão de cálculo em uma expressão característica, bastaria multiplicar a expressão de cálculo pelo coeficiente de segurança.

$$
\begin{aligned}
& \tau_{\mathrm{rk}}=\gamma_{\mathrm{c}} \cdot \tau_{\mathrm{rd}}=\gamma_{\mathrm{c}} \cdot 0,12 \xi(100 \rho)^{(1 / 3)} \sqrt[3]{\mathrm{f}_{\mathrm{ck}}}=1,5 \cdot 0,12 \xi(100 \rho)^{(1 / 3)} \sqrt[3]{\mathrm{f}_{\mathrm{ck}}} \\
& \tau_{\mathrm{rk}}=0,18 \xi(100 \rho)^{(1 / 3)} \sqrt[3]{\mathrm{f}_{\mathrm{ck}}}
\end{aligned}
$$

Agora, retirado o coeficiente de segurança, bastaria substituir $\mathrm{f}_{\mathrm{ck}}$ por $\mathrm{f}_{\mathrm{c}}$, para se obter um valor médio da resistência experimental de uma ligação. Este procedimento é adotado por HALLGREN \& KINNUNEN (1996) e RAMDANE (1996).

No entanto, a fib (1999), no seu item 7.4, menciona que o coeficiente aplicado à expressão deve ser de 1,33 e não de 1,5. Portanto, tem-se que o valor característico da tensão de cisalhamento resistente é dada pela expressão:

$$
\tau_{\mathrm{rk}}=0,16 \xi(100 \rho)^{(1 / 3)} \sqrt[3]{\mathrm{f}_{\mathrm{ck}}}
$$

A justificativa dada é que, embora o coeficiente de segurança igual a 1,5 não esteja diretamente aplicado à expressão, quando se transfere um coeficiente de 1,33 para dentro da raiz cúbica, o coeficiente de segurança diretamente aplicado ao $\mathrm{f}_{\mathrm{ck}}$ é superior a 1,5.

Embora esta recomendação tenha sido adotada neste trabalho, faz-se aqui uma crítica ao método usado para definir o coeficiente de segurança.

Como um exemplo, o mais prático seria, após a plotagem de diversos pontos em um gráfico, que relacionassem a resistência da ligação com a resistência dos corpos-de-prova $\left(f_{c}\right)$, obter uma curva representada através de uma função que, por sua vez, sofreria a influência de um coeficiente de segurança.

Como exemplo, será adotada uma expressão da resistência da ligação dada pela raiz cúbica da resistência à compressão do corpo-de-prova $\mathrm{f}_{\mathrm{c}}$ (figura 5.9). 


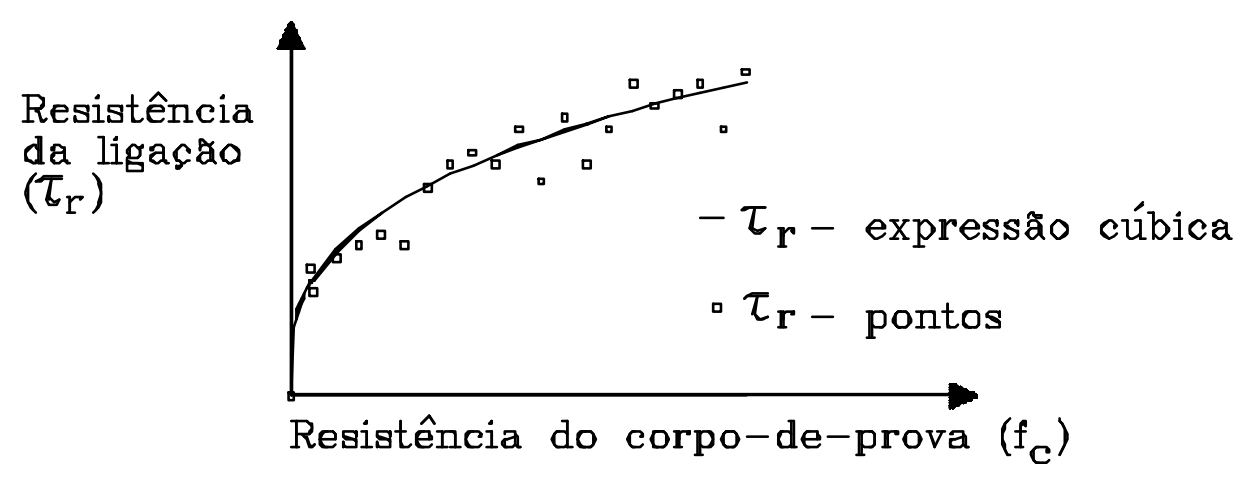

Figura 5.9 - Curva obtida em função de resultados experimentais

Como a resistência média não é um bom parâmetro para caracterizar a resistência do material, com relação ao projeto de estruturas, substitui-se na expressão o valor de $\mathrm{f}_{\mathrm{ck}}$ ao invés do valor de $\mathrm{f}_{\mathrm{c}}$, garantindo uma melhor caracterização da resistência do material. Supondo-se que a relação entre a resistência da ligação e a resistência do material possa ser dada por uma expressão do tipo ilustrado abaixo, questiona-se agora como aplicar o coeficiente de segurança $\gamma_{c}$.

$$
\tau_{\mathrm{rk}}=\text { coeficiente } \cdot \sqrt[3]{\mathrm{f}_{\mathrm{ck}}}
$$

Lembra-se que a substituição de $\mathrm{f}_{\mathrm{c}}$ por $\mathrm{f}_{\mathrm{ck}}$ apenas visa a uma melhor caracterização da resistência do material. Caso o coeficiente de segurança seja aplicado diretamente em $\mathrm{f}_{\mathrm{ck}}$, observa-se que o coeficiente de segurança da ligação ficaria afetado do efeito da raiz cúbica, diminuindo do valor de 1,5 para 1,14.

Isto quer dizer que a resistência da ligação estaria afetada por um fator de segurança igual a 1,14, o que não é lógico, uma vez que a ruína por punção é do tipo frágil e a margem de segurança da ligação estaria sendo diminuída.

$$
\tau_{\mathrm{rd}}=\text { coef. } \sqrt[3]{\frac{\mathrm{f}_{\mathrm{ck}}}{\gamma_{\mathrm{c}}}}=\operatorname{coef} \cdot \sqrt[3]{\frac{\mathrm{f}_{\mathrm{ck}}}{1,5}}=\frac{\operatorname{coef} \cdot \sqrt[3]{\mathrm{f}_{\mathrm{ck}}}}{\sqrt[3]{1,5}}=\frac{\operatorname{coef} \cdot \sqrt[3]{\mathrm{f}_{\mathrm{ck}}}}{1,14} \quad \text { (Inadequado) }
$$


A outra opção que resta seria a de se aplicar a segurança diretamente na expressão que define a resistência da ligação. Este procedimento está ilustrado na figura 5.10. Portanto, considera-se que esta última opção seja a mais adequada.

$$
\tau_{\mathrm{rd}}=\frac{\tau_{\mathrm{rk}}}{\gamma_{\mathrm{c}}}=\frac{\text { coef. } \sqrt[3]{\mathrm{f}_{\mathrm{ck}}}}{\gamma_{\mathrm{c}}}=\frac{\text { coef. } \sqrt[3]{\mathrm{f}_{\mathrm{ck}}}}{1,5}
$$

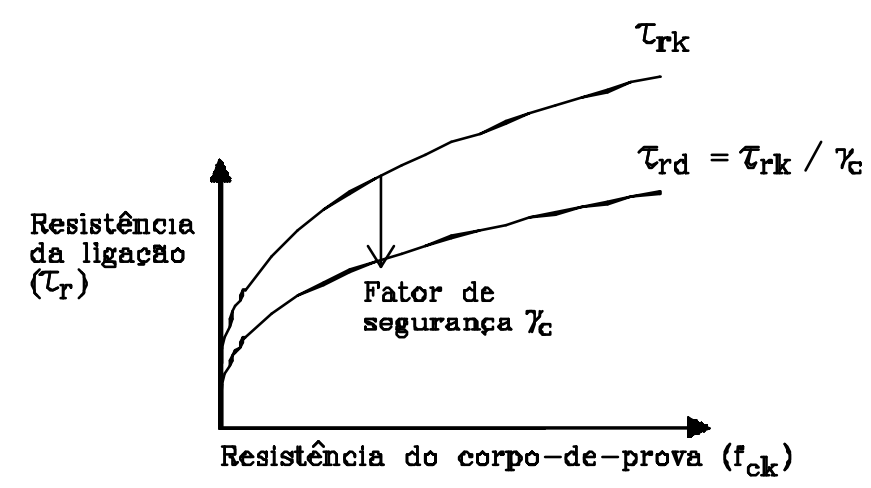

Figura 5.10 - Procedimento para a aplicação do coeficiente de segurança $\gamma_{c}$

Com relação ao ACI 318/95, para a verificação da punção de uma ligação lajepilar, sem armadura de punção, tem-se a seguinte expressão:

$$
\mathrm{v}_{\mathrm{u}} \leq \mathrm{v}_{\mathrm{n}}=\phi \mathrm{v}_{\mathrm{c}}=\phi \sqrt{\mathrm{f}^{\prime}{ }_{\mathrm{c}}}=0,85 \sqrt{\mathrm{f}^{\prime}{ }_{\mathrm{c}}} ; \text { onde: }
$$

$\mathrm{v}_{\mathrm{u}}=$ tensão atuante de cálculo

$\mathrm{v}_{\mathrm{n}}=$ tensão resistente de cálculo

$\phi=$ coeficiente de segurança igual a 0,85 para o caso de torção e cisalhamento.

$\mathrm{f}_{\mathrm{c}}=$ resistência característica do concreto (análogo a $\mathrm{f}_{\mathrm{ck}}$ )

Pode-se observar que o coeficiente de segurança $\phi$ está explícito na formulação do ACI. Já nas recomendações dadas pela revisão da NB-1 (2000), pela FIP (1999) e fib (1999), não se tem explicitamente definido o coeficiente de segurança utilizado para a verificação da punção. 
Sendo assim, seguindo a recomendação da fib (1999), adotou-se o coeficiente de 1,33, relativo à parcela correspondente à resistência do concreto, tanto para a FIP (1999) como para a fib (1999). Como a revisão da NB-1 (2000) é baseada nas recomendações do CEB/90 e, para estar a favor da segurança, adotou-se o mesmo coeficiente. Já para a NBR 6118, adotou-se um coeficiente de segurança igual a 1,4.

Portanto, para a correta comparação das normas com resultados experimentais, com relação à previsão da carga de ruína, deve-se utilizar o valor de $\mathrm{f}_{\mathrm{c}}$ ao invés de $\mathrm{f}_{\mathrm{ck}} \mathrm{e}$ retirar os parâmetros de segurança que diminuem a resistência dos materiais.

As planilhas relativas à previsão das cargas de ruína, com relação à punção e às normas mencionadas estão no Anexo J. Já as recomendações das normas e códigos encontram-se nos Anexos K a O. As recomendações presentes nestes anexos referem-se apenas à situação de ligações laje-pilar interno, com carregamento centrado.

Nas tabelas 5.39 e 5.40, têm-se os valores calculados e os obtidos experimentalmente. $\mathrm{Na}$ tabela 5.41 tem-se a posição da superfície de ruína previstas pelas normas. Na figura 5.11, tem-se a representação gráfica dos dados representados da tabela 5.39 .

Tabela 5.39 - Previsão da força de ruína

\begin{tabular}{|c|c|c|c|c|c|c|}
\hline \multirow{2}{*}{ Modelo } & \multicolumn{7}{|c|}{ Força de ruptura } \\
\cline { 2 - 7 } & NBR 6118 & ACI & Revisão da & FIP/99 \\
$(\mathrm{kN})$ & $(\mathrm{kN})$ & NB-1 $(\mathrm{kN})$ & $\begin{array}{c}\text { fib/99 } \\
(\mathrm{kN})\end{array}$ & $\begin{array}{c}\text { Força medida } \\
(\mathrm{kN})\end{array}$ & no ensaio $(\mathrm{kN})$ \\
\hline M1 & 231,86 & 268,31 & 399,93 & 327,72 & 369,17 & 441,6 \\
\hline M2 & 623,01 & 332,11 & 676,51 & 552,17 & 624,47 & 863,8 \\
\hline M3 & 608,07 & 410,63 & 779,42 & 634,88 & 719,46 & 905,8 \\
\hline M4 & 367,13 & 512,33 & 476,34 & 411,52 & 452,08 & 772,6 \\
\hline M5 & 749,90 & 360,98 & 690,01 & 581,63 & 641,38 & 1104,1 \\
\hline M6 & 693,53 & 450,47 & 776,69 & 656,77 & 724,92 & 1077,8 \\
\hline
\end{tabular}


Tabela 5.40 - Previsão da força de ruína (em porcentagem)

\begin{tabular}{|c|c|c|c|c|c|c|}
\hline \multirow{3}{*}{ Modelo } & \multicolumn{6}{|c|}{ Força de ruptura (em porcentagem) } \\
\cline { 2 - 7 } & $\begin{array}{c}\text { NBR 6118 } \\
(\mathrm{kN})\end{array}$ & $\begin{array}{c}\text { ACI } \\
(\mathrm{kN})\end{array}$ & $\begin{array}{c}\text { Revisão da } \\
\text { NB-1 }(\mathrm{kN})\end{array}$ & $\begin{array}{c}\text { FIP/99 } \\
(\mathrm{kN})\end{array}$ & $\begin{array}{c}\text { fib/99 } \\
(\mathrm{kN})\end{array}$ & $\begin{array}{c}\text { Força medida } \\
\text { no ensaio }(\mathrm{kN})\end{array}$ \\
\hline M1 & $53 \%$ & $61 \%$ & $91 \%$ & $74 \%$ & $84 \%$ & $100 \%$ \\
\hline M2 & $72 \%$ & $38 \%$ & $78 \%$ & $64 \%$ & $72 \%$ & $100 \%$ \\
\hline M3 & $67 \%$ & $45 \%$ & $86 \%$ & $70 \%$ & $79 \%$ & $100 \%$ \\
\hline M4 & $48 \%$ & $66 \%$ & $62 \%$ & $53 \%$ & $59 \%$ & $100 \%$ \\
\hline M5 & $68 \%$ & $33 \%$ & $62 \%$ & $53 \%$ & $58 \%$ & $100 \%$ \\
\hline M6 & $64 \%$ & $42 \%$ & $72 \%$ & $61 \%$ & $67 \%$ & $100 \%$ \\
\hline
\end{tabular}

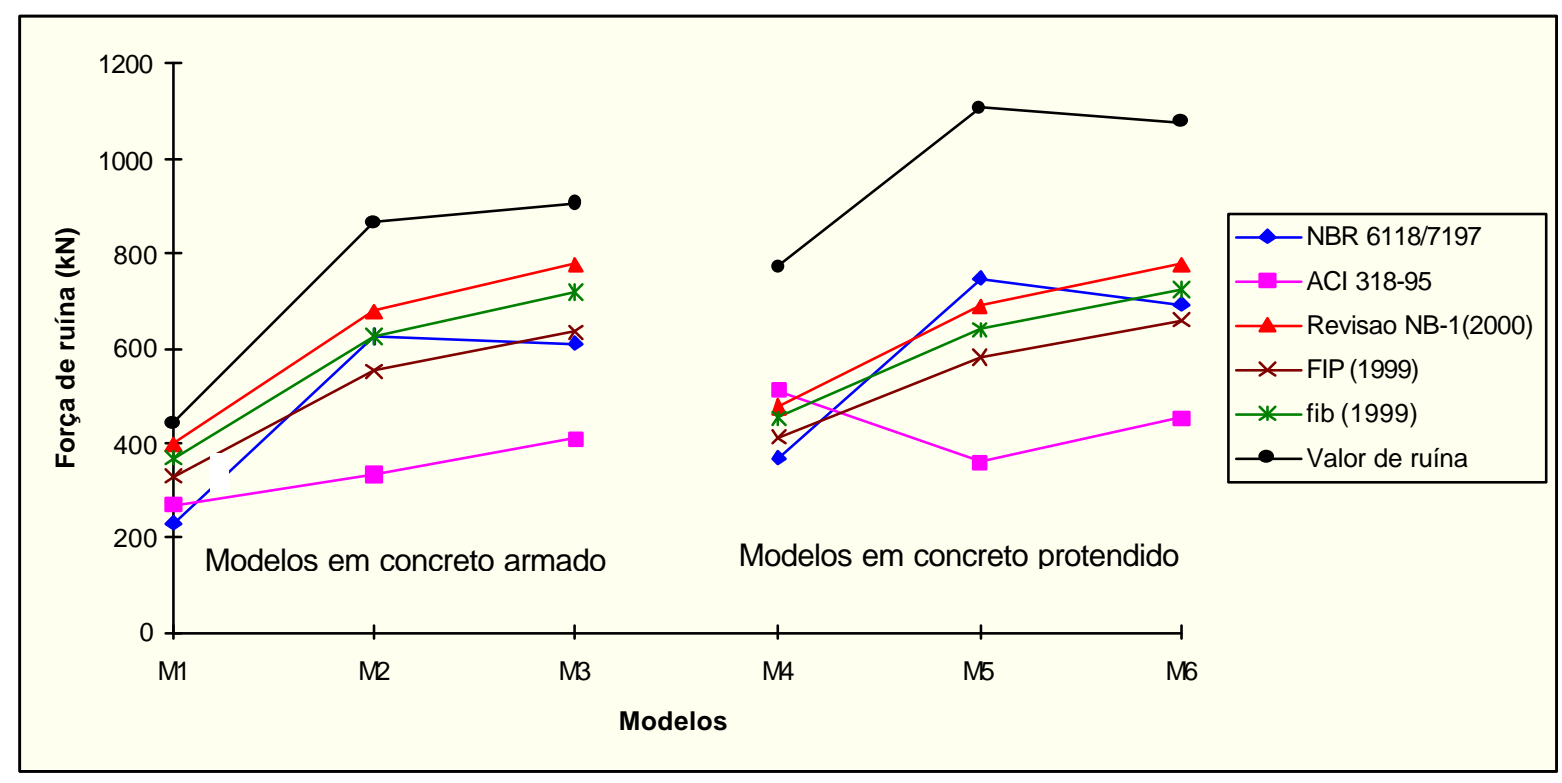

Figura 5.11 - Representação gráfica dos dados apresentados na tabela 5.5

Tabela 5.41 - Previsão da posição da superfície de ruína

\begin{tabular}{|c|c|c|c|c|c|c|}
\hline & \multicolumn{7}{|c|}{ Posição da superfície de ruína } \\
\cline { 2 - 7 } Modelo & NBR 6118 & ACI & $\begin{array}{c}\text { Revisão da } \\
\text { NB-1 }\end{array}$ & FIP/99 & fib/99 & $\begin{array}{c}\text { Ruína } \\
\text { observada no } \\
\text { ensaio }\end{array}$ \\
\hline M1 & I & I & I & I & I & I \\
\hline M2 & I & III & III & III & III & III \\
\hline M3 & I & III & III & III & III & III \\
\hline M4 & I & I & I & I & I & I \\
\hline M5 & I & III & III & III & III & III \\
\hline M6 & I & III & III & III & III & III \\
\hline
\end{tabular}

I. Superfície de ruína afastada da face do pilar de: d/2 para NBR 6118 e ACI 318, 2d para Revisão da NB-1 e CEB/90 (FIP/1999 e fib/1999).

II. Superfície de ruína localizada além da região transversalmente armada.

III. Superfície de ruína localizada na região adjacente ao pilar, entre a face deste e a primeira linha de armaduras transversais. 
Com relação ao ACI 318-95, observou-se que, tanto para o modelo M2 como para o M5, a superfície de ruína está localizada além da região transversalmente armada. No entanto, a força de ruína prevista para essa superfície corresponde a um valor inferior à de uma ligação sem armadura de punção. Isto significa que foram adotadas poucas linhas de armadura de punção. Este comportamento não foi confirmado experimentalmente. Nas figuras 5.12 e 5.13, tem-se os perímetros críticos usados para o dimensionamento dos modelos M2 e M3. Para os modelos M3 e M6, foram usados perímetros análogos aos mostrados nessas figuras.

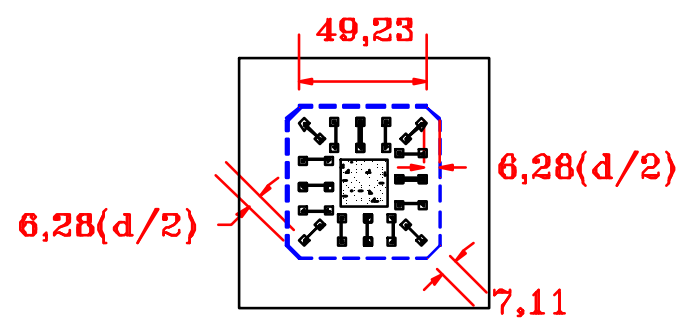

Figura 5.12 - Perímetro crítico usado para dimensionar o modelo M2 (ACI 318-95)

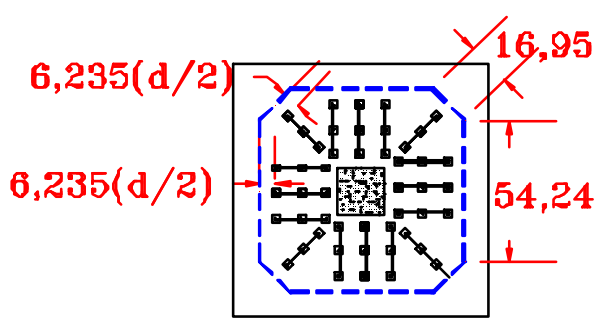

Figura 5.13 - Perímetro crítico usado para dimensionar o modelo M3 (ACI 318-95)

No cálculo segundo o ACI considerou-se apenas as cordoalhas que atravessaram o perímetro crítico a d/2 da face do pilar, mesmo para os modelos com armadura de punção. Na verificação da região além da transversalmente armada, tomou-se a inclinação da cordoalha na posição desse perímetro crítico correspondente.

Com relação à NBR 6118, observa -se que a armadura de punção do modelo M2 está praticamente dentro da região limitada pela NBR 6118 (figura 5.14). O mesmo já não acontece para o modelo M3. Neste caso, parte da armadura transversal do modelo M3 ficou fora da região limitada pela norma, sendo, portanto, desconsiderada (figura 5.15). 


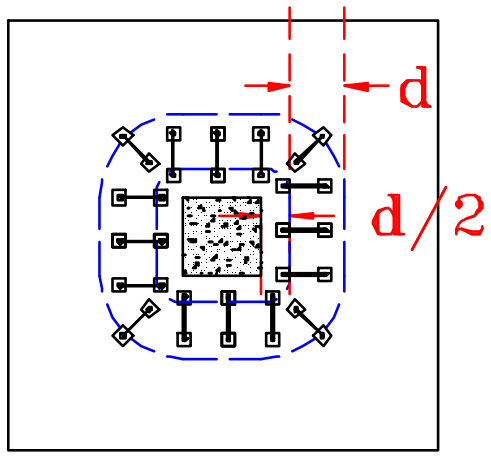

Figura 5.14- Região transversalmente armada, para os modelos M2 e M5, segundo a NBR 6118

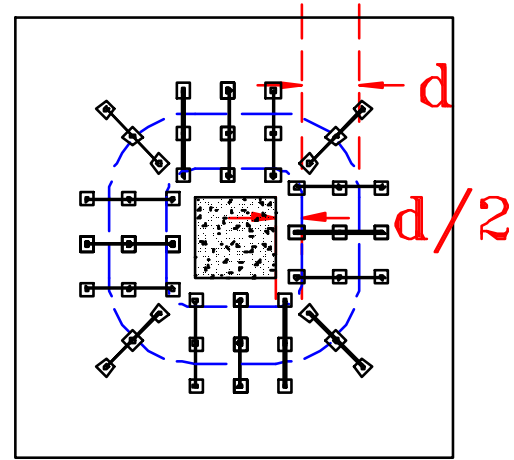

Figura 5.15 - Região transversalmente armada, para os modelos M3 e M6, segundo a NBR 6118

Ainda com relação à NBR 6118, foram consideradas as projeções, no plano perpendicular ao plano médio da laje, das forças oriundas da protensão das cordoalhas que atravessaram a superfície crítica definida pela norma. Para determinar a inclinação das cordoalhas nesta superfície, foram usadas as equações das parábolas, mencionadas no capítulo 4.

Foi adotado um valor médio da força de protensão para as cordoalhas dispostas na direção x e outro para as dispostas na direção y. Considerou-se a contribuição de 16 projeções (oito para cada direção), conforme a figura 5.16.

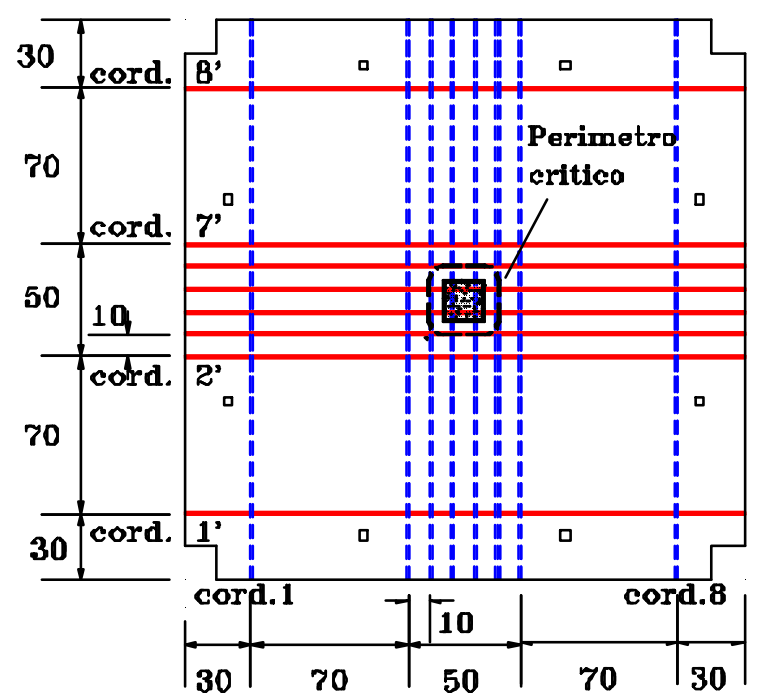

Figura 5.16 - Número de cordoalhas que atravessam o perímetro crítico: 4 em cada direção 
Tanto a FIP (1999) como a fib (1999) representam uma atualização das recomendações do CEB/90, razão esta pela qual este código foi substituído por aqueles. No entanto, a FIP (1999) e a fib (1999) apresentam algumas diferenças. Sendo assim, foi feita uma análise para cada um deles. Com relação à protensão, tanto a FIP (1999) como a fib (1999) mencionam que devem ser seguidas as recomendações da "FIP Recommendations for the design of post-tensioned slabs and fundations rafts". Como esta publicação não foi encontrada, o dimensionamento dos modelos foi feito com base no CEB/90, o qual permite incluir o efeito vertical da força de protensão que atua dentro de um perímetro localizado a uma distância numericamente igual à metade da altura útil, com relação à face do pilar. Para determinar este efeito vertical, utiliza-se a inclinação das cordoalhas no perímetro em que se deseja verificar a resistência da ligação com relação à punção. Este procedimento também foi o adotado para a Revisão da NB 1 (2000), considerando-se apenas as cordoalhas posicionadas, no máximo, a d/2 da face do pilar.

Por uma questão de simplificação, em função da armadura de flexão estar igualmente espaçada, a taxa de armadura foi calculada, para cada direção, considerandose a área de uma barra, a altura útil nesta direção e o espaçamento entre as barras. Além disso, a taxa de armadura relativa à região além da transversalmente armada foi considerada como sendo igual à calculada para a região transversalmente armada.

$\mathrm{Na}$ figura 5.17, tem-se um exemplo do perímetro crítico adotado para as recomendações da FIP (1999), fib (1999) e Revisão da NB-1 (2000).

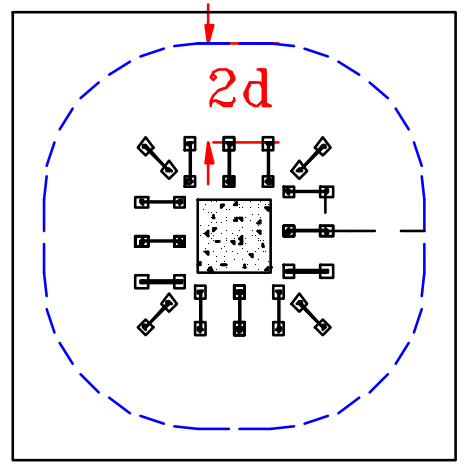

Figura 5.17 - Região transversalmente armada 
Portanto, conclui-se que, de um modo geral, a melhor norma que reflete o comportamento da ligação laje-pilar é a Revisão da NB-1 (2000).

Com relação aos modelos protendidos, o ACI poderia ter tido um bom desempenho, caso não houvesse uma restrição tão rígida com relação ao uso de armaduras de punção. Em mais de um caso, a inclusão de armadura de punção fez com que a força prevista de ruína fosse inferior à de uma ligação correspondente, só que sem armadura de punção. Como as resistências do concreto relativas aos modelos M1 e M5 foram, respectivamente baixa e alta, optou-se por se fazer uma adaptação nos valores experimentais obtidos. $\mathrm{O}$ procedimento adotado foi o seguinte: usando-se a resistência do concreto real, 26,6 MPa para o modelo M1, e 59,4 MPa para o M5, previu-se, através da Revisão da NB-1, as forças de ruptura já mostradas na tabela 5.39. Observa-se que as forças previstas para os modelos M1 e M5 foram de, respectivamente, $91 \%$ e $62 \%$ da força experimental obtida. Utilizando-se novamente a Revisão da NB-1 para prever a resistência do modelo, só que desta vez para uma resistência do concreto igual a $50 \mathrm{MPa}$, e utilizando-se a mesma proporção obtida entre a força prevista e a força experimental, para a resistência do concreto real, obtém-se, então, uma força experimental estimada, mostrada na tabela 5.42. Destaca-se que este procedimento visou apenas analisar, de modo simplificado, a influência da protensão e da armadura de punção na resistência da ligação. Estes cálculos estão ilustrados no Anexo P.

Tabela 5.42 - Influência da protensão e da armadura de punção na resistência da ligação, adaptando-se os valores da força de ruína para os modelos M1 e M5

\begin{tabular}{|l|c|c|c|c|c|c|}
\hline Modelo & M1 & M2 & M3 & M4 & M5 & M6 \\
\hline $\begin{array}{c}\text { Força de } \\
\text { ruína }\end{array}$ & $\begin{array}{c}544,9 \mathrm{kN}^{*} \\
(51 \%)\end{array}$ & $\begin{array}{c}863,8 \mathrm{kN} \\
(80 \%)\end{array}$ & $\begin{array}{c}905,8 \mathrm{kN} \\
(84 \%)\end{array}$ & $\begin{array}{c}772,6 \mathrm{kN} \\
(72 \%)\end{array}$ & $\begin{array}{c}1047,6 \mathrm{kN} * \\
(97 \%)\end{array}$ & $\begin{array}{c}1077,8 \mathrm{kN} \\
(100 \%)\end{array}$ \\
\hline * Valores adaptados \\
** Valores percentuais, em relação à força de ruína obtida \\
M1 - modelo de concreto armado, sem armadura de punção \\
M2 - modelo de concreto armado, com duas linhas de conectores \\
M3 - modelo de concreto armado, com três linhas de conectores \\
M4 - modelo de concreto protendido, sem armadura de punção \\
M5 - modelo de concreto protendido, com duas linhas de conectores \\
M6 - modelo de concreto protendido, com três linhas de conectores
\end{tabular}


Com base na tabela 5.42, a introdução dos conectores tipo pino proporcionaram um aumento significativo na resistência da ligação, tanto para os modelos de concreto armado, como nos de concreto protendido.

Observa-se ainda que, embora diminuindo a taxa de armadura dos modelos de concreto armado, para que se introduzissem as cordoalhas de protensão, os valores experimentais obtidos mostram que a presença da protensão aumentou a resistência da ligação. 


\section{CONCLUSÕES}

São apresentadas as conclusões deste trabalho, bem como sugestões para trabalhos futuros.

Com base na análise feita no capítulo 5, observa-se que, de um modo aproximado, a armadura de punção eleva significativamente a resistência do modelo à punção, seja ele de concreto armado ou protendido. Observa-se ainda que, embora diminuindo a taxa de armadura dos modelos de concreto armado, para que se introduzissem as cordoalhas de protensão, os valores experimentais obtidos mostram que a presença da protensão aumentou a resistência da ligação.

Os ensaios foram considerados satisfatórios com relação à excentricidade do carregamento.

Os resultados experimentais obtidos constatam a necessidade de se utilizarem dois extensômetros em barras com diâmetro igual ou superior a $12,5 \mathrm{~mm}$, em função do efeito de flexão localizada.

De um modo geral, as deformações tangenciais medidas tanto no concreto como com relação à armadura foram superiores às deformações longitudinais.

Com relação à armadura de punção, no modelo M2 observou-se uma tendência dos conectores dispostos na direção x em apresentar deformações maiores que os dispostos na direção y.

Associou-se a este fato a possibilidade de uma melhor ancoragem dos conectores dispostos na direção x, em função da face inferior da chapa de ancoragem superior estar diretamente apoiada na armadura de flexão.

Esta tendência, no entanto, não foi observada no modelo M3. 
Com relação à instrumentação do concreto na face comprimida dos modelos M2 e M3, podem ser feitas as seguintes observações:

a) Na região próxima à chapa metálica usada para aplicar o carregamento ao modelo:

- no canto da chapa, a deformação tangencial foi maior que a deformação radial, tanto para o modelo M2 como para o M3;

- no meio da chapa, o comportamento do modelo M2 diferiu do modelo M3, uma vez que no M2 foram observados picos de deformação não observados no modelo M3;

- para o modelo M2, a deformação radial no meio foi maior que a deformação radial no canto; já para o modelo M3, a deformação radial no meio teve um comportamento muito próximo com relação à deformação radial no canto;

- a partir de um determinado nível do carregamento, os extensômetros indicaram uma diminuição nas deformações de compressão e, alguns deles, chegaram, no final do carregamento, a apresentar deformações de tração.

b) Na região afastada da chapa metálica usada para aplicar o carregamento ao modelo:

- para os modelos M2 e M3, na direção do canto da chapa, a deformação tangencial foi bem maior que a deformação radial; pôde-se observar uma tendência da deformação tangencial em aumentar a deformação de compressão durante todo o carregamento, enquanto que, a partir de um determinado nível do carregamento, a deformação de compressão medida na direção radial diminuiu, chegando, no final do carregamento, a apresentar deformações de tração;

- para os modelos M2 e M3, na direção do meio da chapa, o comportamento foi análogo ao mencionado no item anterior;

- no modelo M2, a deformação tangencial no meio foi ligeiramente superior à deformação tangencial no canto; já para o modelo M3, a deformação tangencial no meio foi bem menor que a deformação tangencial no canto; 
- no modelo M2, a deformação radial de compressão no canto apresentou valores ligeiramente inferiores à deforma ção radial de compressão no meio; já para o modelo M3, a deformação radial de compressão no canto foi bem maior que a deformação radial de compressão no meio.

c) Com relação à distância entre os extensômetros e a chapa metálica usada para aplicar o carregamento ao modelo:

- para os modelos M2 e M3, as deformações radiais próximas à chapa, até um determinado nível de carregamento, foram bem maiores que as deformações radiais afastadas da chapa;

- para os modelos M2 e M3, as deformações tangenciais próximas à chapa, até um determinado nível de carregamento, também foram bem maiores que as deformações tangenciais afastadas da chapa;

- tanto no modelo M2 como no M3, observa-se que, a partir de um determinado nível de carregamento, existe uma tendência de diminuírem as deformações por compressão, excetuando-se os extensômetros afastados da chapa e dispostos na direção tangencial.

Embora a superfície de ruína não tenha sido perfeitamente simétrica, na face tracionada do modelo, a extração do cone de punção pôde mostrar que houve uma completa separação entre o cone de punção e o restante do modelo. Destaca-se que, para os dois modelos analisados, a superfície de ruptura ocorreu além da região transversalmente armada.

A análise da instrumentação dos macacos, dos deslocamentos transversais e de alguns extensômetros posicionados nas malhas positiva e negativa, mostra que não houve excentricidades significativas com relação ao carregamento aplicado pelos macacos.

Comportamento análogo foi observado para os modelos protendidos. 
Com relação ao ACI 318-95, observou-se que, tanto para o modelo M2 como para o modelo M5, a superfície de ruína está localizada além da região transversalmente armada. No entanto, a força de ruína prevista para essa superfície corresponde a um valor inferior à de uma ligação sem armadura de punção. Isto significa que foram adotadas poucas linhas de armadura de punção. Este comportamento não é confirmado experimentalmente.

Portanto, conclui-se que, de um modo geral, a melhor norma que reflete o comportamento da ligação laje-pilar é a Revisão da NB-1 (2000). Com relação aos modelos protendidos, o ACI poderia ter tido um bom desempenho, caso não houvesse uma restrição tão rígida com relação ao uso de armaduras de punção. Em mais de um caso, a inclusão de armadura de punção fez com que a força prevista de ruína fosse inferior à uma ligação correspondente, só que sem armadura de punção. Tem-se como sugestões para o prosseguimento deste trabalho:

a) estudo envolvendo a teoria de alguns modelos mecânicos e os resultados experimentais obtidos;

b) ensaios envolvendo pilares internos com momento fletor atuando em uma das direções;

c) substituição dos conectores tipo-pino por fibras;

d) variação da taxa de armadura e do nível de protensão nas lajes. 


\section{REFERÊNCIAS}

ALEXANDER, S.D.B.; SIMMONDS, S.H. (1992). ACI Structural Journal, v.89, n.4, July/August.

AMERICAN CONCRETE INSTITUTE (1989). ACI 318-89 - Building code requirements for structural concrete (ACI 318-89) and Commentary (ACI 318R-89). Farmington Hills.

AMERICAN CONCRETE INSTITUTE (1995). ACI 318-95 - Building code requirements for structural concrete (ACI 318-95) and Commentary (ACI 318R-95). Farmington Hills.

ANDRADE, M.A.S. (1999). Punção em lajes-cogumelo - estudo do posicionamento da armadura de cisalhamento em relação à armadura de flexão. Goiânia. Dissertação (Mestrado) - Escola de Engenharia Civil, Universidade Federal de Goiás.

ASSOCIAÇÃO BRASILEIRA DE NORMAS TÉCNICAS (1982). NBR 6118 - Projeto e execução de obras de concreto armado. Rio de Janeiro. 76p.

ASSOCIAÇÃO BRASILEIRA DE NORMAS TÉCNICAS (1992). NBR 6152 - Materiais metálicos - determinação das propriedades mecânicas à tração. Rio de Janeiro. 13p.

ASSOCIAÇÃO BRASILEIRA DE NORMAS TÉCNICAS (1983). NBR 7222 - Argamassas e concretos - determinação da resistência à tração por compressão diametral de corpos-de-prova cilíndricos - Método de Ensaio. Rio de Janeiro. 3p.

ASSOCIAÇÃO BRASILEIRA DE NORMAS TÉCNICAS (1982). NBR 7223 - Concreto determinação da consistência pelo abatimento do tronco de cone - Método de Ensaio. Rio de Janeiro. 6p.

ASSOCIAÇÃO BRASILEIRA DE NORMAS TÉCNICAS (1984). NBR 8522 - Concreto determinação do módulo de deformação estática e diagrama tensão-deformação - Método de Ensaio. Rio de Janeiro. 9p.

ASSOCIAÇÃO BRASILEIRA DE NORMAS TÉCNICAS (1980). NBR 5739 - Ensaio de compressão de corpos-de-prova cilíndricos. Rio de Janeiro. 3p.

ASSOCIAÇÃO BRASILEIRA DE NORMAS TÉCNICAS (1984). NBR 5738 - Moldagem e cura de corpos-de-prova cilíndricos ou prismáticos. Rio de Janeiro. 11p. 
ASSOCIAÇÃO BRASILEIRA DE NORMAS TÉCNICAS (1989). NBR 7197 - Projeto de estruturas de concreto protendido. Rio de Janeiro. 71p.

ASSOCIAÇÃO BRASILEIRA DE NORMAS TÉCNICAS (1993). Texto para revisão da NB-1 e comentários.

ASSOCIAÇÃO BRASILEIRA DE NORMAS TÉCNICAS (2000). Texto para revisão da NB-1 e comentários.

AZEVEDO, A.P. (1999). Resistência e ductilidade das ligações laje-pilar em lajes-cogumelo de concreto de alta resistência armado com fibras de aço e armadura transversal de pinos. São Carlos. Dissertação (Mestrado) - Escola de Engenharia de São Carlos, Universidade de São Paulo.

BRAESTRUP, M.W.; REGAN, P.E. (1985). Punching shear in reinforced concrete: a state of the art report. CEB Bulletin d'Information, n.168.

CAUDURO, E.L. (1996). Protensão com cordoalhas engraxadas e plastificadas: pós-protensão com sistema não aderente. In: REUNIÃO DO IBRACON, 38., Ribeirão Preto. Anais. v.2, p.785-798.

CAUDURO, E.L. (1997). Em favor da leveza. Téchne - Revista de Tecnologia da Construção, ano 5, n.26, p.30-33. Jan./Fev.

COMITE EURO-INTERNATIONAL DU BETON (1991). CEB-FIP model code 1990: Bulletin d'Information, n.204.

CORDOVIL, F.A.B. (1995). Punção em placas de concreto armado. São Paulo. Tese (Doutorado) - Escola Politécnica, Universidade de São Paulo.

CORLEY, W.G.; HAWKINS, N.M. (1968) Shearhead reinforcement for slabs. ACI Journal, v.65, n.10, p.811-824.

DECON® (1998) Studrail® approvals http://www.decon.on.ca/railfaq.htm. (22 Jul.)

DILGER, W.H. (1990). Practical shear reinforcement for concrete flat slabs. Concrete Construction, v.35, n.2, p.223-225, Feb.

DUARTE, E.P. (1994). Execução de lajes planas protendidas. In: JORNADA IBERO-LATINOAMERICANA DE CONCRETO PROTENDIDO, 3., São Paulo, 1994. Anais. São Paulo, ABPT (Associação Brasileira da Pós-Tensão) / BMS (Empresa Belgo-Mineira). p.105-116.

ELGABRY, A.A.; GHALI, A. (1990). Design of stud-shear reinforcement for slabs. ACI Structural Journal, v.87, n.3, p.350-61, May/June.

ELGABRY, A.A.; GHALI, A. (1996a). Moment transfer by shear in slab-column connections. ACI Structural Journal, v.93, n.2, p.187-96, Mar./Apr.

ELGABRY, A.A.; GHALI, A. (1996b). Transfer of moments between columns and slabs: proposed code revisions. ACI Structural Journal, v.93, n.1, p.56-61, Jan./Feb. 
ELSTNER, R.C.; HOGNESTAD, E. (1956). Shearing strength of reinforced concrete slabs. ACI Journal, v.28, n.1, p.29-57, July.

EQUIPE DE FURNAS, LABORATÓRIO DE CONCRETO (1997). Concretos massa, estrutural, projetado e compactado com rolo - ensaios e propriedades. São Paulo, Pini .

EC 2 (1991). Eurocode 2: Design of Concrete Structures - Part 1: General Rules and Rules for Buildings. European Prestandard ENV 1992-1-1:1991, European Committee for Standardization, Brussels, 253p.

FÉDÉRATION INTERNATIONALE DE LA PRECONTRAINTE - FIP (1999). Practical design of structural concrete. London, SETO. (FIP recommendations)

FÉDÉRATION INTERNATIONALE DU BETON - fib (1999). Structural concrete: textbook on behaviour, design and performance updated knowledge of the CEB/FIP model code 1990: fib Bulletin, v.2.

FIGUEIREDO FILHO, J.R. (1981). Estudo experimental da ruína de ligações laje-pilar em casos característicos de cantos de lajes-cogumelo. São Carlos. Dissertação (Mestrado) Escola de Engenharia de São Carlos, Universidade de São Paulo.

FIGUEIREDO FILHO, J.R. (1989). Sistemas estruturais de lajes sem vigas: subsídios para o projeto e execução. São Carlos. Tese (Doutorado) - Escola de Engenharia de São Carlos, Universidade de São Paulo.

FOUTCH, D.A.; GAMBLE, W.L.; SUNIDJA, F. (1990). Tests of post-tensioned concrete slab-edge column connections. ACI Structural Journal, v.87, n.2, p.167-179, Mar./Apr.

FRANCO, M. (1994). Concreto protendido em edifícios. In: JORNADA IBERO-LATINOAMERICANA DE CONCRETO PROTENDIDO, 3., São Paulo. Anais. São Paulo, ABPT (Associação Brasileira da Pós-Tensão) / BMS (Empresa Belgo-Mineira). p.117-133.

FUSCO, P.B. (1984). Estruturas de concreto - solicitações tangenciais: problemas básicos de cisalhamento no concreto estrutural, problemas gerais de dimensionamento. São Paulo, Escola Politécnica, Universidade de São Paulo. (apostila)

FUSCO, P.B. (1985). Investigação experimental sobre o cisalhamento em lajes de concreto armado. São Paulo, EPUSP. (Boletim Técnico, BT/PEF 8505)

FUSCO, P.B. (1995). Técnica de armar as estruturas de concreto. 1.ed. São Paulo, Pini.

GANTE, J.A.S. (1991). Suprimindo as vigas. Revista IBRACON, n.1, p.14-18.

GHOSH, S.K. (1983). Simplified design for two-way slabs. In: NEVILLE, G.B., ed. Simplified design: reinforced concrete buildings of moderate size and height. Skokie, Portland Cement Association. p. 4.1-4.53

GOMES, R.B. (1991). Punching resistance of reinforced concrete flat slabs with shear reinforcement. London. Ph.D. Thesis, The Polytechnic of Central London. 
GOMES, R.B. (1994). Resistência à punção de lajes cogumelo de concreto armado com furos e armadura de cisalhamento. Furnas Centrais Elétricas S.A., Relatório DCT.T.1.141.93-R0.

GONÇALVES, R.M. (1986). Estudo experimental da ruína de ligações laje-pilar em bordas de lajes-cogumelo com reforço transversal constituído de perfis metálicos. São Carlos. Dissertação (Mestrado) - Escola de Engenharia de São Carlos, Universidade de São Paulo.

HALLGREN, M. (1996). Punching shear capacity or reinforced high strength concrete. Stockholm. $\mathrm{PhD}$ Thesis, Royal Institute of Technology.

HALLGREN, M.; KINNUNEN, S. (1996). Increase of punching shear capacity by using high strength concrete. In: INTERNATIONAL SYMPOSIUM ON THE UTILIZATION OF HIGH STRENGTH / HIGH PERFORMANCE CONCRETE, 4., Paris, 1996. Proceedings. Paris, AFPC/AFREM/ENPC. v.3, p.1037-1046.

HELENE, Paulo R. L.; TERZIAN, Paulo (1992). Manual de dosagem e controle do concreto. São Paulo, Pini, 349p.

HOGNESTAD, E. (1953). Shearing strength of reinforced column footings. ACI Journal, v.50, n.3, p.189-208.

LAJE concentrada (1993). Téchne, São Paulo, v.2, n.7, p.12-16, nov./dez.

LANGOHR, P.H.; GHALI, A.; DILGER, W.H. (1976). Special shear reinforcement for concrete flat plates. ACI Journal, v.73, n.3, p.141-146, March.

LEONHARDT, F.; MÖNIG, E. (1978). Construções de concreto: casos especiais de dimensionamento de estruturas de concreto armado. Rio de Janeiro, Interciência. v.2.

LEONHARDT, F. (1979). Construções de concreto: verificação da capacidade de utilização. Trad. por João Luis Escosteguy Merino. Rio de Janeiro, Interciência. v.4.

LIBÓRIO, J.B.L. (1985). Estudo experimental da ruína de ligações laje-pilar em bordas com pilares de seção retangular. São Carlos. Dissertação (Mestrado) - Escola de Engenharia de São Carlos, Universidade de São Paulo.

LIN, T.Y. (1966). Design of prestressed concrete structures. 2.ed. New York, John Wiley \& Sons.

MARTINELLI, D.A. (1974) Sobre a ruína das ligações laje-pilar nos cantos de lajescogumelo. São Carlos, EESC.

MELGES, J.L.P. (1995). Punção em lajes: exemplos de cálculo e análise teórico-experimental. São Carlos. Dissertação (Mestrado) - Escola de Engenharia de São Carlos, Universidade de São Paulo.

MELO, G.S.S.A. (1994). Proposição de item de norma com referência ao cálculo de armadura contra colapso progressivo em lajes cogumelo. In: REIBRAC, 36., Porto Alegre. Anais. v.2, p.725-734. 
MICROSOFT encarta 96 encyclopedia - CD-ROM. (s.d.). Microsoft Corporation.

MODOTTE, W.P. (1986). Estudo experimental da ruína de ligações laje-pilar em bordas de lajes-cogumelo com carregamento assimétrico. São Carlos. Dissertação (Mestrado) - Escola de Engenharia de São Carlos, Universidade de São Paulo.

MOE, J. (1961). Shearing strength of reinforced concrete slabs and footings under concentrated loads. Bulletin D47. Portland Cement Association.

MONTANARI, I. (1988). SET-113 - Concreto protendido. São Carlos, Escola de Engenharia de São Carlos, Universidade de São Paulo. (apostila-reimpressão)

MOURA, E. (s.d. ${ }^{*}$, a). World Trade Center de São Paulo. Arquitetura do concreto protendido, Belgo-Mineira / Pini, v.2, p.17-19.

MOURA, E. (s.d.*, b). Edifício Dalamachia. Arquitetura do concreto protendido, BelgoMineira / Pini, v.2, p.20-22.

NASSER, G.D. (1969). A look at prestressed flat plate construction. PCI Journal, v.14, n.6, p.6277, Dec.

NILSON, A.H. (1987). Design of prestressed concrete. 2.ed. New York, John Wiley \& Sons.

NOTABLE structures engineered by T. Y. Lin Firms (1976). PCI Journal, v.21, n.5, p.30-34, Sept/Oct.

OLIVEIRA, D.R.C. (1998). Análise experimental de lajes cogumelo de concreto armado com armadura de cisalhamento ao puncionamento. Brasília. Dissertação (Mestrado) - Faculdade de Tecnologia, Universidade de Brasília.

PARK, R.; GAMBLE, W.L. (1980) Reinforced concrete slabs. New York, John Wiley \& Sons.

PARK, R.; ISLAM, S. (1976) Strength of slab-column connections with shear and unbalanced flexure. Journal of the Structural Division, ASCE, 102, ST9, p.1879-1901

PFEIL, W. (1980). Concreto protendido: processos construtivos, perdas de protensão, sistemas estruturais. Rio de Janeiro, Livros Técnicos e Científicos.

PILAKOUTAS, K.; LI, X. (1997). Shear band: novel punching shear reinforcement for flat slabs. In: TOPPING, B.H.V.; LEEMING, M.B., eds. Innovation in composite materials and structures (The Mouchel Centenary Conference On Innovation in Civil and Structural Engineering, Cambridge, England, 19-21 August, 1997). Edinburgh, Civil-Comp Press. p.35-45

PINTO, R.C.A. (1993) Punção assimétrica de lajes. Rio de Janeiro. Dissertação (mestrado) COPPE/UFRJ.

\footnotetext{
* Matérias referentes a concreto protendido, publicadas na revista "AU - Arquitetura e Urbanismo", na seção "Tecnologia".

* Matérias referentes a concreto protendido, publicadas na revista "AU - Arquitetura e Urbanismo", na seção

"Tecnologia".
} 
RAMDANE, K.E. (1996). Punching shear of high performance concrete slabs. In: INTERNATIONAL SYMPOSIUM ON THE UTILIZATION OF HIGH STRENGTH / HIGH PERFORMANCE CONCRETE, 4., Paris, 1996. Proceedings. Paris, AFPC/AFREM/ENPC. v.3, p.1015-1026.

REGAN, P.E. (1985) Shear combs, reinforcement against punching. The Structural Engineer, v.63B, n.4, p.76-84, december.

REGAN, P.E. (1984) The dependence of punching resistance upon the geometry of the failure surface. Magazine of concrete research, v.36, n.126, p.3-8, march.

RICHART, F.E. (1948). Reinforced concrete wall and column footings. ACI Journal, v.45, n.2, p.97-127; n.3, p.237-260.

SANTOS, S.M.G. (1958). Formas em concreto armado. Revista Estrutura, Rio de Janeiro, n.4, p.107-128.

SCHMID, M.T. (1993). Lajes planas protendidas. São Paulo, Rudloff-VSL Industrial Ltda. (Publicação técnica)

SCORDELIS, A.C.; LIN, T.Y.; ITAYA, R. (1959). Behavior of a continuous slab prestressed in two directions. ACI Journal, v.31 - part 1, n.6, p.441-459, December.

SEIBLE, F.; GHALI, A.; DILGER, W.H. (1980). Preassembled shear reinforcing units for flat plates. ACI Journal, v.77, n.1, p.28-35, Jan/Feb.

SHEHATA, I.A.E.M. (1990). Simplified model for estimating the punching resistance of reinforced concrete slabs. Materials and Structures, n.23, p.364 - 371.

SHEHATA, I.A.M. (1985). Theory of punching in concrete slabs. London. PhD Thesis, The Polytechnic of Central London.

SHEHATA, I.A.M. (1982). Punching of prestressed and non-prestressed reinforced concrete flat slabs. London. Master Thesis, The Polytechnic of Central London.

SKAF, K.J.; STUCCHI, F.R. (1994). Alternativas de representação da protensão no projeto de estruturas de concreto. In: JORNADA IBERO-LATINO-AMERICANA DE CONCRETO PROTENDIDO, 3., São Paulo. Anais. São Paulo, ABPT (Associação Brasileira da PósTensão) / BMS (Empresa Belgo-Mineira). p.79-104.

SOUZA, V.C.M.; CUNHA, A.J.P. (1994). Lajes em concreto armado e protendido. Niterói, Eduff.

TAKEYA, T. (1981). Estudo experimental da ruína de ligações laje-pilar em bordas de lajescogumelo. São Carlos. Dissertação (Mestrado) - Escola de Engenharia de São Carlos, Universidade de São Paulo. 
YITZHAKI, D. (1966). Punching strength of reinforced concrete slabs. ACI Journal, v.63, n.5, p.527-540, May.

ZAMBRANA VARGAS, E.N. (1997). Punção em lajes-cogumelo de concreto de alta resistência reforçado com fibras de aço. São Carlos. Dissertação (Mestrado) - Escola de Engenharia de São Carlos, Universidade de São Paulo. 


\title{
ANÁLISE EXPERIMENTAL DA PUNCEÃO EM LAJES DE CONCRETO ARMADO E PROTENDIDO - ANEXOS -
}

\author{
JOSÉ LUIZ PINHEIRO MELGES
}

\begin{abstract}
Tese apresentada à Escola de Engenharia de São Carlos, da Universidade de São Paulo, como parte dos requisitos para obtenção do Título de Doutor em Engenharia de Estruturas.
\end{abstract}

ORIENTADOR: Libânio Miranda Pinheiro 


\section{ANEXOS}

ANEXO A: Detalhamento do sistema de reação utilizado nos ensaios

ANEXO B: Detalhamento da fôrma

ANEXO C: Informações relacionadas ao concreto usado nos modelos de ensaio

ANEXO D: Posicionamento das cordoalhas de protensão

ANEXO E: Armadura de flexão

ANEXO F: Armadura de punção

ANEXO G: Informações relacionadas à instrumentação da armadura de flexão tracionada dos modelos ensaiados

ANEXO H: Informações relacionadas à instrumentação da armadura de punção

ANEXO I: Dimensionamento dos modelos de concreto armado e protendido com relação àflexão

ANEXO J: Previsão da resistência dos modelos com relação à punção, em função da NBR 6118 (1978) e NBR 7197 (1989), da Revisão da NB-1 (2000), da FIP (1999), da fib (1999) e do ACI 318/95

ANEXO K: Recomendações da NBR 6118 (1978) e da NBR 7197 (1989)

ANEXO L: Recomendações da FIP (1999)

ANEXO M: Recomendações da fib (1999)

ANEXO N: Recomendações da Revisão da NB-1 (2000)

ANEXO O: Recomendações do ACI

ANEXO P: Previsão da resistência dos modelos M1 e M5, com relação à punção, em função das recomendações da Revisão da NB-1 (2000), para adequar a resistência do concreto a $50 \mathrm{MPa}$ 


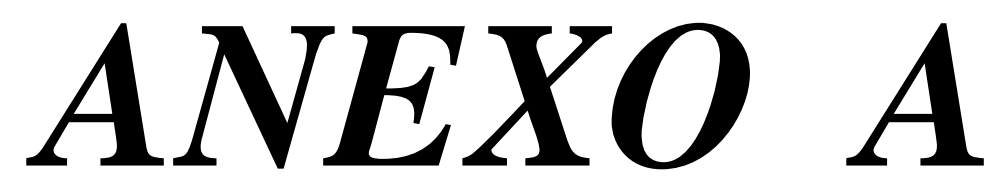

Detalhamento do sistema de reação utilizado nos ensaios 


\section{ANEXO A - Detalhes do sistema de reação}

Como sistema de reação para o carregamento aplicado, foram adotadas vigas metálicas e tirantes. Deste modo, o carregamento aplicado no modelo era equilibrado por vigas colocadas na sua face superior, que transferiam o carregamento para vigas colocadas abaixo do modelo, através de tirantes. Essas vigas, por sua vez, transferiam o carregamento para a laje de reação. São apresentados, a seguir, os dados relacionados ao sistema de reação projetado.

\section{A.1 DADOS RELACIONADOS AOS TIRANTES E AO SISTEMA DE ANCORAGEM}

Como tirantes, foram usados cabos de protensão da Dywidag, cujas características, fornecidas através de um catálogo, estão mostradas na figura A.1.

Características do tirante:

Aço ST 85/105

Diâmetro: $32 \mathrm{~mm}$

Duplo filetado, com rosca de passo $16 \mathrm{~mm}$

Laminado em quente em todo o comprimento

Limite de escoamento: $8500 \mathrm{~kg} / \mathrm{cm}^{2}$

Limite de escoamento: $10500 \mathrm{~kg} / \mathrm{cm}^{2}$

Carga de escoamento: 68,34 t

Carga de ruptura: $84,42 \mathrm{t}$

Distância mínima entre centros de ancoragem: $22 \mathrm{~cm}$

Distância mínima entre barras: 7,6 cm

Figura A.1 - Tirantes metálicos: barras de protensão Dywidag 
Nas extremidades dos tirantes foi utilizada uma ancoragem tipo placa, constituída por uma placa quadrada de dimensões $160 \mathrm{~mm} \times 160 \mathrm{~mm} \times 40 \mathrm{~mm}$, sobre a qual se apoiava uma porca sextavada (figura A.2).

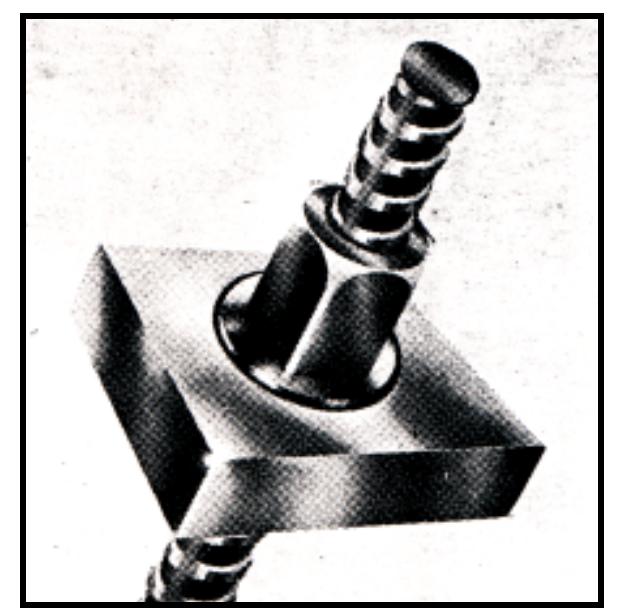

Figura A.2 - Placa de ancoragem

\section{A.2 DADOS RELACIONADOS ÀS VIGAS METÁLICAS}

Para a construção das vigas, foram usados perfis "C", cujas características foram obtidas através de BELLEI, 1994 (figura A.3).

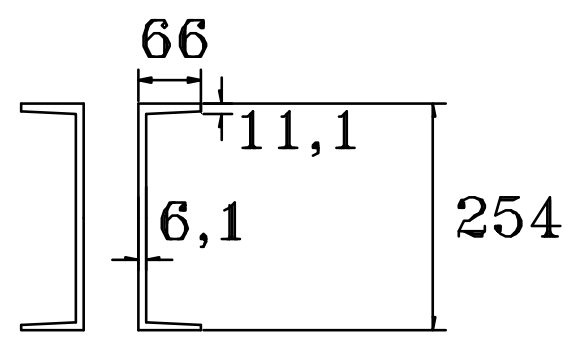

Figura A.3 - Perfis usados (unidades em mm) 
Os dados relacionados às características do perfil tipo "C" estão presentes na tabela A.1.

Tabela A.1 - Características do perfil tipo "C"

Altura: $254 \mathrm{~mm}$ (10 polegadas); Massa: $22,8 \mathrm{~kg} / \mathrm{m}$;

Área: $29 \mathrm{~cm}^{2}$; Largura da mesa: $66 \mathrm{~mm}$;

Espessura média da mesa: 11,1 mm; Espessura da alma: 6,1 mm;

$$
\begin{gathered}
\mathrm{I}_{\mathrm{X}}=2800 \mathrm{~cm}^{4} ; \quad \mathrm{W}_{\mathrm{X}}=221 \mathrm{~cm}^{3} ; \quad \mathrm{r}_{\mathrm{X}}=9,84 \mathrm{~cm} \\
\mathrm{I}_{\mathrm{y}}=95 \mathrm{~cm}^{4} ; \quad \mathrm{W}_{\mathrm{y}}=19 \mathrm{~cm}^{3} ; \quad \mathrm{r}_{\mathrm{y}}=1,81 \mathrm{~cm}
\end{gathered}
$$

Constante de torção: $8,78 \mathrm{~cm}^{4}$

Para o dimensionamento dessas vigas, estimou-se uma força máxima de $1300 \mathrm{kN} \mathrm{a}$ ser aplicada ao modelo. Considerou-se que a tensão máxima no material não poderia ser superior a $15 \mathrm{kN} / \mathrm{cm}^{2}$.

Nas figuras A.4 a A.6, têm-se os esquemas usados para o dimensionamento das vigas metálicas.

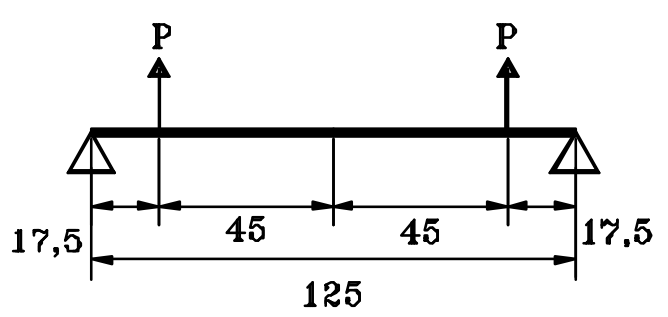

Esquema estático (unidades em cm)

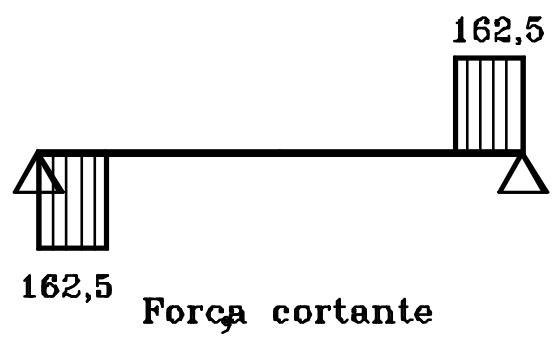

(unidades em $\mathrm{kN}$ )

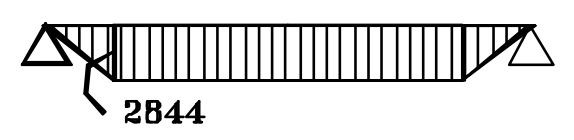

Momento fletor

(unidades em kN.cm)

Figura A.4 - Viga inferior tipo I: $\mathrm{P}=\mathrm{P}_{\text {total }} / 8=1300 / 8=162,5 \mathrm{kN}$ 


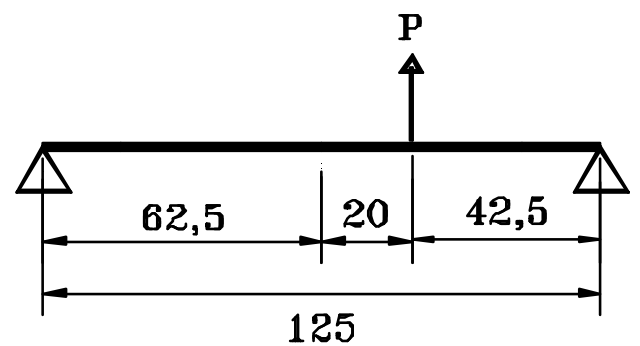

Esquema estático

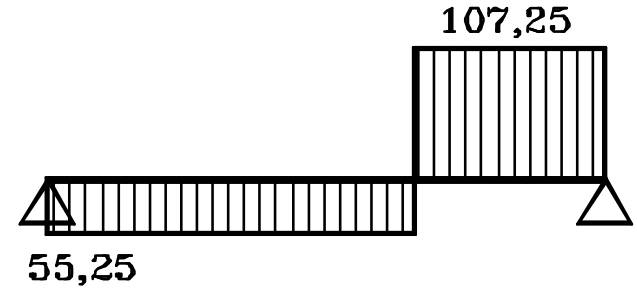

Forca cortante

(unidades em $\mathrm{kN}$ )

(unidades em cm)

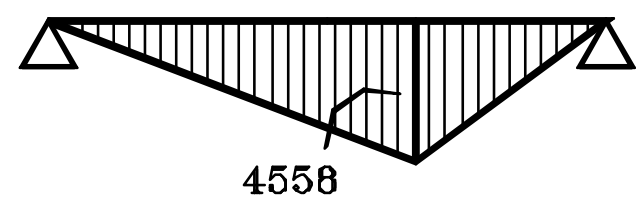

Momento fletor

(unidades em kN.cm)

Figura A.5 - Viga inferior tipo II: $\mathrm{P}=\mathrm{P}_{\text {total }} / 8=1300 / 8=162,5 \mathrm{kN}$

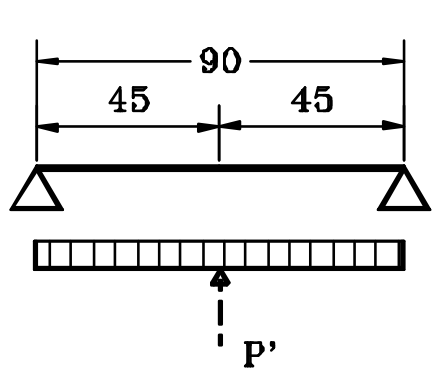

Esquema estático

(unidades em $\mathrm{cm}$ )

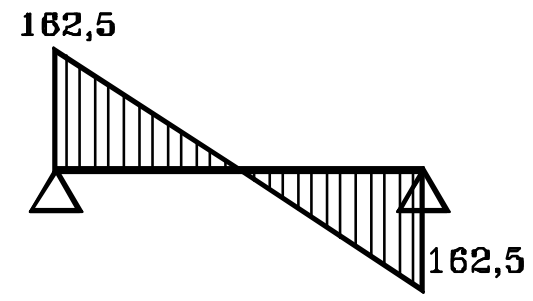

Forca cortante

(unidades em kN)

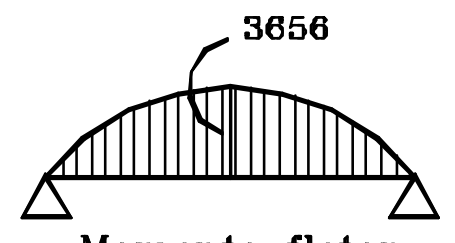

Momento fletor

(unidades em kN.cm)

Figura A.6 - Viga superior: $\mathrm{P}^{\prime}=\mathrm{P}_{\text {total }} / 4=325 \mathrm{kN}$

$\left(\mathrm{p}_{\text {distribuída }}=325 \mathrm{kN} / 90=3,611 \mathrm{kN} / \mathrm{cm}\right)$ 
Nas figuras A.7 a A.9, tem-se o detalhamento usado para a montagem das vigas.

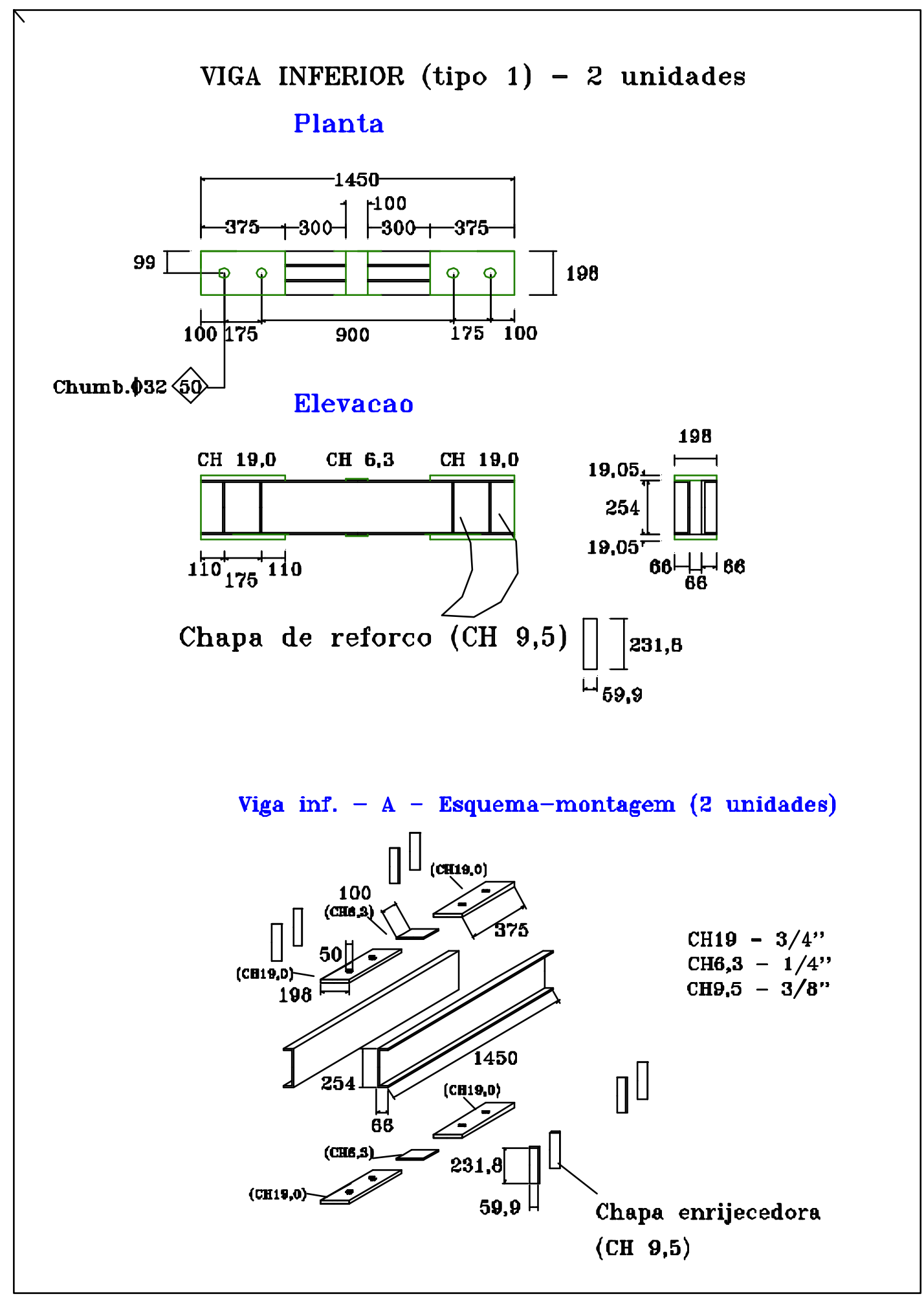

Figura A.7 - Viga inferior tipo 1 


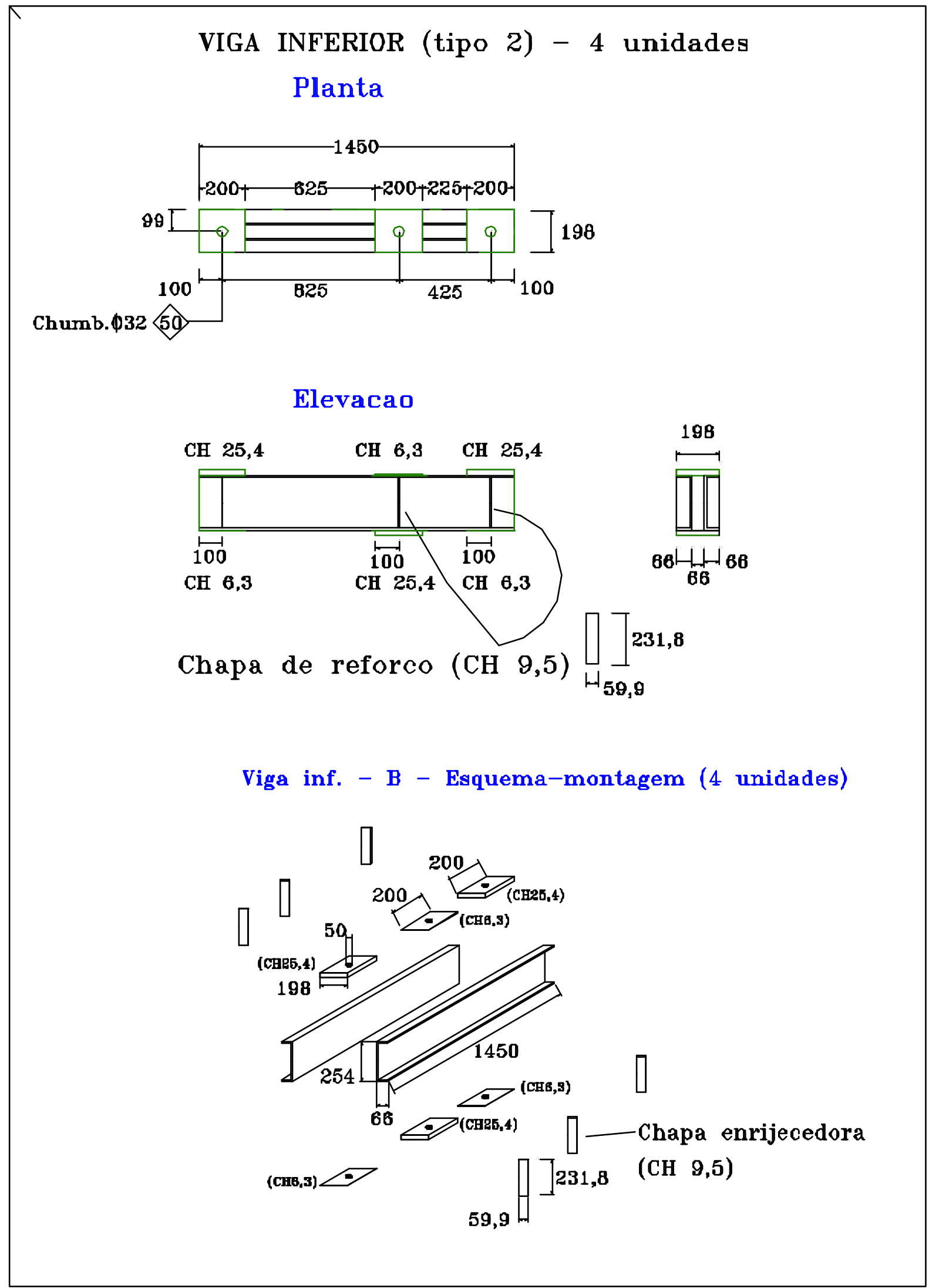

Figura A.8 - Viga inferior tipo 2 


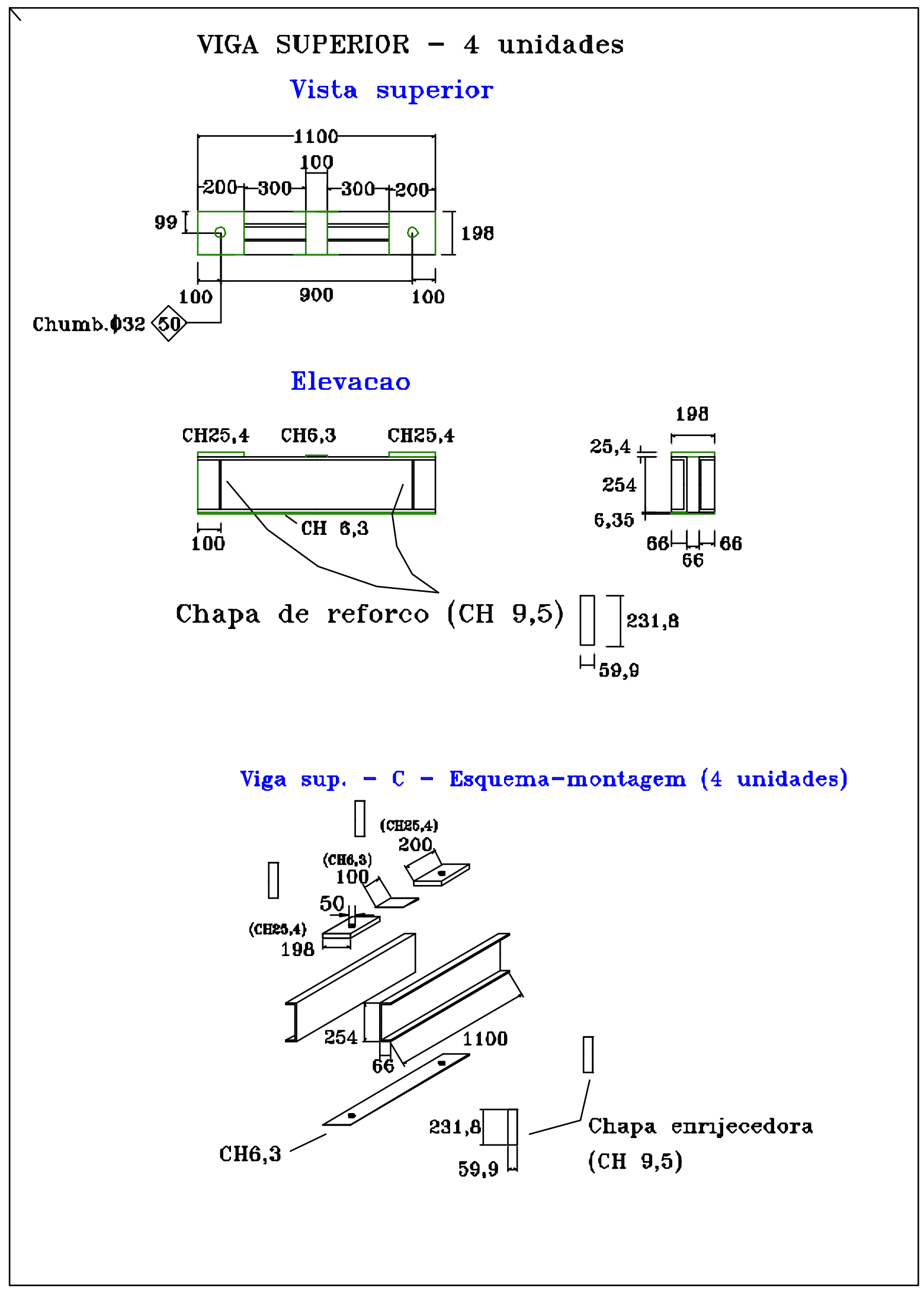

Figura A.9 - Viga superior 


\section{A.3 ANÁLISE DOS DESLOCAMENTOS}

Para a elaboração desta análise, foram usados os seguintes dados:

- Módulo de deformação longitudinal dos tirantes: $210000 \mathrm{MPa}$

- Área dos tirantes: $8 \mathrm{~cm}^{2}$

- Comprimento dos cabos que ligam as vigas superiores às inferiores: $130,1 \mathrm{~cm}$

- Comprimento dos cabos que ligam as vigas inferiores ao piso: $75,4 \mathrm{~cm}$

- Força concentrada aplicada à laje, a ser transferida para a laje de reação: 1300 kN

Observa-se que a diferença entre os deslocamentos ocorridos no apoio das vigas superiores, conectadas às vigas inferiores tipo 1, e os ocorridos no apoio das vigas superiores, conectadas às vigas inferiores tipo 2 , é da ordem de $0,15 \mathrm{~mm}$, sendo este valor considerado pequeno para provocar alguma anomalia na distribuição do carregamento entre as vigas superiores (figuras A.10 e A.11).

\section{Viga inferior tipo 1}

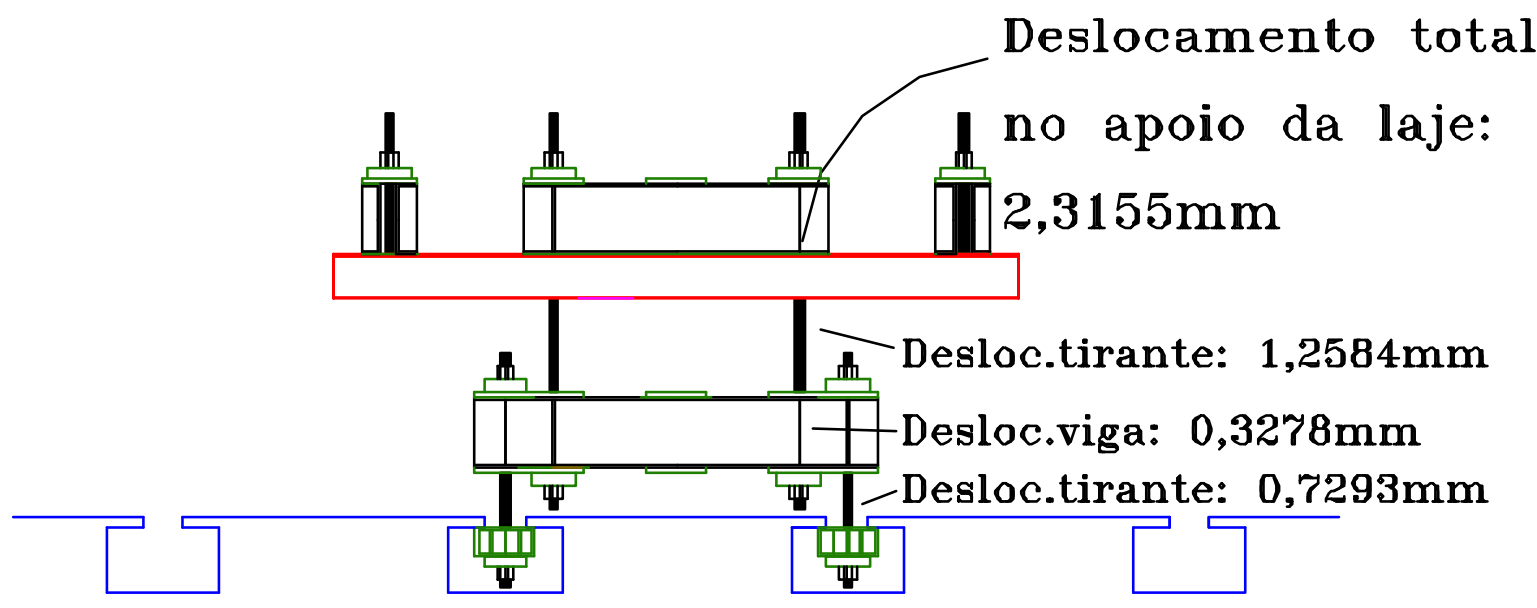

Figura A.10 - Análise dos deslocamentos - Viga inferior tipo 1 


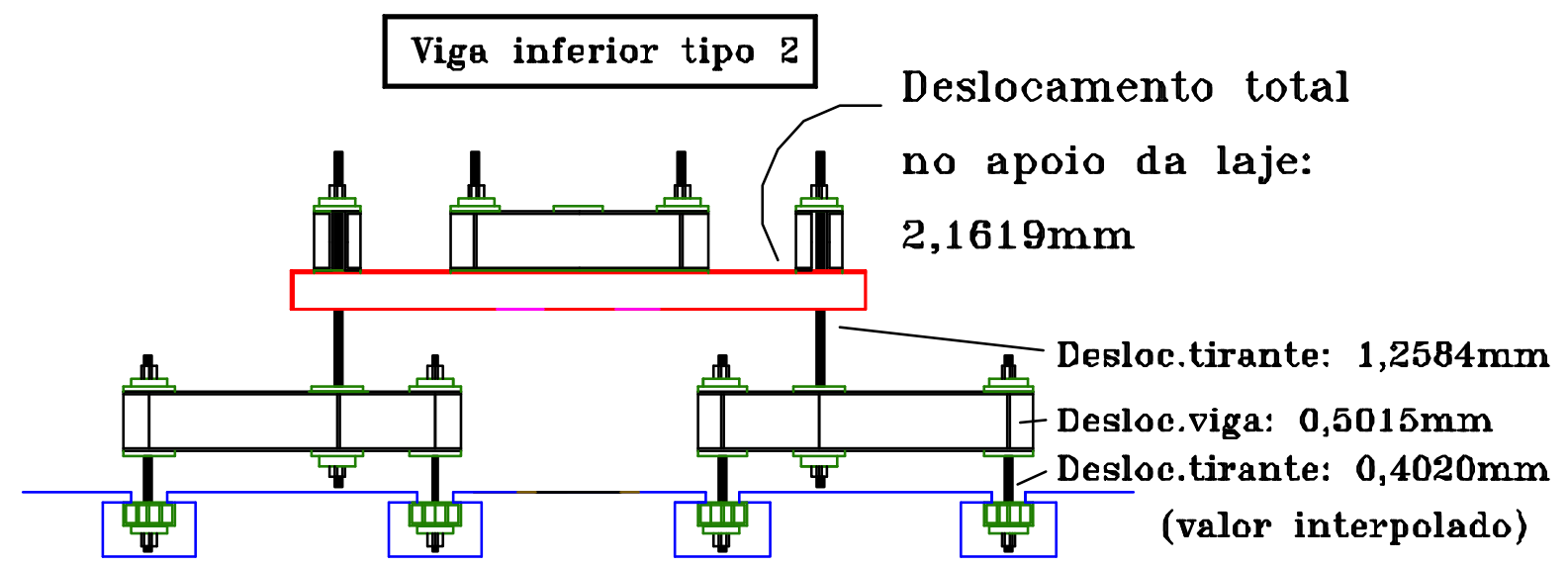

Figura A.11 - Análise dos deslocamentos - Viga inferior tipo 2 
ANEXO B

Detalhamento da fôrma 


\section{ANEXO B - Detalhes do projeto da fôrma}

Apresentam-se alguns detalhes do projeto da fôrma. Para a sua face inferior, foram usados 5 painéis de madeira compensada com dimensões de $220 \mathrm{~cm}$ x $110 \mathrm{~cm}$ x 2 $\mathrm{cm}$. A união destes painéis se deu através de sarrafos de $5 \mathrm{~cm}$ de largura por $2,5 \mathrm{~cm}$ de espessura, conforme indicado na figura B.1. Nas figuras B.2 e B.3 tem-se o detalhamento das faces laterais da fôrma, que, por sua vez, eram ligadas à face inferior através de parafusos que atravessavam a face inferior e eram parafusados na face lateral.

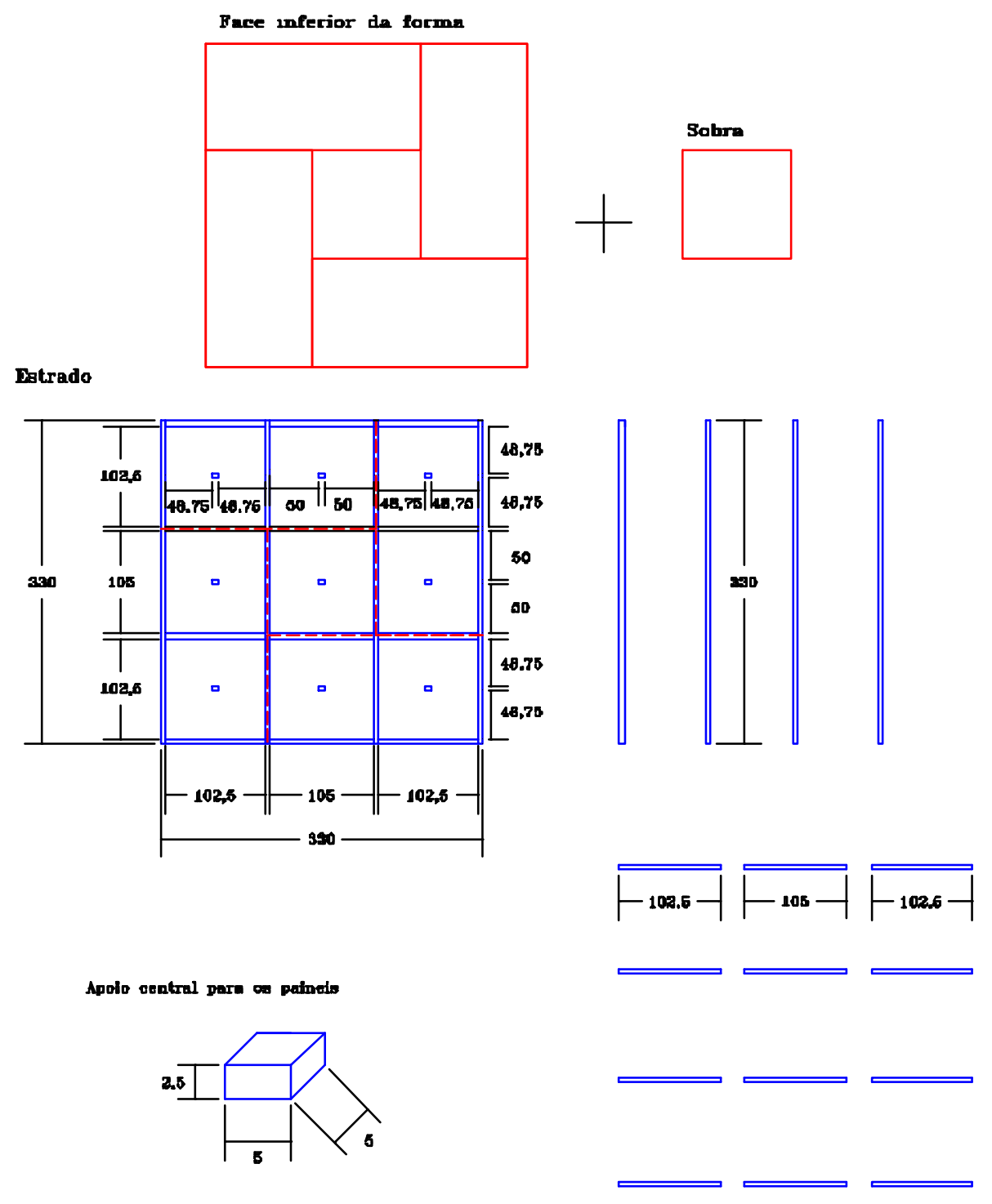

Figura B.1 - Esquema para montagem da face inferior da fôrma 


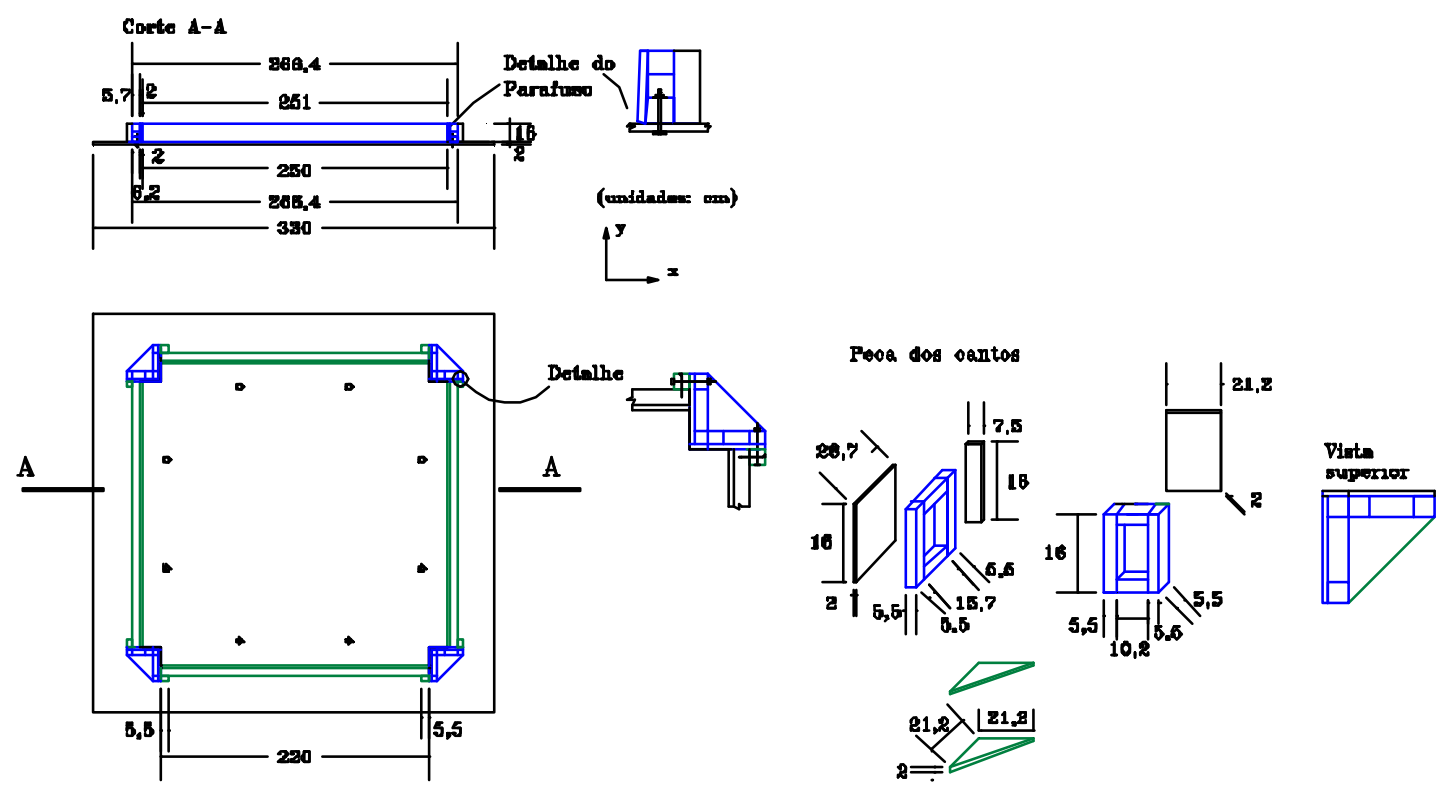

Figura B.2 - Detalhamento das faces laterais da fôrma
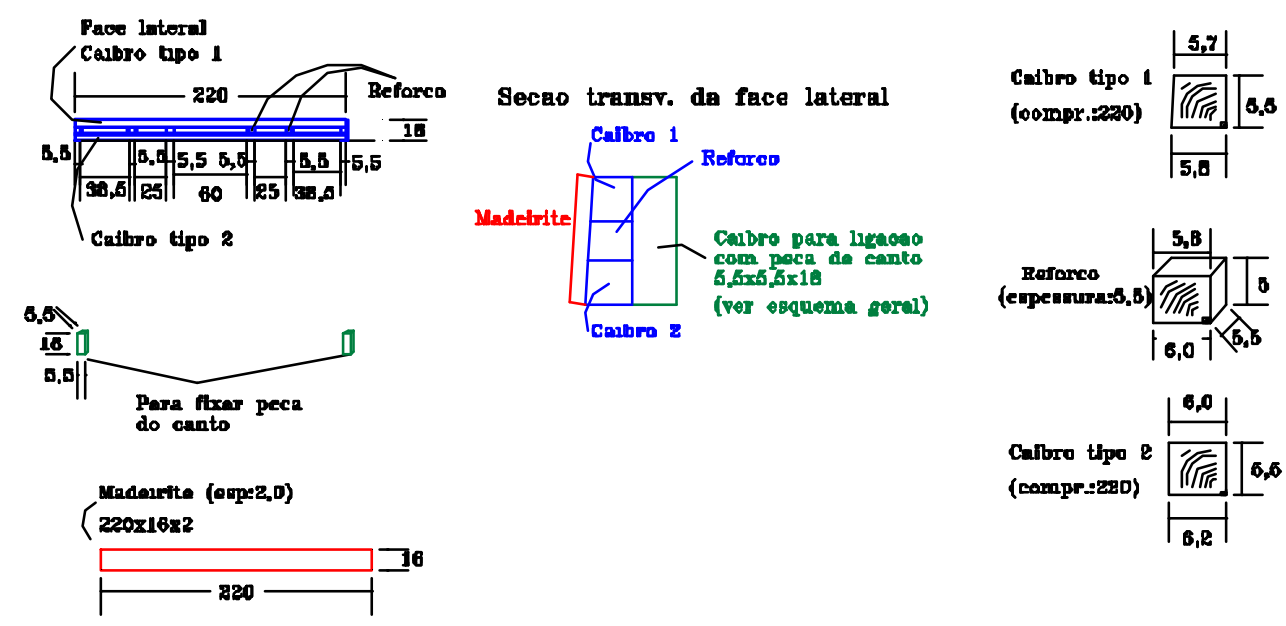

Figura B.3 - Detalhamento das faces laterais da fôrma 

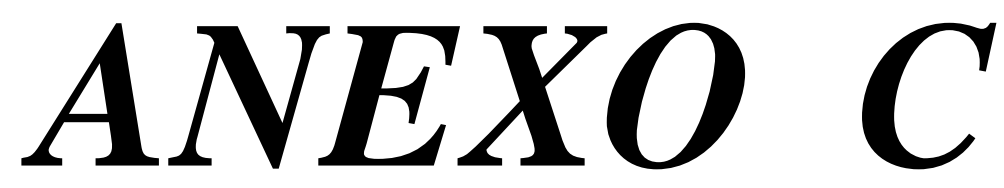

Informações relacionadas ao concreto usado nos modelos de ensaio 


\section{ANEXO C - Informações relacionadas ao}

concreto usado nos modelos de ensaio

Tabela C.1 - MODELO M1 - Resultados dos ensaios

\begin{tabular}{|c|c|c|c|c|c|c|c|}
\hline \multirow{2}{*}{$\begin{array}{l}\text { Nro. } \\
\text { c.d.p }\end{array}$} & \multicolumn{2}{|c|}{ Data de } & \multirow{2}{*}{$\begin{array}{l}\text { Idade } \\
\text { j dias }\end{array}$} & \multirow{2}{*}{$\begin{array}{c}\text { Tipo } \\
\text { de Ensaio }\end{array}$} & \multirow{2}{*}{$\begin{array}{c}\text { Carga de } \\
\text { ruptura }(\mathrm{kN})\end{array}$} & \multirow{2}{*}{$\begin{array}{c}f_{c j} \\
(\mathrm{MPa})\end{array}$} & \multirow{2}{*}{$\begin{array}{c}\mathrm{ftj} \\
(\mathrm{MPa})\end{array}$} \\
\hline & Moldagem & Ensaio & & & & & \\
\hline 01 & $27 / 05 / 99$ & $31 / 05 / 99$ & 4 & Compr. & 277,6 & 15,71 & - \\
\hline 02 & $"$ & $02 / 06 / 99$ & 6 & Compr. & 292,2 & 16,53 & - \\
\hline 03 & $"$ & $10 / 06 / 99$ & 14 & Compr. & 329,5 & 18,65 & - \\
\hline 04 & $"$ & $17 / 06 / 99$ & 21 & Compr. & 421,8 & 23,87 & - \\
\hline 05 & $"$ & $23 / 06 / 99$ & 27 & Compr. & 457,1 & 25,87 & - \\
\hline 06 & $"$ & $02 / 07 / 99$ & 36 & Compr. & 468,6 & 26,52 & - \\
\hline 07 & $"$ & $"$ & $"$ & Compr. & 507,4 & $28,71 *$ & - \\
\hline 08 & $"$ & $"$ & $"$ & Compr. & 458,8 & $25,96 *$ & - \\
\hline 09 & $"$ & " & $"$ & Compr. & 468,0 & $26,48 *$ & - \\
\hline 10 & $"$ & $"$ & $"$ & Compr. & 472,8 & $26,76 *$ & - \\
\hline 11 & $"$ & $"$ & $"$ & Compr. & 471,6 & $26,29 *$ & - \\
\hline 12 & $"$ & $"$ & $"$ & Compr. & 451,1 & 25,53 & - \\
\hline 13 & $"$ & $"$ & $"$ & Compr. & 462,6 & 26,18 & - \\
\hline 14 & " & " & $"$ & Tração & 191,5 & - & 2,709 \\
\hline 15 & $"$ & $"$ & $"$ & Tração & 195,0 & - & 2,758 \\
\hline 16 & $"$ & $"$ & " & Tração & 141,1 & - & $1,996 * *$ \\
\hline 17 & $"$ & $"$ & $"$ & Tração & 195,6 & - & 2,768 \\
\hline 18 & $"$ & $"$ & $"$ & Tração & 184,4 & - & 2,608 \\
\hline \multicolumn{8}{|c|}{ * - Corpos-de-prova que tiveram o seu módulo de elasticidade tangente determinado: } \\
\hline \multicolumn{8}{|c|}{ Corpo-de-prova 07: $\mathrm{E}=29228 \mathrm{MPa}$} \\
\hline \multicolumn{8}{|c|}{ Corpo-de-prova 08: $\mathrm{E}=29376 \mathrm{MPa}$} \\
\hline \multicolumn{8}{|c|}{ Corpo-de-prova 09: $\mathrm{E}=28013 \mathrm{MPa}$} \\
\hline \multicolumn{8}{|c|}{ Corpo-de-prova 10: $\mathrm{E}=30562 \mathrm{MPa}$} \\
\hline \multicolumn{8}{|c|}{ Corpo-de-prova 11: $\mathrm{E}=27959 \mathrm{MPa}$} \\
\hline
\end{tabular}


Tabela C.2 - MODELO M2 - Resultados dos ensaios

\begin{tabular}{|c|c|c|c|c|c|c|c|}
\hline \multirow{2}{*}{$\begin{array}{l}\text { Nro. } \\
\text { c.d.p }\end{array}$} & \multicolumn{2}{|c|}{ Data de } & \multirow{2}{*}{$\begin{array}{l}\text { Idade } \\
\text { j dias }\end{array}$} & \multirow{2}{*}{$\begin{array}{c}\text { Tipo } \\
\text { de Ensaio }\end{array}$} & \multirow{2}{*}{$\begin{array}{c}\text { Carga de } \\
\text { ruptura }(\mathrm{kN})\end{array}$} & \multirow{2}{*}{$\begin{array}{c}\mathrm{f}_{\mathrm{cj}} \\
(\mathrm{MPa}) \\
\end{array}$} & \multirow{2}{*}{$\begin{array}{c}\mathrm{ftj} \\
(\mathrm{MPa})\end{array}$} \\
\hline & Moldagem & Ensaio & & & & & \\
\hline 01 & $06 / 05 / 99$ & $10 / 05 / 99$ & 4 & Compr. & 443,26 & 25,08 & - \\
\hline 02 & $"$ & $14 / 05 / 99$ & 8 & Compr. & 653,12 & 36,96 & - \\
\hline 03 & " & $20 / 05 / 99$ & 14 & Compr. & 811,70 & 45,94 & - \\
\hline 04 & " & $28 / 05 / 99$ & 22 & Compr. & 894,5 & 50,62 & - \\
\hline 05 & $"$ & $"$ & " & Compr. & 894,1 & 50,60 & - \\
\hline 06 & $"$ & $"$ & " & Compr. & 868,7 & $49,16 *$ & - \\
\hline 07 & $"$ & $"$ & " & Compr. & 883,4 & $49,99 *$ & - \\
\hline 08 & $"$ & $"$ & " & Compr. & 867,9 & $49,11 *$ & - \\
\hline 09 & $"$ & $"$ & $"$ & Tração & 211,4 & - & 2,991 \\
\hline 10 & " & " & " & Tração & 225,8 & - & 3,195 \\
\hline 11 & $"$ & $"$ & $"$ & Tração & 278,7 & - & 3,943 \\
\hline 12 & $"$ & $"$ & $"$ & Tração & 272,7 & - & 3,858 \\
\hline \multicolumn{8}{|c|}{ * - Corpos-de-prova que tiveram o seu módulo de elasticidade tangente determinado: } \\
\hline \multicolumn{8}{|c|}{ Corpo-de-prova 06: $\mathrm{E}=30364 \mathrm{MPa}$} \\
\hline \multicolumn{8}{|c|}{ Corpo-de-prova 07: $\mathrm{E}=31898 \mathrm{MPa}$} \\
\hline \multicolumn{8}{|c|}{ Corpo-de-prova 08: $\mathrm{E}=33997 \mathrm{MPa}$} \\
\hline
\end{tabular}


Tabela C.3 - MODELO M3 - Resultados dos ensaios

\begin{tabular}{|c|c|c|c|c|c|c|c|}
\hline \multirow{2}{*}{$\begin{array}{l}\text { Nro. } \\
\text { c.d.p }\end{array}$} & \multicolumn{2}{|c|}{ Data de } & \multirow{2}{*}{$\begin{array}{l}\text { Idade } \\
\text { j dias }\end{array}$} & \multirow{2}{*}{$\begin{array}{c}\text { Tipo } \\
\text { de Ensaio }\end{array}$} & \multirow{2}{*}{$\begin{array}{c}\text { Carga de } \\
\text { ruptura }(\mathrm{kN})\end{array}$} & \multirow{2}{*}{$\begin{array}{c}f_{\mathrm{cj}} \\
(\mathrm{MPa}) \\
\end{array}$} & \multirow{2}{*}{$\begin{array}{c}\mathrm{ftj} \\
(\mathrm{MPa})\end{array}$} \\
\hline & Moldagem & Ensaio & & & & & \\
\hline 01 & $21 / 07 / 99$ & $23 / 07 / 99$ & 2 & Compr. & 441,9 & 25,01 & - \\
\hline 02 & " & $28 / 07 / 99$ & 7 & Compr. & 684,1 & 38,71 & - \\
\hline 03 & " & 28/07/99 & 7 & Compr. & 653,2 & 36,96 & - \\
\hline 04 & " & $04 / 08 / 99$ & 14 & Compr. & 807,0 & 45,67 & - \\
\hline 05 & $"$ & 04/08/99 & 14 & Compr. & 812,4 & 45,97 & - \\
\hline 06 & " & $11 / 08 / 99$ & 21 & Compr. & 872,6 & 49,38 & - \\
\hline 07 & " & $12 / 08 / 99$ & 22 & Compr. & 855,6 & $48,42 *$ & - \\
\hline 08 & $"$ & $"$ & " & Compr. & 869,8 & $49,22 *$ & - \\
\hline 09 & $"$ & $"$ & $"$ & Compr. & 839,0 & $47,48 *$ & - \\
\hline 10 & $"$ & " & $"$ & Compr. & 849,0 & $48,04 *$ & - \\
\hline 11 & $"$ & $"$ & $"$ & Compr. & 844,8 & 47,81 & - \\
\hline 12 & $"$ & $"$ & $"$ & Compr. & 843,1 & 47,71 & - \\
\hline 13 & $"$ & $"$ & $"$ & Compr. & 894,5 & 50,62 & - \\
\hline 14 & " & " & " & Tração & 283,7 & - & 4,014 \\
\hline 15 & $"$ & $"$ & $"$ & Tração & 270,3 & - & 3,824 \\
\hline 16 & $"$ & $"$ & $"$ & Tração & 268,1 & - & 3,793 \\
\hline 17 & $"$ & $"$ & $"$ & Tração & 255,3 & - & 3,612 \\
\hline 18 & " & " & $"$ & Tração & 254,2 & - & 3,596 \\
\hline
\end{tabular}

* - Corpos-de-prova que tiveram o seu módulo de elasticidade tangente determinado (por um problema técnico, a correlação dos corpos-de-prova com os seus módulos não pôde ser feita em função da falta de numeração dos corpos-de-prova):

Corpo-de-prova: $\mathrm{E}=33151 \mathrm{MPa}$

Corpo-de-prova: $\mathrm{E}=34024 \mathrm{MPa}$

Corpo-de-prova: $\mathrm{E}=33406 \mathrm{MPa}$

Corpo-de-prova: $\mathrm{E}=33890 \mathrm{MPa}$ 
Tabela C.4 - MODELO M4 - Resultados dos ensaios

\begin{tabular}{|c|c|c|c|c|c|c|c|}
\hline \multirow{2}{*}{$\begin{array}{l}\text { Nro. } \\
\text { c.d.p }\end{array}$} & \multicolumn{2}{|c|}{ Data de } & \multirow{2}{*}{$\begin{array}{l}\text { Idade } \\
\text { j dias }\end{array}$} & \multirow{2}{*}{$\begin{array}{c}\text { Tipo } \\
\text { de Ensaio }\end{array}$} & \multirow{2}{*}{$\begin{array}{c}\text { Carga de } \\
\text { ruptura }(\mathrm{kN})\end{array}$} & \multirow{2}{*}{$\begin{array}{c}\mathrm{f}_{\mathrm{cj}} \\
(\mathrm{MPa}) \\
\end{array}$} & \multirow{2}{*}{$\begin{array}{c}\mathrm{ftj} \\
(\mathrm{MPa}) \\
\end{array}$} \\
\hline & Moldagem & Ensaio & & & & & \\
\hline 01 & 06/10/99 & 08/10/99 & 2 & Compr. & 364,3 & 20,61 & - \\
\hline 02 & $"$ & 13/10/99 & 7 & Compr. & 593,0 & 33,56 & - \\
\hline 03 & " & $13 / 10 / 99$ & 7 & Compr. & 598,3 & 33,85 & - \\
\hline 04 & $"$ & $20 / 10 / 99$ & 14 & Compr. & 756,4 & 42,80 & - \\
\hline 05 & $"$ & 20/10/99 & 14 & Compr. & 747,0 & 42,27 & - \\
\hline 06 & $"$ & 28/10/99 & 22 & Compr. & 804,4 & 45,52 & - \\
\hline 07 & $"$ & $01 / 12 / 99$ & 56 & Compr. & 913,0 & $51,66 *$ & - \\
\hline 08 & $"$ & $"$ & $"$ & Compr. & 911,7 & $51,59 *$ & - \\
\hline 09 & $"$ & $"$ & " & Compr. & 926,0 & $52,40 *$ & - \\
\hline 10 & $"$ & $"$ & $"$ & Compr. & 915,6 & $51,81 *$ & - \\
\hline 11 & $"$ & $"$ & $"$ & Compr. & 897,9 & $50,81 *$ & - \\
\hline 12 & $"$ & $"$ & " & Compr. & 958,3 & 54,23 & - \\
\hline 13 & " & $"$ & $"$ & Compr. & 917,9 & 51,94 & - \\
\hline 14 & $"$ & $"$ & $"$ & Compr. & 900,3 & 50,95 & - \\
\hline 15 & $"$ & $"$ & " & Tração & 277,5 & - & 3,925 \\
\hline 16 & $"$ & $"$ & $"$ & Tração & 284,0 & - & 4,017 \\
\hline 17 & $"$ & $"$ & " & Tração & 267,2 & - & 3,780 \\
\hline 18 & $"$ & $"$ & " & Tração & 265,9 & - & 3,762 \\
\hline \multicolumn{8}{|c|}{ * - Corpos-de-prova que tiveram o seu módulo de elasticidade tangente determinado: } \\
\hline \multicolumn{8}{|c|}{ Corpo-de-prova 07: $\mathrm{E}=35559 \mathrm{MPa}$} \\
\hline \multicolumn{8}{|c|}{ Corpo-de-prova 08: $\mathrm{E}=33431 \mathrm{MPa}$} \\
\hline \multicolumn{8}{|c|}{ Corpo-de-prova 09: $\mathrm{E}=34274 \mathrm{MPa}$} \\
\hline \multicolumn{8}{|c|}{ Corpo-de-prova 10: $\mathrm{E}=31885 \mathrm{MPa}$} \\
\hline \multicolumn{8}{|c|}{ Corpo-de-prova 11: $\mathrm{E}=34054 \mathrm{MPa}$} \\
\hline
\end{tabular}


Tabela C.5 - MODELO M5 - Resultados dos ensaios

\begin{tabular}{|c|c|c|c|c|c|c|c|}
\hline \multirow{2}{*}{$\begin{array}{l}\text { Nro. } \\
\text { c.d.p }\end{array}$} & \multicolumn{2}{|c|}{ Data de } & \multirow{2}{*}{$\begin{array}{l}\text { Idade } \\
\text { j dias }\end{array}$} & \multirow{2}{*}{$\begin{array}{c}\text { Tipo } \\
\text { de Ensaio }\end{array}$} & \multirow{2}{*}{$\begin{array}{c}\text { Carga de } \\
\text { ruptura }(\mathrm{kN})\end{array}$} & \multirow{2}{*}{$\begin{array}{c}f_{\mathrm{cj}} \\
(\mathrm{MPa})\end{array}$} & \multirow{2}{*}{$\begin{array}{c}\mathrm{ftj} \\
(\mathrm{MPa})\end{array}$} \\
\hline & Moldagem & Ensaio & & & & & \\
\hline 01 & $09 / 12 / 99$ & $16 / 12 / 99$ & 7 & Compr. & 685,2 & 38,77 & - \\
\hline 02 & " & $16 / 12 / 99$ & 7 & Compr. & 720,5 & 40,77 & - \\
\hline 03 & " & $06 / 01 / 00$ & 28 & Compr. & 945,6 & 53,51 & - \\
\hline 04 & " & $16 / 02 / 00$ & 69 & Compr. & 1040 & $58,87^{*}$ & - \\
\hline 05 & $"$ & $"$ & $"$ & Compr. & 1066 & $60,31 *$ & - \\
\hline 06 & " & $"$ & " & Compr. & 1065 & $60,27 *$ & - \\
\hline 07 & $"$ & $"$ & $"$ & Compr. & 1044 & $59,08^{*}$ & - \\
\hline 08 & $"$ & " & " & Compr. & 1089 & $61,63^{*}$ & - \\
\hline 09 & $"$ & $"$ & " & Compr. & 1054 & $59,67^{*}$ & - \\
\hline 10 & " & $"$ & " & Compr. & 1034 & 58,50 & - \\
\hline 11 & $"$ & $"$ & " & Compr. & 1074 & 60,76 & - \\
\hline 12 & $"$ & $"$ & " & Compr. & 981,2 & 55,53 & - \\
\hline 13 & $"$ & $"$ & " & Tração & 309,3 & - & 4,376 \\
\hline 14 & $"$ & $"$ & $"$ & Tração & 314,9 & - & 4,455 \\
\hline 15 & $"$ & $"$ & $"$ & Tração & 330,6 & - & 4,677 \\
\hline 16 & $"$ & $"$ & $"$ & Tração & 265,9 & - & 3,762 \\
\hline 17 & $"$ & $"$ & $"$ & Tração & 299,9 & - & 4,243 \\
\hline 18 & " & $"$ & " & Tração & 303,6 & - & 4,295 \\
\hline \multicolumn{8}{|c|}{ * - Corpos-de-prova que tiveram o seu módulo de elasticidade tangente determinado: } \\
\hline \multicolumn{8}{|c|}{ Corpo-de-prova 04: $E=34600$} \\
\hline \multicolumn{8}{|c|}{ Corpo-de-prova 05: $\mathrm{E}=38299 \mathrm{MPa}$} \\
\hline \multicolumn{8}{|c|}{ Corpo-de-prova 06: $\mathrm{E}=37529 \mathrm{MPa}$} \\
\hline \multicolumn{8}{|c|}{ Corpo-de-prova 07: $\mathrm{E}=37694 \mathrm{MPa}$} \\
\hline \multicolumn{8}{|c|}{ Corpo-de-prova 08: $\mathrm{E}=39548 \mathrm{MPa}$} \\
\hline \multicolumn{8}{|c|}{ Corpo-de-prova 09: $\mathrm{E}=37024 \mathrm{MPa}$} \\
\hline
\end{tabular}


Tabela C.6 - MODELO M6 - Resultados dos ensaios

\begin{tabular}{|c|c|c|c|c|c|c|c|}
\hline \multirow{2}{*}{$\begin{array}{l}\text { Nro. } \\
\text { c.d.p }\end{array}$} & \multicolumn{2}{|c|}{ Data de } & \multirow{2}{*}{$\begin{array}{l}\text { Idade } \\
\text { j dias }\end{array}$} & \multirow{2}{*}{$\begin{array}{c}\text { Tipo } \\
\text { de Ensaio }\end{array}$} & \multirow{2}{*}{$\begin{array}{c}\text { Carga de } \\
\text { ruptura }(\mathrm{kN})\end{array}$} & \multirow{2}{*}{$\begin{array}{c}\mathrm{f}_{\mathrm{cj}} \\
(\mathrm{MPa}) \\
\end{array}$} & \multirow{2}{*}{$\begin{array}{c}\mathrm{ftj} \\
(\mathrm{MPa}) \\
\end{array}$} \\
\hline & Moldagem & Ensaio & & & & & \\
\hline 01 & $28 / 10 / 99$ & $01 / 11 / 99$ & 4 & Compr. & 499,9 & 28,29 & - \\
\hline 02 & " & $05 / 11 / 99$ & 8 & Compr. & 612,9 & 34,68 & - \\
\hline 03 & $"$ & $11 / 11 / 99$ & 14 & Compr. & 733,0 & 41,48 & - \\
\hline 04 & " & $18 / 11 / 99$ & 21 & Compr. & 762,9 & 43,17 & - \\
\hline 05 & $"$ & $27 / 12 / 99$ & 60 & Compr. & 860,0 & 48,67 & - \\
\hline 06 & $"$ & $28 / 01 / 00$ & 92 & Compr. & 900,9 & 50,98 & - \\
\hline 07 & $"$ & $"$ & $"$ & Compr. & 915,8 & 51,82 & - \\
\hline 08 & $"$ & $"$ & $"$ & Compr. & 899,2 & $50,88^{*}$ & - \\
\hline 09 & $"$ & $"$ & $"$ & Compr. & 916,6 & $51,87 *$ & - \\
\hline 10 & " & $"$ & $"$ & Compr. & 910,4 & $51,52 *$ & - \\
\hline 11 & $"$ & $"$ & $"$ & Compr. & 918,3 & $51,96^{*}$ & - \\
\hline 12 & $"$ & $"$ & $"$ & Compr. & 922,5 & $52,20 *$ & - \\
\hline 13 & $"$ & $"$ & $"$ & Compr. & 906,3 & $51,28 *$ & - \\
\hline 14 & $"$ & $"$ & $"$ & Tração & 219,2 & - & 3,101 \\
\hline 15 & $"$ & $"$ & $"$ & Tração & 253,4 & - & 3,585 \\
\hline 16 & " & $"$ & $"$ & Tração & 303,8 & - & 4,298 \\
\hline 17 & $"$ & $"$ & $"$ & Tração & 267,6 & - & 3,786 \\
\hline 18 & $"$ & $"$ & $"$ & Tração & 255,3 & - & 3,611 \\
\hline \multicolumn{8}{|c|}{ * _ Corpos-de-prova que tiveram o seu módulo de elasticidade tangente determinado: } \\
\hline \multicolumn{8}{|c|}{ Corpo-de-prova 08: $\mathrm{E}=31765 \mathrm{MPa}$} \\
\hline \multicolumn{8}{|c|}{ Corpo-de-prova 09: $\mathrm{E}=32608 \mathrm{MPa}$} \\
\hline \multicolumn{8}{|c|}{ Corpo-de-prova 10: $\mathrm{E}=31815 \mathrm{MPa}$} \\
\hline \multicolumn{8}{|c|}{ Corpo-de-prova 11: $\mathrm{E}=31590 \mathrm{MPa}$} \\
\hline \multicolumn{8}{|c|}{ Corpo-de-prova 12: $\mathrm{E}=32355 \mathrm{MPa}$} \\
\hline \multicolumn{8}{|c|}{ Corpo-de-prova 13: $\mathrm{E}=31946 \mathrm{MPa}$} \\
\hline
\end{tabular}



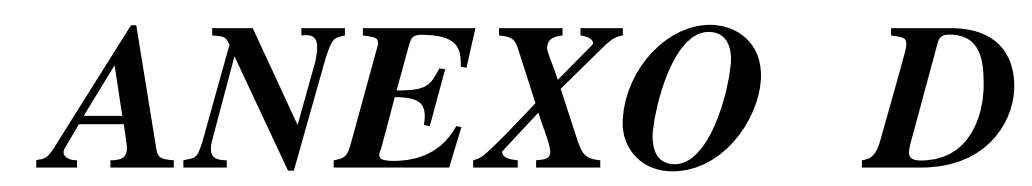

Posicionamento das cordoalhas de protensão 


\section{ANEXO D - Posicionamento das cordoalhas}

As equações das parábolas, que representam o traçado das cordoalhas, são dadas a seguir.

Equações das cordoalhas dispostas na direção x (cordoalhas 1' a 8'):

$$
\begin{aligned}
& \mathrm{h}_{\mathrm{x}}=\left(\frac{-4 \mathrm{e}_{\mathrm{x}}}{\mathrm{L}^{2}}\right) \mathrm{x}^{2}+\frac{4 \mathrm{e}_{\mathrm{x}}}{\mathrm{L}} \mathrm{x} ; \text { onde: } \\
& \mathrm{x} \quad=\text { posição na qual se deseja saber a excentricidade da cordoalha } \\
& \mathrm{L} \quad=\text { comprimento da cordoalha }(=250 \mathrm{~cm}) \\
& \mathrm{e}_{\mathrm{X}} \quad=\text { excentricidade máxima da cordoalha no meio do vão } \\
& \mathrm{e}_{\mathrm{X}} \quad=8-1,5-1,25-1,25-1,285 / 2=3,358 \mathrm{~cm} ; \\
& \mathrm{h}_{\mathrm{X}} \quad=\text { excentricidade da cordoalha na posição } \mathrm{x} \text { (figura D.1) } \\
& \mathrm{h}_{\mathrm{x}}=-0,00021488 \mathrm{x}^{2}+0,05372 \mathrm{x} ; \text { com } \mathrm{h}_{\mathrm{X}} \text { e } \mathrm{x} \text { em } \mathrm{cm} .
\end{aligned}
$$

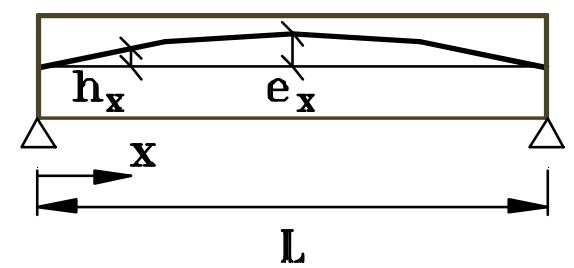

Figura D.1 - Esquema para obtenção da parábola

Equações das cordoalhas dispostas na direção y (cordoalhas 1 a 8 ):

$$
\begin{aligned}
& \mathrm{h}_{\mathrm{y}}=\left(\frac{-4 \mathrm{e}_{\mathrm{y}}}{\mathrm{L}^{2}}\right) \mathrm{y}^{2}+\frac{4 \mathrm{e}_{\mathrm{y}}}{\mathrm{L}} \mathrm{y} ; \text { onde: } \\
& \mathrm{y} \quad=\text { posição na qual se deseja saber a excentricidade da cordoalha } \\
& \mathrm{L} \quad=\text { comprimento da cordoalha } \\
& \mathrm{e}_{\mathrm{y}} \quad=\text { excentricidade máxima da cordoalha no meio do vão } \\
& \mathrm{e}_{\mathrm{y}} \quad=8-1,5-1,25-1,285 / 2=4,608 \mathrm{~cm} \\
& \mathrm{~h}_{\mathrm{y}} \quad=\text { excentricidade da cordoalha na posição y } \\
& \mathrm{h}_{\mathrm{y}}=-0,00029488 \mathrm{y}^{2}+0,07372 \mathrm{y} ; \text { com } \mathrm{h}_{\mathrm{y}} \mathrm{e} \mathrm{y} \mathrm{em} \mathrm{cm.}
\end{aligned}
$$


Nas figuras D.2 a D.5, têm-se ilustrados os traçados das cordoalhas, visando a sua compatibilização.

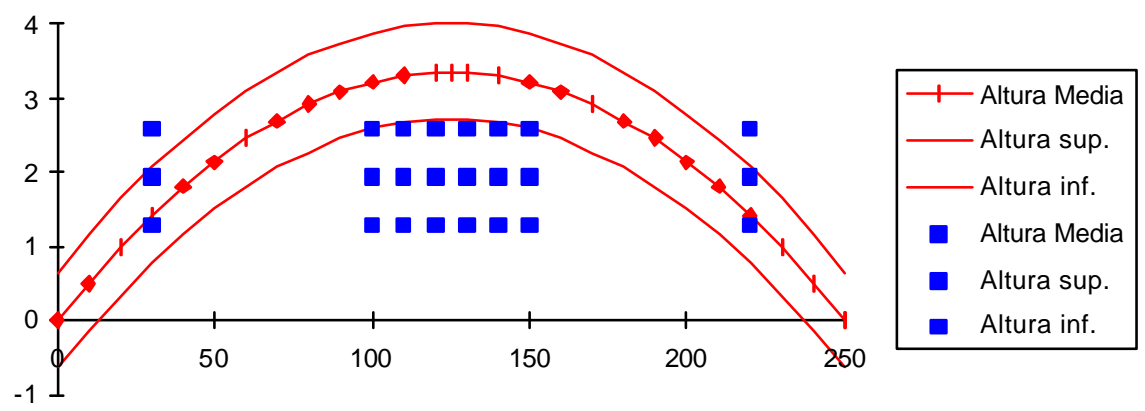

Figura D.2 - Encontro Cordoalha 1' (vermelho) com cordoalhas 1, 2, 3, 4, 5, 6, 7, 8, numeradas, sequiencialmente, da esquerda para a direita

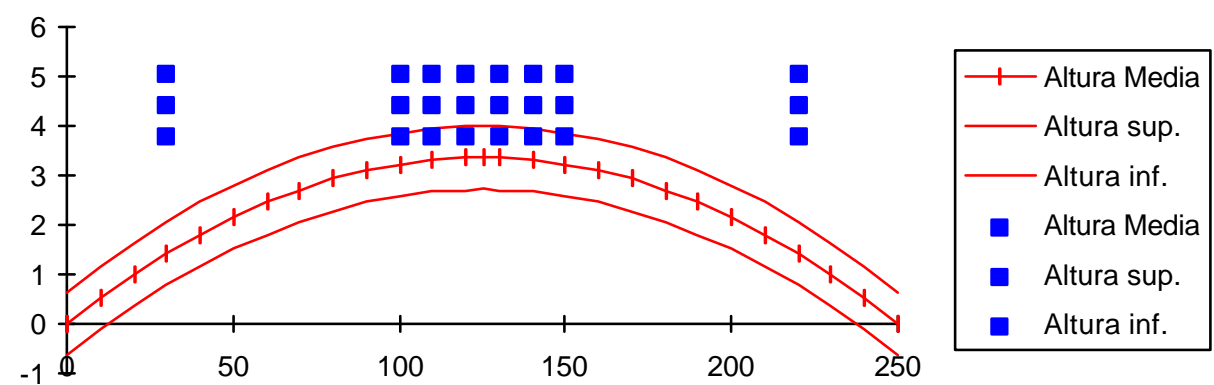

Figura D.3 - Encontro Cordoalha 2' (vermelho) com cordoalhas 1, 2, 3, 4, 5, 6, 7, 8, numeradas, seqüencialmente, da esquerda para a direita

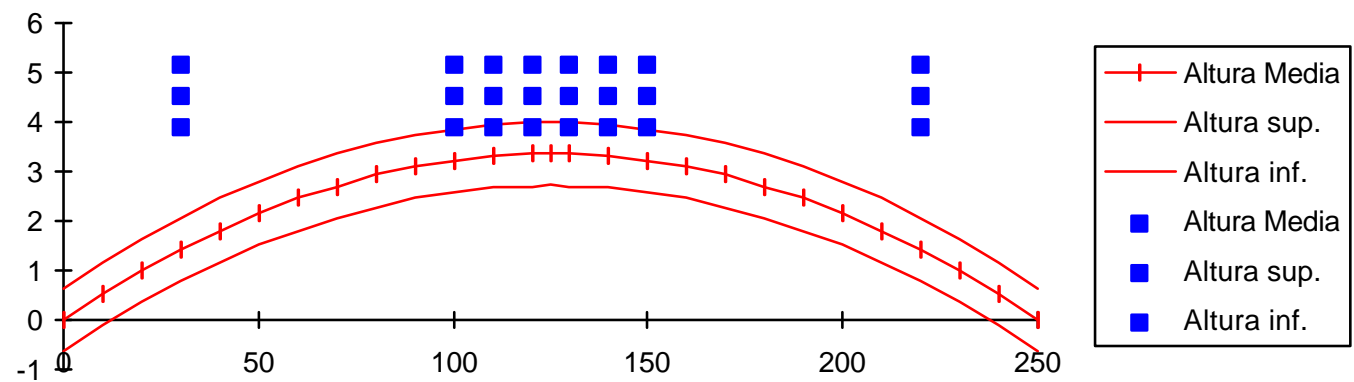

Figura D.4 - Encontro Cordoalha 3' (vermelho) com cordoalhas 1, 2, 3, 4, 5, 6, 7, 8, numeradas, seqüencialmente, da esquerda para a direita 


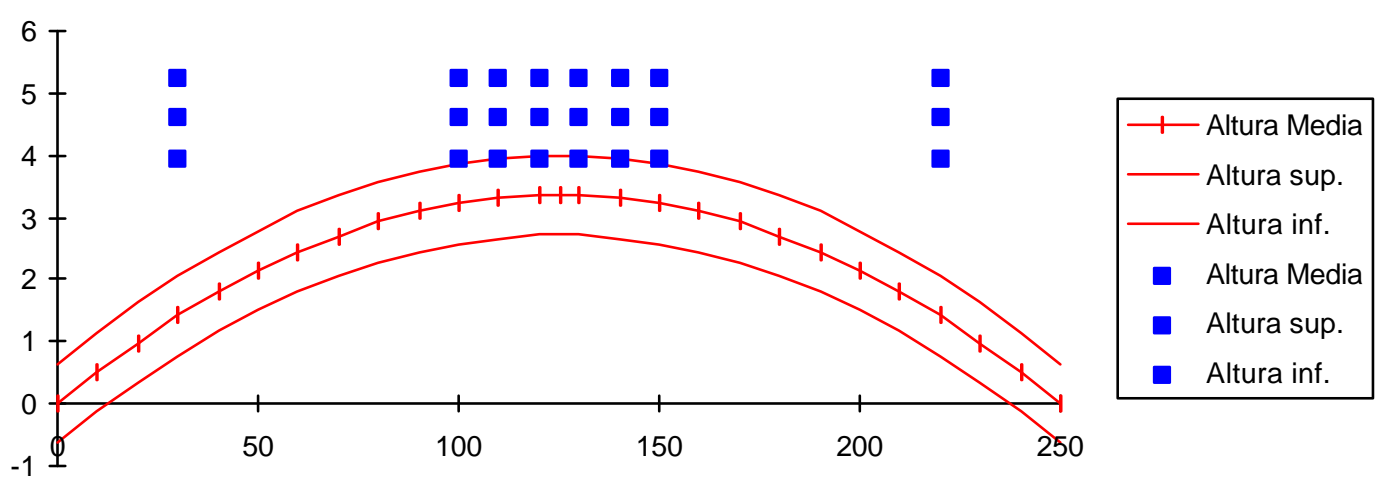

Figura D.5 - Encontro Cordoalha 4' (vermelho) com cordoalhas 1, 2, 3, 4, 5, 6, 7, 8, numeradas, sequiencialmente, da esquerda para a direita 


\section{ANEXO E}

Armadura de flexão 


\section{ANEXO E - Armadura de flexão}

São apresentados os procedimentos usados para caracterizar as barras usadas nos modelos em concreto armado e protendido, com relação às suas propriedades geométricas e mecânicas.

\section{E.1. PRIMEIRO LOTE DE BARRAS}

Este primeiro lote de barras, constituído por 11 barras de $16 \mathrm{~mm}$ de diâmetro e 11 barras de $8 \mathrm{~mm}$ de diâmetro, foi usado para a construção de um protótipo que teve por objetivo apenas verificar os procedimentos a serem executados nos modelos seguintes. Para cada diâmetro, foram separadas três barras e, para cada uma dessas barras, foram extraídos dois conjuntos de corpos-de-prova, a serem ensaiados, respectivamente, por dois tipos de máquinas. O primeiro tipo refere-se à máquina universal de ensaios AMSLER (figura E.1), e o segundo tipo refere-se às máquinas servo-controladas INSTRON e DARTEC (figura E.2).

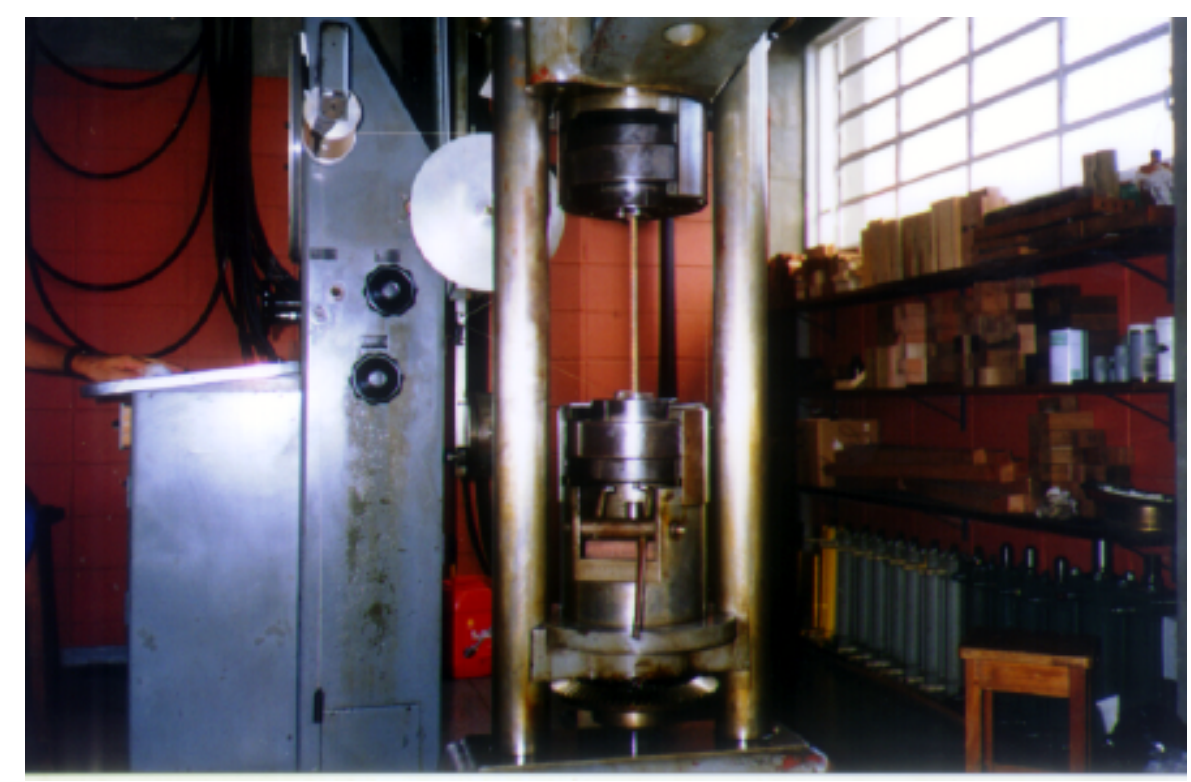

Figura E.1 - Máquina AMSLER 


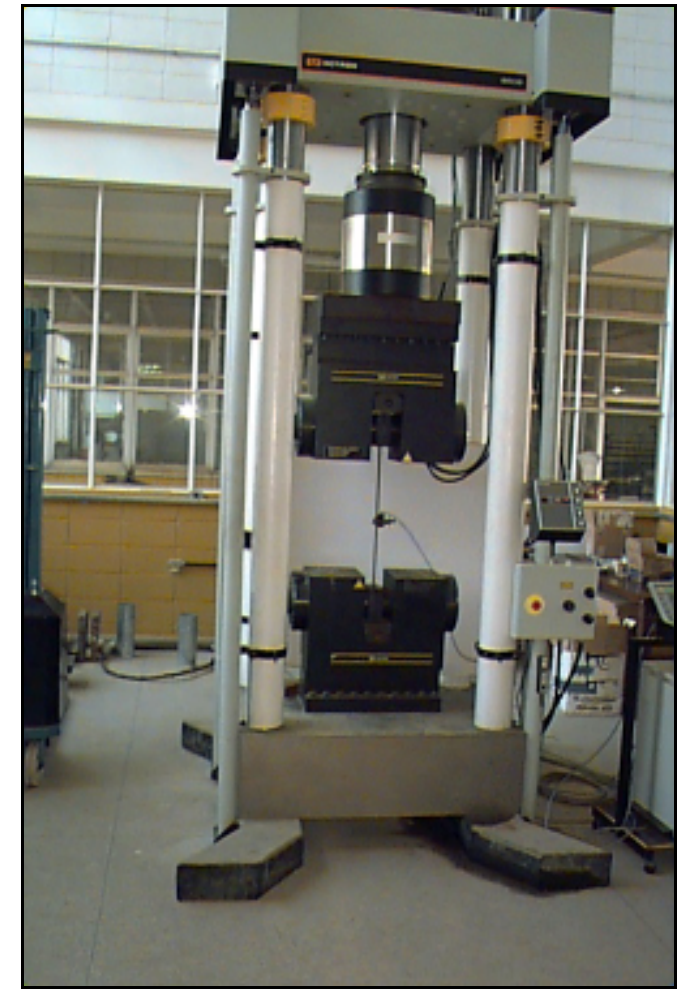

a) Instron

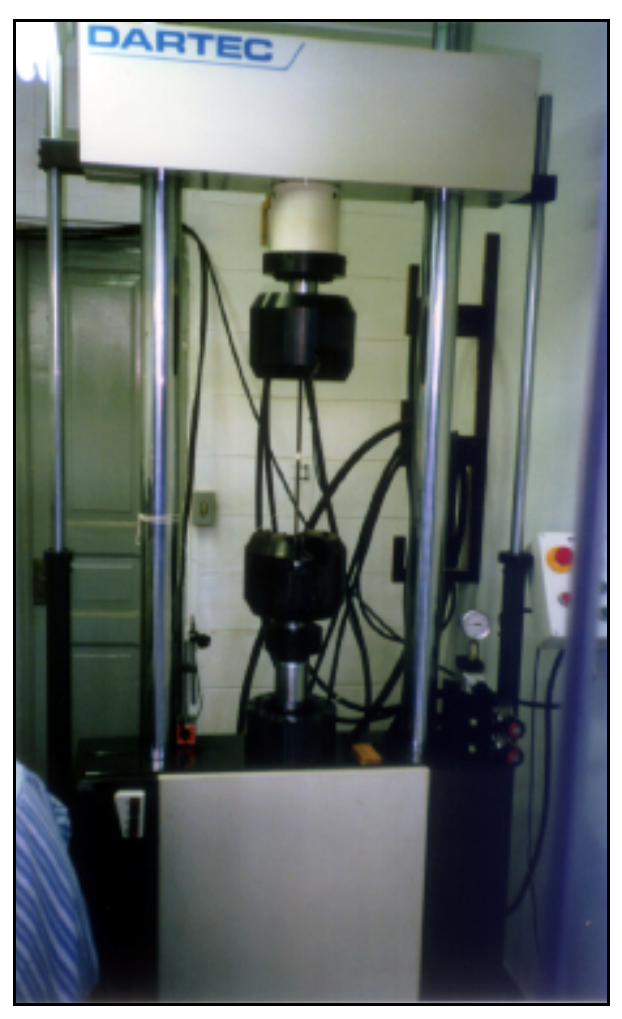

b) Dartec

Figura E.2 - Máquinas servo-controladas usadas nos ensaios

O tipo de extensômetro mecânico usado para medir as deformações na barra, nos ensaios relacionados às máquinas Instron e Dartec, está ilustrado na figura E.3.

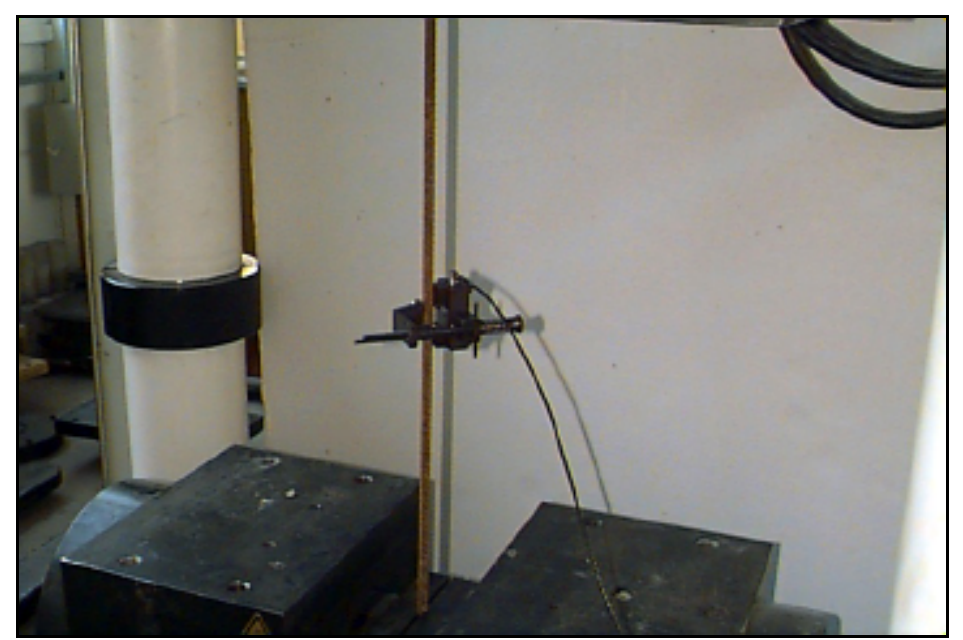

Figura E.3 - Tipo de extensômetro mecânico usado para medir as deformações nas barras 
Para os corpos-de-prova das barras com $16 \mathrm{~mm}$, três deles foram ensaiados na máquina universal de ensaios AMSLER, do Laboratório de Madeiras e de Estruturas de Madeiras, que forneceu os valores das tensões de escoamento e de ruptura à tração, e três deles, na máquina de universal de ensaios mecânicos, servo-controlada e computadorizada, para ensaios estáticos e dinâmicos, marca INSTRON, no Laboratório do Departamento de Engenharia de Estruturas, que, além de fornecer os valores das tensões de escoamento e de ruptura, forneceu o valor do módulo de elasticidade do corpo-de-prova. Já para os corpos-de-prova das barras com $8 \mathrm{~mm}$, três deles foram ensaiados na máquina universal de ensaios AMSLER, que forneceu os valores das tensões de escoamento e de ruptura, e três deles, na máquina universal de ensaios, servocontrolada e computadorizada, marca DARTEC, no Laboratório de Madeiras e de Estruturas de Madeiras, que, além de fornecer os valores das tensões de escoamento e de ruptura, forneceu o valor do módulo de elasticidade do corpo-de-prova.

\section{a) Ensaios realizados na máquina AMSLER ( $\phi 16 \mathrm{~mm}$ e $\phi 8 \mathrm{~mm})$}

Os dados e resultados relativos aos ensaios realizados na máquina $\boldsymbol{A M S L E R}$ estão ilustrados nas tabelas E.1 e E.2.

Tabela E.1 - Características geométricas das barras usadas na máquina $\boldsymbol{A M S L E R}$

\begin{tabular}{|c|c|c|c|c|c|c|}
\hline Diâm. $(\mathbf{m m})$ & $\boldsymbol{C P}$ & Peso $(\mathbf{g})$ & Comp/to $(\mathbf{c m})$ & Área $\left(\mathbf{c m}^{2}\right)$ & $f_{\boldsymbol{y}}(\mathbf{M P a})$ & $f_{\boldsymbol{r}}(\mathbf{M P a})$ \\
\hline \multirow{3}{*}{16} & 1 & 719,6 & 45,1 & 2,033 & 610,2 & 733,2 \\
\cline { 2 - 7 } & 2 & 721,4 & 45,1 & 2,038 & 596,8 & 726,6 \\
\cline { 2 - 7 } & 3 & 716,2 & 44,9 & 2,032 & 598,4 & 726,3 \\
\hline \multirow{3}{*}{8} & 1 & 176,2 & 45,1 & 0,498 & - & 708,9 \\
\cline { 2 - 7 } & 2 & 176,2 & 45,2 & 0,497 & 576,5 & 702,9 \\
\cline { 2 - 7 } & 3 & 175,3 & 45,1 & 0,495 & 588,1 & 704,9 \\
\hline
\end{tabular}

Tabela E.2 - Valores médios da área e tensões de escoamento e ruptura das barras usadas na máquina $\boldsymbol{A M S L E R}$

\begin{tabular}{|c|c|c|c|}
\hline Diâm. (mm) & Área $\left(\mathrm{cm}^{2}\right)$ & $f_{\boldsymbol{y}}$ (MPa) & $f_{\boldsymbol{r}}$ (MPa) \\
\hline 16 & $2,034 \pm 0,003( \pm 0,2 \%)$ & $601,8 \pm 7,3( \pm 1,2 \%)$ & $728,7 \pm 3,9( \pm 0,3 \%)$ \\
\hline 8 & $0,497 \pm 0,002( \pm 0,3 \%)$ & $582,3 \pm 8,2 \pm 1,4 \%)$ & $705,6 \pm 3,1( \pm 0,5 \%)$ \\
\hline
\end{tabular}


Todas as amostras ensaiadas na máquina AMSLER apresentaram o mesmo tipo de gráfico força versus deslocamento, mostrado na figura E.4. A presença do patamar de escoamento caracterizou a armadura como sendo do tipo A.

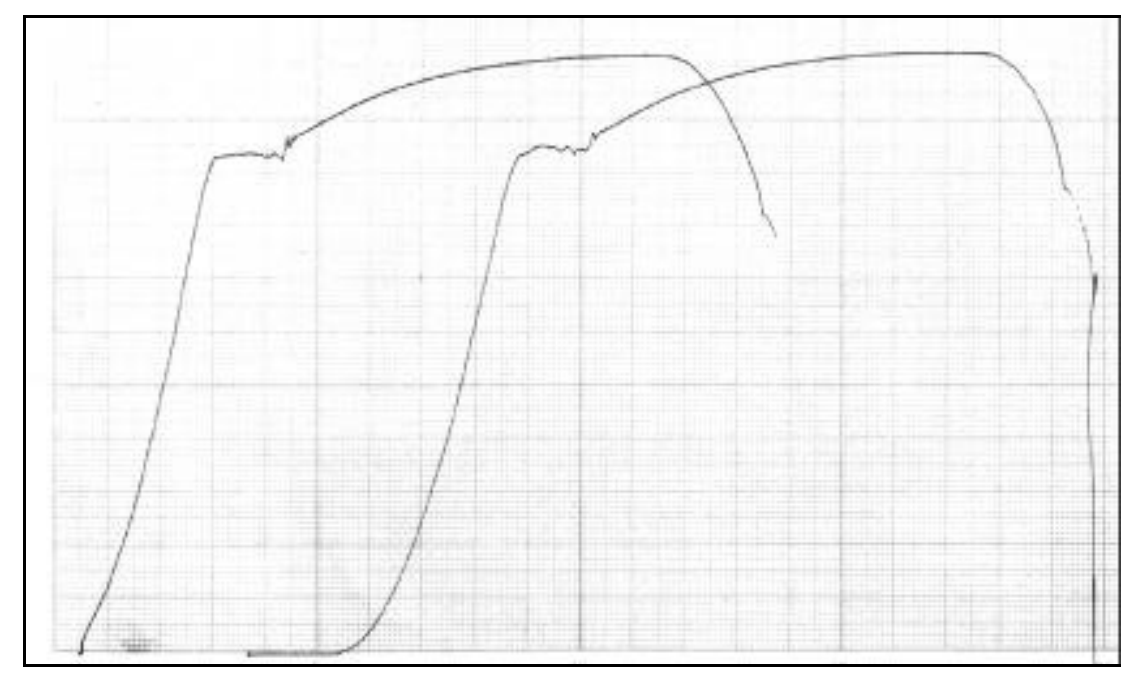

Figura E.4 - Diagrama força x deslocamento

\section{b) Ensaios realizados nas máquinas INSTRON (申16 mm) e $\operatorname{DARTEC}(\boldsymbol{\phi} 8 \mathrm{~mm})$}

Já os dados e os resultados relativos aos ensaios realizados nas máquinas INSTRON e DARTEC estão ilustrados nas tabelas E.3 e E.4. Nestes corpos-de-prova, seguiram-se as recomendações da NBR 6152, com relação à velocidade de ensaio. O termo "Corr.", na tabela E.3, representa o coeficiente de correlação entre as deformações e as tensões, ou seja, o quanto o conjunto de pontos obtidos no ensaio se aproxima de uma reta. Esta medida pode assumir valores entre -1 e 1 . Como exemplo, para um valor do coeficiente de correlação igual a 0,95, tem-se o grau de associabilidade linear em 95\%. Este coeficiente foi considerado útil para definir se o conjunto de pontos usados para calcular o Módulo de Deformação Longitudinal apresentava um alto grau de associabilidade linear. 
Tabela E.3 - Características geométricas das barras usadas

\begin{tabular}{|c|c|c|c|c|c|c|c|c|}
\hline $\begin{array}{c}\text { Diâm. } \\
(\mathbf{m m})\end{array}$ & $\boldsymbol{C P}$ & $\begin{array}{c}\text { Peso } \\
(\mathbf{g})\end{array}$ & $\begin{array}{c}\text { Comp/to } \\
(\mathbf{c m})\end{array}$ & $\begin{array}{c}\text { Área } \\
\left(\mathbf{c m}^{2}\right)\end{array}$ & $\begin{array}{c}f_{\boldsymbol{y}} \\
(\mathbf{M P a})\end{array}$ & $\begin{array}{c}f_{\boldsymbol{r}} \\
(\mathbf{M P a})\end{array}$ & $\begin{array}{c}\text { Mod. de Def. } \\
\text { Longit. }(\mathbf{M P a})\end{array}$ & Corr. \\
\hline \multirow{3}{*}{16} & 1 & 1232,6 & 77,3 & 2,031 & 597,7 & 721,7 & 199941 & 1,0000 \\
\cline { 2 - 9 } & 2 & 1218,8 & 76,5 & 2,030 & 605,5 & 737,4 & 179910 & 1,0000 \\
\cline { 2 - 9 } & 3 & 1226,4 & 76,8 & 2,034 & 601,4 & 731,6 & 190777 & 1,0000 \\
\hline \multirow{3}{*}{8} & 1 & 166,6 & 42,7 & 0,497 & 581,2 & 710,3 & 211342 & 1,0000 \\
\cline { 2 - 8 } & 2 & 165,5 & 42,3 & 0,498 & 583,3 & 706,4 & 215817 & 1,0000 \\
\cline { 2 - 8 } & 3 & 166,2 & 42,6 & 0,497 & 588,3 & 707,8 & 215309 & 1,0000 \\
\hline
\end{tabular}

- No cálculo do Módulo de Deformação Longitudinal, usou-se o trecho de reta limitado pelas tensões de $50 \mathrm{MPa}$ e $450 \mathrm{MPa}$.

Tabela E.4 - Valores médios da área e das tensões de escoamento e de ruptura

\begin{tabular}{|c|c|c|c|c|}
\hline Diâm. $(\mathbf{m m})$ & Área $\left(\mathbf{c m}^{2}\right)$ & $f_{\boldsymbol{y}}(\mathbf{M P a})$ & $f_{\boldsymbol{r}}$ (MPa) & Mód. de Def. Long. (MPa) \\
\hline 16 & $2,032 \pm 0,002$ & $601,5 \pm 3,9$ & $730,2 \pm 7,9$ & $190209 \pm 10028$ \\
& $( \pm 0,1 \%)$ & $( \pm 0,7 \%)$ & $( \pm 1,1 \%)$ & $( \pm 5,3 \%)$ \\
\hline 8 & $0,497 \pm 0,001$ & $584,3 \pm 3,6$ & $708,2 \pm 2,0$ & $214156 \pm 2450$ \\
& $( \pm 0,2 \%)$ & $( \pm 0,6 \%)$ & $( \pm 0,3 \%)$ & $( \pm 1,1 \%)$ \\
\hline
\end{tabular}

$\mathrm{Na}$ tabela E.5, têm-se as velocidades de carregamento usadas nos ensaios. O ensaio foi realizado, até o escoamento, com uma determinada velocidade; após o escoamento, esta velocidade foi aumentada.

Tabela E.5 - Velocidades de ensaio usadas

\begin{tabular}{|c|c|c|}
\hline $\begin{array}{l}\text { Diâm. } \\
(\mathrm{mm})\end{array}$ & $\begin{array}{c}\text { Veloc. p/determinação da tensão de } \\
\text { escoamento }(\mathrm{mm} / \mathrm{s})\end{array}$ & $\begin{array}{c}\text { Veloc. p/determinação da tensãa de } \\
\text { ruptura }(\mathrm{mm} / \mathrm{s})\end{array}$ \\
\hline 16 & 0,02 (Limite NBR 6152: 0,0245) & 0,2 (Limite NBR 6152: 3,43) \\
\hline 8 & 0,014 (Limite NBR 6152: 0,019) & 0,14 (Limite NBR 6152: 2,67) \\
\hline
\end{tabular}

O valor do Módulo de Deformação Longitudinal da armadura foi obtido através da inclinação de uma linha de tendência no trecho retilíneo do gráfico. Como exemplo, na figura E.5, tem-se o gráfico tensão-deformação obtido no ensaio do corpo-de-prova 1, de 16 mm de diâmetro. 
Já na figura E.6, tem-se ilustrado o trecho retilíneo que foi usado para calcular o módulo de deformação longitudinal desta barra.

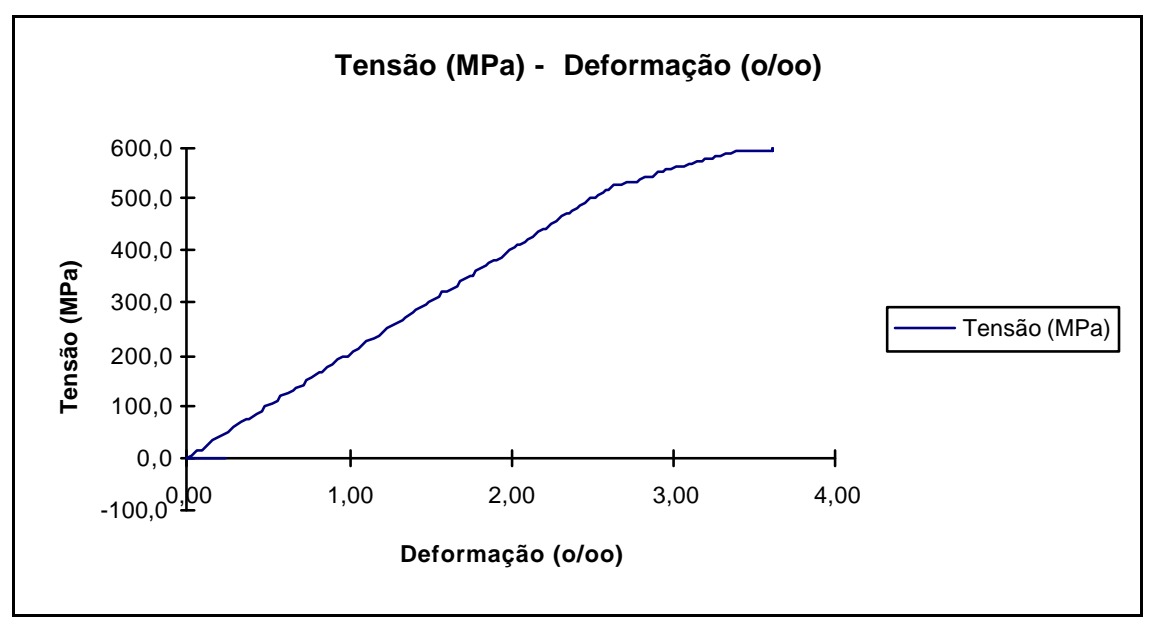

Figura E.5 - Gráfico tensão - deformação no ensaio

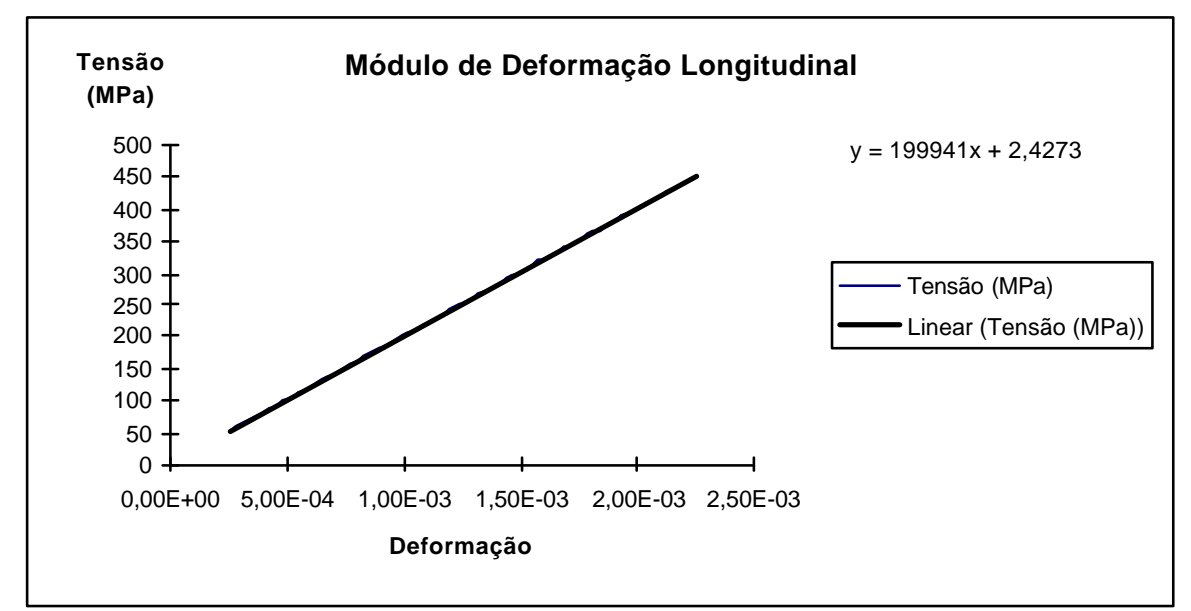

Figura E.6 - Gráfico usado para obter o Módulo de Deformação Longitudinal

\section{c) Comparação dos resultados obtidos}

Na tabela E.6, têm-se os valores comparativos entre as máquinas. Pode-se observar que as diferenças são irrelevantes, sendo inferiores a $0,5 \%$. 
Tabela E.6 - Comparação entre os valores medidos pelas máquinas de ensaio

\begin{tabular}{|c|c|c|c|}
\hline Diâmetro (mm) & Máquina & $\boldsymbol{f}_{\boldsymbol{y}}(\mathbf{M P a})$ & $\boldsymbol{f}_{\boldsymbol{r}}(\mathbf{M P a})$ \\
\hline \multirow{3}{*}{16} & AMSLER & 601,8 & 728,7 \\
\cline { 2 - 4 } & INSTRON & 601,5 & 730 \\
\cline { 2 - 4 } & Dif. (\%) & $0,05 \%$ & $0,21 \%$ \\
\hline \multirow{3}{*}{8} & AMSLER & 582,3 & 705,6 \\
\cline { 2 - 4 } & DARTEC & 584,3 & 708,2 \\
\cline { 2 - 4 } & Dif. (\%) & $0,34 \%$ & $0,37 \%$ \\
\hline
\end{tabular}

\section{E.2. SEGUNDO LOTE DE BARRAS}

Neste segundo lote, foram pedidas 22 barras de $16 \mathrm{~mm}$ e 22 barras de $8 \mathrm{~mm}$, a serem usadas nos modelos M1 e M2.

Para cada diâmetro, foram extraídos 4 corpos-de-prova de barras diferentes.

Em vista do fornecedor ser o mesmo e do pequeno período de tempo entre o pedido deste lote e o do primeiro (2 meses), optou-se por usar a máquina AMSLER, na definição das tensões de escoamento e ruptura, e também por se adotar o valor dos módulos obtidos no primeiro lote de barras.

Os resultados obtidos estão mostrados nas tabelas E.7 e E.8, e pode ser observado que os valores da área e das tensões de escoamento e de ruptura, para este lote, estão bem próximos dos valores relativos ao primeiro lote ensaiado na máquina AMSLER.

É importante destacar que o tipo de diagrama para todas as barras ensaiadas na máquina AMNSLER, mostrado na figura E.7, caracterizou o aço como sendo do tipo A. 


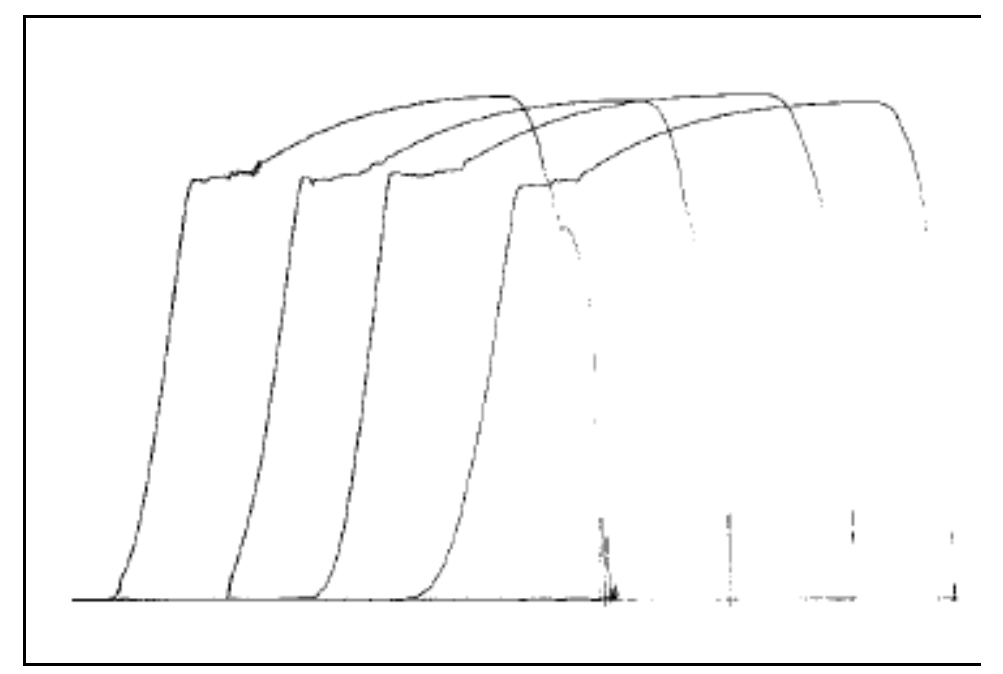

Figura E.7 - Relação entre a força e o deslocamento das barras ensaiadas

Tabela E.7 - Características geométricas das barras usadas na máquina $\boldsymbol{A M S L E R}$

\begin{tabular}{|c|c|c|c|c|c|c|}
\hline Diâm. (mm) & $\boldsymbol{C P}$ & Peso $(\mathbf{g})$ & Comp/to $(\mathbf{c m})$ & Área $\left(\mathbf{c m}^{2}\right)$ & $f_{\boldsymbol{y}}(\mathbf{M P a})$ & $f_{\boldsymbol{r}}(\mathbf{M P a})$ \\
\hline \multirow{3}{*}{16} & 1 & 792,3 & 50,5 & 1,999 & 583,8 & 721,1 \\
\cline { 2 - 7 } & 2 & 791,4 & 50,5 & 1,996 & 579,8 & 714,9 \\
\cline { 2 - 7 } & 3 & 794,9 & 50,5 & 2,005 & 611,4 & 738,6 \\
\cline { 2 - 7 } & 4 & 795,2 & 50,5 & 2,006 & 586,6 & 713,7 \\
\hline \multirow{3}{*}{8} & 1 & 195,8 & 50,3 & 0,496 & 597,1 & 713,8 \\
\cline { 2 - 7 } & 2 & 194,9 & 50,2 & 0,495 & 602,3 & 709,2 \\
\cline { 2 - 7 } & 3 & 196,8 & 50,2 & 0,499 & 601,4 & 711,4 \\
\cline { 2 - 7 } & 4 & 194,7 & 50,3 & 0,493 & 590,8 & 710,1 \\
\hline
\end{tabular}

Tabela E.8 - Valores médios da área e das tensões de escoamento e de ruptura

\begin{tabular}{|c|c|c|c|c|}
\hline Diâm. $(\mathbf{m m})$ & Área $\left(\mathbf{c m}^{2}\right)$ & $f_{\boldsymbol{y}}(\mathbf{M P a})$ & $f_{\boldsymbol{r}}(\mathbf{M P a})$ & Mód. de Def. Long. (MPa) \\
\hline 16 & $2,001 \pm 0,005$ & $590,4 \pm 14,3$ & $722,1 \pm 11,5$ & $190209 *$ \\
& $( \pm 0,2 \%)$ & $( \pm 2,4 \%)$ & $( \pm 1,6 \%)$ & $214156 *$ \\
\hline 8 & $0,496 \pm 0,003$ & $597,9 \pm 5,2$ & $711,1 \pm 2,0$ & \\
& $( \pm 0,5 \%)$ & $( \pm 0,9 \%)$ & $( \pm 0,3 \%)$ & \\
\hline
\end{tabular}




\section{E.3. TERCEIRO LOTE DE BARRAS}

Neste terceiro lote, foram pedidas 22 barras de $16 \mathrm{~mm}$ e 22 barras de $8 \mathrm{~mm}$, a serem usadas nos modelos M3 e parcialmente no modelo M4 (apenas parte das barras de $8 \mathrm{~mm}$ de diâmetro).

Para cada diâmetro, foram extraídos 4 corpos-de-prova de barras diferentes.

Em vista do fornecedor ser o mesmo e do pequeno período de tempo entre o pedido deste lote e o do primeiro (3 meses), optou-se por usar a máquina AMSLER, na definição das tensões de escoamento e ruptura.

Os resultados obtidos estão mostrados nas tabelas E.9 e E.10.

Tabela E.9 - Características geométricas das barras usadas inicialmente na máquina $\boldsymbol{A M S L E R}$

\begin{tabular}{|c|c|c|c|c|c|c|}
\hline $\begin{array}{c}\text { Diâm. } \\
(\boldsymbol{m m})\end{array}$ & $\boldsymbol{C d p}$ & Peso $(\mathbf{g})$ & Comp/to (cm) & Área $\left(\mathbf{c m}^{2}\right)$ & $f_{\boldsymbol{y}}(\mathbf{M P a})$ & $f_{\boldsymbol{r}}(\mathbf{M P a})$ \\
\hline \multirow{3}{*}{16} & 1 & 758,9 & 50,2 & 1,926 & 514,3 & 817,2 \\
\cline { 2 - 7 } & 2 & 754,0 & 50,0 & 1,921 & 505,4 & 814,2 \\
\cline { 2 - 7 } & 3 & 748,4 & 50,0 & 1,907 & 504,0 & 812,5 \\
\cline { 2 - 7 } & 4 & 752,1 & 49,8 & 1,924 & 509,7 & 815,5 \\
\hline \multirow{3}{*}{8} & 1 & 193,0 & 49,5 & 0,497 & - & 801,1 \\
\cline { 2 - 7 } & 2 & 192,9 & 49,6 & 0,495 & - & 802,4 \\
\cline { 2 - 7 } & 3 & 192,9 & 49,5 & 0,496 & - & 800,7 \\
\cline { 2 - 7 } & 4 & 192,4 & 49,5 & 0,495 & - & 816,2 \\
\hline
\end{tabular}

Tabela E.10 - Valores médios da área e das tensões de escoamento e de ruptura das barras, ensaiadas na máquina AMSLER

\begin{tabular}{|c|c|c|c|c|}
\hline Diâm. $(\mathrm{mm})$ & Área $\left(\mathrm{cm}^{2}\right)$ & $f_{y}(M P a)$ & $f_{r}(M P a)$ & Mód. de Def. Long. (GPa) \\
\hline 16 & $\begin{array}{c}1,919 \pm 0,009 \\
( \pm 0,5 \%)\end{array}$ & $\begin{array}{c}508,3 \pm 4,6 \\
( \pm 0,9 \%)\end{array}$ & $\begin{array}{c}814,9 \pm 2,0 \\
( \pm 0,2 \%)\end{array}$ & $190209^{*}$ \\
\hline 8 & $\begin{array}{c}0,496 \pm 0,001( \pm \\
0,1 \%)\end{array}$ & $\begin{array}{c}\text { Sem patamar } \\
\text { de escoamento }\end{array}$ & $\begin{array}{c}805,1 \pm 7,4 \\
( \pm 0,9 \%)\end{array}$ & $214156^{*}$ \\
\hline
\end{tabular}


Para as barras de $16 \mathrm{~mm}$, pode ser observado que os valores da área e das tensões de escoamento e de ruptura para este lote não estão tão próximos dos valores relativos ao primeiro lote ensaiado na máquina AMSLER, quando comparados com as barras do segundo lote.

No entanto, em função do tipo de aço deste lote ter sido caracterizado como sendo do tipo A, foi adotado o valor do módulo obtido no primeiro lote de barras.

Já para as barras de $8 \mathrm{~mm}$, pode-se observar uma mudança significativa com relação ao comportamento mecânico da barra, mostrado na figura E8. Neste caso, o corpo-deprova não apresentou patamar de escoamento, ficando o aço caracterizado como sendo do tipo B.

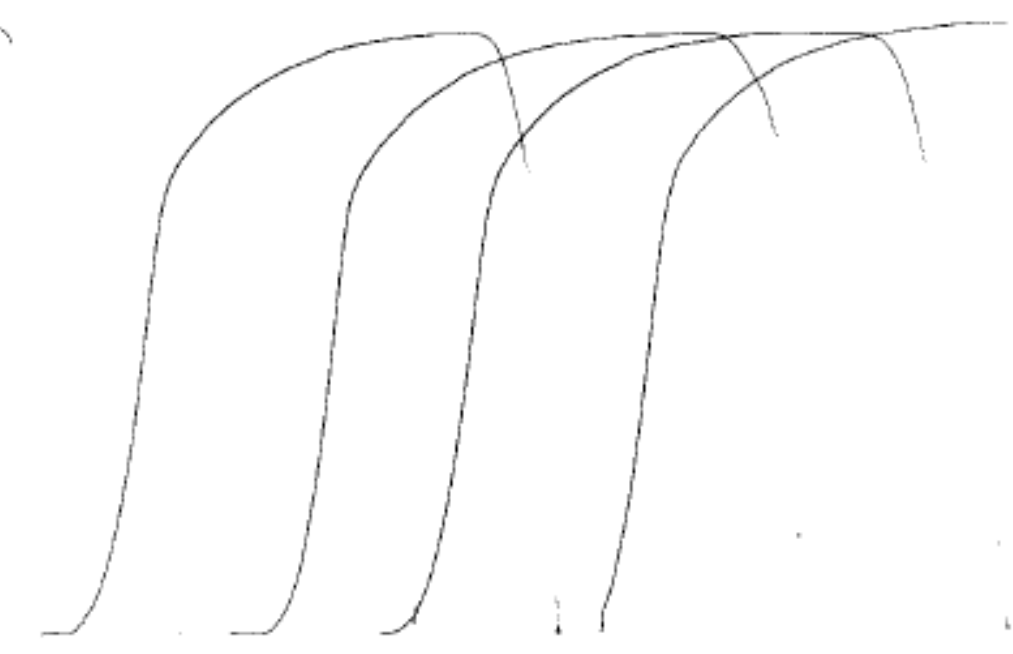

Figura E.8 - Diagrama Força x Deslocamento para corpos-de-prova de $8 \mathrm{~mm}$ de diâmetro

Para o aço tipo B, pode-se destacar dois comportamentos diferentes: até um determinado limite, a relação entre a força e o deslocamento é uma reta, e, a partir deste limite até a ruptura, pode-se adotar uma curva.

Deste modo, para barras com $8 \mathrm{~mm}$ de diâmetro, foi feito um novo estudo para a caracterização do comportamento mecânico do aço, usando-se a máquina INSTRON e o extensômetro mecânico. 
Foram ensaiados três corpos-de-prova, extraídos de barras diferentes do lote, visando a determinação da tensão a partir da qual o comportamento do corpo-de-prova deixa de ser elástico, e também a equação de uma curva que represente o comportamento mecânico da barra, após a tensão limite de proporcionalidade ser ultrapassada.

No entanto, contrariamente ao esperado, das três amostras, duas delas foram caracterizadas como sendo do tipo A (figura E.9), e somente um dos corpos-de-prova como sendo do tipo B (figura E.10).

Constatou-se, desse modo, que, no mesmo lote, foram entregues dois tipos diferentes de barras, com comportamentos mecânicos diferentes.

Os dados relativos a estes ensaios estão mostrados na tabela E.11.

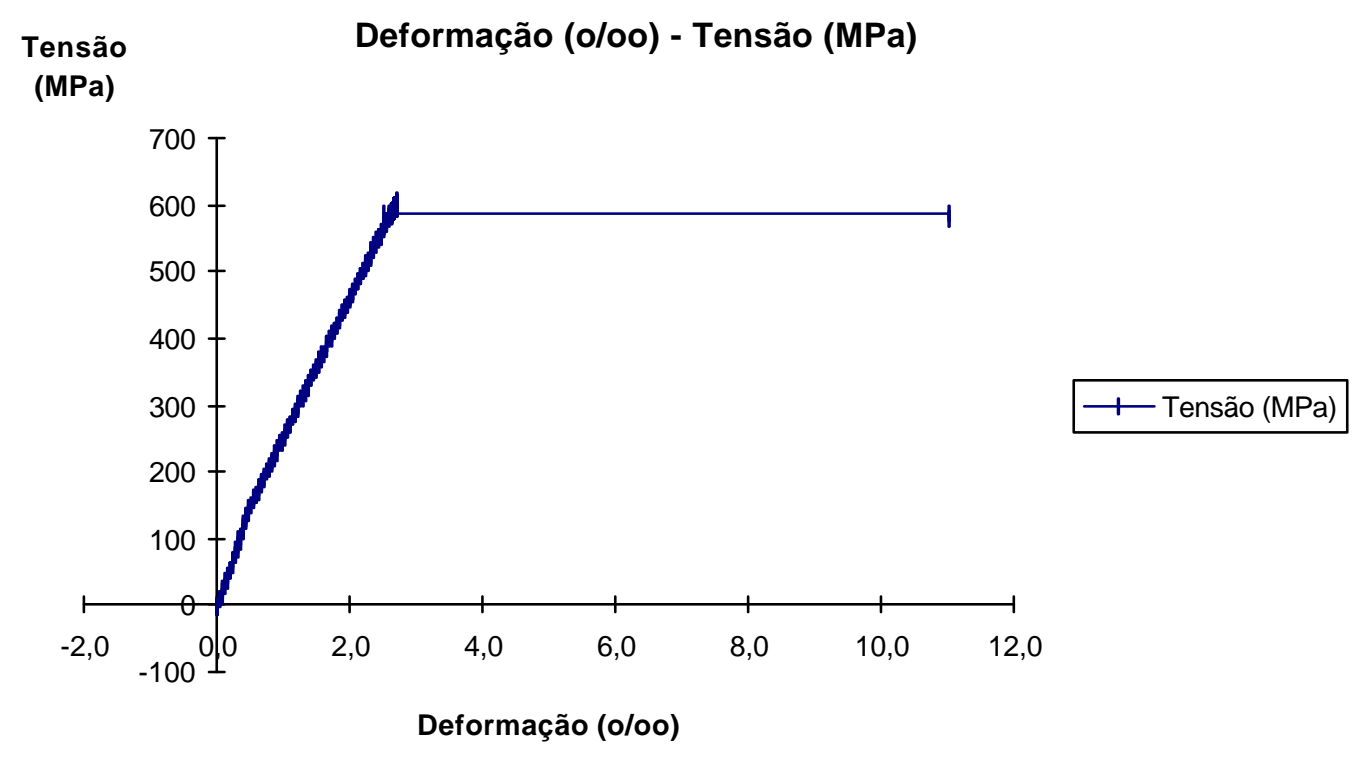

Figura E.9 - Gráfico representativo dos corpos-de-prova 1 e 2. 


\section{Deformação (o/0o) - Tensão (MPa)}

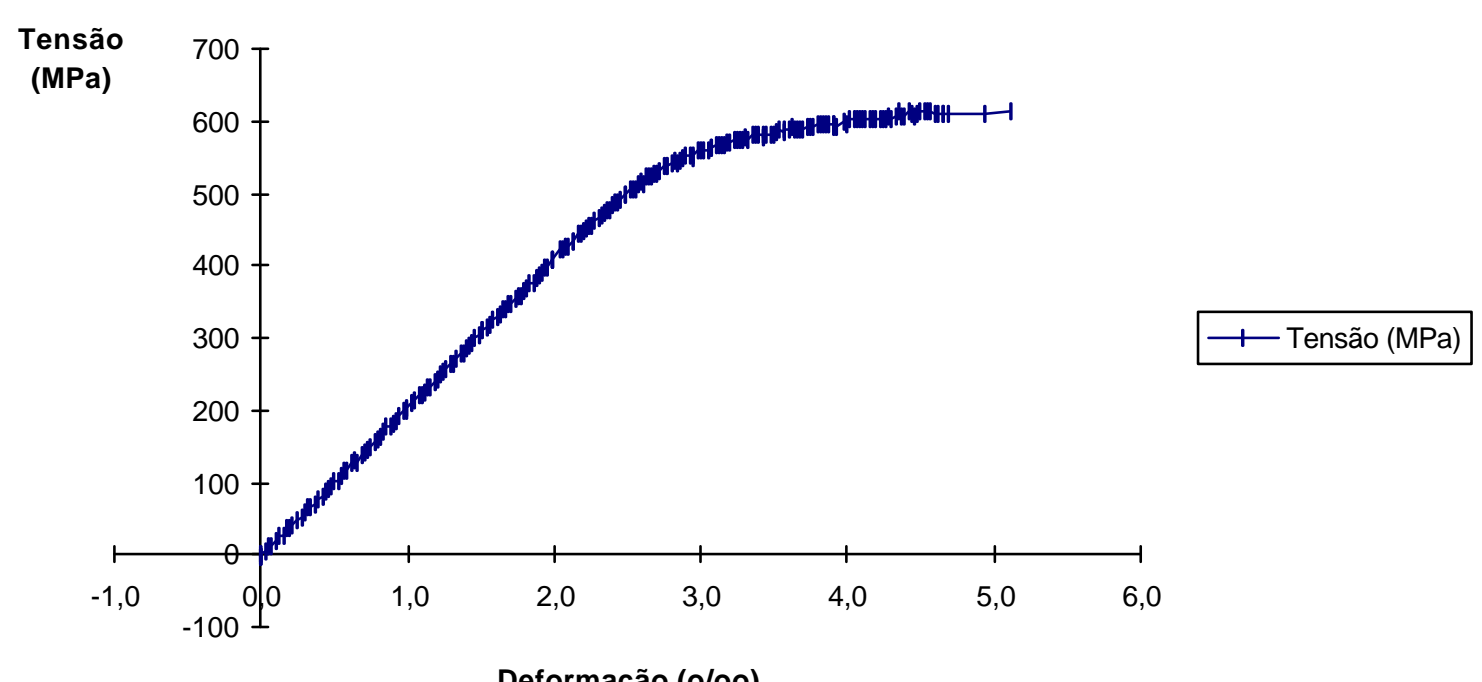

Figura E.10 - Gráfico representativo do corpo-de-prova 3

Tabela E.11- Características mecânicas para barras com 8 mm, relativas ao terceiro lote de barras

\begin{tabular}{|c|c|c|c|c|c|c|c|}
\hline \multicolumn{8}{|c|}{$A C ̧ O C L A S S E A$} \\
\hline$C P$ & $\begin{array}{c}\text { Peso } \\
(g)\end{array}$ & $\begin{array}{c}\text { Comp/to } \\
(\mathrm{cm})\end{array}$ & $\begin{array}{l}\text { Área } \\
\left(\mathrm{cm}^{2}\right)\end{array}$ & $\begin{array}{c}f_{y} \\
(M P a)\end{array}$ & $\begin{array}{c}f_{r} \\
(M P a)\end{array}$ & $\begin{array}{c}\text { Modulo de Def. } \\
\text { Long. (MPa) }\end{array}$ & Corr. \\
\hline 1 & 332,2 & 85,1 & 0,497 & 602,6 & 710,3 & 204415 & 0,9998 \\
\hline 2 & 333,1 & 85,3 & 0,497 & 601,0 & 713,5 & 209385 & 0,9998 \\
\hline \multicolumn{8}{|c|}{$A C ̧ O$ CLASSE B } \\
\hline$C P$ & $\begin{array}{c}\text { Peso } \\
(g)\end{array}$ & $\begin{array}{c}\text { Comp/to } \\
(\mathrm{cm})\end{array}$ & $\begin{array}{l}\text { Área } \\
\left(\mathrm{cm}^{2}\right)\end{array}$ & $\begin{array}{c}f_{p} * \\
(M P a)\end{array}$ & $\begin{array}{c}f_{r} \\
(M P a)\end{array}$ & $\begin{array}{c}\text { Modulo de Def. } \\
\text { Long. (MPa) }\end{array}$ & Corr. \\
\hline 3 & 331,2 & 85,2 & 0,495 & 476,3 & 793,9 & 205826 & 0,9999 \\
\hline \multicolumn{8}{|c|}{$\begin{array}{l}\text { Observaçães: } \\
\text { - } f_{p}^{*}: \text { limite a partir do qual a relação entre a tensão e a deformação deixa de ser linear } \\
\text { - Relação entre a deformação e a tensão, após o limite elástico de 485,3 MPa (aproximação por } \\
\text { equação do } 3^{o} . \text { grau, com erro inferior a } 1,5 \% \text { entre o valor da curva e o dos pontos usados para } \\
\text { constuí-la: } \\
\sigma(M P a)=1,253.10^{10} . \varepsilon^{3}-1,6255.10^{8} . \varepsilon^{2}+7,17439.10^{5} . \varepsilon-4,71326.10^{2}\end{array}$} \\
\hline
\end{tabular}


Em vista da dificuldade na caracterização do material, optou-se pela simplicação nos cálculos, adotando-se, para este lote, as características dadas pelas barras do tipo A, mostrados na tabela E.12.

Tabela E.12 - Valores médios obtidos para barras com 8 mm, relativas ao terceiro lote de barras

\begin{tabular}{|c|c|c|c|}
\hline Área $\left(\mathbf{c m}^{\mathbf{2}}\right)$ & $\boldsymbol{f}_{\boldsymbol{y}}(\mathbf{M P a})$ & $\boldsymbol{f}_{\boldsymbol{r}}(\mathbf{M P a})$ & Módulo de Deformação Longitudinal (MPa) \\
\hline $0,497 \pm 0,0$ & $601,8 \pm 1,13$ & $711,9 \pm 2,26$ & $206900 \pm 3514$ \\
$( \pm 0 \%)$ & $( \pm 0,2 \%)$ & $( \pm 0,3 \%)$ & $( \pm 1,7 \%)$ \\
\hline
\end{tabular}

\section{E.4. QUARTO LOTE DE BARRAS}

Neste quarto lote, foram pedidas 35 barras de $16 \mathrm{~mm}$ e 25 barras de $8 \mathrm{~mm}$, a serem usadas nos modelos M4, M5 e M6. No modelo M4, foram usadas barras de $8 \mathrm{~mm}$ provenientes do lote anterior. Para cada diâmetro, foram extraídos 5 corpos-de-prova de barras. Os ensaios foram feitos na máquina INSTRON, sendo o módulo obtido através de um extensômetro mecânico. Os dados relativos a estes ensaios estão mostrados nas tabelas E.13 e E.14.

Tabela E.13 - Caracterização das propriedades mecânicas e geométricas das barras

\begin{tabular}{|c|c|c|c|c|c|c|c|c|}
\hline $\begin{array}{r}\text { Diâm. } \\
(\mathrm{mm})\end{array}$ & $C P$ & $\begin{array}{r}\text { Peso } \\
(g)\end{array}$ & $\begin{array}{c}\text { Comp/to } \\
(\mathrm{cm})\end{array}$ & $\begin{array}{l}\text { Área } \\
\left(\mathrm{cm}^{2}\right)\end{array}$ & $\begin{array}{c}f_{y} \\
(M P a)\end{array}$ & $\begin{array}{c}f_{r} \\
(M P a)\end{array}$ & $\begin{array}{l}\text { Mod. de Def. } \\
\text { Longit. (MPa) }\end{array}$ & Corr. \\
\hline \multirow{5}{*}{12,5} & 1 & 847,5 & 90,05 & 1,199 & 660,7 & 800,9 & 205156 & 1,0000 \\
\hline & 2 & 838,7 & 90,10 & 1,186 & 655,5 & 793,9 & 199245 & 1,0000 \\
\hline & 3 & 831,4 & 89,95 & 1,177 & 646,4 & 785,6 & 195811 & 1,0000 \\
\hline & 4 & 837,5 & 90,30 & 1,181 & 643,1 & 784,3 & 192850 & 0,9997 \\
\hline & 5 & 848,2 & 90,40 & 1,195 & 651,1 & 796,7 & 214642 & 0,9998 \\
\hline \multirow{5}{*}{8} & 1 & 347,4 & 90,10 & 0,491 & 651,7 & 745,6 & 197124 & 0,9999 \\
\hline & 2 & 348,2 & 90,05 & 0,493 & 652,7 & 741,4 & 190788 & 0,9998 \\
\hline & 3 & 346,8 & 90,25 & 0,490 & 633,1 & 723,9 & 201437 & 0,9999 \\
\hline & 4 & 346,4 & 90,30 & 0,489 & 625,6 & 725,2 & 204232 & 0,9998 \\
\hline & 5 & 346,8 & 90,15 & 0,490 & 621,4 & $\begin{array}{l}718,6 \\
\end{array}$ & 200743 & 0,9999 \\
\hline
\end{tabular}


Tabela E.14 - Valores médios da área, das tensões de escoamento e de ruptura e do módulo de deformação longitudinal das barras, ensaiadas na máquina Instron

\begin{tabular}{|c|c|c|c|c|}
\hline Diâm. $(\mathbf{m m})$ & Área $\left(\mathbf{c m}^{2}\right)$ & $f_{y}(\mathbf{M P a})$ & $f_{\boldsymbol{r}}(\mathbf{M P a})$ & Mód. de Def. Long. (GPa) \\
\hline 12,5 & $1,188 \pm 0,009$ & $651,4 \pm 7,0$ & $792,3 \pm 7,2$ & $201541 \pm 8636$ \\
& $( \pm 0,8 \%)$ & $( \pm 1,1 \%)$ & $( \pm 0,9 \%)$ & $( \pm 4,3 \%)$ \\
\hline 8 & $0,491 \pm 0,002$ & $636,8 \pm 14,6$ & $730,9 \pm 11,8$ & $198865 \pm 5177$ \\
& $( \pm 0,3 \%)$ & $( \pm 2,3 \%)$ & $( \pm 1,6 \%)$ & $( \pm 2,6 \%)$ \\
\hline
\end{tabular}

Na figura E.11, tem-se o diagrama tensão versus deformação que caracterizou o comportamento mecânico das barras. Pode-se observar que todas as barras ensaiadas foram caracterizadas como sendo do tipo A.

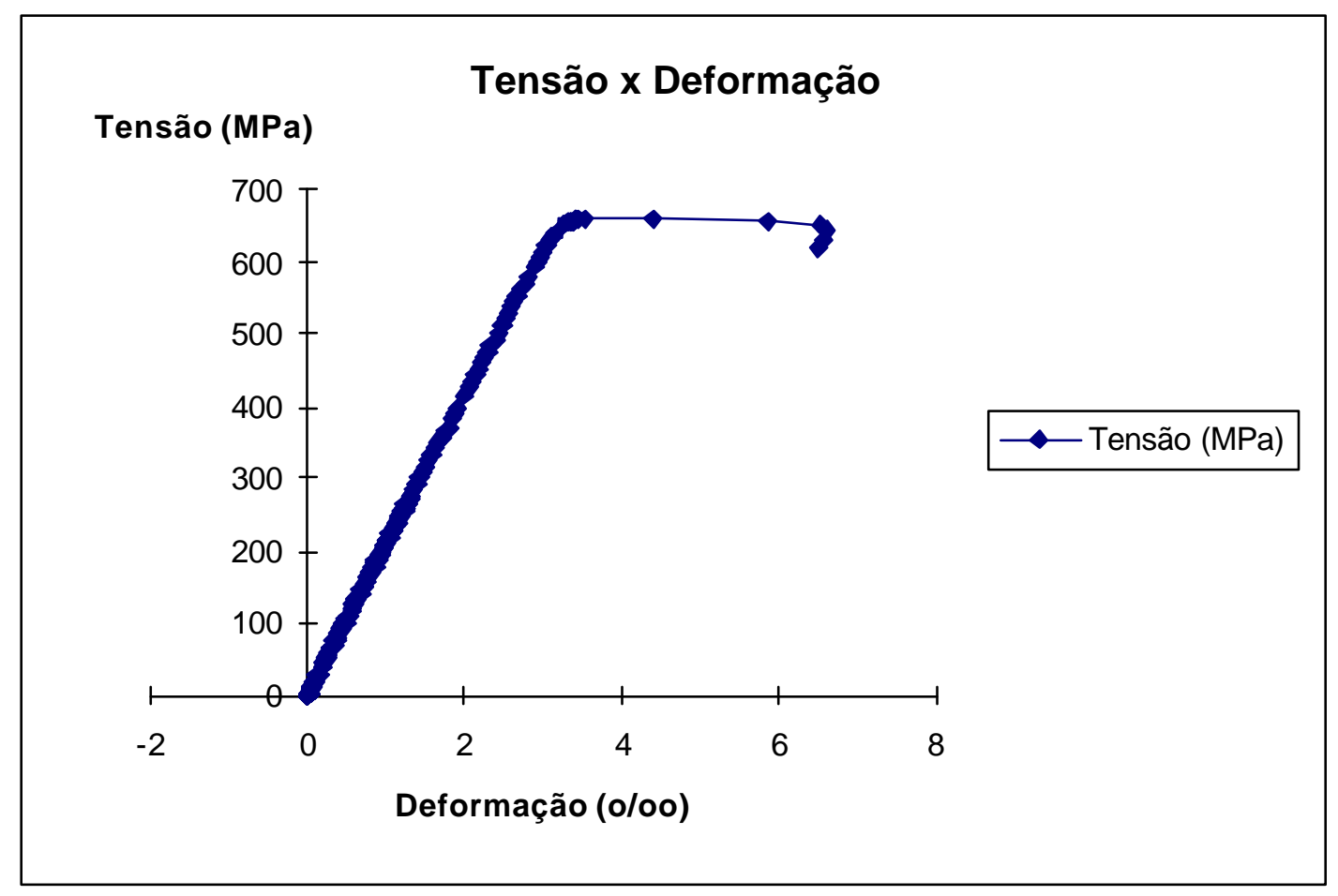

Figura E.11 - Diagrama tensão versus deformação, para barras do quarto lote 
ANEXO F

Armadura de punção 


\section{ANEXO F - Procedimentos usados para construir e caracterizar as propriedades mecânicas e geométricas da armadura de punção}

São apresentados os procedimentos para construir a armadura de punção e caracterizar as barras e os conectores usados nos modelos com armadura de punção, com relação às suas propriedades geométricas e mecânicas.

Nas figuras F.1 a F.8, tem-se o modo como os conectores foram feitos.

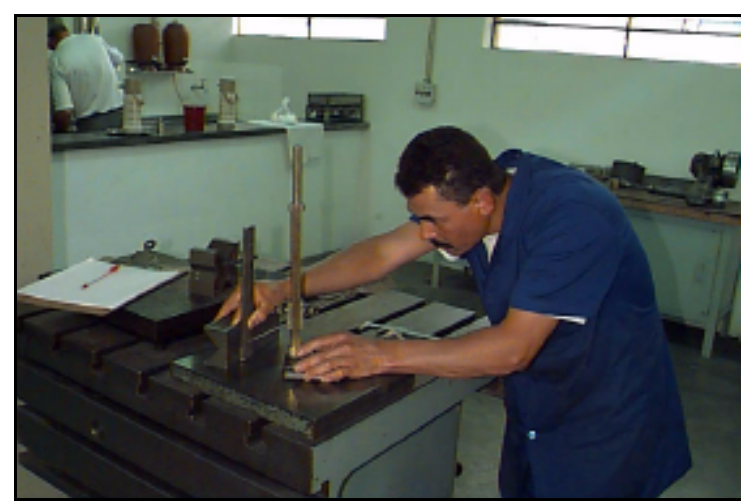

Figura F.1 - Marcação da posição dos furos nas chapas metálicas

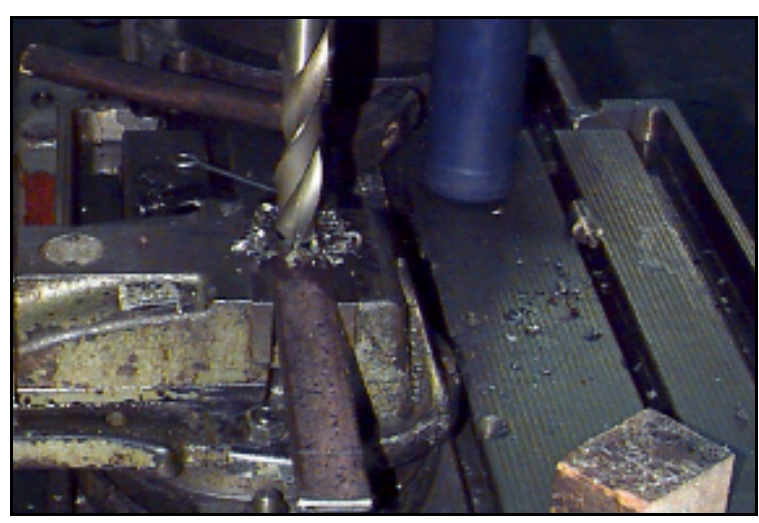

Figura F.3 - "Escareamento" dos furos, visando facilitar a aplicação da solda elétrica

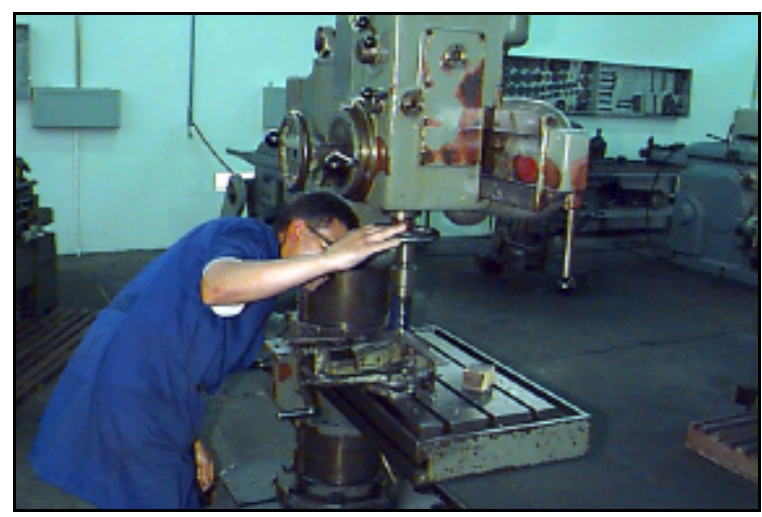

Figura F.2 - Furação das chapas metálicas para futuro encaixe dos pinos

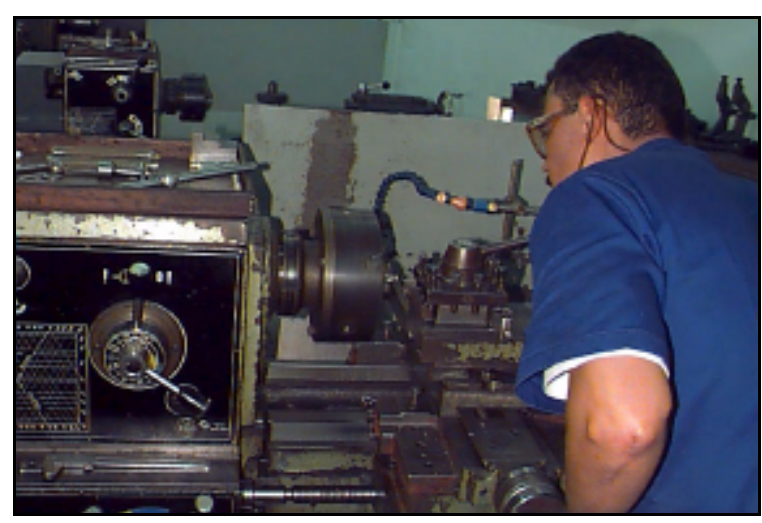

Figura F.4 - Acerto do comprimento do pino e torneamento de suas extremidades para encaixe nas chapas metálicas 


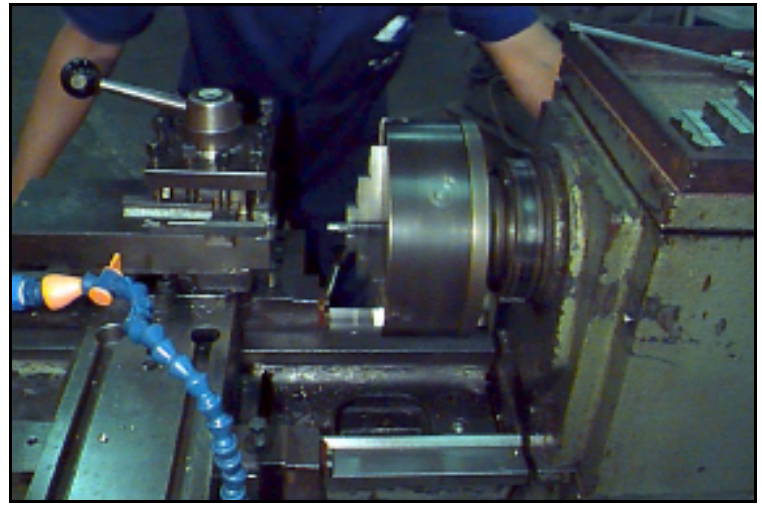

Figura F.5 - Detalhe da extremidade torneada do pino

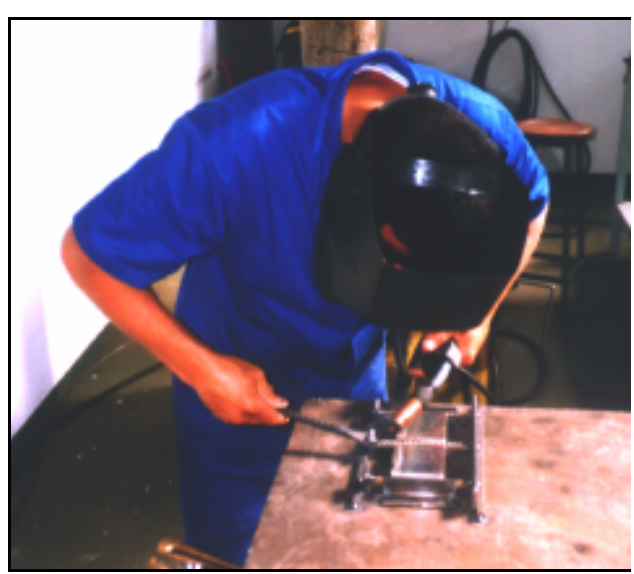

Figura F.7 - Através de um gabarito metálico soldado na mesa, aplicou-se a solda tipo MIG

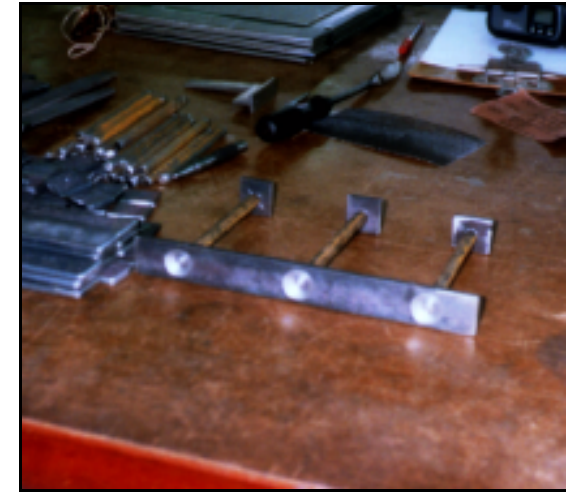

Figura F.6 - Detalhe do encaixe dos pinos nas chapas metálicas

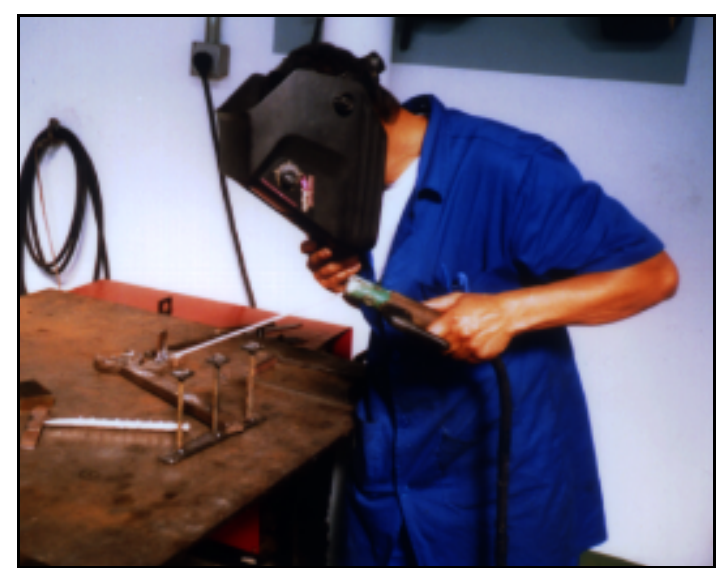

Figura F.8 - Após realizar a solda MIG, executou-se a solda elétrica

Apresentam-se, a seguir, as características dos pinos usados para cada um dos modelos armados transversalmente.

\section{F.1. MODELO M2}

Para a execução dos conectores usados no modelo M2, foi comprada uma barra de diâmetro igual a $10 \mathrm{~mm}$ e comprimento de $12 \mathrm{~m}$.

Na tabela F.1, têm-se os resultados de dois corpos-de-prova extraídos da barra, com relação às suas propriedades geométricas e mecânicas.

Na tabela F.2 estão os valores das características mecânicas de alguns dos conectores ensaiados. 
Já na tabela F.3, os conectores foram instrumentados com extensômetros da marca Kyowa KFG-5-C1-11, fator 2,12, em duas faces opostas do pino, visando a determinação do módulo de elasticidade. Foi adotado o valor médio das leituras das deformações.

Os equipamentos usados para a aquisição dos dados relacionados ao cálculo do módulo de elasticidade dos pinos estão mostrados na figura F.9.

Para a fixação do pino à máquina de ensaio, foram usados os dispositivos mostrados na figura F.10.

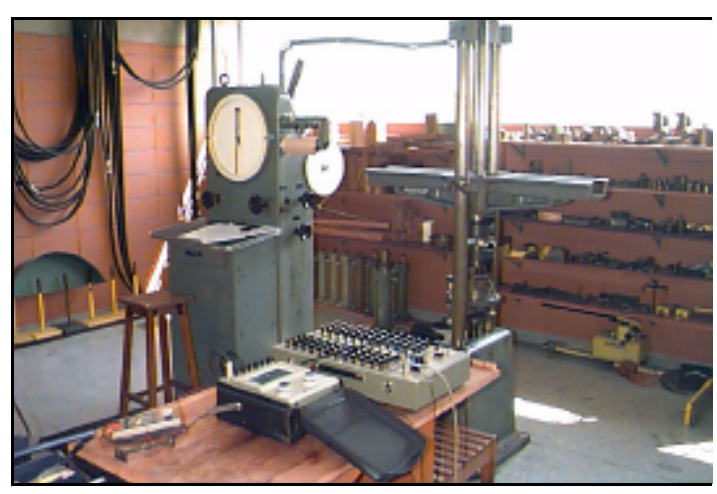

a) Máquina AMSLER e sistema de aquisição de dados usados

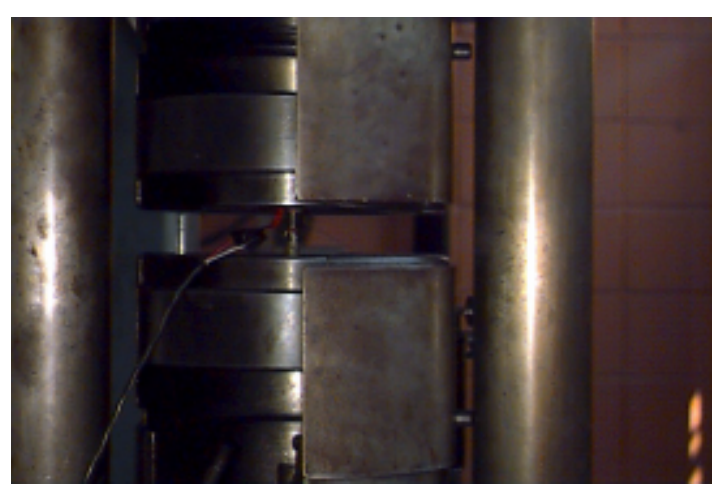

b) Detalhe da instrumentação e da fixação do conector à máquina de ensaio

Figura F.9- Equipamento usado para a obtenção do módulo de elasticidade dos conectores

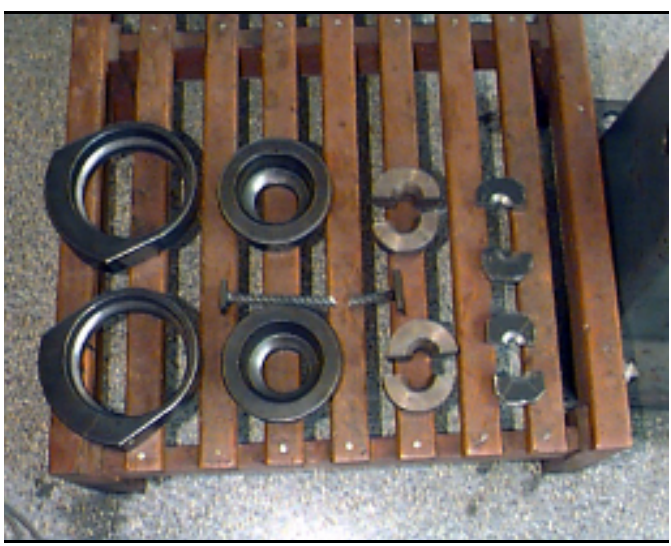

a) Peças desmontadas

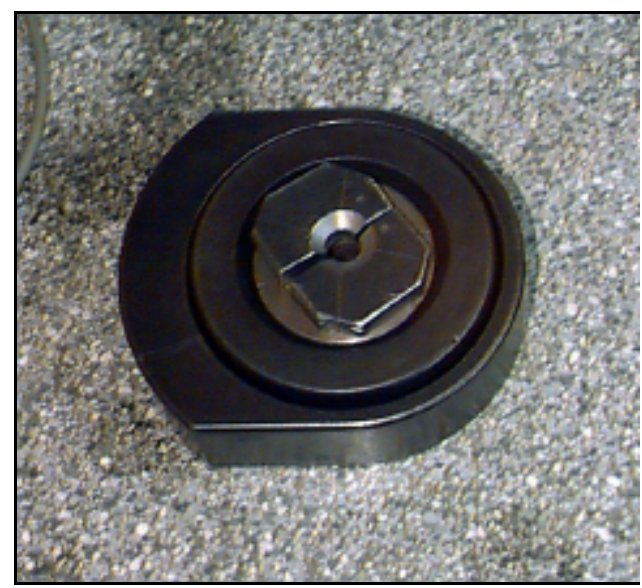

b) Peças montadas

Figura F.10 - Dispositivos usados para fixar os conectores à máquina de ensaio 
Pode-se observar que os valores médios da tabela F.2 são ligeiramente superiores aos da tabela F.3. Para efeito de cálculo, foram adotados os valores presentes na tabela F.3.

Tabela F.1- Ensaio de barras com diâmetro de 10 mm

\begin{tabular}{|c|c|c|c|c|c|c|c|}
\hline \multicolumn{8}{|c|}{ 3arra - Diâmetro: $10 \mathrm{~mm}$ - Aço do tipo A (apresentou patamar de escoamento) } \\
\hline$C d p$ & $\begin{array}{c}\text { Peso } \\
(\mathrm{g})\end{array}$ & $\begin{array}{c}\text { Comp/to } \\
(\mathrm{cm})\end{array}$ & $\begin{array}{l}\text { Área } \\
\left(\mathrm{cm}^{2}\right)\end{array}$ & $\begin{array}{c}f_{y} \\
(M P a)\end{array}$ & $\begin{array}{c}f_{\boldsymbol{r}} \\
(\boldsymbol{M P a})\end{array}$ & $\begin{array}{c}F_{y} \\
(k N)\end{array}$ & $\begin{array}{c}F_{\boldsymbol{r}} \\
(\boldsymbol{k} N)\end{array}$ \\
\hline 1 & 245,6 & 40,5 & 0,773 & 597,0 & 716,4 & 46,09 & 55,31 \\
\hline 2 & 244,5 & 40,5 & 0,769 & 599,4 & 720,5 & 46,09 & 55,41 \\
\hline \multicolumn{3}{|c|}{ Valores Médios: } & 0,771 & 598,2 & 718,5 & 46,09 & 55,36 \\
\hline \multicolumn{8}{|c|}{$\begin{array}{l}\text { Obs.: } \boldsymbol{f}_{\boldsymbol{y}} \text { e } \boldsymbol{F}_{\boldsymbol{y}} \text { são, respectivamente, a tensão e a força que provoca o escoamento da barra; } \\
\text { já } \boldsymbol{f}_{\boldsymbol{r}} \text { e } \boldsymbol{F}_{\boldsymbol{r}} \text { são, respectivamente, a tensão e a força que provoca a ruptura da barra }\end{array}$} \\
\hline
\end{tabular}

Tabela F.2 - Conectores ensaiados - sem instrumentação

\begin{tabular}{|c|c|c|}
\hline Corpo-de-prova & $\begin{array}{c}\boldsymbol{F}_{\boldsymbol{y}} \text { - Força que provoca o } \\
\text { escoamento da barra }(\mathrm{kN})\end{array}$ & $\begin{array}{c}\boldsymbol{F}_{\boldsymbol{r}} \text { - Força que provoca a } \\
\text { ruptura da barra }(\mathrm{kN})\end{array}$ \\
\hline 1 & 45,60 & 55,41 \\
2 & 46,58 & 56,49 \\
3 & 46,09 & 56,00 \\
\hline Valor médio & $46,09 \pm 0,49( \pm 1,1 \%)$ & $55,96 \pm 0,54 \quad( \pm 1,0 \%)$ \\
\hline
\end{tabular}

Tabela F.3 - Conectores ensaiados - com instrumentação

\begin{tabular}{|c|c|c|c|}
\hline $\mathrm{Cdp}$ & $\boldsymbol{F}_{\boldsymbol{\gamma}}(\mathrm{kN})$ & $\boldsymbol{F}_{\boldsymbol{r}}(\mathrm{kN})$ & Mod. de Def. Longitudinal $(\boldsymbol{G P a})$ \\
\hline 1 & 45,11 & 53,54 & Extensômetro com defeito \\
2 & 44,13 & 54,13 & 176,46 \\
3 & 41,38 & 51,58 & 152,17 \\
4 & 44,62 & 53,74 & 170,72 \\
\hline Valor médio: & $43,81 \pm 1,67$ & $53,25 \pm 1,14$ & $166,45 \pm 12,70$ \\
& $( \pm 3,8 \%)$ & $( \pm 2,1 \%)$ & $( \pm 7,6 \%)$ \\
\hline
\end{tabular}

Tanto os conectores com extensômetros, como os sem, romperam fora da região da ligação do pino com as chapas metálicas soldadas em suas extremidades.

O detalhe é que, para os conectores com extensômetros, a ruptura se deu exatamente na posição onde este foi colado no pino (figura F.11). 


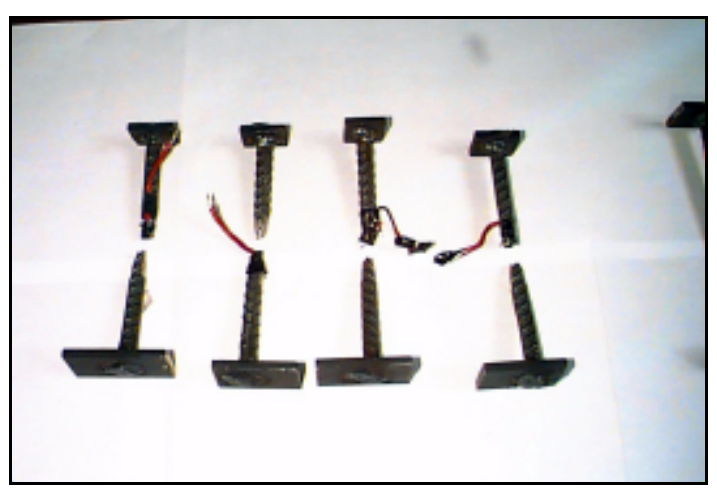

a) Conetores rompidos

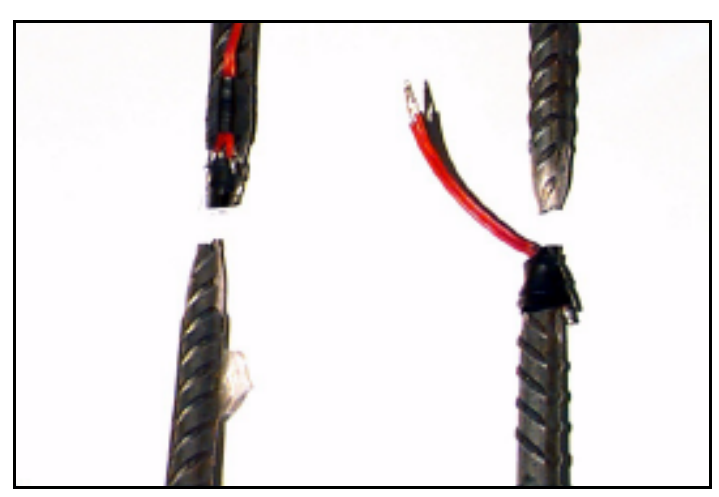

b) Detalhe da ruptura

Figura F.11 - Forma de ruptura dos conectores

\section{F.2. MODELOS M3, M5 E M6}

Para a execução dos pinos usados nos modelos M3, M5 e M6, foram compradas três barras de $10 \mathrm{~mm}$ de diâmetro e $12 \mathrm{~m}$ de comprimento. Na tabela F.4, têm-se os resultados de três corpos-de-prova, extraídos de cada uma das barras, com relação às suas propriedades geométricas e mecânicas.

Tabela F.4- Ensaio de barras com diâmetro de 10 mm

\begin{tabular}{|c|c|c|c|c|c|c|c|c|}
\hline \multicolumn{9}{|c|}{ Barra - Diâmetro: 10 mm - Aço do tipo A } \\
\hline$C P$ & $\begin{array}{c}\text { Peso } \\
(g)\end{array}$ & $\begin{array}{c}\text { Comp/to } \\
(\mathrm{cm})\end{array}$ & $\begin{array}{l}\text { Área } \\
\left(\mathrm{cm}^{2}\right)\end{array}$ & $\begin{array}{c}f_{y} \\
(M P a)\end{array}$ & $\begin{array}{c}f_{r} \\
(M P a)\end{array}$ & $\begin{array}{c}\boldsymbol{F}_{\boldsymbol{y}} \\
(\boldsymbol{k} N)\end{array}$ & $\begin{array}{c}\boldsymbol{F}_{\boldsymbol{r}} \\
(k N)\end{array}$ & $\begin{array}{c}E \\
(G P a)\end{array}$ \\
\hline $\begin{array}{l}1 \\
2 \\
3 \\
\end{array}$ & $\begin{array}{l}302,6 \\
541,0 \\
542,6\end{array}$ & $\begin{array}{l}50,6 \\
90,3 \\
90,3 \\
\end{array}$ & $\begin{array}{l}0,762 \\
0,763 \\
0,765 \\
\end{array}$ & $\begin{array}{l}630,6 \\
639,0 \\
632,2 \\
\end{array}$ & $\begin{array}{l}765,7 \\
760,4 \\
752,6 \\
\end{array}$ & $\begin{array}{l}48,05 \\
48,77 \\
48,39 \\
\end{array}$ & $\begin{array}{l}58,35 \\
58,04 \\
57,60\end{array}$ & $\begin{array}{l}- \\
- \\
-\end{array}$ \\
\hline \multicolumn{3}{|c|}{ Valores Médios } & 0,763 & 633,9 & 759,6 & 48,40 & 58,00 & - \\
\hline \multicolumn{9}{|c|}{$\begin{array}{l}\text { Obs.: } f_{\boldsymbol{y}} \text { e } \boldsymbol{F}_{\boldsymbol{y}} \text { são, respectivamente, a tensão e a força que provoca o escoamento da barra; já } \boldsymbol{f}_{\boldsymbol{r}} \text { e } \\
\boldsymbol{F}_{\boldsymbol{r}} \text { são, respectivamente, a tensão e a força que provocam a ruptura da barra } \\
\text { Devido a um problema observado no extensômetro mecânico, não puderam ser obtidos valores } \\
\text { relativos ao módulo de deformação longitudinal ( E ) }\end{array}$} \\
\hline
\end{tabular}

A seguir, será feita uma apresentação dos conectores para cada um dos modelos. 


\section{a) Modelo M3}

Na tabela F.5 estão os valores das características mecânicas dos conectores ensaiados. Alguns deles romperam na região da ligação do pino com as chapas metálicas soldadas em suas extremidades. Tal comportamento, embora não desejável, ocorreu após o escoamento do pino, garantindo, assim, um bom comportamento com relação ao seu uso no modelo. Esta situação pode ser vista nas figuras F.12 e F.13.

Tabela F.5 - Conectores ensaiados

\begin{tabular}{|c|c|c|}
\hline Corpo-de-prova & $\begin{array}{c}\boldsymbol{F}_{\boldsymbol{y}} \text { - Força que provoca o } \\
\text { escoamento da barra }(\mathrm{kN})\end{array}$ & $\begin{array}{c}\boldsymbol{F}_{\boldsymbol{r}} \text { - Força que provoca a } \\
\text { ruptura da barra }(\mathrm{kN})\end{array}$ \\
\hline 1 & 48,54 & $52,66^{*}$ \\
2 & 48,54 & 59,33 \\
3 & 49,52 & $51,29^{*}$ \\
4 & 48,64 & 59,33 \\
5 & 48,54 & 58,35 \\
6 & 48,64 & $50,01^{*}$ \\
\hline Valor médio & $48,74 \pm 0,39 \quad( \pm 0,8 \%)$ & - \\
\hline * Ruptura na região da ligação do pino com uma das chapas metálicas soldadas em suas \\
extremidades
\end{tabular}

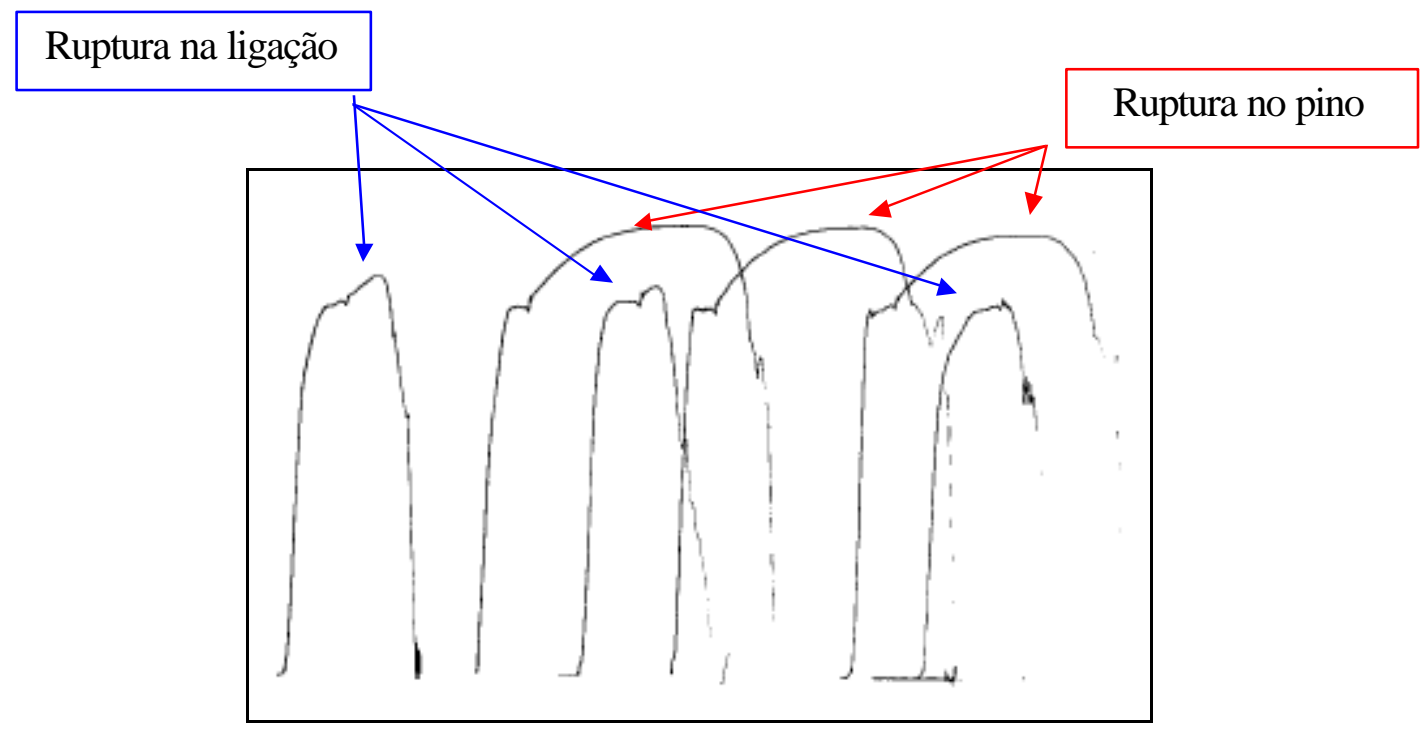

Figura F.12 - Diagramas dos conectores usados no modelo M3 

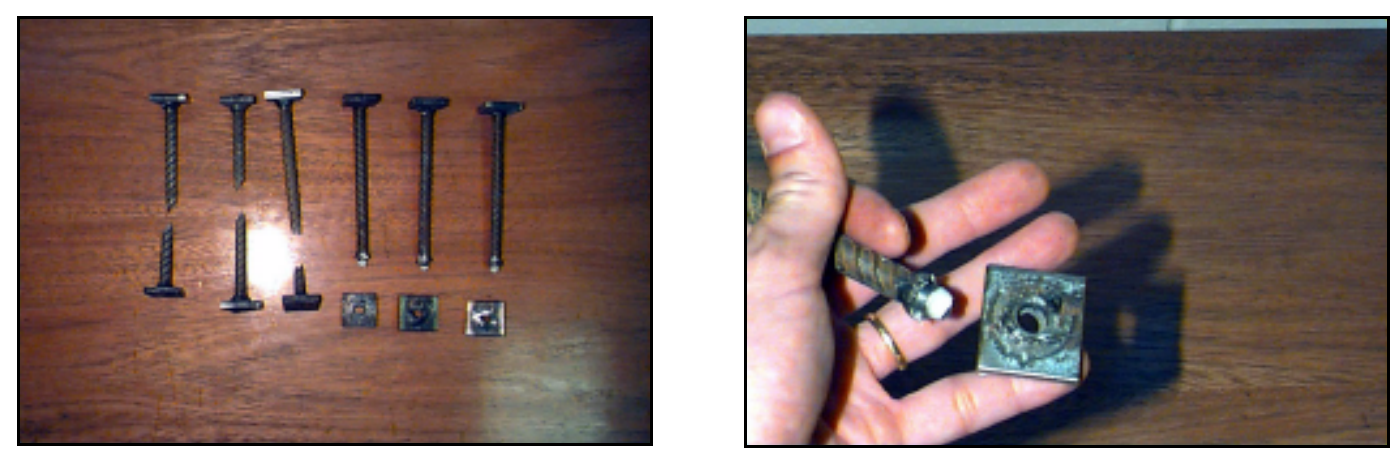

Figura F.13 - Tipos de ruptura nos conectores usados no modelo M3

Para definir melhor o comportamento, foram ensaiados mais três conectores intrumentados com extensômetros elétricos. Os resultados encontram-se na tabela F.6. Pode-se observar que todos os conectores romperam na porção média do pino, junto ao extensômetro colado. No entanto, pode ser observado que, mesmo rompendo no pino, algumas regiões da solda foram danificadas.

Tabela F.6 - Resultados dos conectores instrumentados

\begin{tabular}{|c|c|c|c|}
\hline Corpo-de-prova & $\begin{array}{c}\boldsymbol{F}_{\boldsymbol{y}} \text { - Força que } \\
\text { provoca o escoamento } \\
\text { da barra }(\mathrm{kN})\end{array}$ & $\begin{array}{c}\boldsymbol{F}_{\boldsymbol{r}} \text { - Força que } \\
\text { provoca a ruptura da } \\
\text { barra }(\mathrm{kN})\end{array}$ & $\begin{array}{c}\boldsymbol{E} \text { - Mod. de Def. } \\
\text { Longitudinal } \\
(\boldsymbol{G P a})\end{array}$ \\
\hline 1 & 47,56 & 56,39 & 172,638 \\
2 & 47,56 & 55,90 & 170,226 \\
3 & 48,05 & 57,07 & 174,390 \\
\hline Valor médio & $47,73 \pm 0,28$ & $56,45 \pm 0,59$ & $172,418 \pm 2,091$ \\
& $( \pm 0,6 \%)$ & $( \pm 1,0 \%)$ & $( \pm 1,2 \%)$ \\
\hline
\end{tabular}

Como uma tentativa para explicar a diferença de comportamento entre os conectores deste modelo e os do modelo anterior, pode-se mencionar que a resistência de escoamento e de ruptura, de um modo geral, é superior para este modelo, podendo indicar uma maior presença de carbono no aço, o que, se por um lado aumenta a resistência da barra, por outro, prejudica a soldagem da barra com a chapa metálica.

Para os cálculos, foram adotados os valores dados pela tabela F.6, com relação às forças de escoamento e de ruptura. 


\section{b) Modelo M5}

Na tabela F.7 estão os valores das características mecânicas dos conectores ensaiados. Todos eles romperam fora da região da ligação do pino com as chapas metálicas soldadas em suas extremidades.

Tabela F.7 - Conectores ensaiados

\begin{tabular}{|c|c|c|}
\hline Corpo-de-prova & $\begin{array}{c}\boldsymbol{F}_{\boldsymbol{y}} \text { - Força que provoca o } \\
\text { escoamento da barra }(\mathrm{kN})\end{array}$ & $\begin{array}{c}\boldsymbol{F}_{\boldsymbol{r}} \text { - Força que provoca a } \\
\text { ruptura da barra }(\mathrm{kN})\end{array}$ \\
\hline 1 & 49,03 & 59,62 \\
2 & 47,27 & 58,25 \\
3 & 47,07 & 56,88 \\
4 & 48,05 & 58,84 \\
5 & 48,05 & 58,25 \\
6 & 48,54 & 59,33 \\
7 & 47,56 & 57,86 \\
8 & 47,56 & 57,66 \\
\hline Valor médio & $47,89 \pm 0,66( \pm 1,4 \%)$ & $58,34 \pm 0,90 \quad( \pm 1,5 \%)$ \\
\hline
\end{tabular}

\section{c) Modelo M6}

Na tabela F.8 estão os valores das características mecânicas dos conectores ensaiados. Todos eles romperam fora da região da ligação do pino com as chapas metálicas soldadas em suas extremidades.

Tabela F.8 - Conectores ensaiados

\begin{tabular}{|c|c|c|}
\hline Corpo-de-prova & $\begin{array}{c}\boldsymbol{F}_{\boldsymbol{y}} \text { - Força que provoca o } \\
\text { escoamento da barra }(\mathrm{kN})\end{array}$ & $\begin{array}{c}\boldsymbol{F}_{\boldsymbol{r}} \text { - Força que provoca a } \\
\text { ruptura da barra }(\mathrm{kN})\end{array}$ \\
\hline 1 & 46,88 & 57,20 \\
2 & 47,56 & 57,96 \\
3 & 48,05 & 58,06 \\
4 & 47,56 & 58,06 \\
5 & 48,54 & 58,35 \\
6 & 47,66 & 58,06 \\
7 & 47,46 & 57,86 \\
8 & 47,07 & 57,86 \\
\hline Valor médio & $47,60 \pm 0,52( \pm 1,1 \%)$ & $57,93 \pm 0,31 \quad( \pm 0,5 \%)$ \\
\hline
\end{tabular}




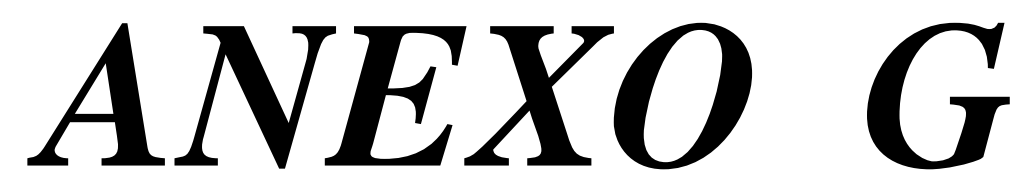

Informações relacionadas à

instrumentação da armadura

de flexão tracionada dos

modelos ensaiados 


\section{ANEXO G - Informações relacionadas à instrumentação da armadura de flexão tracionada dos modelos ensaiados}

Nos gráficos que relacionam as deformações de cada par de extensômetros à força total aplicada pelos macacos, o valor entre parênteses refere-se à diferença percentual entre as deformações dos extensômetros usados para instrumentar uma determinada posição. Essa diferença percentual refere-se à situação de iminência de ruína do modelo. Nas posições onde ocorreu o escoamento da armadura, ao invés do valor da diferença percentual, tem-se o termo "escoamento" entre parênteses. Nesses casos, o trecho vertical indicado no gráfico mostra que a força responsável pela ruína da ligação foi maior que aquela responsável por provocar o escoamento da armadura na posição indicada.

\section{G.1. MODELO MI}

Para o modelo M1, as figuras G.1 a G.11 ilustram as deformações de cada par de extensômetros relativos às posições indicadas na figura 4.7, do capítulo 4.

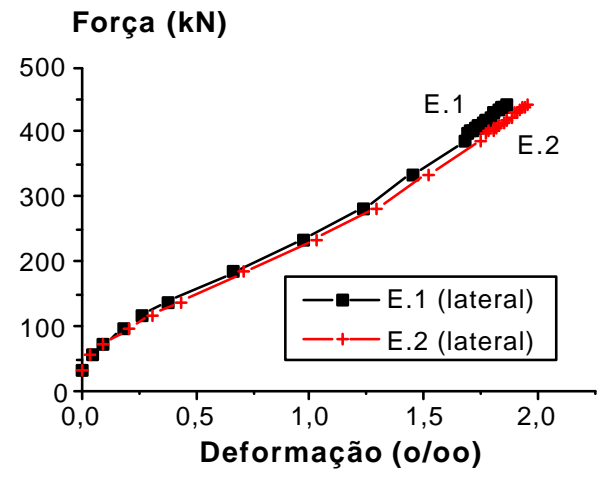

Figura G.1 - M1: posição 1' $(-4,8 \%)$

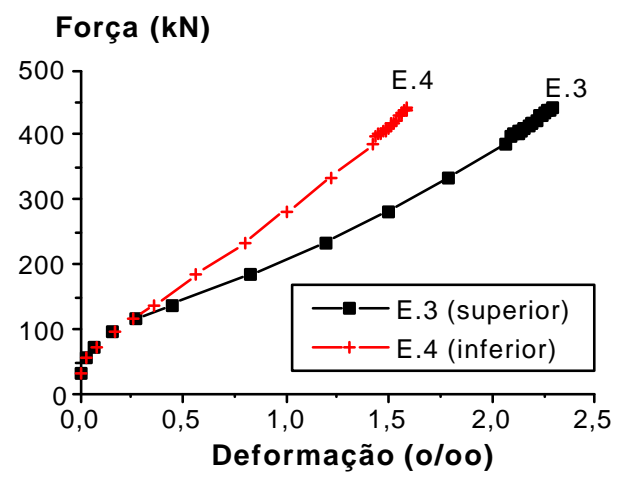

Figura G.2 - M1: posição 2' (+44,0\%) 


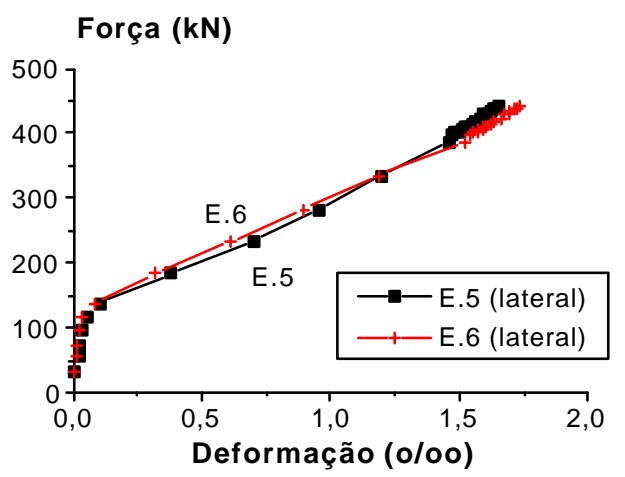

Figura G.3 - M1: posição 3' (-4,6\%)

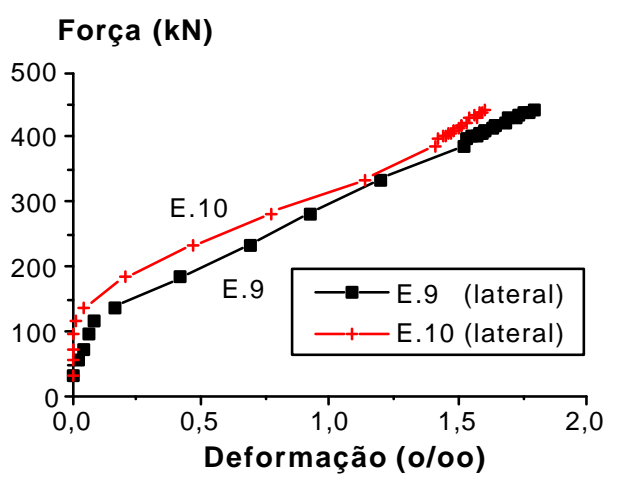

Figura G.5 - M1: posição 5' (+11,8\%)

Força (kN)

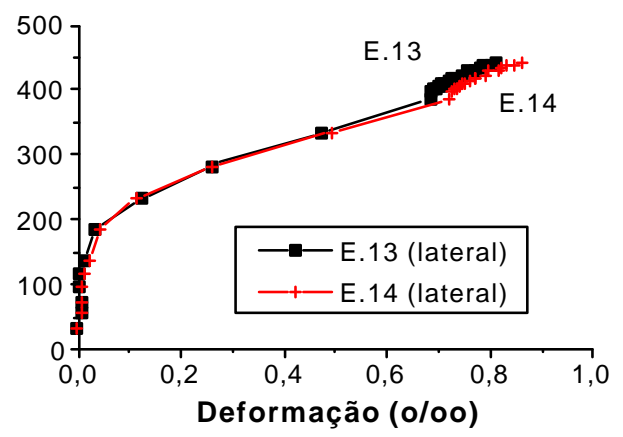

Figura G.7 - M1: posição 7' (-5,6\%)

\section{Força $(k N)$}

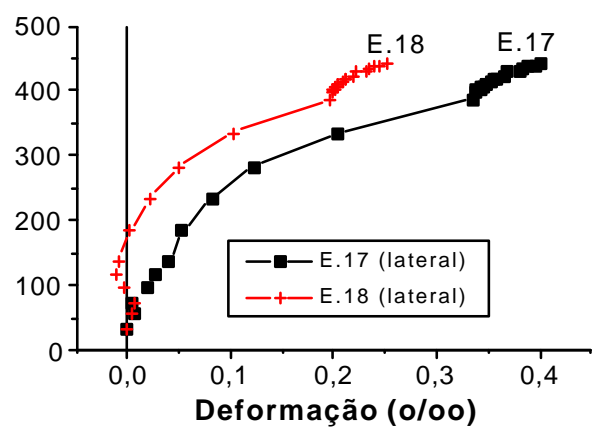

Figura G.9 - M1: posição 9' (+60\%)

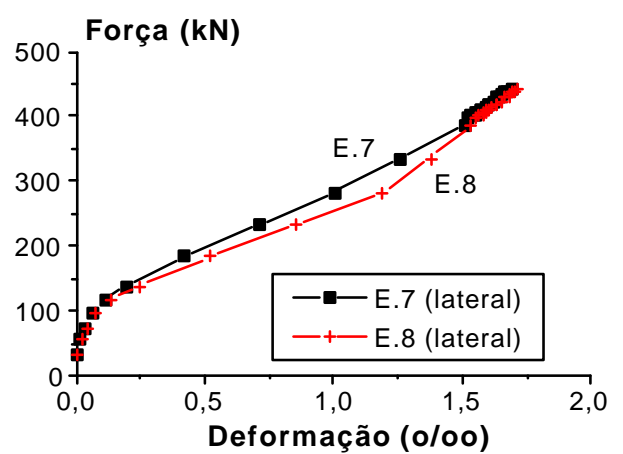

Figura G.4 - M1: posição 4' (-1,5\%)

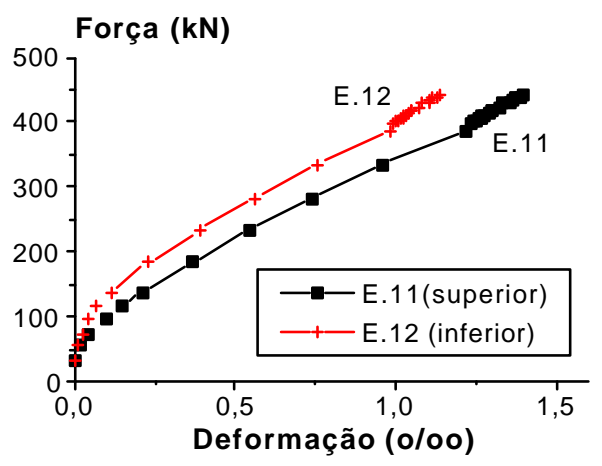

Figura G.6 - M1: posição 6' (+22,9\%)

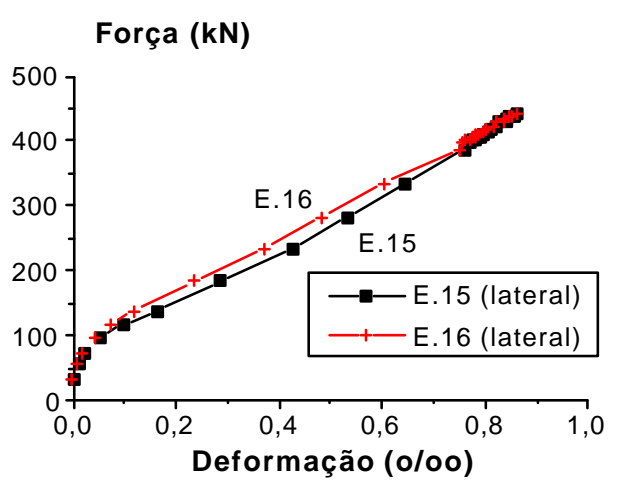

Figura G.8 - M1: posição 8' (-0,1\%)

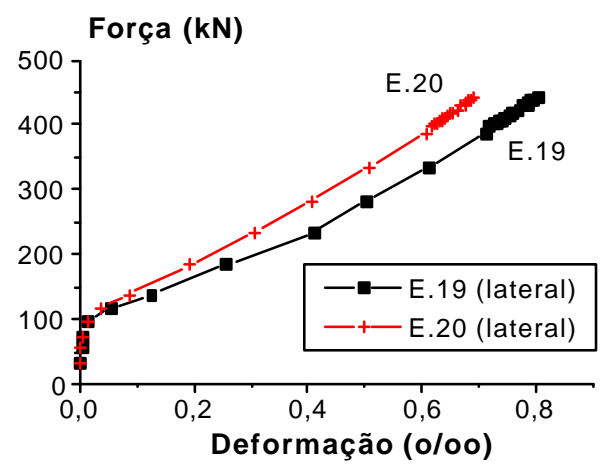

Figura G.10 - M1: posição 10' (+15,9\%) 


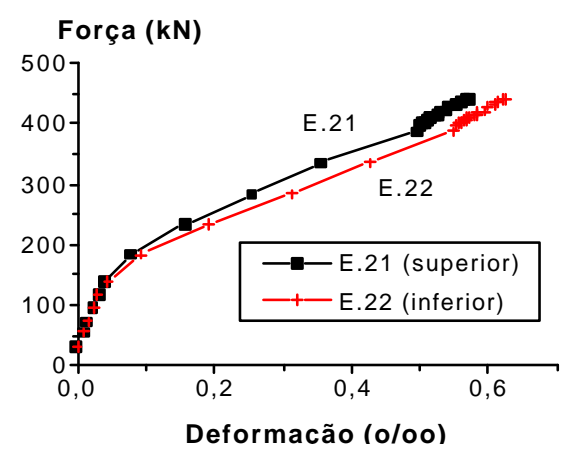

Figura G.11 - M1: posição 11' (-8,5\%)

\section{G.2. MODELO M2}

Para o modelo M2, as figuras G.12 a G.23 ilustram as deformações de cada par de extensômetros relativos às posições indicadas na figura 4.8, do capítulo 4.

$\mathrm{Na}$ figura G.12, observa-se que o E.1 apresentou problemas. No entanto, o seu comportamento acompanhou o comportamento do E.2. Nota-se o escoamento da barra no ponto instrumentado.

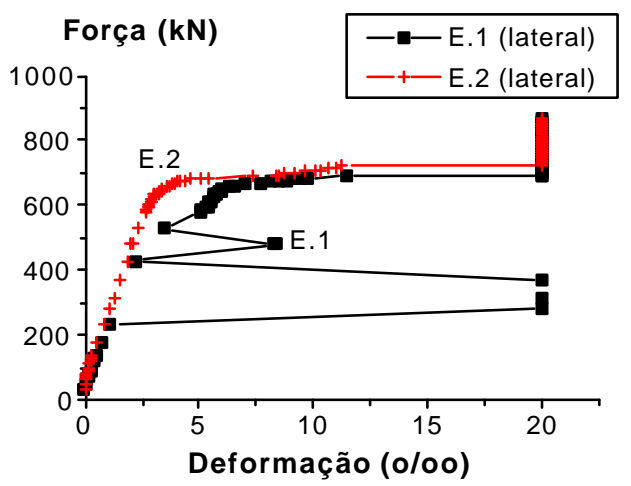

Figura G.12 - M2: posição 1' (escoamento)

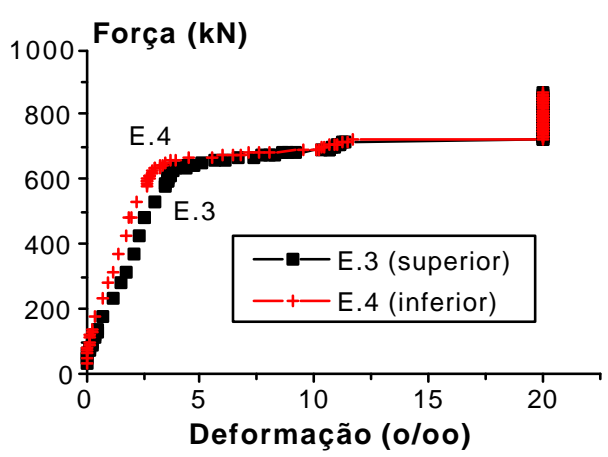

Figura G.13 - M2: posição 2' (escoamento) 
Força (kN)

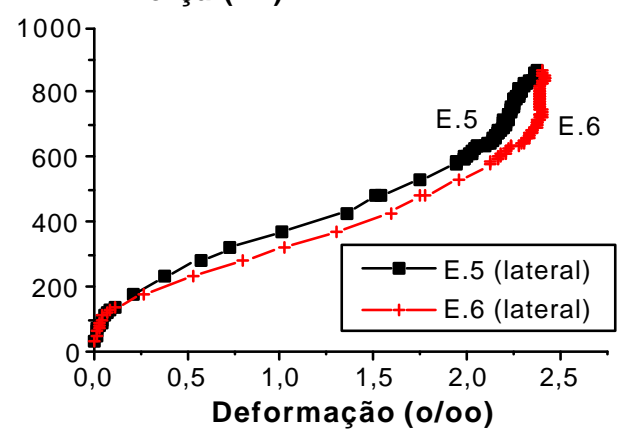

Figura G.14 - M2: posição 3' (-1,4\%)

Força (kN)

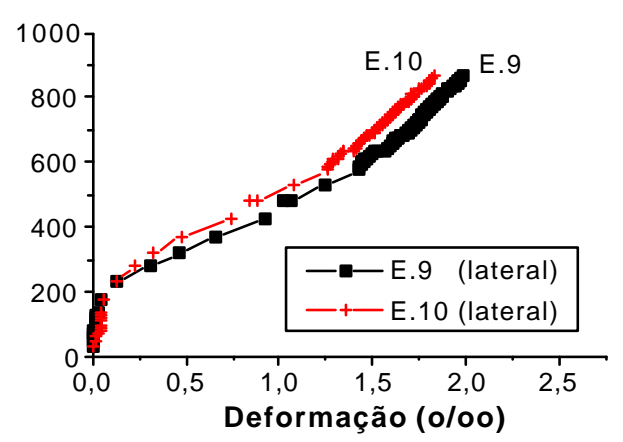

Figura G.16 - M2: Posição 5' (+8,7\%)

Força (kN)

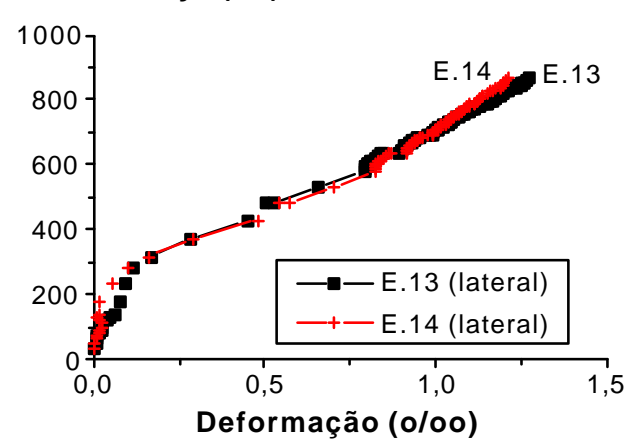

Figura G.18 - M2: posição 7' (+4,9\%)

Força (kN)

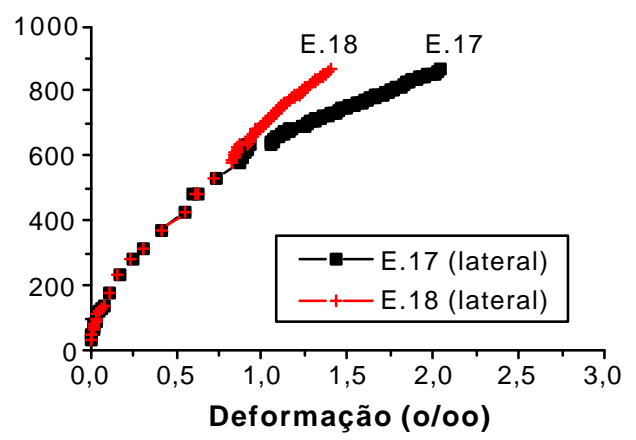

Figura G.20 - M2: posição 9' (45,2\%)
Força (kN)

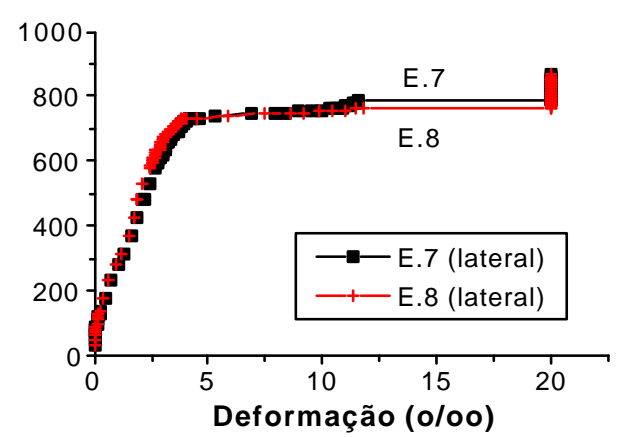

Figura G.15 - M2: posição 4' (escoamento)

$$
\text { Força (kN) }
$$

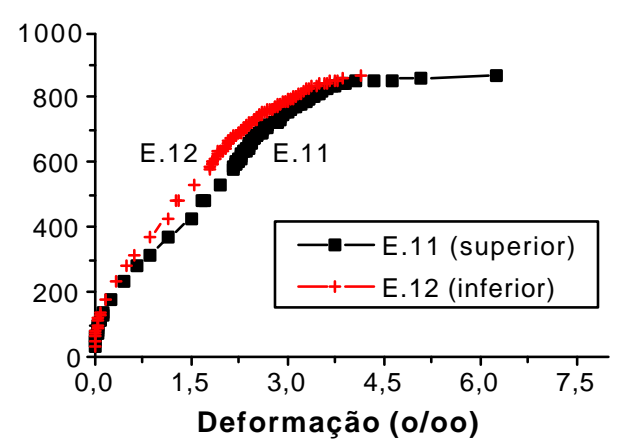

Figura G.17 - M2: posição 6' (escoamento)

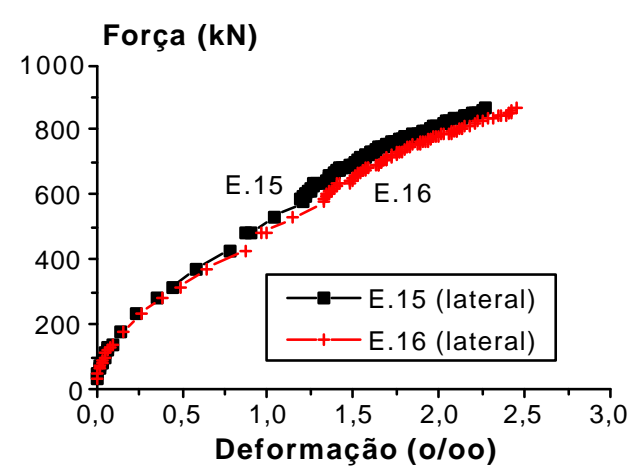

Figura G.19 - M2: posição 8' (-7,4\%)

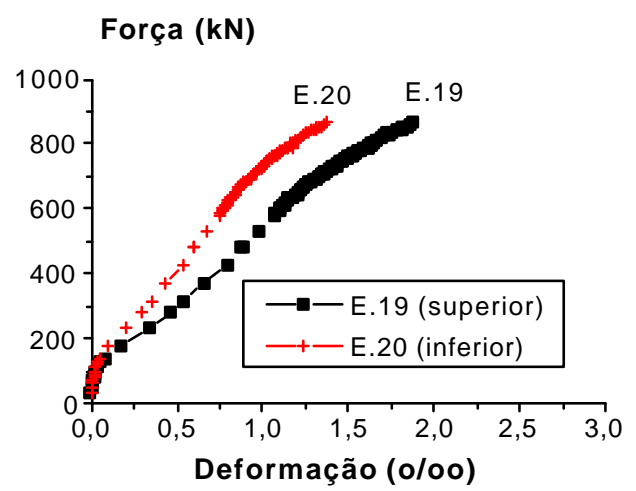

Figura G.21 - M2: posição 10' $(36,2 \%)$ 
Força $(k N)$

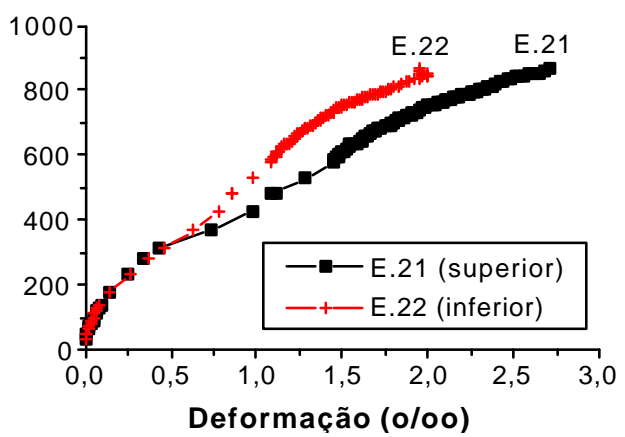

Figura G.22 - M2: posição 11' (38,8\%)

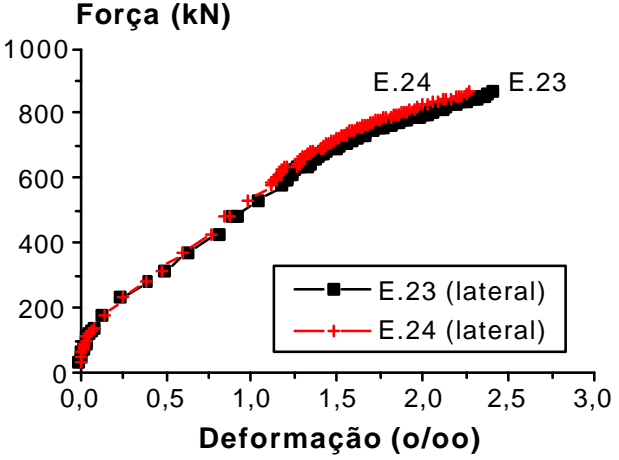

Figura G.23 - M2: posição 12' (5,8\%)

\section{G.3. MODELO M3}

Para o modelo M3, as figuras G.24 a G.30 ilustram as deformações de cada par de extensômetros relativos às posições indicadas na figura 4.9, do capítulo 4 .

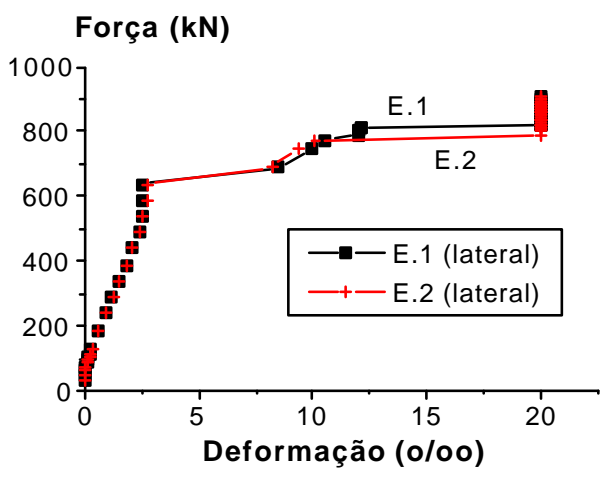

Figura G.24 - M3: posição 1' (escoamento)

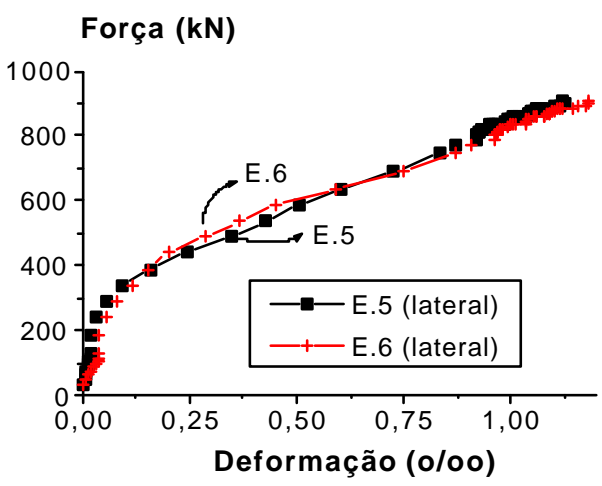

Figura G.26 - M3: posição 3' (-4,8\%)

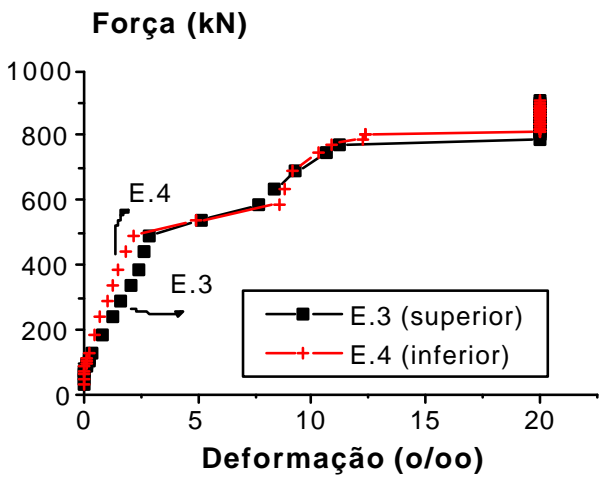

Figura G.25 - M3: posição 2' (escoamento)

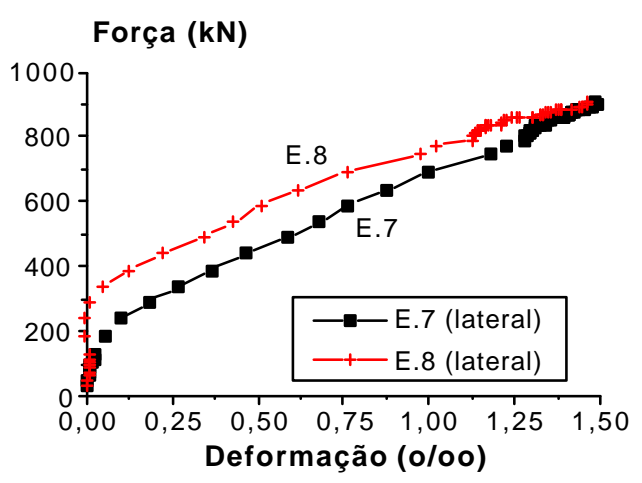

Figura G.27 - M3: posição 4' (1,8\%) 


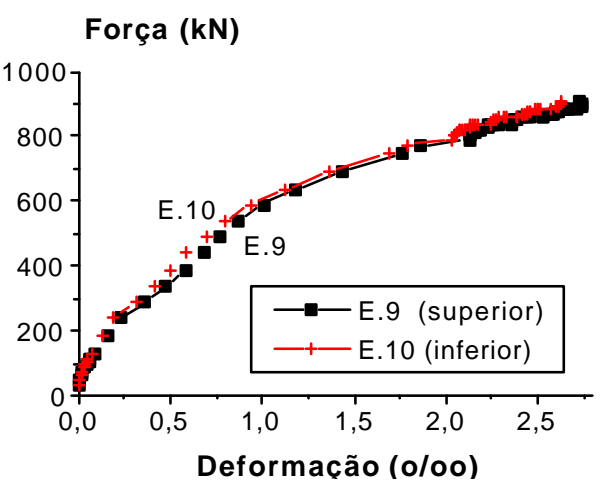

Figura G.28 - M3: posição 5' $(4,1 \%)$

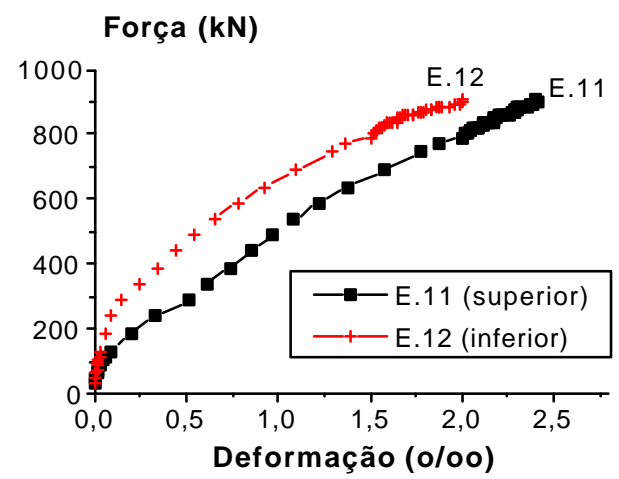

Figura G.29 - M3: posição 6' (20\%)

\section{Força $(k N)$}

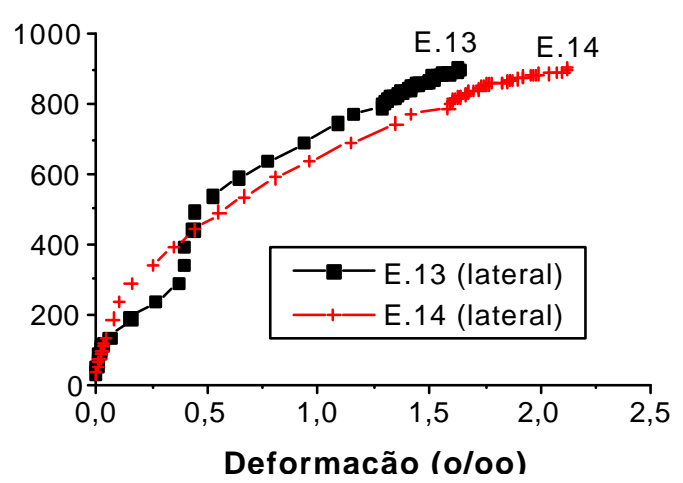

Figura G.30 - M3: posição 7' $(-23,1 \%)$

\section{G.4. MODELO M4}

Para o modelo M4, as figuras G.31 a G.37 ilustram as deformações de cada par de extensômetros relativos às posições indicadas na figura 4.10, do capítulo 4 .

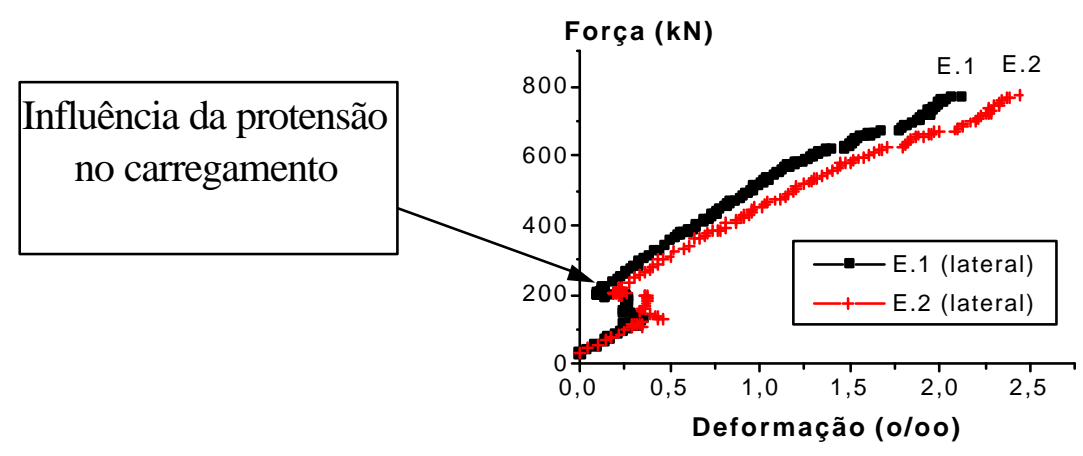

Figura G.31 - M4: posição 1' $\quad(-13,2 \%)$ 


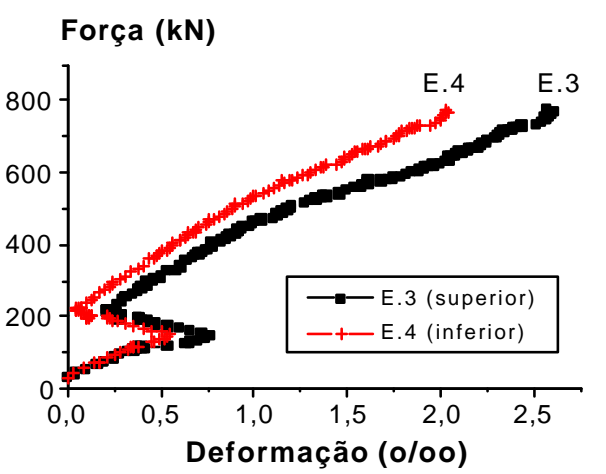

Figura G.32 - M4: posição 2' (27,0\%)

Força $(\mathbf{k N})$

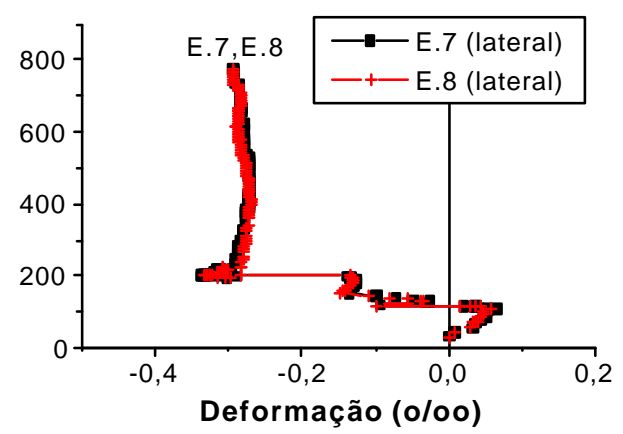

Figura G.34 - M4: posição 4' (-0,4\%)

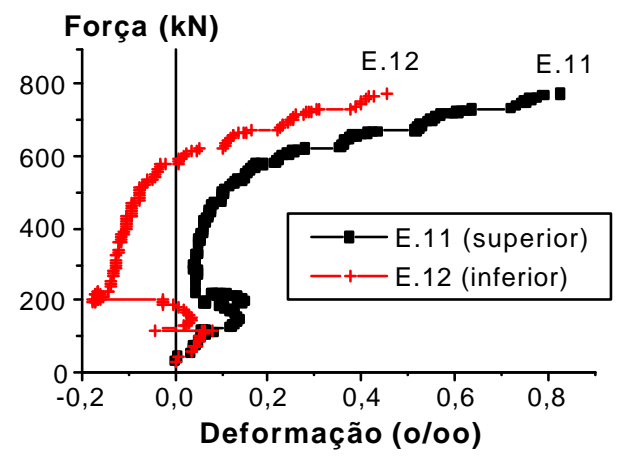

Figura G.36 - M4: posição 6’ $(81,5 \%)$
Força (kN)

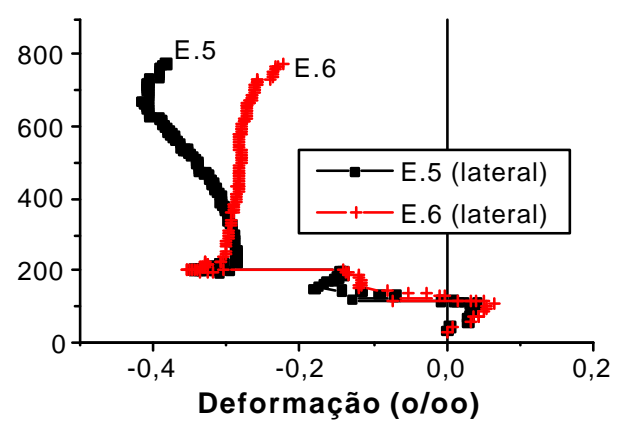

Figura G.33 - M4: posição 3' (72,6\%)

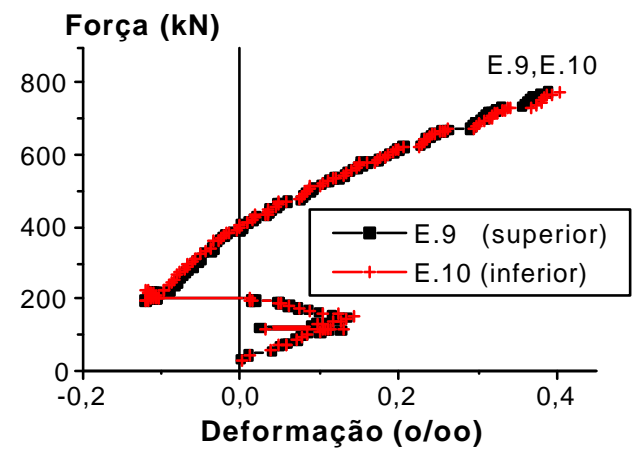

Figura G.35 - M4: posição 5' (-3,8\%)

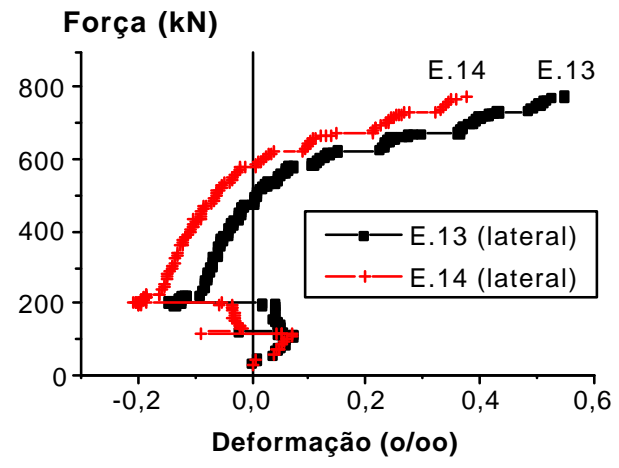

Figura G.37 - M4: posição 7' (45,5\%) 


\section{G.5. MODELO M5}

Para o modelo M5, as figuras G.38 a G.44 ilustram as deformações de cada par de extensômetros relativos às posições indicadas na figura 4.11, do capítulo 4.

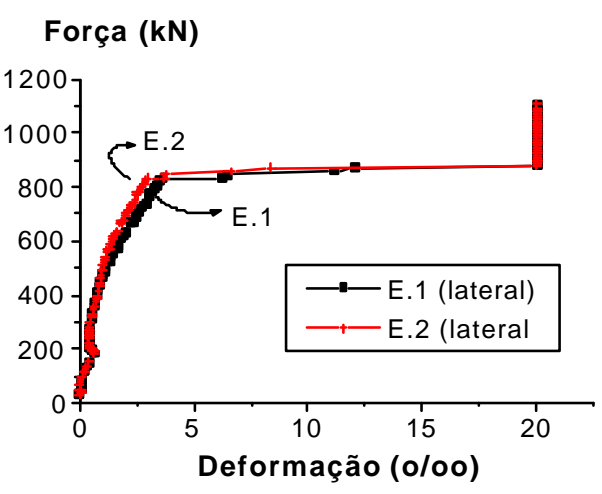

Figura G.38 - M5: posição 1' (escoamento)

Força (kN)

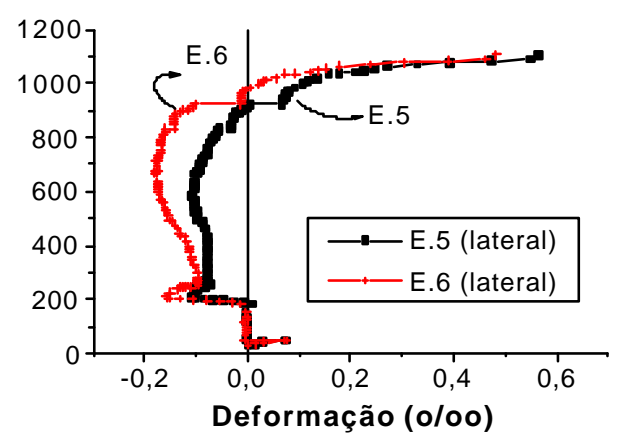

Figura G.40 - M5: posição 3' (17,1\%)

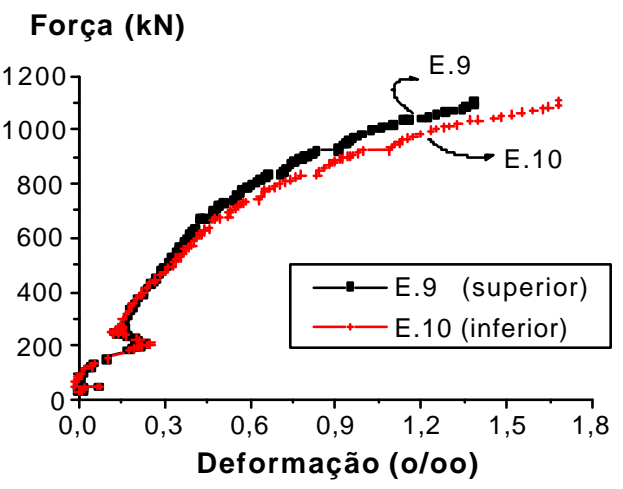

Figura G.42 - M5: posição 5' (-17,5\%)

\section{Força $(\mathbf{k N})$}

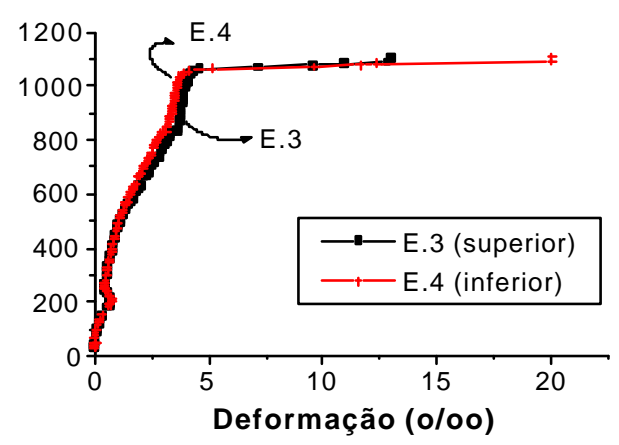

Figura G.39 - M5: posição 2' (escoamento)

\section{Força $(k N)$}

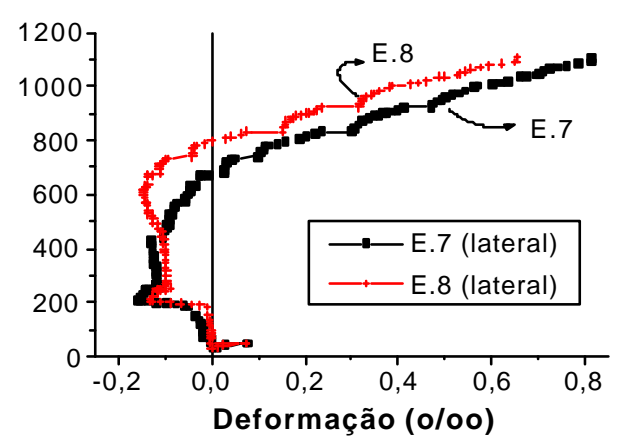

Figura G.41 - M5: posição 4’ (24,3\%)

\section{Força (kN)}

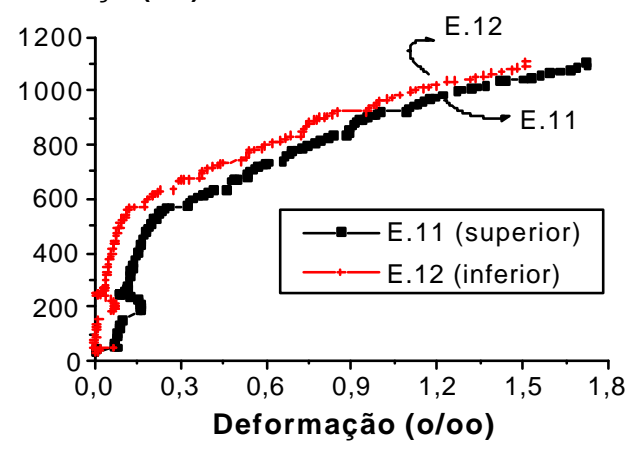

Figura G.43 - M5: posição 6' (14,3\%) 


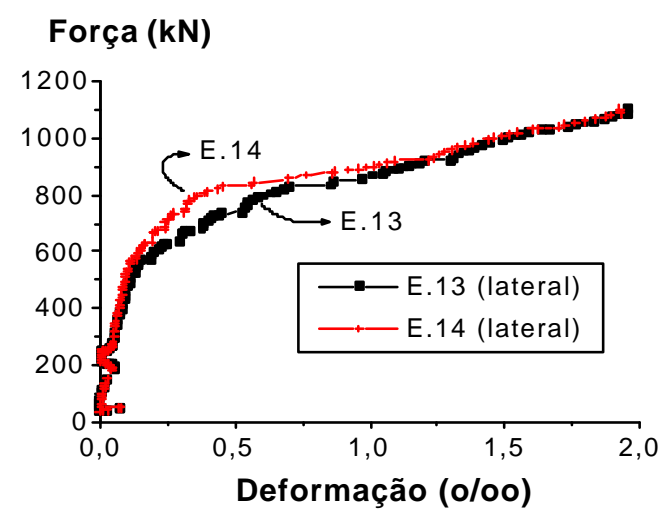

Figura G.44 -M5: posição 7' (1,5\%)

\section{G.6. MODELO M6}

Para o modelo M6, as figuras G.45 a G.51 ilustram as deformações de cada par de extensômetros relativos às posições indicadas na figura 4.12, do capítulo 4 .

Na figura G.49, como o E.9 (superior) apresentou problemas, somente o E.10 (inferior) é mostrado. Na figura G.51, o E.13 apresentou problemas após aplicação da protensão, razão esta pela qual não é mostrado neste gráfico a partir deste ponto.

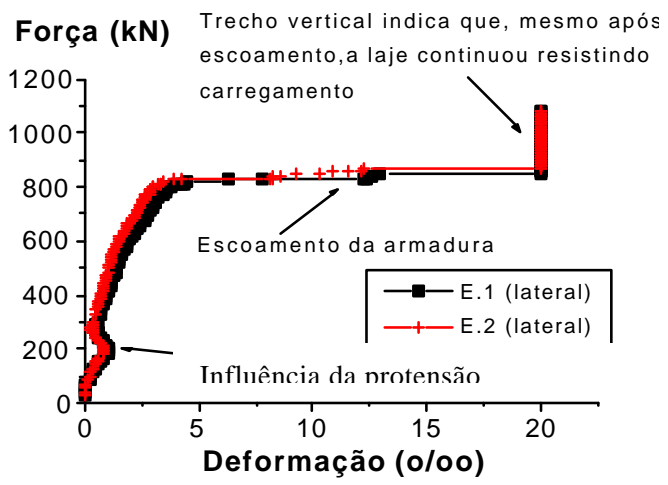

Figura G.45 - M6: posição 1' (escoamento)

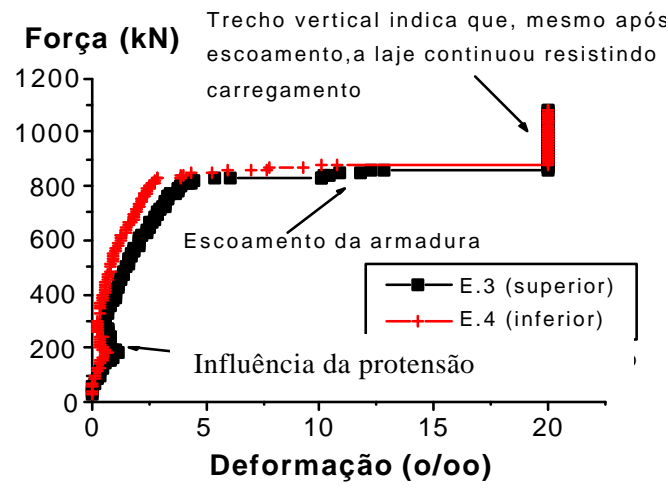

Figura G.46 - M6: posição 2' (escoamento) 
Força (kN)

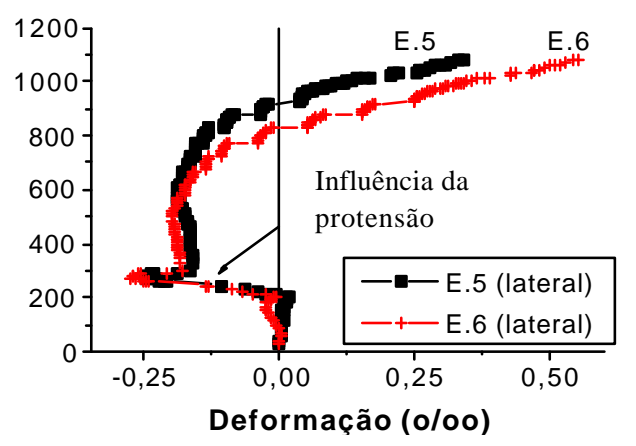

Figura G.47 - M6: posição 3' (-38,3\%)

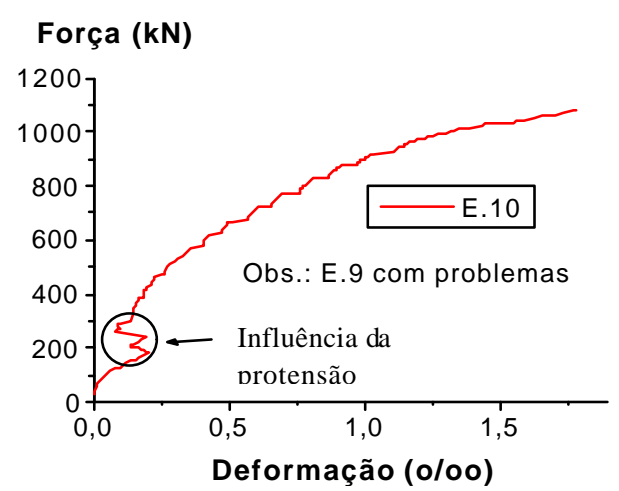

Figura G.49 - M6: posição 5'

\section{Força (kN)}

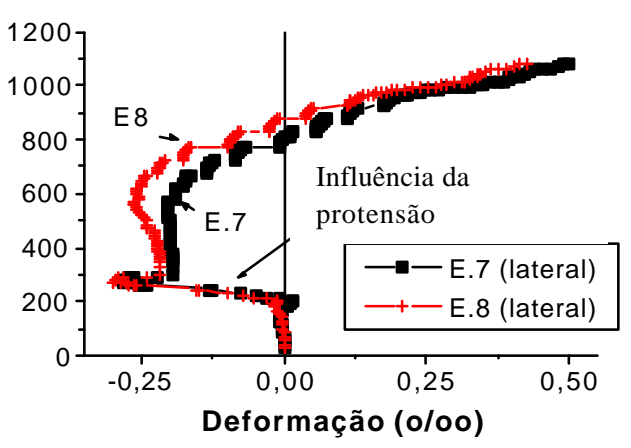

Figura G.48 - M6: posição 4' (+17,1\%)

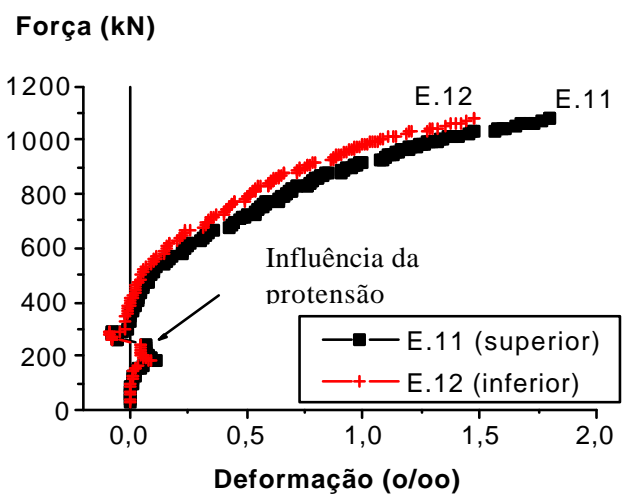

Figura G.50 - M6: posição 6’ (+22,1\%)

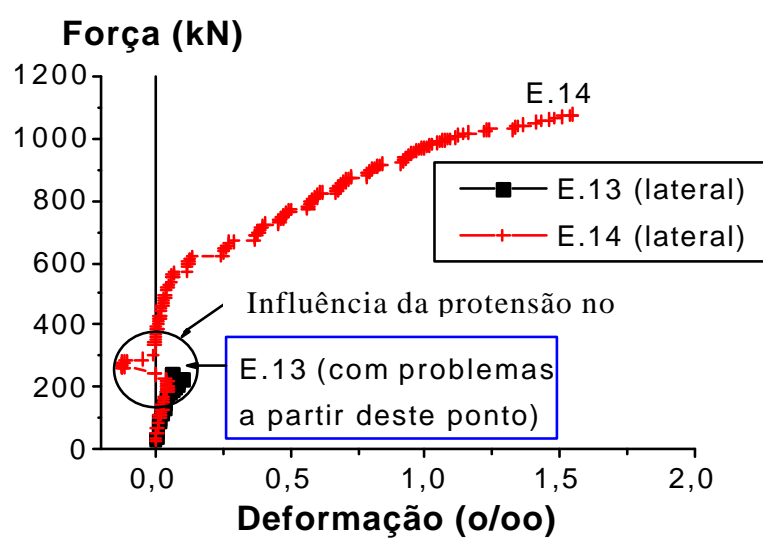

Figura G.51 - M6: posição 7’ 


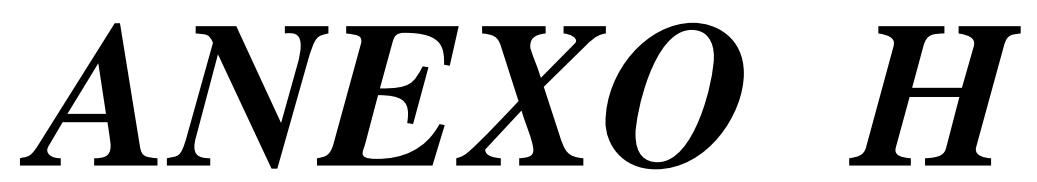

Informações relacionadas à

instrumentação da armadura

de punção 


\section{ANEXO H - Informações relacionadas à instrumentação da armadura de punção}

São apresentadas as informações relacionadas à instrumentação da armadura de punção para cada um dos extensômetros posicionados nos modelos M2, M3, M5 e M6. Nos modelos M2 e M5, os extensômetros com numeração ímpar encontram-se mais próximos da região onde foi aplicado o carregamento. Já para os modelos M3 e M6, os extensômetros com números menores encontram-se mais próximos da região onde foi aplicado o carregamento e os com valores números intermediários estão mais relacionados aos pinos posicionados no meio das chapas de ancoragem inferiores.

Visando facilitar a análise dos resultados, apresentam-se primeiro os resultados obtidos para os modelos com duas linhas de conectores (M2 e M5), e, a seguir, os obtidos para os modelos com três linhas de conectores (M3 e M6).

\section{H.1. MODELO M2}

Para o modelo M2, as figuras H.1 a H.7 ilustram as deformações de cada extensômetro relativo às posições indicadas na figura 4.93, do capítulo 4.

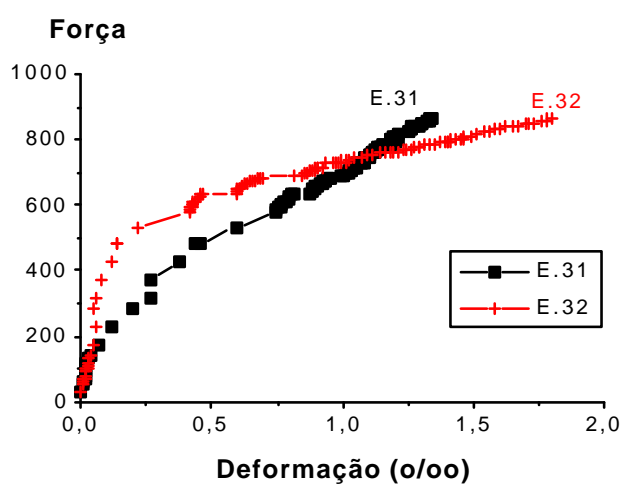

Figura H.1 - Modelo M2 - E.31 e E.32 (inclinado)

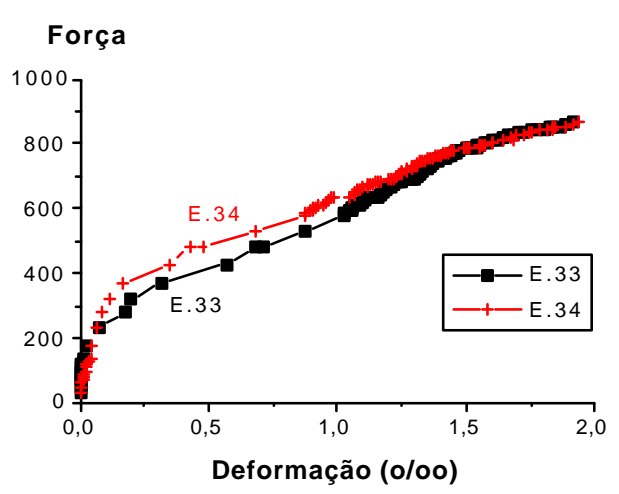

Figura H.2 - Modelo M2: E.33 e E.34 (na direção y) 


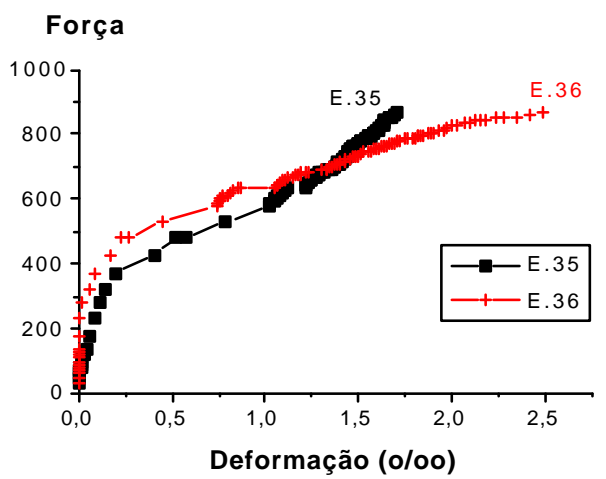

Figura H.3 - Modelo M2: E.35 e E.36 (na direção $\mathrm{x}$ )

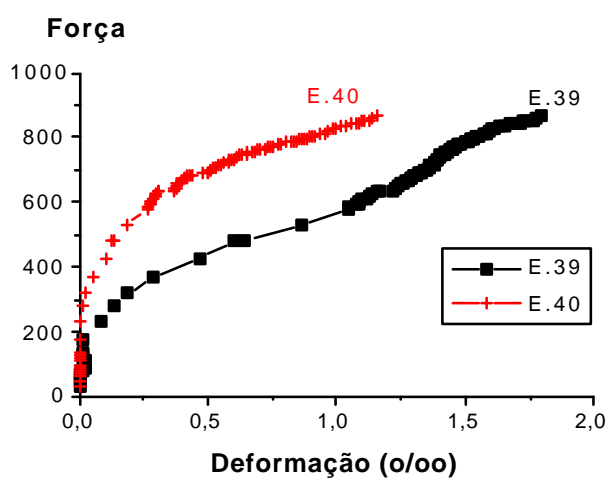

Figura H.5 - Modelo M2: E.39 e E.40 (na direção y)

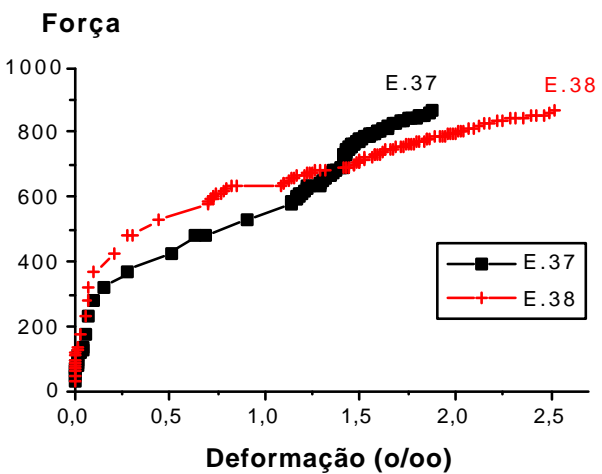

Figura H.4 - Modelo M2: E.37 e E.38 (na direção $\mathrm{x}$ )

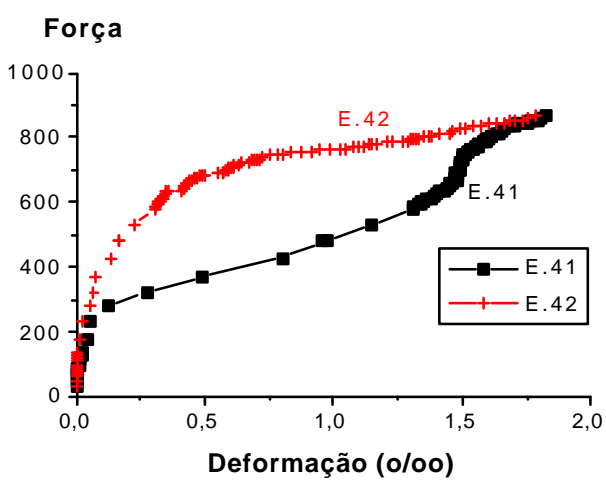

Figura H.6 - Modelo M2: E.41 e E.42 (na direção y)

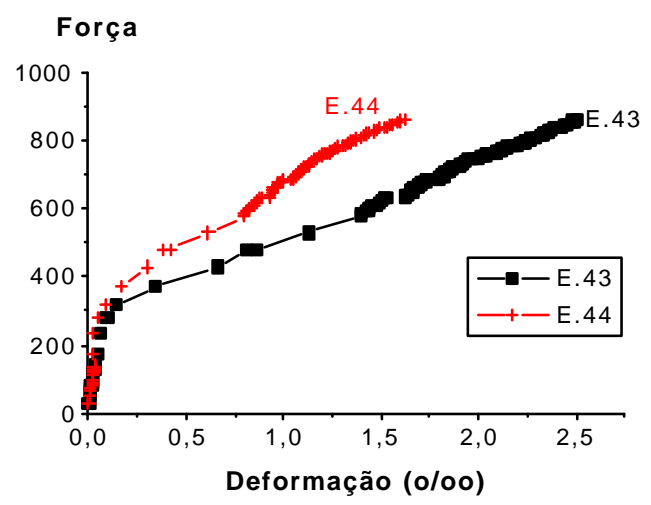

Figura H.7 - Modelo M2: E.43 e E.44 (na direção x)

\section{H.2. MODELO M5}

Para o modelo M5, as figuras H.8 a H.14 ilustram as deformações de cada extensômetro relativo às posições indicadas na figura 4.93, do capítulo 4.

Foram observados defeitos nos extensômetros E.23 e E.24, razão esta pela qual eles não são apresentados. 


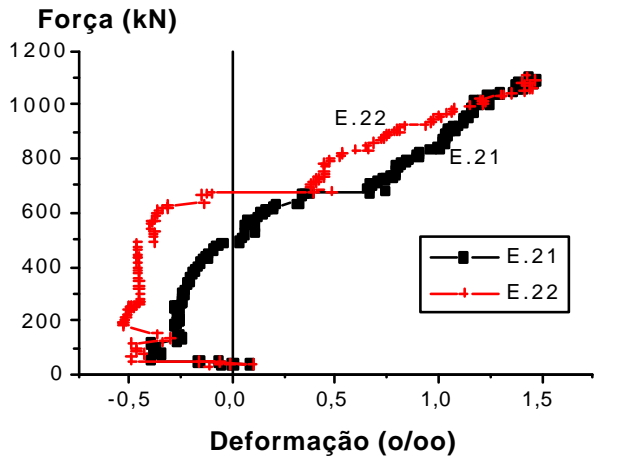

Figura H.8 - Modelo M5: E.21 e o E.22 (direção y)

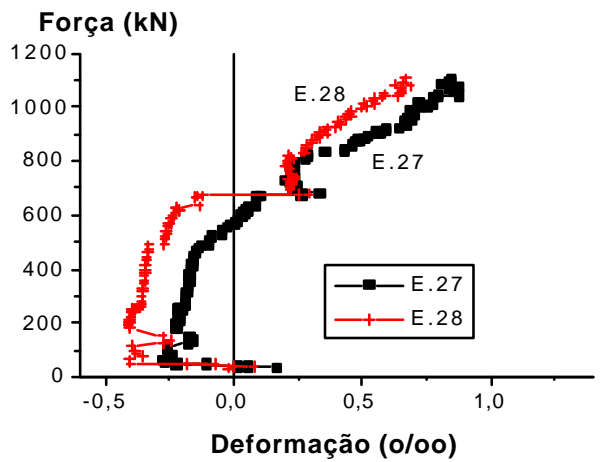

Figura H.10 - Modelo M5: E.27 e E.28 (direção inclinada)

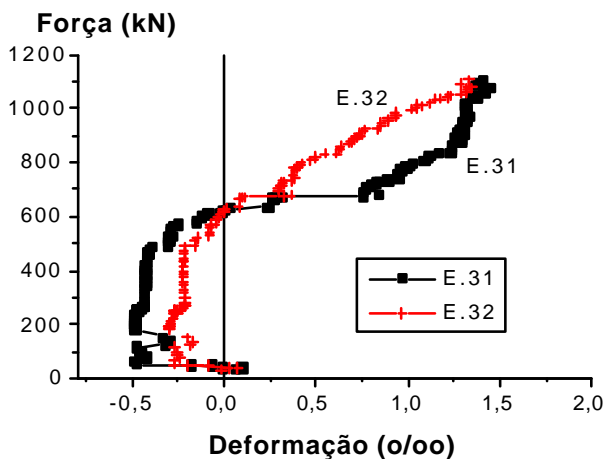

Figura H.12 - Modelo M5: E.31 e E.32 (direção $\mathrm{x}$ )

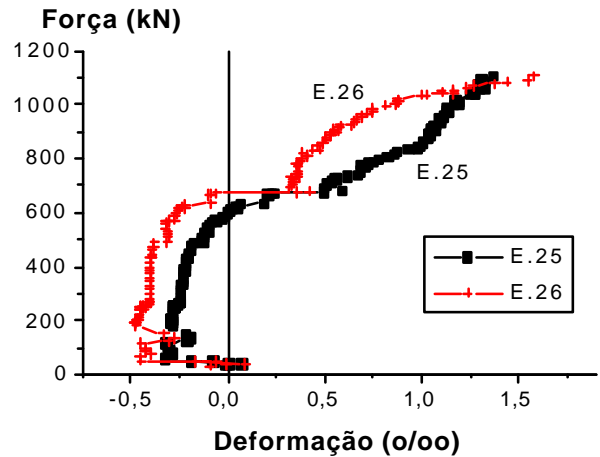

Figura H.9 - Modelo M5: E.25 e E.26 (direção $\mathrm{x}$ )

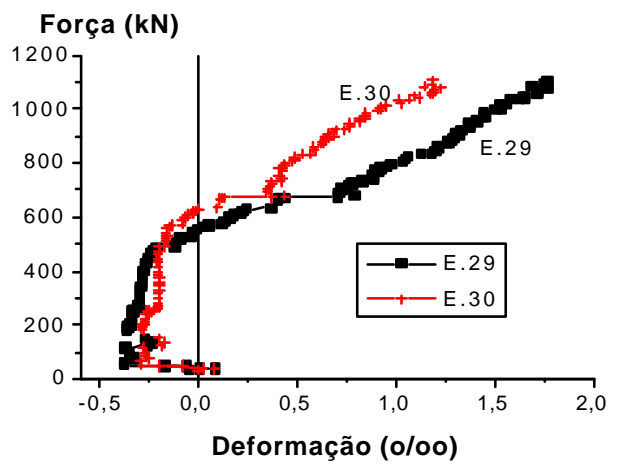

Figura H.11 - Modelo M5: E.29 e E.30 (direção y)

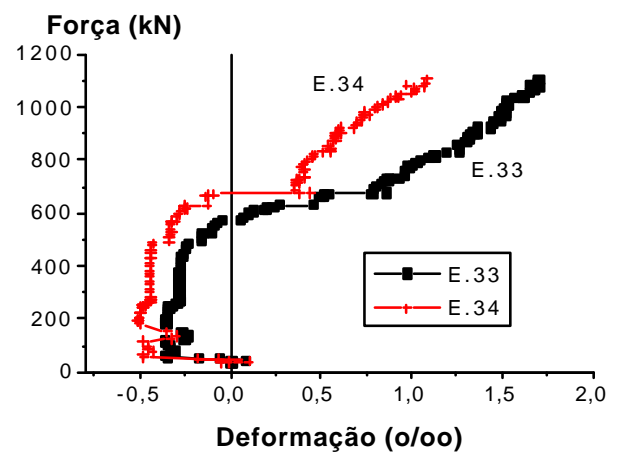

Figura H.13- Modelo M5: E.33 e E.34 (direção x) 


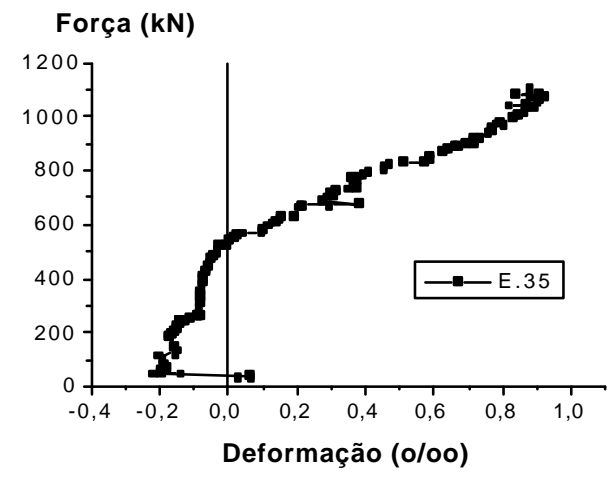

Figura H.14 - Modelo M5: E.35 - direção inclinada (E.36 com defeito)

\section{H.3. MODELO M3}

Para o modelo M3, as figuras H.15 a H.22 ilustram as deformações de cada extensômetro relativo às posições indicadas na figur a 4.104, do capítulo 4.

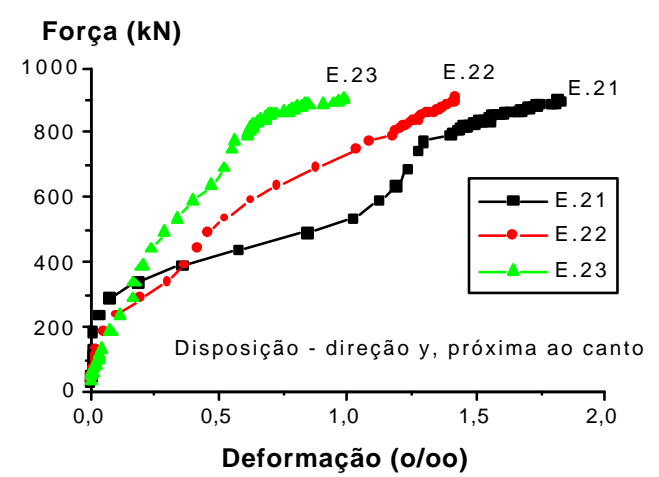

Figura H.15 - Modelo M3: E.21, E.22 e E.23 (direção do eixo y)

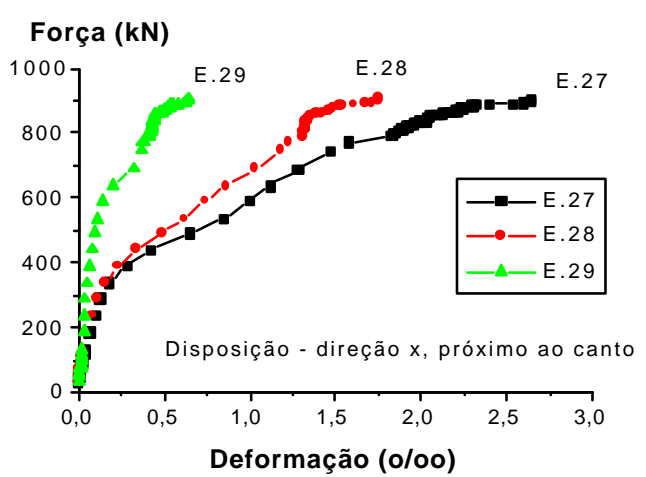

Figura H.17 - Modelo M3: E.27, E.28 e E.29 (direção do eixo x)

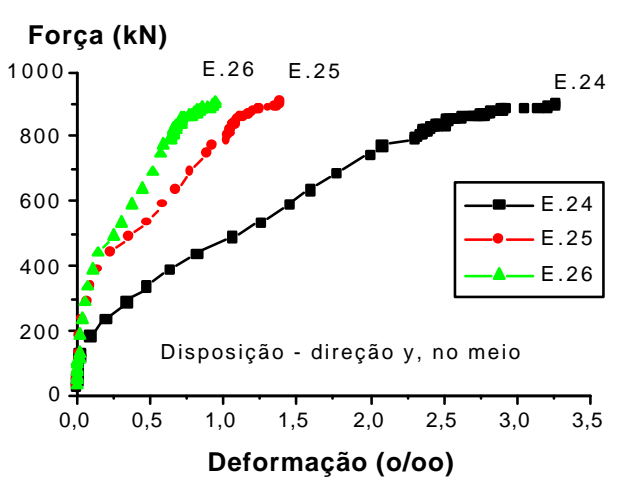

Figura H.16 - Modelo M3: E.24, E.25 e E.26 (direção do eixo y)

\section{Força $(k N)$}

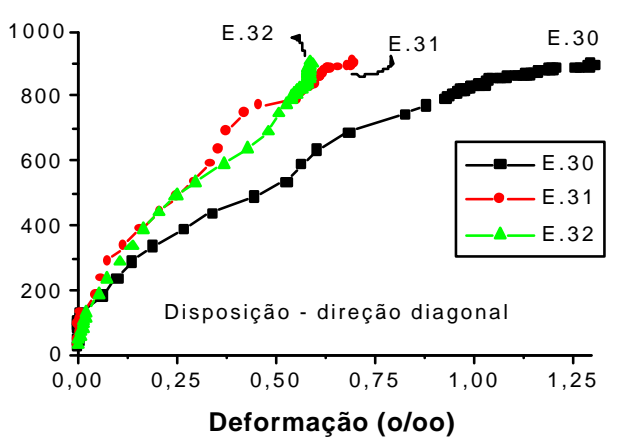

Figura H.18 - Modelo M3: E.30, E.31 e E.32 (direção inclinada) 


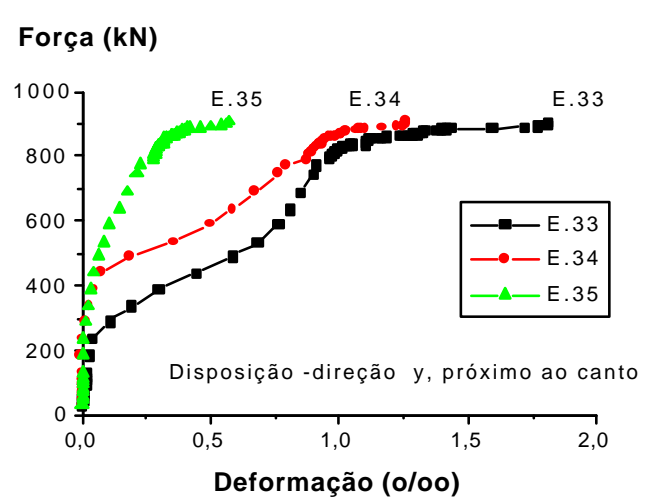

Figura H.19 - E.33, E.34 e E.35 (direção do eixo y)

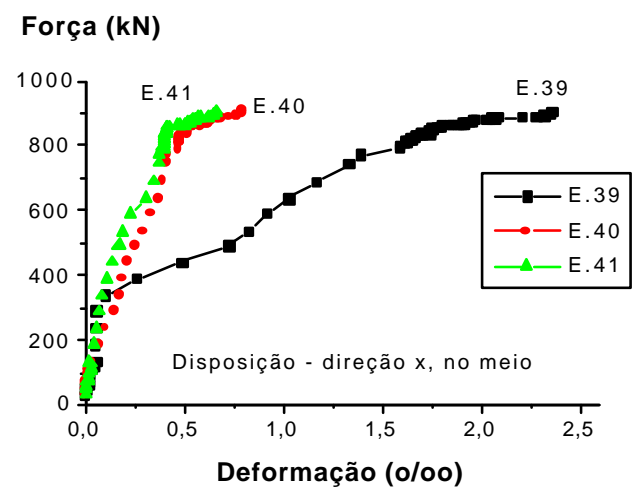

Figura H.21 - E.39, E.40 e E.41

(direção do eixo $\mathrm{x}$ )

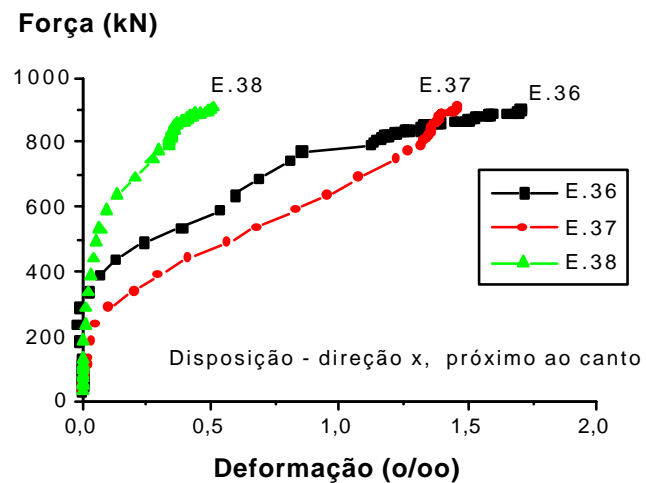

Figura H.20 - E.36, E.37 e E.38 (direção do eixo $\mathrm{x}$ )

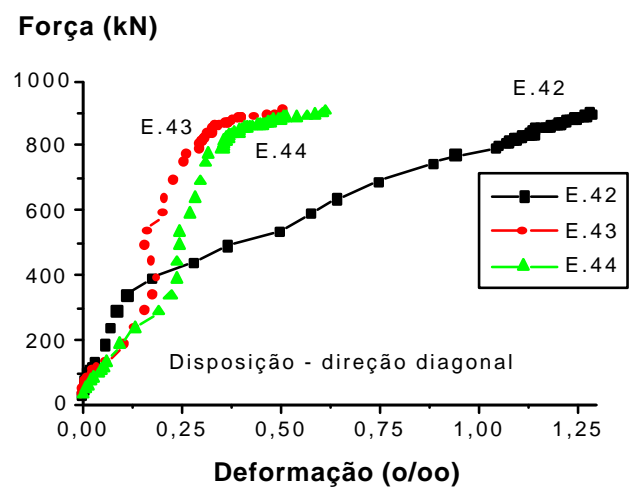

Figura H.22 - E.42, E.43 e E.44

(direção inclinada)

\section{H.4. MODELO M6}

Para o modelo M6, as figuras H.23 a H.30 ilustram as deformações de cada extensômetro relativo às posições indicadas na figura 4.104, do capítulo 4.

Conforme pode ser visto nas figuras a seguir, apenas do E.40 ao E.44 parecem ter funcionado bem. A explicação provável para o mau funcionamento dos extensômetros pode ter sido a falta de cuidado na execução, o que resultou em baixo isolamento, ou durante o posicionamento da malha passiva de tração superior sobre os caranguejos. 


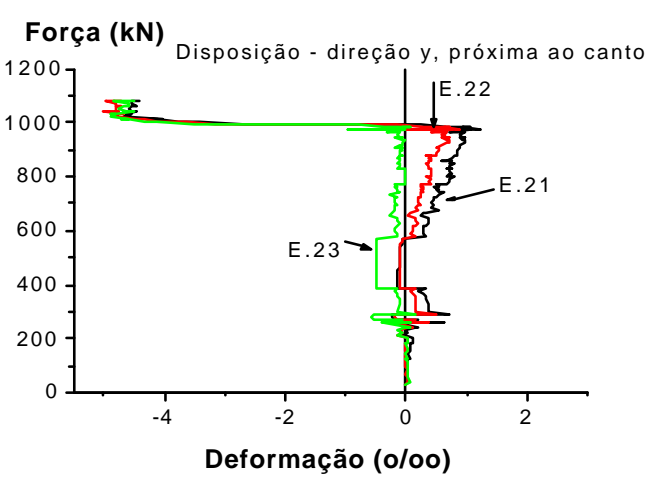

Figura H.23 - Modelo M6: E.21, E.22 e E.23

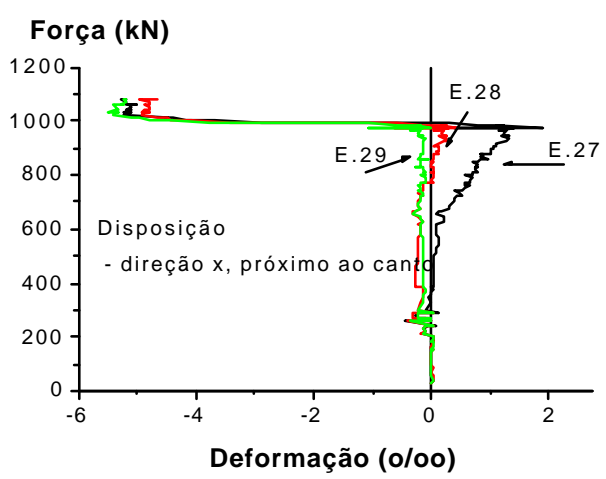

Figura H.25 - Modelo M6: E.27, E.28 e E.29

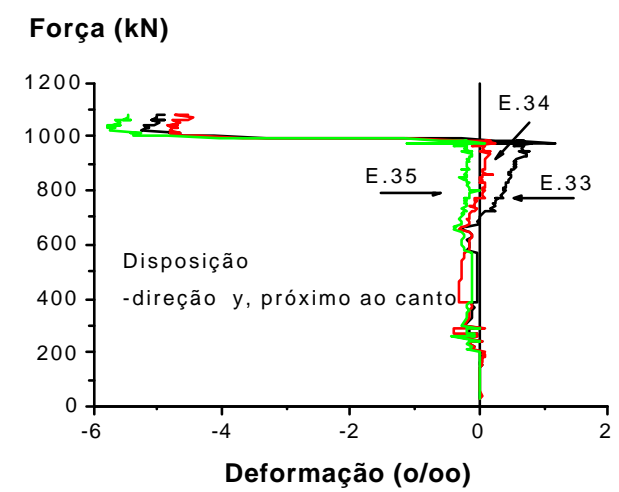

Figura H.27 - Modelo M6: E.33, E.34 e E.35

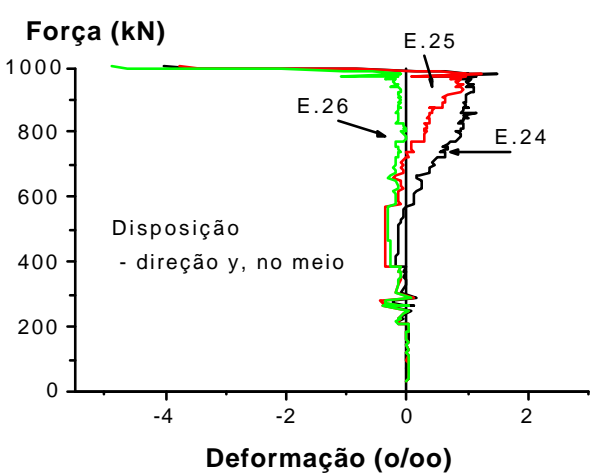

Figura H.24 - Modelo M6: E.24, E.25 e E.26

\section{Força (kN)}

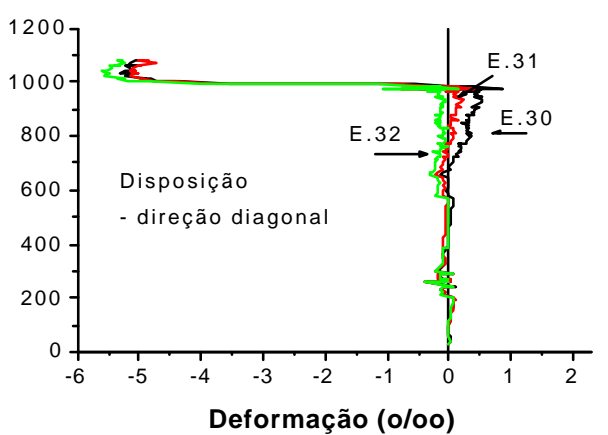

Figura H.26- Modelo M3: E.30, E.31 e E.32

\section{Força (kN)}

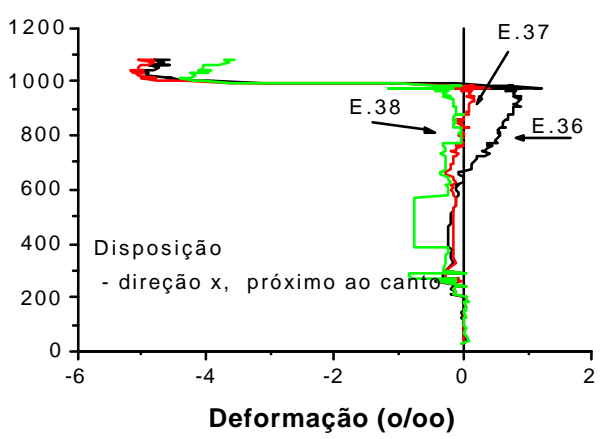

Figura H.28 - Modelo M6: E.36, E.37 e E.38 


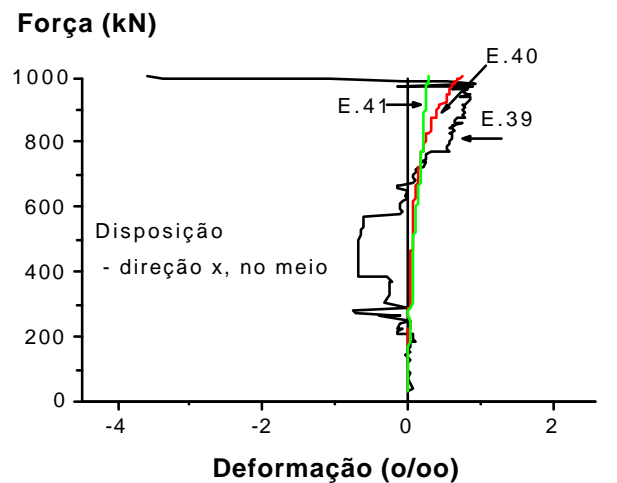

Figura H.29 - Modelo M6: E.39, E.40 e E.41

\section{Força (kN)}

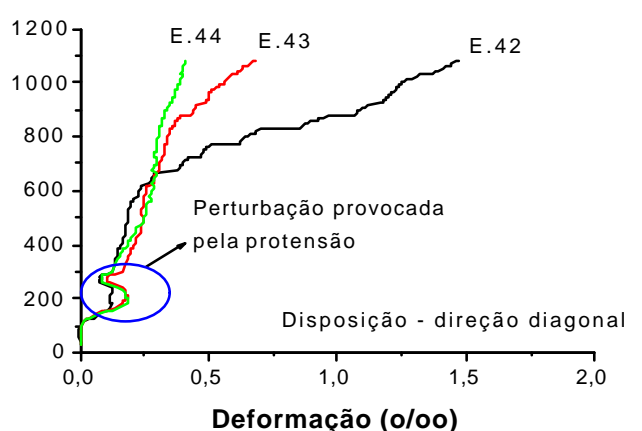

Figura H.30 - Modelo M6: E.42, E.43 e E.44 


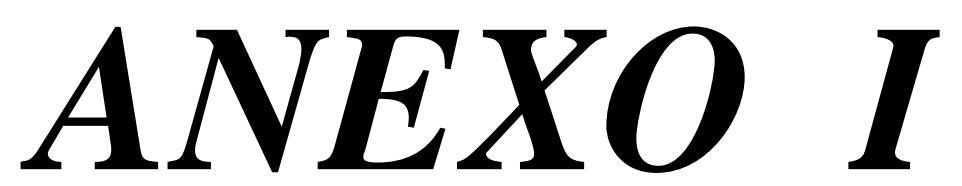

Dimensionamento dos modelos de concreto armado e protendido com relação à flexão 


\section{I.1. MODELO M1}

MODELO M1 - Domínio 3: Cálculo de mx

Considerar deformação no concreto ( $\varepsilon$ c) igual a $0,35 \%, \quad \varepsilon y d=<\varepsilon s=<1 \%$

Considerar deformação na armadura positiva no intervalo: $\quad \varepsilon y d=<\varepsilon s=<1 \%$

Com uma estimativa para a linha neutra, obtém-se os valores das deformações

Obs.: foram usadas as equações modificadas para ensaio experimental: 0,95 fc

Obs.: Como a armadura positiva apresentou características diferentes da armadura negativa, definiu-se o índice - as - para armadura positiva e - as1 - para a armadura negativa

Dados (unidades em kN, cm, kN/cm2):

$$
\begin{aligned}
& \mathrm{d}:=16-1.66-\frac{1.6}{2} \quad \mathrm{dl}:=1.5+\frac{0.8}{2} \quad \text { fc }:=2.66 \quad \mathrm{~b}:=10 \quad \text { As }:=2.001 \quad \text { As } 1:=0.496 \\
& \text { fyas }:=59.04 \quad \text { fyas } 1:=59.79 \quad \text { Eas }:=19020.9 \quad \text { Eas1 }:=21415.6 \quad \mathrm{~d}=13.54 \quad \mathrm{dl}=1.9
\end{aligned}
$$

No domínio 3, a deformação no concreto é fixa em $0.35 \%$

Neste ponto - estima-se valor de $\mathrm{x}$ p/ cálculo das deformações:

$$
\begin{gathered}
x:=4.689 \varepsilon s:=0.0035 \frac{d-x}{x} \quad \varepsilon s 1:=0.0035 \frac{x-d l}{x} \quad \text { Portanto } s=0.00661=<0,01 \text { e }>=\varepsilon y d \quad \varepsilon y d:=\frac{\text { fyas }}{\text { Eas }} \\
\varepsilon \text { yd }=0.0031
\end{gathered}
$$

Achar o valor de $k$ (altura da seção plastificada) : $k:=\left\{\frac{1.5}{3.5}\right\} \cdot x \quad k=2.00957$

Cálculo das resultantes no concreto:

Rc1 $:=0.95 \mathrm{fc} \cdot \mathrm{b} \cdot \mathrm{k} \quad \mathrm{Rc} 2:=\mathrm{b} \cdot 0.95 \cdot \mathrm{fc} \cdot \int_{0}^{\mathrm{x}-\mathrm{k}} 1-\left(1-\frac{\mathrm{a}}{\mathrm{x}-\mathrm{k}}\right)^{2} \mathrm{da} \quad \mathrm{Rc} 1=50.78187 \quad \mathrm{Rc} 2=45.13944$

Cálculo da resultante na armadura comprimida $\sigma \mathrm{s} 1:=\varepsilon \mathrm{s} 1$ Eas $1 \quad \sigma \mathrm{s} 1=44.58272$

$\sigma \mathrm{s} 1:=44.58272$ Repetir valor se estiver no regime elástico $($ CA-50A $)<$ fyas $1=59.79$

Rs1 $:=\sigma s 1 \cdot$ As1 $\quad$ Rs1 $=22.11303$

Cálculo das resultantes na armadura tracionada $\quad$ Rs := fyas ·As $\quad$ Rs $=118.13904$

Equilibrio da seção: Se Ftração diferente de Fcompressão - mudar o x

Ftração $:=$ Rs $\quad$ Fcompressao $:=$ Rc1 + Rc2 + Rs1 Ftração = 118.13904 Fcompressao = 118.03434

VERIFICAR LIMITES NO AÇO E NO CONCRETO - OK!

Diferenca_percentual $:=\frac{\text { Ftração }- \text { Fcompressao }}{\text { Fcompressao }} \cdot 100 \quad$ Diferenca_percentual $=0.09(\%)$

Momentos fletores - calc. com relação à linha neutra

$$
\mathrm{M} 1:=\mathrm{b} \cdot \mathrm{k} \cdot 0.95 \cdot \mathrm{fc} \cdot\left(\mathrm{x}-\frac{\mathrm{k}}{2}\right\} \quad \mathrm{M} 2:=\mathrm{b} \cdot 0.95 \mathrm{fc} \cdot \int_{0}^{\mathrm{x}-\mathrm{k}}\left[1-\left(1-\frac{\mathrm{a}}{\mathrm{x}-\mathrm{k}}\right)^{2}\right] \cdot \mathrm{ada} \quad \begin{aligned}
& \text { M3 }:=\mathrm{Rs} 1 \cdot(\mathrm{x}-\mathrm{dl}) \\
& \mathrm{M} 4:=\mathrm{Rs} \cdot(\mathrm{d}-\mathrm{x})
\end{aligned}
$$

M1 $=187.09129 \quad$ M2 $=75.59244 \quad$ M3 $=61.67324 \quad$ M4 $=1045.64864$

Mfletor $:=\mathrm{M} 1+\mathrm{M} 2+\mathrm{M} 3+\mathrm{M} 4 \quad$ Mfletor $=1370.00561$ mfletordistr $:=\frac{\text { Mfletor }}{\mathrm{b}} \quad$ mfletordistr $=137.00056$ 
MODELO M1 - Domínio 3: Cálculo de my

Considerar deformação no concreto ( $\varepsilon$ c) igual a 0,35\%, $\quad \varepsilon$ yd $=<\varepsilon s=<1 \%$

Considerar deformação na armadura positiva no intervalo: $\quad \varepsilon y d=<\varepsilon s=<1 \%$

Com uma estimativa para a linha neutra, obtém-se os valores das deformações

Obs.: foram usadas as equações modificadas para ensaio experimental: 0,95 fc

Obs.: Como a armadura positiva apresentou características diferentes da armadura negativa, definiu-se o índice - as - para armadura positiva e - as1 - para a armadura negativa

Dados (unidades em kN, cm, kN/cm2):

$$
\begin{aligned}
& \mathrm{d}:=16-1.66-1.6-\frac{1.6}{2} \quad \mathrm{dl}:=1.5+0.8+\frac{0.8}{2} \quad \mathrm{fc}:=2.66 \quad \mathrm{~b}:=10 \quad \text { As }:=2.001 \quad \text { As } 1:=0.496 \\
& \text { fyas }:=59.04 \quad \text { fyas } 1:=59.79 \quad \text { Eas }:=19020.9 \quad \text { Eas } 1:=21415.6 \quad \mathrm{~d}=11.94 \quad \mathrm{dl}=2.7
\end{aligned}
$$

No domínio 3, a deformação no concreto é fixa em $0.35 \%$

Neste ponto - estima-se valor de x p/ cálculo das deformações :

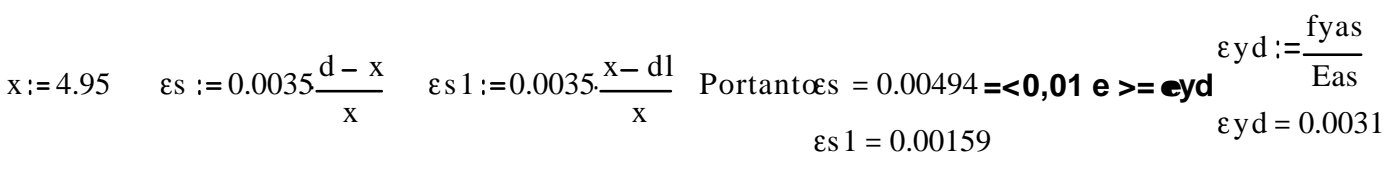

Achar o valor de $\mathbf{k}$ (altura da seção plastificada) : $\mathrm{k}:=\left\{\frac{1.5}{3.5}\right\} \cdot \mathrm{x} \quad \mathrm{k}=2.12143$

Cálculo das resultantes no concreto:

Rc1 : = 0.95.fc $\cdot \mathrm{b} \cdot \mathrm{k} \quad \mathrm{Rc} 2:=\mathrm{b} \cdot 0.95 \cdot \mathrm{fc} \cdot \int_{0}^{\mathrm{x}-\mathrm{k}} 1-\left\{1-\frac{\mathrm{a}}{\mathrm{x}-\mathrm{k}}\right\}^{2} \mathrm{da} \quad \mathrm{Rc} 1=53.6085 \quad \mathrm{Rc} 2=47.652$

Cálculo da resultante na armadura comprimida $\sigma s 1:=\varepsilon s 1$ Eas $1 \quad \sigma s 1=34.07027$

$\sigma \mathrm{s} 1:=34.07027$ Repetir valor se estiver no regime elástico (CA-50A) <fyas $1=59.79$

Rs $1:=\sigma s 1 \cdot A s 1 \quad$ Rs $1=16.89885$

Cálculo das resultantes na armadura tracionada $\quad$ Rs :=fyas.As $\quad$ Rs $=118.13904$

Equilibrio da seção: Se Ftração diferente de Fcompressão - mudar o x

Ftração: $=$ Rs $\quad$ Fcompressao $=$ Rc1+Rc2+Rs1 Ftração=118.13904 Fcompressao= 118.15935

\section{VERIFICAR LIMITES NO AÇO E NO CONCRETO - OK!}

Diferenca_percentuak $\frac{\text { Ftração_Fcompressao }}{\text { Fcompressao }} 100 \quad$ Diferenca_percentuał $-0.02(\%)$

Momentos fletores - calc. com relação à linha neutra

$$
\mathrm{M} 1:=\mathrm{b} \cdot \mathrm{k} \cdot 0.95 \cdot \mathrm{fc} \cdot\left\{\mathrm{x}-\frac{\mathrm{k}}{2}\right\} \quad \mathrm{M} 2:=\mathrm{b} \cdot 0.95 \cdot \mathrm{fc} \cdot \int_{0}^{\mathrm{x}-\mathrm{k}}\left[1-\left\{1-\frac{\mathrm{a}}{\mathrm{x}-\mathrm{k}}\right\}^{2}\right] \cdot \mathrm{ad} a \begin{aligned}
& \text { M } 3:=\mathrm{Rs} 1 \cdot(\mathrm{x}-\mathrm{dl}) \\
& \mathrm{M} 4:=\mathrm{Rs} \cdot(\mathrm{d}-\mathrm{x})
\end{aligned}
$$

M1 $=208.49877 \quad$ M2 $=84.24193 \quad$ M3 $=38.02242 \quad$ M4 $=825.79189$

Mfletor: $=\mathrm{M} 1+\mathrm{M} 2+\mathrm{M} 3+\mathrm{M} 4 \quad$ Mfletor $=1156.55501 \quad$ mfletordistr $:=\frac{\text { Mfletor }}{\mathrm{b}} \quad$ mfletordistr $=115.6555$ 
MODELO M1 - Domínio 2a: Cálculo de m'x (momento negativo)

Considerar deformação no concreto ( $\mathrm{Ec}$ ) inferior a $0,2 \%$

Com uma estimativa para a linha neutra, obtém-se os valores das deformações

Obs.: foram usadas equações modificadas para ensaio experimental: 0,95 fc

Obs.: Como a armadura positiva apresentou características diferentes da armadura negativa, definiu-se o índice - as - para armadura positiva e - as1 - para a armadura negativa

$\mathrm{d}:=16-1.5-\frac{0.8}{2} \quad \mathrm{dl}:=1.66+\frac{1.6}{2} \quad$ fc $:=2.66 \quad \mathrm{~b}:=10 \quad$ As $:=0.496 \quad$ As $1:=2.001$

fyas $:=59.79 \quad$ fyas $1:=59.04 \quad$ Eas $:=21415.6 \quad$ Eas $1:=19020.9 \quad \mathrm{~d}=14.1 \quad \mathrm{~d} \mathbf{l}=2.46$

No domínio 2, a deformação no aço é fixa em 1\% $\varepsilon \mathrm{s}:=0.01$

Neste ponto - "estima-se" valor de $\mathrm{x}$ p/ cálculo das deformações

$\mathrm{x}:=2.2405 \quad \varepsilon \mathrm{s} 1:=0.01 \cdot \frac{\mathrm{x}-\mathrm{dl}}{\mathrm{d}-\mathrm{x}} \quad \varepsilon \mathrm{c}:=0.01 \cdot \frac{\mathrm{x}}{\mathrm{d}-\mathrm{x}}$ Portanto $\quad \varepsilon \mathrm{c}=0.00189<\mathbf{0 , 0 0 2}$ $\varepsilon s 1=-0.0002$

Cálc. da resultante no concreto: $\operatorname{Rc} 1:=\mathrm{b} \cdot 0.95 \cdot \mathrm{fc} \cdot \int_{0}^{\mathrm{x}} 1-\left(1-\frac{\varepsilon \mathrm{c} \cdot \mathrm{a}}{\mathrm{x} \cdot 0.002}\right)^{2} \mathrm{da} \quad \mathrm{Rc} 1=36.6415$

Cálc. da resultante na armadura comprimida $\sigma s 1:=\varepsilon s 1$.Eas 1

$\sigma \mathrm{s} 1=-3.5205$

$\sigma \mathrm{s} 1:=-3.5205$ Repetir valor se estiver no regime elástico $(\mathrm{CA}-50 \mathrm{~A})<$ fyas $1=59.04$

Rs $1:=\sigma s 1 \cdot A s 1 \quad$ Rs $1=-7.0445$

Cálc. da resultante na armadura tracionada: Rs :=fyas $\cdot$ As $\quad$ Rs $=29.6558$

Equilibrio da seção: Se Ftração diferente de Fcompressão - mudar o x

Ftração $:=$ Rs $\quad$ Fcompressao $:=\mathrm{Rc} 1+\mathrm{Rs} 1 \quad$ Ftração $=29.6558 \quad$ Fcompressao $=29.597$

Diferenca_percentual $:=\frac{\text { Ftração }- \text { Fcompressao }}{\text { Fcompressao }} \cdot 100 \quad$ Diferenca_percentual $=0.2 \quad(\%)$

VERIFICAR LIMITES NO AÇO E NO CONCRETO- OK!

Momentos fletores - calc. com relação à linha neutra

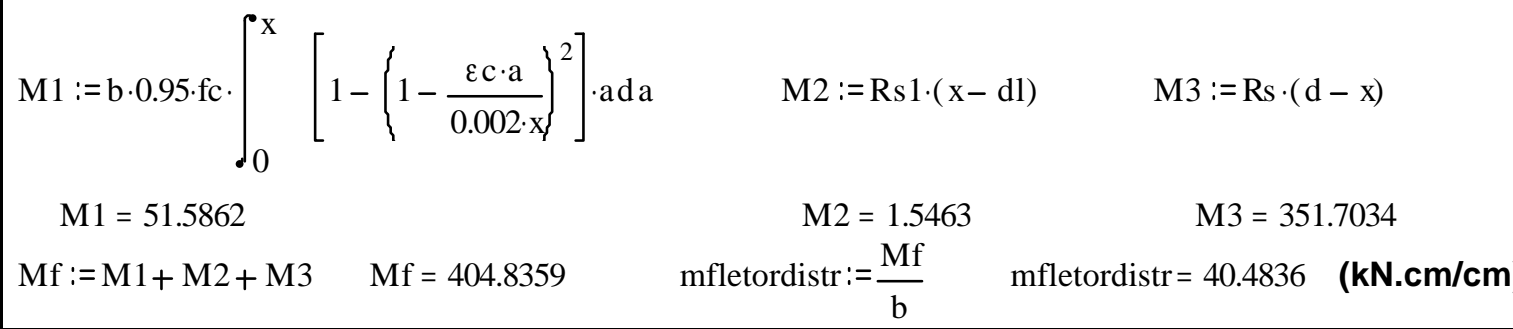


MODELO M1 - Domínio 2b : Cálculo de m'y (momento negativo)

Considerar deformação no concreto (cc) inferior a $0,35 \%$, mas maior ou igual a $0,2 \%$

Com uma estimativa para a linha neutra, obtém-se os valores das deformações

Obs.: foram usadas as equações modificadas para ensaio experimental: $0,95 \mathrm{fc}$

Obs.: Como a armadura positiva apresentou características diferentes da armadura negativa, definiu-se o índice - as - para armadura positiva e - as1 - para a armadura negativa

Dados (unidades em kN, cm, kN/cm2):

$\mathrm{d}:=16-1.5-\frac{0.8}{2}-0.8 \quad \mathrm{dl}:=1.66+\frac{1.6}{2}+1.6 \quad \mathrm{fc}:=2.66 \quad \mathrm{~b}:=10 \quad$ As $1:=2.001$ A s $:=0.496$ fyas $1:=59.04$ fyas $:=59.79 \quad$ Eas $1:=19020.9$ Eas $:=21415.6 \quad \mathrm{~d}=13.3 \quad \mathrm{dl}=4.06$

No domínio 2, a deformação no aço é fixa em $1 \%$ \&s : $=0.01$

Neste ponto - "estima-se" valor de $\mathrm{x}$ p/ cálculo das deformações

$\mathrm{x}:=3.17 \quad \varepsilon s 1:=0.01 \cdot \frac{\mathrm{x}-\mathrm{dl}}{\mathrm{d}-\mathrm{x}} \quad \varepsilon \mathrm{c}:=0.01 \cdot \frac{\mathrm{x}}{\mathrm{d}-\mathrm{x}} \quad$ Portanto $\varepsilon \mathrm{c}=0.003129 \stackrel{>0,002}{<=0,0035}$ $\varepsilon s 1=-0.0009$

Achar o valor de $\mathbf{k}$ (altura da seção plastificada) : $\mathrm{k}:=\mathrm{x}-\frac{0.002 \mathrm{x}}{\varepsilon \mathrm{c}} \quad \mathrm{k}=1.144$ Cálculo das resultantes no concreto: $\mathrm{Rc} 1:=0.95 \cdot \mathrm{fc} \cdot \mathrm{b} \cdot \mathrm{k} \quad \mathrm{Rc2}:=\mathrm{b} \cdot 0.95 \mathrm{fc} \cdot \int_{0}^{\mathrm{x}-\mathrm{k}} 1-\left(1-\frac{\mathrm{a}}{\mathrm{x}-\mathrm{k}}\right\}^{2} \mathrm{da} \quad \mathrm{Rc} 1=28.9089 \quad \mathrm{Rc} 2=34.1313$

Cálculo da resultante na armadura comprimida $\sigma \mathrm{s} 1:=\varepsilon s 1 \cdot$ Eas $1 \quad \sigma \mathrm{s} 1=-16.7114$ $\sigma \mathrm{s} 1:=-16.7114$ Repetir valor se estiver no regime elástico (CA-tipo A):fyas $1=59.04$

Rs $1:=\sigma$ s $1 \cdot$ As $1 \quad$ Rs $1=-33.4395$

Cálculo das resultantes na armadura tracionada $\quad$ Rs :=fyas As $\quad$ Rs $=29.6558$

Equilibrio da seção: Se Ftração diferente de Fcompressão - mudar o x

Ftração: $=$ Rs $\quad$ Fcompressa $\dot{0}=\mathrm{Rc} 1+\mathrm{Rc} 2+\mathrm{Rs} 1 \quad$ Ftração= 29.6558 $\quad$ Fcompressa 29.6007

Diferenca_percentuał $\frac{\text { Ftração-Fcompressao }}{\text { Fcompressao }} \cdot 100 \quad$ Diferenca_percentual0.19 (\%)

VERIFICAR LIMITES NO AÇO E NO CONCRETO - OK!

Momentos fletores - calc. com relação à linha neutra

$$
\begin{aligned}
& \mathrm{M} 1:=\mathrm{b} \cdot \mathrm{k} \cdot 0.95 \cdot \mathrm{fc} \cdot\left(\mathrm{x}-\frac{\mathrm{k}}{2}\right\} \quad \mathrm{M} 2:=\mathrm{b} \cdot 0.95 \mathrm{fc} \cdot \int_{0}^{\mathrm{x}-\mathrm{k}}\left[1-\left(1-\frac{\mathrm{a}}{\mathrm{x}-\mathrm{k}}\right)^{2}\right] \cdot \operatorname{ada} \quad \begin{array}{l}
\text { M3 :=Rs } 1 \cdot(\mathrm{x}-\mathrm{dl}) \\
\text { M4:=Rs }(\mathrm{d}-\mathrm{x})
\end{array} \\
& \text { M1 }=75.1053 \quad \text { M2 }=43.2188 \quad \text { M3 }=29.7612 \quad \text { M4 }=300.4137
\end{aligned}
$$

Mfletor: $=\mathrm{M} 1+\mathrm{M} 2+\mathrm{M} 3+\mathrm{M} 4$ Mfletor $=448.4989$ mfletordistr $=\frac{\text { Mfletor }}{\mathrm{b}}$ mfletordistæ 44.8499 


\section{I.2. MODELO M2}

MODELO M2 - Domínio 2b : Cálculo de mx

Considerar deformação no concreto $€$ c) inferior a $0,35 \%$, mas maior ou igual a $0,2 \%$

Com uma estimativa para a linha neutra, obtém-se os valores das deformações

Obs.: foram usadas as equações modificadas para ensaio experimental: 0,95 fc

Obs.: Como a armadura positiva apresentou características diferentes da armadura negativa, definiu-se o índice - as - para armadura positiva e - as1 - para a armadura negativa

Dados (unidades em $\mathrm{kN}, \mathrm{cm}, \mathrm{kN} / \mathrm{cm} 2$ ):

$\mathrm{d}:=16-1.84-\frac{1.6}{2} \quad \mathrm{dl}:=1.5+\frac{0.8}{2} \quad$ fc $:=4.99 \quad \mathrm{~b}:=10 \quad$ As $:=2.001 \quad$ As $1:=0.496$

fyas $:=59.04 \quad$ fyas $1:=59.79 \quad$ Eas $:=19020.9 \quad$ Eas1 $:=21415.6 \quad \mathrm{~d}=13.36 \quad \mathrm{dl}=1.9$

No domínio 2, a deformação no aço é fixa em $1 \%$ \&s :=0.01

Neste ponto - "estima-se" valor de x p/ cálculo das deformações

$\begin{aligned} \mathrm{x}:=2.9569 \quad \varepsilon \mathrm{s} 1:=0.01 \cdot \frac{\mathrm{x}-\mathrm{dl}}{\mathrm{d}-\mathrm{x}} \quad \varepsilon \mathrm{c}:=0.01 \frac{\mathrm{x}}{\mathrm{d}-\mathrm{x}} \quad \text { Portanto } \varepsilon \mathrm{c}=0.00284 & >=0,002 \\ & <=0,0035\end{aligned}$

$$
\varepsilon s 1=0.001
$$

Achar o valor de $\mathbf{k}$ (altura da seção plastificada) : $\mathrm{k}:=\mathrm{x}-\frac{0.002 \mathrm{x}}{\varepsilon \mathrm{c}} \quad \mathrm{k}=0.8763$

Cálculo das resultantes no concreto:

$\mathrm{Rc} 1:=0.95 \mathrm{fc} \cdot \mathrm{b} \cdot \mathrm{k} \quad \mathrm{Rc} 2:=\mathrm{b} \cdot 0.95 \mathrm{fc} \cdot \int_{0}^{\mathrm{x}-\mathrm{k}} 1-\left(1-\frac{\mathrm{a}}{\mathrm{x}-\mathrm{k}}\right)^{2} \mathrm{da} \quad \mathrm{Rc} 1=41.5401 \quad \mathrm{Rc} 2=65.7545$

Cálculo da resultante na armadura comprimida $\sigma \mathrm{s} 1:=\varepsilon \mathrm{s} 1$. Eas $1 \quad \sigma \mathrm{s} 1=21.7571$

$\sigma \mathrm{s} 1:=21.7571$ Repetir valor se estiver no regime elástico (CA-tipo A)yas $1=59.79$

Rs $1:=\sigma \mathrm{s} 1 \cdot$ As1 $\quad$ Rs1 $=10.7915$

Cálculo das resultantes na armadura tracionada $\quad$ Rs := fyas $\cdot$ As $\quad$ Rs $=118.139$

Equilibrio da seção: Se Ftração diferente de Fcompressão - mudar o x

Ftração := Rs $\quad$ Fcompressao $:=\mathrm{Rc} 1+\mathrm{Rc} 2+\mathrm{Rs} 1 \quad$ Ftração $=118.139 \quad$ Fcompressao $=118.0861$

Diferenca_percentual $:=\frac{\text { Ftração-Fcompressao }}{\text { Fcompressao }} \cdot 100 \quad$ Diferenca_percentual $\left.=0.04 \quad \%\right)$

VERIFICAR LIMITES NO AÇO E NO CONCRETO - OK!

Momentos fletores - calc. com relação à linha neutra

$$
\begin{aligned}
& \text { M1 := b k } \cdot 0.95 \mathrm{fc} \cdot\left(\mathrm{x}-\frac{\mathrm{k}}{2}\right\} \quad \mathrm{M} 2:=\mathrm{b} \cdot 0.95 \mathrm{fc} \cdot \int_{0}^{\mathrm{x}-\mathrm{k}}\left[1-\left(1-\frac{\mathrm{a}}{\mathrm{x}-\mathrm{k}}\right)^{2}\right] \cdot \mathrm{ada} \quad \begin{array}{l}
\mathrm{M} 3:=\mathrm{Rs} 1 \cdot(\mathrm{x}-\mathrm{dl}) \\
\mathrm{M} 4:=\mathrm{Rs} \cdot(\mathrm{d}-\mathrm{x})
\end{array} \\
& \mathrm{M} 1=104.6294 \quad \mathrm{M} 2=85.5064 \quad \mathrm{M} 3=11.4056 \quad \mathrm{M} 4=1229.0122
\end{aligned}
$$

Mfletor := M1 + M2 + M3 + M4 Mfletor $=1430.5536$ mfletordistr: $=\frac{\text { Mfletor }}{\mathrm{b}} \quad$ mfletordistr= 143.0554 


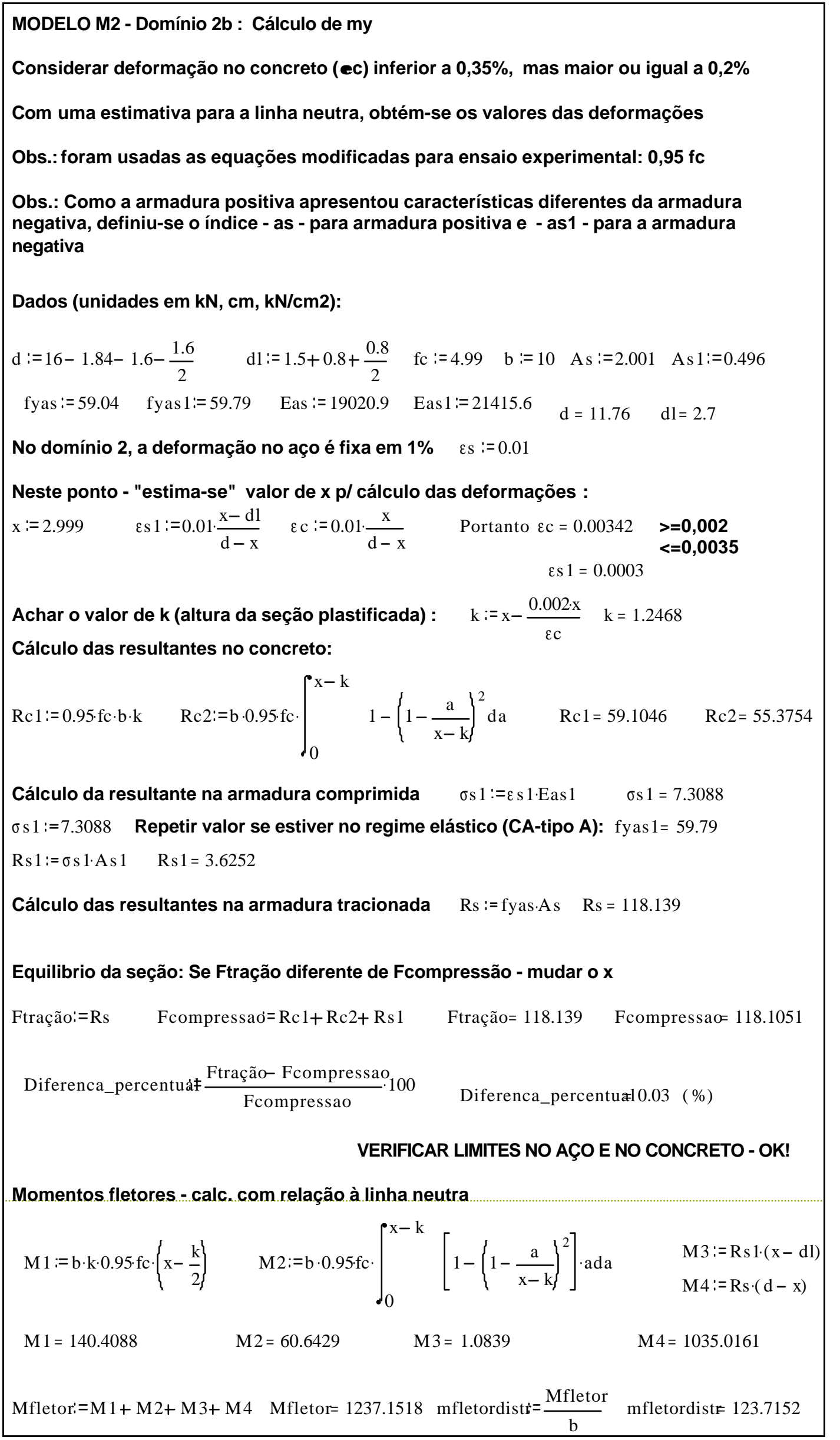


MODELO M2 - Domínio 2a: Cálculo de m'x (momento negativo)

Considerar deformação no concreto $(\varepsilon c)$ inferior a $0,2 \%$

Com uma estimativa para a linha neutra, obtém-se os valores das deformações

Obs.: foram usadas equações modificadas para ensaio experimental: 0,95 fc

Obs.: Como a armadura positiva apresentou características diferentes da armadura negativa, definiu-se o índice - as - para armadura positiva e - as1 - para a armadura negativa

$\mathrm{d}:=16-1.5-\frac{0.8}{2} \quad \mathrm{dl}:=1.84+\frac{1.6}{2} \quad$ fc $:=4.99 \quad \mathrm{~b}:=10 \quad$ As $:=0.496 \quad$ As $1:=2.001$

fyas $:=59.79 \quad$ fyas $1:=59.04 \quad$ Eas $:=21415.6 \quad$ Eas $1:=19020.9 \quad \mathrm{~d}=14.1 \quad \mathrm{dl}=2.64$

No domínio 2, a deformação no aço é fixa em 1\% $\varepsilon s:=0.01$

Neste ponto - "estima-se" valor de x p/ cálculo das deformações:

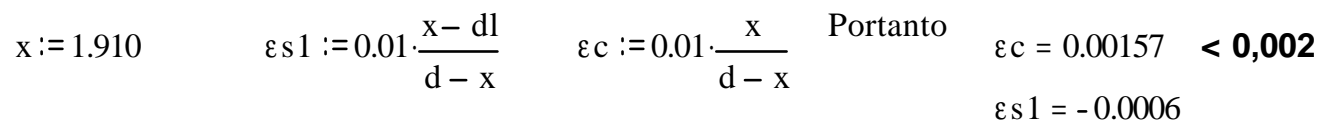

Cálc. da resultante no concreto: $\mathrm{Rc} 1:=\mathrm{b} \cdot 0.95 \cdot \mathrm{fc} \cdot \int_{0}^{\mathrm{x}} 1-\left(1-\frac{\varepsilon \mathrm{c} \cdot \mathrm{a}}{\mathrm{x} \cdot 0.002}\right\}^{2} \mathrm{~d} \mathrm{a} \quad \mathrm{Rc} 1=52.4104$

Cálc. da resultante na armadura comprimida $\sigma \mathrm{s} 1:=\varepsilon \mathrm{s} 1 \cdot$ Eas 1

$\sigma \mathrm{s} 1=-11.3907$

$\sigma \mathrm{s} 1:=-11.3907$ Repetir valor se estiver no regime elástico (CA-50A) < fyas $1=59.04$

Rs $1:=\sigma \mathrm{s} 1 \cdot \mathrm{As} 1 \quad$ Rs $1=-22.7928$

Cálc. da resultante na armadura tracionada: $\quad$ Rs $:=$ fyas $\cdot$ As $\quad$ Rs $=29.6558$

Equilibrio da seção: Se Ftração diferente de Fcompressão - mudar o x

Ftração := Rs $\quad$ Fcompressao $:=$ Rc1 + Rs $1 \quad$ Ftração $=29.6558 \quad$ Fcompressao $=29.6176$

Diferenca_percentual $:=\frac{\text { Ftração }- \text { Fcompressao }}{\text { Fcompressao }} \cdot 100 \quad$ Diferenca_percentual $=0.13 \quad(\%)$

VERIFICAR LIMITES NO AÇO E NO CONCRETO - OK!

Momentos fletores - calc. com relação à linha neutra

$\begin{array}{lll}\mathrm{M} 1:=\mathrm{b} \cdot 0.95 \cdot \mathrm{fc} \cdot \int_{0}^{\mathrm{x}}\left[1-\left(1-\frac{\varepsilon \mathrm{c} \cdot \mathrm{a}}{0.002 \cdot \mathrm{x}}\right\}^{2}\right] \cdot \mathrm{ada} & \mathrm{M} 2:=\mathrm{Rs} 1 \cdot(\mathrm{x}-\mathrm{dl}) & \mathrm{M} 3:=\mathrm{Rs} \cdot(\mathrm{d}-\mathrm{x}) \\ \mathrm{M} 2=16.6387 & \mathrm{M} 3=361.5047\end{array}$

$\mathrm{M} 1=63.7875$

Mf $:=M 1+M 2+M 3 \quad M f=441.9309 \quad$ mfletordistr $:=\frac{M f}{b}$

mfletordistr $=44.1931 \quad(\mathbf{k N} . \mathbf{c m} / \mathbf{c m})$ 
MODELO M2 - Domínio 2b : Cálculo de m'y (momento negativo)

Considerar deformação no concreto $(\varepsilon c)$ inferior a $0,35 \%$, mas maior ou igual a $0,2 \%$

Com uma estimativa para a linha neutra, obtém-se os valores das deformações

Obs.: foram usadas as equações modificadas para ensaio experimental: 0,95 fc

Obs.: Como a armadura positiva apresentou características diferentes da armadura negativa, definiu-se o índice - as - para armadura positiva e - as1 - para a armadura negativa

Dados (unidades em kN, cm, kN/cm2):

$\mathrm{d}:=16-1.5-\frac{0.8}{2}-0.8 \quad \mathrm{~d} 1:=1.84+\frac{1.6}{2}+1.6 \quad \mathrm{fc}:=4.99 \quad \mathrm{~b}:=10 \quad$ As $1:=2.001$ As $:=0.496$

$$
\text { fyas } 1:=59.04 \text { fyas }:=59.79 \quad \text { Eas } 1:=19020.9 \quad \text { Eas }:=21415.6 \quad \mathrm{~d}=13.3 \quad \mathrm{dl}=4.24
$$

No domínio 2, a deformação no aço é fixa em 1\% 1 s := 0.01

Neste ponto - "estima-se" valor de x p/ cálculo das deformações :

$\begin{aligned} \mathrm{x}:=2.58 \quad \varepsilon s 1:=0.01 \cdot \frac{\mathrm{x}-\mathrm{dl}}{\mathrm{d}-\mathrm{x}} \quad \varepsilon \mathrm{c}:=0.01 \cdot \frac{\mathrm{x}}{\mathrm{d}-\mathrm{x}} \quad \text { Portanto } \varepsilon \mathrm{c}=0.002407 & >=\mathbf{0 , 0 0 2} \\ & <=\mathbf{0 , 0 0 3 5}\end{aligned}$

$$
\varepsilon \mathrm{s} 1=-0.0015
$$

Achar o valor de $\mathbf{k}$ (altura da seção plastificada) : $\quad \mathrm{k}:=\mathrm{x}-\frac{0.002 \mathrm{x}}{\varepsilon \mathrm{c}} \quad \mathrm{k}=0.436$

Cálculo das resultantes no concreto:

Rc1 $:=0.95 \cdot \mathrm{fc} \cdot \mathrm{b} \cdot \mathrm{k} \quad \mathrm{Rc} 2:=\mathrm{b} \cdot 0.95 \cdot \mathrm{fc} \cdot \int_{0}^{\mathrm{x}-\mathrm{k}} 1-\left(1-\frac{\mathrm{a}}{\mathrm{x}-\mathrm{k}}\right)^{2} \mathrm{da} \quad \mathrm{Rc} 1=20.6686 \quad \mathrm{Rc} 2=67.7575$

Cálculo da resultante na armadura comprimida $\sigma \mathrm{s} 1:=\varepsilon \mathrm{s} 1$ Eas $1 \quad \sigma \mathrm{s} 1=-29.454$

$\sigma \mathrm{s} 1:=-29.454$ Repetir valor se estiver no regime elástico (CA-tipo A): fyas $1=59.04$

Rs $1:=\sigma$ s $1 \cdot$ As $1 \quad$ Rs $1=-58.9375$

Cálculo das resultantes na armadura tracionada $\quad$ Rs : = fyas.As $\quad$ Rs $=29.6558$

Equilibrio da seção: Se Ftração diferente de Fcompressão - mudar o x

Ftração: $=$ Rs $\quad$ Fcompressao $=$ Rc1+Rc2+Rs1 $\quad$ Ftração= 29.6558 Fcompressao $=29.4887$

Diferenca_percentuałł $\frac{\text { Ftração- Fcompressao }}{\text { Fcompressao }} \cdot 100 \quad$ Diferenca_percentual 0.57 (\%)

VERIFICAR LIMITES NO AÇO E NO CONCRETO - OK!

Momentos fletores - calc. com relação à linha neutra

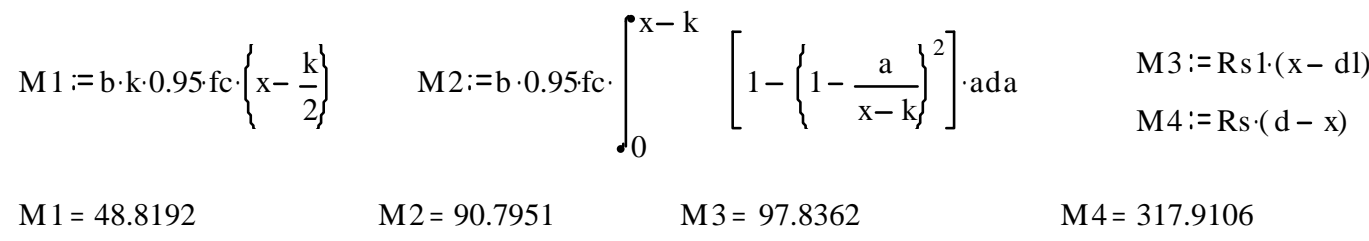

Mfletor: $=\mathrm{M} 1+\mathrm{M} 2+\mathrm{M} 3+\mathrm{M} 4 \quad$ Mfletor $=555.3611 \quad$ mfletordist $\hat{\mathrm{s}}=\frac{\text { Mfletor }}{\mathrm{b}} \quad$ mfletordist $=55.5361$ 


\section{I.3. MODELO M3}

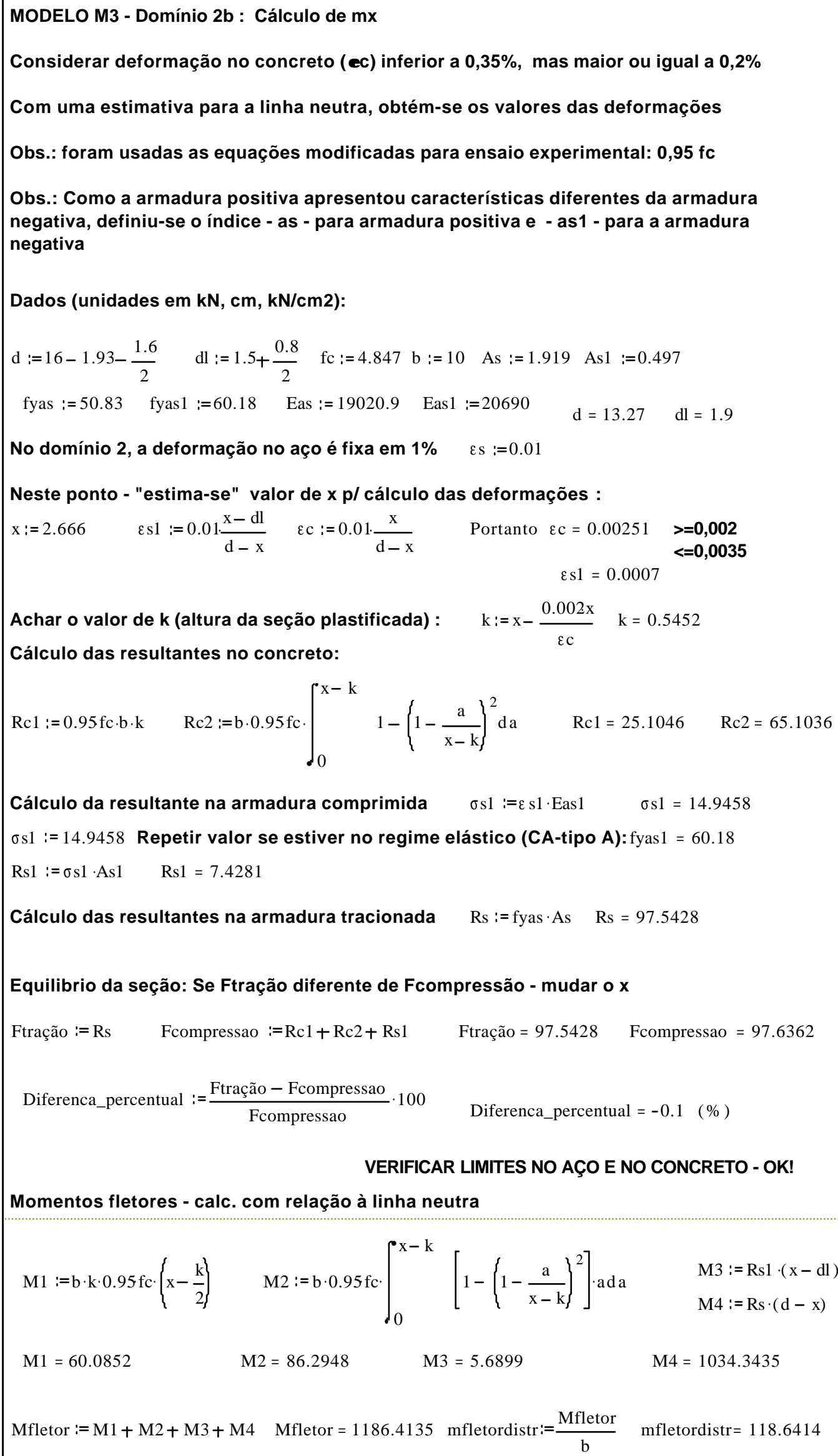


MODELO M3 - Domínio 2b : Cálculo de my

Considerar deformação no concreto $(\varepsilon c)$ inferior a $0,35 \%$, mas maior ou igual a $0,2 \%$

Com uma estimativa para a linha neutra, obtém-se os valores das deformações

Obs.: foram usadas as equações modificadas para ensaio experimental: 0,95 fc

Obs.: Como a armadura positiva apresentou características diferentes da armadura negativa, definiu-se o índice - as - para armadura positiva e - as1 - para a armadura negativa

Dados (unidades em kN, cm, kN/cm2):

$\mathrm{d}:=16-1.93-1.6-\frac{1.6}{2} \mathrm{~d} l:=1.5+0.8+\frac{0.8}{2}$ fc $:=4.847 \quad \mathrm{~b}:=10$ As $:=1.919$ As $1:=0.497$

fyas $:=50.83$ fyas $1:=60.18$ Eas $:=19020.9$ Eas $1:=20690$

$$
\mathrm{d}=11.67 \quad \mathrm{~d} \mathrm{l}=2.7
$$

No domínio 2, a deformação no aço é fixa em $1 \% \quad \varepsilon s:=0.01$

Neste ponto - "estima-se" valor de $\mathrm{x}$ p/ cálculo das deformações :

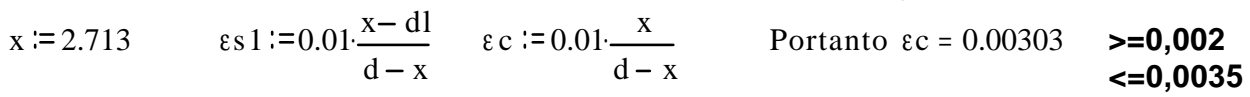

$$
\varepsilon s 1=1.451410^{-5}
$$

Achar o valor de $k$ (altura da seção plastificada) : $\quad \mathrm{k}:=\mathrm{x}-\frac{0.002 \mathrm{x}}{\varepsilon \mathrm{c}} \quad \mathrm{k}=0.9216$

Cálculo das resultantes no concreto:

Rc1 $:=0.95 \cdot \mathrm{fc} \cdot \mathrm{b} \cdot \mathrm{k} \quad \mathrm{Rc} 2:=\mathrm{b} \cdot 0.95 \cdot \mathrm{fc} \cdot \int_{0}^{\mathrm{x}-\mathrm{k}} 1-\left\{1-\frac{\mathrm{a}}{\mathrm{x}-\mathrm{k}}\right\}^{2} \mathrm{da} \quad \mathrm{Rc} 1=42.4365 \quad \mathrm{Rc} 2=54.9918$

Cálculo da resultante na armadura comprimida $\sigma \mathrm{s} 1:=\varepsilon \mathrm{s} 1 \cdot \operatorname{Eas} 1 \quad \sigma \mathrm{s} 1=0.3003$

$\sigma \mathrm{s} 1:=0.3003$ Repetir valor se estiver no regime elástico (CA-tipo A): fyas $1=60.18$

Rs $1:=\sigma \mathrm{s} 1 \cdot$ As $1 \quad$ Rs $1=0.1492$

Cálculo das resultantes na armadura tracionada $\quad$ Rs :=fyas.As $\quad$ Rs $=97.5428$

Equilibrio da seção: Se Ftração diferente de Fcompressão - mudar o x

Ftração:=Rs $\quad$ Fcompressao= Rc1+Rc2+Rs1 Ftração= $97.5428 \quad$ Fcompressao= 97.5775

Diferenca_percentuałł $\frac{\text { Ftração-Fcompressao }}{\text { Fcompressao }} \cdot 100 \quad$ Diferenca_percentual-0.04 (\%)

VERIFICAR LIMITES NO AÇO E NO CONCRETO - OK!

Momentos fletores - calc. com relação à linha neutra

$$
\begin{aligned}
& \mathrm{M} 1:=\mathrm{b} \cdot \mathrm{k} \cdot 0.95 \cdot \mathrm{fc} \cdot\left\{\mathrm{x}-\frac{\mathrm{k}}{2}\right\} \quad \mathrm{M} 2:=\mathrm{b} \cdot 0.95 \cdot \mathrm{fc} \cdot \int_{0}^{\mathrm{x}-\mathrm{k}}\left[1-\left(1-\frac{\mathrm{a}}{\mathrm{x}-\mathrm{k}}\right\}^{2}\right] \cdot \mathrm{ada} \quad \begin{array}{l}
\mathrm{M} 3:=\mathrm{Rs} 1 \cdot(\mathrm{x}-\mathrm{dl}) \\
\mathrm{M} 4:=\mathrm{Rs} \cdot(\mathrm{d}-\mathrm{x})
\end{array} \\
& \text { M1 }=95.5754 \quad \mathrm{M} 2=61.5702 \quad \mathrm{M} 3=0.0019 \quad \mathrm{M} 4=873.6906
\end{aligned}
$$

Mfletor: $=M 1+M 2+M 3+M 4$ Mfletor $=1030.8381$ mfletordist $=\frac{\text { Mfletor }}{b}$ mfletordist $=103.0838$ 
MODELO M3 - Domínio 2a: Cálculo de m'x (momento negativo)

Considerar deformação no concreto $(\varepsilon c)$ inferior a $0,2 \%$

Com uma estimativa para a linha neutra, obtém-se os valores das deformações

Obs.: foram usadas equações modificadas para ensaio experimental: 0,95 fc

Obs.: Como a armadura positiva apresentou características diferentes da armadura negativa, definiu-se o índice - as - para armadura positiva e - as1 - para a armadura negativa

$\mathrm{d}:=16-1.5-\frac{0.8}{2} \quad \mathrm{dl}:=1.93+\frac{1.6}{2} \quad$ fc $:=4.847 \quad \mathrm{~b}:=10 \quad$ As $:=0.497 \quad$ As $1:=1.919$

fyas $:=60.18 \quad$ fyas $1:=50.83 \quad$ Eas $:=20690.0 \quad$ Eas $1:=19020.9 \quad \mathrm{~d}=14.1 \quad \mathrm{dl}=2.73$

No domínio 2, a deformação no aço é fixa em 1\% $\varepsilon s:=0.01$

Neste ponto - "estima-se" valor de $x$ p/ cálculo das deformações:

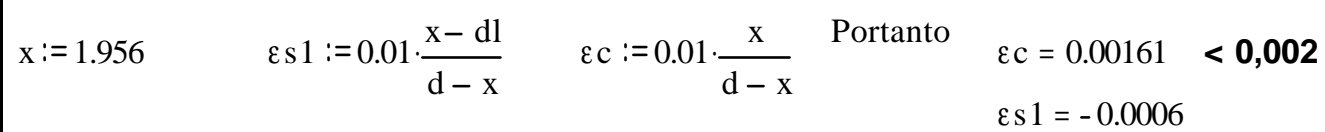

Cálc. da resultante no concreto: $\mathrm{Rc} 1:=\mathrm{b} \cdot 0.95 \cdot \mathrm{fc} \cdot \int_{0}^{\mathrm{x}} 1-\left(1-\frac{\varepsilon \mathrm{c} \cdot \mathrm{a}}{\mathrm{x} \cdot 0.002}\right\}^{2} \mathrm{~d} \mathrm{a} \quad \mathrm{Rc} 1=53.0627$

Cálc. da resultante na armadura comprimida $\sigma \mathrm{s} 1:=\varepsilon s 1 \cdot$ Eas 1

$\sigma \mathrm{s} 1=-12.123$

$\sigma \mathrm{s} 1:=-12.123$ Repetir valor se estiver no regime elástico $(\mathbf{C A}-50 \mathrm{~A})<$ fyas $1=50.83$

Rs $1:=\sigma s 1 \cdot$ As $1 \quad$ Rs $1=-23.264$

Cálc. da resultante na armadura tracionada: $\quad$ Rs :=fyas $\cdot$ As $\quad$ Rs $=29.9095$

Equilibrio da seção: Se Ftração diferente de Fcompressão - mudar o x

Ftração := Rs $\quad$ Fcompressao $:=$ Rc1 $1+$ Rs $1 \quad$ Ftração $=29.9095 \quad$ Fcompressao $=29.7987$

Diferenca_percentual $:=\frac{\text { Ftração }- \text { Fcompressao }}{\text { Fcompressao }} \cdot 100 \quad$ Diferenca_percentual $=0.37 \quad(\%)$

VERIFICAR LIMITES NO AÇO E NO CONCRETO - OK!

Momentos fletores - calc. com relação à linha neutra

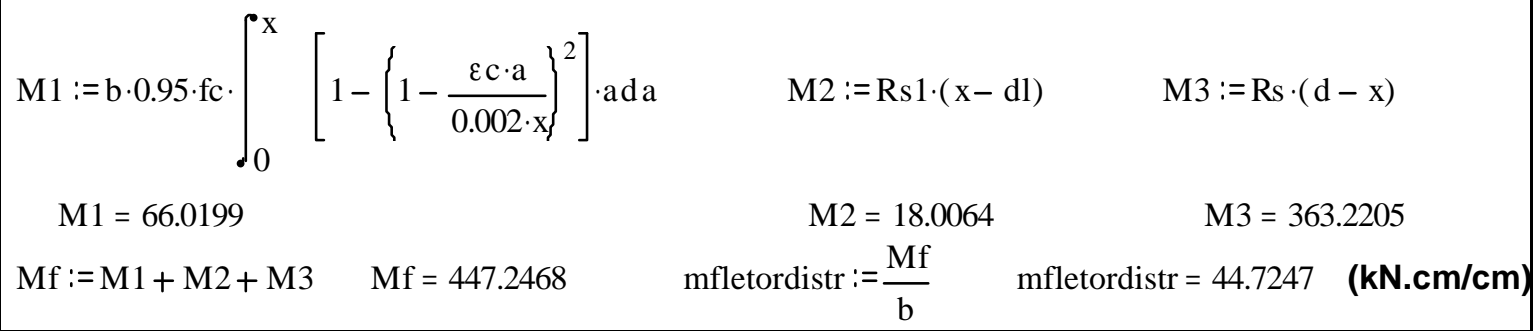


MODELO M3 - Domínio 2b : Cálculo de m'y (momento negativo)

Considerar deformação no concreto $(\varepsilon c)$ inferior a $0,35 \%$, mas maior ou igual a $0,2 \%$

Com uma estimativa para a linha neutra, obtém-se os valores das deformações

Obs.: foram usadas as equações modificadas para ensaio experimental: 0,95 fc

Obs.: Como a armadura positiva apresentou características diferentes da armadura negativa, definiu-se o índice - as - para armadura positiva e - as1 - para a armadura negativa

Dados (unidades em kN, cm, kN/cm2):

$\mathrm{d}:=16-1.5-\frac{0.8}{2}-0.8 \mathrm{dl}:=1.84+\frac{1.6}{2}+1.6 \quad \mathrm{fc}:=4.847 \quad \mathrm{~b}:=10 \quad$ As $1:=1.919$ As $:=0.497$

$$
\text { fyas } 1:=50.83 \text { fyas }:=60.18 \quad \text { Eas } 1:=19020.9 \text { Eas }:=20690.0 \quad \mathrm{~d}=13.3 \quad \mathrm{~d} 1=4.24
$$

No domínio 2, a deformação no aço é fixa em 1\% 1 s := 0.01

Neste ponto - "estima-se" valor de $x$ p/ cálculo das deformações :

$\begin{aligned} \mathrm{x}:=2.585 \quad \varepsilon \mathrm{s} 1:=0.01 \cdot \frac{\mathrm{x}-\mathrm{dl}}{\mathrm{d}-\mathrm{x}} \quad \varepsilon \mathrm{c}:=0.01 \cdot \frac{\mathrm{x}}{\mathrm{d}-\mathrm{x}} \quad \text { Portanto } \varepsilon \mathrm{c}=0.002413 \quad & >=\mathbf{0 , 0 0 2} \\ & <=\mathbf{0 , 0 0 3 5}\end{aligned}$

$$
\varepsilon \mathrm{s} 1=-0.0015
$$

Achar o valor de k (altura da seção plastificada) : $\quad k$ : $=x-\frac{0.002 \times x}{\varepsilon c} \quad k=0.442$

Cálculo das resultantes no concreto:

Rc1 $:=0.95 \cdot \mathrm{fc} \cdot \mathrm{b} \cdot \mathrm{k} \quad \mathrm{Rc} 2:=\mathrm{b} \cdot 0.95 \cdot \mathrm{fc} \cdot \int_{0}^{\mathrm{x}-\mathrm{k}} 1-\left(1-\frac{\mathrm{a}}{\mathrm{x}-\mathrm{k}}\right\}^{2} \mathrm{da} \quad \mathrm{Rc} 1=20.3526 \quad \mathrm{Rc} 2=65.7851$

Cálculo da resultante na armadura comprimida $\sigma \mathrm{s} 1:=\varepsilon \mathrm{s} 1$ Eas $1 \quad \sigma \mathrm{s} 1=-29.379$

$\sigma \mathrm{s} 1:=-29.379$ Repetir valor se estiver no regime elástico (CA-tipo A): fyas $1=50.83$

Rs $1:=\sigma$ s $1 \cdot$ As $1 \quad$ Rs $1=-56.3783$

Cálculo das resultantes na armadura tracionada $\quad$ Rs := fyas.As $\quad$ Rs $=29.9095$

Equilibrio da seção: Se Ftração diferente de Fcompressão - mudar o x

Ftração: $=$ Rs $\quad$ Fcompressao $=$ Rc1+Rc2+Rs1 $\quad$ Ftração= 29.9095 Fcompressao $=29.7594$

Diferenca_percentuàł $\frac{\text { Ftração- Fcompressao }}{\text { Fcompressao }} \cdot 100$

Diferenca_percentual 0.5 (\%)

\section{VERIFICAR LIMITES NO AÇO E NO CONCRETO - OK!}

Momentos fletores - calc. com relação à linha neutra

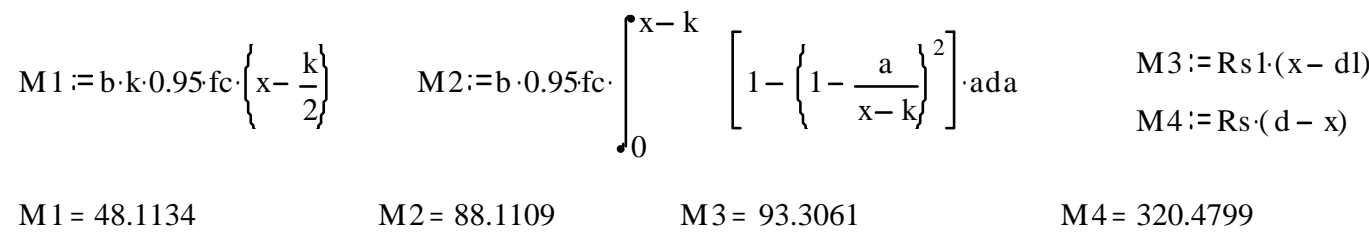

Mfletor: $=\mathrm{M} 1+\mathrm{M} 2+\mathrm{M} 3+\mathrm{M} 4$ Mfletor $=550.0103 \quad$ mfletordist $\hat{\mathrm{c}}=\frac{\mathrm{Mflet}}{\mathrm{b}} \quad$ mfletordist $\mathbf{k} 55.001$ 


\section{I.4. MODELO M4}

MODELO M4 - Domínio 2b : Cálculo de mx - adaptado para FLEXO-COMPRESSÃO Considerar deformação no concreto๕(c) inferior a $0,35 \%$, mas maior ou igual a $0,2 \%$ Com uma estimativa para a linha neutra, obtém-se os valores das deformações Obs.: foram usadas as equações modificadas para ensaio experimental: 0,95 fc Obs.: Como a armadura positiva apresentou características diferentes da armadura negativa, definiu-se o índice - as - para armadura positiva e - as1 - para a armadura negativa

Dados (unidades em kN, cm, kN/cm2):

$\mathrm{d}:=16-1.28-\frac{1.25}{2} \quad \mathrm{dl}:=1.5+\frac{0.8}{2} \quad$ fc $:=5.192 \quad \mathrm{~b}:=10 \quad$ As $:=1.188$ As1 $:=0.497$

fyas $:=65.14$ fyas $1:=60.18$ Eas $:=20154.1$ Eas $1:=20690.0$

$\mathrm{P}:=43.74 \quad \mathrm{kN} \quad$ Força de protensão atuando na seção

No domínio 2, a deformação no aço é fixa em $1 \%$ \& $\mathrm{s}:=0.01$

Neste ponto - "estima-se" valor de $x$ p/ cálculo das deformações

$\mathrm{x}:=2.99 \quad \varepsilon s 1:=0.01 \frac{\mathrm{x}-\mathrm{dl}}{\mathrm{d}-\mathrm{x}} \quad \varepsilon \mathrm{c}:=0.01 \cdot \frac{\mathrm{x}}{\mathrm{d}-\mathrm{x}} \quad$ Portanto $\varepsilon c=0.002692>=0,002$

$$
\varepsilon s 1=0.001
$$

Achar o valor de $\mathbf{k}$ (altura da seção plastificada) : $\mathrm{k}:=\mathrm{x}-\frac{0.002 \mathrm{x}}{\varepsilon \mathrm{c}} \quad \mathrm{k}=0.769$

Cálculo das resultantes no concreto:

Rc1 $:=0.95 \mathrm{fc} \cdot \mathrm{b} \cdot \mathrm{k} \quad \mathrm{Rc} 2:=\mathrm{b} \cdot 0.95 \mathrm{fc} \cdot \int_{0}^{\mathrm{x}-\mathrm{k}} 1-\left(1-\frac{\mathrm{a}}{\mathrm{x}-\mathrm{k}}\right)^{2} \mathrm{da} \quad \mathrm{Rc} 1=37.9302 \quad \mathrm{Rc} 2=73.0324$

Cálculo da resultante na armadura comprimida $\sigma s 1:=\varepsilon s 1 \cdot$ Eas $1 \quad \sigma s 1=20.3081$

$\sigma s 1:=20.3081$ Repetir valor se estiver no regime elástico (CA-tipo A)gas1 = 60.18

Rs1 := $\sigma \mathrm{s} 1 \cdot$ As1 $\quad$ Rs1 $=10.0931$

Cálculo da resultante na armadura tracionada $\quad$ Rs := fyas $\cdot$ As $\quad$ Rs $=77.3863$

Equilibrio da seção: Se Valor1 for diferente de Valor2 - mudar o x

Valor $1:=\mathrm{Rs} \quad$ Valor2: $\mathrm{Rc} 1+\mathrm{Rc} 2+\mathrm{Rs} 1-\mathrm{P} \quad$ Valor $1=77.3863 \quad$ Valor2 $=77.3157$

Diferenca_percentual: $=\frac{\text { Valor1- Valor2 }}{\text { Valor2 }} \cdot 100 \quad$ Diferenca_percentual $=0.09(\%)$

VERIFICAR LIMITES NO AÇO E NO CONCRETO - OK!

Momentos fletores - calc. com relação à linha neutra

Existem 2 possibilidades - uma delas é supor que $\mathbf{x}<\mathbf{8} \mathbf{c m}: \mathrm{x}=2.99 \quad \mathrm{~d}=14.095 \quad \mathrm{dl}=1.9$

$\mathrm{M} 1:=\mathrm{b} \cdot \mathrm{k} \cdot 0.95 \mathrm{fc} \cdot\left(\mathrm{x}-\frac{\mathrm{k}}{2}\right\} \quad \mathrm{M} 2:=\mathrm{b} \cdot 0.95 \mathrm{fc} \cdot \int_{0}^{\mathrm{x}-\mathrm{k}}\left[1-\left(1-\frac{\mathrm{a}}{\mathrm{x}-\mathrm{k}}\right)^{2}\right] \cdot \mathrm{ada} \quad \begin{aligned} & \mathrm{M} 3:=\mathrm{Rs} 1 \cdot(\mathrm{x}-\mathrm{dl}) \\ & \mathrm{M} 4:=\mathrm{Rs} \cdot(\mathrm{d}-\mathrm{x}) \\ & \mathrm{M} 5:=\mathrm{P} \cdot(8-\mathrm{x})\end{aligned}$

M1 $=98.827 \quad$ M2 $=101.3781 \quad$ M3 $=11.0015 \quad$ M4 $=859.3751 \quad$ M5 $=219.1374$

Mfletor: $=\mathrm{M} 1+\mathrm{M} 2+\mathrm{M} 3+\mathrm{M} 4+\mathrm{M} 5 \quad$ Mfletor $=1289.7191$ mfletordistr: $=\frac{\text { Mfletor }}{\mathrm{b}}$ mfletordistr= 128.9719 
MODELO M4 - Domínio 2b : Cálculo de my - adaptado para FLEXO-COMPRESSÃo

Considerar deformação no concreto $(\varepsilon c)$ inferior a $0,35 \%$, mas maior ou igual a $0,2 \%$

Com uma estimativa para a linha neutra, obtém-se os valores das deformações

Obs.: foram usadas as equações modificadas para ensaio experimental: 0,95 fc

Obs.: Como a armadura positiva apresentou características diferentes da armadura negativa, definiu-se o índice - as - para armadura positiva e - as 1 - para a armadura negativa

Dados (unidades em $\mathrm{kN}, \mathrm{cm}, \mathrm{kN} / \mathrm{cm} 2$ ):

$\mathrm{d}:=16-1.28-\frac{1.25}{2}-1.25 \quad \mathrm{dl}:=1.5+\frac{0.8}{2}+0.8 \quad \mathrm{fc}:=5.192 \quad \mathrm{~b}:=10 \quad$ As $:=1.188 \quad$ As $1:=0.497$

fyas $:=65.14$ fyas $1:=60.18 \quad$ Eas $:=20154.1 \quad$ Eas $1:=20690.0$

$\mathrm{P}:=44.11 \quad \mathrm{kN} \quad$ Força de protensão atuando na seção

$\mathrm{d}=12.845 \quad \mathrm{dl}=2.7$

No domínio 2, a deformação no aço é fixa em $1 \% \quad \varepsilon s:=0.01$

Neste ponto - "estima-se" valor de $\mathrm{x}$ p/ cálculo das deformações:

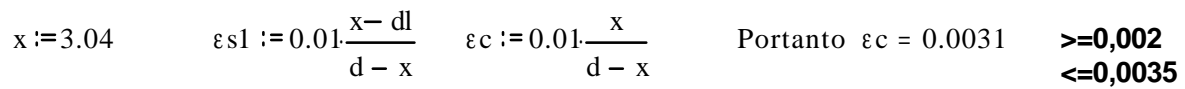

$\varepsilon s 1=0.0003$

Achar o valor de $\mathbf{k}$ (altura da seção plastificada) : $\quad \mathrm{k}:=\mathrm{x}-\frac{0.002 \mathrm{x}}{\varepsilon \mathrm{c}} \quad \mathrm{k}=1.079$

Cálculo das resultantes no concreto:

Rc1 $:=0.95 \cdot \mathrm{fc} \cdot \mathrm{b} \cdot \mathrm{k} \quad \mathrm{Rc} 2:=\mathrm{b} \cdot 0.95 \mathrm{fc} \cdot \int_{0}^{\mathrm{x}-\mathrm{k}} 1-\left(1-\frac{\mathrm{a}}{\mathrm{x}-\mathrm{k}}\right)^{2} \mathrm{da} \quad \mathrm{Rc} 1=53.2206 \quad \mathrm{Rc} 2=64.4829$

Cálculo da resultante na armadura comprimida $\sigma s 1:=\varepsilon s 1$ Eas $1 \quad \sigma s 1=7.1745$

$\sigma s 1:=7.1745$ Repetir valor se estiver no regime elástico (CA-tipo A) fyas $1=60.18$

Rs1 $:=\sigma s 1 \cdot$ As1 $\quad$ Rs1 $=3.5657$

Cálculo da resultante na armadura tracionada $\quad$ Rs $:=$ fyas $\cdot$ As $\quad$ Rs $=77.3863$

Equilibrio da seção: Se Valor1 for diferente de Valor2 - mudar o x

Valor $1:=\mathrm{Rs} \quad$ Valor $2:=\mathrm{Rc} 1+\mathrm{Rc} 2+\mathrm{Rs} 1-\mathrm{P} \quad$ Valor $1=77.3863 \quad$ Valor2=77.1592

Diferenca_percentual $:=\frac{\text { Valor } 1-\text { Valor2 }}{\text { Valor2 }} \cdot 100 \quad$ Diferenca_percentual $=0.29(\%)$

VERIFICAR LIMITES NO AÇO E NO CONCRETO - OK!

Momentos fletores - calc. com relação à linha neutra

Existem 2 possibilidades - uma delas é supor que $x<8 \mathbf{c m}: x=3.04 \quad \mathrm{~d}=12.845 \quad \mathrm{dl}=2.7$

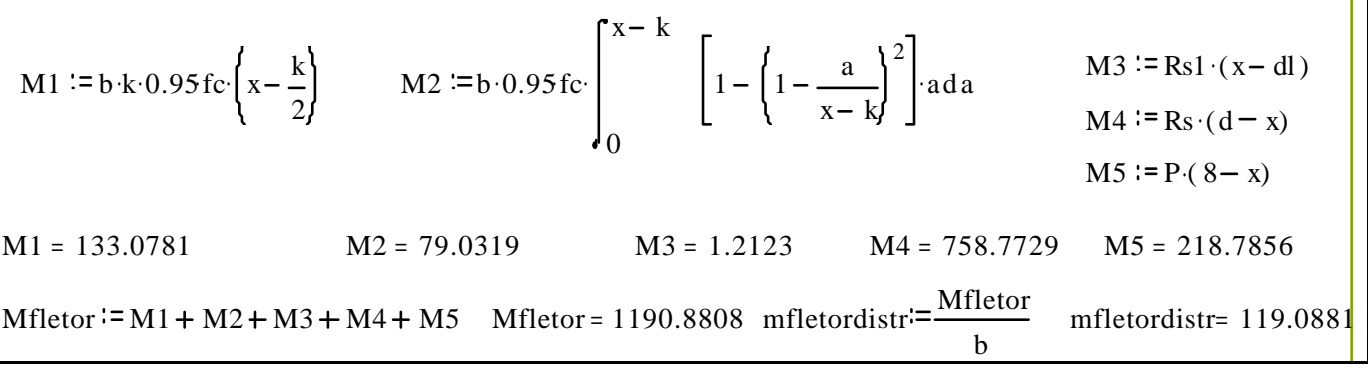




\section{I.5. MODELO M5}

MODELO M5 - Domínio 2b : Cálculo de mx - adaptado para FLEXO-COMPRESSÃO

Considerar deformação no concreto $(\varepsilon c)$ inferior a $0,35 \%$, mas maior ou igual a $0,2 \%$

Com uma estimativa para a linha neutra, obtém-se os valores das deformações

Obs.: foram usadas as equações modificadas para ensaio experimental: 0,95 fc

Obs.: Como a armadura positiva apresentou características diferentes da armadura negativa, definiu-se o índice - as - para armadura positiva e - as1 - para a armadura negativa

Dados (unidades em kN, cm, kN/cm2):

$\mathrm{d}:=16-1.49-\frac{1.25}{2} \quad \mathrm{dl}:=1.5+\frac{0.8}{2} \quad \mathrm{fc}:=5.940 \quad \mathrm{~b}:=10 \quad$ As $:=1.188 \quad$ As1 $:=0.491$
fyas $:=65.14 \quad$ fyas $1:=63.68 \quad$ Eas $:=20154.1 \quad$ Eas $1:=19886.5 \quad \mathrm{~d}=13.885 \quad \mathrm{dl}=1.9$
$\mathrm{P}:=43.76 \quad \mathrm{kN} \quad$ Força de protensão atuando na seção

No domínio 2, a deformação no aço é fixa em $1 \%$ \&s :=0.01

Neste ponto - "estima-se" valor de $x \mathrm{p} /$ cálculo das deformações:

$\begin{aligned} \mathrm{x}:=2.75 \quad \varepsilon \mathrm{s} 1:=0.01 \cdot \frac{\mathrm{x}-\mathrm{dl}}{\mathrm{d}-\mathrm{x}} \quad \varepsilon \mathrm{c}:=0.01 \frac{\mathrm{x}}{\mathrm{d}-\mathrm{x}} \quad \text { Portanto } \varepsilon \mathrm{c}=0.00247 & >=0,002 \\ & \varepsilon \mathrm{s} 1=0.0008\end{aligned}$

Achar o valor de $\mathbf{k}$ (altura da seção plastificada) : $\quad \mathrm{k}:=\mathrm{x}-\frac{0.002 \mathrm{x}}{\varepsilon \mathrm{c}} \quad \mathrm{k}=0.523$

Cálculo das resultantes no concreto:

Rc1 $:=0.95 \mathrm{fc} \cdot \mathrm{b} \cdot \mathrm{k} \quad \mathrm{Rc} 2:=\mathrm{b} \cdot 0.95 \mathrm{fc} \cdot \int_{0}^{\mathrm{x}-\mathrm{k}} 1-\left(1-\frac{\mathrm{a}}{\mathrm{x}-\mathrm{k}}\right)^{2} \mathrm{da} \quad \mathrm{Rc} 1=29.5129 \quad \mathrm{Rc} 2=83.7797$

Cálculo da resultante na armadura comprimida $\sigma \mathrm{s} 1:=\varepsilon s 1$ Eas $1 \quad \sigma s 1=15.1805$

$\sigma s 1:=15.1805$ Repetir valor se estiver no regime elástico (CA-tipo A) :fyas $1=63.68$

Rs1 $:=\sigma s 1 \cdot$ As1 $\quad$ Rs $1=7.4536$

Cálculo da resultante na armadura tracionada $\quad$ Rs $:=$ fyas $\cdot A s \quad$ Rs $=77.3863$

Equilibrio da seção: Se Valor1 for diferente de Valor2 - mudar o x

$\begin{array}{ll}\text { Valor1 }:=\mathrm{Rs} \quad \text { Valor2 }:=\mathrm{Rc} 1+\mathrm{Rc} 2+\mathrm{Rs} 1-\mathrm{P} & \text { Valor1 }=77.3863 \quad \text { Valor2 }=76.9863 \\ \text { Diferenca_percentual }:=\frac{\text { Valor1 }- \text { Valor2 }}{\text { Valor2 }} \cdot 100 & \text { Diferenca_percentual }=0.52 \quad \%)\end{array}$

VERIFICAR LIMITES NO AÇO E NO CONCRETO - OK!

Momentos fletores - calc. com relação à linha neutra

Existem 2 possibilidades - uma delas é supor que $\mathrm{x}<\mathbf{8} \mathbf{c m}: \mathrm{x}=2.75 \quad \mathrm{~d}=13.885 \quad \mathrm{dl}=1.9$ $\mathrm{M} 1:=\mathrm{b} \cdot \mathrm{k} \cdot 0.95 \mathrm{fc} \cdot\left(\mathrm{x}-\frac{\mathrm{k}}{2}\right\} \quad \mathrm{M} 2:=\mathrm{b} \cdot 0.95 \mathrm{fc} \cdot \int_{0}^{\mathrm{x}-\mathrm{k}}\left[1-\left(1-\frac{\mathrm{a}}{\mathrm{x}-\mathrm{k}}\right)^{2}\right] \cdot \mathrm{ada} \quad \begin{aligned} & \text { M3 }:=\operatorname{Rs} 1 \cdot(\mathrm{x}-\mathrm{dl}) \\ & \text { M4 }:=\operatorname{Rs} \cdot(\mathrm{d}-\mathrm{x}) \\ & \text { M5 }:=\mathrm{P} \cdot(8-\mathrm{x})\end{aligned}$

M1 $=73.4428 \quad$ M2 $=116.6109 \quad$ M3 $=6.3356 \quad$ M4 $=861.6967 \quad$ M5 $=229.74$

Mfletor: $=$ M1 + M2 + M3 + M4 + M5 Mfletor $=1287.826$ mfletordistr $:=\frac{\text { Mfletor }}{b} \quad$ mfletordistr $=128.7826$ 
MODELO M5 - Domínio 2b : Cálculo de my - adaptado para FLEXO-COMPRESSÃO

Considerar deformação no concreto ( $\varepsilon$ c) inferior a $0,35 \%$, mas maior ou igual a $0,2 \%$

Com uma estimativa para a linha neutra, obtém-se os valores das deformações

Obs.: foram usadas as equações modificadas para ensaio experimental: $0,95 \mathrm{fc}$

Obs.: Como a armadura positiva apresentou características diferentes da armadura negativa, definiu-se o índice - as - para armadura positiva e - as1 - para a armadura negativa

Dados (unidades em kN, cm, kN/cm2):

$$
\begin{aligned}
& \mathrm{d}:=16-1.49-\frac{1.25}{2}-1.25 \quad \mathrm{dl}:=1.5+\frac{0.8}{2}+0.8 \quad \text { fc }:=5.940 \quad \mathrm{~b}:=10 \quad \text { As }:=1.188 \quad \text { As } 1:=0.491 \\
& \text { fyas }:=65.14 \quad \text { fyas } 1:=63.68 \quad \text { Eas }:=20154.1 \quad \text { Eas } 1:=19886.5 \quad \mathrm{~d}=12.635 \quad \mathrm{dl}=2.7 \\
& \mathrm{P}:=46.76 \quad \mathrm{kN} \quad \text { Força de protensão atuando na seção }
\end{aligned}
$$

No domínio 2, a deformação no aço é fixa em $1 \% \quad \varepsilon s$ : $=0.01$

Neste ponto - "estima-se" valor de $x$ p/ cálculo das deformações :

$$
\begin{aligned}
\mathrm{x}:=2.83 \quad \varepsilon s 1:=0.01 \frac{\mathrm{x}-\mathrm{dl}}{\mathrm{d}-\mathrm{x}} \quad \varepsilon \mathrm{c}:=0.01 \cdot \frac{\mathrm{x}}{\mathrm{d}-\mathrm{x}} \quad \text { Portanto } \varepsilon \mathrm{c}=0.002886 & >=0,002 \\
\varepsilon \mathrm{s} 1=0.0001 & <=0,0035
\end{aligned}
$$

Achar o valor de $\mathbf{k}$ (altura da seção plastificada) : $\quad k:=x-\frac{0.002 \cdot x}{\varepsilon c} \quad k=0.869$

Cálculo das resultantes no concreto:

$\mathrm{Rc} 1:=0.95 \cdot \mathrm{fc} \cdot \mathrm{b} \cdot \mathrm{k} \quad \mathrm{Rc} 2:=\mathrm{b} \cdot 0.95 \cdot \mathrm{fc} \cdot \int_{0}^{\mathrm{x}-\mathrm{k}} 1-\left\{1-\frac{\mathrm{a}}{\mathrm{x}-\mathrm{k}}\right\}^{2} \mathrm{da} \quad \mathrm{Rc} 1=49.0377 \quad \mathrm{Rc} 2=73.7728$

Cálculo da resultante na armadura comprimida $\sigma \mathrm{s} 1:=\varepsilon s 1 \cdot \operatorname{Eas} 1 \quad \sigma \mathrm{s} 1=2.6367$

os $1:=2.6367$ Repetir valor se estiver no regime elástico (CA-tipo $\mathbf{A}$ ): fyas $1=63.68$

Rs $1:=\sigma s 1 \cdot A s 1 \quad$ Rs $1=1.2946$

Cálculo da resultante na armadura tracionada

Rs :=fyas $\cdot$ As $\quad$ Rs $=77.3863$

Equilibrio da seção: Se Valor1 for diferente de Valor2 - mudar o x

Valor1:=Rs $\quad$ Valor2 $:=\mathrm{Rc} 1+\mathrm{Rc} 2+\mathrm{Rs} 1-\mathrm{P} \quad$ Valor $1=77.3863 \quad$ Valor $2=77.3451$

Diferenca_percentual $=\frac{\text { Valor1- Valor2 }}{\text { Valor2 }} \cdot 100 \quad$ Diferenca_percentuał $0.05(\%)$

VERIFICAR LIMITES NO AÇO E NO CONCRETO - OK!

Momentos fletores - calc. com relação à linha neutra

Existem 2 possibilidades - uma delas é supor que $\mathbf{x}<\mathbf{8} \mathbf{c m}: \quad \mathrm{x}=2.83 \quad \mathrm{~d}=12.635 \quad \mathrm{dl}=2.7$

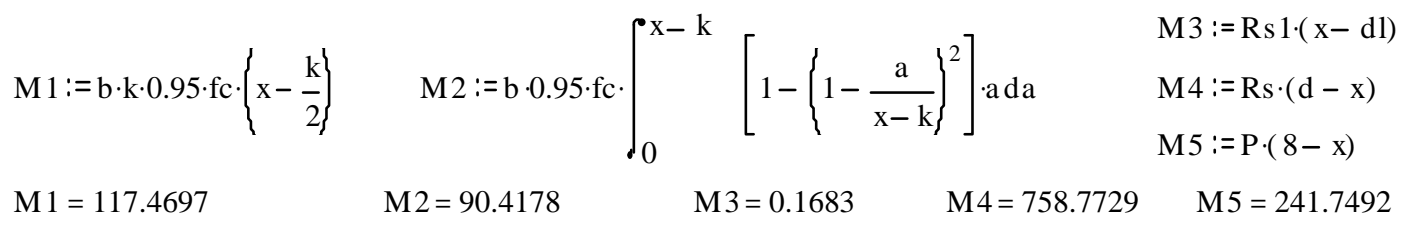

Mfletor: $=$ M1 + M2 + M3 + M4 + M5 Mfletor $=1208.5779$ mfletordistr: $=\frac{\text { Mfletor }}{b}$ mfletordistr $=120.8578$ 


\section{I.6. MODELO M6}

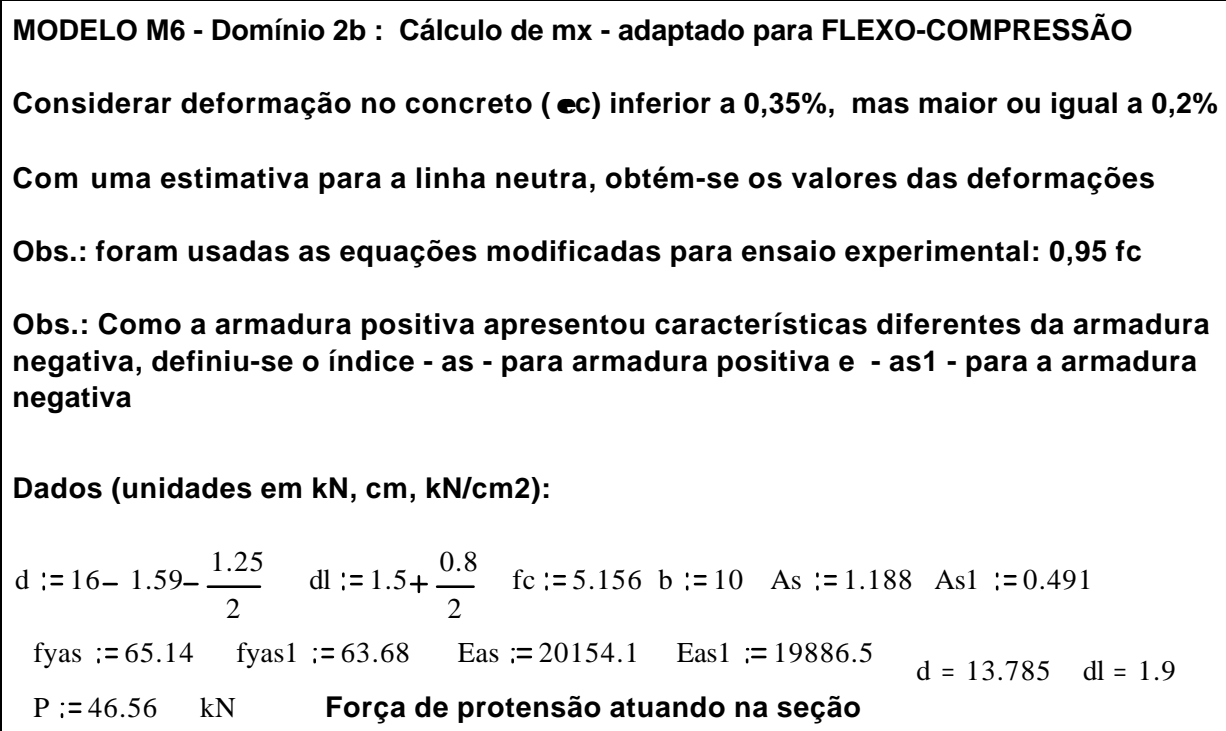

Momentos fletores - calc. com relação à linha neutra

Existem 2 possibilidades - uma delas é supor que $\mathrm{x}<\mathbf{8} \mathbf{c m}: \quad \ldots \ldots=3.03 \quad \mathrm{x}=13.785 \quad \mathrm{dl}=1.9$ $\mathrm{M} 1:=\mathrm{b} \cdot \mathrm{k} \cdot 0.95 \mathrm{fc} \cdot\left\{\mathrm{x}-\frac{\mathrm{k}}{2}\right\} \quad \mathrm{M} 2:=\mathrm{b} \cdot 0.95 \cdot \mathrm{fc} \cdot \int_{0}^{\mathrm{x}-\mathrm{k}}\left[1-\left\{1-\frac{\mathrm{a}}{\mathrm{x}-\mathrm{k}}\right\}^{2}\right] \cdot \mathrm{ada} \quad \begin{aligned} & \text { M3 }:=\mathrm{Rs} 1 \cdot(\mathrm{x}-\mathrm{dl}) \\ & \text { M4 }:=\mathrm{Rs} \cdot(\mathrm{d}-\mathrm{x}) \\ & \text { M5 }:=\mathrm{P} \cdot(8-\mathrm{x})\end{aligned}$

M1 = 111.5344 M2 $=94.4292 \quad$ M3 $=11.5927 \quad$ M4 $=832.2899 \quad$ M5 $=231.4032$ Mfletor : $=\mathrm{M} 1+\mathrm{M} 2+\mathrm{M} 3+\mathrm{M} 4+\mathrm{M} 5$ Mfletor $=1281.2494$ mfletordistr $:=\frac{\text { Mfletor }}{\mathrm{b}}$ mfletordistr $=128.1249$ 
MODELO M6 - Domínio 2b : Cálculo de my - adaptado para FLEXO-COMPRESSÃO

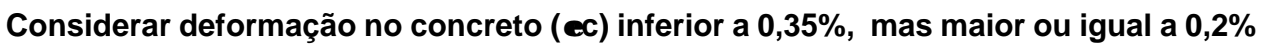

Com uma estimativa para a linha neutra, obtém-se os valores das deformações

Obs.: foram usadas as equações modificadas para ensaio experimental: 0,95 fc

Obs.: Como a armadura positiva apresentou características diferentes da armadura negativa, definiu-se o índice - as - para armadura positiva e - as1 - para a armadura negativa

Dados (unidades em kN, cm, kN/cm2):

$$
\begin{aligned}
& \mathrm{d}:=16-1.59-\frac{1.25}{2}-1.25 \quad \mathrm{dl}:=1.5+\frac{0.8}{2}+0.8 \quad \text { fc }:=5.156 \quad \mathrm{~b}:=10 \quad \text { As }:=1.188 \quad \text { As } 1:=0.491 \\
& \text { fyas }:=65.14 \quad \text { fyas } 1:=63.68 \quad \text { Eas }:=20154.1 \quad \text { Eas } 1:=19886.5 \quad \mathrm{~d}=12.535 \quad \mathrm{dl}=2.7 \\
& \mathrm{P}:=47.81 \quad \mathrm{kN} \quad \text { Força de protensão atuando na seção }
\end{aligned}
$$

No domínio 2, a deformação no aço é fixa em $1 \% \quad \varepsilon \mathrm{s}:=0.01$ Neste ponto - "estima-se" valor de $\mathrm{x}$ p/ cálculo das deformações :

$$
\begin{aligned}
\mathrm{x}:=3.11 \quad \varepsilon \mathrm{s} 1:=0.01 \cdot \frac{\mathrm{x}-\mathrm{d} l}{\mathrm{~d}-\mathrm{x}} \quad \varepsilon \mathrm{c}:=0.01 \cdot \frac{\mathrm{x}}{\mathrm{d}-\mathrm{x}} \quad \text { Portanto } \varepsilon \mathrm{c}=0.0033 & >\mathbf{> 0 , 0 0 2} \\
\varepsilon \mathrm{s} 1=0.0004 & <=0,0035
\end{aligned}
$$

Achar o valor de $\mathbf{k}$ (altura da seção plastificada) : $\quad \mathrm{k}:=\mathrm{x}-\frac{0.002 \mathrm{x}}{\varepsilon \mathrm{c}} \quad \mathrm{k}=1.225$

Cálculo das resultantes no concreto:

Rc1: $=0.95 \cdot \mathrm{fc} \cdot \mathrm{b} \cdot \mathrm{k} \quad \mathrm{Rc} 2:=\mathrm{b} \cdot 0.95 \cdot \mathrm{fc} \cdot \int_{0}^{\mathrm{x}-\mathrm{k}} 1-\left\{1-\frac{\mathrm{a}}{\mathrm{x}-\mathrm{k}}\right\}^{2} \mathrm{da} \quad \mathrm{Rc} 1=60.0029 \quad \mathrm{Rc} 2=61.554$

Cálculo da resultante na armadura comprimida $\sigma \mathrm{s} 1:=\varepsilon \mathrm{s} 1 \cdot$ Eas $1 \quad \sigma \mathrm{s} 1=8.6509$

$\sigma \mathrm{s} 1:=8.6509$ Repetir valor se estiver no regime elástico (CA-tipo $\mathbf{A}$ ): $\quad$ fyas $1=63.68$

Rs $1:=\sigma$ s $1 \cdot$ As $1 \quad$ Rs $1=4.2476$

Cálculo da resultante na armadura tracionada $\quad$ Rs : =fyas.As $\quad$ Rs $=77.3863$

Equilibrio da seção: Se Valor1 for diferente de Valor2 - mudar o x

Valor1:= Rs $\quad$ Valor2: $=$ Rc1+Rc2+Rs1-P $\quad$ Valor1 $=77.3863 \quad$ Valor $2=77.9946$

Diferenca_percentuał $\frac{\text { Valor1- Valor2 }}{\text { Valor2 }} \cdot 100 \quad$ Diferenca_percentual- $0.78(\%)$

VERIFICAR LIMITES NO AÇO E NO CONCRETO - OK!

Momentos fletores - calc. com relação à linha neutra

Existem 2 possibilidades - uma delas é supor que $x<8 \mathrm{~cm}$ :

$\mathrm{x}=3.11 \quad \mathrm{~d}=12.535 \quad \mathrm{~d} \mathrm{l}=2.7$

$$
\mathrm{M} 1:=\mathrm{b} \cdot \mathrm{k} \cdot 0.95 \cdot \mathrm{fc} \cdot\left\{\mathrm{x}-\frac{\mathrm{k}}{2}\right\} \quad \mathrm{M} 2:=\mathrm{b} \cdot 0.95 \cdot \mathrm{fc} \cdot \int_{0}^{\mathrm{x}-\mathrm{k}}\left[1-\left\{1-\frac{\mathrm{a}}{\mathrm{x}-\mathrm{k}}\right\}^{2}\right] \cdot \mathrm{ad} a \quad \begin{aligned}
& \text { M3:=Rs } 1 \cdot(\mathrm{x}-\mathrm{dl}) \\
& \mathrm{M} 4:=\mathrm{Rs} \cdot(\mathrm{d}-\mathrm{x}) \\
& \mathrm{M} 5:=\mathrm{P} \cdot(8-\mathrm{x})
\end{aligned}
$$

M1 $=149.8574$

$\mathrm{M} 2=72.5184$

$\mathrm{M} 3=1.7415$

$\mathrm{M} 4=729.3661$

M5 $=233.7909$

Mfletor: $=$ M1 + M2+M3 + M4+ M5 Mfletor $=1187.2742$ mfletordistr $=\frac{\text { Mfletor }}{b}$ mfletordistr 118.7274 


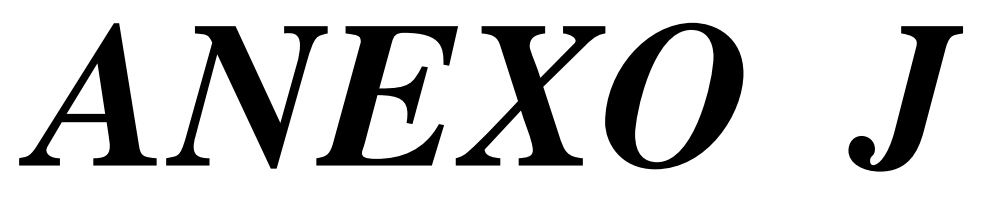

Previsão da resistência dos modelos com relação à punção, em função da NBR 6118 (1978) e NBR 7197 (1989), da Revisão da NB-1 (2000), da FIP (1999), da fib (1999) e do ACI 318/95 


\section{J.1 NBR 6118 E NBR 7197}

a) Modelo M1

NBR 6118 - Modelo M1: Punção $d, c 1, c 2$ em cm / fc em MPa
Dados - Obs.:usando formulação para ensaio experimental: sem coef.de s
Dados: $\mathrm{dx}:=13.54 \quad \mathrm{dy}:=11.94 \quad \mathrm{fck}:=26.6 \quad \mathrm{cx}:=18 \quad \mathrm{cy}:=18$
Cálculos: $\quad \mathrm{d}:=\frac{\mathrm{dx}+\mathrm{dy}}{2} \quad \mathrm{~d}=12.74 \quad \mathrm{u}:=2 \cdot(\mathrm{cx}+\mathrm{cy})+2 \cdot \pi \cdot\left\{\frac{\mathrm{d}}{2}\right\}$
Taurk $:=0.63 \sqrt{\mathrm{fck}} \quad$ Taurk $=3.2492 \quad$ Resist $:=\frac{\text { Taurk }}{(102)} \cdot \mathrm{u} \cdot \mathrm{d} \quad$ Resist $=231.863$

\section{b) Modelo M2}

NBR 6118 - Modelo M2: Punção- d, c1, c2 em cm / fc em MPa

Dados - Obs.: usando formulação para ensaio experimental: sem coef.de se Dados: $\mathrm{dx}:=13.36$ dy $:=11.76 \quad$ fck $:=49.9 \quad \mathrm{cx}:=18 \quad$ cy $:=18$

Cálculos: $\quad \mathrm{d}:=\frac{\mathrm{dx}+\mathrm{dy}}{2} \quad \mathrm{~d}=12.56 \quad \mathrm{u}:=2 \cdot(\mathrm{cx}+\mathrm{cy})+2 \cdot \pi \cdot\left\{\frac{\mathrm{d}}{2}\right\}$

Taurk $:=0.63 \sqrt{\mathrm{fck}} \quad$ Taurk $=4.4503 \quad$ Resist $:=\frac{\text { Taurk }}{(10)} \cdot \mathrm{u} \cdot \mathrm{d} \quad$ Resist $=623.0075$ Verificando quantidade de armadura:

Armadura_minima $=0.75 \frac{\text { Resist }}{30} \quad$ Armadura_minima $=15.5752$

Armadura_usada $:=32 \cdot 0.771 \quad$ Armadura_usada $=24.672$

$(\mathrm{OK})$

\section{c) Modelo M3}

NBR 6118 - Modelo M2: Punção - d, c1, c2 em cm / fc em MPa

Dados - Obs.: usando formulação para ensaio experimental: sem coef.de seg. Dados: $\mathrm{dx}:=13.27$ dy $:=11.67$ fck $:=48.47 \quad$ cx $:=18 \quad$ cy $:=18$ Cálculos: $\quad \mathrm{d}:=\frac{\mathrm{dx}+\mathrm{dy}}{2} \quad \mathrm{~d}=12.47 \quad \mathrm{u}:=2 \cdot(\mathrm{cx}+\mathrm{cy})+2 \cdot \pi \cdot\left\{\frac{\mathrm{d}}{2}\right\}$ Taurk $:=0.63 \cdot \sqrt{\mathrm{fck}} \quad$ Taurk $=4.3861 \quad$ Resist $:=\frac{\text { Taurk }}{(10)} \cdot \mathrm{u} \cdot \mathrm{d} \quad$ Resist $=608.0695$ Verificando quantidade de armadura:

Armadura_minima $:=0.75 \frac{\text { Resist }}{30} \quad$ Armadura_minima $=15.2017$

Armadura_usada $:=32 \cdot 0.771 \quad$ Armadura_usada $=24.672 \quad(\mathrm{OK})$ 


\section{d) Modelo M4}

NBR 6118 - Modelo M4: Punção - d, c1, c2 e m cm / fc em MPa

Dados - Obs.: usando formulação para ensaio experimental: sem coef.de seg.

Dados: $\mathrm{dx}:=16-1.28-\frac{1.25}{2} \quad \mathrm{dy}:=\mathrm{dx}-1.25 \quad$ fck $:=51.92 \quad \mathrm{cx}:=18$ cy $:=18$

Cálculos: $\quad \mathrm{d}:=\frac{\mathrm{dx}+\mathrm{dy}}{2} \quad \mathrm{~d}=13.47 \quad \mathrm{u}:=2 \cdot(\mathrm{cx}+\mathrm{cy})+2 \cdot \pi \cdot\left\{\frac{\mathrm{d}}{2}\right\}$

Taurk $:=0.63 \cdot \sqrt{\mathrm{fck}} \quad$ Taurk $=4.5395 \quad$ Resist_concreto $=\frac{\text { Taurk }}{(10 \cdot 2)} \cdot \mathrm{u} \cdot \mathrm{d} \quad$ Resist_concreto $=349.5081$ Contribuição da protensão:

Direção do eixo $x$

$\mathrm{hx}(\mathrm{x}):=-0.00021488 \mathrm{x}^{2}+0.05372 \mathrm{x}$

$\mathrm{x}:=\frac{250}{2}-\frac{\mathrm{cx}}{2}-\frac{\mathrm{d}}{2} \quad \mathrm{x}=109.265$

alfa_radx $=\operatorname{atan}\left\{\frac{\mathrm{d}^{1}}{\mathrm{~d}^{1} \mathrm{~h}} \mathrm{hx}(\mathrm{x})\right\} \quad$ alfa_radx $=0.0068$

1 Direção do eixo y

/ $\quad \mathrm{hy}(\mathrm{y}):=-0.00029488 \mathrm{y}^{2}+0.07372 \mathrm{y}$

alfa_radx $=0.0068$

Pxm:= 136.69

$y:=\frac{250}{2}-\frac{c y}{2}-\frac{d}{2} \quad y=109.265$

/ alfa_rady:= atan $\left\{\frac{\mathrm{d}^{1}}{\mathrm{~d} \mathrm{y} 1} \mathrm{hy}(\mathrm{y})\right\}$ alfa_rady $=0.0093$

$\mathrm{Vpx}:=2 \cdot 4 \cdot \mathrm{Pxm} \cdot \sin ($ alfa_rad $\Varangle \quad \mathrm{Vpx}=7.3945$

Pym:=137.83

1

/ $\quad$ ppy $:=2 \cdot 4 \cdot P y m \cdot \sin ($ alfa_rady) $\quad \mathrm{Vpy}=10.2319$

Resist_total $=\mathrm{Vpx}+\mathrm{Vpy}+$ Resist_concreto 
e) Modelo M5

NBR 6118 - Modelo M5 Punção - d, c1, c2 e m cm / fc em MPa

Dados - Obs.: usando formulação para ensaio experimental: sem coef.de seg.

Dados: $\quad \mathrm{dx}:=16-1.49-\frac{1.25}{2} \quad \mathrm{dy}:=\mathrm{dx}-1.25 \quad \mathrm{fck}:=59.4 \quad \mathrm{cx}:=18 \quad \mathrm{cy}:=18$

Cálculos: $\quad \mathrm{d}:=\frac{\mathrm{dx}+\mathrm{dy}}{2} \quad \mathrm{~d}=13.26 \quad \mathrm{u}:=2 \cdot(\mathrm{cx}+\mathrm{cy})+2 \cdot \pi \cdot\left\{\frac{\mathrm{d}}{2}\right\}$

Taurk $:=0.63 \cdot \sqrt{\mathrm{fck}} \quad$ Taurk $=4.8555$ Resist_concreto $=\frac{\text { Taurk }}{(10)} \cdot \mathrm{u} \cdot \mathrm{d} \quad$ Resist_concret $=731.7715$

Verificando quantidade de armadura:

Armadura_minima $=0.75 \cdot \frac{\text { Resist_concreto }}{30}$ Armadura_minima 18.2943

Armadura_usad $\mathfrak{d}=32 \cdot 0.763 \quad$ Armadura_usada $24.416 \quad(\mathrm{OK})$

Contribuição da protensão:

Direção do eixo $x$

$\mathrm{hx}(\mathrm{x}):=-0.00021488 \mathrm{x}^{2}+0.05372 \mathrm{x}$

$\mathrm{x}:=\frac{250}{2}-\frac{\mathrm{cx}}{2}-\frac{\mathrm{d}}{2} \quad \mathrm{x}=109.37$

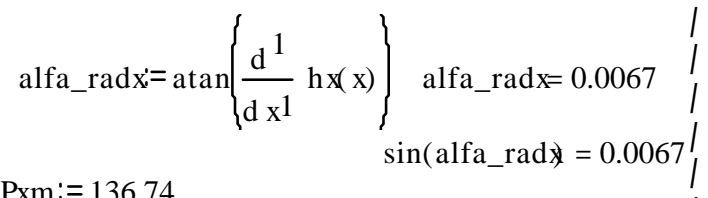

Pxm: $=136.74$

$\mathrm{Vpx}:=2 \cdot 4 \cdot \mathrm{Pxm} \cdot \sin ($ alfa_radx $) \quad \mathrm{Vpx}=7.3479$

| Pym:=146.14

I

/ $\quad V p y:=2 \cdot 4 \cdot P y m \cdot \sin ($ alfa_rady $) \quad V p y=10.7764$

\section{Direção do eixo $y$}

$$
\text { hy }(y):=-0.00029488 y^{2}+0.07372 y
$$$$
y:=\frac{250}{2}-\frac{c y}{2}-\frac{d}{2} \quad y=109.37
$$

alfa_rady: $=\operatorname{atan}\left\{\frac{\mathrm{d}^{1}}{\mathrm{~d} \mathrm{y} 1} \mathrm{hy}(\mathrm{y})\right\}$ alfa_rady $=0.0092$ $\sin ($ alfa_rady $)=0.0092$

Resist_total $=$ Vpx+Vpy+Resist_concreto

Resist_totak 749.8957 


\section{f) Modelo M6}

NBR 6118 - Modelo M6 - Punção - d, c1, c2 e m cm / fc em MPa

Dados - Obs.: usando formulação para ensaio experimental: sem coef.de seg.

Dados: $\mathrm{dx}:=16-1.59-\frac{1.25}{2} \quad \mathrm{dy}:=\mathrm{dx}-1.25 \quad \mathrm{fck}:=51.56 \quad \mathrm{cx}:=18 \quad \mathrm{cy}:=18$

Cálculos: $\quad \mathrm{d}:=\frac{\mathrm{dx}+\mathrm{dy}}{2} \quad \mathrm{~d}=13.16 \quad \mathrm{u}:=2 \cdot(\mathrm{cx}+\mathrm{cy})+2 \cdot \pi \cdot\left\{\frac{\mathrm{d}}{2}\right\}$

Taurk $:=0.63 \cdot \sqrt{\mathrm{fck}} \quad$ Taurk $=4.5237 \quad$ Resist_concreto $=\frac{\text { Taurk }}{(10)} \cdot \mathrm{u} \cdot \mathrm{d} \quad$ Resist_concreto $=674.7594$

Verificando quantidade de armadura:

Armadura_minima $=0.75 \cdot \frac{\text { Resist_concreto }}{30}$ Armadura_minima 16.869

Armadura_usad $\mathbf{a}=32 \cdot 0.763 \quad$ Armadura_usadæ $24.416 \quad(\mathrm{OK})$

Contribuição da protensão:

Direção do eixo $x$

$\mathrm{hx}(\mathrm{x}):=-0.00021488 \mathrm{x}^{2}+0.05372 \mathrm{x}$

$\mathrm{x}:=\frac{250}{2}-\frac{\mathrm{cx}}{2}-\frac{\mathrm{d}}{2} \quad \mathrm{x}=109.42$

alfa_radx: $=\operatorname{atan}\left\{\frac{\mathrm{d}^{1}}{\mathrm{~d} \mathrm{x} 1} \mathrm{hx}(\mathrm{x})\right\}$ alfa_radx $=0.0067$

| Direção do eixo y

/ $\quad \mathrm{hy}(\mathrm{y}):=-0.00029488 \mathrm{y}^{2}+0.07372 \mathrm{y}$

Pxm: $=145.49$
Vpx:= 2.4.Pxm.sin(alfa_radx $) \quad V p x=7.793$ $\sin ($ alfa_rad $)=0.0067$ !

$y:=\frac{250}{2}-\frac{c y}{2}-\frac{d}{2} \quad y=109.42$

alfa_rady: $=\operatorname{atan}\left\{\frac{\mathrm{d}^{1}}{\mathrm{dy} 1} \mathrm{hy}(\mathrm{y})\right\} \quad$ alfa_rady $=0.0092$

| Pym:=149.42

I

I $\quad$ py: $=2 \cdot 4 \cdot P y m \cdot \sin ($ alfa_rady $) \quad$ Vpy $=10.9831$

Resist_total: $=\mathrm{Vpx}+\mathrm{Vpy}+$ Resist_concreto 


\section{J.2 REVISÃO DA NB-1 (1997)}

\section{a) Modelo M1}

\section{Revisão da NB-1 - MODELO M1 - Punção - d, c1, c2 em cm / fc em MPa}

Dados - Obs.: usando formulação para ensaio experimental: sem coef.de seg.

$\mathrm{dx}:=16-1.66-\frac{1.6}{2} \quad \mathrm{dy}:=16-1.66-1.6-\frac{1.6}{2} \quad \mathrm{dx}=13.54 \quad \mathrm{dy}=11.94 \quad$ fck $:=26.6$

$$
\mathrm{A}_{\mathrm{Sx}}:=2.001 \quad \mathrm{~A}_{\mathrm{Sy}}:=2.001 \quad \text { Lados do pilar (c1, c2): } \quad \mathrm{cx}:=18 \quad \mathrm{cy}:=18
$$

espaçamento entre barras: $10 \mathrm{~cm}$

Calculos iniciais:

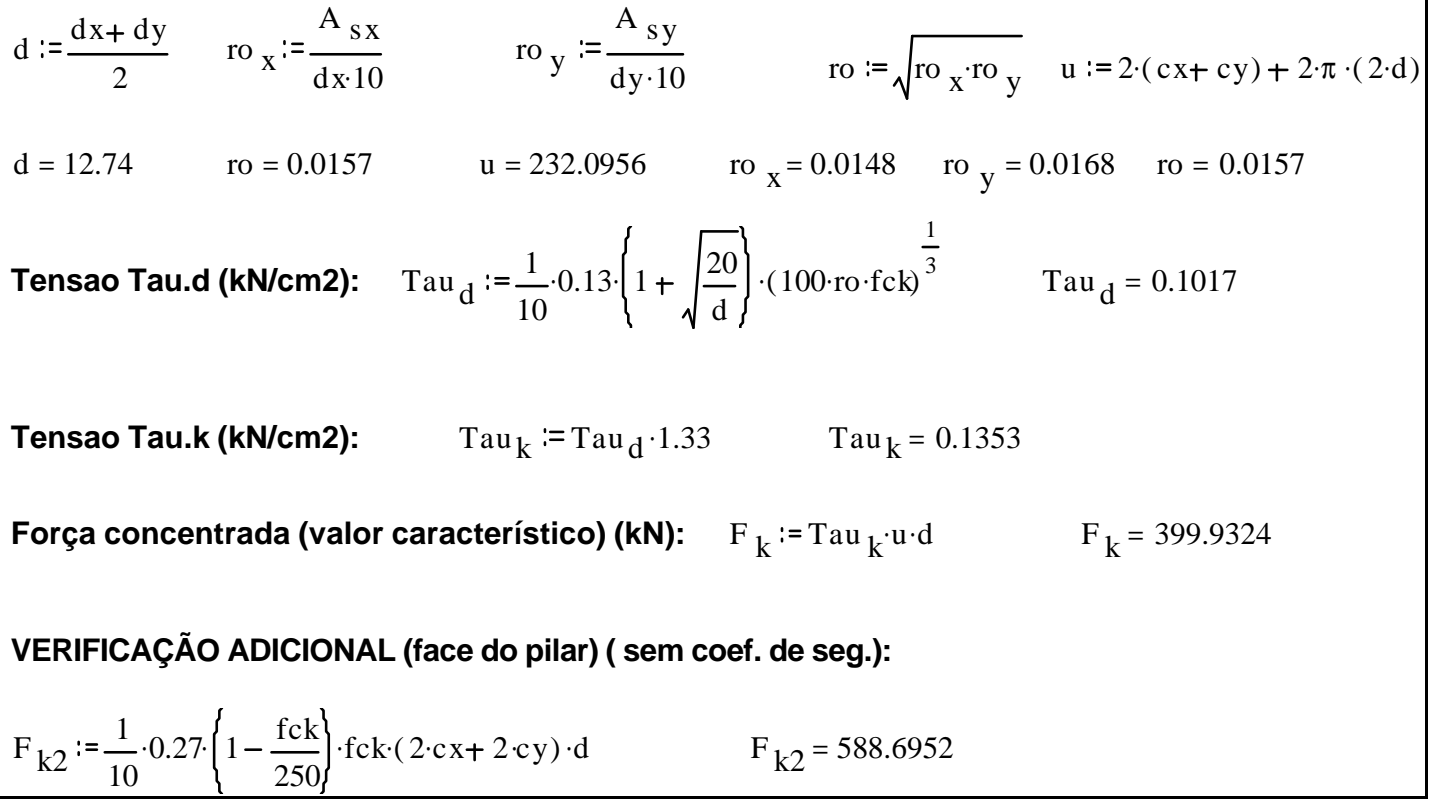




\section{b) Modelo M2}

Revisão da NB-1 - MODELO M2 - Punçãod, c1, c2 em cm / fc em MPa

Dados - Obs.:usando formulação para ensaio experimental: sem coef.de seg.

$\mathrm{dx}:=16-1.84-\frac{1.6}{2} \quad \mathrm{dy}:=16-1.84-1.6-\frac{1.6}{2} \quad \mathrm{dx}=13.36 \quad \mathrm{dy}=11.76 \quad$ fck $:=49.9$

$\mathrm{d}:=\frac{\mathrm{dx}+\mathrm{dy}}{2} \quad \mathrm{~d}=12.56 \quad$ Lados do pilar $(\mathbf{c 1}, \mathbf{c 2}): \mathrm{cx}:=18 \quad \mathrm{cy}:=18$

espaçamento entre barras: $10 \mathrm{~cm}$

VERIFICAÇÃO DA REGIÃO ARMADA

Dados: $\mathrm{A}_{\mathrm{Sx}}:=2.001 \quad \mathrm{~A}_{\mathrm{sy}}:=2.001$ Asw $:=16.0 .771$ sr $:=9.5 \quad$ (limite $=0.75 \mathrm{~d}=9.42 \quad$ ) fy $:=590.4 \boldsymbol{p} / \boldsymbol{A s t}-\mathbf{M P a}) \quad$ fywd $:=\frac{\text { fy }}{1.15} \quad$ fywd $=513.3913$ (limite de $\mathbf{3 0 0} \mathbf{M P a}$ )

Cálculos: fywd :=300 Repetir valor se inferior a $\mathbf{3 0 0} \mathbf{M P}$

ro $:=\frac{A_{\text {sx }}}{\mathrm{dx} \cdot 10}$

$$
\text { ro } y:=\frac{A_{\text {sy }}}{\mathrm{dy} \cdot 10}
$$$$
\text { ro }:=\sqrt{\mathrm{ro}_{\mathrm{x}} \cdot \mathrm{ro}_{\mathrm{y}}}
$$

$u:=2 \cdot(c x+c y)+2 \cdot \pi \cdot(2 \cdot d)$

ro $_{\mathrm{x}}=0.015$

$$
\text { ro }_{y}=0.017
$$

$\mathrm{ro}=0.016$

$\mathrm{u}=229.8336$

Como quero comparar com resultados experimentais, multiplicar:

parcela do concreto - 1,33 ; parcela do aço-1,15

TAU $1:=\frac{1}{10} \cdot\left[1.330 .10\left\{1+\sqrt{\frac{20}{\mathrm{~d}}}\right\} \cdot(100 \mathrm{ro} \cdot \mathrm{fck})^{\frac{1}{3}}+1.151 .5 \frac{\mathrm{d}}{\mathrm{sr}} \cdot \frac{\text { Asw } \cdot \mathrm{fywd} \cdot 1}{\mathrm{u} \cdot \mathrm{d}}\right]$

$\mathrm{F}_{\mathrm{k} 1}:=\mathrm{TAU} 1 \cdot \mathrm{u} \cdot \mathrm{d}$

Portanto: $\mathrm{F}_{\mathrm{k} 1}=1217.6726$

VERIFICACÃO NA FACE DO PILAR (sem coef. de seg.):

$\mathrm{F}_{\mathrm{k} 2}:=\frac{1}{10} \cdot 0.27\left(1-\frac{\mathrm{fck}}{250}\right\} \cdot \mathrm{fck} \cdot(2 \cdot \mathrm{cx}+2 \cdot \mathrm{cy}) \cdot \mathrm{d} \quad$ Portanto: $\quad \mathrm{F}_{\mathrm{k} 2}=975.1996$

VERIFICACÃO ALÉM DA REGIÃO ARMADA (sem coef. de seg.):

Dados: so $:=4.865 \quad$ (limite $=0.5 \cdot \mathrm{d}=6.28 \quad$ ) $\mathrm{n}:=2 \quad$ ( $\boldsymbol{n}=$ nro. de pinos no conector)

$\mathrm{r}_{\text {ext }}:=\mathrm{so}+(\mathrm{n}-1) \cdot \mathrm{sr}+2 \cdot \mathrm{d} \quad \mathrm{u}_{\mathrm{nef}}:=2 \cdot(\mathrm{cx}+\mathrm{cy})+2 \cdot \pi \cdot \mathrm{r}_{\mathrm{ext}} \quad \mathrm{u}_{\mathrm{nef}}=320.0916$

Verificar se u.nef pode ser calculado desta maneira ${ }^{\mathrm{u}}$ nef $\mathrm{i}=320.0916$ caso seja possível - repetir valor

Tau $_{d}:=\frac{1}{10} \cdot 0.13\left(1+\sqrt{\frac{20}{d}}\right\} \cdot(100 \text { ro } \cdot f c k)^{\frac{1}{3}} \quad$ Tau $_{d}=0.1265$

Força concentrada (valor característico) $(\boldsymbol{k N N})_{\mathrm{k} 3}:=1.33 \mathrm{Tau}_{\mathrm{d}} \cdot \mathrm{u}_{\mathrm{nef}^{\mathrm{d}}}{ }^{\mathrm{d}} \quad \mathrm{F}_{\mathrm{k} 3}=676.5137$

Adotaro valor mais crítico: ${ }^{\mathrm{F}} \mathrm{k} 1=1217.6726$ (região- armada)

$\mathrm{F}_{\mathrm{k} 2}=975.1996 \quad$ (região- adjacente- pilar)

$\mathrm{F}_{\mathrm{k} 3}=676.5137 \quad$ (região - externa) 


\section{c) Modelo M3}

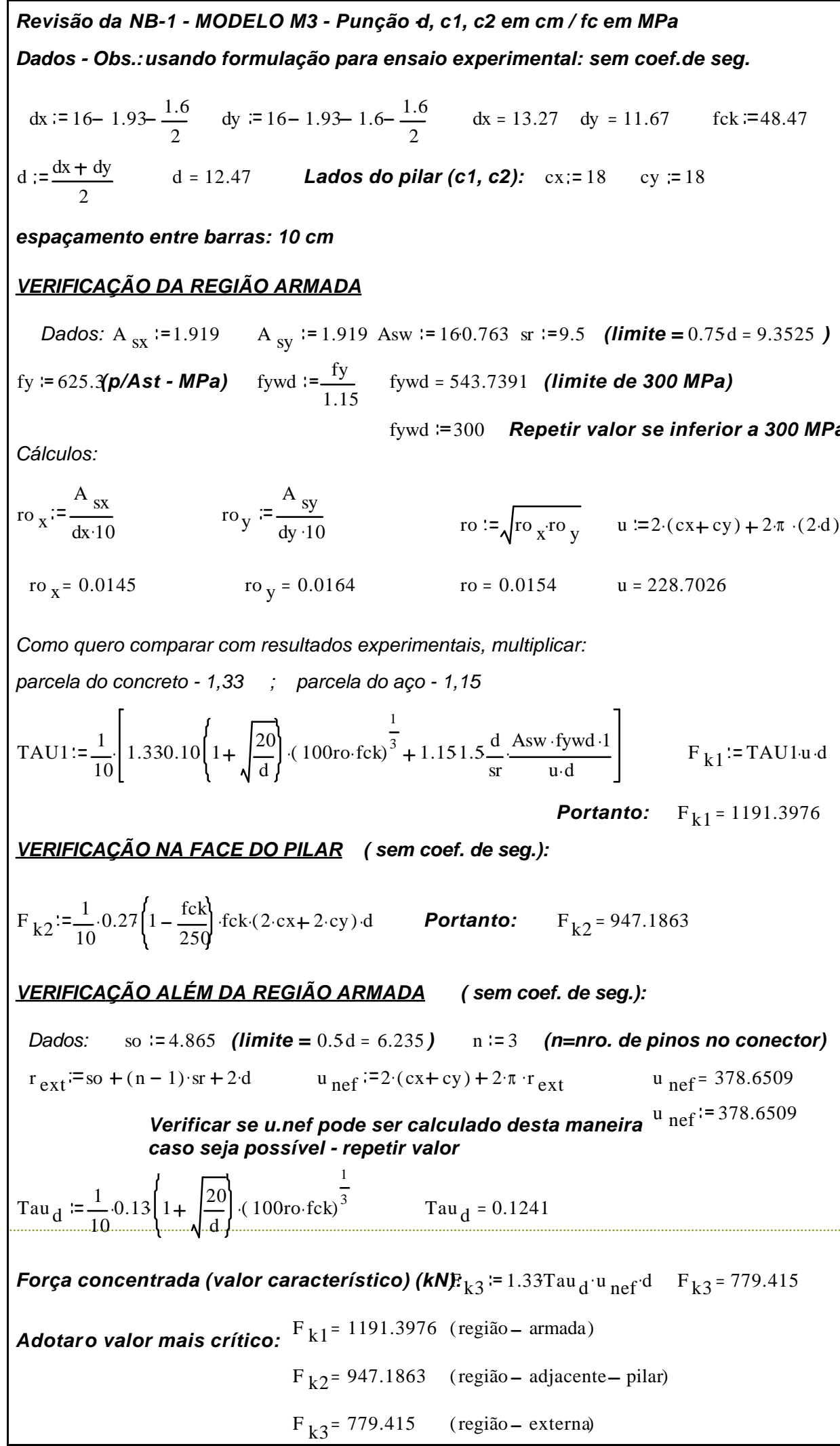




\section{d) Modelo M4}

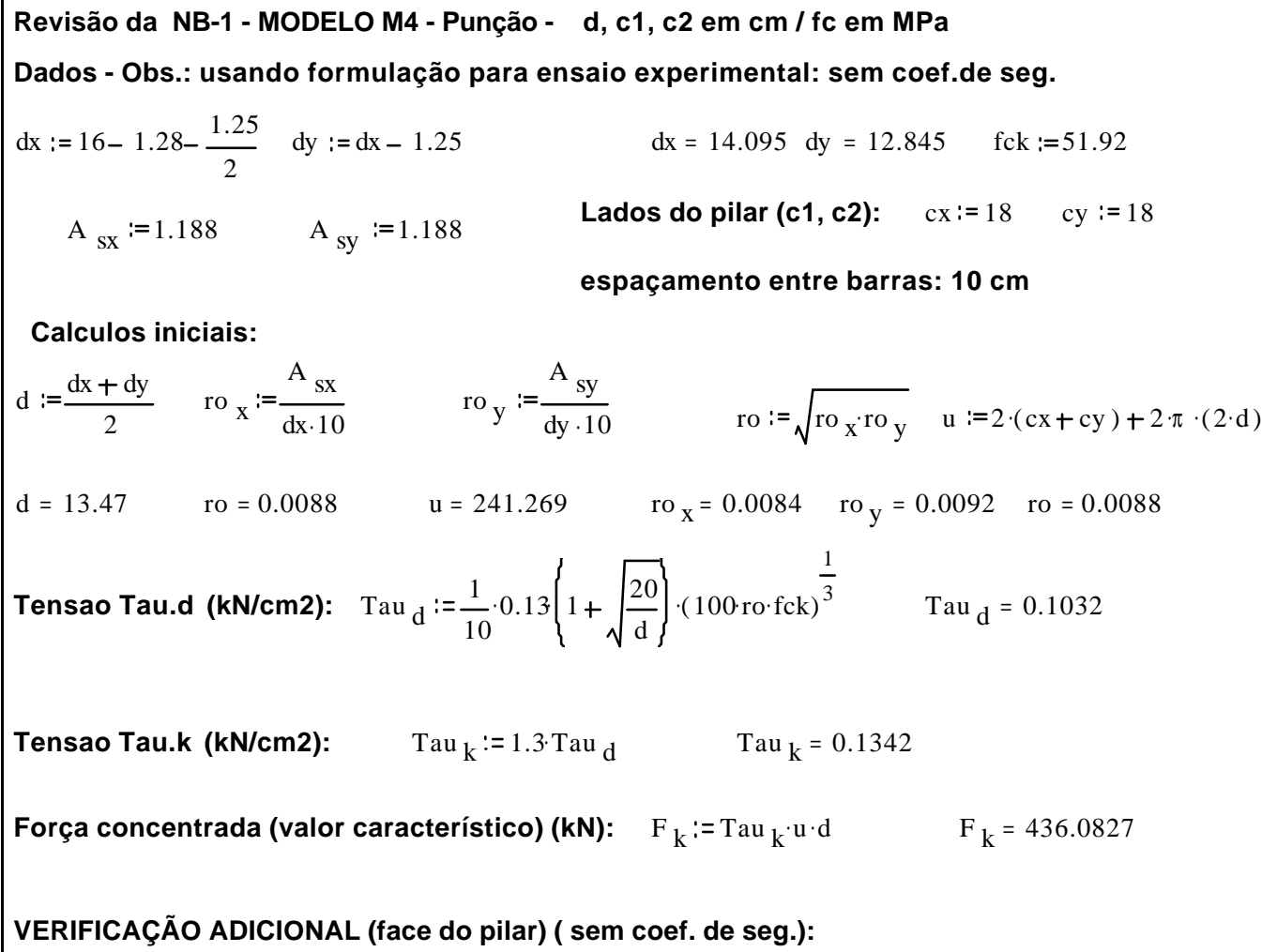

Calculos iniciais:

$\mathrm{d}:=\frac{\mathrm{dx}+\mathrm{dy}}{2} \quad$ ro $\mathrm{x}:=\frac{\mathrm{A}_{\mathrm{sx}}}{\mathrm{dx} \cdot 10} \quad$ ro $\mathrm{y}:=\frac{\mathrm{A}_{\mathrm{sy}}}{\mathrm{dy} \cdot 10} \quad$ ro $:=\sqrt{\mathrm{ro}_{\mathrm{x}} \cdot \mathrm{ro}_{\mathrm{y}}} \quad \mathrm{u}:=2 \cdot(\mathrm{cx}+\mathrm{cy})+2 \cdot \pi \cdot(2 \cdot \mathrm{d})$

$\mathrm{d}=13.47 \quad$ ro $=0.0088 \quad \mathrm{u}=241.269 \quad$ ro $_{\mathrm{x}}=0.0084 \quad$ ro $_{\mathrm{y}}=0.0092 \quad$ ro $=0.0088$

Tensao Tau.d (kN/cm2): Tau ${ }_{\mathrm{d}}:=\frac{1}{10} \cdot 0.13\left(1+\sqrt{\frac{20}{\mathrm{~d}}}\right\} \cdot(100 \cdot \mathrm{ro} \cdot \mathrm{fck})^{\frac{1}{3}} \quad$ Tau $_{\mathrm{d}}=0.1032$

Tensao Tau.k (kN/cm2): $\quad \operatorname{Tau}_{\mathrm{k}}:=1.3 \cdot \mathrm{Tau}_{\mathrm{d}} \quad \mathrm{Tau}_{\mathrm{k}}=0.1342$

Força concentrada (valor característico) $(\mathbf{k N}): \quad \mathrm{F}_{\mathrm{k}}:=\mathrm{Tau}_{\mathrm{k}} \cdot \mathrm{u} \cdot \mathrm{d} \quad \mathrm{F}_{\mathrm{k}}=436.0827$

VERIFICAÇÃO ADICIONAL (face do pilar) ( sem coef. de seg.):

$\mathrm{F}_{\mathrm{k} 2}:=\frac{1}{10} \cdot 0.27 \cdot\left(1-\frac{\mathrm{fck}}{250}\right) \cdot \mathrm{fck} \cdot(2 \cdot \mathrm{cx}+2 \cdot \mathrm{cy}) \cdot \mathrm{d} \quad \mathrm{F}_{\mathrm{k} 2}=1077.207$

Contribuição da protensão:

\section{Direção do eixo $x$}

$\mathrm{hx}(\mathrm{x}):=-0.00021488 \mathrm{x}^{2}+0.05372 \mathrm{x}$

$\mathrm{x}:=\frac{250}{2}-\frac{\mathrm{cx}}{2}-2 \cdot \mathrm{d} \quad \mathrm{x}=89.06$

alfa_radx $:=\operatorname{atan}\left\{\frac{\mathrm{d}^{1}}{\mathrm{dx}^{1}} \mathrm{hx}(\mathrm{x})\right\}$
$\operatorname{Pxm}:=136.69$
$\sin ($ alfa_radx $)=0.0154$

$\mathrm{Vpx}:=2 \cdot 4 \cdot \mathrm{Pxm} \sin ($ alfa_radx $) \quad \mathrm{Vpx}=16.888$

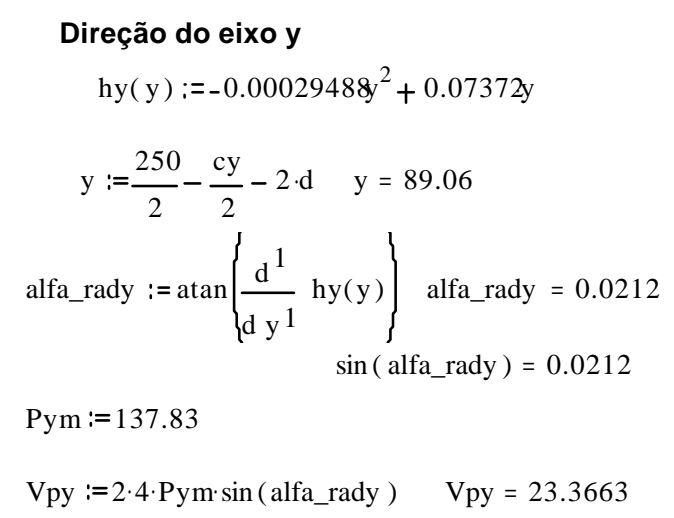

Resist_total $:=\mathrm{Vpx}+\mathrm{Vpy}+\mathrm{F}_{\mathrm{k}} \quad$ Resist_total $=476.3371 \quad$ Tem que ser menor que o Fk2: OK! 
e) Modelo M5

Revisão da NB-1 - MODELO M5 - Punção - $d$, c1, c2 em cm / fc em MPa

Dados - Obs.: usando formulação para ensaio experimental: sem coef.de seg.

$\mathrm{dx}:=16-1.49-\frac{1.25}{2} \quad \mathrm{dy}:=\mathrm{dx}-1.25 \quad \mathrm{dx}=13.885 \quad \mathrm{dy}=12.635 \quad$ fck $:=59.4$
$\mathrm{~d}:=\frac{\mathrm{dx}+\mathrm{dy}}{2} \quad \mathrm{~d}=13.26 \quad$ Lados do pilar $(c 1, \mathrm{c} 2): \quad \mathrm{cx}:=18 \quad \mathrm{cy}:=18$

espaçamento entre barras: $10 \mathrm{~cm}$

VERIFICACÃO DA REGIĨO ARMADA

Dados: $\mathrm{A}_{\mathrm{sx}}:=1.188 \quad \mathrm{~A}_{\mathrm{sy}}:=1.188$ Asw $:=16 \cdot 0.763 \quad \mathrm{sr}:=9.5 \quad($ limite $=0.75 \cdot \mathrm{d}=9.945 \quad)$

fy $:=633.9(\boldsymbol{p} / \boldsymbol{A s} \boldsymbol{s}-\boldsymbol{M P a}) \quad$ fywd $:=\frac{\text { fy }}{1.15} \quad$ fywd $=551.2174 \quad$ (limite de $300 \mathrm{MPa}$ )

Cálculos: fywd :=300 Repetir valor se inferior a $300 \mathrm{MPa}$

$\operatorname{ro}_{\mathrm{x}}:=\frac{\mathrm{A}_{\mathrm{Sx}}}{\mathrm{dx} \cdot 10}$ ro $_{\mathrm{y}}:=\frac{\mathrm{A}_{\mathrm{sy}}}{\mathrm{dy} \cdot 10}$ ro $:=\sqrt{\mathrm{ro}_{\mathrm{x}} \cdot \mathrm{ro} \mathrm{y}}$ $u:=2 \cdot(c x+c y)+2 \cdot \pi \cdot(2 \cdot d)$

ro $_{\mathrm{x}}=0.0086$ ro $_{\mathrm{y}}=0.0094$

ro $=0.009$ $\mathrm{u}=238.6301$

Como quero comparar com resultados experimentais, multiplicar:

parcela do concreto-1,33 ; parcela do aço-1,15

TAU1 $:=\frac{1}{10} \cdot\left[1.33 \cdot 0.10 \cdot\left(1+\sqrt{\frac{20}{\mathrm{~d}}}\right\} \cdot(100 \cdot \mathrm{ro} \cdot \mathrm{fck})^{\frac{1}{3}}+1.15 \cdot 1.5 \cdot \frac{\mathrm{d}}{\mathrm{sr}} \cdot \frac{\mathrm{Asw} \cdot \mathrm{fywd} \cdot 1}{\mathrm{u} \cdot \mathrm{d}}\right] \quad \mathrm{F}_{\mathrm{k} 1}:=\mathrm{TAU} 1 \cdot \mathrm{u} \cdot \mathrm{d}$

Contribuição da protensão:

Direção do eixo $x$

$\mathrm{hx}(\mathrm{x}):=-0.00021488 \mathrm{x}^{2}+0.05372 \mathrm{x}$

$\mathrm{x}:=\frac{250}{2}-\frac{\mathrm{cx}}{2}-2 \cdot \mathrm{d} \quad \mathrm{x}=89.48$

alfa_radx:= $\operatorname{atan}\left\{\frac{\mathrm{d}^{1}}{\mathrm{~d} \mathrm{x} 1} \mathrm{hx}(\mathrm{x})\right\}_{\sin (\text { alfa_rad } x=0.0153 /}^{\text {alfa_radx }=0.0153}$

Pxm:= 136.74

/ Pym:=146.14

$\mathrm{Vpx}:=2 \cdot 4 \cdot \operatorname{Pxm} \cdot \sin ($ alfa_radx $) \quad \mathrm{Vpx}=16.6968$

Vpy:=2·4·Pym $\cdot \sin ($ alfa_rady) $\quad$ Vpy $=24.4857$

$\mathrm{F}_{\mathrm{k} 1 \text { total }}:=\mathrm{Vpx}+\mathrm{Vpy}+\mathrm{F}_{\mathrm{k} 1} \quad \mathrm{~F}_{\mathrm{k} 1 \text { total }}=1275.8292$ 


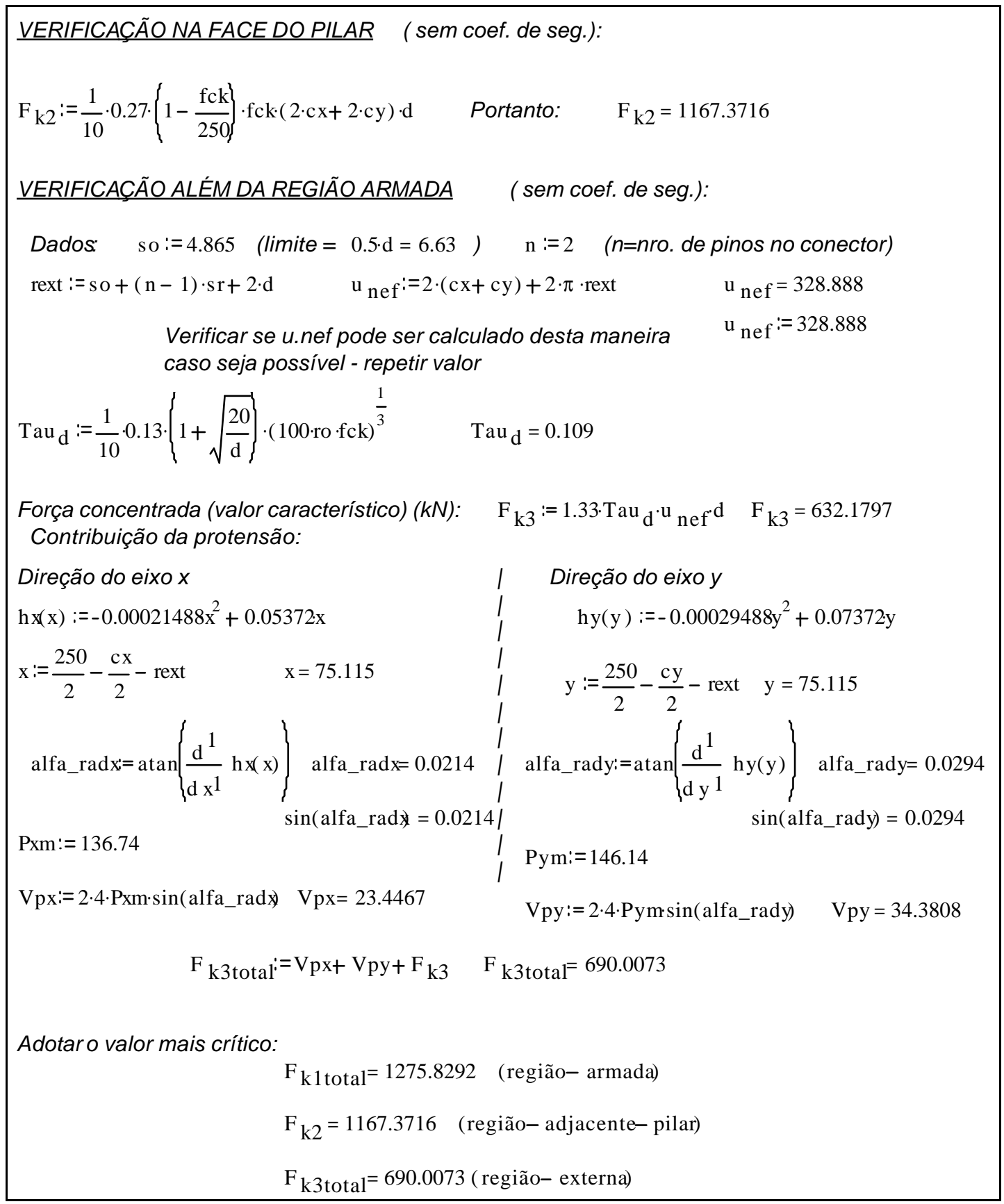




\section{f) Modelo M6}

Revisão da NB-1 - MODELO M6 - Punção - $d$, c1, c2 em cm / fc em MPa

Dados - Obs.: usando formulação para ensaio experimental: sem coef.de seg.

$\mathrm{dx}:=16-1.59-\frac{1.25}{2} \quad \mathrm{dy}:=\mathrm{dx}-1.25 \quad \mathrm{dx}=13.785 \quad \mathrm{dy}=12.535 \quad \mathrm{fck}:=51.56$

$\mathrm{d}:=\frac{\mathrm{dx}+\mathrm{dy}}{2} \quad \mathrm{~d}=13.16 \quad$ Lados do pilar $(c 1, \mathrm{c} 2): \quad \mathrm{cx}:=18 \quad \mathrm{cy}:=18$

espaçamento entre barras: $10 \mathrm{~cm}$

VERIFICACÃO DA REGIÃO ARMADA

Dados: $\mathrm{A}_{\mathrm{SX}}:=1.188 \quad \mathrm{~A}_{\mathrm{Sy}}:=1.188 \quad$ Asw $:=16 \cdot 0.763 \quad \mathrm{sr}:=9.5 \quad($ limite $=0.75 \cdot \mathrm{d}=9.87 \quad)$

fy $:=633.9\left(\boldsymbol{p} /\right.$ Ast - MPa) $\quad$ fywd $:=\frac{\text { fy }}{1.15} \quad$ fywd $=551.2174 \quad$ (limite de $300 \mathrm{MPa}$ )

Cálculos:

fywd : $=300$ Repetir valor se inferior a $300 \mathrm{MPa}$

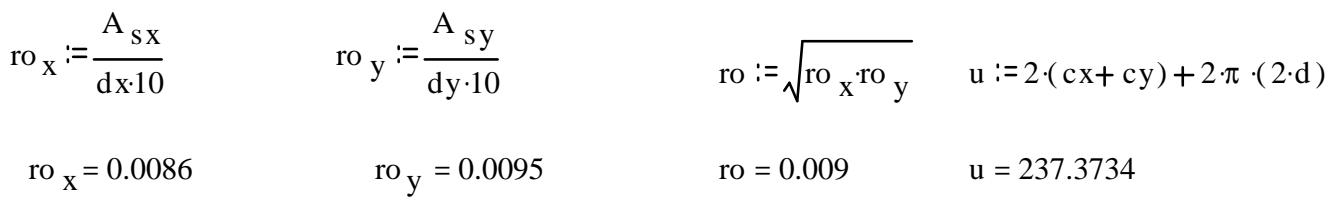

Como quero comparar com resultados experimentais, multiplicar:

parcela do concreto-1,33 ; parcela do aço-1,15

TAU $1:=\frac{1}{10} \cdot\left[1.33 \cdot 0.10 \cdot\left\{1+\sqrt{\frac{20}{\mathrm{~d}}}\right\} \cdot(100 \cdot \mathrm{ro} \cdot \mathrm{fck})^{\frac{1}{3}}+1.15 \cdot 1.5 \cdot \frac{\mathrm{d}}{\mathrm{sr}} \cdot \frac{\mathrm{Asw} \cdot \mathrm{fywd} \cdot 1}{\mathrm{u} \cdot \mathrm{d}}\right] \quad \mathrm{F}_{\mathrm{k} 1}:=\mathrm{TAU} 1 \cdot \mathrm{u} \cdot \mathrm{d}$

Contribuição da protensão:

Direção do eixo $x$

$\mathrm{hx}(\mathrm{x}):=-0.00021488 \mathrm{x}^{2}+0.05372 \mathrm{x}$

$\mathrm{x}:=\frac{250}{2}-\frac{\mathrm{cx}}{2}-2 \cdot \mathrm{d} \quad \mathrm{x}=89.68$

alfa_rad $x:=\operatorname{atan}\left\{\frac{\mathrm{d}^{1}}{\mathrm{~d} \mathrm{x} 1} \mathrm{hx}(\mathrm{x})\right\}_{\sin (\text { alfa_rad } x=0.0152 /}^{\text {alfa_radx }=0.0152 /}$

Pxm:= 145.49

$\mathrm{Vpx}:=2 \cdot 4 \cdot \operatorname{Pxm} \cdot \sin ($ alfa_radx $) \quad \mathrm{Vpx}=17.6653$

$\mathrm{F}_{\mathrm{k} 1 \text { total }} \mathrm{i}=\mathrm{Vpx}+\mathrm{Vpy}+\mathrm{F}_{\mathrm{k} 1}$
Direção do eixo y

$$
\mathrm{hy}(\mathrm{y}):=-0.00029488 \mathrm{y}^{2}+0.07372 \mathrm{y}
$$$$
y:=\frac{250}{2}-\frac{c y}{2}-2 \cdot d \quad y=89.68
$$

alfa_rady: $=\operatorname{atan}\left\{\frac{\mathrm{d}^{1}}{\mathrm{~d} \mathrm{y} 1} \mathrm{hy}(\mathrm{y})\right\} \quad$ alfa_rady $=0.0208$ $\sin ($ alfa_rady $)=0.0208$

Pym: $=149.42$

Vpy $:=2 \cdot 4 \cdot P y m \cdot \sin ($ alfa_rady) $\quad$ Vpy $=24.8943$

$\mathrm{F}_{\mathrm{k} 1 \text { total }}=1251.5354$ 


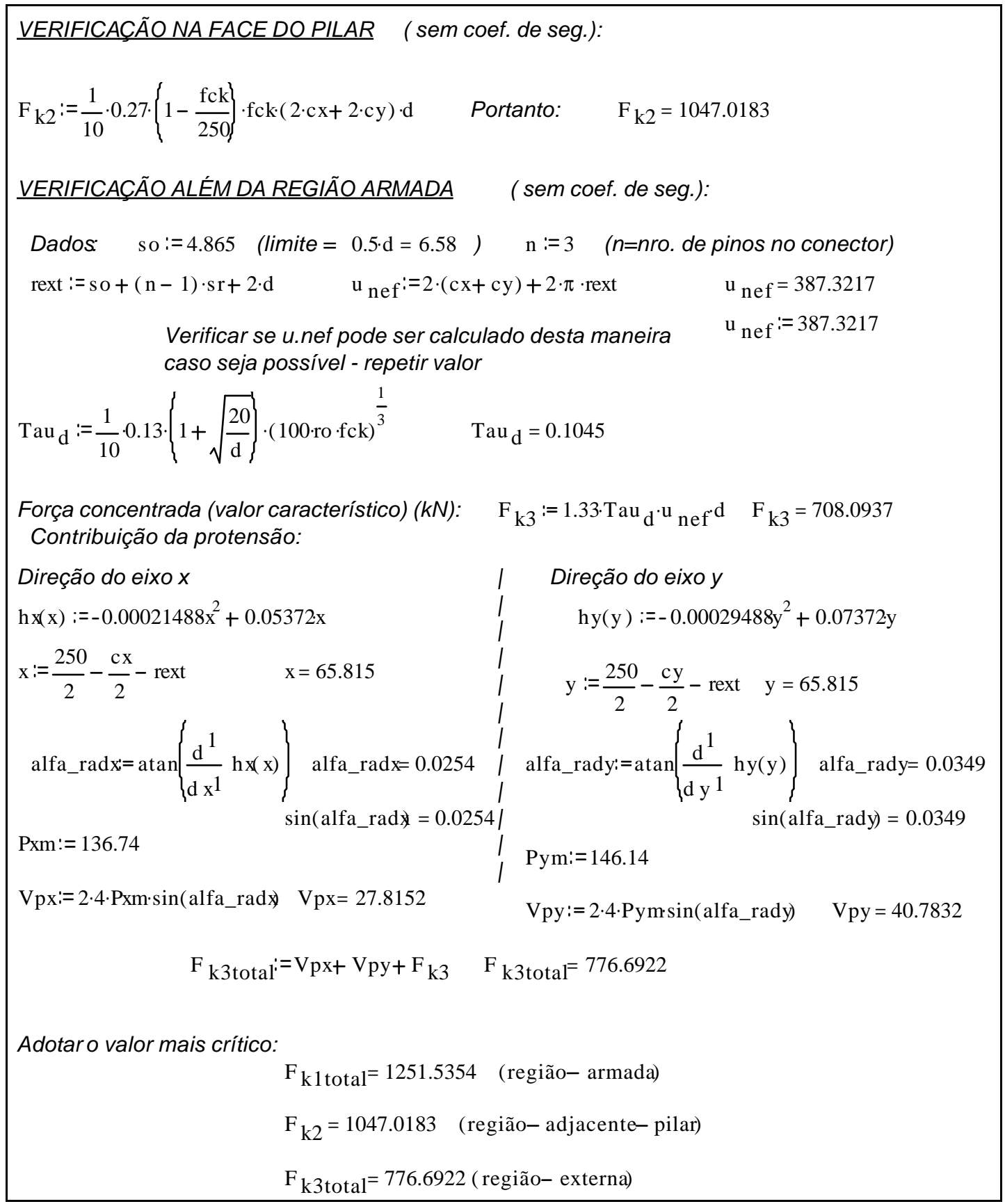




\section{J.3. $\quad F I P(1999)$}

\section{a) Modelo M1}

FIP (1999) - MODELO M1 - Punção - d, c1, c2 em cm / fc em MPa

Dados - Obs.: usando formulação para ensaio experimental: sem coef.de seg.

$\mathrm{dx}:=16-1.66-\frac{1.6}{2} \quad \mathrm{dy}:=16-1.66-1.6-\frac{1.6}{2} \quad \mathrm{dx}=13.54 \quad \mathrm{dy}=11.94 \quad$ fck $:=26.6$

$$
\begin{array}{ll}
\mathrm{A}_{\mathrm{sx}}:=2.001 \quad \mathrm{~A}_{\mathrm{sy}}:=2.001 \quad \text { Lados do pilar }(\mathrm{c} 1, \mathrm{c} 2): \quad \mathrm{cx}:=18 \quad \mathrm{cy}:=18 \\
& \text { espaçamento entre barras: } 10 \mathrm{~cm}
\end{array}
$$

Calculos iniciais:

$$
\begin{aligned}
& \mathrm{d}:=\frac{\mathrm{dx}+\mathrm{dy}}{2} \quad \text { ro }_{\mathrm{x}}:=\frac{\mathrm{A}_{\mathrm{sx}}}{\mathrm{dx} \cdot 10} \quad \text { ro } \mathrm{y}:=\frac{\mathrm{A}_{\mathrm{sy}}}{\mathrm{dy} \cdot 10} \quad \mathrm{u}=232.0956 \quad \text { ro }:=\sqrt{\mathrm{ro}_{\mathrm{x}} \cdot \mathrm{ro}_{\mathrm{y}}} \quad \mathrm{u}:=2 \cdot(\mathrm{cx}+\mathrm{cy})+2 \cdot \pi \cdot(2 \cdot \mathrm{d}) \\
& \mathrm{d}=12.74 \quad \text { ro }=0.0157 \quad \text { Kapa }=2.2529 \\
& \text { Kapa }:=1+\sqrt{\frac{20}{\mathrm{~d}}} \quad \begin{array}{l}
\text { Kapa }:=2.0 \quad \text { Repetir valor se kapa for menor ou igual a } 2 \\
\mathrm{~K}
\end{array}
\end{aligned}
$$

Tensao Tau.d(kN/cm2): $\quad$ Tau $_{d}:=(100 \cdot r o \cdot f c k)^{\frac{1}{3}} \cdot \frac{1}{10} \cdot 0.12 \cdot \mathrm{Kapa} \quad \mathrm{Tau}_{\mathrm{d}}=0.0833$

Tensao Tau.k(kN/cm2): $\quad \operatorname{Tau}_{\mathrm{k}}:=1.33 \cdot \mathrm{Tau}_{\mathrm{d}} \quad \operatorname{Tau}_{\mathrm{k}}=0.1108$

Força concentrada (valor característico) $(\mathrm{kN}): \quad \mathrm{F}_{\mathrm{k}}:=\mathrm{Tau}_{\mathrm{k}} \cdot \mathrm{u} \cdot \mathrm{d} \quad \mathrm{F}_{\mathrm{k}}=327.7215$

VERIFICAÇÃO ADICIONAL (face do pilar) ( sem coef. de seg.):

$\mathrm{f} 1 \mathrm{~cd}:=0.85 \cdot \frac{\mathrm{fck}}{1.5} \quad \mathrm{f} 1 \mathrm{~cd}=15.0733$

$\mathrm{F}_{\mathrm{k} 2}:=\frac{1}{10} \cdot 0.5 \cdot \mathrm{f} 1 \mathrm{~cd} \cdot(2 \cdot \mathrm{cx}+2 \cdot \mathrm{cy}) \cdot \mathrm{d} \quad \mathrm{F}_{\mathrm{k} 2}=691.3234$ 


\section{b) Modelo M2}

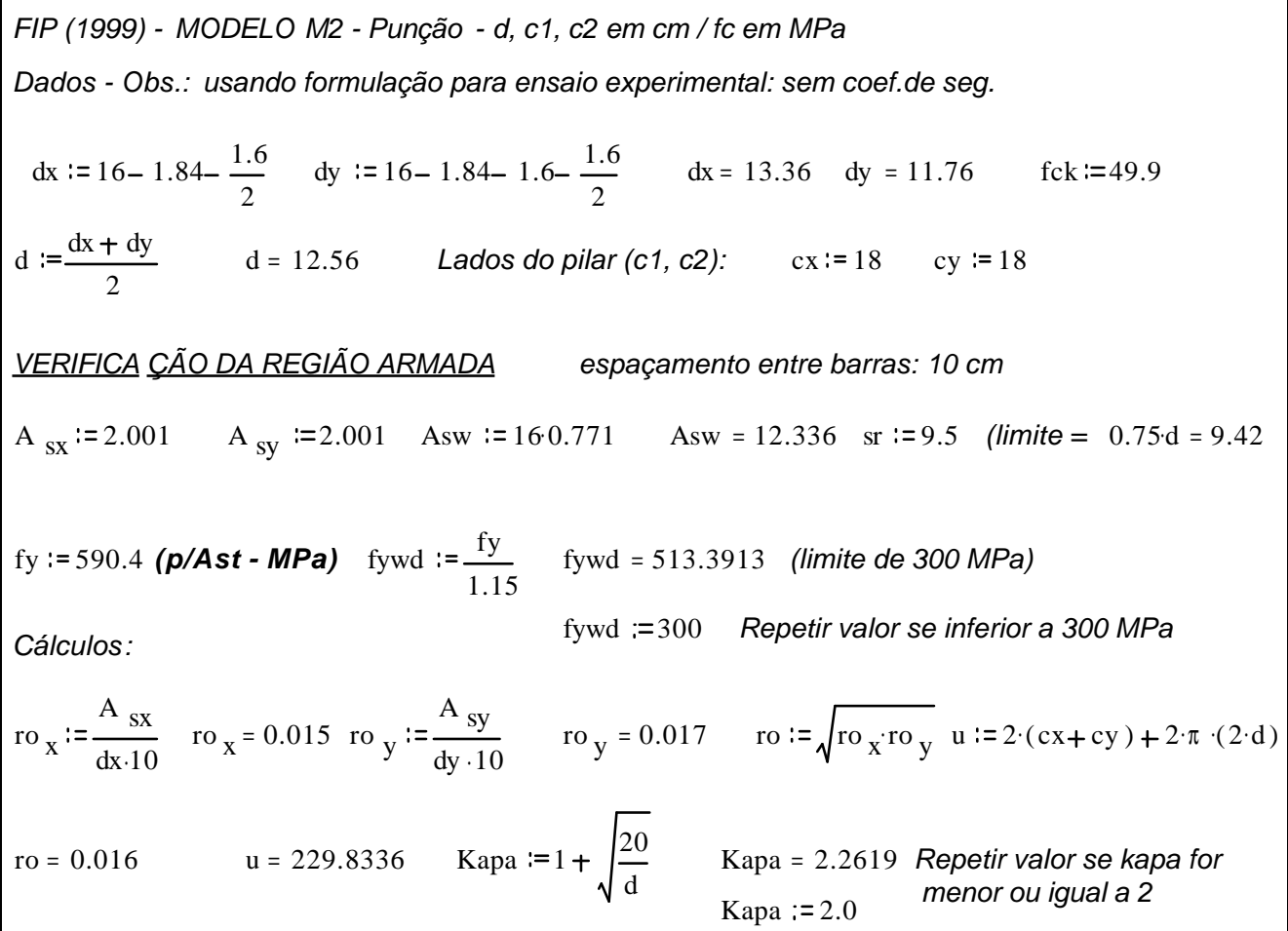

Como quero comparar com resultados experimentais, multiplicar:

TAU1 $:=\frac{1}{10} \cdot\left[1.330 .09 \cdot(\right.$ Kapa $\left.) \cdot(100 \mathrm{ro} \cdot \mathrm{fck})^{\frac{1}{3}}+1.151 .5 \cdot \frac{\mathrm{d}}{\mathrm{sr}} \cdot \frac{\text { Asw } \cdot \mathrm{fywd} \cdot 1}{\mathrm{u} \cdot \mathrm{d}}\right] \begin{aligned} & \mathrm{F}_{\mathrm{k} 1}:=\mathrm{TAU} 1 \cdot \mathrm{u} \cdot \mathrm{d} \\ & \mathrm{F}_{\mathrm{k} 1}=1141.3705\end{aligned}$

VERIFICA CÃO NA FACE DO PILAR (sem coef. de seg.):

$\mathrm{f} 1 \mathrm{~cd}:=0.85 \frac{\mathrm{fck}}{1.5} \quad \mathrm{~F}_{\mathrm{k} 2}:=\frac{1}{10} \cdot 0.5 \cdot \mathrm{f} 1 \mathrm{~cd} \cdot(2 \cdot \mathrm{cx}+2 \cdot \mathrm{cy}) \cdot \mathrm{d} \quad$ Portanto: $\quad \mathrm{F}_{\mathrm{k} 2}=1278.5578$ VERIFICA CÃ̃ ALÉM DA REGIÃO ARMADA (sem coef. de seg.):

Dados: $\quad$ so $:=4.865 \quad$ (limite $=0.5 \cdot \mathrm{d}=6.28) \quad \mathrm{n}:=2 \quad$ ( $n=$ nro. de pinos no conector) $\mathrm{r}_{\text {ext }}:=\mathrm{so}+(\mathrm{n}-1) \cdot \mathrm{sr}+2 \cdot \mathrm{d} \quad \mathrm{u}_{\mathrm{nef}}:=2 \cdot(\mathrm{cx}+\mathrm{cy})+2 \cdot \pi \cdot \mathrm{r}_{\mathrm{ext}} \quad \mathrm{u}_{\mathrm{nef}}=320.0916$ Verificar se u.nef pode ser calculado assim. Caso seja possível - repetir valor: $u_{\text {nef }}:=320.0916$ Tau $_{d}:=\frac{1}{10} \cdot 0.12 \cdot($ Kapa $) \cdot\left(100 \mathrm{ro} \cdot \mathrm{fck}^{\frac{1}{3}} \quad\right.$ Tau $_{\mathrm{d}}=0.1033$ Força concentrada (valor característico) $(k N): \quad \mathrm{F}_{\mathrm{k} 3}:=1.33 \mathrm{Tau}_{\mathrm{d}} \cdot \mathrm{u}_{\text {nef }} \cdot \mathrm{d} \quad \mathrm{F}_{\mathrm{k} 3}=552.1712$ Adotar o valor mais crítico:

$\mathrm{F}_{\mathrm{k} 1}=1141.3705$ (r.armada) $\mathrm{F}_{\mathrm{k} 2}=1278.5578$ (r.armada) $\quad \mathrm{F}_{\mathrm{k} 3}=552.1712$ (r.externa à armada) Taxa de armadura minima: Asminimo $:=\frac{0.03(100 \mathrm{ro} \cdot \mathrm{fck})}{1.5 \cdot \mathrm{fywd}} \cdot\left(\frac{1}{3}\right) \cdot \mathrm{u} \cdot \mathrm{sr} \quad$ Asminimo $=0.6263$ Taxa de armadura minima: $\quad$ Asw $=12.336$ 


\section{c) Modelo M3}

FIP (1999) -MODELO M3 - Punção - d, c1, c2 em cm / fc em MPa

Dados - Obs.: usando formulação para ensaio experimental: sem coef.de seg.

$\mathrm{dx}:=16-1.93-\frac{1.6}{2} \quad \mathrm{dy}:=16-1.93-1.6-\frac{1.6}{2} \quad \mathrm{dx}=13.27 \quad \mathrm{dy}=11.67 \quad \mathrm{fck}:=48.47$

$\mathrm{d}:=\frac{\mathrm{dx}+\mathrm{dy}}{2} \quad \mathrm{~d}=12.47 \quad$ Lados do pilar $(c 1, \mathrm{c} 2): \quad \mathrm{cx}:=18 \quad \mathrm{cy}:=18$

VERIFICACÃO DA REGIÃO ARMADA espaçamento entre barras: $10 \mathrm{~cm}$

$\mathrm{A}_{\mathrm{sx}}:=1.919 \quad \mathrm{~A}_{\mathrm{sy}}:=1.919 \quad$ Asw $:=160.763 \quad$ Asw $=12.208 \quad \mathrm{sr}:=9.5 \quad$ (limite $=0.75 \cdot \mathrm{d}=9.3525$

fy $:=625.3$ (p/Ast - MPa) fywd $:=\frac{\text { fy }}{1.15} \quad$ fywd $=543.7391 \quad$ (limite de 300 MPa)

Cálculos

fywd:=300 Repetir valor se inferior a $300 \mathrm{MPa}$

ro $_{x}:=\frac{A_{\mathrm{sx}}}{\mathrm{dx} \cdot 10} \quad$ ro $\mathrm{x}=0.0145$ ro $\mathrm{y}:=\frac{\mathrm{A}_{\mathrm{sy}}}{\mathrm{dy} \cdot 10} \quad$ ro $_{\mathrm{y}}=0.0164 \quad$ ro $:=\sqrt{\mathrm{ro}_{\mathrm{x}} \cdot \mathrm{ro}_{\mathrm{y}}} \mathrm{u}:=2 \cdot(\mathrm{cx}+\mathrm{cy})+2 \cdot \pi \cdot(2 \cdot \mathrm{d})$

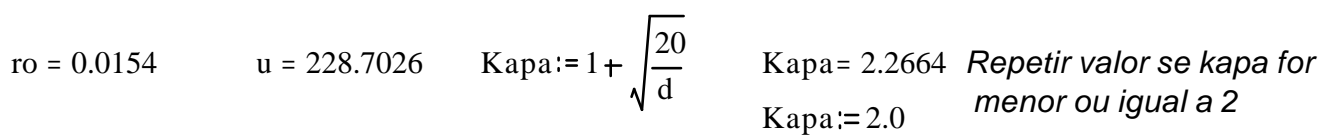

$P /$ comparar com resultados experimentais, multiplicar concreto por 1,33 e aço por 1,15:

TAU $1:=\frac{1}{10} \cdot\left[1.33 \cdot 0.09 \cdot(\right.$ Kapa $\left.) \cdot(100 \mathrm{ro} \cdot \mathrm{fck})^{\frac{1}{3}}+1.15 \cdot 1.5 \cdot \frac{\mathrm{d}}{\mathrm{sr}} \cdot \frac{\text { As w } \cdot \mathrm{fywd} \cdot 1}{\mathrm{u} \cdot \mathrm{d}}\right] \quad \begin{aligned} & \mathrm{F}_{\mathrm{k} 1}:=\mathrm{TAU} 1 \cdot \mathrm{u} \cdot \mathrm{d} \\ & \mathrm{F}_{\mathrm{k} 1}=1116.8724\end{aligned}$

VERIFICACÃO NA FACE DO PILAR (sem coef. de seg.):

$\mathrm{f} 1 \mathrm{~cd}:=0.85 \cdot \frac{\mathrm{fck}}{1.5} \quad \mathrm{~F}_{\mathrm{k} 2}:=\frac{1}{10} \cdot 0.5 \cdot \mathrm{f} 1 \mathrm{~cd}(2 \cdot \mathrm{cx}+2 \cdot \mathrm{cy}) \cdot \mathrm{d} \quad$ Portanto: $\quad \mathrm{F}_{\mathrm{k} 2}=1233.0186$

VERIFICACÃO ALÉM DA REGIÃO ARMADA (sem coef. de seg.):

Dados: $\quad$ so $:=4.865 \quad$ (limite $=0.5 \cdot \mathrm{d}=6.235) \quad \mathrm{n}:=3 \quad$ ( $n=$ nro. de pinos no conector)

$\mathrm{r}_{\text {ext }}:=\mathrm{so}+(\mathrm{n}-1) \cdot \mathrm{sr}+2 \cdot \mathrm{d} \quad \mathrm{u}_{\mathrm{nef}}:=2 \cdot(\mathrm{cx}+\mathrm{cy})+2 \cdot \pi \cdot \mathrm{r}_{\mathrm{ext}} \quad \mathrm{u}_{\mathrm{nef}}=378.6509$

Verificar se u.nef pode ser calculado desta maneira. Se foru nef : $=378.6509$ possível, então repetir valor

Tau $_{d}:=\frac{1}{10} \cdot 0.12 \cdot($ Kapa $) \cdot(100 \cdot \text { ro } \cdot f c k)^{\frac{1}{3}} \quad$ Tau $_{d}=0.1011$

Força concentrada (valor característico) (kN): $\quad \mathrm{F}_{\mathrm{k} 3}:=1.33 \cdot \mathrm{Tau}_{\mathrm{d}} \cdot \mathrm{u}_{\mathrm{nef}}{ }^{\mathrm{d}} \quad \mathrm{F}_{\mathrm{k} 3}=634.8835$

Adotar o valor mais crítico:

$\mathrm{F}_{\mathrm{k} 1}=1116.8724$ (r.armada) $\mathrm{F}_{\mathrm{k} 2}=1233.0186$ (r.adjacente) $\quad \mathrm{F}_{\mathrm{k} 3}=634.8835$ (r.alem da armada)

Taxa de armadura minima: Asminimo: $=\frac{0.03(100 \cdot \mathrm{ro} \cdot \mathrm{fck})^{\left(\frac{1}{3}\right)} \cdot \mathrm{u}}{1.5 \cdot \mathrm{fywd}} \cdot \mathrm{sr} \quad$ Asminimo $=0.6101$

Taxa de armadura minima: $\quad \mathrm{Asw}=12.208$ 


\section{d) Modelo M4}

FIP (1999) - MODELO M4 - Punção - d, c1, c2 em cm / fc em MPa

Dados - Obs.: usando formulação para ensaio experimental: sem coef.de seg.

$\mathrm{dx}:=16-1.28-\frac{1.25}{2} \quad \mathrm{dy}:=\mathrm{dx}-1.25$

$\mathrm{dx}=14.095 \mathrm{dy}=12.845 \quad$ fck $:=51.92$

$$
\mathrm{A}_{\mathrm{Sx}}:=1.188 \quad \mathrm{~A}_{\mathrm{Sy}}:=1.188
$$

Lados do pilar (c1, c2): $\quad$ cx $:=18 \quad$ cy $:=18$

espaçamento entre barras: $10 \mathrm{~cm}$

Calculos iniciais:

$$
\begin{aligned}
& \mathrm{d}:=\frac{\mathrm{dx}+\mathrm{dy}}{2} \quad \text { ro }_{\mathrm{x}}:=\frac{\mathrm{A}_{\mathrm{sx}}}{\mathrm{dx} \cdot 10} \quad \text { ro }_{\mathrm{y}}:=\frac{\mathrm{A}_{\mathrm{sy}}}{\mathrm{dy} \cdot 10} \quad \text { ro }:=\sqrt{\text { ro }_{\mathrm{x}} \text { ro } y} \quad u:=2 \cdot(\mathrm{cx}+\mathrm{cy})+2 \cdot \pi \cdot(2 \cdot \mathrm{d}) \\
& \mathrm{d}=13.47 \quad \text { ro }=0.0088 \quad \mathrm{u}=241.269 \quad \text { ro }_{\mathrm{x}}=0.0084 \quad \text { ro }_{\mathrm{y}}=0.0092 \quad \text { ro }=0.0088 \\
& \text { Kapa }:=1+\sqrt{\frac{20}{d}} \quad \text { Kapa }=2.2185
\end{aligned}
$$

Tensao Tau.d(kN/cm2): $\quad$ Tau $_{d}:=(100 \cdot \mathrm{ro} \cdot \mathrm{fck})^{\frac{1}{3}} \cdot \frac{1}{10} \cdot 0.12 \cdot \mathrm{Kapa}_{\mathrm{K}} \quad \mathrm{Tau}_{\mathrm{d}}=0.0859$

Tensao Tau.k(kN/cm2): $\quad \operatorname{Tau}_{\mathrm{k}}:=1.33 \cdot \mathrm{Tau}_{\mathrm{d}} \quad \mathrm{Tau}_{\mathrm{k}}=0.1142$

$$
\text { Força concentrada (valor característico) }(\mathrm{kN}): \quad \mathrm{F}_{\mathrm{k}}:=\mathrm{Tau}_{\mathrm{k}} \cdot \mathrm{u} \cdot \mathrm{d} \quad \mathrm{F}_{\mathrm{k}}=371.2637
$$

Contribuição da protensão:

Direção do eixo $x$

$\mathrm{hx}(\mathrm{x}):=-0.00021488 \mathrm{x}^{2}+0.05372 \mathrm{x}$

$\mathrm{x}:=\frac{250}{2}-\frac{\mathrm{cx}}{2}-2 \cdot \mathrm{d} \quad \mathrm{x}=89.06$

alfa_radx $=\operatorname{atan}\left\{\frac{\mathrm{d}^{1}}{\mathrm{~d} \mathrm{x} 1} \mathrm{hx}(\mathrm{x})\right\}_{\sin (\text { alfa_rad } x)=0.0154}$ alfa_radx $=0.0154 \mid$
Pxm: $=136.69$

Direção do eixo y

$$
\text { hy }(y):=-0.00029488 y^{2}+0.07372 y
$$$$
\mathrm{y}:=\frac{250}{2}-\frac{\mathrm{cy}}{2}-2 \cdot \mathrm{d} \quad \mathrm{y}=89.06
$$

alfa_rady: $=\operatorname{atan}\left\{\frac{\mathrm{d}^{1}}{\mathrm{dy} 1} \mathrm{hy}(\mathrm{y})\right\} \quad$ alfa_rady $=0.0212$ $\sin ($ alfa_rady $)=0.0212$

Pym:=137.83

$\mathrm{Vpx}:=2 \cdot 4 \cdot \mathrm{Pxm} \cdot \sin ($ alfa_radx $) \quad \mathrm{Vpx}=16.888$

Vpy $:=2 \cdot 4 \cdot P y m \cdot \sin ($ alfa_rady $) \quad V p y=23.3663$

Resist_total $=\mathrm{Vpx}+\mathrm{Vpy}+\mathrm{F}_{\mathrm{k}} \quad$ Resist_total 411.5181 Tem que ser menor que o Fk2:

OK!

VERIFICAÇÃO ADICIONAL (face do pilar) ( sem coef. de seg.):

$\mathrm{f} 1 \mathrm{~cd}:=0.85 \frac{\mathrm{fck}}{1.5} \quad \mathrm{f} 1 \mathrm{~cd}=29.4213 \quad \mathrm{~F}_{\mathrm{k} 2}:=\frac{1}{10} \cdot 0.5 \cdot \mathrm{f} 1 \mathrm{~cd} \cdot(2 \cdot \mathrm{cx}+2 \cdot \mathrm{cy}) \cdot \mathrm{d} \quad \mathrm{F}_{\mathrm{k} 2}=1426.6993$ 


\section{f) Modelo M5}

FIP (1999) - MODELOM5 - Punção - d, c1, c2 em cm / fc em MPa

Dados - Obs.: usando formulação para ensaio experimental: sem coef.de seg.

$$
\mathrm{dx}:=16-1.49-\frac{1.25}{2} \quad \mathrm{dy}:=\mathrm{dx}-1.25 \quad \mathrm{dx}=13.885 \quad \mathrm{dy}=12.635 \quad \mathrm{fck}:=59.4
$$

$\mathrm{d}:=\frac{\mathrm{dx}+\mathrm{dy}}{2} \quad \mathrm{~d}=13.26 \quad$ Lados do pilar $(c 1, \mathrm{c} 2): \quad \mathrm{cx}:=18 \quad \mathrm{cy}:=18$

\section{VERIFICACÃO DA REGIÃO ARMADA espaçamento entre barras: $10 \mathrm{~cm}$}

$\mathrm{A}_{\mathrm{sx}}:=1.188 \quad \mathrm{~A}_{\mathrm{sy}}:=1.188 \quad$ Asw $:=16 \cdot 0.763 \quad$ Asw $=12.208 \quad \mathrm{sr}:=9.5 \quad$ (limite $=0.75 \cdot \mathrm{d}=9.945$

fy $:=633.9$ (p/Ast - MPa) fywd $:=\frac{\text { fy }}{1.15} \quad$ fywd $=551.2174 \quad$ (limite de $300 \mathrm{MPa}$ )

Cálculos: fywd :=300 Repetir valor se inferior a $300 \mathrm{MPa}$

ro $_{x}:=\frac{A_{s x}}{d x \cdot 10} \quad$ ro $x=0.0086$ ro $_{y}:=\frac{A_{s y}}{d y \cdot 10} \quad$ ro $_{y}=0.0094 \quad$ ro $:=\sqrt{\text { ro }_{x} \cdot r_{y}} u:=2 \cdot(c x+c y)+2 \cdot \pi \cdot(2 \cdot d)$ $\mathrm{ro}=0.009 \quad \mathrm{u}=238.6301 \quad$ Kapa $:=1+\sqrt{\frac{20}{\mathrm{~d}}} \quad \begin{aligned} & \text { Kapa }=2.2281 \\ & \text { Kapa }:=2.0 \quad \begin{array}{l}\text { Repetir valor se } k \text { kapa for } \\ \text { menor ou igual } \mathrm{a} 2\end{array}\end{aligned}$

Como quero comparar com resultados experimentais, multiplicar:

PRtanto: $: \frac{1}{10} \cdot\left[1.33 \cdot 0.09 \cdot(\mathrm{Kapa}) \cdot(100 \cdot \mathrm{ro} \cdot \mathrm{fck})^{\frac{1}{3}}+1.15 \cdot 1.5 \cdot \frac{\mathrm{d}}{\mathrm{sr}} \cdot \frac{\mathrm{Asw} \cdot \mathrm{fywd} \cdot 1}{\mathrm{u} \cdot \mathrm{d}}\right] \begin{aligned} & \mathrm{F}_{\mathrm{k} 1}:=\mathrm{TAU} 1 \cdot \mathrm{u} \cdot \mathrm{d} \\ & \mathrm{F}_{\mathrm{k} 1}=1166.8503\end{aligned}$

Contribuição da protensão:

Direção do eixo $x$

$\mathrm{hx}(\mathrm{x}):=-0.00021488 \mathrm{x}^{2}+0.05372 \mathrm{x}$

$\mathrm{x}:=\frac{250}{2}-\frac{\mathrm{cx}}{2}-2 \cdot \mathrm{d} \quad \mathrm{x}=89.48$

alfa_radx: $\operatorname{atan}\left\{\frac{\mathrm{d}^{1}}{\mathrm{dx}^{1}} \mathrm{hx}(\mathrm{x})\right\}_{\sin (\text { alfa_rad } x=0.0153 /}^{\text {alfa_radx }=0.0153 /}$

Pxm:= 136.74

$V p x:=2 \cdot 4 \cdot P x m \cdot \sin ($ alfa_radx $) \quad V p x=16.6968$

/ Pym:=146.14

Direção do eixo y

$$
\text { hy }(y):=-0.00029488 y^{2}+0.07372 y
$$$$
y:=\frac{250}{2}-\frac{c y}{2}-2 \cdot d \quad y=89.48
$$

alfa_rady: $=\operatorname{atan}\left\{\frac{\mathrm{d}^{1}}{\mathrm{~d} \mathrm{y} 1} \mathrm{hy}(\mathrm{y})\right\}$ alfa_rady $=0.0209$ $\sin ($ alfa_rady $)=0.0209$

Vpy $:=2 \cdot 4 \cdot P y m \cdot \sin ($ alfa_rady $) \quad V p y=24.4857$

$$
\mathrm{F}_{\mathrm{k} 1 \text { total }}:=\mathrm{Vpx}+\mathrm{Vpy}+\mathrm{F}_{\mathrm{k} 1}
$$

$\mathrm{F}_{\mathrm{k} 1 \text { total }}=1208.0328$ 


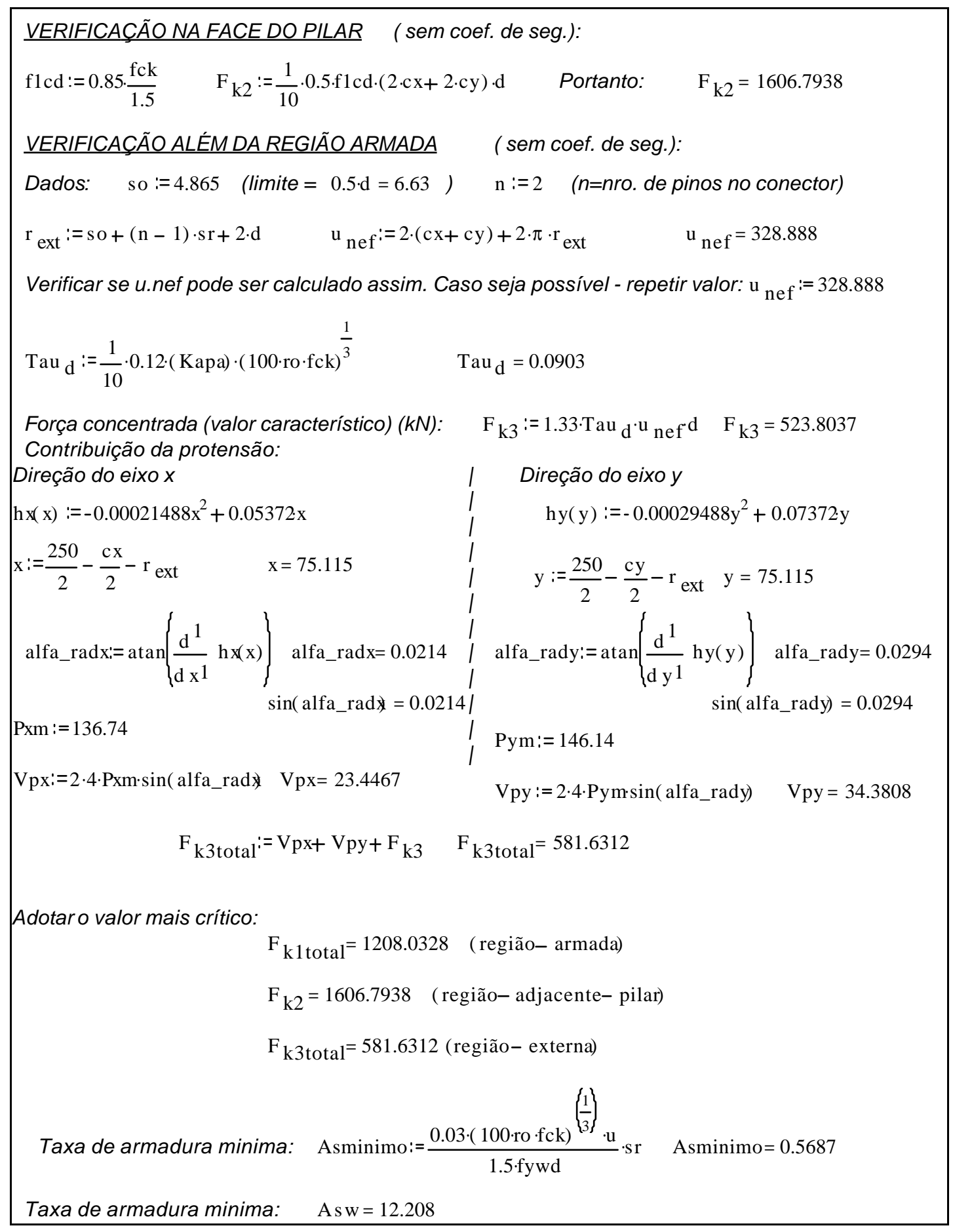




\section{g) Modelo M6}

FIP (1999) - MODELOM6 - Punção - d, c1, c2 em cm / fc em MPa

Dados - Obs.: usando formulação para ensaio experimental: sem coef.de seg.

$$
\mathrm{dx}:=16-1.59-\frac{1.25}{2} \quad \mathrm{dy}:=\mathrm{dx}-1.25 \quad \mathrm{dx}=13.785 \quad \mathrm{dy}=12.535 \quad \mathrm{fck}:=51.56
$$

$\mathrm{d}:=\frac{\mathrm{dx}+\mathrm{dy}}{2} \quad \mathrm{~d}=13.16 \quad$ Lados do pilar $(c 1, \mathrm{c} 2): \quad \mathrm{cx}:=18 \quad \mathrm{cy}:=18$

\section{VERIFICACÃO DA REGIÃO ARMADA espaçamento entre barras: $10 \mathrm{~cm}$}

$\mathrm{A}_{\mathrm{sX}}:=1.188 \quad \mathrm{~A}_{\mathrm{sy}}:=1.188 \quad$ Asw $:=16 \cdot 0.763 \quad$ Asw $=12.208 \quad \mathrm{sr}:=9.5 \quad$ (limite $=0.75 \cdot \mathrm{d}=9.87$

fy $:=633.9$ (p/Ast - MPa) fywd $:=\frac{\text { fy }}{1.15} \quad$ fywd $=551.2174 \quad$ (limite de $300 \mathrm{MPa}$ )

Cálculos: fywd :=300 Repetir valor se inferior a $300 \mathrm{MPa}$

ro $_{x}:=\frac{A_{s x}}{d x \cdot 10} \quad$ ro $x=0.0086$ ro $_{y}:=\frac{A_{s y}}{d y \cdot 10} \quad$ ro $_{y}=0.0095 \quad$ ro $:=\sqrt{\text { ro }_{x} \cdot r_{y}} u:=2 \cdot(c x+c y)+2 \cdot \pi \cdot(2 \cdot d)$ ro $=0.009 \quad \mathrm{u}=237.3734 \quad$ Kapa $:=1+\sqrt{\frac{20}{\mathrm{~d}}} \quad \begin{aligned} & \text { Kapa }=2.2328 \\ & \text { Kapa }:=2.0 \quad \begin{array}{l}\text { Repetir valor se } \text { kapa for } \\ \text { menor ou igual } a 2\end{array}\end{aligned}$

Como quero comparar com resultados experimentais, multiplicar:

PRtanto: $: \frac{1}{10} \cdot\left[1.33 \cdot 0.09 \cdot(\mathrm{Kapa}) \cdot(100 \cdot \mathrm{ro} \cdot \mathrm{fck})^{\frac{1}{3}}+1.15 \cdot 1.5 \cdot \frac{\mathrm{d}}{\mathrm{sr}} \cdot \frac{\mathrm{Asw} \cdot \mathrm{fywd} \cdot 1}{\mathrm{u} \cdot \mathrm{d}}\right] \begin{aligned} & \mathrm{F}_{\mathrm{k} 1}:=\mathrm{TAU} 1 \cdot \mathrm{u} \cdot \mathrm{d} \\ & \mathrm{F}_{\mathrm{k} 1}=1144.2716\end{aligned}$

Contribuição da protensão:

Direção do eixo $x$

$\mathrm{hx}(\mathrm{x}):=-0.00021488 \mathrm{x}^{2}+0.05372 \mathrm{x}$

$\mathrm{x}:=\frac{250}{2}-\frac{\mathrm{cx}}{2}-2 \cdot \mathrm{d} \quad \mathrm{x}=89.68$

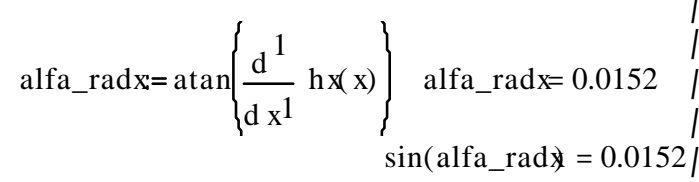

Pxm:= 145.49

$V p x:=2 \cdot 4 \cdot P x m \cdot \sin ($ alfa_radx $) \quad V p x=17.6653$

/ Pym:=149.42

Direção do eixo y

$$
\text { hy }(y):=-0.00029488 y^{2}+0.07372 y
$$$$
y:=\frac{250}{2}-\frac{c y}{2}-2 \cdot d \quad y=89.68
$$

alfa_rady: $=\operatorname{atan}\left\{\frac{\mathrm{d}^{1}}{\mathrm{~d} \mathrm{y} 1} \mathrm{hy}(\mathrm{y})\right\}$ alfa_rady $=0.0208$ $\sin ($ alfa_rady $)=0.0208$

Vpy $:=2 \cdot 4 \cdot P y m \cdot \sin ($ alfa_rady $) \quad V p y=24.8943$

$$
\mathrm{F}_{\mathrm{k} 1 \text { total }}:=\mathrm{Vpx}+\mathrm{Vpy}+\mathrm{F}_{\mathrm{k} 1}
$$

$\mathrm{F}_{\mathrm{k} 1 \text { total }}=1186.8312$ 


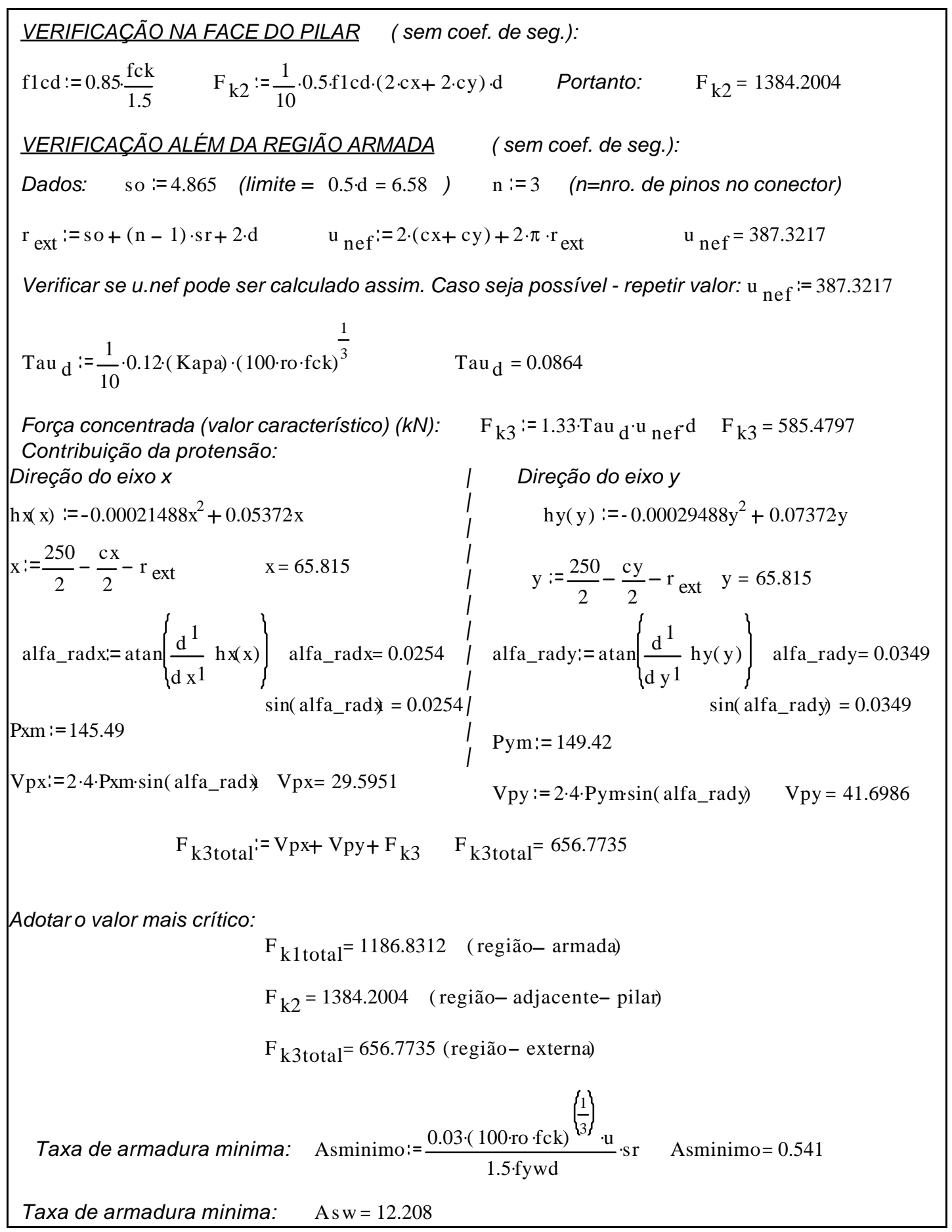




\section{J.4. fib (1999)}

\section{a) Modelo M1}

fib (1999) - MODELO M1 - Punção - d, c1, c2 em cm / fc em MPa

Dados - Obs.: usando formulação para ensaio experimental: sem coef.de seg.

$\mathrm{dx}:=16-1.66-\frac{1.6}{2} \quad \mathrm{dy}:=16-1.66-1.6-\frac{1.6}{2} \quad \mathrm{dx}=13.54 \quad \mathrm{dy}=11.94 \quad$ fck $:=26.6$

$$
\begin{array}{lll}
\mathrm{A}_{\mathrm{Sx}}:=2.001 \quad \mathrm{~A}_{\mathrm{Sy}}:=2.001 \quad \text { Lados do pilar }(\mathbf{c 1}, \mathbf{c 2}): \quad \mathrm{cx}:=18 \quad \mathrm{cy}:=18 \\
& \text { espaçamento entre barras: } \mathbf{1 0} \mathbf{~ c m}
\end{array}
$$

Calculos iniciais:

$$
\begin{aligned}
& \mathrm{d}:=\frac{\mathrm{dx}+\mathrm{dy}}{2} \quad \text { ro }_{\mathrm{x}}:=\frac{\mathrm{A}_{\mathrm{sx}}}{\mathrm{dx} \cdot 10} \quad \text { ro } \mathrm{y}:=\frac{\mathrm{A}_{\mathrm{sy}}}{\mathrm{dy} \cdot 10} \quad \text { ro }:=\sqrt{\text { ro }_{\mathrm{x}} \cdot \mathrm{ro}_{\mathrm{y}}} \quad \mathrm{u}:=2 \cdot(\mathrm{cx}+\mathrm{cy})+2 \cdot \pi \cdot(2 \cdot \mathrm{d}) \\
& \mathrm{d}=12.74 \quad \text { ro }=0.0157 \quad \mathrm{u}=232.0956 \quad \text { ro }_{\mathrm{x}}=0.0148 \quad \text { ro } \mathrm{y}=0.0168 \quad \text { ro }=0.0157
\end{aligned}
$$

Kapa $:=1+\sqrt{\frac{20}{d}} \quad$ Kapa $=2.2529 \quad$ (sem limitação para o valor de kapa)

Tensao Tau.d (kN/cm2): $\quad \mathrm{Tau}_{\mathrm{d}}:=(100 \cdot \mathrm{ro} \cdot \mathrm{fck})^{\frac{1}{3}} \cdot \frac{1}{10} \cdot 0.12 \cdot \mathrm{Kapa} \quad \mathrm{Tau}_{\mathrm{d}}=0.0939$

Tensao Tau.k (kN/cm2): $\quad \operatorname{Tau}_{\mathrm{k}}:=1.33 \cdot \mathrm{Tau}_{\mathrm{d}} \quad \mathrm{Tau}_{\mathrm{k}}=0.1248$

Força concentrada (valor característico) (kN): $\quad \mathrm{F}_{\mathrm{k}}:=\mathrm{Tau}_{\mathrm{k}} \cdot \mathrm{u} \cdot \mathrm{d} \quad \mathrm{F}_{\mathrm{k}}=369.1684$

VERIFICAÇÃO ADICIONAL (face do pilar) ( sem coef. de seg.):

$\begin{array}{ll}\mathrm{fcd} 2:=\left\{1-\frac{\mathrm{fck}}{250}\right\} \cdot 0.6 \cdot \mathrm{fck} \quad \mathrm{fcd} 2=14.2619 & \\ \mathrm{~F}_{\mathrm{k} 2}:=\frac{1}{10} \cdot 0.5 \cdot \mathrm{fcd} 2 \cdot(2 \cdot \mathrm{cx}+2 \cdot \mathrm{cy}) \cdot \mathrm{d} & \mathrm{F}_{\mathrm{k} 2}=654.1058\end{array}$ 


\section{b) Modelo M2}

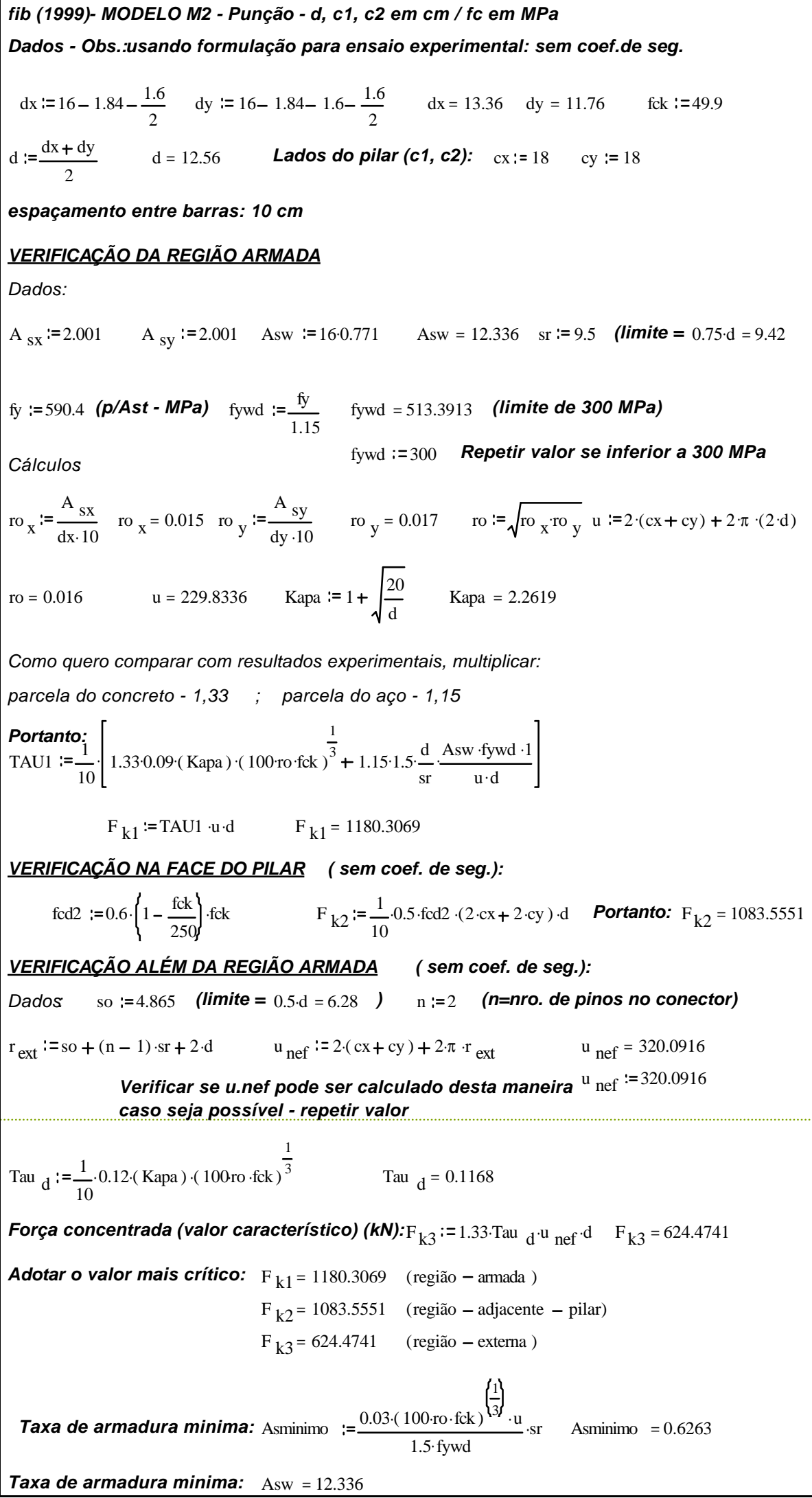




\section{c) Modelo M3}

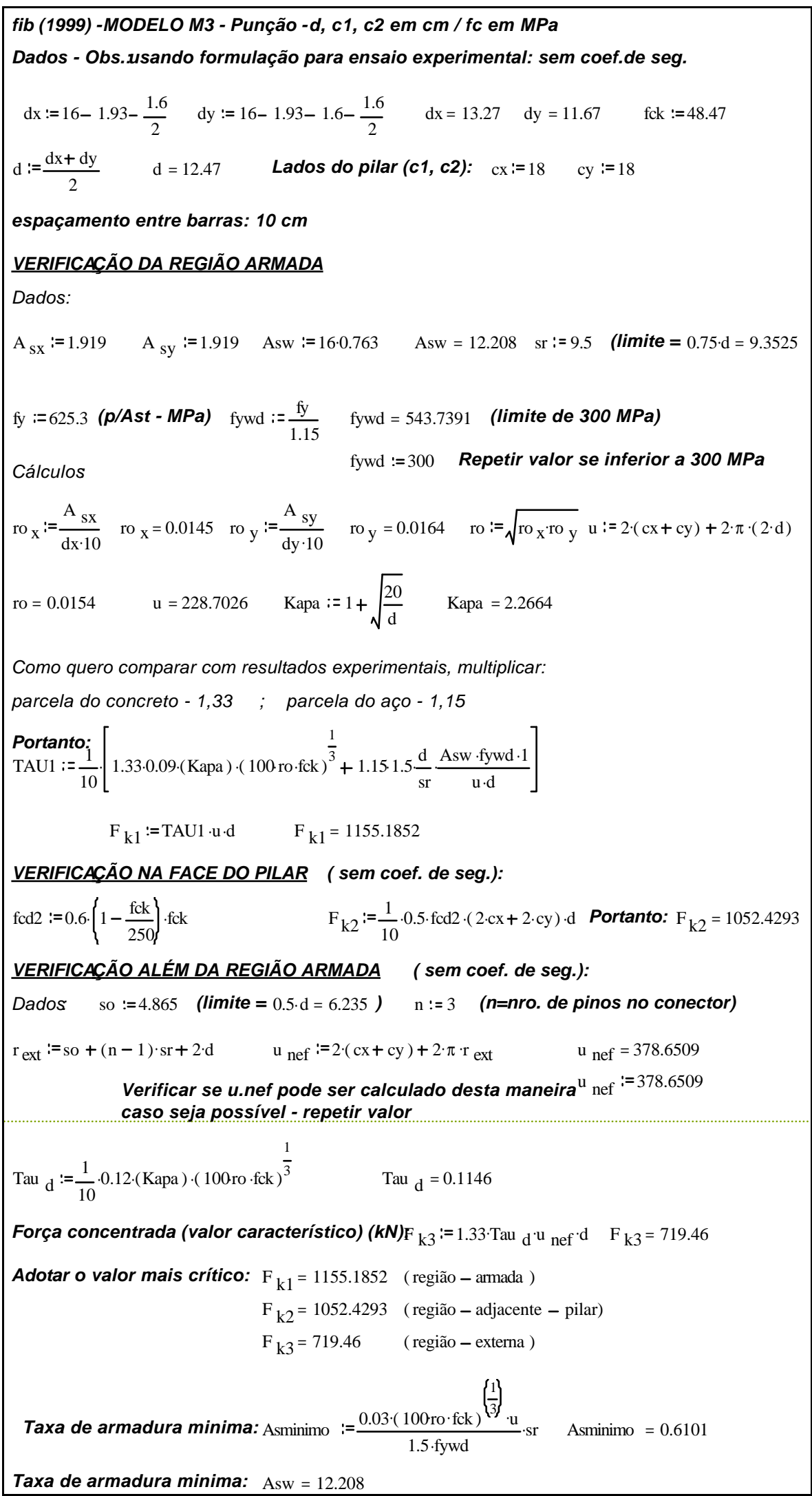




\section{d) Modelo M4}

fib (1999)- MODELO M4 - Punção - d, c1, c2 em cm / fc em MPa

Dados - Obs.: usando formulação para ensaio experimental: sem coef.de seg.

$\mathrm{dx}:=16-1.28-\frac{1.25}{2} \quad \mathrm{dy}:=\mathrm{dx}-1.25 \quad \mathrm{dx}=14.095 \quad \mathrm{dy}=12.845 \quad$ fck $:=51.92$

$$
\mathrm{A}_{\mathrm{sx}}:=1.188 \quad \mathrm{~A}_{\mathrm{sy}}:=1.188 \quad \text { Lados do pilar }(\mathrm{c} 1, \mathrm{c} 2): \quad \mathrm{cx}:=18 \quad \mathrm{cy}:=18
$$

espaçamento entre barras: $10 \mathrm{~cm}$

Calculos iniciais:

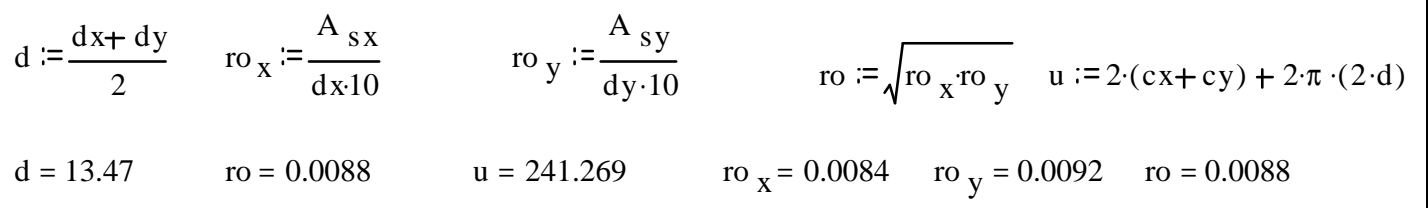

Kapa $:=1+\sqrt{\frac{20}{d}} \quad$ Kapa $=2.2185$ (sem limitação para o valor de Kapa)

Tensao Tau.d(kN/cm2): $\quad$ Tau $_{d}:=(100 \cdot \mathrm{ro} \cdot \mathrm{fck})^{\frac{1}{3}} \cdot \frac{1}{10} \cdot 0.12 \cdot \mathrm{Kapa} \quad \mathrm{Tau}_{\mathrm{d}}=0.0953$

Tensao Tau.k(kN/cm2): $\quad$ Tau $_{\mathrm{k}}:=1.33 \cdot \mathrm{Tau}_{\mathrm{d}} \quad \mathrm{Tau}_{\mathrm{k}}=0.1267$

Força concentrada (valor característico) $(\mathrm{kN}): \quad \mathrm{F}_{\mathrm{k}}:=\mathrm{Tau}_{\mathrm{k}} \cdot \mathrm{u} \cdot \mathrm{d} \quad \mathrm{F}_{\mathrm{k}}=411.8273$

Contribuição da protensão:

Direção do eixo $x$

$\mathrm{hx}(\mathrm{x}):=-0.00021488 \mathrm{x}^{2}+0.05372 \mathrm{x}$

$\mathrm{x}:=\frac{250}{2}-\frac{\mathrm{cx}}{2}-2 \cdot \mathrm{d} \quad \mathrm{x}=89.06$

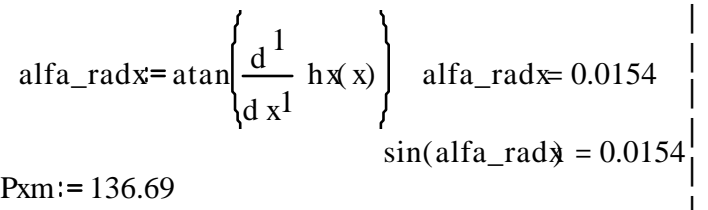

Pxm:= 136.69

$\mathrm{Vpx}:=2 \cdot 4 \cdot \mathrm{Pxm} \cdot \sin ($ alfa_radx $) \quad \mathrm{Vpx}=16.888$

\section{Direção do eixo y}

$$
\mathrm{hy}(\mathrm{y}):=-0.00029488 \mathrm{y}^{2}+0.07372 \mathrm{y}
$$$$
\mathrm{y}:=\frac{250}{2}-\frac{\mathrm{cy}}{2}-2 \cdot \mathrm{d} \quad \mathrm{y}=89.06
$$

alfa_rady: $=\operatorname{atan}\left\{\frac{\mathrm{d}^{1}}{\mathrm{~d} \mathrm{y} 1} \mathrm{hy}(\mathrm{y})\right\} \quad$ alfa_rady $=0.0212$ $\sin ($ alfa_rady $)=0.0212$

Pym: $=137.83$

Vpy:=2·4·Pym $\sin ($ alfa_rady) $\quad$ py $=23.3663$

Resist_total $=\mathrm{Vpx}+\mathrm{Vpy}+\mathrm{F}_{\mathrm{k}} \quad$ Resist_totak $452.0816 \quad$ Tem que ser menor que o Fk2:

$\mathrm{OK}$ ! VERIFICAÇÃO ADICIONAL (face do pilar) ( sem coef. de seg.):

$\mathrm{fcd} 2:=\left\{1-\frac{\mathrm{fck}}{250}\right\} \cdot 0.6 \cdot \mathrm{fck} \quad \mathrm{fcd} 2=24.6824 \quad \mathrm{~F}_{\mathrm{k} 2}:=\frac{1}{10} \cdot 0.5 \cdot \mathrm{fcd} 2 \cdot(2 \cdot \mathrm{cx}+2 \cdot \mathrm{cy}) \cdot \mathrm{d} \quad \mathrm{F}_{\mathrm{k} 2}=1196.8966$ 


\section{e) Modelo M5}

fib (1999) -MODELOM5 - Punção - d, c1, c2 em cm / fc em MPa

Dados - Obs.: usando formulação para ensaio experimental: sem coef.de seg.

$$
\mathrm{dx}:=16-1.49-\frac{1.25}{2} \quad \mathrm{dy}:=\mathrm{dx}-1.25 \quad \mathrm{dx}=13.885 \quad \mathrm{dy}=12.635 \quad \mathrm{fck}:=59.4
$$

$\mathrm{d}:=\frac{\mathrm{dx}+\mathrm{dy}}{2} \quad \mathrm{~d}=13.26 \quad$ Lados do pilar $(\mathrm{c} 1, \mathrm{c} 2): \quad \mathrm{cx}:=18 \quad \mathrm{cy}:=18$

\section{VERIFICACÃO DA REGIÃO ARMADA espaçamento entre barras: $10 \mathrm{~cm}$}

$\mathrm{A}_{\mathrm{sx}}:=1.188 \quad \mathrm{~A}_{\mathrm{sy}}:=1.188 \quad$ Asw $:=16.0 .763 \quad$ Asw $=12.208 \quad$ sr $:=9.5 \quad$ (limite $=0.75 \cdot \mathrm{d}=9.945$

fy $:=633.9$ (p/Ast - MPa) $\quad$ fywd $:=\frac{\text { fy }}{1.15} \quad$ fywd $=551.2174 \quad$ (limite de $300 \mathrm{MPa}$ )

Cálculos:

fywd :=300 Repetir valor se inferior a $300 \mathrm{MPa}$

ro $_{x}:=\frac{A_{\mathrm{sx}}}{\mathrm{dx} \cdot 10} \quad$ ro $_{\mathrm{x}}=0.008$ ro $_{\mathrm{y}}:=\frac{\mathrm{A}_{\mathrm{sy}}}{\mathrm{dy} \cdot 10} \quad$ ro $_{\mathrm{y}}=0.0094 \quad$ ro $:=\sqrt{\mathrm{ro}_{\mathrm{x}} \cdot \mathrm{ro}_{\mathrm{y}}} \mathrm{u}:=2 \cdot(\mathrm{cx}+\mathrm{cy})+2 \cdot \pi \cdot(2 \cdot \mathrm{d})$ ro $=0.009 \quad \mathrm{u}=238.6301 \quad$ Kapa $:=1+\sqrt{\frac{20}{\mathrm{~d}}} \quad$ Kapa $=2.2281 \quad \begin{aligned} & \text { Sem limitação para o valor } \\ & \text { de Kapa }\end{aligned}$

Como quero comparar com resultados experimentais, multiplicar:

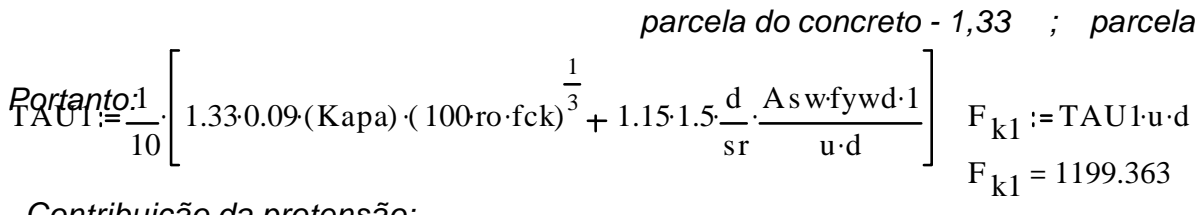

Contribuição da protensão:

Direção do eixo $x$

$\mathrm{hx}(\mathrm{x}):=-0.00021488 \mathrm{x}^{2}+0.05372 \mathrm{x}$

$\mathrm{x}:=\frac{250}{2}-\frac{\mathrm{cx}}{2}-2 \cdot \mathrm{d} \quad \mathrm{x}=89.48$

alfa_radx $=\operatorname{atan}\left\{\frac{\mathrm{d}^{1}}{\mathrm{~d} \mathrm{x}^{1}} \mathrm{hx}(\mathrm{x})\right\}_{\sin (\text { alfa_rad } x)=0.0153 /}^{\text {alfa_radx }=0.0153 /}$

Pxm:= 136.74

/ Pym:=146.14

$V p x:=2 \cdot 4 \cdot P x m \cdot \sin ($ alfa_radx $) \quad V p x=16.6968$

$$
\mathrm{Vpy}:=2 \cdot 4 \cdot \mathrm{Pym} \cdot \sin (\text { alfa_rady }) \quad \mathrm{Vpy}=24.4857
$$

$$
\mathrm{F}_{\mathrm{k} 1 \text { total }}:=\mathrm{Vpx}+\mathrm{Vpy}+\mathrm{F}_{\mathrm{k} 1}
$$

$\mathrm{F}_{\mathrm{k} 1 \text { total }}=1240.5455$ 
VERIFICACÃO NA FACE DO PILAR (sem coef. de seg.):

$\mathrm{fcd} 2:=\left\{1-\frac{\mathrm{fck}}{250}\right\} \cdot 0.6 \cdot \mathrm{fck} \quad \mathrm{fcd} 2=27.1719 \quad \mathrm{~F}_{\mathrm{k} 2}:=\frac{1}{10} \cdot 0.5 \cdot \mathrm{fcd} 2 \cdot(2 \cdot \mathrm{cx}+2 \cdot \mathrm{cy}) \cdot \mathrm{d} \quad \mathrm{F}_{\mathrm{k} 2}=1297.0795$

\section{VERIFICACÃO ALÉM DA REGIÃO ARMADA (sem coef. de seg.):}

Dados: $\quad$ so $:=4.865 \quad$ (limite $=0.5 \cdot \mathrm{d}=6.63 \quad$ ) $\mathrm{n}:=2 \quad$ ( $n=$ nro. de pinos no conector)

$\mathrm{r}_{\text {ext }}:=\mathrm{so}+(\mathrm{n}-1) \cdot \mathrm{sr}+2 \cdot \mathrm{d} \quad \mathrm{u}_{\mathrm{nef}}:=2 \cdot(\mathrm{cx}+\mathrm{cy})+2 \cdot \pi \cdot \mathrm{r}_{\text {ext }} \quad \mathrm{u}_{\mathrm{nef}}=328.888$

Verificar se u.nef pode ser calculado assim. Caso seja possível - repetir valor: u nef $:=328.888$

Tau $_{d}:=\frac{1}{10} \cdot 0.12 \cdot($ Kapa $) \cdot\left(100 \cdot \mathrm{ro} \cdot \mathrm{fck}^{\frac{1}{3}} \quad \mathrm{Tau}_{\mathrm{d}}=0.1006\right.$

Força concentrada (valor característico) $(k N): \quad \mathrm{F}_{\mathrm{k} 3}:=1.33 \cdot \mathrm{Tau}_{\mathrm{d}} \cdot \mathrm{u}_{\mathrm{nef}}{ }^{\mathrm{d}} \quad \mathrm{F}_{\mathrm{k} 3}=583.5505$

Contribuição da protensão:

Direção do eixo $x$

$\mathrm{hx}(\mathrm{x}):=-0.00021488 \mathrm{x}^{2}+0.05372 \mathrm{x}$

$\mathrm{x}:=\frac{250}{2}-\frac{\mathrm{cx}}{2}-\mathrm{r}$ ext $\quad \mathrm{x}=75.115$ alfa_radx:= $\operatorname{atan}\left\{\frac{\mathrm{d}^{1}}{\mathrm{~d} \mathrm{x}^{1}} \mathrm{hx}(\mathrm{x})\right\}_{\sin (\text { alfa_rad } x)=0.0214 /}^{\text {alfa_radx }=0.0214}$

Pxm : $=136.74$

$\mathrm{Vpx}:=2 \cdot 4 \cdot \mathrm{Pxm} \cdot \sin ($ alfa_radx $\quad \mathrm{Vpx}=23.4467$

/ Pym:=146.14

| Direção do eixo y

/ $\quad \mathrm{hy}(\mathrm{y}):=-0.00029488 \mathrm{y}^{2}+0.07372 \mathrm{y}$

/ $\quad \mathrm{y}:=\frac{250}{2}-\frac{\mathrm{cy}}{2}-\mathrm{r}$ ext $\mathrm{y}=75.115$

/ alfa_rady: $=\operatorname{atan}\left\{\frac{\mathrm{d}^{1}}{\mathrm{dy} 1} \mathrm{hy}(\mathrm{y})\right\}$ alfa_rady $=0.0294$ 1

Vpy $:=2 \cdot 4 \cdot P y m \cdot \sin ($ alfa_rady) $\quad$ Vpy $=34.3808$

$$
F_{k 3 \text { total }}:=V p x+V p y+F_{k 3} \quad F_{k 3 \text { total }}=641.3781
$$

Adotar o valor mais crítico:

$$
\begin{aligned}
& \mathrm{F}_{\mathrm{k} 1 \text { total }}=1240.5455 \quad(\text { região }- \text { armada }) \\
& \mathrm{F}_{\mathrm{k} 2}=1297.0795 \quad(\text { região- } \text { adjacente- pilar }) \\
& \left.\mathrm{F}_{\mathrm{k} 3 \text { total }}=641.3781 \text { (região- externa }\right)
\end{aligned}
$$

Taxa de armadura minima: Asminimo: $=\frac{0.03 \cdot(100 \cdot \mathrm{ro} \cdot \mathrm{fck})^{\left(\frac{1}{3}\right)} \cdot \mathrm{u}}{1.5 \cdot \mathrm{fywd}} \cdot \mathrm{sr} \quad$ Asminimo $=0.5687$

Taxa de armadura minima: $\quad$ Asw $=12.208$ 


\section{f) Modelo M6}

fib (1999b) -MODELOM6 - Punção - d, c1, c2 em cm / fc em MPa

Dados - Obs.: usando formulação para ensaio experimental: sem coef.de seg.

$$
\mathrm{dx}:=16-1.59-\frac{1.25}{2} \quad \mathrm{dy}:=\mathrm{dx}-1.25 \quad \mathrm{dx}=13.785 \quad \mathrm{dy}=12.535 \quad \text { fck }:=51.56
$$

$\mathrm{d}:=\frac{\mathrm{dx}+\mathrm{dy}}{2} \quad \mathrm{~d}=13.16 \quad$ Lados do pilar (c1, c2): $\quad \mathrm{cx}:=18 \quad \mathrm{cy}:=18$

\section{VERIFICACÃO DA REGIÃO ARMADA espaçamento entre barras: $10 \mathrm{~cm}$}

$\mathrm{A}_{\mathrm{SX}}:=1.188 \quad \mathrm{~A}_{\mathrm{sy}}:=1.188 \quad$ Asw $:=16 \cdot 0.763 \quad$ Asw $=12.208 \quad \mathrm{sr}:=9.5 \quad$ (limite $=0.75 \cdot \mathrm{d}=9.87$

fy $:=633.9$ (p/Ast - MPa) fywd $:=\frac{\text { fy }}{1.15} \quad$ fywd $=551.2174 \quad$ (limite de $300 \mathrm{MPa}$ )

Cálculos:

fywd :=300 Repetir valor se inferior a $300 \mathrm{MPa}$

ro $_{x}:=\frac{A_{\text {sx }}}{d x \cdot 10} \quad$ ro $x=0.0086$ ro $_{y}:=\frac{A_{s y}}{d y \cdot 10} \quad$ ro $_{y}=0.0095 \quad$ ro $:=\sqrt{\text { ro }_{x} \cdot r_{y}} u:=2 \cdot(c x+c y)+2 \cdot \pi \cdot(2 \cdot d)$ ro $=0.009 \quad \mathrm{u}=237.3734 \quad$ Kapa $:=1+\sqrt{\frac{20}{\mathrm{~d}}} \quad$ Kapa $=2.2328 \quad \begin{aligned} & \text { Sem limitação para o valor } \\ & \text { de Kapa }\end{aligned}$

Como quero comparar com resultados experimentais, multiplicar:

Partanto: $: \frac{1}{10} \cdot\left[1.33 \cdot 0.09 \cdot(\mathrm{Kapa}) \cdot(100 \cdot \mathrm{ro} \cdot \mathrm{fck})^{\frac{1}{3}}+1.15 \cdot 1.5 \cdot \frac{\mathrm{d}}{\mathrm{sr}} \cdot \frac{\text { A s w } \cdot f \mathrm{ywd} \cdot 1}{\mathrm{u} \cdot \mathrm{d}}\right] \begin{aligned} & \mathrm{F}_{\mathrm{k} 1}:=\mathrm{TAU} 1 \cdot \mathrm{u} \cdot \mathrm{d} \\ & \mathrm{F}_{\mathrm{k} 1}=1175.5941\end{aligned}$

Contribuição da protensão:

Direção do eixo $x$

$h x(x):=-0.00021488 x^{2}+0.05372 x$

$\mathrm{x}:=\frac{250}{2}-\frac{\mathrm{cx}}{2}-2 \cdot \mathrm{d} \quad \mathrm{x}=89.68$

alfa_radx:=atan $\left\{\frac{\mathrm{d}^{1}}{\mathrm{dx} 1} \mathrm{hx}(\mathrm{x})\right\} \underset{\sin (\text { alfa_rad } x)=0.0152}{\text { alfa_radx }=0.0152}$

Pxm:= 145.49

$V p x:=2 \cdot 4 \cdot P x m \cdot \sin ($ alfa_radx $) \quad V p x=17.6653$

$$
\mathrm{F}_{\mathrm{k} 1 \text { total }} \mathrm{i}=\mathrm{Vpx}+\mathrm{Vpy}+\mathrm{F}_{\mathrm{k} 1}
$$

\section{Direção do eixo $y$}

$$
\mathrm{hy}(\mathrm{y}):=-0.00029488 \mathrm{y}^{2}+0.07372 \mathrm{y}
$$$$
\mathrm{y}:=\frac{250}{2}-\frac{\mathrm{cy}}{2}-2 \cdot \mathrm{d} \quad \mathrm{y}=89.68
$$

alfa_rady: $=\operatorname{atan}\left\{\frac{\mathrm{d}^{1}}{\mathrm{~d} \mathrm{y} 1} \mathrm{hy}(\mathrm{y})\right\} \quad$ alfa_rady $=0.0208$ $\sin ($ alfa_rady $)=0.0208$

/ Pym: $=149.42$

Vpy $:=2 \cdot 4 \cdot P y m \cdot \sin ($ alfa_rady $) \quad$ Vpy $=24.8943$

$\mathrm{F}_{\mathrm{k} 1 \text { total }}=1218.1537$ 


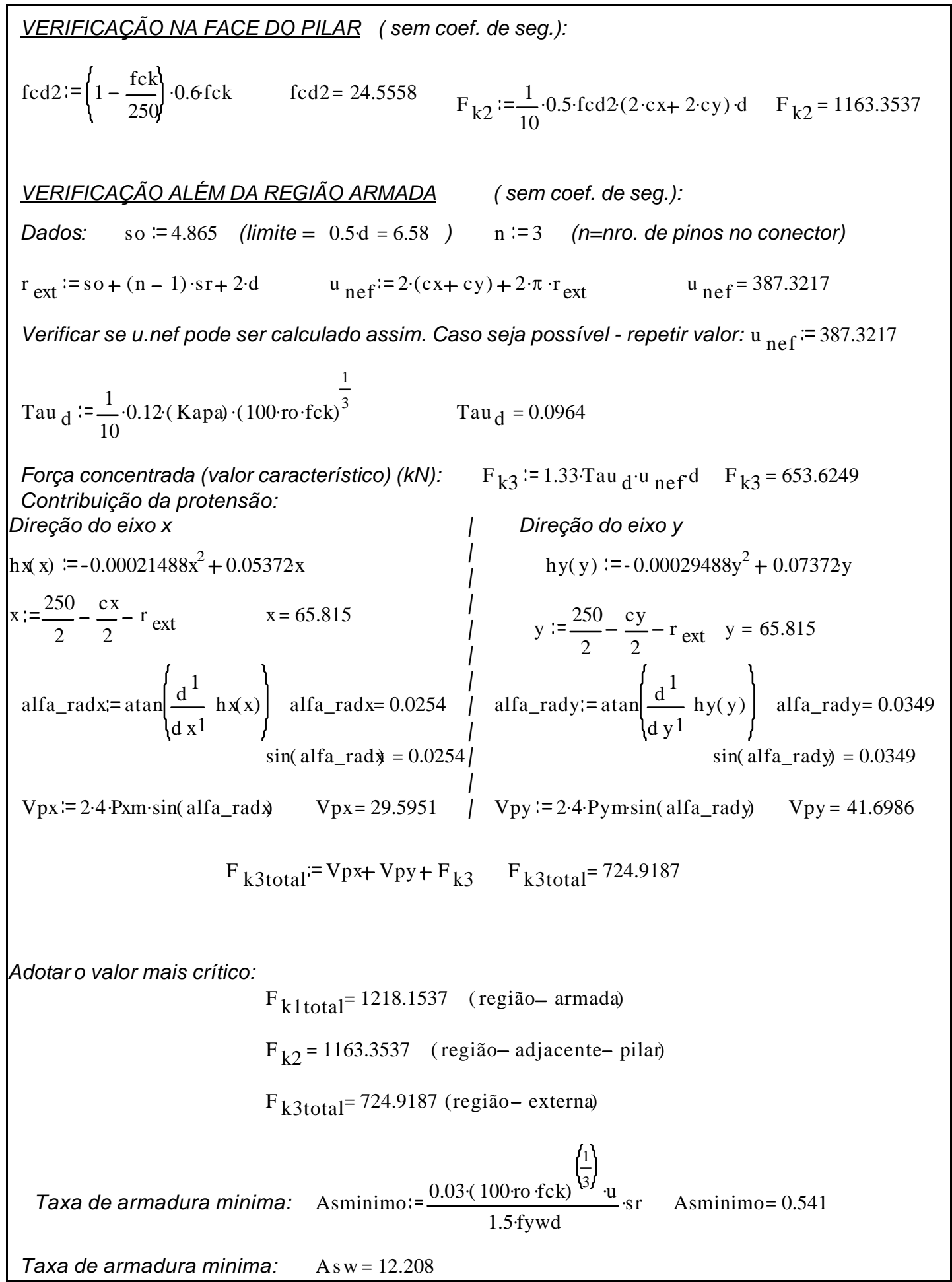




\section{J.5. ACI 318}

\section{a) Modelo M1}

$A C l$ - Punção - Modelo M1 (s/ armadura de punção): $d, c 1, c 2 \mathrm{em} \mathrm{cm} \mathrm{/} \mathrm{fc} \mathrm{em} \mathrm{MPa}$ Dados - Obs.: usando formulação para ensaio experimental: sem coef.de seg.

$\mathrm{dx}:=16-1.66-\frac{1.6}{2} \quad \mathrm{dx}=13.54 \quad \mathrm{dy}:=\mathrm{dx}-1.6 \quad \mathrm{dy}=11.94$

fc $:=26.60 \quad$ cx $:=18 \quad$ cy $:=18 \quad$ ladomaiordopilar $:=c x \quad \alpha s:=40$

ladomenordopilar := cy

Cálculos: $\quad \mathrm{d}:=\frac{\mathrm{dx}+\mathrm{dy}}{2} \quad \beta \mathrm{c}:=\frac{\text { ladomaiordopilar }}{\text { ladomenordopilar }} \quad$ bo $:=2 \cdot(\mathrm{cx}+\mathrm{d})+2 \cdot(\mathrm{cy}+\mathrm{d})$

$$
\mathrm{d}=12.74 \quad \quad \beta \mathrm{c}=1 \quad \text { bo }=122.96
$$

\section{VERIFICACÃO}

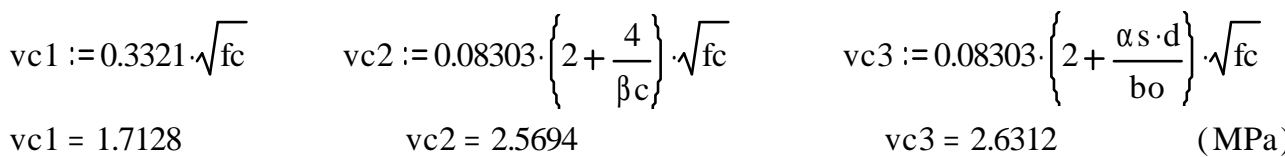

CALCULO DA FORCA MAXIMA:

$\mathrm{vc}:=\mathrm{vc1} \quad$ (escolher menor entre vc1, vc2, vc3) $\mathrm{P}:=\frac{\mathrm{vc}}{10} \cdot \mathrm{bo} \cdot \mathrm{d} \quad \mathrm{P}=268.3138 \quad(\mathrm{kN})$ 


\section{b) Modelo M2}

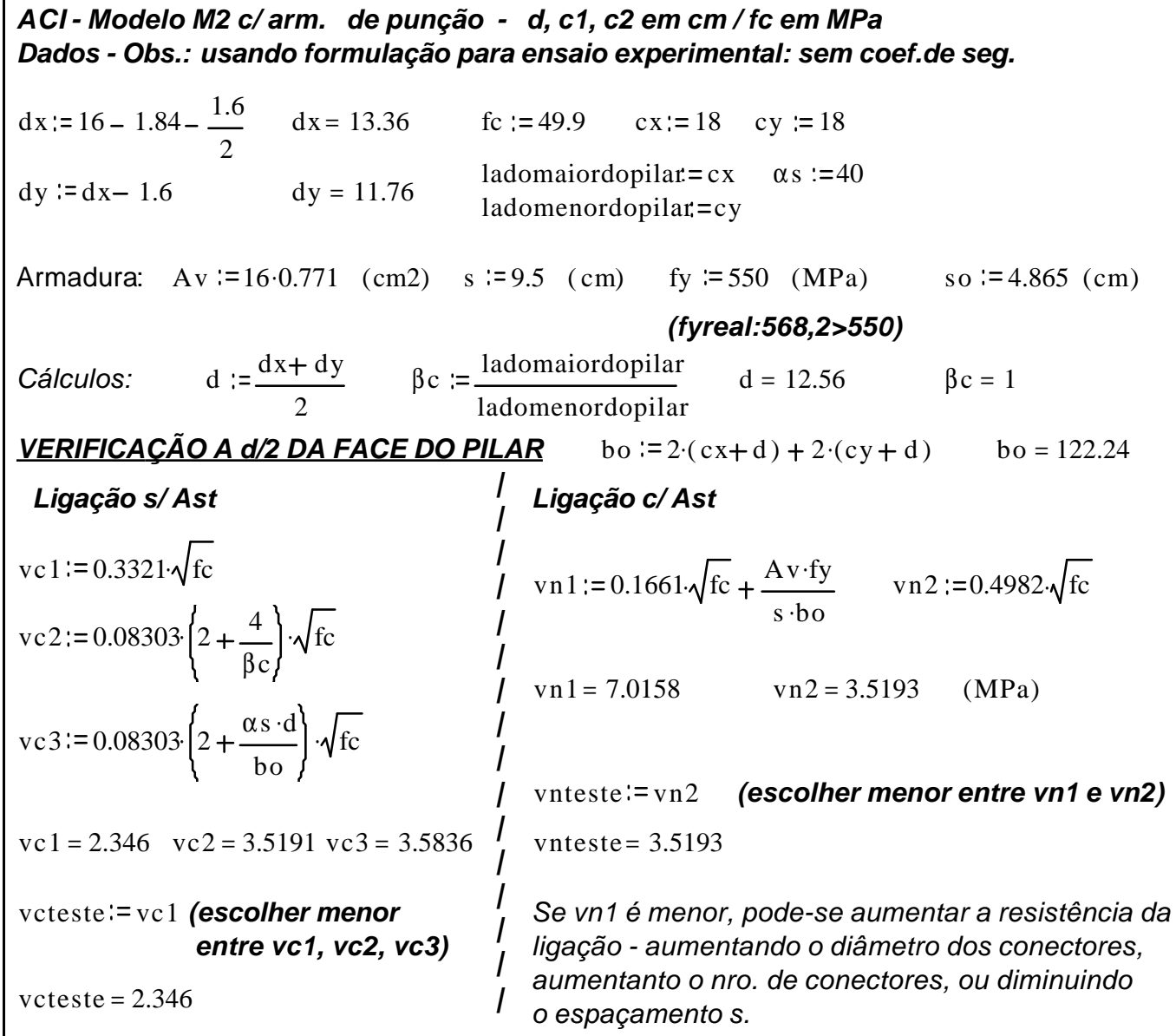

\section{VERIFICACÃO ALÉM DA REGIÃO ARMADA}

boexterno: $=4 \cdot 49.23+4 \cdot 7.11$

boexterno $=225.36$

CALCULO DAS FORCAS MAXIMAS:

A d/2 do pilar (sem armadura):

$\mathrm{P} 1:=\frac{\text { vcteste }}{10} \cdot \mathrm{bo} \cdot \mathrm{d}$

$\mathrm{P} 1=360.1821(\mathrm{kN})$

A d/2 do pilar (com armadura):

$\mathrm{P} 2:=\frac{\text { vnteste }}{10} \cdot \mathrm{bo} \cdot \mathrm{d}$

$\mathrm{P} 2=540.3274(\mathrm{kN})$

Além da região transv. armada : $\mathrm{P} 3:=\frac{\mathrm{vcexterno}}{10} \cdot$ boexterno-d

$\mathrm{P} 3=332.1134(\mathrm{kN})$

Observação -

Se P3<P1 - então nao precisa de armadura (estou com poucas camadas de Ast)

Se $P 2<P 3$ - então aumentar armadura ou, se nao for possivel, modificar projeto

Exemplo: elevar fc, aumentar d, aumentar cx,cy

Se $P 1<P 3<P 2$ - então laje corretamente dimensionada 
c) Modelo M3

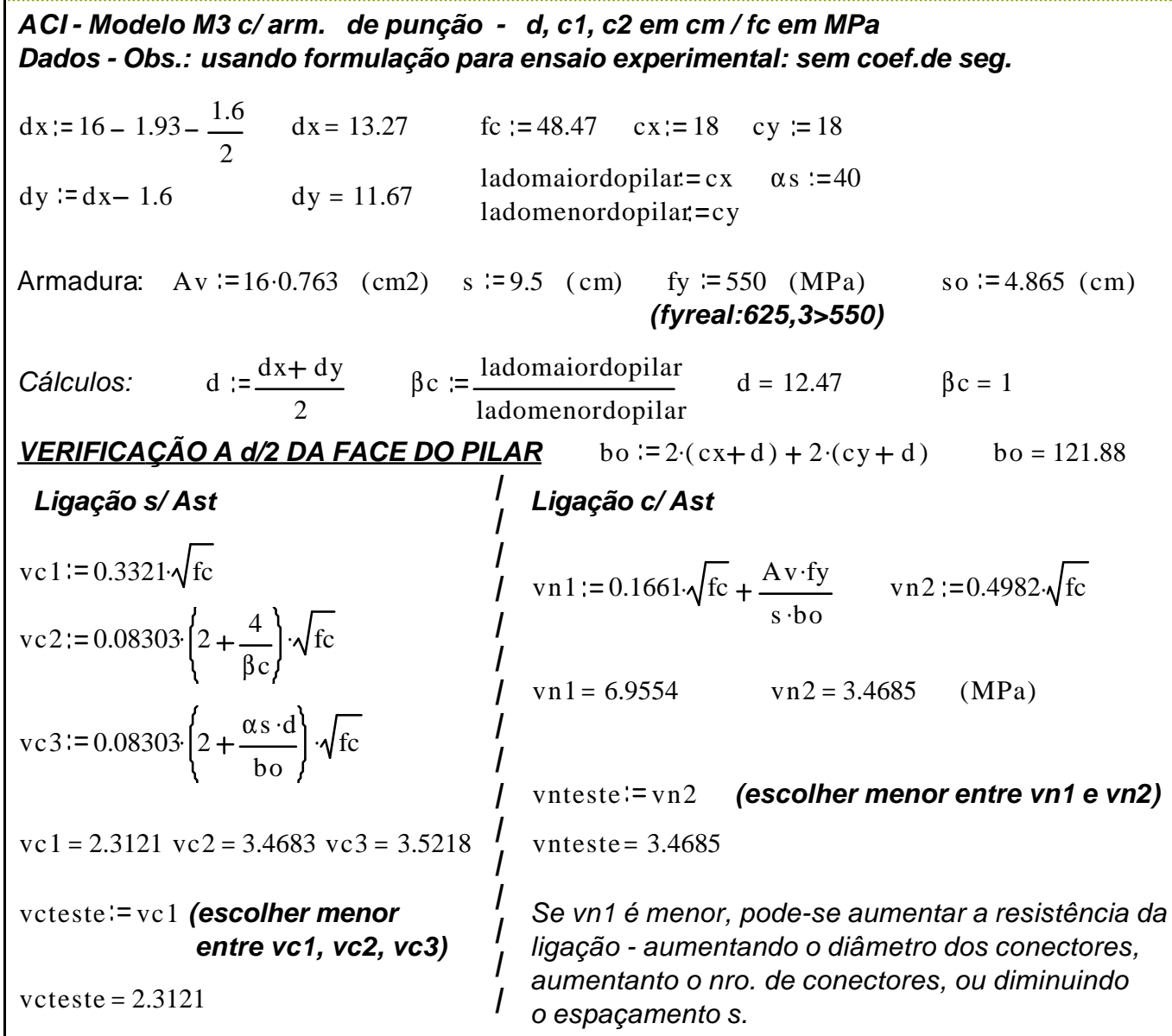

\section{VERIFICACÃO ALÉM DA REGIÃO ARMADA}

boexterno: $=4 \cdot 54.24+4 \cdot 16.95$

boexterno $=284.76$

CALCULO DAS FORCAS MAXIMAS:

A d/2 do pilar (sem armadura):

$\mathrm{P} 1:=\frac{\text { vcteste }}{10} \cdot \mathrm{bo} \cdot \mathrm{d}$

$\mathrm{P} 1=351.402 \quad(\mathrm{kN})$

A d/2 do pilar (com armadura):

$\mathrm{P} 2:=\frac{\text { vnteste }}{10} \cdot \mathrm{bo} \cdot \mathrm{d}$

$\mathrm{P} 2=527.156 \quad(\mathrm{kN})$

Além da região transv. armada : $\mathrm{P} 3:=\frac{\mathrm{vcexterno}}{10} \cdot$ boexterno-d

$\mathrm{P} 3=410.6309(\mathrm{kN})$

Observação -

Se $P 3<P 1$ - então nao precisa de armadura (há poucas camadas de Ast)

Se $P 2<P 3$ - então aumentar armadura ou, se nao for possivel, modificar projeto

Exemplo: elevar $f c$, aumentar $d$, aumentar $c x, c y$

Se $P 1<P 3<P 2$ - então laje corretamente dimensionada

(rompendo além da região transv. armada) 
d) Modelo M4: opção 01 (sem armadura de punção e sem protensão)

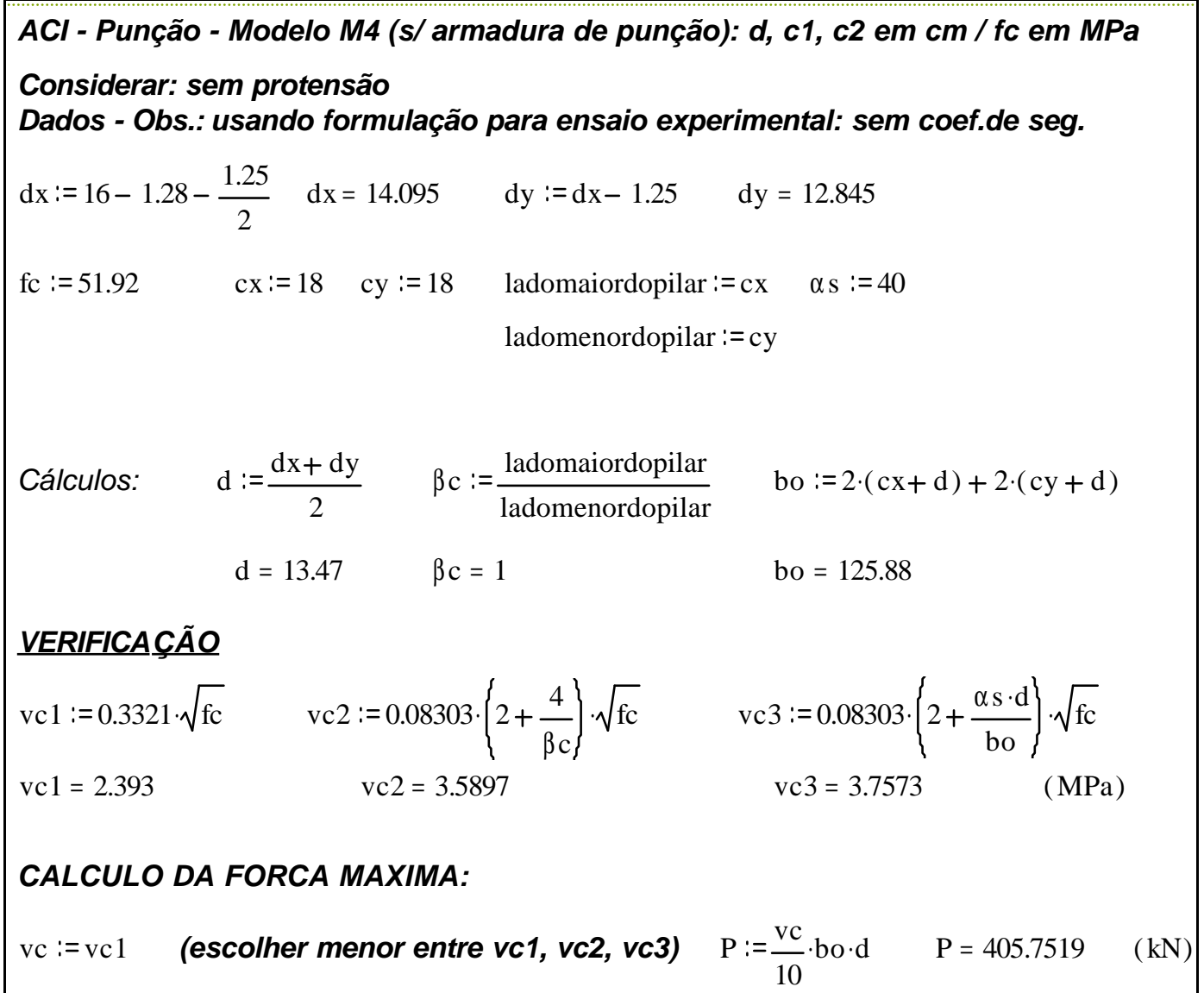


e) Modelo M4: opção 02 (sem armadura de punção, com protensão)

ACl-Modelo M4 - Punção - s/ Ast e com protensão - d, c1, c2 em cm / fc em MPa

Dados - Obs.: usando formulação para ensaio experimental: sem coef.de seg.

Dados: $\quad \mathrm{dx}:=16-1.28-\frac{1.25}{2} \quad \mathrm{dy}:=\mathrm{dx}-1.25 \quad(\mathrm{~cm}) \quad \mathrm{fc}:=51.92(\mathrm{MPa}) \quad \mathrm{cx}:=18 \quad \mathrm{cy}:=18(\mathrm{~cm})$ $\mathrm{dx}=14.095 \quad \mathrm{dy}=12.845$

ladomenordopilat $=\mathrm{cy} \quad$ ladomaiordopilat $=\mathrm{cx} \quad \alpha \mathrm{s}:=40$

espessuradalaje $=16(\mathrm{~cm}) \quad$ dist_facedopilar_bordamaisproxima $\frac{250}{2}-\frac{18}{2}$

$\mathrm{d}:=\frac{\mathrm{dx}+\mathrm{dy}}{2} \quad \mathrm{~d}=13.47 \quad$ dist_facedopilar_bordamaisproxinfa1 16

Forcaprotensaodirecaor $135.04+136.07+138.34+135.99+136.03+137.89+140.08+134.10$ Forcaprotensaodirecao 1093.54

$\mathrm{Fx}:=$ Forcaprotensaodirecaox

(usar a soma das forças)

Forcaprotensaodirecao $=131.25+139.93+140.58+142.32+137.16+141.03+134.88+135.52$

Forcaprotensaodirecao $¥ 1102.67$ (usar a soma das forças)

Fy := Forcaprotensaodirecaoy

Secaox: $=250 \cdot 16 \quad(\mathrm{~cm} 2) \quad$ Secaoy $:=250 \cdot 16(\mathrm{~cm} 2)$

\section{$\underline{\text { P/calculo de Vp }}$}

Contribuição da protensão:

Direção do eixo $x$

$\mathrm{hx}(\mathrm{x}):=-0.00021488 \mathrm{x}^{2}+0.05372 \mathrm{x}$

$\mathrm{x}:=\frac{250}{2}-\frac{\mathrm{cx}}{2}-\frac{\mathrm{d}}{2} \quad \mathrm{x}=109.265$

alfa_radx:= $\operatorname{atan}\left\{\frac{\mathrm{d}^{1}}{\mathrm{~d} \mathrm{x}^{1}} \mathrm{hx}(\mathrm{x})\right\} \quad$ alfa_radx $=0.0068$

Pxm $:=\frac{\text { Fx }}{8} \quad$ Pxm $=136.6925^{\sin (\text { alfa_rad } x}=0.0068 /$

$\mathrm{Vpx}:=2 \cdot 4 \cdot \mathrm{Pxm} \cdot \sin ($ alfa_radx $) \quad \mathrm{Vpx}=7.3946$

/ Pym: $=\frac{\text { Fy }}{8} \quad$ Pym $=137.8337$

/ Vpy $:=2 \cdot 4 \cdot$ Pymsin (alfa_rady) $\quad$ Vpy $=10.2322$

Direção do eixo $y$

hy $(y):=-0.00029488 y^{2}+0.07372 \cdot y$

$\mathrm{y}:=\frac{250}{2}-\frac{\mathrm{cy}}{2}-\frac{\mathrm{d}}{2} \quad \mathrm{y}=109.265$

alfa_rady: $=\operatorname{atan}\left\{\frac{\mathrm{d}^{1}}{\mathrm{~d} \mathrm{y} 1} \mathrm{hy}(\mathrm{y})\right\} \quad$ alfa_rady $=0.0093$ $\sin ($ alfa_rady $)=0.0093$

I

$\mathrm{Vp}:=\mathrm{Vpx}+\mathrm{Vpy} \quad \mathrm{Vp}=17.6268$ 


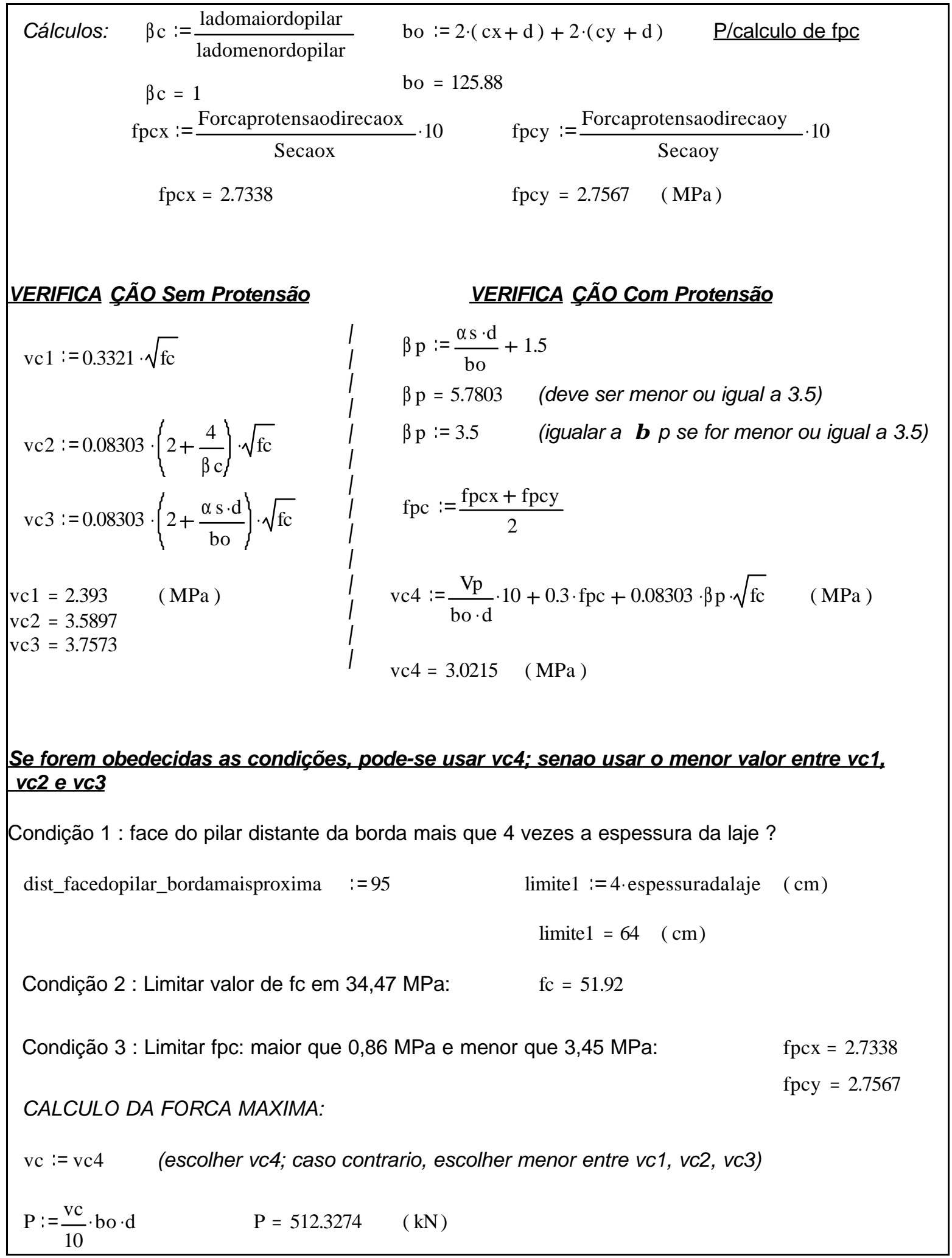


f) Modelo M5: opção 01 (sem armadura de punção com protensão)

ACl -Modelo M5 - Punção - s/ Ast e com protensão - d, c1, c2 em cm / fc em MPa

Dados - Obs.: usando formulação para ensaio experimental: sem coef.de seg.

Dados: $\mathrm{dx}:=16-1.49-\frac{1.25}{2} \quad \mathrm{dy}:=\mathrm{dx}-1.25 \quad(\mathrm{~cm}) \quad \mathrm{fc}:=59.4 \quad(\mathrm{MPa}) \quad \mathrm{cx}:=18 \quad \mathrm{cy}:=18(\mathrm{~cm})$ $\mathrm{dx}=13.885 \quad \mathrm{dy}=12.635$

ladomenordopilat $=\mathrm{cy} \quad$ ladomaiordopilat $=\mathrm{cx} \quad \alpha \mathrm{s}:=40$

espessuradalaje: $=16(\mathrm{~cm}) \quad$ dist_facedopilar_bordamaisproximra $\frac{250}{2}-\frac{18}{2}$

$\mathrm{d}:=\frac{\mathrm{dx}+\mathrm{dy}}{2} \quad \mathrm{~d}=13.26 \quad$ dist_facedopilar_bordamaisproxinæa1 16

Forcaprotensaodirecaor $131.2+135.1+134.4+119.2+141.6+144.4+150.5+137.5$

Forcaprotensaodireca $\approx 1093.9$

Fx := Forcaprotensaodirecaox

(usar a soma das forças)

Forcaprotensaodirecao $=138.4+146.3+152.3+149.4+140.2+152.7+144.4+145.4$

Forcaprotensaodirecao 1169.1 (usar a soma das forças)

Fy $:=$ Forcaprotensaodirecaoy

Secaox:=250.16 $(\mathrm{cm} 2) \quad$ Secaoy $:=250 \cdot 16(\mathrm{~cm} 2)$

\section{$\underline{\text { P/calculo de Vp}}$}

Contribuição da protensão:

Direção do eixo $x$

$\mathrm{hx}(\mathrm{x}):=-0.00021488 \mathrm{x}^{2}+0.05372 \mathrm{x}$

$\mathrm{x}:=\frac{250}{2}-\frac{\mathrm{cx}}{2}-\frac{\mathrm{d}}{2} \quad \mathrm{x}=109.37$

$\operatorname{alfa\_ radx}=\operatorname{atan}\left\{\frac{\mathrm{d}^{1}}{\mathrm{~d} \mathrm{x}^{1}} \mathrm{hx}(\mathrm{x})\right\} \begin{aligned} & \text { alfa_radx }=0.0067 \\ & \sin (\text { alfa_rad } x=0.0067\end{aligned}$

Pxm: $=\frac{F x}{8} \quad$ Pxm $=136.7375^{\sin (\text { alfa_rad } \Varangle=0.0067}$

$\mathrm{Vpx}:=2 \cdot 4 \cdot \operatorname{Pxm} \cdot \sin ($ alfa_radx $) \quad \mathrm{Vpx}=7.3477$

/ Pym: $=\frac{\text { Fy }}{8} \quad$ Pym $=146.1375$

/ Vpy $:=2 \cdot 4 \cdot$ Pymsin(alfa_rady) $\quad \mathrm{Vpy}=10.7762$

Direção do eixo y

hy $(y):=-0.00029488 y^{2}+0.07372 \cdot y$

$y:=\frac{250}{2}-\frac{c y}{2}-\frac{d}{2} \quad y=109.37$

alfa_rady: $\operatorname{atan}\left\{\frac{\mathrm{d}^{1}}{\mathrm{~d} \mathrm{y}^{1}} \mathrm{hy}(\mathrm{y})\right\} \quad$ alfa_rady $=0.0092$ $\sin ($ alfa_rady $)=0.0092$

I

$\mathrm{Vp}:=\mathrm{Vpx}+\mathrm{Vpy} \quad \mathrm{Vp}=18.124$ 


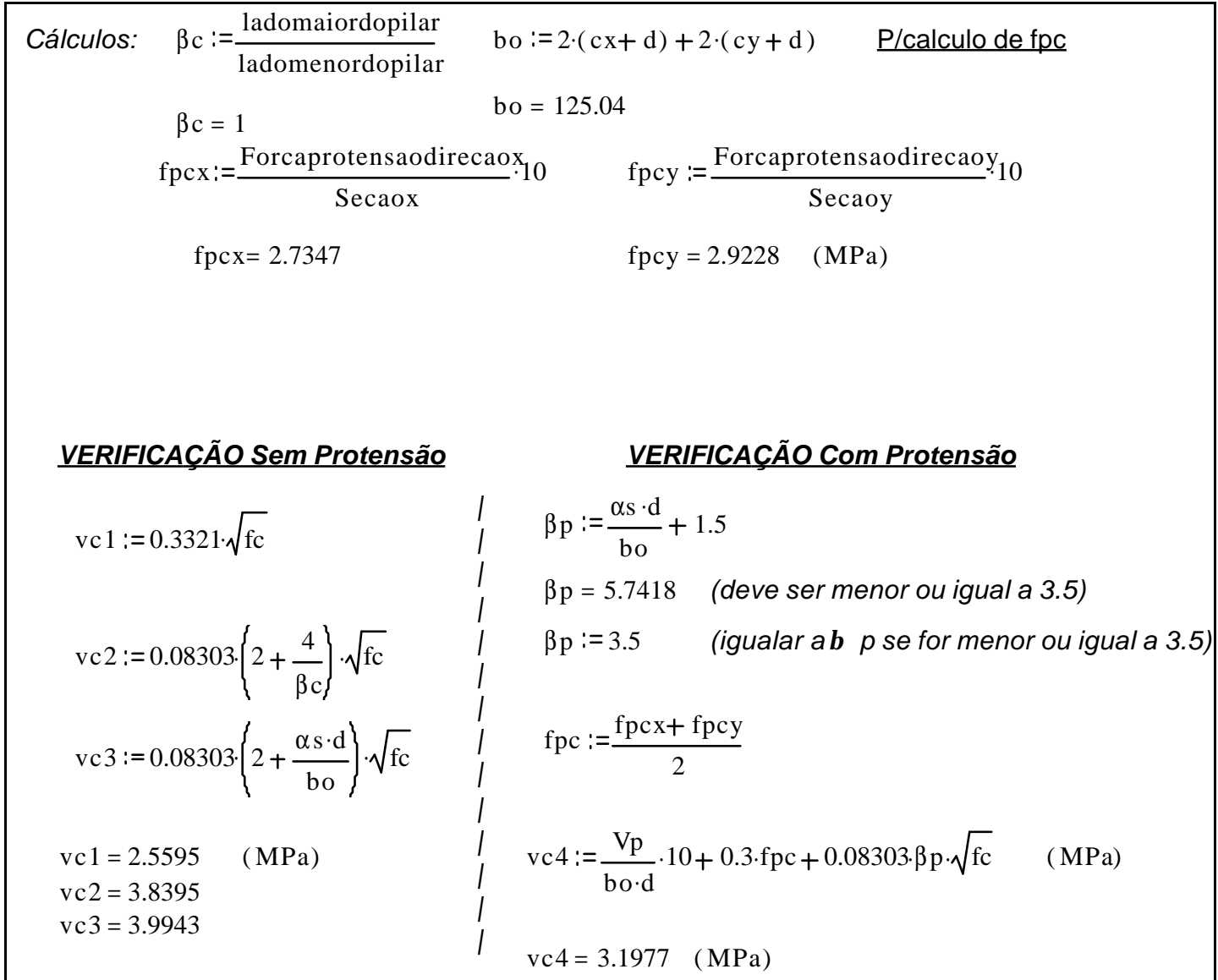

Se forem obedecidas as condições - pode usar vc4, senao usar o menor valor entre vc1, vc2 e vc3

Condição 1 : face do pilar distante da borda mais que 4 vezes a espessura da laje ?

dist_facedopilar_bordamaisproxima $=95 \quad$ limite $1:=4 \cdot \operatorname{espessuradalaje~}(\mathrm{cm})$ limite $1=64 \quad(\mathrm{~cm})$

Condição 2 : Limitar valor de fc em 34,47 MPa: $\quad$ fc $=59.4$

Condição 3 : Limitar fpc: maior que 0,86 MPa e menor que 3,45 MPa: $\quad$ fpcx $=2.7347$

CALCULO DA FORCA MAXIMA:

$\mathrm{vc}:=\mathrm{vc4}$ (escolher vc4; caso contrario, escolher menor entre vc1, vc2, vc3)

$\mathrm{P}:=\frac{\mathrm{vc}}{10} \cdot \mathrm{bo} \cdot \mathrm{d} \quad \mathrm{P}=530.1832 \quad(\mathrm{kN})$ 
g) Modelo M5: opção 02 (com armadura de punção, sem protensão)

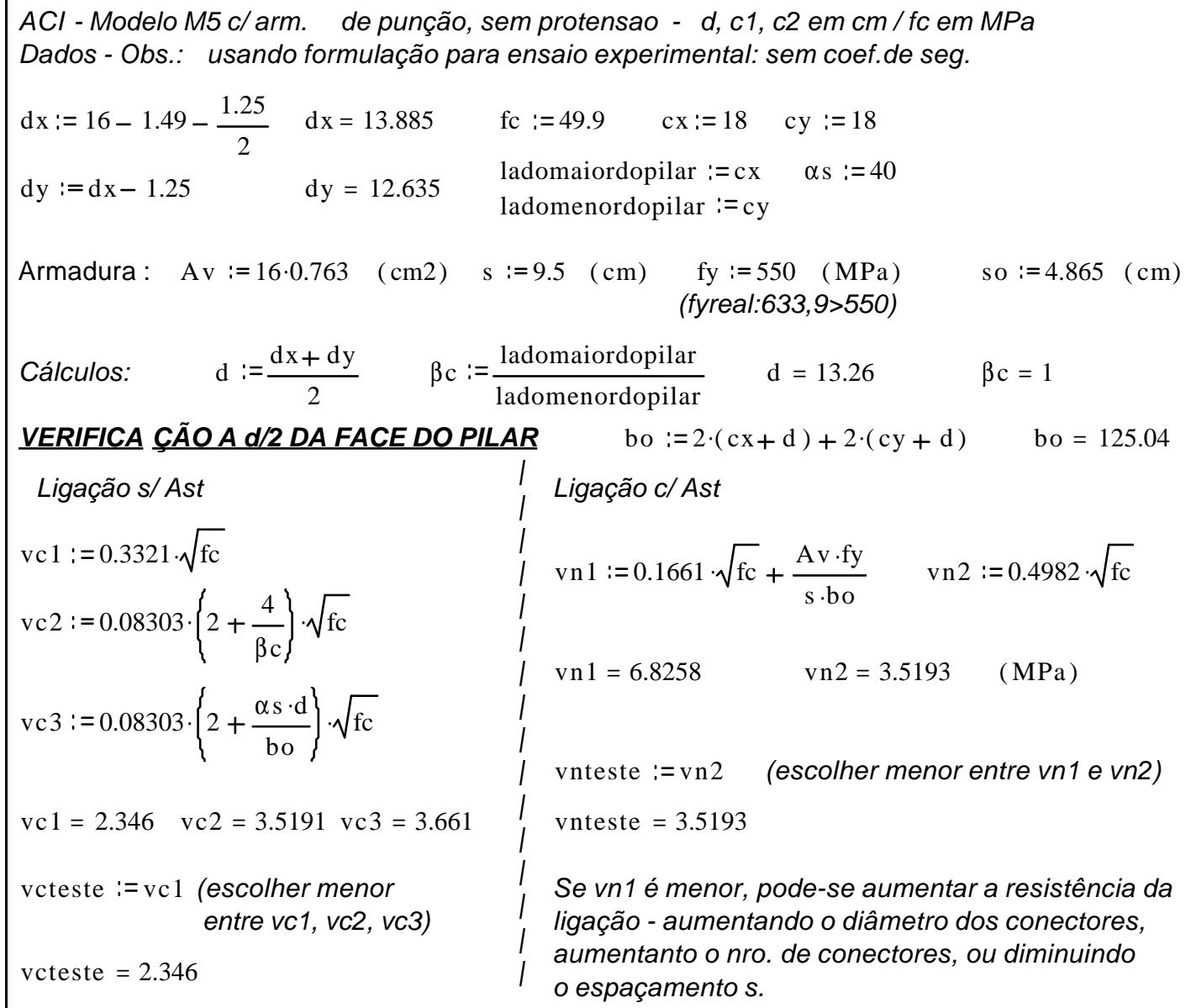

vcteste $=2.346$

\section{VERIFICA CÃO ALÉM DA REGIÃO ARMADA}

boexterno $:=4 \cdot 49.61+4 \cdot 7.49$

boexterno $=228.4$

CALCULO DAS FORCAS MAXIMAS:

$\begin{array}{lcc}\text { A d/2 do pilar (sem armadura): } & \mathrm{P} 1:=\frac{\mathrm{vcteste}}{10} \cdot \mathrm{bo} \cdot \mathrm{d} & \mathrm{P} 1=388.966 \quad(\mathrm{kN}) \\ \text { A d/2 do pilar (com armadura): } & \mathrm{P} 2:=\frac{\mathrm{vnteste}}{10} \cdot \mathrm{bo} \cdot \mathrm{d} & \mathrm{P} 2=583.5076(\mathrm{kN}) \\ \text { Além da região transv. armada }: & \mathrm{P} 3:=\frac{\mathrm{vcexterno}}{10} \cdot \text { boexterno } \cdot \mathrm{d} & \mathrm{P} 3=355.3526(\mathrm{kN})\end{array}$

Observação -

Se $P 3<P 1$ - então nao precisa de armadura (estou com poucas camadas de Ast)

Se $P 2<P 3$ - então aumentar armadura ou, se nao for possivel, modificar projeto

Exemplo: elevar fc, aumentar d, aumentar cx,cy

Se $P 1<P 3<P 2$ - então laje corretamente dimensionada 


\section{h) Modelo M6: opção 01 (sem armadura de punção, com protensão)}

ACl -Modelo M6 - Punção - s/ Ast e com protensão - d, c1, c2 em cm / fc em MPa

Dados - Obs.: usando formulação para ensaio experimental: sem coef.de seg. $\begin{array}{rlll}\text { Dados: } & \mathrm{dx}:=16-1.59-\frac{1.25}{2} & \mathrm{dy}:=\mathrm{dx}-1.25 & (\mathrm{~cm}) \quad \mathrm{fc}:=51.56(\mathrm{MPa}) \quad \mathrm{cx}:=18 \quad \mathrm{cy}:=18 \quad(\mathrm{~cm}) \\ \mathrm{dx} & =13.785 & \mathrm{dy}=12.535 & \end{array}$

ladomenordopilat $=\mathrm{cy} \quad$ ladomaiordopilat $=\mathrm{cx} \quad \alpha \mathrm{s}:=40$

espessuradalaje: $=16(\mathrm{~cm}) \quad$ dist_facedopilar_bordamaisproximim $\frac{250}{2}-\frac{18}{2}$

$\mathrm{d}:=\frac{\mathrm{dx}+\mathrm{dy}}{2} \quad \mathrm{~d}=13.16 \quad$ dist_facedopilar_bordamaisproxinæa1 16

Forcaprotensaodirecao: $133.71+151.26+151.48+126.53+153.36+146.17+157.42+143.95$ Forcaprotensaodirecaox 1163.88

Fx := Forcaprotensaodirecaox (usar a soma das forças)

Forcaprotensaodirecao $=143.65+154.56+154.59+160.22+124.16+160.61+157.28+140.27$

Forcaprotensaodirecaoł 1195.34 (usar a soma das forças)

Fy $:=$ Forcaprotensaodirecaoy

Secaox: $=250 \cdot 16 \quad(\mathrm{~cm} 2) \quad$ Secaoy $:=250 \cdot 16(\mathrm{~cm} 2)$

\section{$\underline{P / c a l c u l o ~ d e ~ V p}$}

Contribuição da protensão:

Direção do eixo $x$

$\mathrm{hx}(\mathrm{x}):=-0.00021488 \mathrm{x}^{2}+0.05372 \mathrm{x}$

$\mathrm{x}:=\frac{250}{2}-\frac{\mathrm{cx}}{2}-\frac{\mathrm{d}}{2} \quad \mathrm{x}=109.42$

alfa_radx:= atan $\left\{\frac{\mathrm{d}}{\mathrm{d} \mathrm{x}^{1}} \mathrm{hx}(\mathrm{x})\right\}$ alfa_radx $=0.0067$

Pxm $:=\frac{\text { Fx }}{8} \quad \operatorname{Pxm}=145.485 \quad \sin ($ alfa_rad $x=0.0067 /$

$\mathrm{Vpx}:=2 \cdot 4 \cdot \mathrm{Pxm} \cdot \sin ($ alfa_radx $) \quad \mathrm{Vpx}=7.7928$

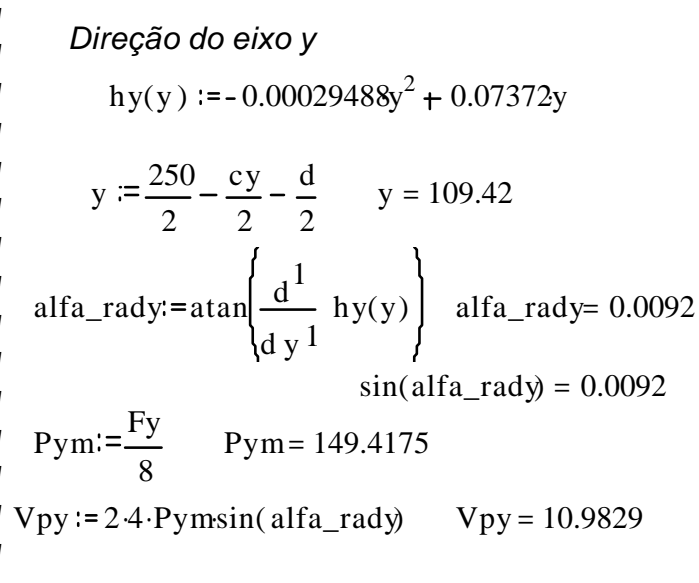

$\mathrm{Vp}:=\mathrm{Vpx}+\mathrm{Vpy} \quad \mathrm{Vp}=18.7756$ 


$$
\begin{aligned}
& \text { Cálculos: } \quad \beta c:=\frac{\text { ladomaiordopilar }}{\text { ladomenordopilar }} \quad \text { bo }:=2 \cdot(c x+d)+2 \cdot(c y+d) \quad \underline{P / \text { calculo de fpc }} \\
& \beta c=1 \\
& \text { bo }=124.64 \\
& \text { fpcx }:=\frac{\text { Forcaprotensaodirecaox }}{\text { Secaox }} \cdot 10 \quad \text { fpcy }:=\frac{\text { Forcaprotensaodirecaoy }}{\text { Secaoy }} \cdot 10 \\
& \mathrm{fpcx}=2.9097 \quad \text { fpcy }=2.9884 \quad(\mathrm{MPa}) \\
& \mathrm{vc} 1:=0.3321 \cdot \sqrt{\mathrm{fc}} \\
& \operatorname{vc} 2:=0.08303 \cdot\left(2+\frac{4}{\beta c}\right) \cdot \sqrt{\mathrm{fc}} \\
& \mathrm{vc} 3:=0.08303 \cdot\left(2+\frac{\alpha \mathrm{s} \cdot \mathrm{d}}{\mathrm{bo}}\right) \cdot \sqrt{\mathrm{fc}} \\
& \mathrm{vc} 1=2.3847 \quad(\mathrm{MPa}) \\
& \mathrm{vc} 2=3.5772 \\
& \mathrm{vc} 3=3.7104
\end{aligned}
$$

\section{VERIFICA CÃO Com Protensão}

\section{Se forem obedecidas as condiç̃es - pode usar vc4, senao usar o menor valor entre $v c 1, v c 2$ e vc3}

Condição 1 : face do pilar distante da borda mais que 4 vezes a espessura da laje ?

dist_facedopilar_bordamaisproxima $:=95$

$$
\begin{aligned}
& \text { limite } 1:=4 \cdot \text { espessuradalaje } \quad(\mathrm{cm}) \\
& \text { limite } 1=64 \quad(\mathrm{~cm})
\end{aligned}
$$

Condição 2 : Limitar valor de fc em 34,47 MPa:

$$
\mathrm{fc}=51.56
$$

Condição 3 : Limitar fpc: maior que 0,86 MPa e menor que 3,45 MPa:

CALCULO DA FORCA MAXIMA:

$\mathrm{vc}:=\mathrm{vc4} \quad$ (escolher vc4; caso contrario, escolher menor entre vc1, vc2, vc3)

$\mathrm{P}:=\frac{\mathrm{vc}}{10} \cdot \mathrm{bo} \cdot \mathrm{d} \quad \mathrm{P}=506.1641 \quad(\mathrm{kN}) \quad \mathrm{d}=13.16$ 


\section{i) Modelo M6: opção 02 (c/ armadura de punção s/protensão)}

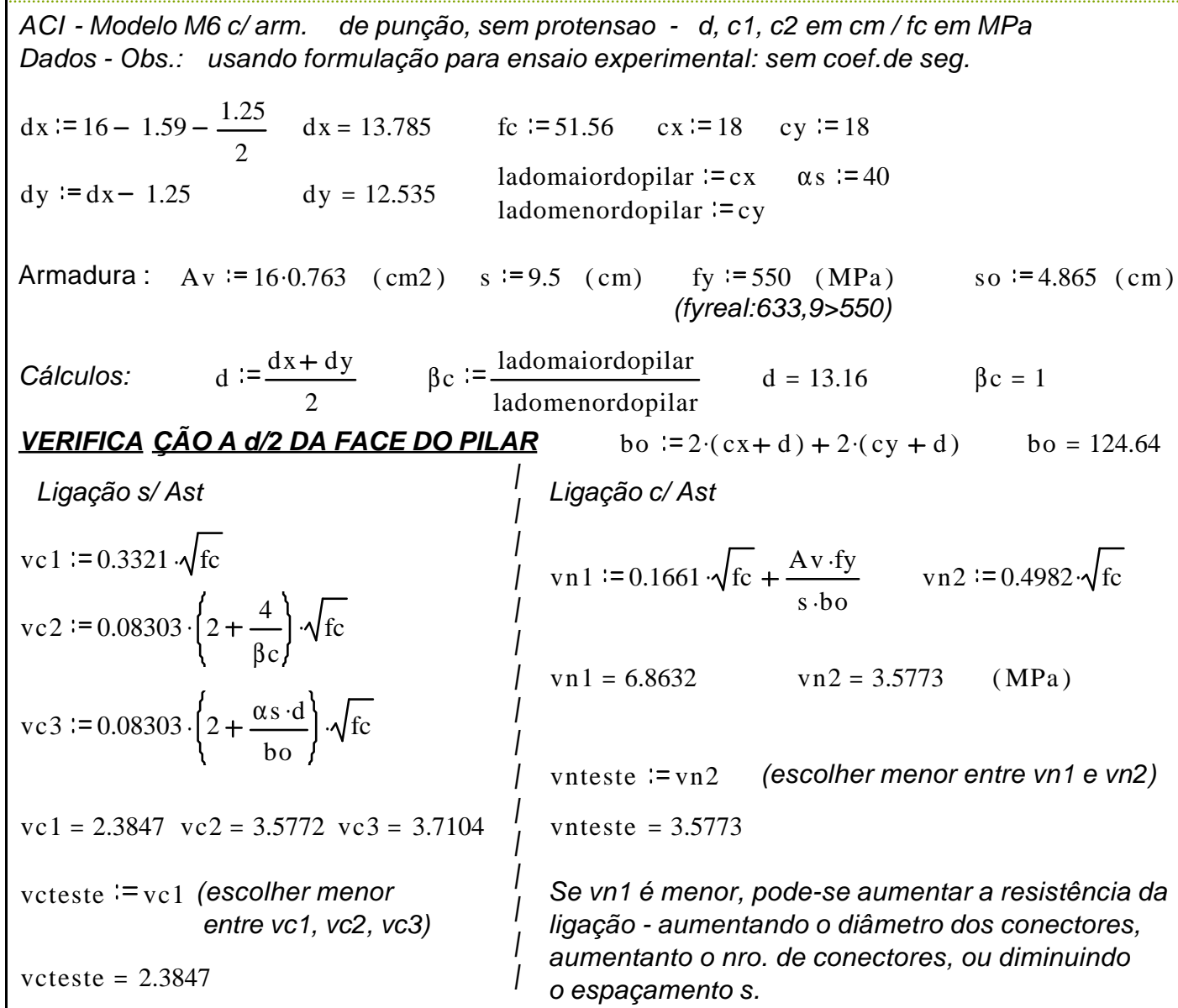

\section{VERIFICA CÃO ALÉM DA REGIÃO ARMADA}

$\begin{array}{ll}\text { boexterno }:=4 \cdot 54.52+4 \cdot 17.23 & \text { vcexterno }:=0.1661 \cdot \sqrt{\mathrm{fc}} \quad \text { vcexterno }=1.1927 \\ \text { boexterno }=287 & \end{array}$

CALCULO DAS FORCAS MAXIMAS:

A d/2 do pilar (sem armadura): $\quad \mathrm{P} 1:=\frac{\mathrm{vcteste}}{10} \cdot \mathrm{bo} \cdot \mathrm{d} \quad \mathrm{P} 1=391.1458(\mathrm{kN})$

A d/2 do pilar (com armadura): $\quad \mathrm{P} 2:=\frac{\mathrm{vnteste}}{10} \cdot \mathrm{bo} \cdot \mathrm{d} \quad \mathrm{P} 2=586.7776(\mathrm{kN})$

Além da região transv. armada : $\quad \mathrm{P} 3:=\frac{\mathrm{vcexterno}}{10} \cdot$ boexterno $\cdot \mathrm{d} \quad \mathrm{P} 3=450.4679(\mathrm{kN})$

Observação -

Se $P 3<P 1$ - então nao precisa de armadura (estou com poucas camadas de Ast)

Se $P 2<P 3$ - então aumentar armadura ou, se nao for possivel, modificar projeto

Exemplo: elevar fc, aumentar d, aumentar cx,cy

Se $P 1<P 3<P 2$ - então laje corretamente dimensionada 


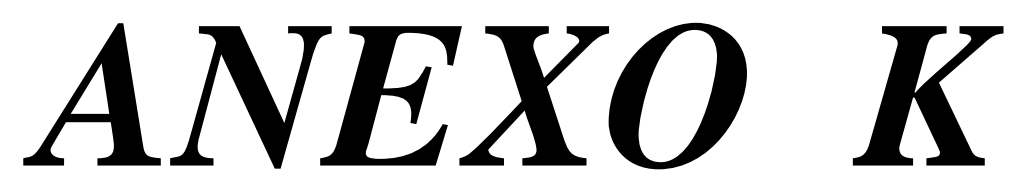

Recomendações da NBR 6118/78

e da NBR 7197/89 


\section{ANEXO K - Recomendações \\ da NBR $6118 / 78$ e NBR 7197/89}

Segundo a NBR 6118/78, salvo cálculo rigoroso, supõe-se que a carga produza uma tensão tangencial uniformemente distribuída na área ud, tensão essa calculada através da expressão:

$$
\tau_{\mathrm{Sd}}=\frac{\mathrm{F}_{\mathrm{Sd}}}{\mathrm{ud}} \quad \text { onde: }
$$

- $\quad$ FSd:força atuante de cálculo;

- $\quad$ d: altura útil da laje ao longo do contorno C da área de aplicação da carga;

- $\quad$ u: perímetro do contorno C', externo ao contorno $\mathrm{C}$ e deste distante $\mathrm{d} / 2$ no plano da laje (figura K.1).
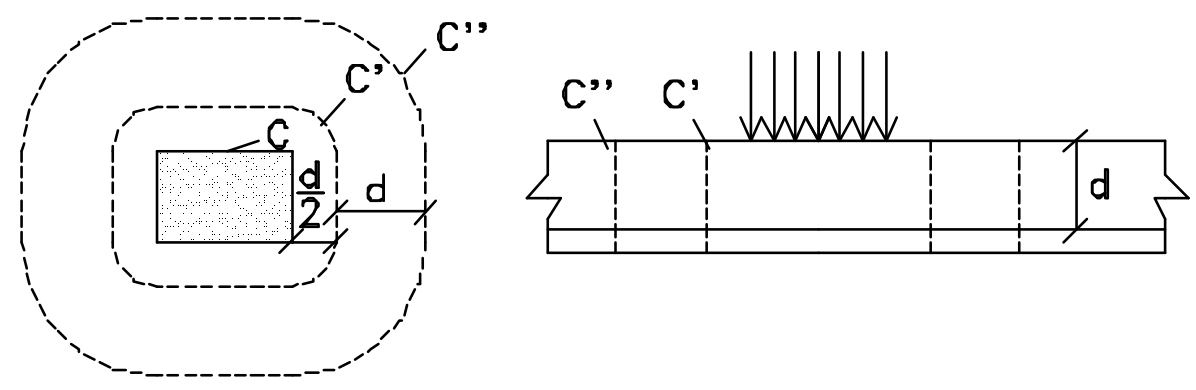

Figura K.1 - Perímetro crítico segundo a NBR 6118/78

Esta tensão $\tau_{\mathrm{Sd}}$ não poderá ultrapassar o valor último de uma resistência de cálculo $\tau_{\mathrm{Rd}}$, dado pela seguinte expressão, mesmo quando for colocada armadura de cisalhamento: 


$$
\tau_{\mathrm{Rd}}=\frac{0,63 \sqrt{\mathrm{f}_{\mathrm{ck}}}}{\gamma_{\mathrm{c}}} \quad \text { onde: }
$$

- $\mathrm{f}_{\text {ck: }}$ resistência característica do concreto à compressão (valor em MPa);

- $\gamma_{\mathrm{c}}$ : coeficiente de minoração da resistência do concreto, usualmente tomado como sendo igual a 1,4 .

Sempre que a tensão $\tau_{\mathrm{Sd}}$ no concreto for superior à metade do valor dado por $\tau_{\mathrm{Rd}}$, deverá ser colocada uma armadura de cisalhamento, tal que a componente dos esforços por ela absorvida, perpendicular ao plano médio da laje, corresponda no mínimo a $75 \%$ do valor de cálculo da força concentrada aplicada à laje.

Essa armadura será calculada com a resistência de cálculo fyd, não se tomando valores superiores a $300 \mathrm{MPa}$, e será constituída por estribos distribuídos na faixa delimitada pelos perímetros C'e C"' (figura K.1).

O perímetro C" é definido como o lugar geométrico dos pontos localizados a $3 \mathrm{~d} / 2$ do contorno da área carregada.

A NBR 6118/78 menciona ainda que, na face tracionada da laje, deverá ser calculada e colocada armadura de flexão que atravesse a projeção da área em que se aplica a carga concentrada, estando esta armadura suficientemente ancorada além do perímetro C".

Com relação à protensão, a NBR 7197/89 menciona que se pode considerar o efeito favorável das componentes das forças de protensão perpendiculares ao plano médio da laje, no contorno crítico de punção definido pela NBR 6118/78, aplicando-se um coeficiente de minoração igual a 0,8 às forças de protensão, no tempo infinito. 


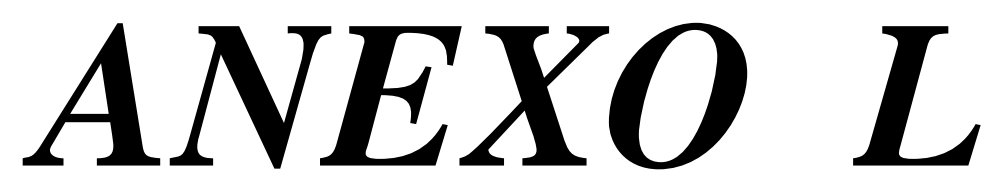

Recomendações da FIP/99 


\section{ANEXO L - Recomendações da FIP(1999)}

Para lajes sem armadura de punção, devem ser feitas duas verificações, definidas nos itens L.1 e L.2. A primeira delas refere-se a uma superfície crítica distante de $2 \mathrm{~d}$ da face do pilar. Já a outra refere-se à região adjacente ao pilar, onde a superfície crítica é definida junto àface do pilar.

Para lajes com armadura de punção, além das verificações mencionadas, deve ser feita ainda uma outra verificação, dada no item L.3, referente à região localizada além da região transversalmente armada.

A altura efetiva da laje (d) é considerada constante, sendo igual à média aritmética das alturas úteis segundo duas direções perpendiculares.

A taxa de armadura $(\rho)$, utilizada para resistir aos momentos fletores, é considerada como sendo a média geométrica das taxas dispostas segundo duas direções perpendiculares. Em cada direção, a taxa deve ser calculada para uma largura igual à dimensão do pilar (ou da área carregada) acrescida de 3d para cada lado, ou até a borda da laje, se esta estiver mais próxima (figura L.1).

Apresentam-se na tabela L.1 os coeficientes de segurança utilizados pelo CEB/90 para majorar e minorar, respectivamente, os valores das ações e das resistências características.

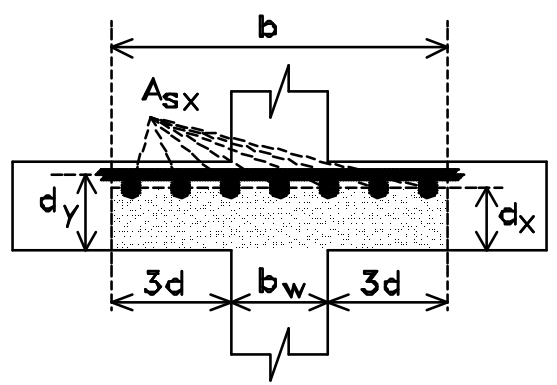

$$
\begin{aligned}
& \text { - } \mathrm{d}=\left(\mathrm{d}_{\mathrm{x}}+\mathrm{d}_{\mathrm{y}}\right) / 2 \\
& \text { - } \rho=\sqrt{\rho_{x} \rho_{y}} \\
& \rho_{\mathrm{X}}=\mathrm{A}_{\mathrm{SX}} /\left(\begin{array}{ll}
\mathrm{b} & \mathrm{d}_{\mathrm{X}}
\end{array}\right) \\
& \rho_{\mathrm{y}}=\mathrm{A}_{\mathrm{sy}} /\left(\begin{array}{ll}
\mathrm{b} & \mathrm{d}_{\mathrm{y}}
\end{array}\right)
\end{aligned}
$$

Figura L.1 - Altura útil (d) e taxa de armadura àflexão ( $\rho)$ 
Tabela L.1 - Coeficientes de segurança para ações e para resistências (CEB/90)

\begin{tabular}{|c|c|c|c|c|c|}
\hline \multicolumn{3}{|c|}{ Ações $\left(\gamma_{F}\right)$} & \multicolumn{3}{|c|}{ Resistências $\left(\gamma_{\mathbf{M}}\right)$} \\
\hline Tipos de ações & $\begin{array}{c}\text { Efeito } \\
\text { desfavorável }\end{array}$ & $\begin{array}{c}\text { Efeito } \\
\text { favorável }\end{array}$ & $\begin{array}{c}\text { Situação de } \\
\text { projeto }\end{array}$ & $\begin{array}{l}\text { Persistente } \\
\text { / transiente }\end{array}$ & Excepcional \\
\hline$\underset{\left(\gamma_{G}\right)}{\text { Permanentes }}$ & 1,35 & 1,0 & $\begin{array}{c}\text { Concreto: } \gamma_{c} \\
\text { (compressão } \\
\text { ) }\end{array}$ & 1,5 & 1,2 \\
\hline $\begin{array}{c}\text { Protensão } \\
\left(\gamma_{\mathbf{P}}\right)\end{array}$ & 1,1 & 1,0 & $\begin{array}{c}\text { Armadura } \\
\left.\text { (tração: } \gamma_{S}\right)\end{array}$ & 1,15 & 1,0 \\
\hline $\begin{array}{c}\text { Variáveis } \\
\left(\gamma_{Q}\right)\end{array}$ & 1,5 & $\begin{array}{l}\text { geralmente } \\
\text { desprezada }\end{array}$ & & & \\
\hline
\end{tabular}

\section{L.1 VERIFICAÇÃO DO PERÍMETRO CRÍTICO A 2d DA FACE DO PILAR}

Nesta verificação, a tensão atuante de cálculo $\left(\tau_{\mathrm{Sd}}\right)$ deverá sempre ser menor ou igual à tensão resistente de cálculo $\left(\tau_{\mathrm{Rd}}\right)$.

\section{a) Tensão atuante de cálculo $\left(\tau_{S d}\right)$}

A tensão atuante de cálculo é dada por: $\quad \tau_{\mathrm{Sd}}=\frac{\mathrm{F}_{\mathrm{Sd}}}{\mathrm{u}_{1} \mathrm{~d}}$, onde:

$\mathrm{u}_{1} \quad=$ perímetro crítico a $2 \mathrm{~d}$ da face do pilar (figura L.2);

$\mathrm{u}_{1}=2\left(\mathrm{c}_{1}+\mathrm{c}_{2}\right)+2 \pi(2 \mathrm{~d})$, onde $\mathrm{c}_{1}$ e $\mathrm{c}_{2}$ são os lados do pilar;

$\mathrm{F}_{\mathrm{Sd}}=$ força ou reação concentrada de cálculo provocada pelas ações que agem na estrutura; pode-se incluir o efeito vertical da protensão que age dentro de um perímetro compreendido por uma distância igual à metade da altura útil, medida a partir do contorno da área carregada. Para as lajes protendidas, os efeitos benéficos da protensão podem ser considerados de acordo com a publicação FIP Recommendations for the design of post-tensioned slabs and foundation rafts. 


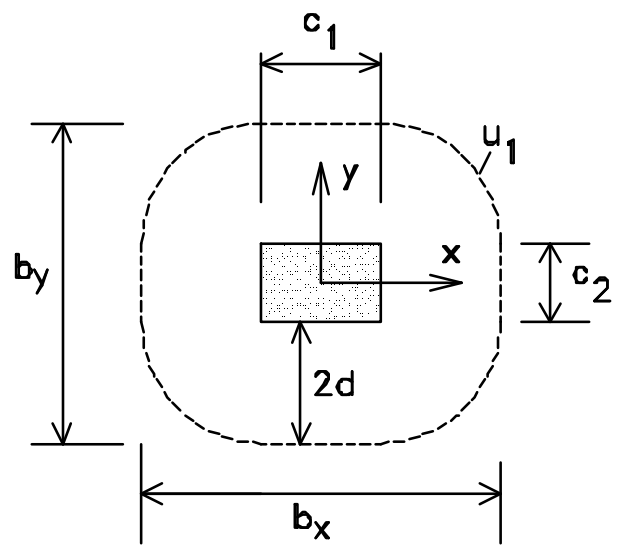

Figura L.2- Perímetro crítico u1

\section{b) Tensão resistente de cálculo $\left(\tau_{R d}\right)$}

A tensão resistente de cálculo $\left(\tau_{\mathrm{Rd}}\right)$ é dada em função da presença ou não de armadura de punção.

Para a utilização das expressões dadas a seguir, considera-se essa tensão bem como a resistência característica do concreto $\left(\mathrm{f}_{\mathrm{ck}}\right)$ dadas em MPa.

- Para lajes ou trechos sem armadura de punção

$\tau_{\mathrm{Rd}}=0,12 \kappa \sqrt[3]{100 \rho f_{\mathrm{ck}}}, \quad$ onde: $\kappa=1+\sqrt{20 / \mathrm{d}} \leq 2,0$, com d em cm

- Para lajes ou trechos com armadura de punção

Deve-se mencionar que a notação aqui utilizada foi adaptada, visando a comparação de tensões e não de forças concentradas. Nas expressões dadas a seguir, são utilizadas as unidades $\mathrm{MPa}, \mathrm{cm}$ e $\mathrm{cm}^{2}$.

$$
\tau_{\mathrm{Rd}}=0,09 \kappa \sqrt[3]{100 \rho f_{\mathrm{ck}}}+1,5\left(\frac{\mathrm{d}}{\mathrm{s}_{\mathrm{r}}}\right)\left(\frac{\mathrm{A}_{\mathrm{Sw}} \mathrm{f}_{\mathrm{ywd}} \operatorname{sen} \alpha}{\mathrm{u}_{1} \mathrm{~d}}\right)
$$


- ASw: área de armadura em uma linha homotética ao perímetro crítico a $2 \mathrm{~d}$ da face do pilar. Na figura L.3, têm-se algumas disposições de armadura de punção mostradas na FIP (1999).;

- $\mathrm{s}_{\mathrm{r}}$ : espaçamento radial $(\leq 0,75 \mathrm{~d})$;

- fywd: tensão de escoamento da armadura transversal ( $\leq 300 \mathrm{MPa}$ );

- $\alpha$ : ângulo entre a armadura e o plano médio da laje (geralmente igual a $90^{\circ}$ ).
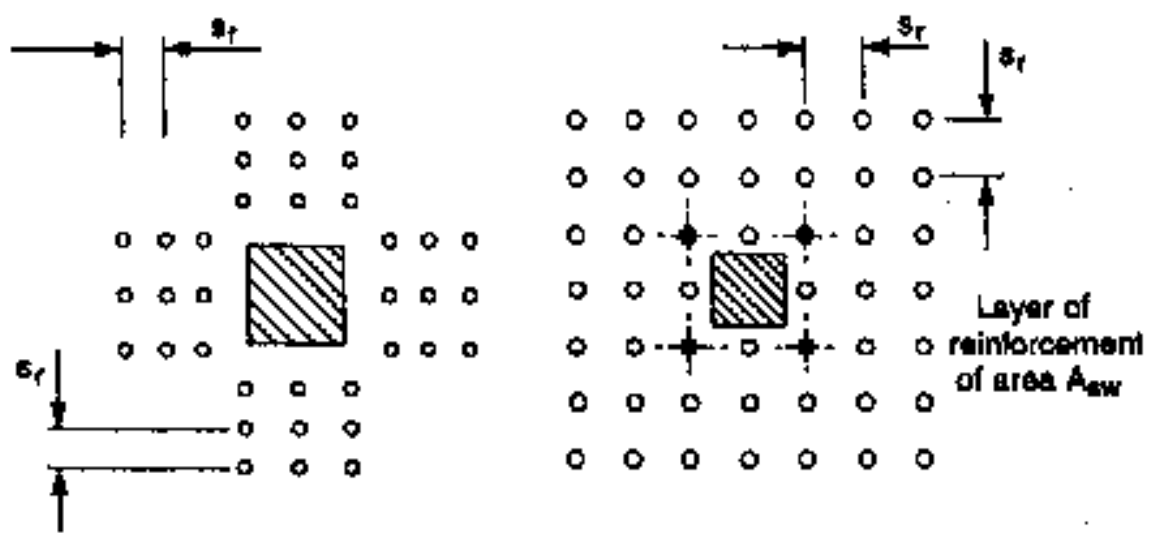

Figura L.3 - Disposição da armadura de punção em ligações laje- pilar interno

Quando necessária, deve-se garantir uma quantidade mínima de armadura de punção, definida pela expressão:

$$
\frac{\mathrm{A}_{\mathrm{Sw}}}{\mathrm{s}_{\mathrm{r}}} \geq \frac{0,03\left(\sqrt[3]{100 \rho \mathrm{f}_{\mathrm{ck}}}\right) \mathrm{u}_{1}}{1,5 \mathrm{f}_{\mathrm{ywd}} \operatorname{sen} \alpha}
$$

Além disso, a distância entre os conectores mais próximos à face do pilar e essa face não deve ser superior a $0,5 \mathrm{~d}$, conforme a figura L. 4 . 


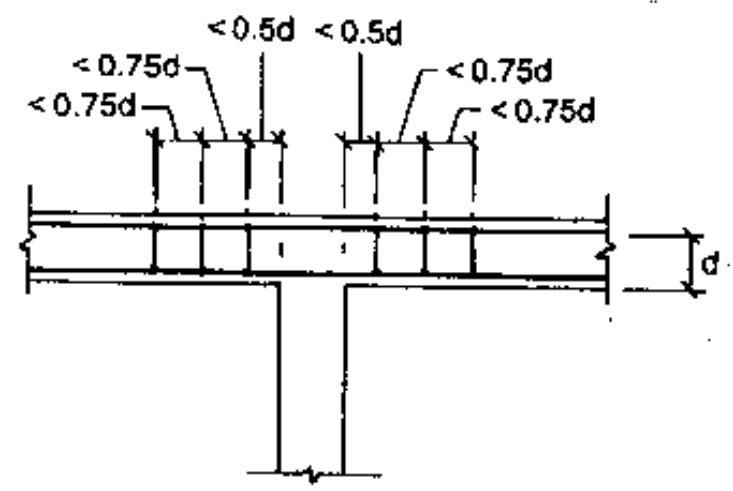

Figura L.4 - Espaçamentos máximos

\section{L.2 VERIFICAÇ̃̃O DO PERÍMETRO CRÍTICO NA FACE DO PILAR}

Nesta verificação, a tensão atuante de cálculo $\left(\tau_{\text {Sdo }}\right)$ deverá sempre ser inferior à tensão resistente de cálculo $\left(\tau_{\operatorname{Rd} 2}\right)$.

\section{a) Tensão atuante de cálculo ( $\left.\tau_{S d o}\right)$}

A tensão atuante de cálculo $\left(\tau_{\mathrm{Sdo}}\right)$ é dada por:

$$
\begin{aligned}
& \tau_{\mathrm{Sdo}}=\frac{\mathrm{F}_{\mathrm{Sd}}}{\mathrm{u}_{\mathrm{o}} \mathrm{d}}, \text { onde: } \\
& \mathrm{u}_{\mathrm{O}} \quad=\text { perímetro do pilar (figura L.5) } \\
& \mathrm{u}_{\mathrm{O}} \quad=2\left(\mathrm{c}_{1}+\mathrm{c}_{2}\right)
\end{aligned}
$$

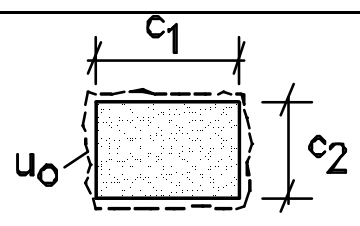

Figura L.5 - Pilar interno

\section{b) Tensão resistente de cálculo $\left(\tau_{R} d 2\right)$}

A tensão resistente de cálculo é dada por:

$$
\tau_{\mathrm{Rd} 2}=0,5 \mathrm{f}_{1 \mathrm{~cd}}, \quad \text { onde: } \quad \mathrm{f}_{1 \mathrm{~cd}}=\frac{\alpha \mathrm{f}_{\mathrm{ck}}}{\gamma_{\mathrm{c}}}, \operatorname{com}\left\{\begin{array}{l}
\alpha=0,85 \\
\gamma_{\mathrm{c}}=1,5
\end{array}\right.
$$


Neste caso, o termo $\alpha$ refere-se a um coeficiente relacionado à resistência do corpo-de-prova submetido a um ensaio de compressão uniaxial e à duração do carregamento (item 2.1.2). No entanto, o CEB/90 e a fib (1999) mencionam que se deve usar, ao invés de uma resistência $\mathrm{f}_{1 \mathrm{~cd}}$, uma resistência $\mathrm{f}_{\mathrm{cd} 2}$, que leve em conta, também, a fissuração da laje. Portanto, supõe-se que possa ter havido um equívoco nas recomendações da FIP (1999) com relação a esta verificação.

Portanto, por ser mais coerente, para se obter a tensão resistente de cálculo $\left(\tau_{\mathrm{Rd}}\right)$, será adotada a seguinte expressão:

$$
\tau_{\mathrm{Rd} 2}=0,5 \mathrm{f}_{2 \mathrm{~cd}} ; \text { com } \quad \mathrm{f}_{\mathrm{cd} 2}=0,6\left(1-\frac{\mathrm{f}_{\mathrm{ck}}}{250}\right) \mathrm{f}_{\mathrm{cd}}
$$

\section{L.3 VERIFICAÇÃo Do PERÍMETRO CRÍtiCo ALÉM DA REGĩ̃o TRANSVERSALMENTE ARMADA}

Nesta verificação, a tensão atuante de cálculo $\left(\tau_{\mathrm{Sd}}{ }^{\prime}\right)$ deverá sempre ser inferior à tensão resistente de cálculo $\left(\tau_{\mathrm{Rd}}\right)$.

\section{a) Tensão atuante de cálculo ( $\left.\tau_{S d}{ }^{\prime}\right)$}

$$
\text { A tensão atuante de cálculo }\left(\tau_{\mathrm{Sd}}\right) \text { é dada por: } \quad \tau_{\mathrm{Sd}}{ }^{\prime}=\frac{\mathrm{F}_{\mathrm{Sd}}}{\mathrm{u}_{\mathrm{n}, \mathrm{ef}} \mathrm{d}}
$$

O termo $u_{n, e f}$ refere-se ao perímetro crítico localizado a $2 d$ da linha de conectores mais afastada da face do pilar, conforme ilustrado na figura L.6. Quando os conectores mais distantes da face do pilar tiverem a distância entre si superior a 2d, devese desprezar parte deste perímetro crítico. 


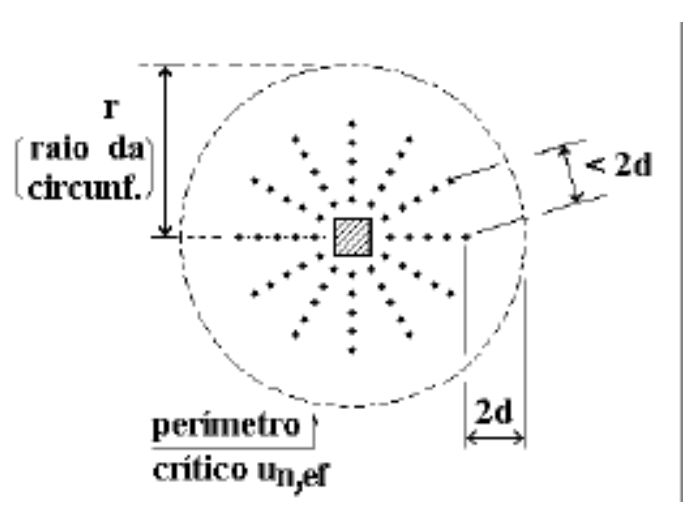

a) Disposição radial

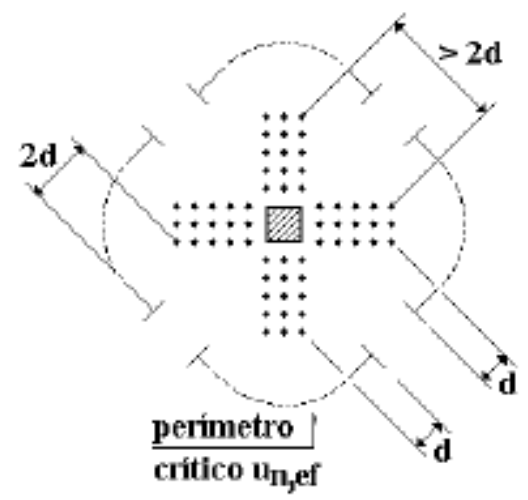

b) Disposição em cruz

Figura L.6 - Perímetro crítico $u_{n, e f}$

\section{b) Tensão resistente de cálculo $\left(\tau_{R d}\right)$}

Para este caso utiliza-se a expressão de $\tau_{\mathrm{Rd}}$ mostrada no item L.1b, relativa a peças ou trechos sem armadura de punção. A FIP (1999) não menciona se é necessário o cálculo de uma outra taxa de armadura, definida agora em função das barras longitudinais que atravessam o perímetro crítico $u_{n, e f}$. 


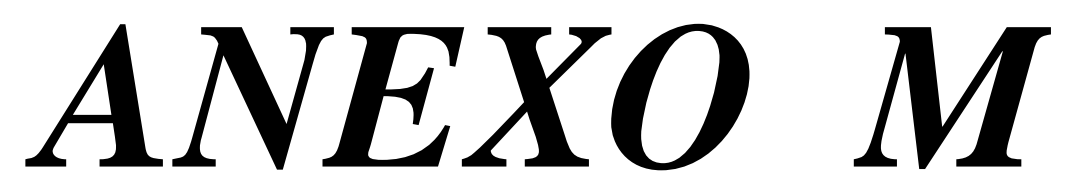

Recomendações da fib/99 


\section{ANEXO M - Recomendações da fib(1999)}

Analogamente à FIP (1999), para lajes sem armadura de punção, devem ser feitas duas verificações, definidas nos itens M.1 e M.2. Para lajes com armadura de punção, além das verificações mencionadas, deve ser feita ainda uma outra verificação, dada no item M.3.

O cálculo da altura efetiva da laje (d) e da taxa de armadura ( $\rho$ ), utilizada para resistir aos momentos fletores, é feito do mesmo modo que na FIP (1999).

\section{M.1 VERIFICAÇÃO DO PERÍMETRO CRÍTICO A 2d DA FACE DO PILAR}

Nesta verificação, a tensão atuante de cálculo $\left(\tau_{\mathrm{Sd}}\right)$ deverá sempre ser menor ou igual à tensão resistente de cálculo $\left(\tau_{\mathrm{Rd}}\right)$.

\section{a) Tensão atuante de cálculo $\left(\tau_{S d}\right)$}

A tensão atuante de cálculo é dada pela expressão $\tau_{\mathrm{Sd}}=\frac{\mathrm{F}_{\mathrm{Sd}}}{\mathrm{u}_{1} \mathrm{~d}}$, onde os termos já foram definidos no Anexo L.

\section{b) Tensão resistente de cálculo $\left(\tau_{R d}\right)$}

A tensão resistente de cálculo $\left(\tau_{\mathrm{Rd}}\right)$ é dada em função da presença ou não de armadura de punção.

Para a utilização das expressões dadas a seguir, considera-se essa tensão bem como a resistência característica do concreto $\left(\mathrm{f}_{\mathrm{ck}}\right)$ dadas em $\mathrm{MPa}$. 


\section{- Para lajes ou trechos sem armadura de punção}

São dados os valores das tensões resistentes de cálculo e característica:

$$
\begin{array}{ll}
\tau_{\mathrm{Rd}}=0,12 \kappa \sqrt[3]{100 \rho f_{\mathrm{ck}}}, & \text { onde: } \kappa=1+\sqrt{20 / \mathrm{d}} \leq 2,0, \text { com d em cm } \\
\tau_{\mathrm{Rk}}=0,16 \kappa \sqrt[3]{100 \rho f_{\mathrm{ck}}}, & \text { onde: } \kappa=1+\sqrt{20 / \mathrm{d}} \leq 2,0, \text { com d em cm }
\end{array}
$$

\section{- Para lajes ou trechos com armadura de punção}

Tal qual na FIP (1999), a notação aqui utilizada foi adaptada, visando a comparação de tensões e não de forças concentradas. Nas expressões dadas a seguir, são utilizadas as unidades $\mathrm{MPa}, \mathrm{cm}$ e $\mathrm{cm}^{2}$.

$$
\tau_{\mathrm{Rd}}=0,09 \kappa \sqrt[3]{100 \rho f_{\mathrm{ck}}}+1,5\left(\frac{\mathrm{d}}{\mathrm{s}_{\mathrm{r}}}\right)\left(\frac{\mathrm{A}_{\mathrm{Sw}_{\mathrm{w}} \mathrm{f}_{\mathrm{ywd}}}}{\mathrm{u}_{1} \mathrm{~d}}\right)
$$

- ASw: área de armadura em uma linha homotética ao perímetro crítico a $2 \mathrm{~d}$ da face do pilar. Caso a armadura não tenha sido disposta em linhas circunferenciais, pode-se considerar o valor de ASW como sendo a soma das áreas dos elementos que cruzam uma superfície inclinada de arc cot 1,5. A fib (1999) considera o ângulo entre a armadura de punção e o plano médio da laje em $90^{\circ}$;

- $\mathrm{s}_{\mathrm{r}}$ : espaçamento radial ( $\leq 0,75 \mathrm{~d}$ ); na figura M1 tem-se ilustrada a limitação do espaçmento entre conectores;

- fywd: tensão de escoamento da armadura transversal ( $\leq 300 \mathrm{MPa}$ ). 


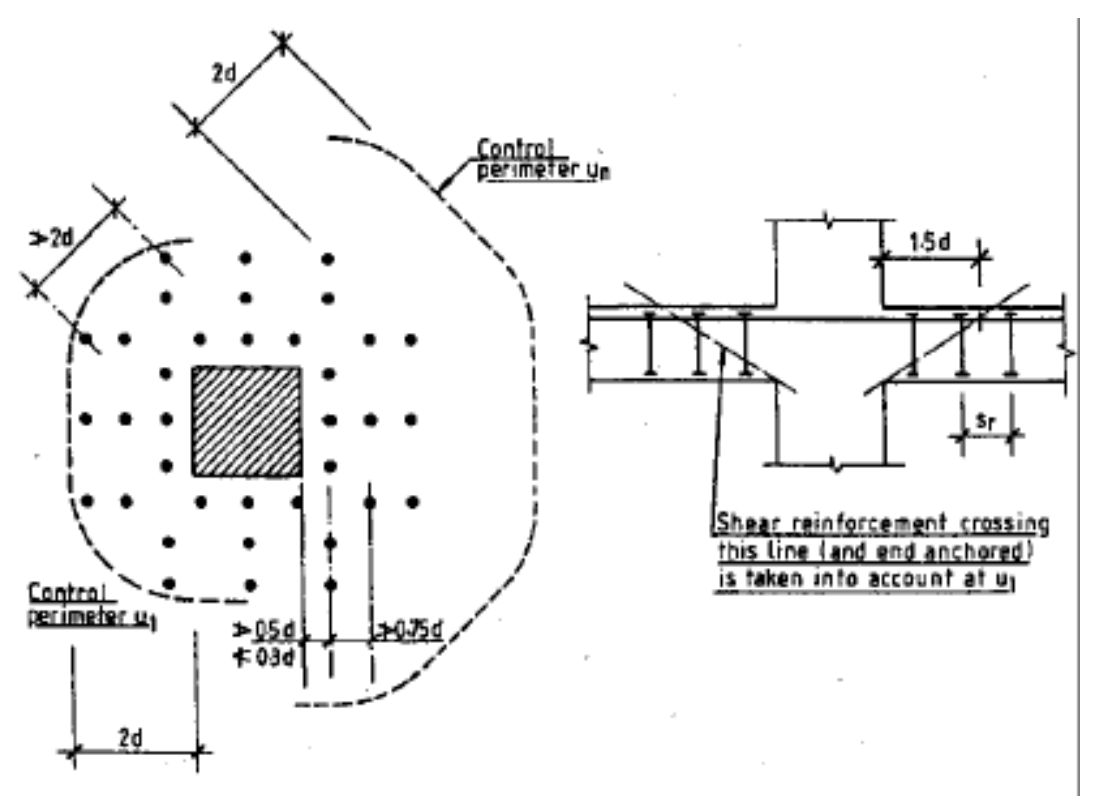

Figura M1 - Limitação do espaçamento da armadura de punção

\section{M.2 VERIFICAÇÃO DO PERÍMETRO CRÍTICO NA FACE DO PILAR}

Nesta verificação, semelhante à dada pela FIP (1999), a tensão atuante de cálculo $\left(\tau_{\mathrm{Sdo}}\right)$ deverá sempre ser inferior à tensão resistente de cálculo $\left(\tau_{\mathrm{Rd} 2}\right)$.

\section{a) Tensão atuante de cálculo $\left(\tau_{S d o}\right)$}

A tensão atuante de cálculo $\left(\tau_{\mathrm{Sdo}}\right)$ é dada por: $\quad \tau_{\mathrm{Sdo}}=\frac{\mathrm{F}_{\mathrm{Sd}}}{\mathrm{u}_{\mathrm{o}} \mathrm{d}}$, onde:

$\mathrm{u}_{\mathrm{O}} \quad=$ perímetro do pilar (já mostrada na figura L.5)

$\mathrm{u}_{\mathrm{O}} \quad=2\left(\mathrm{c}_{1}+\mathrm{c}_{2}\right)$

\section{b) Tensão resistente de cálculo $\left(\tau_{R d 2}\right)$}

A tensão resistente de cálculo, neste caso, é bem diferente da definida pela FIP (1999): $\quad \tau_{\mathrm{Rd} 2}=0,5 \mathrm{f}_{\mathrm{cd} 2}, \quad$ onde: $\quad \mathrm{f}_{\mathrm{cd} 2}=0,6 \mathrm{f}_{\mathrm{cd} 2}\left(1-\frac{\mathrm{f}_{\mathrm{ck}}}{250}\right)$ 


\section{M.3 VERIFICAÇÃO DO PERÍMETRO CRÍTICO ALÉM DA REGIÃo TRANSVERSALMENTE ARMADA}

Nesta verificação, a fib (1999) menciona apenas que a tensão que atua em um perímetro além da região armada $\left(u_{n}\right)$ deve ser inferior à tensão resistente de cálculo $\left(\tau_{\mathrm{Rd}}\right)$, calculada para lajes sem armadura de punção. $\mathrm{O}$ perímetro $u_{\mathrm{n}}$ está mostrado na figura M2.

$$
\text { Portanto: } \tau_{\mathrm{Rd}} \geq \frac{\mathrm{F}_{\mathrm{Sd}}}{\mathrm{u}_{\mathrm{n}} \mathrm{d}}
$$

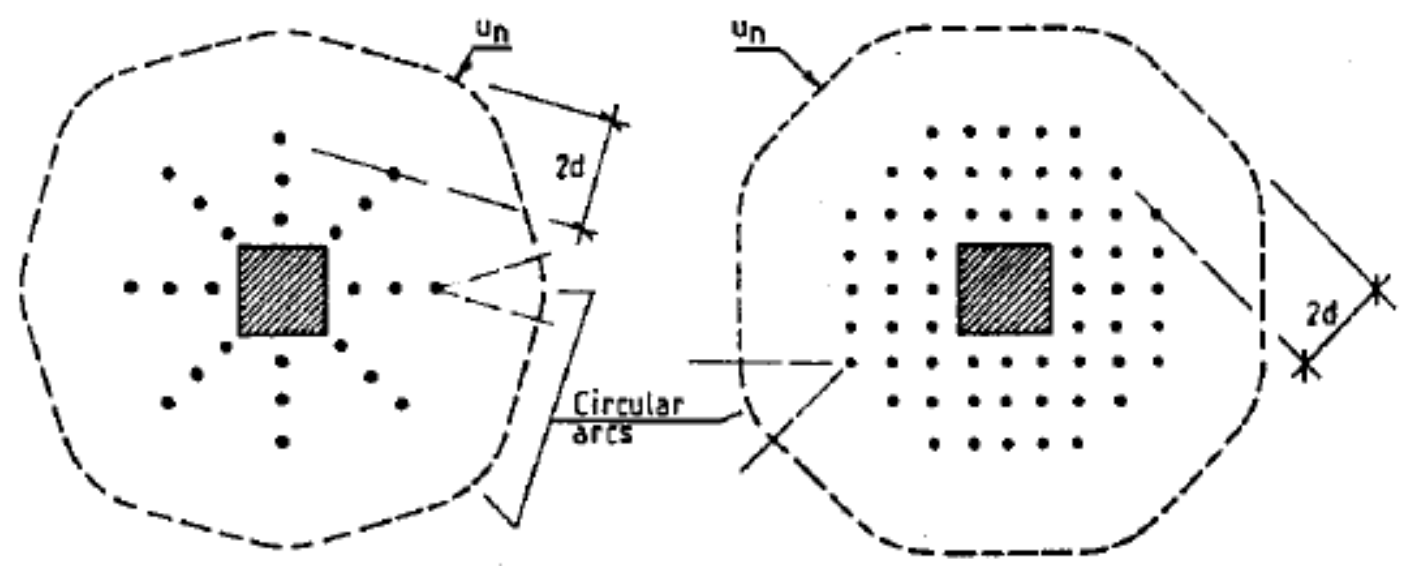

Figura M2 - Perímetros críticos além da região com armadura de punção

\section{M.4 PROTENSÃO}

A fib (1999) menciona que, para lajes protendidas, devem ser seguidas as recomendações da FIP. 


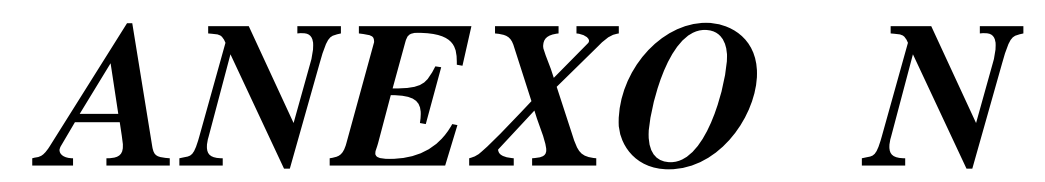

Recomendações da Revisão

$$
\text { da NB-1 (2000) }
$$




\section{ANEXO N - Recomendações \\ da revisão da NB-1 (2000)}

A revisão da NB-1 (2000) é basicamente uma adaptação das recomendações do CEB/90, com relação à punção em lajes. Ela é aplicada às estruturas d e concreto do grupo I de resistência (C10 a C50), conforme classificação da NBR 8953 (1992).

Para lajes sem armadura de punção, devem ser feitas duas verificações, definidas nos itens N.1 e N.2. A primeira delas refere-se a uma superfície crítica distante de $2 \mathrm{~d}$ da face do pilar, análoga à superfície dada pelo CEB/90, já mostrada na figura L.2 do Anexo L. Já a outra refere-se à região adjacente ao pilar, onde a superfície crítica é definida junto à face do pilar, superfície esta já ilustrada na figura L.5 do Anexo L.

Para lajes com armadura de punção, além das verificações mencionadas, deve ser feita ainda uma outra verificação, dada no item N.3, referente à região localizada além da região transversalmente armada.

Analogamente ao CEB/90, a altura efetiva da laje (d) é considerada constante, sendo igual à média aritmética das alturas úteis segundo duas direções perpendiculares, e a taxa de armadura $(\rho)$ é considerada como sendo a média geométrica das taxas dispostas segundo duas direções perpendiculares. Em cada direção, a taxa deve ser calculada para uma largura igual à dimensão do pilar (ou da área carregada) acrescida de $3 \mathrm{~d}$ para cada lado, ou até a borda da laje, se esta estiver mais próxima, conforme já mostrado na figura L.1 do Anexo L.

\section{N.1 VERIFICAÇÃO DO PERÍMETRO CRÍTICO A 2d DA FACE DO PILAR}

Nesta verificação, a tensão atuante de cálculo $\left(\tau_{S d}\right)$ deverá sempre ser menor ou igual àtensão resistente de cálculo $\left(\tau_{\mathrm{Rd}}\right)$. 


\section{a) Tensão atuante de cálculo $\left(\tau_{S d}\right)$}

A tensão atuante de cálculo é dada por: $\quad \tau_{\mathbf{S d}}=\mathbf{F}_{\mathbf{S d}} /\left(\mathbf{u}_{\mathbf{1}} \mathbf{d}\right)$, onde:

$\mathrm{u}_{1}=$ perímetro crítico a $2 \mathrm{~d}$ da face do pilar (figura L.2, Anexo L);

$\mathrm{F}_{\mathrm{Sd}}=$ força ou reação concentrada de cálculo.

\section{b) Tensão resistente de cálculo $\left(\tau_{R d}\right)$}

A tensão resistente de cálculo $\left(\tau_{\mathrm{Rd}}\right)$ é dada em função da presença ou não de armadura de punção. Para a utilização das expressões dadas a seguir, considera-se essa tensão bem como a resistência característica do concreto $\left(\mathrm{f}_{\mathrm{ck}}\right)$ dadas em $\mathrm{MPa}$.

- Para lajes ou trechos sem armadura de punção

$\tau_{\mathrm{Sd}} \leq \tau_{\mathrm{Rd}}=0,13(1+\sqrt{20 / \mathrm{d}}) \sqrt[3]{100 \rho \mathrm{f}_{\mathrm{ck}}}$, com d em cm

- Para lajes ou trechos com armadura de punção

$$
\tau_{\mathrm{Rd}}=0,10(1+\sqrt{20 / \mathrm{d}}) \sqrt[3]{100 \rho \mathrm{f}_{\mathrm{ck}}}+1,5\left(\frac{\mathrm{d}}{\mathrm{s}_{\mathrm{r}}}\right)\left(\frac{\mathrm{A}_{\mathrm{Sw}} \mathrm{f}_{\mathrm{ywd}} \operatorname{sen} \alpha}{\mathrm{u}_{1} \mathrm{~d}}\right)
$$

- $\mathrm{A}_{\mathrm{Sw}}$ : área de armadura de punção num contorno completo paralelo ao perímetro crítico adotado nesta verificação (figura N.1). Essa armadura deve ser preferencialmente constituída por três ou mais linhas de conectores tipo pino;

- $\mathrm{s}_{\mathrm{r}}$ : espaçamento radial $(\leq 0,75 \mathrm{~d})$;

- $\alpha$ : $\quad$ ângulo entre a armadura e o plano médio da laje (geralmente igual a $90^{\circ}$ );

- $\mathrm{f}_{\mathrm{ywd}}$ : resistência de cálculo da armadura de punção, não maior do que $300 \mathrm{MPa}$ para conectores ou $250 \mathrm{MPa}$ para estribos (CA 50 ou CA 60), para lajes com espessura até $15 \mathrm{~cm}$. 


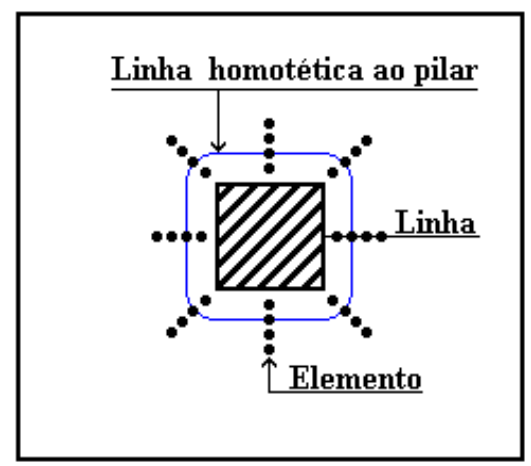

Figura N.1 Definição de $\mathrm{A}_{\mathrm{SW}}$

Para lajes com espessura maior do que $35 \mathrm{~cm}$, pode-se ser usada a resistência dos estribos fywd $\leq 435 \mathrm{MPa}$. Permite-se a interpolação linear para casos de espessuras intermediárias aos valores mencionados. A distância entre os conectores mais próximos à face do pilar e essa face não deve ser superior a $0,5 \mathrm{~d}$ (figura N.2).

A revisão apresenta alguns detalhes com relação aos conectores tipo pino, mostradas na figura N.3

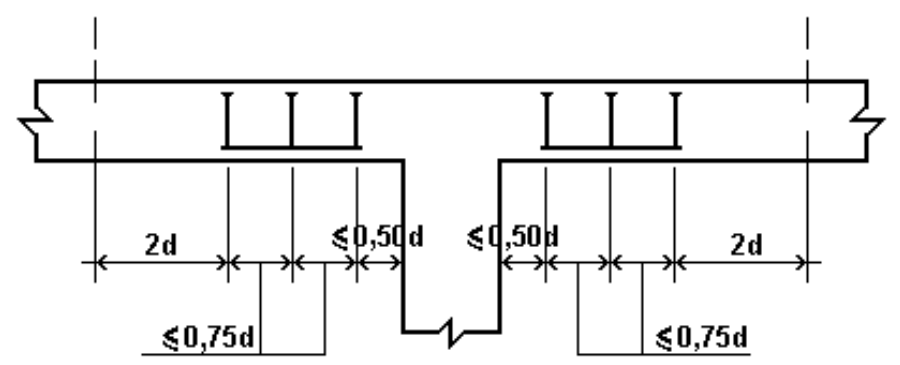

Figura N.2 - Disposição da armadura de punção em corte
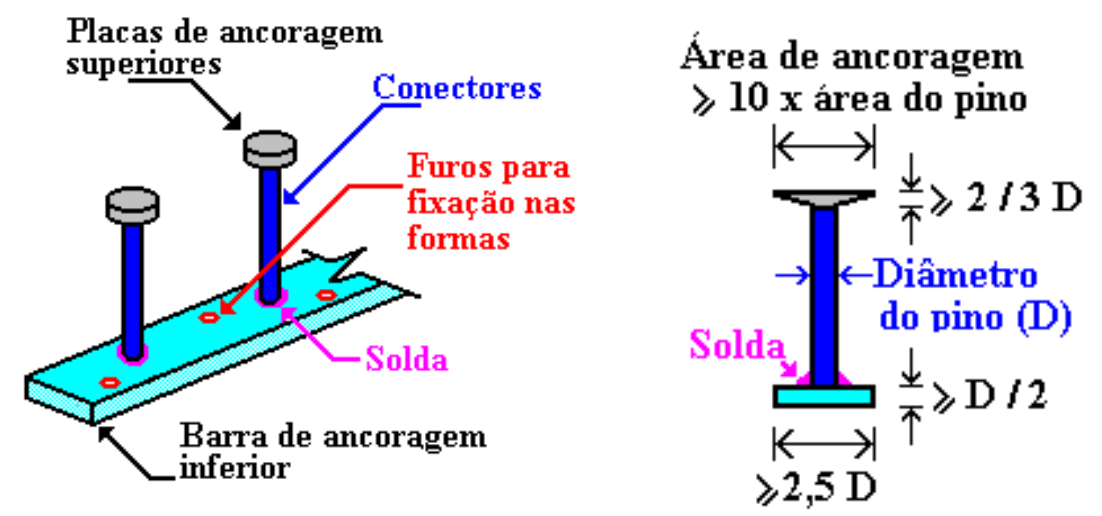

Figura N.3 - Detalhes dos conectores tipo pino 


\section{N.2 VERIFICAÇÃO DO PERÍMETRO CRÍTICO NA FACE DO PILAR}

Esta verificação, relativa ao estado limite último dado pela compressão diagonal do concreto, visa quantificar a máxima resistência que uma ligação, protendida ou não, pode atingir.

Neste caso, a tensão atuante de cálculo $\left(\tau_{\mathrm{Sdo}}\right)$ deverá sempre ser menor ou igual à tensão resistente de cálculo $\left(\tau_{\mathrm{Rd} 2}\right)$.

\section{a) Tensão atuante de cálculo $\left(\tau_{S d o}\right)$}

A tensão atuante de cálculo $\left(\tau_{\mathrm{Sdo}}\right)$ é dada por: $\quad \tau_{\mathbf{S d o}}=\mathbf{F}_{\mathbf{S d}} /\left(\mathbf{u}_{\mathbf{o}} \mathbf{d}\right)$, onde $\mathrm{u}_{\mathrm{O}}$ é tomado como sendo o perímetro do pilar (figura L.5, Anexo L).

\section{b) Tensão resistente de cálculo $\left(\tau_{R d 2}\right)$}

A tensão resistente de cálculo é dada por: $\boldsymbol{\tau}_{\mathbf{R d} \mathbf{2}}=\mathbf{0 , 2 7} \boldsymbol{\alpha}_{\mathbf{v}} \mathbf{f}_{\mathbf{c d}}, \quad$ onde:

$\alpha_{\mathrm{V}}=\left(1-\mathrm{f}_{\mathrm{ck}} / 250\right)$

$\mathrm{f}_{\mathrm{cd}} \quad=$ resistência de cálculo do concreto à compressão.

\section{N.3 VERIFICAÇÃO DO PERÍMETRO CRÍTICO ALÉM DA REGIÃo TRANSVERSALMENTE ARMADA}

Nesta verificação, a tensão atuante de cálculo ( $\left.\tau_{\mathrm{Sd}}{ }^{\prime}\right)$ deverá sempre ser menor ou igual àtensão resistente de cálculo $\left(\tau_{\mathrm{Rd}}\right)$.

\section{a) Tensão atuante de cálculo ( $\left.\tau_{S d}{ }^{\prime}\right)$}

A tensão atuante de cálculo $\left(\tau_{\mathrm{Sd}^{\prime}}\right)$ é dada por: $\quad \boldsymbol{\tau}_{\mathbf{S d}}{ }^{\prime}=\mathbf{F}_{\mathbf{S d}} /\left(\mathbf{u}_{\mathbf{n}, \mathbf{e f}} \mathbf{d}\right)$ 
O termo $u_{n, e f}$ refere-se ao perímetro crítico localizado a $2 d$ da linha de conectores mais afastada da face do pilar, conforme a figura N.4. Quando os conectores mais distantes da face do pilar tiverem a distância entre si superior a 2d, devese desprezar parte deste perímetro crítico.

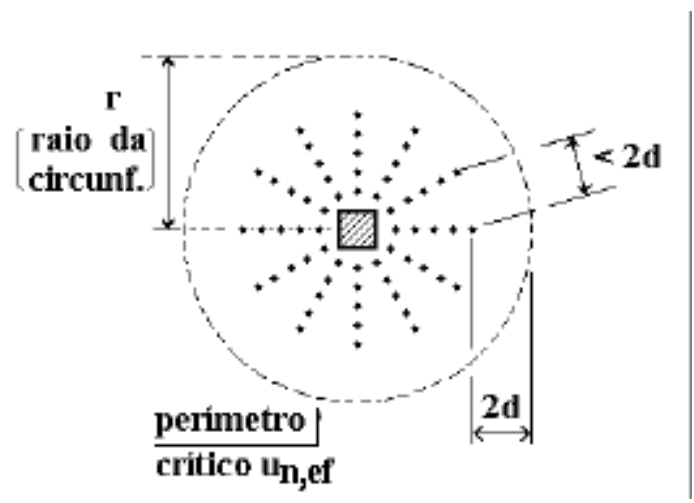

a) Radial

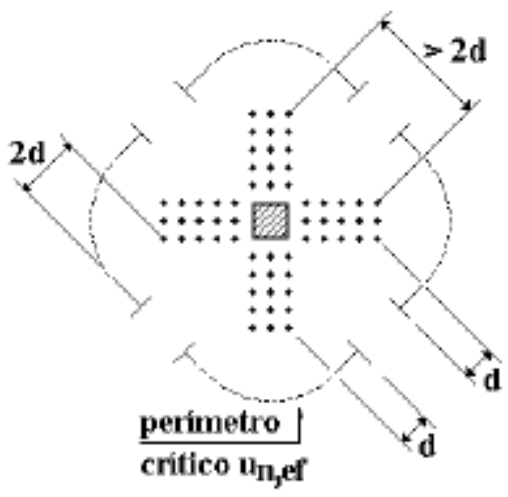

b) Em cruz

Figura N.4 - Perímetro crítico $u_{n, e f}$

\section{b) Tensão resistente de cálculo $\left(\tau_{R d}\right)$}

Para este caso utiliza-se a expressão de $\tau_{\mathrm{Rd}} \operatorname{mostrada}$ no item N.1b, relativa a peças ou trechos sem armadura de punção.

\section{N.4 COLAPSO PROGRESSIVO}

Para garantir a dutilidade local e a conseqüente proteção contra o colapso progressivo, a armadura de flexão que atravessar o contorno $\mathrm{C}$ deve estar suficientemente ancorada além do perímetro C', conforme a figura N.5, e deve ser tal que :

$A_{s} f_{y d} \geq F_{S d}$, onde $A_{s}$ é somatória de todas as áreas das barras que cruzam cada uma das faces do pilar. 


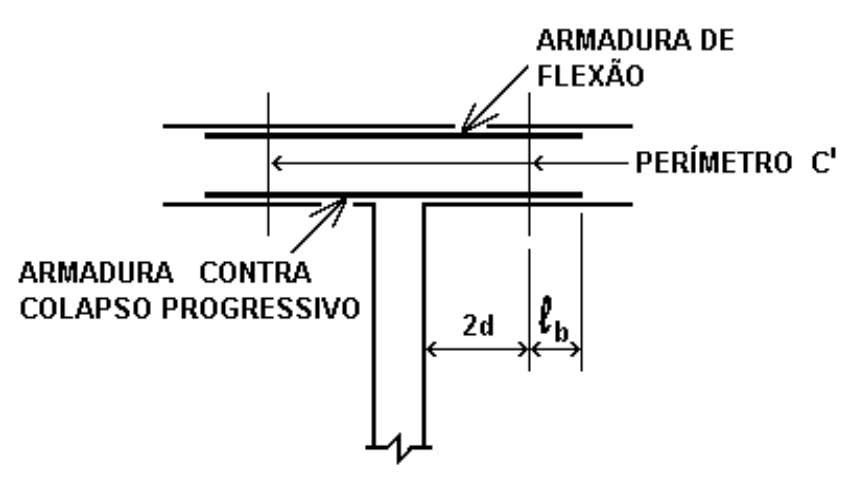

Figura N.5 - Armadura contra colapso progressivo

\section{N.5 VERIFICAÇÃO DE PEÇAS PROTENDIDAS}

O efeito favorável da protensão na resistência da ligação é considerado através de um alívio na tensão atuante de cálculo. Sendo assim tem-se que:

$$
\tau_{\mathrm{Sd}, \mathrm{ef}}=\tau_{\mathrm{Sd}}-\tau_{\mathrm{Pd}}, \quad \text { onde: }
$$

$\tau_{\mathrm{Pd}}$ : tensão devida ao efeito dos cabos de protensão inclinados que atravessam o contorno considerado e passam a menos de $\mathrm{d} / 2$ da face do pilar, conforme figura N.6.

$\tau_{\mathrm{Pd}}=\frac{\sum \mathrm{P}_{\mathrm{kinf,i}} \operatorname{sen} \alpha_{\mathrm{i}}}{\mathrm{u} \mathrm{d}}$

$\mathrm{P}_{\mathrm{K} \text { inf,i }}=$ força de protensão no cabo $\mathrm{i}$;

$\alpha_{i}=$ inclinação do cabo i em relação ao plano da laje no contorno considerado;

$\mathrm{u}=$ perímetro crítico do contorno considerado, em que se calcula $\tau_{\mathrm{Sd} \text {,ef }}$.

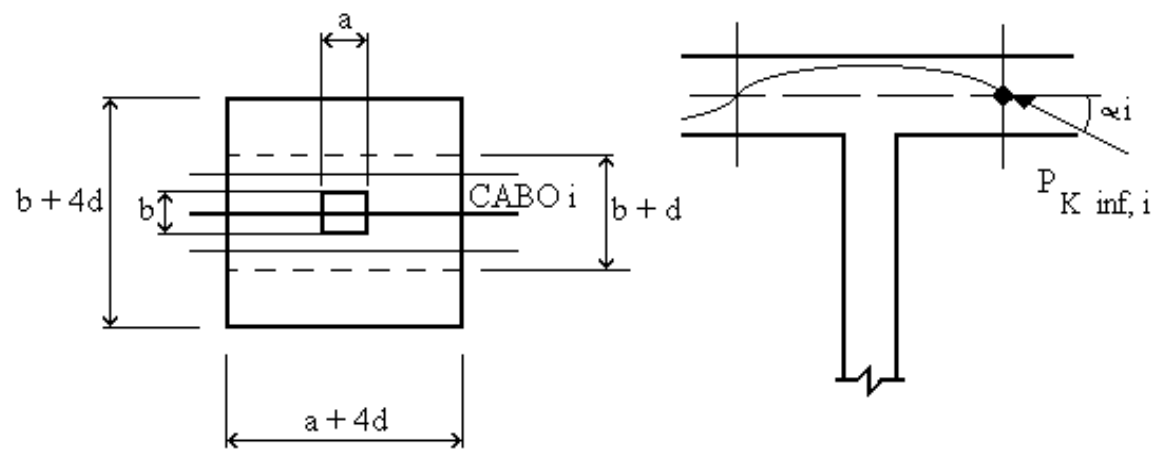

Figura N.6 - Efeito favorável dos cabos inclinados (Revisão da NB-1, 2000) 

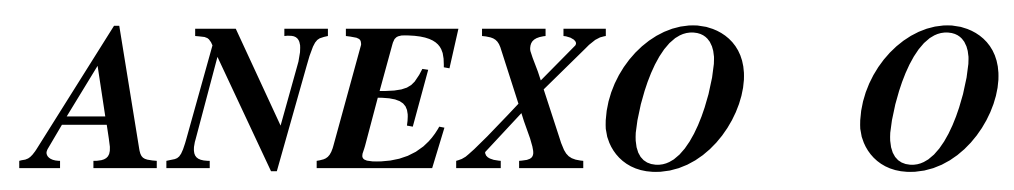

Recomendações do ACI 


\section{ANEXO O - Recomendações do ACI}

São apresentadas algumas das recomendações do ACI318-95, ACI 421.1R-92 e ACI 352.1R-89.

\section{O.1 RECOMENDAÇÕES DO ACI 318-95}

A verificação da ligação com relação à punção é feita através da expressão:

$\mathrm{v}_{\mathrm{u}} \leq \phi \mathrm{v}_{\mathrm{n}}$, onde:

- $\phi$ : é o coeficiente de minoração da resistência da ligação, igual a 0,85 para os casos de torção e de cisalhamento;

- vu: é a tensão atuante de cálculo em um determinado perímetro crítico;

- $\mathrm{v}_{\mathrm{n}}$ : é a resistência nominal de cálculo. Para ligações com armadura de cisalhamento, uma determinada parcela da força cortante é resistida pelo concreto e a outra pela armadura.

Para lajes sem armadura de punção, deve ser feita apenas uma verificação relativa a uma superfície crítica localizada a d/2 da face do pilar, onde d é a altura útil média da laje.

Já para lajes com armadura de punção, deve-se verificar também a região localizada a d/2 além da transversalmente armada.

Segundo o comentário R11.1.2, como não há muitos resultados sobre punção em lajes de concreto de alta resistência, até que evidências experimentais sejam obtidas através de ensaios, as recomendações com relação ao cisalhamento e ao comprimento de ancoragem estão limitadas a concretos com resistência inferior a $69 \mathrm{MPa}(10000$ psi). 


\section{O.1.1 VERIFICAÇÃO DO PERÍMETRO CRÍTICO A d/2 DA FACE DO PILAR}

A tensão atuante de cálculo é dada por:

$$
\begin{aligned}
\mathrm{b}_{\mathrm{O}}= & \text { comprimento do perímetro crítico } \\
& \text { localizado a d/2 do contorno do } \\
& \text { pilar (figura } \mathrm{O} .1 \text { ) } \\
\mathrm{d}= & \text { altura útil da laje (média aritmética das } \\
& \text { alturas segundo as duas direções x e y); } \\
\mathrm{V}_{\mathrm{u}}= & \text { força cortante atuante, sendo, no caso, a } \\
& \text { força ou reação concentrada de cálculo. }
\end{aligned}
$$

$$
\mathbf{v}_{\mathbf{u}}=\mathbf{V}_{\mathbf{u}} /\left(\mathbf{b}_{\mathbf{o}} \mathbf{d}\right), \quad \text { onde: }
$$

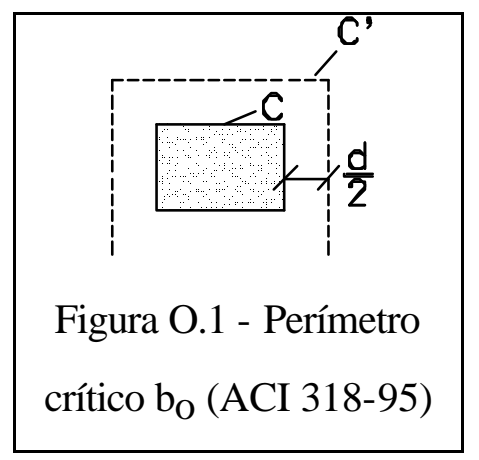

Já a tensão nominal resistente $v_{n}$ é dada em função da presença ou não da armadura de punção.

\section{- Para lajes ou trechos sem armadura de punção}

Para este caso: $\quad v_{n}=v_{c}$, onde $v_{c}$ é a resistência obtida através da contribuição do concreto. $\mathrm{O}$ valor de $\mathrm{v}_{\mathrm{c}}$ é o menor dos valores obtidos através das expressões:

$$
\begin{aligned}
& \mathrm{v}_{\mathrm{c}}=0,3321 \sqrt{\mathrm{f}_{\mathrm{c}}{ }^{\prime}} \\
& \mathrm{v}_{\mathrm{c}}=0,08303\left(2+\frac{4}{\beta_{\mathrm{c}}}\right) \sqrt{\mathrm{f}_{\mathrm{c}}{ }^{\prime}} \\
& \mathrm{v}_{\mathrm{c}}=0,08303\left(\frac{\alpha_{\mathrm{s}} \mathrm{d}}{\mathrm{b}_{\mathrm{o}}}+2\right) \sqrt{\mathrm{f}_{\mathrm{c}}{ }^{\prime}}
\end{aligned}
$$

$\beta_{\mathrm{c}}=$ razão entre os lados mais longo e mais curto do pilar;

$\mathrm{f}_{\mathrm{c}^{\prime}}{ }^{\prime}=$ resistência do concreto à compressão, medida em corpos-de-prova cilíndricos, com diâmetro igual a $152 \mathrm{~mm}$ (6 in.) e altura igual a $305 \mathrm{~mm}$ (12in.). Esta resistência pode ser considerada como sendo semelhante ao valor de $\mathrm{f}_{\mathrm{ck}}$, sendo dada em MPa;

$\alpha_{\mathrm{S}}=$ constante igual a 40 para o caso de pilares internos. 
Segundo o comentário R11.3.2.1, o termo $\sqrt{\mathrm{f}_{\mathrm{c}}{ }^{\prime}}$ representa uma medida da resistência do concreto à tração.

Inicialmente, o valor para tensões de cisalhamento correspondentes a carregamentos últimos estava limitado pela expressão (O.1). Observou-se que este valor não era conservativo para os casos em que o coeficiente $\beta_{\mathrm{c}}$ assumia valores maiores que 2 , tratando-se de pilares retangulares alongados. Para estes pilares, a tensão real de cisalhamento na seção crítica, correspondente à situação de ruína por punção, atinge o valor máximo dado pela expressão (O.1) apenas na região dos cantos do pilar, diminuindo este valor em direção à região central do lado maior do pilar. Outros ensaios constataram ainda que, na medida em que o valor da razão $b_{0} / d$ aumentava, o valor de $v_{c}$ diminuía. Baseados nestas evidências é que foram desenvolvidas as expressões (O.2) e (O.3).

O valor dado pela expressão (O.3) corresponde a uma ruína do concreto por tração diagonal, que se inicia na seção crítica definida. Este modo de ruína difere da provocada pela compressão do concreto ao longo do perímetro da região carregada, prevista pela expressão (O.2).

Para lajes protendidas, a resistência é dada através da seguinte expressão:

$$
\mathrm{v}_{\mathrm{c}}=0,08303 \beta_{\mathrm{p}} \sqrt{\mathrm{f}_{\mathrm{c}}{ }^{\prime}}+0,3 \mathrm{f}_{\mathrm{pc}}+\frac{\mathrm{V}_{\mathrm{p}}}{\mathrm{b}_{\mathrm{o}} \mathrm{d}}
$$

onde:

- $\beta_{\mathrm{p}}=$ coeficiente dado através da expressão: $\beta_{\mathrm{p}}=\left(\frac{\alpha_{\mathrm{S}} \mathrm{d}}{\mathrm{b}_{\mathrm{o}}}+1,5\right) \leq 3,5$;

- $\mathrm{f}_{\mathrm{pc}}=$ valor médio das tensões de compressão que atuam no concreto segundo as duas direções, relativas ao centróide da seção transversal da laje;

- $\mathrm{V}_{\mathrm{p}}=$ é a componente vertical de todas as forças efetivas de protensão que atravessam a seção crítica. Este termo contribui apenas com uma pequena parcela na resistência ao cisalhamento. Portanto, ela pode ser conservativamente tomada como sendo igual a zero. No entanto, caso ela seja incluída, deve-se especificar o traçado do cabo. 
Segundo o ACI, pesquisas mencionam que a expressão $(\mathrm{O} .4)$ fornece valores conservativos. Ainda assim, ela só pode ser aplicada se forem respeitadas as seguintes condições:

- nenhuma parte da seção transversal do pilar pode estar a uma distância da borda livre da laje inferior a quatro vezes a espessura da laje. Para pilares posicionados junto à borda livre, a protensão não é completamente efetiva ao redor do perímetro crítico $b_{0}$. Sendo assim, conservativamente, desconsidera-se a influência positiva da protensão na resistência ao cisalhamento da laje;

- o máximo valor de $\mathrm{f}_{\mathrm{c}}$ ' que pode ser usado na expressão (O.4) é de $35 \mathrm{MPa}$ (5000 psi);

- a tensão fo para cada direção não deve ser inferior a 0,86 MPa (125 psi) e nem superior a 3,45 MPa (500 psi). No cálculo do valor de fpc devem ser consideradas todas as perdas de protensão.

Caso as condições não sejam respeitadas, devem ser usadas as expressões (O.1), (O.2) e (O.3)

\section{- Para lajes ou trechos com armadura de punção}

Pesquisas mostram que o uso de barras como armadura de cisalhamento podem ser usadas em lajes, desde que elas estejam devidamente ancoradas.

A ancoragem de estribos pode ser difícil de ser obtida em lajes delgadas, com espessura inferior a $25 \mathrm{~cm}$.

Sendo assim, os estribos devem ser usados como quadros fechados e possuir uma barra de armadura longitudinal em cada um de seus cantos, conforme mostrado na figura O.2.

Não foram incluídas neste trabalho as recomendações específicas para perfis metálicos ("shearheads"). 


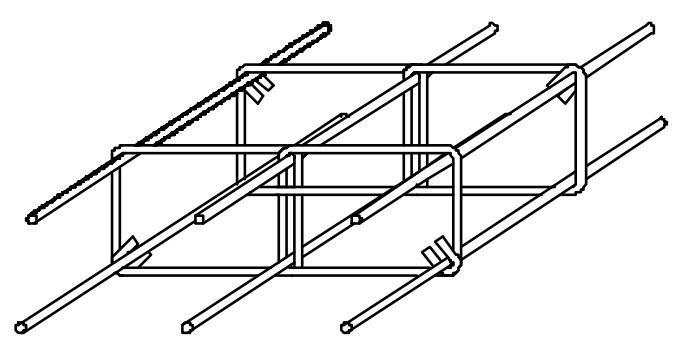

Figura O.2 - Estribos (ACI 318-95)

O ACI 318-95 menciona ainda que têm sido utilizados conectores tipo, que, em função de suas boas características mecânicas de ancoragem, permitem que seja atingida a tensão de escoamento da armadura de punção.

O valor de $v_{n}$ é dado através da expressão:

$$
\mathrm{v}_{\mathrm{n}}=\mathrm{v}_{\mathrm{c}}+\mathrm{v}_{\mathrm{s}} \leq 0,4982 \sqrt{\mathrm{f}_{\mathrm{c}}}
$$

Enquanto le é a contribuição do concreto, dada na expressão (O.6), o termo vs representa a contribuição da armadura de punção na resistência da ligação, dada na expressão (O.7), sendo esta expressão específica para estribos perpendiculares ao plano médio da laje.

$$
\begin{aligned}
& \mathrm{v}_{\mathrm{c}}=0,1661 \sqrt{\mathrm{f}_{\mathrm{c}}{ }^{\prime}} ; \\
& \mathrm{v}_{\mathrm{s}}=\frac{\mathrm{A}_{\mathrm{v}} \mathrm{f}_{\mathrm{y}}}{\mathrm{s} \mathrm{b_{ \textrm {O } }}}, \quad \text { onde: }
\end{aligned}
$$

$\mathrm{s}$ = espaçamento da armadura de punção, que não deve ser superior a d/2 para elementos sem protensão e nem a $0,75 \mathrm{~h}$ para elementos protendidos;

$\mathrm{A}_{\mathrm{V}}=$ área da armadura de punção dentro da distância s;

$\mathrm{f}_{\mathrm{y}}=$ tensão de escoamento da armadura, não podendo ser superior a $414 \mathrm{MPa}$ (60 000 psi). Esta limitação visa a um controle da abertura das fissuras diagonais. Entretanto, na versão de 1995 deste código, este limite foi aumentado para $550 \mathrm{MPa}$ (80 000 psi) para alguns tipos de fios e de arames de aço. 
Não se tem um valor de área mínima de armadura de cisalhamento para lajes, em função da possibilidade do carregamento ser compartilhado por áreas menos e mais resistentes.

Como a armadura de cisalhamento deve ser projetada para absorver as tensões que excederem a resistência do concreto ao cisalhamento, pode-se usar a seguinte expressão como um pré-dimensionamento:

$$
\frac{A_{v}}{s}=\frac{\left(v_{u}-\phi v_{c}\right) b_{o}}{\phi f_{y}}
$$

Não foram encontradas recomendações que abordem a influência da protensão na região transversalmente armada.

\section{O.1.2 VERIFICAÇÃO DO PERÍMETRO CRÍTICO A d/2 ALÉM DA REGIÃO TRANSVERSALMENTE ARMADA}

Embora o ACI 318-95 mencione uma seção crítica externa à região transversalmente armada (figura O.3), ele não fornece maiores informações para que seja feita uma verificação e nem como a protensão influencia a resistência da ligação nesta região.
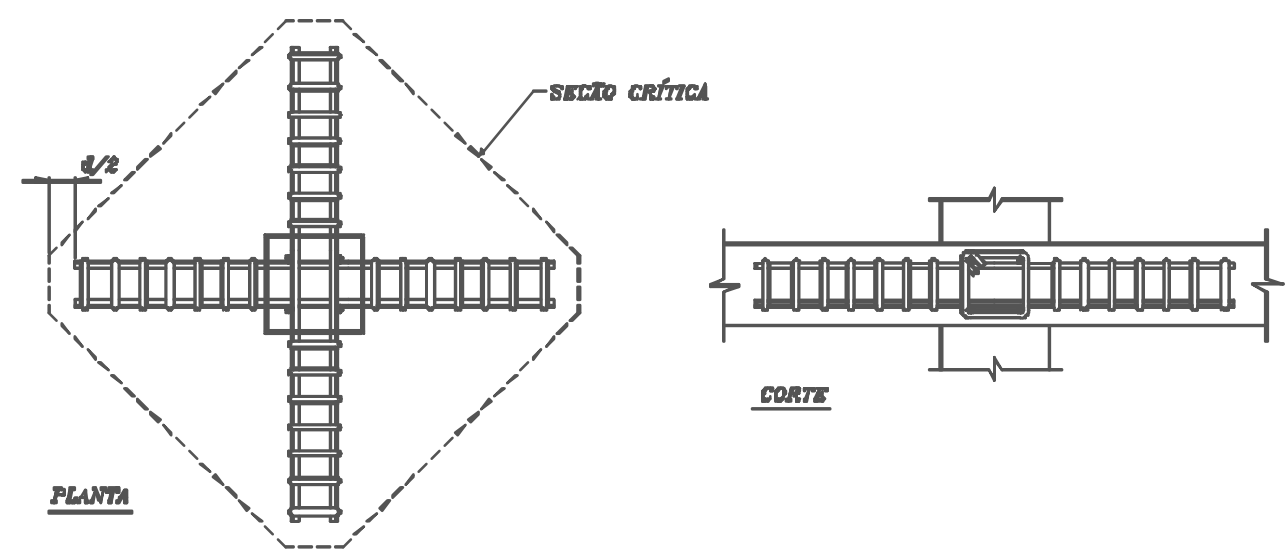

Figura O.3 - Seção crítica externa à região transversalmente armada (ACI 318-95) 


\section{O.2 RECOMENDAÇÕES DO ACI 421.1R-92}

O ACI 318-95 traz recomendações específicas apenas para estribos e "shearheads"; já Comitê 421, do ACI-ASCE, procura abordar outros tipos de armadura de cisalhamento, compostas por elementos verticais, com ancoragens mecânicas em suas extremidades, como, por exemplo, os conectores tipo pino.

A armadura de cisalhamento é usada para interceptar as fissuras inclinadas oriundas do cisalhamento e restringir a sua abertura. A deformação na armadura é máxima nessa intersecção.

Uma ancoragem efetiva é essencial e a sua posição deve ser a mais próxima possível das faces superior e inferior da laje, visando garantir, ao segmento vertical dessa armadura, o maior comprimento possível. Deste modo, evita-se a possibilidade de que as fissuras passem por cima ou por baixo da armadura.

A ancoragem dos segmentos verticais da armadura de cisalhamento nas lajes pode ser feita através de chapas de ancoragem nas extremidades do segmento, dobras ou ganchos. No entanto, ensaios experimentais constataram que, no caso de estribos, ocorre uma movimentação na região da dobra do estribo, antes que a tensão de escoamento da armadura seja atingida, causando uma perda de tensão (figura O.4).

Além disso, o concreto sob a dobra está sujeito a tensões que podem exceder a 0,4 vezes a tensão de escoamento do estribo, causando o seu esmagamento. Este movimento pode ser reduzido pela utilização de uma barra de armadura longitudinal posicionada no ponto B da figura O.4. Entretanto, esta barra não pode ser posicionada mais próxima do canto sem que ocorra redução da altura útil $d$. Também pode ser observado que esta melhoria das condições de ancoragem do estribo só é efetiva se existir um contato direto entre as barras, conforme mostrado no ponto B da figura O.4.

Na obra, é muito difícil garantir este contato para todos os estribos. Esta quantidade de movimento que ocorre nas dobras é a mesma, tanto para estribos com segmentos verticais longos, como para curtos. Sendo assim, proporcionalmente, a perda de tensão é mais crítica para lajes mais delgadas. Este problema de ancoragem pode ser eliminado através de ancoragens mecânicas nas extremidades dos estribos. 


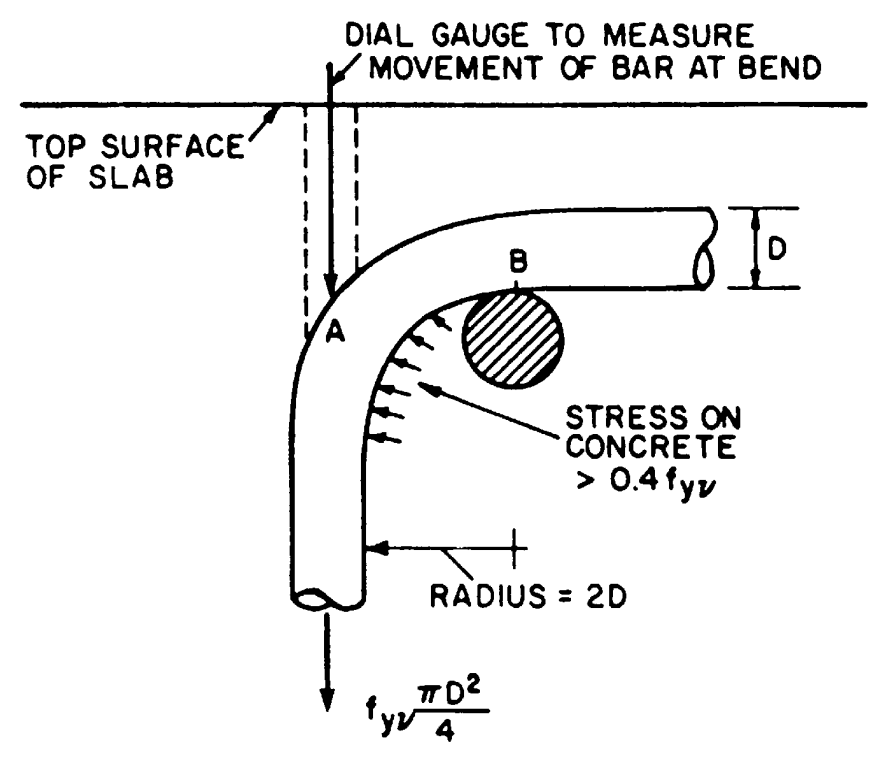

Figura O.4 - Condições geométricas e com relação à tensão no concreto na região de dobra de um estribo (ACI 421.1R-92)

O projeto da ligação é feito basicamente em conformidade com as recomendações do ACI 318, considerando-se o conector tipo pino como sendo equivalente ao segmento vertical de um estribo. Ensaios mostram que pinos com chapas de ancoragem com área igual a 10 vezes a área da seção transversal do pino preencheram os requisitos para o seu bom funcionamento.

O ACI 421.1R-92 apresenta algumas modificações com relação às recomendações dadas pelo ACI 318-95.

O ACI 421.1R-92 apresenta um outro limite para vn, calculado com base na seção crítica a d/2 da face do pilar, para lajes com armadura de punção, quer sejam protendidas ou não:

$$
\mathrm{v}_{\mathrm{n}}=\mathrm{v}_{\mathrm{c}}+\mathrm{v}_{\mathrm{s}} \leq 0,6642 \sqrt{\mathrm{f}_{\mathrm{c}}{ }^{\prime}}
$$

A distância $s_{O}$ entre a primeira linha "perimetral" de conectores e a face do pilar não deve ser inferior a d/4 (figura 0.5 ). 
Já os valores limites para a distância $s_{O}$ e para a distância $s$, que, por sua vez representa a distância entre as linhas "perimetrais" de conectores, são diferentes dos valores propostos pelo ACI 318-95:

$$
\begin{aligned}
& \text { - } \mathrm{s}_{\mathrm{O}} \leq 0,5 \mathrm{~d} \quad \text { e } \quad \mathrm{s} \leq 0,75 \mathrm{~d} \quad \text { quando } \quad \frac{\mathrm{v}_{\mathrm{u}}}{\phi} \leq 0,4982 \sqrt{\mathrm{f}_{\mathrm{c}}{ }^{\prime}} \text {; } \\
& \text { - } \mathrm{s}_{\mathrm{O}} \leq 0,35 \mathrm{~d} \quad \text { e } \quad \mathrm{s} \leq 0,5 \mathrm{~d} \text { quando } \frac{\mathrm{v}_{\mathrm{u}}}{\phi}>0,4982 \sqrt{\mathrm{f}_{\mathrm{c}}{ }^{\prime}} \text {. }
\end{aligned}
$$

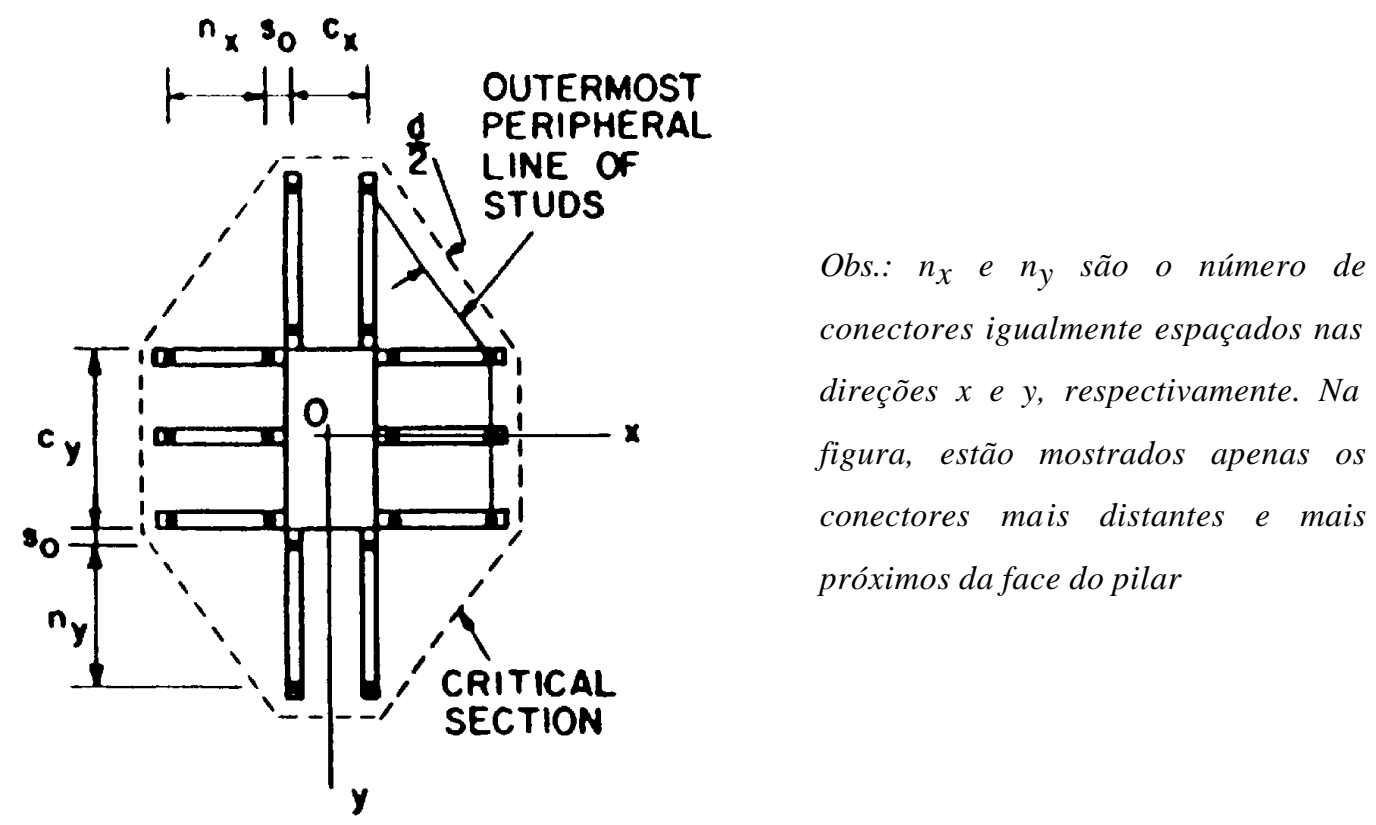

Figura O.5 - Arranjo típico dos conectores tipo pino e definição da seção crítica além da região transversalmente armada (ACI 421.1R-92)

Quando são usados estribos, o ACI 318-95 limita o espaçamento $s$ ao valor de d/2. A modificação proposta é baseada em resultados experimentais. O segmento vertical do estribo é menos eficiente que o pino, no controle das fissuras de cisalhamento, principalmente por duas razões:

- o pino tem o comprimento perfeitamente reto em toda a sua extensão, ao passo que, no estribo, existe uma curvatura nas extremidades do segmento reto; 
- as chapas de ancoragem nas extremidades dos pinos garantem que a tensão de escoamento dos pinos possa ser atingida para todas as seções transversais ao longo do pino; já no estribo, a tensão de escoamento pode ser atingida apenas na região central do segmento vertical do estribo, quando este for suficientemente longo.

Dados experimentais mostram que os pinos são mais eficientes quando estão próximos aos cantos do pilar. Sendo assim, geralmente eles são alinhados com relação às faces do pilar.

Na direção paralela à face do pilar, a distância $g$ entre linhas de conectores não deve exceder ao valor de $2 d$.

O ACI 421.1R-92 também ilustra alguns arranjos típicos para pilares circulares, conforme mostrado na figura O.6.

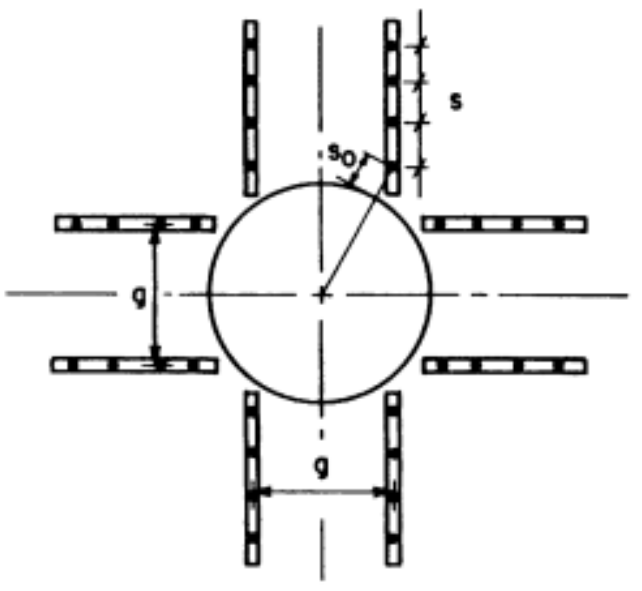

$9 \leq 2 d$, BUT NOT LESS THAN 0.6

DIAMETER OF COLUMN

TOP VIEW

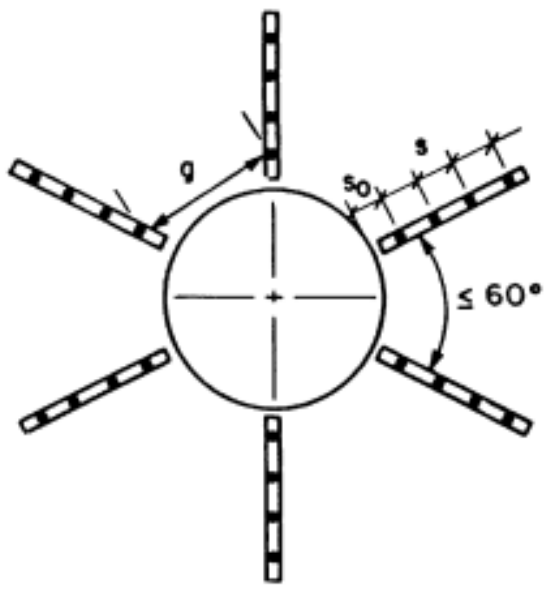

$9 \leq 2 d$

TOP VIEW

Figura O.6 - Disposição dos conectores para pilares circulares (ACI 421.1R-92)

A quantidade mínima de linhas "perimetrais" de conectores, nas proximidades de pilares retangulares e circulares, é de duas. O termo linha "perimetral" refere-se a uma linha que corre paralela e a uma determinada distância da face do pilar. 
Embora os pinos sejam mais eficientes quando as suas ancoragens estão o mais próximo possível das faces superior e inferior da laje, a menos que uma proteção especial seja dada, o cobrimento mínimo especificado para as ancoragens deve ser o mesmo que o definido para a armadura de flexão, seguindo as recomendações da seção 7.7 do ACI 318.

No entanto, o valor máximo do cobrimento dos conectores não deve exceder ao valor mínimo acrescido da metade do valor do diâmetro da barra de armadura longitudinal de flexão (figura O.7).

As ancoragens mecânicas devem ser posicionadas na fôrma, acima dos suportes usados para a armadura longitudinal, de modo a se garantir o valor especificado do cobrimento de concreto.

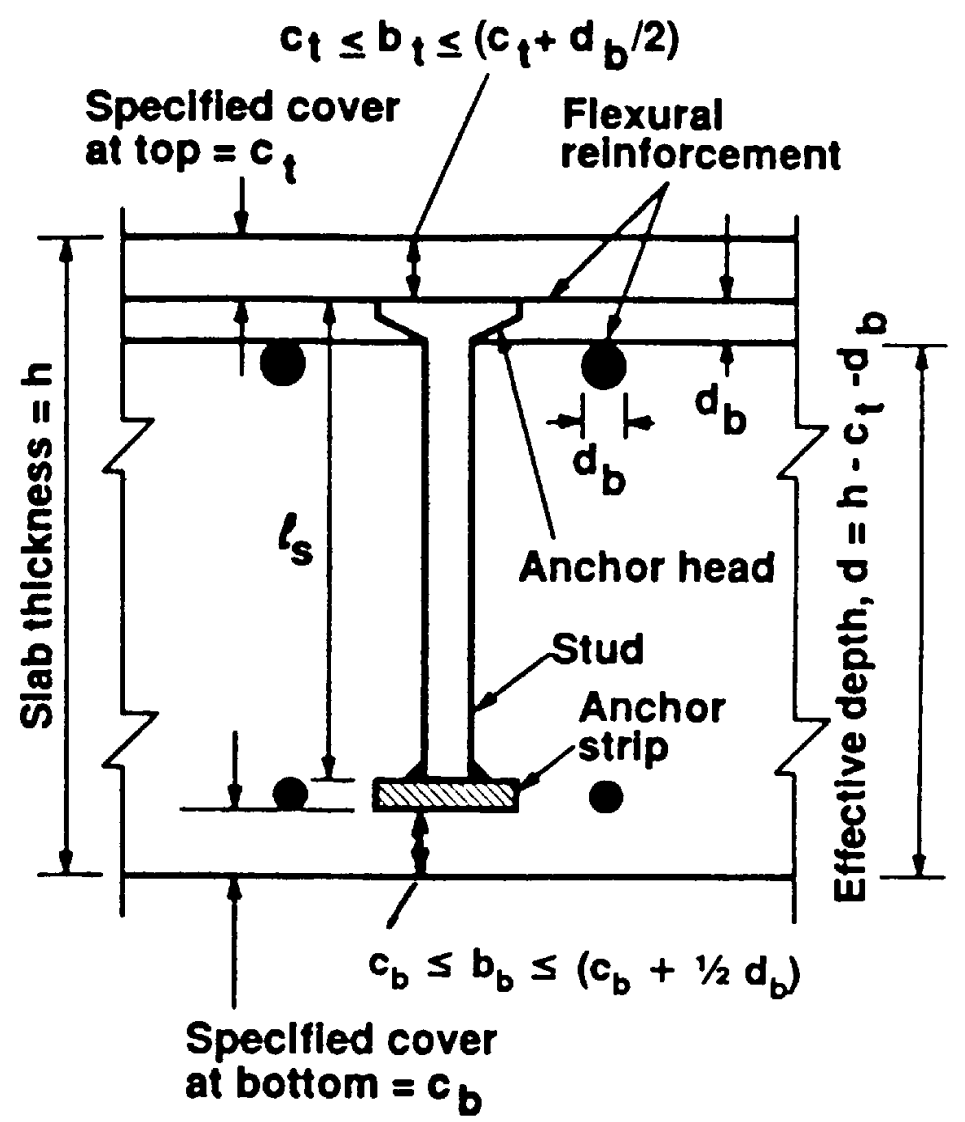

Figura O.7 - Esquema de cobrimentos mínimos e máximos dos conectores 
O ACI 421.1R-92 é um pouco mais específico com relação à superfície crítica externa à região transversalmente armada, mostrada na figura O.8. Nesta seção crítica, a tensão resistente é dada através da expressão:

$$
\mathrm{v}_{\mathrm{n}}=0,1661 \sqrt{\mathrm{f}_{\mathrm{c}}{ }^{\prime}}
$$

O limite dado pela expressão (O.9) parece ser o mesmo, tanto para lajes sem, como para lajes com protensão.

O ACI 421.1R-92 também apresenta a seguinte expressão, usada para calcular o perímetro da seção crítica externa à região transversalmente armada, conforme mostrado na figura O.8.

$$
\mathrm{b}_{\mathrm{o}}=2\left(\ell_{\mathrm{x} 1}+\ell_{\mathrm{y} 1}\right)+4 \ell ; \quad \text { onde: } \ell=\sqrt{\frac{1}{2}\left(\ell_{\mathrm{x} 2}-\ell_{\mathrm{x} 1}\right)^{2}}
$$

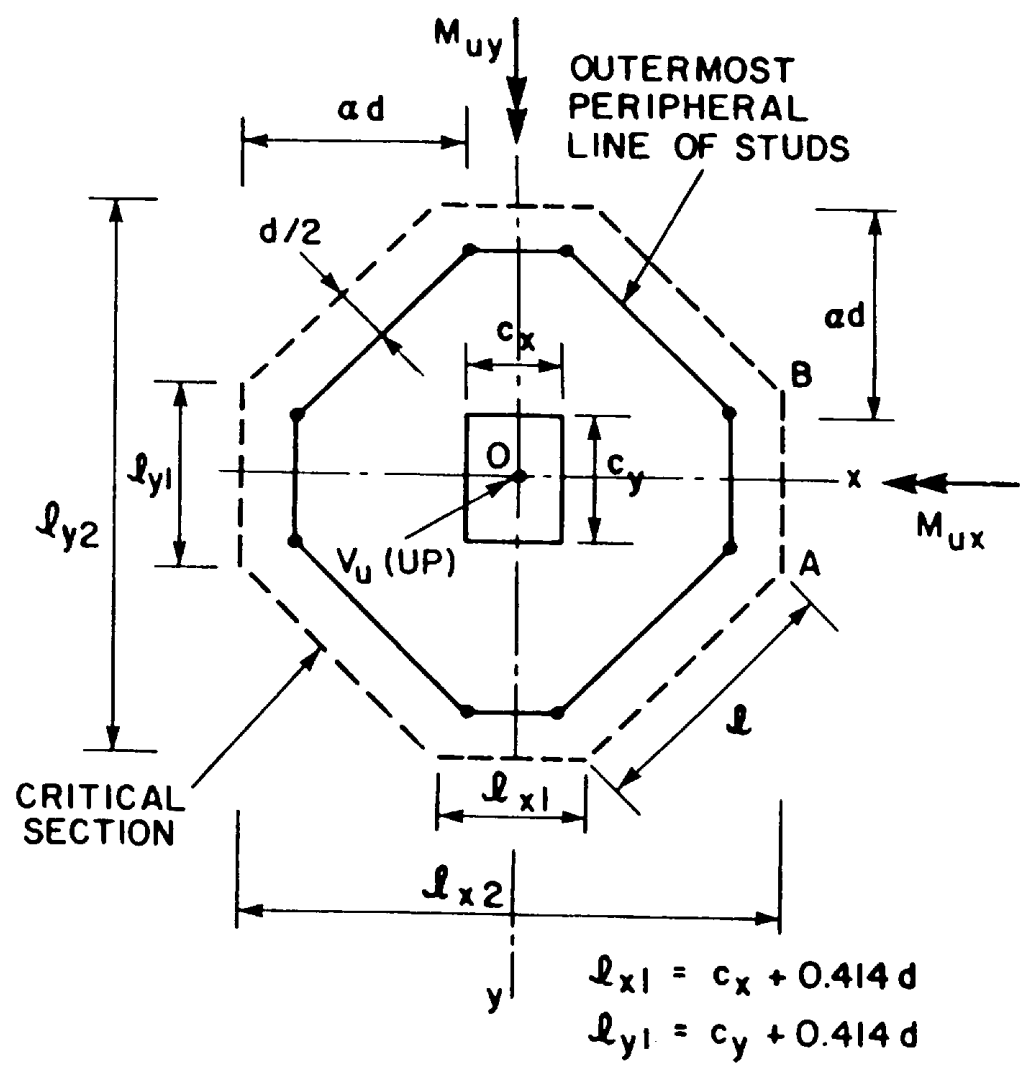

Figura O.8 - Dados para o cálculo do valor do perímetro externo à região transversalmente armada (ACI 421.1R-92) 
ANDRADE \& GOMES (1994a) também apresentam, na figura O.9, expressões para o cálculo dos perímetros críticos considerados apropriados para uma distribuição radial e em cruz dos conectores tipo pino. A expressão para a disposição em cruz é basicamente a mesma que a fornecida pelo ACI 421.1R-92.
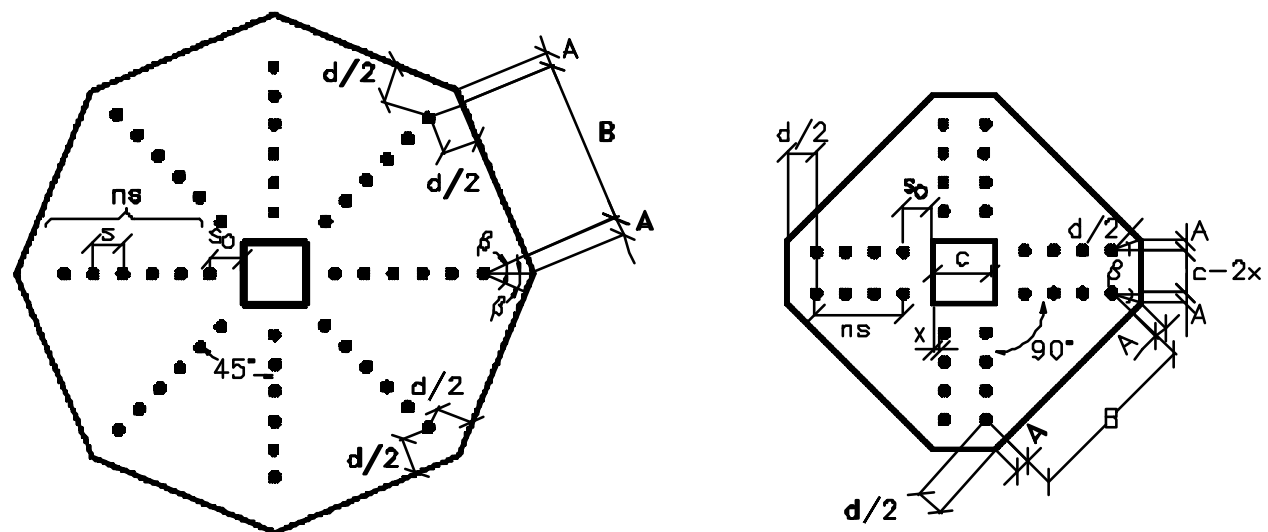

$$
\begin{array}{lr}
\mathrm{U}=8[2 \mathrm{~A}+\mathrm{B}] & \mathrm{U}=4[4 \mathrm{~A}+\mathrm{B}+\mathrm{c}-2 \mathrm{x}] \\
\mathrm{A}=\mathrm{d}(\operatorname{tang} \beta) / 2 & \mathrm{~A}=\mathrm{d}(\operatorname{tang} \beta) / 2 \\
\mathrm{~B}=2 \operatorname{sen} \beta\left(\mathrm{s}_{\mathrm{O}}+\mathrm{ns}\right) & \mathrm{B}=\sqrt{2}\left(\mathrm{~ns}+\mathrm{s}_{\mathrm{O}}+\mathrm{x}\right) \\
\beta=22,5^{\circ} & \beta=22,5^{\circ}
\end{array}
$$$$
\mathrm{A}=\mathrm{d}(\operatorname{tang} \beta) / 2
$$$$
\beta=22,5^{\circ}
$$

\section{a) Disposição radial}

b) Disposição em cruz

Figura O.9 - Expressões dadas para o cálculo do valor dos perímetros críticos recomendadas por ANDRADE; GOMES (1994a)

\section{O.3 RECOMENDAÇÕES DO ACI 352.1R-89}

As recomendações do ACI 352.1R-89 somente se aplicam a ligações laje-pilar monolíticas, sem protensão, sem armadura de cisalhamento, podendo ou não apresentar capitéis.

Com base em evidências experimentais, foi observado que a resistência da ligação da laje com pilares circulares foi superior à da ligação com pilares quadrados de área equivalente. A consideração do pilar circular como sendo um pilar quadrado de área equivalente é uma maneira mais simplificada de se calcular a resistência da ligação, estando, inclusive, a favor da segurança (figura O.10). 


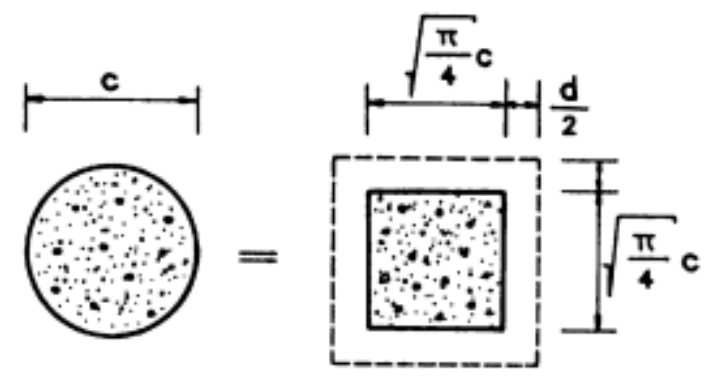

Figura O.10 - Equivalência entre um pilar circular e um pilar quadrado de área equivalente (ACI 352.1R-89)

Com relação ao colapso progressivo, o ACI 352.1R-89 apresenta a seguinte recomendação: para ligações da laje com pilares internos, uma armadura longitudinal contínua deverá ser posicionada próxima à face inferior da laje, passando internamente com relação à armadura longitudinal do pilar, devendo ter uma área mínima igual a:

$$
\mathrm{A}_{\mathrm{sm}}=\frac{0,5 \mathrm{w}_{\mathrm{u}} \ell_{1} \ell_{2}}{\phi \mathrm{f}_{\mathrm{y}}}, \quad \text { onde: }
$$

- $\mathrm{A}_{\mathrm{Sm}}=$ área de barras longitudinais efetivamente contínuas em cada direção principal, posicionada sobre o pilar;

- $\ell_{1}, \ell_{2}=$ vãos de centro a centro, em cada direção principal;

- $\mathrm{f}_{\mathrm{y}} \quad=$ tensão de escoamento da armadura;

- $\phi \quad=$ coeficiente que, neste caso, é igual a 0,9 ;

- $\mathrm{w}_{\mathrm{u}} \quad=$ carga uniformemente distribuída, majorada, não devendo este valor ser inferior a 2 vezes a carga permanente de serviço.

Muitos desastres ocorreram durante a construção, quando além do concreto estar novo e com baixa resistência, cargas elevadas de construção foram aplicadas na laje. Resistências baixas do concreto apresentam um efeito maior com relação ao cisalhamento do que com relação à flexão. Sendo assim, existe uma grande tendência de que, no caso de ruína, ela se dê por cisalhamento. O ACI 352.1R-89 menciona que a carga total resistida pela ligação durante a fase de construção chega a ser igual a duas vezes o carregamento permanente adotado. 
Pode ser adotado um valor menor para $\mathrm{w}_{\mathbf{u}}$ se forem feitos cálculos mais precisos com relação à fase de construção e se também for feita uma monitoração no canteiro de obras.

Quando, em uma direção, os valores calculados de $\mathrm{A}_{\mathrm{Sm}}$ forem diferentes para vãos adjacentes, deverá ser adotado o maior valor na ligação. Essa armadura poderá ser considerada contínua se:

- a emenda por traspasse estiver localizada a $2 l_{d}$ da face do pilar e possuir um comprimento mínimo igual a ld, onde $\mathrm{l}_{\mathrm{d}}$ é o comprimento de ancoragem de uma barra reta;

- a emenda por traspasse estiver localizada dentro da região delimitada pelas faces do pilar, com um comprimento mínimo de $\mathrm{l}_{\mathrm{d}}$;

- a emenda estiver localizada na região adjacente ao pilar, com um comprimento mínimo de $2 l_{d}$, desde que, nesta região, também exista uma armadura junto à face superior do pilar;

- elas apresentarem ganchos ou uma ancoragem eficiente próximas à borda livre da laje, de modo que a tensão de escoamento dessa armadura possa ser atingida junto à face do pilar.

A expressão (O.10) foi desenvolvida usando um modelo conceitual representado pela figura O.11.

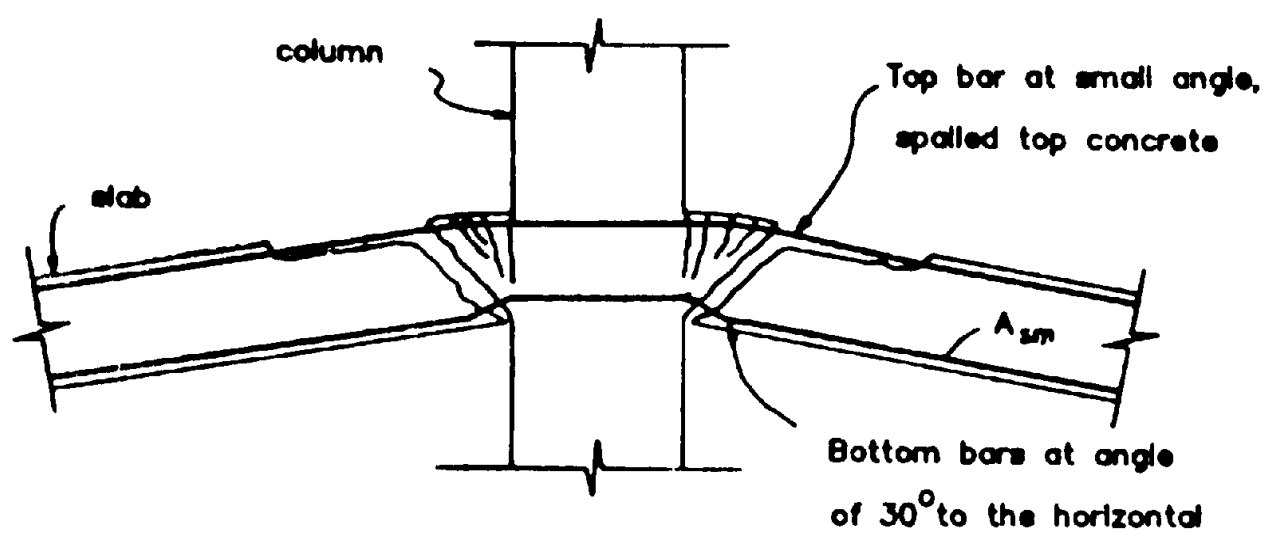

Figura O.11 - Esquema da ligação durante a ruína por punção 
No modelo, após a ruína por punção, a laje é sustentada pela armadura junto à face inferior da laje nas duas direções.

Se for considerado que essa armadura apresenta uma inclinação de $30^{\circ}$ com relação à horizontal, a expressão (O.10) apresenta uma quantidade de armadura suficiente para resistir ao carregamento $w_{\mathfrak{u}}$, relativo à uma área de influência igual a $\ell_{1} \cdot \ell_{2}$. Conforme mostrado na figura O.11, a armadura junto à face superior da laje não é tão eficiente por causa da tendência desta armadura em arrancar o cobrimento de concreto nesta região. 


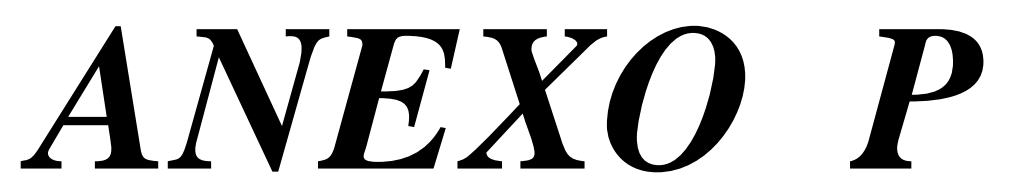

Previsão da resistência dos modelos M1 e M5, com relação à punção, em função das recomendações da Revisão da NB1 (2000), para adequar a resistência do concreto a $50 \mathrm{MPa}$ 


\section{P.1 MODELO M1}

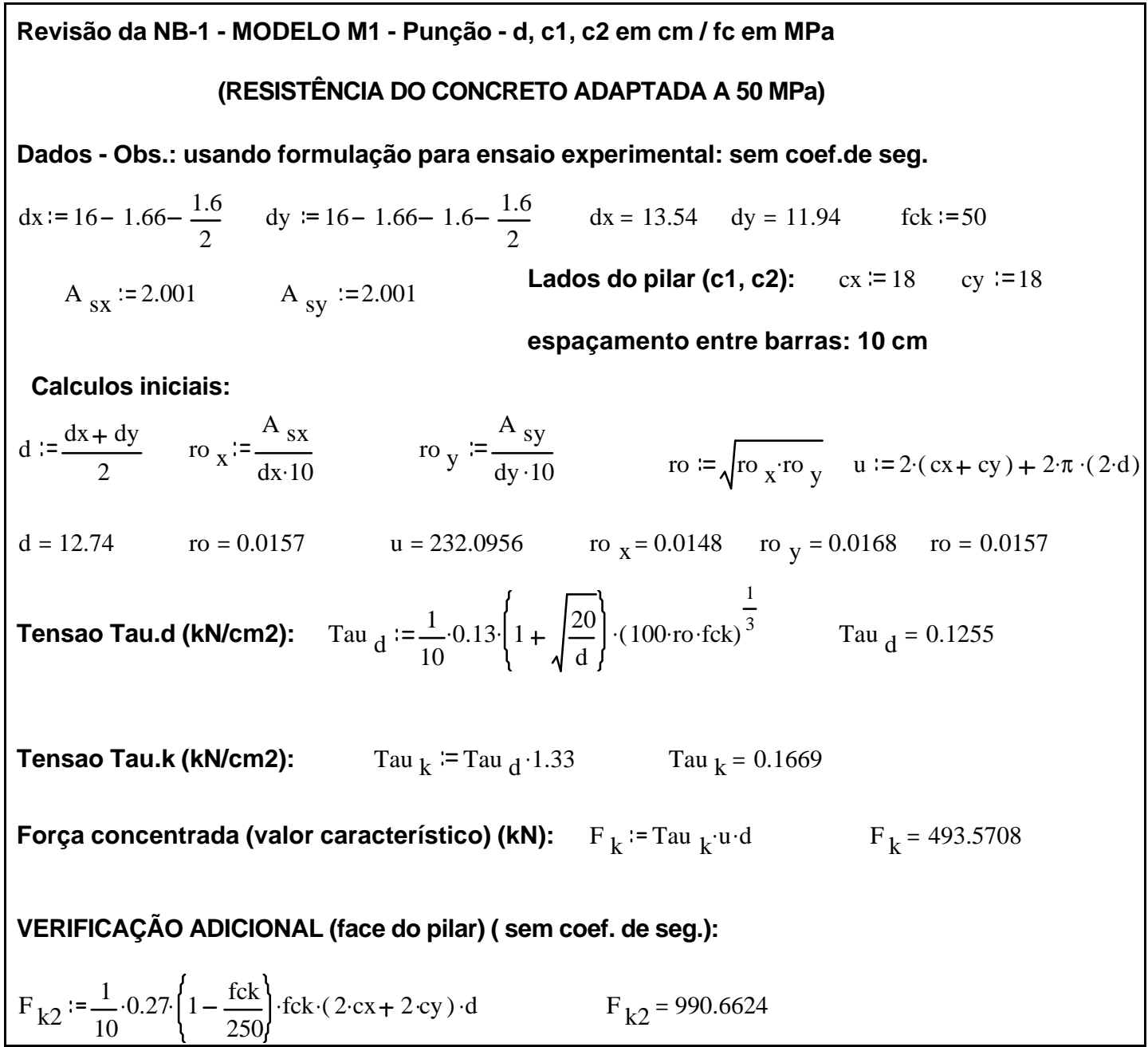

- Resistência do modelo obtida no ensaio (resistência real do concreto, igual a 26,6 MPa): $441,6 \mathrm{kN}$

- Previsão da Revisão da NB-1considerando a resistência real do concreto (igual a 26,6 MPa): $399,93 \mathrm{kN}$

- Relação entre a resistência e a previsão (para resistência real do concreto): 441,6 / 399,93 = 1,104 (portanto a resistência real é 1,104 vezes a previsão)

- Previsão da resistência do modelo, caso a resistência do concreto tivesse sido igual a 50 MPa: $493,57 \mathrm{kN}$

- Aplicando a relação entre a resistência e a previsão obtida para a resistência real do concreto, para obter a resistência estimada para a resistência do concreto igual a $50 \mathrm{MPa}$ :

$\therefore$ Resistência estimada: $1,104.493,57=\mathbf{5 4 4 , 9} \mathbf{~ k N}$ 


\section{P.2 MODELO M5}

Revisão da NB-1 - MODELO M5 - Punção - d, c1, c2 em cm / fc em MPa (RESISTÊNCIA DO CONCRETO ADAPTADA A $50 \mathrm{MPa}$ )

Dados - Obs.: usando formulação para ensaio experimental: sem coef.de seg.

$\mathrm{dx}:=16-1.49-\frac{1.25}{2} \quad \mathrm{dy}:=\mathrm{dx}-1.25 \quad \mathrm{dx}=13.885 \quad \mathrm{dy}=12.635 \quad$ fck $:=50$

$\mathrm{d}:=\frac{\mathrm{dx}+\mathrm{dy}}{2} \quad \mathrm{~d}=13.26 \quad$ Lados do pilar $(\mathrm{c} 1, \mathrm{c} 2): \quad \mathrm{cx}:=18 \quad \mathrm{cy}:=18$

espaçamento entre barras: $10 \mathrm{~cm}$

\section{VERIFICACÃO DA REGIÃO ARMADA}

Dados: $\mathrm{A}_{\mathrm{sx}}:=1.188 \quad \mathrm{~A}_{\mathrm{sy}}:=1.188 \quad$ Asw $:=16 \cdot 0.763 \quad \mathrm{sr}:=9.5 \quad($ limite $=0.75 \cdot \mathrm{d}=9.945 \quad)$

fy $:=633.9\left(\mathbf{p} /\right.$ Ast - MPa) $\quad$ fywd $:=\frac{\text { fy }}{1.15} \quad$ fywd $=551.2174 \quad$ (limite de $300 \mathrm{MPa}$ )

Cálculos:

fywd :=300 Repetir valor se inferior a $300 \mathrm{MPa}$

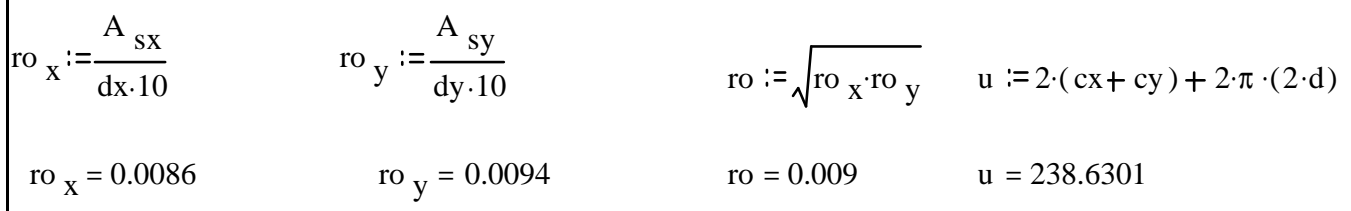

Como quero comparar com resultados experimentais, multiplicar:

parcela do concreto - 1,33 ; parcela do aço-1,15

TAU $1:=\frac{1}{10} \cdot\left[1.33 \cdot 0.10 \cdot\left(1+\sqrt{\frac{20}{\mathrm{~d}}}\right\} \cdot(100 \cdot \mathrm{ro} \cdot \mathrm{fck})^{\frac{1}{3}}+1.15 \cdot 1.5 \cdot \frac{\mathrm{d}}{\mathrm{sr}} \cdot \frac{\mathrm{Asw} \cdot \mathrm{fywd} \cdot 1}{\mathrm{u} \cdot \mathrm{d}}\right] \quad \mathrm{F}_{\mathrm{k} 1}:=\mathrm{TAU} 1 \cdot \mathrm{u} \cdot \mathrm{d}$

Contribuição da protensão:

Direção do eixo $x$

$\mathrm{hx}(\mathrm{x}):=-0.00021488 \mathrm{x}^{2}+0.05372 \mathrm{x}$

$\mathrm{x}:=\frac{250}{2}-\frac{\mathrm{cx}}{2}-2 \cdot \mathrm{d} \quad \mathrm{x}=89.48$

$\operatorname{alfa\_ radx}:=\operatorname{atan}\left\{\frac{\mathrm{d}^{1}}{\mathrm{dx}^{1}} \mathrm{hx}(\mathrm{x})\right\}_{\sin (\text { alfa_radx })=0.0153 /}^{\text {alfa_radx }=0.0153 /}$

Pxm : $=136.74$

$\mathrm{Vpx}:=2 \cdot 4 \cdot \mathrm{Pxm} \cdot \sin ($ alfa_radx $) \quad \mathrm{Vpx}=16.6968$

$$
\mathrm{F}_{\mathrm{k} 1 \text { total }}:=\mathrm{Vpx}+\mathrm{Vpy}+\mathrm{F}_{\mathrm{k} 1}
$$

\section{Direção do eixo y}

$$
\text { hy }(y):=-0.00029488 y^{2}+0.07372 y
$$$$
\mathrm{y}:=\frac{250}{2}-\frac{\mathrm{cy}}{2}-2 \cdot \mathrm{d} \quad \mathrm{y}=89.48
$$$$
\text { alfa_rady }:=\operatorname{atan}\left\{\frac{\mathrm{d}^{1}}{\mathrm{~d} \mathrm{y} 1} \operatorname{hy}(\mathrm{y})\right\}_{\sin (\text { alfa_rady })=0.0209} \text { alfa_rady }=0.0209
$$

Pym:= 146.14

$\mathrm{Vpy}:=2 \cdot 4 \cdot \mathrm{Pym} \cdot \sin ($ alfa_rady $) \quad \mathrm{Vpy}=24.4857$

$\mathrm{F}_{\mathrm{k} 1 \text { total }}=1256.1388$ 


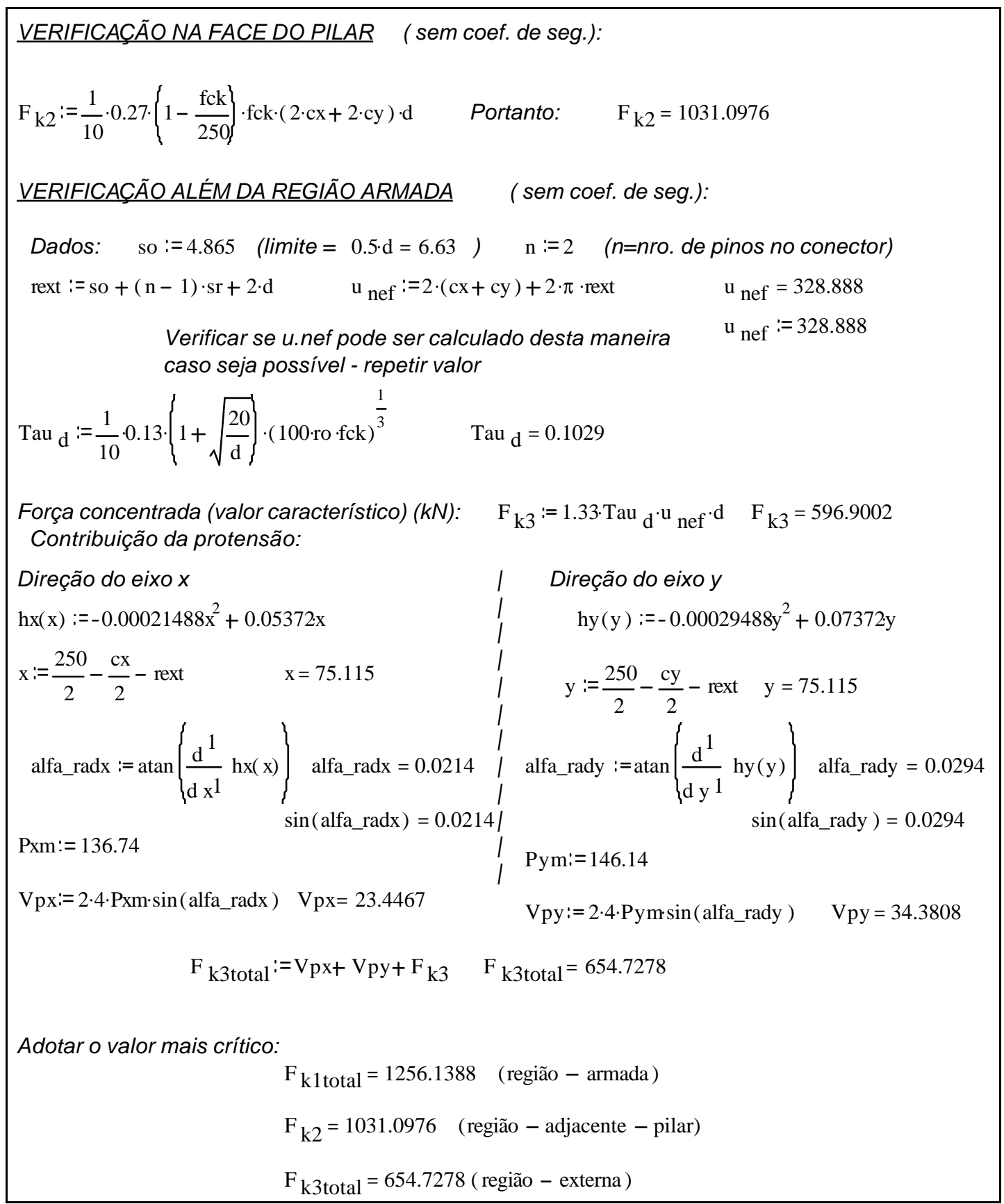

- Resistência do modelo obtida no ensaio (resistência real do concreto, igual a 59,4 MPa): $1104,1 \mathrm{kN}$

- Previsão da Revisão da NB-1considerando a resistência real do concreto (igual a 59,4 MPa): 690,01 kN

- Relação entre a resistência e a previsão (para resistência real do concreto):

1 104,1 / 690,01 = 1,600 (portanto a resistência real é 1,6 vezes a previsão)

- Previsão da resistência do modelo, caso a resistência do concreto tivesse sido igual a $50 \mathrm{MPa}: \quad 654,73 \mathrm{kN}$

- Aplicando a relação entre a resistência e a previsão obtida para a resistência real do concreto, para obter a resistência estimada para a resistência do concreto igual a $50 \mathrm{MPa}$ :

$\therefore$ Resistência estimada: $1,600.654,73=1047,6$ kN 